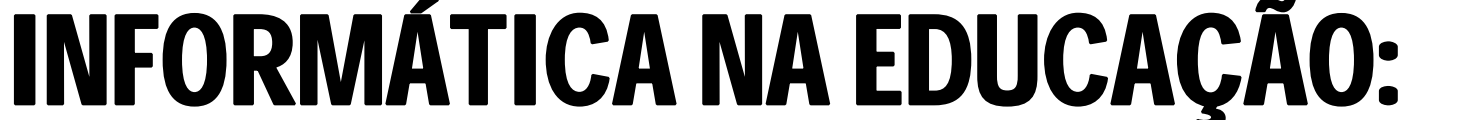

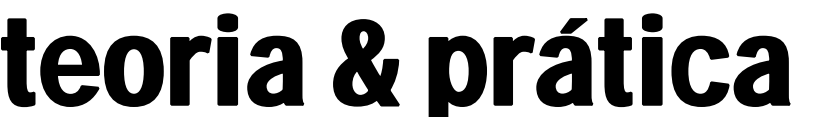

Programa de Pós-Graduação em Informática na Educação - PPGIE Centro Interdisciplinar de Novas Tecnologias na Educação - CINTED Universidade Federal do Rio Grande do Sul - UFRGS V.20, n. 2 - mai./ago. 2017 ISSN digital 1982-1654 ISSN impresso 1516-084x 
DADOS INTERNACIONAIS DE CATALOGAÇÃO-NA-PUBLICAÇÃO BIBLIOTECA SETORIAL DE EDUCAÇÃO da UFRGS, Porto Alegre, RS - BR

Informática na Educação: teoria \& prática - Vol. 1, n. 1 (1998).

Porto Alegre: UFRGS, Centro Interdisciplinar de Novas Tecnologias na Educação, Programa de Pós-Graduação em Informática na Educação, 1998-

Semestral. Anual de 1998 a 2000. Semestral de 2001 em diante.

ISSN digital 19821654

ISSN impresso 1516-084x

1. Informática na Educação - Periódicos. 2. Educação - Inovação tecnológica Periódicos. 3. Computador na educação - Ambiente de aprendizagem - Ensino a distância. Periódicos I. Universidade Federal do Rio Grande do Sul. Centro Interdisciplinar de Novas Tecnologias na Educação. Programa de Pós-Graduação em Informática na Educação.

CDU - 371.694:681.3

Imagem da capa: detalhe de obra de Aldo Locatelli (1915-1962)

Acervo da Pinacoteca Barão de Santo Ângelo/IA/UFRGS 


\section{+ $\square \square$}

Informática na Educação: teoria \& prática - v. 20 n. 2 maio/agosto 2017.

Publicação trimestral do PPGIE/CINTED/UFRGS

ISSN digital: 1982-1654

ISSN impresso 1516-084X

Universidade Federal do Rio Grande do Sul (UFRGS)

Reitor: Rui Vicente Oppermann

Centro Interdisciplinar de Tecnologias na Educação (CINTED)

Diretor: Leandro Krug Wives

Programa de Pós-Graduação em Informática na Educação (PPGIE)

Coordenador: Liane Margarida Rockenbach Tarouco

Editores

José Valdeni de Lima

Liliana Maria Passerino

Conselho Editorial

Alberto Cañas (University of West Florida - UWF/EUA)

Alda M. S. Pereira (Universidade Aberta - Lisboa/Portugal)

Antonio Carlos da Rocha Costa (Universidade Católica de Pelotas)

Antonio Quincas Mendes (Universidade Aberta - Lisboa/Portugal)

Cleci Maraschin (Universidade Federal do Rio Grande do Sul)

Cristina Contera (Universidad de La Republica - UDELAR/Uruguai)

Denise Leite (Universidade Federal do Rio Grande do Sul)

Eliza Helena de Oliveira Echternacht, Universidade Federal de Minas Gerais, Brasil

Edel Ern (Universidade Federal de Santa Catarina)

Edla M. Faust Ramos (Universidade Federal de Santa Catarina)

Eduardo H. Passos (Universidade Federal Fluminense)

Flávia Maria Santoro (Universidade Federal do Rio de Janeiro)

Francisco Javier Díaz, Universidad Nacional de La Plata, Argentina

Gentil Lucena (Universidade Católica de Brasília)

Hugo Fuks (Pontifícia Universidade Católica do Rio de Janeiro)

Luis Roque Klering (Universidade Federal do Rio Grande do Sul)

Javier Días (Universidade de La Plata - UDLP/Argentina)

José Silvio (Instituto de Estudos para America Latina e Caribe - IESALC/UNESCO)

Mauro Pequeno (Universidade Federal do Ceará)

Nicholas C. Burbules (University of Illinois - Urbana-Champaign/EUA)

Nicole Caparraos Mencacci, Université de Nice, França

Otto Peters (FernUniversität Hagen - Alemanha)

Patrícia Behar (Universidade Federal do Rio Grande do Sul)

Pedro Krotsch (Universidad de Buenos Aires - UBA/Argentina)

Regina Maria Varini Mutti (Universidade Federal do Rio Grande do Sul)

Richard Malinski (Ryerson polytechnic University - Canadá)

Sérgio Bairon (Pontifícia Universidade Católica de São Paulo/Universidade Mackenzie)

Sergueï Tchougounnikov, Université de Bourgogne, França

Teresinha Fróes Burnham (Universidade Federal da Bahia)

Vera Menezes (Universidade Federal de Minas Gerais)

Victos Giraldo Valdés Pardo (Universidad Central de las Villas - UCLV/Cuba)

Vilson J osé Leffa (Universidade Católica de Pelotas)

Yves Schwartz, Universidade de Provence, França 


\section{Pareceristas Ad Hoc desde 2014.}

Adetty Pérez Miles - Universidade do Norte do Texas - UNT - Denton, TX - Texas - Estados Unidos Aldimar Jacinto Duarte - Universidade Federal de Goiás - Goiânia - GO - Brasil

Alexandra Lorandi Macedo - Universidade Federal do Rio Grande do Sul - Porto Alegre - RS - Brasil Aline de Campos - Faculdade Senac de Porto Alegre - Porto Alegre - RS - Brasil

Aline Silva de Bona - Universidade Federal do Rio Grande do Sul - Porto Alegre - RS - Brasil

Ana Cláudia Bortolozzi Maia - Universidade Estadual Paulista Julio de Mesquita Filho - São Paulo - SP - Brasil

Ana Irene Alves de Oliveira - Universidade do Estado do Pará - Belém - PA - Brasil

André Luís Marques Silveira - Centro Universitário Ritter dos Reis - Uniritter - Porto Alegre - RS - Brasil

Andrea Paula Osório Duque - Universidade Federal Fluminense - Niterói - RJ - Brasil

Andréia Machado Oliveira - Universidade Federal de Santa Maria - Santa Maria - RS - Brasil

Arlete dos Santos Petry - Pontifícia Universidade Católica de São Paulo - São Paulo - SP - Brasil

Carmen Pimentel - Universidade do Estado do Rio de Janeiro - Rio de Janeiro - RJ - Brasil

Claudia Giannetti - Universidade de Évora - Évora - Portugal

Cristina Maria Carvalho Delou - Pontifícia Universidade Católica de São Paulo - São Paulo - SP - Brasil

Daniel Nehme Müller - Faculdade Monteiro Lobato - Porto Alegre - RS - Brasil

Daniel Revah - Universidade Federal de São Paulo - Guarulhos - SP - Brasil

Daniela Melaré Vieira Barros - Universidade Aberta - Portugal

Debbie Smith-Shank - Ohio State University - Columbus - OH - EUA

Débora Aita Gasparetto - Universidade Federal de Santa Maria - Santa Maria - RS - Brasil

Denia Falcão de Bittencourt - Universidade Estadual de Ponta Grossa - Ponta Grossa - PR - Brasil

Edemilson Jorge Ramos Brandão - Universidade de Passo Fundo - Passo Fundo - RS - Brasil

Elaine Turk Faria - Pontifícia Universidade Católica do Rio Grande do Sul - Porto Alegre - RS - Brasil

Elisa Tomoe Moriya Schlünzen - Pontifícia Universidade Católica de São Paulo - São Paulo - SP - Brasil

Elizabeth Pazito Brandão - Universidade Federal do Rio de Janeiro - Rio de Janeiro - RJ - Brasil

Eromi Izabel Hummel - Universidade Estadual Paulista Júlio de Mesquita Filho - São Paulo - SP - Brasil

Fabio Hebert da Silva - Universidade Federal do Espírito Santo - Vitória - ES - Brasil

Fernanda Antoniolo Hammes de Carvalho - Pontifícia Universidade Católica do Rio Grande do Sul - Porto Alegre - RS Brasil

Fernanda Areias de Oliveira - Universidade Federal do Maranhão - São Luís - MA - Brasil

Fernanda Spanier Amador - Universidade Federal do Rio Grande do Sul - Porto Alegre - RS - Brasil

Flaminio de Oliveira Rangel - Pontifícia Universidade Católica de São Paulo - São Paulo - SP - Brasil

Fúlvia da Silva Spohr - Universidade Federal do Rio Grande do Sul - Porto Alegre - RS - Brasil

Gerusa Ferreira Lourenço - Universidade Federal de São Carlos - São Paulo - SP - Brasil

Giulia Crippa - Universidade de São Paulo - São Paulo - SP - Brasil

Gladis Boff Falavigna - Universidade Estadual do Rio Grande do Sul - Porto Alegre - RS - Brasil

Glaucio J osé Couri Machado - Universidade Federal de Sergipe - São Cristóvão - SE - Brasil

I vette Kafure Muñoz - Universidade de Brasília - Brasília - DF - Brasil

J erusa Machado Rocha - Universidade Federal do Rio de Janeiro - Rio de Janeiro - RJ - Brasil

José Valter Pereira - Universidade do Estado do Rio de Janeiro - Rio de Janeiro - RJ - Brasil

Justin Peter Sutters - Southern Illinois University - Edwardsville - IL - Estados Unidos

Karen Hutzel - The Ohio State University - Columbus - OH - Estados Unidos

Katyuscia Sosnowski - Instituto Federal do Paraná - IFPR - Coronel Vivida - PR - Brasil

Kevin Tavin - Aalto University School of Arts Design and Architecture - Helzinski - Finlândia

Leonidas Leão Borges - Instituto Federal de Alagoas - Maceió - AL - Brasil

Ligia Maria Presumido Braccialli - Universidade Estadual Paulista Júlio de Mesquita Filho - São Paulo - SP - Brasil

Liliana Maria Passerino - Universidade Federal do Rio Grande do Sul - Porto Alegre - RS - Brasil

Luciana Silva Aguiar Mendes Barros - Instituto Federal do Maranhão - IFMA - Pinheiro - MA - Brasil

Luciane Magalhães Corte Real - Universidade Federal do Rio Grande do Sul - Porto Alegre - RS - Brasil

Lúcio França Teles - Universidade de Brasília - Brasília - DF - Brasil

Luís Alfredo Martins Amaral - Universidade do Minho - Braga - Portugal

Luís Carlos Petry - Pontifícia Universidade Católica de São Paulo - São Paulo - SP - Brasil

Luis Enrique Aguilar - Universidade Estadual de Campinas - Campinas - SP - Brasil

Luis Roque Klering - Universidade Federal do Rio Grande do Sul - Porto Alegre - RS - Brasil

Magali Dias de Souza - Universidade Federal do Rio Grande do Sul - Porto Alegre - RS - Brasil

Manisha Sharma - The University of Arizona - Tucson - AZ - Estados Unidos

Manoel dos Santos Costa - Universidade Ceuma - São Luís - MA - Brasil

Marco Antônio Sandini Trentin - Universidade Federal do Rio Grande do Sul - Porto Alegre - RS - Brasil

Marco Aurélio Locateli Verdade - Universidade Federal do Rio Grande do Sul - Porto Alegre - RS - Brasil

Maria Amélia Almeida - Universidade Federal de São Carlos - São Paulo - SP - Brasil

Maria Auxiliadora Soares Padilha - Universidade Federal de Pernambuco - Recife - PE - Brasil

Maria Elizabeth Barros de Barros - Universidade Federal do Espírito Santo - Vitória - ES - Brasil

Maria Lucia Pozzatti Flôres - Universidade Federal do Rio Grande do Sul - Porto Alegre - RS - Brasil

Marineide Câmara - Universidade Federal do Maranhão - UFMA - São Luís - MA - Brasil

Mário Ferreira Resende - Universidade Federal de Santa Catarina - Florianópolis - SC - Brasil

Mary da Rocha Biancamano - Universidade Federal do Rio Grande do Sul - Porto Alegre - RS - Brasil

Monica Rabello de Castro - Pontifícia Universidade Católica do Rio de Janeiro - Rio de Janeiro - RJ - Brasil

Patrícia Brandalise Scherer Bassani - Universidade Federal do Rio Grande do Sul - Porto Alegre - RS - Brasil

Patricia dos Santos Nunes - Universidade do Vale do Rio dos Sinos - São Leopoldo - RS - Brasil

Rafael Wild - Universidade Tecnológica Federal do Paraná - UTFPR - Francisco Beltrão - PR - Brasil

Raimundo Helvécio Almeida Aguiar - Universidade Estadual de Campinas - Campinas - SP - Brasil

Renata de Oliveira Mascarenhas - Universidade Federal da Bahia - Salvador - BA - Brasil

Rosa Maria Bueno Fischer - Universidade Federal do Rio Grande do Sul - Porto Alegre - RS - Brasil

Roseclea Duarte Medina - Universidade Federal do Rio Grande do Sul - Porto Alegre - RS - Brasil 
Sandra Beltran Pedreros - Universidade Federal do Amazônas - Manaus - AM - Brasil

Sandra Cristina Fonseca Pires - Universidade de São Paulo - São Paulo - SP - Brasil

Sérgio Roberto Kieling Franco - Universidade Federal do Rio Grande do Sul - Porto Alegre - RS - Brasil

Silvestre Novak - Universidade Federal do Rio Grande do Sul - Porto Alegre - RS - Brasil

Sílvia Meirelles Leite - Universidade Federal do Rio Grande do Sul - Porto Alegre - RS - Brasil

Sílvio César Cazella - Unisinos - São Leopoldo - RS - Brasil

Tania Mara Galli Fonseca - Universidade Federal do Rio Grande do Sul - Porto Alegre - RS - Brasil

Tania Maria Esperon Porto - Universidade de São Paulo - São Paulo - SP - Brasil

Teresa Torres Eça - Universidade do Porto - Cidade do Porto - Portugal

Tiago Emanuel Klüber - Universidade Federal de Santa Catarina - Florianópolis - SC - Brasil

Valéria Aroeira Garcia - Universidade Estadual de Campinas - Campinas - SP - Brasil

Vera Lucia Doyle Louzada de Mattos Dodebei - Universidade Federal do Rio de Janeiro - Rio de Janeiro - RJ - Brasil

Vera Lúcia Menezes de Oliveira e Paiva - Universidade Federal do Rio de Janeiro - Rio de Janeiro - RJ - Brasil

Wojciech Andrzej Kulesza - Universidade Estadual de Campinas - Campinas - SP - Brasil 
Revisão

José Valdeni de Lima

Tiago Comassetto Froes

Comissão de Publicação

José Valdeni de Lima

Tiago Comassetto Froes

\section{Colaboradores}

Kátia Soares Coutinho

Bibliotecária Responsável

Kátia Soares Coutinho

CRB: $10 / 684$

Números avulsos (até 2007) e permuta

revista@pgie.ufrgs.br

Diagramação e Editoração

Tiago Comassetto Froes

Capa, Projeto Gráfico

Airton Cattani 
Pedidos de números impressos (até 2007) devem ser enviados, juntamente com o cheque cruzado em nome de Informática na Educação: teoria \& prática para:

\author{
Revista I nformática na Educação: teoria \& prática \\ Av. Paulo Gama, 110 - prédio 12105 - 3o andar sala 327 \\ 90040-060 - Porto Alegre (RS) - Brasil \\ Telefone: (51) 3316-3070 (Secretaria) \\ E-mail: revistapgie@pgie.ufrgs.br \\ URL: www.pgie.ufrgs.br/revista
}

Conteúdos, correção linguística e estilo relativos aos artigos publicados e assinados são de inteira responsabilidade de seus respectivos autores e não representam necessariamente a opinião da Revista

Informática na Educação: teoria \& prática. Permitida a reprodução, desde que citada a fonte.

Informática na Educação: teoria \& prática é um periódico científico editado pelo programa de PósGraduação em Informática na Educação, do Centro Interdisciplinar de Novas Tecnologias na EducaçãoCINTED, da Universidade Federal do Rio Grande do Sul. Publicado desde 1998, privilegia perspectivas interdisciplinares de natureza regional, nacional e internacional. Publicam-se dois números anualmente com artigos, pesquisas, relatos sobre trabalhos em andamento, resumos de teses e resenhas.

Missão: Operar como agente difusor de pesquisa científica e tecnológica em temas educacionais de cunho teórico-conceitual ou prático-metodológico, pertinentes à inserção, ao uso e à avaliação da informática e de outras tecnologias, no âmbito das Artes e das Ciências. Neste contexto, o curso de Doutorado do PPGIE publica a revista científica Informática na Educação: teoria \& prática, em que a prioridade da linha editorial

é a de contribuir para um debate filosófico-científico-epistemológico, resultante de pesquisas e/ou reflexões polêmicas, segundo objetivos orientados por compromissos ético-estéticos na construção de conhecimento, na preservação da biodiversidade e no respeito à diferença.

Linha Editorial: As tecnologias, sob este olhar, se fazem presentes e atuantes nos modos de subjetivação e educação em todos os âmbitos da vida social e individual, sendo indissociáveis da formação humana e dos modos de viver em sociedade. A sociedade da informação e do conhecimento na qual nos situamos nos dias de hoje -, provê imensos desafios às formações subjetivas e aos processos educativos, tornando-se significativas todas aquelas escutas e prospecções da pesquisa e de reflexões que indiquem a pluralidade de caminhos e a importância da singularização dos mesmos. Querse, assim, dar passagem e voz aos gestos - individuais e coletivos-, atravessados por estratégias de resistência e de invenção e que estejam, por fim, compromissados com os processos de produção da diferenciação. Aposta-se na composição de sentidos que, através das possibilidades oferecidas pelas 
tecnologias, potencializem as vias de criação a partir da perspectiva de um finito, mas sempre ilimitado horizonte.

A seleção dos artigos toma como referência sua contribuição ao escopo editorial da revista, de cunho interdisciplinar, a originalidade do tema ou do tratamento dado ao mesmo, a consistência e o rigor da abordagem teórica. Cada artigo é examinado por três consultores ad hoc, ou membros do Conselho Editorial, no sistema blind peer review, sendo necessários dois pareceres favoráveis para sua publicação.

Reconhecendo a importância de contribuição para o diálogo interpares, para o aprofundamento teórico na área e para a crescente qualificação de nossos critérios e processos, comunicamos que a Revista recebe fluxo contínuo e pelo sistema on line, artigos, ensaios, resumos de teses, relatos de experiência e resenhas inéditos que focalizem temas de cunho teórico-conceitual ou prático-metodológico. Sendo assim, após o responsável pela submissão haver se cadastrado no sistema, solicita-se observar as normas de formatação, de uso padrão pela revista.

\section{Diretrizes para Autores}

Os textos devem ser inéditos, de autores brasileiros ou estrangeiros, em português, espanhol, inglês ou francês, sendo o conteúdo, a correção linguística e o estilo de responsabilidade do autor. A seleção dos artigos toma como referência sua contribuição à área específica e à linha editorial da revista, a originalidade do tema ou do tratamento dado ao mesmo, a consistência e o rigor da abordagem teórica. Cada artigo é examinado por três consultores ad hoc ou membros do Conselho Editorial, no sistema blind peer review, sendo necessários dois pareceres favoráveis para sua publicação. É importante salientar que o autor só pode assinar um artigo por número. Cada artigo pode ser assinado por, no máximo, três autores (co-autoria).

O artigo deverá ser encaminhado à editoria, através do site http://www.pgie.ufrgs.br/revista, na seguinte forma:

- Nome de cada um dos autores e instituição, assim como deverá aparecer na publicação (completo, por extenso, somente prenome e sobrenome, etc) nos campos destinados ao preenchimento dos metadados;

- Título do artigo na língua de origem do texto, e em língua inglesa, não devendo exceder 15 palavras;

- Resumo informativo, na língua de origem do texto e em língua inglesa, contendo até 150 palavras, indicando ao leitor contexto teórico, temático e problemático do artigo, finalidades, metodologia, resultados e conclusões do artigo, de tal forma que possa dispensar a consulta ao original. Deve ser constituído de uma seqüência de frases concisas e objetivas; 
- Palavras-chave (de três a cinco), na língua de origem do texto, separadas entre si por ponto, e com as iniciais maiúsculas, representando o conteúdo do artigo;

- Corpo do Texto, que não deve ter identificação dos autores, deve apresentar fielmente os mesmos títulos indicados, seguidos do desenvolvimento do conteúdo do artigo, incluindo figuras e tabelas. (O nome do autor será inserido no formulário de submissão, nos campos destinados ao preenchimento dos metadados);

- $\mathrm{O}$ arquivo submetido deve ser do tipo Microsoft Word (.doc) ou Open Document Format texto (.odt);

- Os artigos deverão ter sua extensão ditada pela necessidade de clareza na explicitação dos argumentos, respeitado o limite de 33.000 a 50.000 caracteres com espaço, incluindo resumo e abstract, títulos, notas de fim e referências bibliográficas, espaçamento de linha 11/2, uma fonte legível, tamanho 12; ênfase de expressões no corpo do texto em itálico, ao invés de sublinha ou negrito (exceto em endereços URL); citações breves no interior do parágrafo, entre aspas; citações longas, em parágrafo com recuo, sem aspas, fonte menor; notas de fim, fonte menor; figuras (jpg; png) e tabelas inseridas no corpo do texto, e não em seu final; títulos e sub-títulos destacados, fonte maior, e numerados;

- Resenhas, assim como relatos e discussão de pesquisas ou experiências em andamento devem ter 1.500 a 3.000 palavras de igual formatação ao descrito acima, podendo excepcionalmente ultrapassar este limite, a critério da revista, ouvido o conselho editorial;

- Resumos de teses - relacionados à temática central da revista - devem ter 150 a 500 palavras;

- Artigos aceitos para publicação nas seções Em Foco e Ponto de Vista possuem autonomia em seu formato de apresentação.

- Os textos dos artigos devem seguir as normas da ABNT (Associação Brasileira de Normas Técnicas).

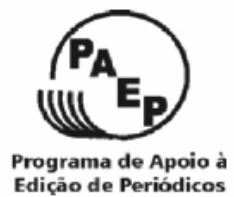

O periódico tem o apoio do Programa de Apoio à Edição de Periódicos - PAEP 2015-2016 da Universidade Federal do Rio Grande do Sul por intermédio da Pró-Reitoria de Pesquisa (PROPESQ). 


\section{$* 0 \mathrm{at}$}

EDITORI AL

\section{ARTIGOS}

Plataforma Matematech: um recurso didático no ensino de matemática nos Anos Iniciais do Ensino Fundamental

J oão Paulo Pereira Araújo

José Geraldo Ribeiro Júnior

Tecnologias Móveis de Comunicação e Informação: Impactos nas

Práticas Docentes e Discentes

Maria de Faria Gomes

Hiolanda Ladislau Vieira

Rita Alves Luna

Avaliação da Utilização de Recursos de Ensino On-line Relacionados a

Diferentes Estilos de Aprendizagem

Anderson Amendoeira Namen

Cassia Mousinho de Figueiredo

Danielle Spada Tavares

Elisa Troian Rodrigues

Paulo Marcos Figueiredo de Andrade

Reynaldo Gomes Lopes

Ensino de BIM no Brasil - Análise do Cenário Acadêmico

Henrique Benedetto

Maurício Moreira e Silva Bernardes

Roberto Wanner Pires

Considerando Estilos de Aprendizagem, Emoções e Personalidade

em Informática na Educação

Janderson Jason Barbosa Aguiar

Formação em tecnologia assistiva através de um curso aberto, massivo, online e de uma biblioteca virtual de soluções assistivas

Rosana Wagner

Roberto Franciscatto

Liliana Maria Passerino

José Valdeni de Lima

Sidnei Renato Silveira 
A Acessibilidade de Pessoas com Daltonismo:

A Construção de um Protótipo de AVA Inclusivo

Rita de Cassia Miranda da Costa

Adriana Aparecida de Lima Terçariol

Fernanda Sutkus de Oliveira Mello

Sidinei de Oliveira Sousa

Elisangela Aparecida Bulla Ikeshoji

Acesso ao computador: comparação do desempenho

de jovens com diferentes dispositivos de entrada

Gláucia Sanches Guimarães

Marcelo Grandini Spiller

Lígia Maria Presumido Braccialli

New user interface using a single Braille cell approach

Marcelo Bernart Schmidt

Luiz Gustavo Metzger

Robert Mortimer

Alejandro Rafael Garcia Ramirez

Integração de Objetos de Aprendizagem em Matemática

utilizando SCORM em Ambiente Virtual de Aprendizagem

Paulo J osé Evaristo da Silva

Thaís de Oliveira

Rodrigo Palucci Pantoni

Desenvolvimento do Pensamento Computacional com Valores da Ética Hacker

Flávia Linhalis Arantes

Paula Eduarda Justino Ribeiro

Experiência com alunos surdos no ambiente virtual de

Camila Guedes Guerra Góes

Lucila Maria Costi Santarosa

Avaliação informatiza adaptativa do ENADE pelo MOODLE:

evidências de validade

Lucio Ferreira Santana

Daniel Bartholomeu

José Maria Montiel

Gleiber Couto

Arthur Almeida Berberian

Fernando Pessoto

Scribblenauts Unmasked: Avaliação do J ogo Digital e seus Aspectos Educativos

Fabiano Naspolini de Oliveira

Eliane Pozzebon

Luciana Bolan Frigo

Tecnologias e Saúde Mental: uma plataforma de jogos digitais para

jovens com transtorno de desenvolvimento

Francisco Milton Mendes Neto

Karla Rosane do Amaral Demoly

Everton Jales de Oliveira

Mariza Souza Moura

Rafael de Almeida Rodrigues

Ramiro de Vasconcelos dos Santos Junior 
O Webfólio como Procedimento Avaliativo no Processo de Aprendizagens:

Sentidos, Significados e desafios Joseval dos Reis Miranda 
EDI TORI AL

\section{DOSSI ER}

Platform Matematech: an educational resource in the teaching

of mathematics in the early years of basic education
João Paulo Pereira Araújo
José Geraldo Ribeiro J únior

Technology Mobile Communication and Information:

Impacts in Pratice teachrs and students

Maria de Faria Gomes

Hiolanda Ladislau Vieira

Rita Alves Luna

Evaluation of the Use of Online Resources Related to Different

Learning Styles

Anderson Amendoeira Namen

Cassia Mousinho de Figueiredo

Danielle Spada Tavares

Elisa Troian Rodrigues

Paulo Marcos Figueiredo de Andrade

Reynaldo Gomes Lopes

Teaching BIM in Brazil: Analysis of the Academic Scenario

Henrique Benedetto

Maurício Moreira e Silva Bernardes

Roberto Wanner Pires

Considering Learning Styles, Emotions and Personality

in Computers in Education

Janderson Jason Barbosa Aguiar

Assistive Technology Training Through An Open, Mass Online

Course And A Virtual Library Of Assistive Solutions

Roberto Franciscatto

Liliana Maria Passerino

José Valdeni de Lima

Sidnei Renato Silveira

The Accessibility People with Color Blindness:

Construction of a Prototype AVA Inclusive

Rita de Cassia Miranda da Costa

Adriana Aparecida de Lima Terçariol

Fernanda Sutkus de Oliveira Mello

Sidinei de Oliveira Sousa

Elisangela Aparecida Bulla Ikeshoji

Computer Access: Comparison Of The Youth Performance With

Different Input Devices

Gláucia Sanches Guimarães

Marcelo Grandini Spiller

Lígia Maria Presumido Braccialli 
New User Interface Based On A Single Braille Cell Approach

Marcelo Bernart Schmidt

Luiz Gustavo Metzger

Robert Mortimer

Alejandro Rafael Garcia Ramirez

Mathematics Learning Objects Integration Using SCROM in

Learning Virtual Environment

Paulo J osé Evaristo da Silva

Thaís de Oliveira

Rodrigo Palucci Pantoni

Computational Thinking With Hacker's Ethics

Flávia Linhalis Arantes

Paula Eduarda Justino Ribeiro

Experience With Deaf Students In The Virtual Learning Environment

Of The Letter/Brazilian Sign Language/UFSC Program

Camila Guedes Guerra Góes

Lucila Maria Costi Santarosa

Adaptive Computerization Assessmnt Of ENADE By MOODLE:

Evidence Of Validity

Lucio Ferreira Santana

Daniel Bartholomeu

José Maria Montiel

Gleiber Couto

Arthur Almeida Berberian

Fernando Pessoto

Scribblenauts Unmasked: Evaluation of Digital Game and his Educational Aspects

Fabiano Naspolini de Oliveira

Eliane Pozzebon

Luciana Bolan Frigo

Technology and Mental Health: a Digital Game Platform for Young People

With Developmental Disorders

Francisco Milton Mendes Neto

Karla Rosane do Amaral Demoly

Everton Jales de Oliveira

Mariza Souza Moura

Rafael de Almeida Rodrigues

Ramiro de Vasconcelos dos Santos Junior

The Webfolio as Assessement Procedure in the Process of Learning:

Senses, Meaning and Challenges

Joseval dos Reis Miranda 


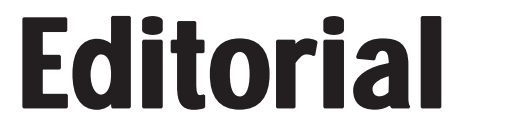

É com imenso prazer que, na qualidade de Diretor do CINTED, preparo o editorial para o número 20, volume 2 de 2017 da Revista Informática na Educação: Teoria \& Prática. Aproveito para informar que, a partir deste momento, farei parte do corpo editorial da revista, o que me deixa muito contente. Este número apresenta uma grande quantidade de artigos, o que torna o trabalho mais interessante.

Os artigos selecionados para este número abordam plataformas, tecnologias e recursos didáticos, metodologias, tecnologias assistivas, o impacto das TIC nas práticas docentes, além de técnicas adaptativas e personalização.

No artigo "Plataforma Matematech: um Recurso Didático no Ensino de Matemática nos Anos Iniciais do Ensino Fundamental", os autores propõem e discutem o uso de uma plataforma de ensino de Matemática que foi utilizada em uma escola da rede pública, tendo obtido sucesso no aprendizado dessa área para alunos das séries iniciais da Educação Básica.

Em “Tecnologias Móveis de Comunicação e Informação: Impactos nas Práticas Docentes e Discentes", os autores analisam o impacto das tecnologias móveis nos anos finais do ensino fundamental. O estudo contou com mais de 400 participantes e identificou que, apesar de alunos e professores disporem desses mecanismos no seu dia a dia, eles são subutilizados em termos de ensino-aprendizagem e práticas pedagógicas.

Já em "Avaliação da Utilização de Recursos de Ensino On-line Relacionados a Diferentes Estilos de Aprendizagem" são apresentados os resultados de uma pesquisa de comportamento relacionada com a criação e o uso de recursos on-line (objetos de aprendizagem) para apoio ao ensino de uma disciplina presencial. Esses recursos foram elaborados de forma a levar em conta diferentes estilos de aprendizagem, aprimorando 0 processo de ensino-aprendizagem.

O artigo "Ensino de BIM no Brasil - Análise do Cenário Acadêmico" discute a técnica de Modelagem de Informações de Construção e sua importância na formação de profissionais para as áreas de Arquitetura, Engenharia, Construção e Operação. Os autores concluem que, apesar de importante e de haver muita discussão sobre a adoção dessa prática no cenário acadêmico, há poucos relatos sobre seu uso e discussão na academia.

Em "Considerando Estilos de Aprendizagem, Emoções e Personalidade em Informática na Educação", o foco está em apresentar conceitos e reflexões relacionadas com o uso das tecnologias da informação e comunicação sua possibilidade de explorar as especificidades dos alunos. Os autores demonstram que os perfis são heterogêneos, mesmo quando os alunos possuem o mesmo nível de ensino e são da mesma área, e que esse fato nem sempre é levado em conta ao se utilizar tecnologias digitais de informação e comunicação.

O artigo seguinte, intitulado "SolAssist Learning: Formação em Tecnologias Assistivas através de um MOOC e uma biblioteca Virtual de Soluções Assistivas" discute os conceitos relacionados com tecnologias educacionais e assistivas, além de descrever o processo de desenvolvimento um MOOC e uma biblioteca virtual assistiva, os quais foram projetados e estruturados para auxiliar na formação em tecnologias assistivas e educação inclusiva.

Na mesma linha, o artigo "A Acessibilidade de Pessoas com Daltonismo: A Construção de um Protótipo de AVA inclusivo" descreve um estudo conduzido para o desenvolvimento de módulo que melhora e adequa um ambiente virtual de aprendizagem para pessoas daltônicas. Como resultado tem-se um conjunto de especificidades que devem ser levadas em conta para promover o acesso dessas pessoas a esses ambientes.

No artigo "Acesso ao Computador: Comparação do Desempenho de Jovens com Diferentes Dispositivos de Entrada", avalia-se a eficácia dos diferentes dispositivos de acesso (entrada de dados) ao computador. Cinquenta jovens participaram de um experimento a fim de medir seu desempenho e grau de satisfação ao usar o computador com diferentes dispositivos. Os resultados são bem interessantes e relevantes. 
Esta edição traz ainda um artigo em inglês, intitulado "New User Interface using a Single Braille Cell Approach", o qual apresenta um sistema de leitura em Braille baseado em uma abordagem de célula única. O sistema foi utilizado por 3 pessoas com problemas de visão, as quais tinham conhecimentos variados de Braille e de uso do computador. Os resultados demonstram que a abordagem proposta auxilia o aprendizado de Braille.

Em "Integração de Objetos de Aprendizagem em Matemática Utilizando SCORM em um Ambiente Virtual de Aprendizagem" os autores apresentam um estudo da viabilidade de integração de objetos de aprendizagem. Para tanto, empacotaram aplicativos do GeoGebra através do SCORM e avaliaram seu uso em diferentes ambientes. Sua conclusão é que mesmo com a adoção de um padrão como o SCORM, ainda há muitos desafios para que objetos interoperáveis, acessíveis e reutilizáveis sejam produzidos e utilizados sem problemas, na prática.

Em “Desenvolvimento do Pensamento Computacional com Valores da Ética Hacker" é discutida necessidade de introdução de conceitos relacionados com a computação aos jovens. Em especial, o artigo descreve o projeto e a avaliação de oficina sobre a tecnologia Scratch realizada com um conjunto de jovens. Os autores salientam a importância de orientar os jovens a terem senso crítico e ética voltados ao compartilhamento de ideias e soluções de software.

No documento "Acessibilidade para Alunos Surdos no Ambiente Virtual de Aprendizagem do curso de Letras/Libras/UFSC, em Polos do Rio Grande do Sul", os autores fazem uma análise de um curso de graduação em Licenciatura em Letras/LIBRAS oferecido na modalidade EAD. O foco está em discutir aspectos de acessibilidade para alunos surdos ao utilizaram o ambiente virtual de ensino. Tal discussão é muito relevante para a criação de cursos acessíveis totalmente a distância.

O artigo "Avaliação Informatiza Adaptativa do ENADE pelo Moodle: Evidências de Validade" apresenta um estudo de aplicação de testes informatizados adaptativos em relação a testes em papel, ambos de múltipla escolha. O estudo envolveu 92 pessoas de um curso de Direito. Ambos os testes tiveram dados do ENADE como base, de forma a correlacionar e ajustar os modelos utilizados. Os resultados mostraram que ambos os formatos tiveram forte correlação em termos de níveis de dificuldade em relação à avaliação do ENADE, podendo ser utilizados como mecanismos úteis de avaliação.

Em "Scribblenauts Unmasked: Avaliação do Jogo Digital e seus Aspectos Educativos" é apresentado o desenvolvimento de um jogo digital. Em especial, são destacados seus objetivos, jogabilidade, mecanismos e outras dimensões relevantes. Essas dimensões são correlacionadas com o nível de diversão e com aspectos educativos. Um estudo de aplicação do jogo com alunos foi realizado e os resultados demonstram que é possível utilizar o jogo a fim de propiciar uma aprendizagem mais ativa dos conceitos trabalhados.

O artigo “Tecnologias e Saúde Mental: Uma Plataforma de Jogos Digitais para Jovens com Transtornos de Desenvolvimento" descreve o desenvolvimento de uma plataforma de jogos digitais que é utilizada em oficinas oferecidas a jovens com diferentes transtornos, em especial com o autismo. O artigo discute as transformações cognitivas e afetivas observadas durante as oficinas.

Finalmente, em "O Webfólio como Procedimento Avaliativo no Processo de Aprendizagens: Sentidos, Significados e Desafios" são apresentadas algumas reflexões e desafios sobre a utilização dessa ferramenta, o webfólio, como mecanismo de avaliação de aprendizagem. Em um estudo de caso, os autores identificaram que a abordagem proporciona maior espaço para a construção, a reflexão e a criatividade acerca das aprendizagens pelos estudantes, além de permitir melhor acompanhamento e estimular a convivência com os recursos tecnológicos.

Boa leitura! 


\title{
Plataforma Matematech: um Recurso Didático no Ensino de Matemática nos Anos Iniciais do Ensino Fundamental
}

\section{Platform Matematech: an Educational Resource in the Teaching of Mathematics in the Early Years of Basic Education}

\author{
J oão Paulo Araújo Pereira de Araújo \\ José Geraldo Ribeiro J únior \\ Centro Federal de Educação Tecnológica de Minas Gerais - Unidade Leopoldina
}

\begin{abstract}
Resumo: Atualmente, a educação no Brasil encontra-se em uma situação muito delicada. Os índices gerados com base em avaliações que medem o nível de proficiência dos alunos não têm desenhado o melhor cenário para o processo de aprendizagem no Brasil. Quando o assunto é matemática, os resultados são caóticos. Nesse contexto, a tecnologia tem sido colocada como uma aliada na tentativa de mudar essa realidade. Partindo dessas observações, o presente trabalho propõe o uso de uma solução tecnológica para dar suporte ao ensino de matemática nos Anos Iniciais da Educação Básica. Esse trabalho foi orientado a partir de uma metodologia baseada em diagnósticos prévios, estudo da ferramenta, aplicação da Plataforma na escola, avaliações diagnósticas finais e análise dos resultados. A Plataforma foi aplicada a alunos dos Anos Iniciais do Ensino Fundamental de uma escola da rede pública e observou-se que ela é uma ferramenta eficiente na garantia de um aprendizado contextualizado.
\end{abstract}

Palavras-chave: Tecnologia. Educação. Plataforma de Aprendizagem.

\begin{abstract}
Nowadays, education in Brazil is in a very delicate situation. The index of the tests which measure student's proficiency level have not shown the best scenario for the learning process in Brazil. When mathematics is subject, the results are chaotic. In this context, technology has been used as an ally in trying to change that. From these observations, this paper aims solutions utilizing technology to support the teaching of mathematics in the early years of basic education. This work was directed from a methodology based on previous diagnoses, tool study, Application Platform at school, final diagnostic evaluations and analysis of results. Platform was applied in a group of pupils in the early years of basic education in a school from the government and it was noticed that the Platform is an efficient tool to insure a contextualized learning.
\end{abstract}

Keywords: Technology. Education. Learning Platform.

BEZ, Maria Rosangela; PASSERINO, Liliana Maria; VALDENI, José Valdeni de. Instruções para Autores da Revista de Informática na Educação: teoria \& prática. Informática na Educação: teoria \& prática, Porto Alegre, v. 20, n. 2, p. 17-35, mai./ago. 2017. 


\section{I ntrodução}

É impossível negar o desenvolvimento tecnológico que estamos vivenciando, assim como, não podemos rejeitar que a tecnologia se faz presente nos mais variados setores (KENSKI, 2008). A sociedade do século XXI se vê mergulhada em um mar de artefatos tecnológicos que atinge diretamente a vida do homem em todos os aspectos, seja no trabalho, no lazer e principalmente na escola. Dentro da área educacional, essas tecnologias, se bem utilizadas, devem contribuir para disseminar o acesso de todos à educação.

A popularização de recursos tecnológicos, promovida nas últimas décadas, fez com que, por mais carente de recursos que talvez seja uma determinada comunidade, de alguma forma, seus sujeitos estão em contato com equipamentos tecnológicos e chegam dentro da sala de aula dominando-os de forma surpreendente.

A questão é que mesmo em meio a essa onda tecnológica, muitas escolas ainda não dialogam de forma direta com os recursos tecnológicos e o aprendizado ainda é conduzido de forma tradicional. A permanência da prática pedagógica pautada na forma tradicional nem sempre é voluntária. Muitas escolas sofrem com falta de recursos financeiros para adquirir investimentos tecnológicos e situações que envolvem formação de professor acabam por dificultar a implantação de tecnologias no cotidiano escolar e dessa forma travar o crescimento dos índices que avaliam a melhora da educação no país.

Perante esses entraves e levando em consideração outros problemas de caráter social que também influenciam no desenvolvimento educacional dos jovens, a situação da educação brasileira está distante de ser a mais animadora. Os resultados oficiais de avaliações externas como o Pisa e a Prova Brasil apontam que ainda é necessário muito trabalho para que se tenha uma educação pública de qualidade.

De acordo com os dados coletados por meio dessas avaliações em larga escala, o resultado ainda é mais dramático quando o assunto é a matemática. A cada ano, mais alunos não conseguem atingir o nível adequado de aprendizagem da disciplina. As dificuldades dos alunos em aplicar conceitos fundamentais da matemática e utilizar o raciocínio lógico é um dos entraves para mudar esses resultados.

Segundo dados da Prova Brasil 2013 (BRASIL, 2014), oito de cada dez alunos que concluem - Ensino Fundamental não aprenderam o mínimo esperado em Matemática. Além dos agravantes comuns a todas as disciplinas, a matemática sofre, de acordo com as pesquisas, repúdio por parte dos alunos pela dificuldade do conteúdo, que é potencializada pela falta de contextualização (PIRES, 2006). Porém, vários setores estão se empenhando para construir um painel diferente da educação no Brasil. Nesse contexto, a tecnologia tem sido colocada como uma aliada na tentativa de mudar esse cenário. A tecnologia tem potencial para promover a qualidade e a equidade na educação, além de ser capaz de promover a aproximação da escola da realidade do aluno (BRASIL, 2002). 
Partindo desse cenário e na busca de dados que possam auxiliar na afirmação de que a tecnologia pode ser uma parceira no processo de melhoria do ensino de matemática, o presente artigo relata a experiência do uso da Plataforma Matematech, desenvolvida no Centro Federal de Educação Tecnológica de Minas Gerais (CEFET/MG), Unidade Leopoldina, para o ensino de matemática dos Anos Iniciais do Ensino Fundamental. Baseada em uma estrutura física simples, a Plataforma Matematech é uma alternativa de baixo custo e viável para a realidade das escolas. Estruturada a partir de concepções de programação para Arduino, a Plataforma Matematech, trabalha conceitos como espaço e forma, medidas, números, operações e tratamento da informação, que são de fundamental importância para o desenvolvimento do raciocínio lógico e matemático da criança.

O restante deste artigo está estruturado da seguinte forma: na Seção 2 é discutida a atual situação do cenário brasileiro em termos educacionais; na Seção 3 são analisados os desafios e as possibilidades do uso das tecnologias na educação; a Seção 4 apresenta uma análise dos trabalhos que estão sendo desenvolvidos na área; na seção 5 é apresentada a Plataforma Matematech e sua lógica de funcionamento; na Seção 6 é descrita a forma como a Plataforma Matematech foi utilizada dentro do ambiente escolar e finalmente, na Seção 7 são analisados os resultados alcançados com a prática e na Seção 8 são realizadas as conclusões do trabalho.

\section{Cenário Atual da Educação no Brasil}

Nos últimos anos tem-se observado um intenso movimento em prol do debate pela melhoria da oferta do ensino no Brasil. Governos, entidades públicas e particulares, assim como toda a sociedade civil têm se mobilizado na luta pela garantia da educação pública de qualidade no país. Todo esse movimento em torno das questões educacionais no Brasil é resultado da atual situação em que o país se encontra no que tange ao ensino e aprendizagem.

A qualidade da educação brasileira, quando mensurada pelo desempenho acadêmico de nossos alunos, coloca o Brasil em níveis inferiores aos de países que se encontram em mesmo estágio de desenvolvimento e até mesmo abaixo de países mais pobres como é o caso da Costa Rica, Tailândia e Chile (PISA, 2012). O cenário da situação do ensino no Brasil é definido pelos resultados das avaliações externas aplicadas no país. Essas avaliações mostram os avanços e retrocessos nos diferentes níveis da educação básica.

Em nível internacional, tem-se o Programa Internacional de Avaliação de Estudantes (PISA, na sigla em inglês), estruturado pela Organização para Cooperação e Desenvolvimento Econômico (OCDE/UNESCO), que busca mensurar a capacidade que jovens de 15 anos possuem em usar os conhecimentos adquiridos ao longo da educação básica para enfrentar desafios da vida real. A avaliação é realizada a cada três anos e busca medir o desempenho dos estudantes em três áreas do conhecimento - leitura, matemática e ciências.

De acordo com os dados do Pisa, em 2012, mesmo diante de uma significativa evolução nos itens avaliados pelo Programa, o Brasil ainda ocupa as posições mais inferiores do ranking (PISA, 2012). Em uma avaliação que analisa a qualidade da educação de 65 países, o Brasil 
caiu quatro posições com relação à última divulgação em 2009, ocupando em 2012, a 58a posição na escala geral. De acordo com relatório divulgado pela OCDE, o Brasil piorou em termos de leitura, não avançou em ciências e em matemática, apesar da modesta melhora, o país caiu da $57^{\mathrm{a}}$ posição para a $58^{\mathrm{a}}$ (PISA, 2012).

Quando se compara os resultados alcançados em matemática, com os resultados nas disciplinas de língua portuguesa e ciências, a nota dos alunos de 15 anos em matemática continua sendo a mais baixa de todas as áreas: 391, contra 410 em leitura e 405 em ciências (PISA, 2014). Ainda sobre essa avaliação, constatou-se que apesar da melhora, dois em cada três alunos com idade de 15 anos possuem dificuldade em interpretar problemas que necessitam apenas de deduções diretas da informação dada e ainda não conseguem entender conteúdo de porcentagem, fração ou gráficos (PISA, 2014).

Em nível nacional tem-se o Saeb (Sistema de Avaliação da Educação Básica) que é organizada pelo INEP (Instituto Nacional de Estudos e Pesquisas Educacionais Anísio Teixeira) (INEP, 2005). O Saeb é composto por três avaliações externas em larga escala: Aneb (Avaliação Nacional da Educação Básica), Ana (Avaliação Nacional da Alfabetização) e Anresc (Avaliação Nacional do Rendimento Escolar), também chamada de Prova Brasil. Vamos nos reter em analisar os resultados da Prova Brasil que é um instrumento importante na elaboração do IDEB (Índice de Desenvolvimento da Educação Básica). A Prova Brasil é uma avaliação censitária aplicada aos alunos do 50 ano e 9o ano do Ensino Fundamental das escolas públicas das redes municipais, estaduais e federal. O objetivo dessa avaliação é mostrar a qualidade do ensino oferecido nas escolas públicas (QEDU, 2016).

De acordo com os resultados da edição de 2013 da Prova Brasil, apenas $40 \%$ dos alunos aprendeu o adequado na competência de leitura e interpretação de textos até o 50 ano na rede pública de ensino. Em matemática o resultado ainda é mais crítico. Apenas 35\% dos alunos aprenderam o adequado na competência de resolução de problemas até o 5o ano na rede pública de ensino. Nos anos finais da educação básica o resultado é alarmante: em português $23 \%$ dos alunos aprenderam o adequado, enquanto matemática foram apenas $11 \%$ (QEDU, 2016). Após ter conhecimento desses dados e levando em consideração que eles são utilizados para o cálculo do IDEB, não é de se espantar que os resultados para 2013 não sejam tão animadores. As duas últimas etapas da educação básica não conseguiram atingir a meta estabelecida e nos Anos Iniciais do Ensino Fundamental houve um crescimento de apenas 0.2 pontos, que para os especialistas, não pode ser considerado um motivo para se comemorar (QEDU, 2015).

Nos Anos Iniciais, o IDEB apontado em 2013 foi de 5,2 pontos, maior que o índice de 2011 $(5,0)$ e maior também que a modesta meta calculada pelo $\operatorname{MEC}(4,9)$. Nos anos finais do Ensino Fundamental, O IDEB alcançou 4,2 pontos, um valor suavemente superior ao conquistado na edição de $2011(4,1)$, mas inferior a meta de 4,4 projetada pelo governo federal. No Ensino Médio, o IDEB no país foi de 3,7 pontos, valor igual ao registrado em 2011. O índice para essa etapa também ficou inferior ao esperado pelo governo em 2013 que era de 3,9 pontos. 


\section{0 uso de tecnologias na educação: desafios e possibilidades}

Atualmente vivemos um cenário em que é impensável ignorar a presença da tecnologia na vida do homem. Porém, quando o assunto é o uso dessas tecnologias dentro do ambiente escolar, os debates entre educadores e acadêmicos ainda não conseguem chegar a um ponto consensual.

Primeiramente, o fato é que, realmente, estamos vivenciando um momento em que é inviável transmitir o conhecimento dentro da sala de aula baseado apenas nos métodos tradicionais, em que os livros didáticos são os atores principais no processo de aprendizagem dos alunos (KENSKI, 2008). A utilização de tecnologias da informação e comunicação (TICS) tem buscado aperfeiçoar o aprendizado dos alunos, lembrando que a educação nem de longe é um sistema para meramente transmitir conhecimentos, mas que deve contextualizar os conhecimentos, colocando-os em perspectiva, para que os alunos possam apropriar-se deles e utilizá-los em outras situações.

O grande desafio talvez seja exatamente o de abandonar tradicionais formas de educar. Segundo José Moran, professor aposentado de novas tecnologias da USP (Universidade de São Paulo), a escola acostumou-se a um modelo consolidado, imóvel e previsível. A educação ainda não está preparada estruturalmente para aderir a todas as possibilidades que as tecnologias podem acarretar para o ensino (RUBIN, 2015). Além desse fato, muitos são os problemas ainda enfrentados quando o assunto é levar a tecnologia para dentro da sala de aula. A falta de recursos financeiros para sustentar essa prática, a ausência de formação dos profissionais da educação e a dificuldade em lidar com recursos mais avançados da informática, acabam por dificultar a presença da tecnologia no exercício da troca de conhecimento.

No entanto, como nos afirma Perrenoud não tem como mais a escola se isolar do que tem acontecido no mundo, principalmente não se pode manter à distância das tecnologias da informação e da comunicação que por sua vez, transformam de uma maneira tão impressionante os modelos de comunicação e de trabalho (PERRENOUD, 2000).

Quando a tecnologia é utilizada de forma satisfatória, o conhecimento contextualizado é concretizado e todos ganham em um processo de aprendizado mútuo. Afinal, as tecnologias vieram para extinguir entraves que impossibilitam o avanço do aluno, potencializando seu desempenho com ferramentas eficazes, condicionando uma qualidade e agilidade, garantindo uma maior aplicabilidade.

Na educação, a tecnologia serve de apoio e instrumento como facilitador na aprendizagem em várias áreas de conhecimento e estudo. A tecnologia não é mais uma novidade, porém ela precisa ser realidade no sistema educacional brasileiro, de modo a permitir ao aluno acessar informações de acordo com seu ritmo, interesse e interatividade, facilitando a intervenção de outros sujeitos na construção e ampliação de conhecimentos. De acordo com os Parâmetros Curriculares Nacionais (PCN) de Matemática, as tecnologias compõem um dos fundamentais agentes de mudança da sociedade, pelas transformações que realizam na vida diária das pessoas (BRASIL, 2002). 


\section{Trabalhos Relacionados}

As últimas décadas têm sido marcadas por uma verdadeira revolução tecnológica. Cada vez mais, deparamos-nos diante de invenções, que há alguns anos pensávamos ser inalcançáveis. No contexto brasileiro, as escolas de todos os níveis têm buscado se equipar para garantir ao aluno, que é fruto de uma sociedade tecnológica, recursos para que o mesmo possa sentir que a tecnologia que ele encontra em casa e nas ruas também chegou dentro da escola e veio para tornar o processo de aprendizagem algo mais prazeroso e produtivo.

Existem várias iniciativas sendo desenvolvidas para ajudar a contextualizar o aprendizado de várias disciplinas da educação básica. Destacam-se aqui algumas dessas iniciativas que buscam tornar o aprendizado na disciplina de matemática mais eficaz, contextualizado e ao mesmo tempo divertido.

A Khan Academy surgiu em 2006 e foi criada pelo educador americano Salman Khan. A Khan Academy é um site que disponibiliza videoaulas e exercícios gratuitos que podem ser acessados a qualquer momento pelo usuário (REVISTA EXAME CEO, 2011). Ele é o maior site dedicado ao ensino de matemática do mundo. O diferencial dessa proposta é que ela proporciona um ensino personalizado, onde é possível identificar quais habilidades o aluno possui e as quais precisam adquirir. Outra facilidade proporcionada pelo site é que o professor possui acesso direto ao desempenho de seus alunos, o que contribui para que o mesmo avalie as dificuldades de cada discente. A Khan Academy também pode ser acessada pelo aluno fora do ambiente escolar, o que às vezes pode ser uma dificuldade se tratando de alunos com baixa renda e sem acesso à internet.

A Tamboro é uma empresa do Brasil que desenvolve jogos virtuais focados no currículo do ensino formal básico. Ela surgiu a partir da vontade de alguns profissionais de implementar e desenvolver iniciativas inovadoras para o setor educacional. A empresa dedica-se a desenvolver soluções que ajudam a melhorar o desempenho de escolas, professores e alunos. Eles se baseiam na construção de processos lúdicos de aprendizagem a partir da utilização de jogos e tecnologias de comunicação, para apresentar novos horizontes cognitivos, humanos e sociais. Entre os principais produtos desenvolvidos pela Tamboro que estão voltados para o ensino aprendizagem de matemática pode-se destacar o Ludz e o Sr. X.

A Xmile é uma empresa brasileira que se dedica ao desenvolvimento de jogos que têm o propósito de auxiliar no aprendizado de crianças. A Xmile visualiza no mundo digital uma oportunidade de encantar os alunos, desenvolver a criatividade, aguçar sua imaginação e fazer o aprendizado algo lúdico e divertido. Todos os produtos da Xmile têm como fundamento fomentar a imaginação das crianças, proporcionando a elas um ambiente de diversão ao mesmo tempo em que se reforçam os estudos. Atualmente, a empresa possui três jogos que constituem a sequência do Mistério dos Sonhos: O Chamado dos Guardiões, A Máquina do Poder e A Grande Jornada, direcionados para 1으, 2o e 3으 anos do Ensino Fundamental.

O jogo "Conquistando com o Resto 1.0" desenvolvido por professores e alunos da Universidade de Pernambuco é composto por um tabuleiro com 48 casas, que possuem 
números não sequenciais. Os jogadores iniciam o jogo na casa 43 (primeira casa do jogo). Depois, um jogador de cada vez lança de forma sequencial o dado dividindo o valor da casa em que se encontra pelo valor que for alcançado no dado. Em seguida avança exatamente o número de casas referente ao resto da divisão. Este jogo é utilizado para apoiar professores e alunos no ensino e aprendizagem da operação matemática de divisão. Os estudantes, por meio de uma atividade lúdica, têm a possibilidade de compreender determinados conceitos fundamentais a operações de divisão.

Nos projetos analisados, alguns requisitos são de fundamental importância para sua estruturação dentro do ambiente escolar. O uso da Internet, o domínio de conhecimentos em informática para manusear essas ferramentas e o custo elevado para sua implementação, podem ser um entrave para fazer dessas tecnologias uma realidade dentro das escolas que, por sua vez, carecem de acesso de qualidade à rede, não possuem recursos para a adoção de tecnologias de alto custo e não tem disponibilidade de professores com formação adequada para manusear essas tecnologias. Nesse sentido a Plataforma Matematech se apresenta como uma ferramenta viável, uma vez que, é uma solução de baixo custo, que dispensa o uso de Internet e conhecimentos mais apurados sobre tecnologias, além do fato de que sua construção teve como alicerce as matrizes de referência de processos importantes de avaliação da educação básica como a Prova Brasil.

\section{Plataforma Matematech}

Partindo de opiniões como a do economista norte americano James Heckman onde ele diz que no caso do Brasil, o país só irá alcançar bons resultados na educação, quando o mesmo compreender que a prioridade deve estar voltada para o investimento nos Anos Iniciais da educação básica, pois eles são o alicerce para a construção de outros conhecimentos (VEJA, 2009), a Plataforma Matematech é um instrumento didático que utiliza tecnologia de baixo custo para sistematizar o ensino de matemática nos Anos Iniciais do Ensino Fundamental.

Através de situações contextualizadas e divertidas, o ambiente proposto pela Plataforma Matematech, trabalha conceitos fundamentais da matemática e temas importantes contidos dentro da matriz de referência da Prova Brasil, como por exemplo, direção, espaço e operações matemáticas. Sua estrutura foi pensada levando em consideração as possibilidades e limitações das escolas, dos professores e dos próprios alunos em relação ao uso de tecnologias. Assim sendo, a Plataforma Matematech foi construída utilizando dispositivos eletrônicos de baixo custo, que não exige recursos avançados da informática como computadores e acesso à Internet e não requer do professor domínio avançado em termos de conhecimentos tecnológicos.

A montagem física da Plataforma é bastante simples, o que possibilita a qualquer um que tenha o programa em mãos, replicar o protótipo. Nela utilizou-se, por questões de necessidade de memória, de um Arduino Mega 2560, 4 módulos de 8 dígitos de display de 7 segmentos, 1 
display LCD e 1 teclado matricial $4 \times 4$, todos dispositivos de baixo custo e fáceis de serem adquiridos e manipulados.

A proposta de uso da Plataforma consiste na ação de percorrer um caminho estabelecido pelo sistema, tendo como base um ponto de partida e um ponto de chegada. Primeiramente, o aluno pode escolher o nível que deseja jogar, quanto maior o nível, maior a dificuldade das situações apresentadas. Escolhido o nível, o aluno terá de vencer três fases para concluir o jogo. Nessas fases ele é incentivado a calcular o menor caminho, indicar o sentido e a direção por onde vai passar até atingir a chegada, além de somar os valores contidos nesse caminho que ele escolheu. Enquanto conteúdo curricular, ao praticar a Fase 1, são trabalhadas questões envolvendo espaço, grandezas e medidas, números e operações, além do tratamento de informações. Na Fase 2, o aluno consolida conceitos relacionados ao conteúdo curricular de espaço, onde se trabalha a localização/movimentação de objetos em representações gráficas, além do tratamento de informações. Na última Fase, o aluno tem a oportunidade de praticar conhecimentos em relação aos conteúdos curriculares de números e operações. Ele deve calcular o resultado de uma adição de números naturais e resolver problemas com números naturais, envolvendo diferentes significados da adição: juntar, alteração de um estado inicial, comparação e mais de uma transformação. É possível também construir conhecimento por meio do tratamento de informações, onde ele lê as informações e os dados apresentados.

Cada fase possui uma pontuação de 10 pontos, sendo que as duas primeiras têm peso dois. O sistema de pontuação foi pensado para incentivar o aluno e não castigá-lo por um erro. Sendo assim, em cada erro o aluno perde apenas um ponto, ou seja, se ele errar cinco vezes o total de pontos que ele vai acumular é igual a 45. Como o total de pontos que pode ser alcançado é igual a 50 pontos, quando o aluno alcança 45, ele não sofre um desestímulo, pois sua pontuação está próxima da máxima, mas para o professor isso indica que ele precisa aprimorar alguns conhecimentos, afinal ele cometeu cinco erros. Na trajetória, a Plataforma trabalha vários conceitos fundamentais da matemática. Além disso, a Plataforma pode ser usada como instrumento de diagnóstico do conhecimento do aluno, assim com também de aprendizado e de avaliação. A Figura 1 mostra o protótipo desenvolvido. A lógica de funcionamento da Plataforma Matematech é apresentada na Seção 5.1. 
Figura 1: Protótipo da Plataforma Matematech. (1) Arduino Mega 2560; (2) módulos de 8 dígitos de display de 7 segmentos; (3) display LCD e (4) teclado matricial $4 \times 4$.

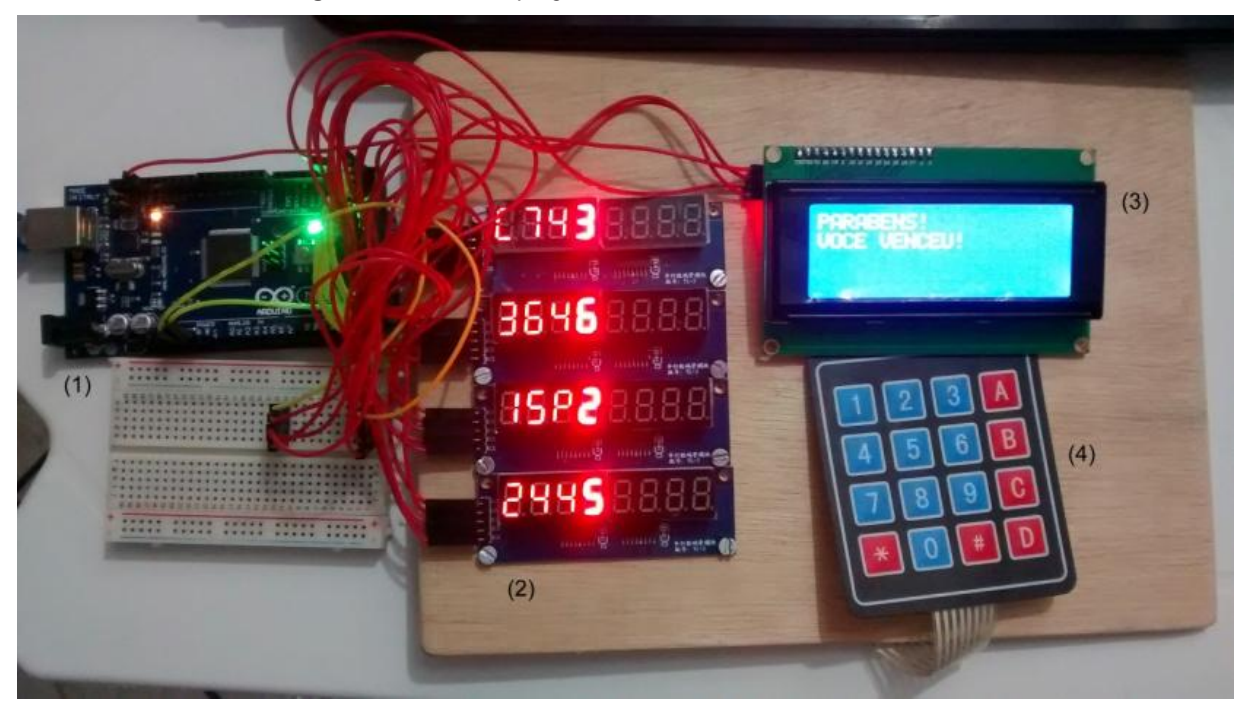

Fonte: Arquivo dos autores.

\subsection{Lógica de Funcionamento}

A lógica de funcionamento da Plataforma se dá de acordo com o fluxograma mostrado na Figura 2. De acordo com a lógica programada, a primeira parte de execução do programa consiste na definição e estruturação do Nível, assim como, na composição da matriz utilizada como base para definição do ambiente. O programa gera uma sequência de números aleatórios compreendidos entre 0 e 7, pois os números 8 e 9 serão utilizados para definição de ponto de partida (8) e ponto de chegada (9). Em seguida é exibido um "MENU" com as opções para escolha do nível que o aluno deseja jogar. Na versão apresentada aqui, existem dois níveis: "1Nível 1" e "2- Nível 2". Para cada Nível existem 3 fases. No Nível 1 é gerada uma matriz quadrada de ordem 3 e no Nível 2, uma matriz quadrada de ordem 4 como mostrado na Figura 1. Em seguida é o momento em que o programa define onde estarão os pontos " $P$ " e " $C$ ", que significam respectivamente, Partida e Chegada. Para essa definição é utilizado um sorteio, levando em consideração a quantidade de linhas e colunas, de modo a forçar que os pontos estejam distantes e que o aluno tenha que utilizar os conceitos de direção como direita, esquerda, cima e baixo.

Após a definição da posição de localização de "P" e "C", esses pontos recebem valores 8 e 9 , respectivamente, e que mais tarde serão convertidos em caracteres " $\mathrm{p}$ " e " $\mathrm{c}$ " para serem exibidos nos módulos de display de 7 segmentos. Na Figura 1 é possível visualizar esses pontos nas linhas 1 e 3 do display.

A única parte do programa que não é condicionado pela variável de controle de execução é a exibição da matriz nos módulos de display de 7 segmentos, que vai acontecer durante todo o tempo que o programa estiver sendo executado. 
Com a variável de controle habilitada, inicia-se a Fase 1 do programa, que consiste na definição do menor caminho a ser percorrido entre a Partida e a Chegada. O programa exibe no display LCD a mensagem "Digite o número de casas:" e aguarda a entrada de dados pelo teclado matricial. Se houver entrada de dados ele incrementa a variável de controle e chama a função fase_1 que vai calcular a matriz de adjacência usada para definir o menor caminho utilizando o algoritmo Dijkstra e verificar se o aluno acertou ou errou. Caso tenha errado, será solicitado que ele entre com outro valor e será chamada novamente a função fase_1. Se ele acertar, passará para a segunda fase do jogo. Caso erre, ele continuará tentando até que consiga avançar de fase. Em todas essas situações será exibida no display LCD uma mensagem indicando se ele errou ou acertou. Ao final dessa fase, a variável de controle é novamente incrementada.

Para acompanhar o processo de evolução dos alunos e também incentivá-los a querer superar suas limitações, definiu-se um sistema de pontuação. A cada fase que o aluno avança ele acumula pontos, podendo chegar ao valor máximo de 50 pontos. Em cada fase o aluno tem a possibilidade de adquirir 10 pontos, porém a Fase 1 e a Fase 2 possuem peso 2, devido ao grau de dificuldade. Caso o aluno tenha um erro, esse erro não é trabalhado de forma a desmotivá-lo, mas é visto apenas como um indicador de que é necessário aprimorar determinadas habilidades. Sendo assim, em cada erro o aluno perde apenas 1 ponto. Ao completar o jogo, mesmo que o aluno tenha 10 erros ele ainda acumula um total de 40 pontos. Esse resultado permite ao professor constatar que o aluno precisa estudar mais e ao mesmo tempo não deixa o aluno desmotivado. 
Figura 2: Fluxograma de funcionamento da Plataforma Matematech.

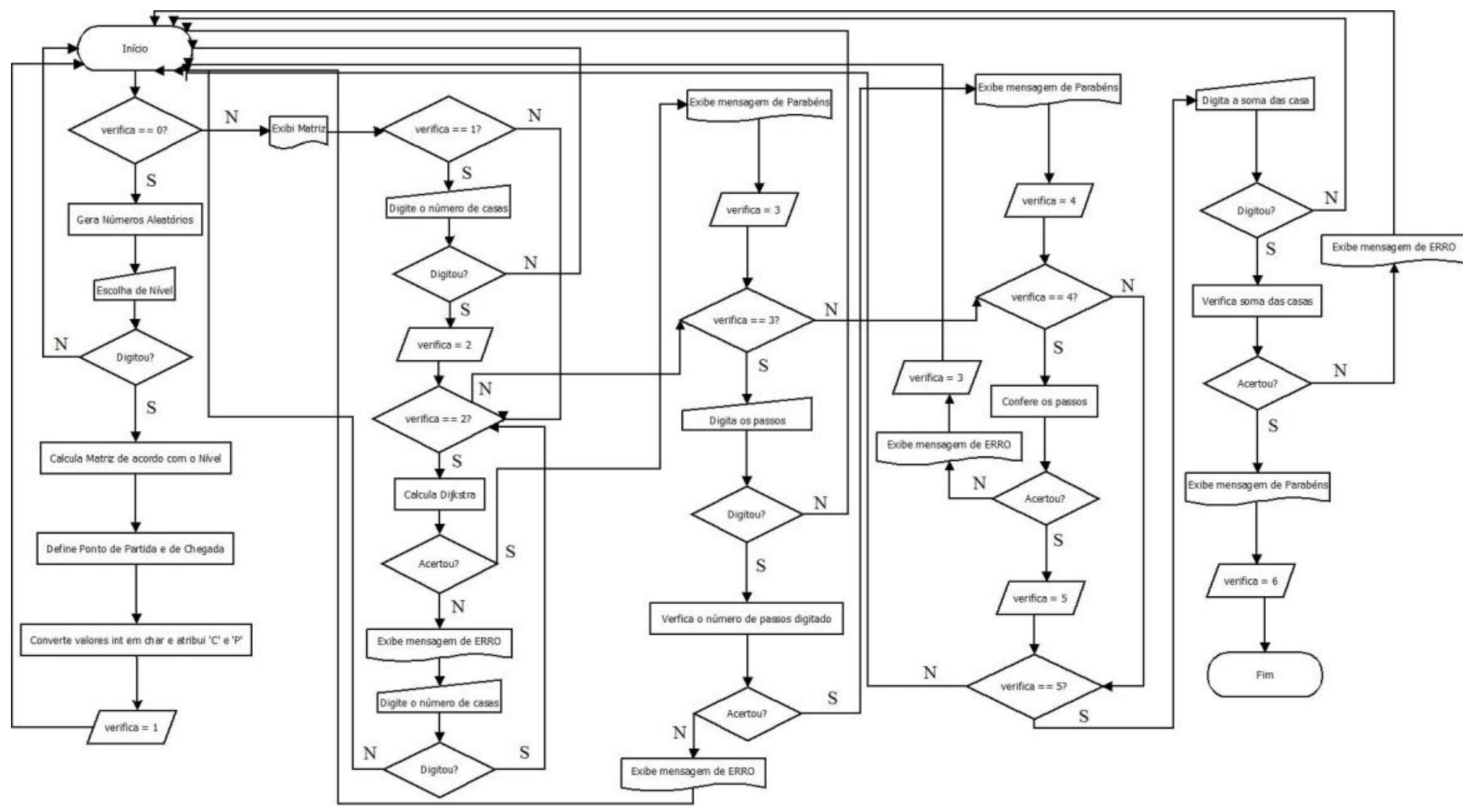

Fonte: Elaborada pelos autores.

A partir da finalização da Fase 1, a variável de controle habilita o início da Fase 2, que é onde o aluno vai definir o sentido e a direção do caminho indicado por ele como o menor para sair de "P" e chegar até "C". O programa exibe no display LCD a mensagem "Digite os X passos percorridos", onde X é a quantidade de passos que o usuário terá que digitar de acordo com o menor caminho informado na Fase 1. O aluno entra com a quantidade de sentidos (D- Direita, E- Esquerda, C-Cima e B-Baixo) que serão armazenados em um único vetor, que mais tarde será percorrido para verificar a veracidade das informações fornecidas. Caso os dados não resultem na chegada até o ponto "C", o programa informa o erro e solicita que ele digite novamente o caminho até que o mesmo acerte o valor. Caso o aluno acerte, a variável de controle é incrementada o que habilita o início da Fase 3. Em todas essas situações será exibido no display LCD mensagem indicando se ele errou ou acertou.

Na Fase 3, o aluno irá somar os valores contidos nas casas que ele percorreu para sair de "P" e chegar até "C". O programa exibe no display LCD a mensagem "Digite valor da soma das casas:". Após o aluno informar esse valor, ele calcula se o valor é igual ao valor da variável que armazenou a soma do caminho percorrido por ele durante a Fase 2. Se for igual, o display LCD 
exibe uma mensagem indicando que o aluno venceu esse nível e será mostrada a pontuação conquistada. Caso contrário, será solicitado que ele envie novamente um valor.

\section{0 uso da Plataforma Matematech dentro do ambiente escolar}

Com o intuito de avaliar os impactos que o uso de recursos tecnológicos pode gerar no ensino de matemática, a Plataforma Matematech foi aplicada nas turmas dos Anos Iniciais do Ensino Fundamental da Escola Estadual Dr. Pompílio Guimarães durante os meses de novembro e dezembro de 2015. A escola está localizada no distrito de Piacatuba, Minas Gerais, e pertence à rede estadual de Ensino, sob a jurisdição da SRE (Superintendência Regional de Ensino) de Leopoldina-MG. Atualmente, essa escola oferece o Ensino Fundamental I e II e possui o projeto de Escola em Tempo Integral.

No momento da aplicação, a Escola contava com 85 alunos, oriundos do distrito e de sítios localizados nas proximidades de Piacatuba. Os alunos em sua maioria são originários de família com baixa renda e de acordo com informações prévias, muitos não têm contato com a tecnologia em seu ambiente familiar.

Os experimentos foram realizados com alunos de todas as séries dos Anos Iniciais do Ensino Fundamental I. Foram escolhidos quatro alunos de cada ano escolar $\left(1^{\circ}, 2^{\circ}, 3^{\circ}, 4^{\circ}\right.$ e $\left.5^{\circ}\right)$. Vale destacar que as turmas de $2^{\circ}$ e $3^{\circ}$ ano compõem apenas uma turma multisseriada. De acordo com as professoras, entre esses quatro alunos de cada ano, tinham-se dois que possuíam facilidade de aprendizagem e dois que apresentavam dificuldade em matemática.

\subsection{Atividade Diagnóstica}

Antes de iniciar o trabalho com a Plataforma Matematech, foi aplicada uma atividade diagnóstica para os alunos. O objetivo dessa atividade era verificar os conhecimentos que os alunos possuíam a respeito dos itens avaliados pela Plataforma e também realizar uma comparação entre o comportamento do aluno ao realizar uma atividade por meios tradicionais e usando tecnologia.

A atividade diagnóstica contém sete questões que foram retiradas da Prova Brasil dos anos de 2011 e 2013 (BRASIL, 2007). As questões da Prova Brasil são de múltipla escolha, em função disso, algumas foram adaptadas para que se pudesse perceber com mais clareza, o desenvolvimento do raciocínio matemático dos alunos.

As questões propostas trabalham itens da matriz de referência da Prova Brasil como, por exemplo, espaço e forma, medidas, números e operações e tratamento da informação (BRASIL, 1997). São questões que exemplificam os objetivos que norteiam a criação da Plataforma Matematech. A Figura 3 apresenta uma das questões contidas nessa atividade diagnóstica. Para que fosse possível acompanhar melhor o desenvolvimento do raciocínio do aluno, essa questão foi adaptada. 
Na questão representada na Figura 3 trabalha-se o primeiro descritor do Tema 1- Espaço e Forma, onde é possível avaliar as habilidades referentes ao reconhecimento, pela criança, da localização e movimentação de uma pessoa ou objeto no espaço, sobre diversos olhares.

Os itens desse descritor abordam noções fundamentais de localização ou movimentação possuindo como referência algum ponto inicial em croquis, itinerários, desenhos de mapas ou representações gráficas, fazendo uso de um único comando ou uma combinação de comandos (esquerda, direita, giro, acima, abaixo, ao lado, na frente, atrás, perto). Nesse sentido, também se avalia a colocação correta da terminologia referente a posições. Pode-se pedir ao aluno que identifique a posição de um elemento em uma imagem, a partir de uma referência ou que ele reconheça e relate um trajeto percorrido.

Após a realização da atividade diagnóstica, é possível fazer algumas observações. Os alunos, de uma maneira geral, não mostraram muito entusiasmo ao realizar esse tipo de atividade teórica. Outra observação é a respeito do nível de conhecimento de cada aluno. As crianças do $1^{\circ}$ ano do Ensino Fundamental não conseguiram realizar todas as questões propostas. Esse resultado era de se esperar, uma vez que, as questões foram retiradas da Prova Brasil que é elaborada para alunos do $5^{\circ}$ ano do Ensino Fundamental. Em função disso, percebeu-se que os alunos do $4^{\circ}$ e $5^{\circ}$ ano tiveram mais facilidade em lidar com as questões, mesmo assim cometeram alguns erros. De forma geral, foi possível perceber através das respostas dadas pelos alunos, que muitos deles ainda têm dúvidas com relação à posição de um objeto em referência a outro objeto. A maioria consegue realizar as operações matemáticas básicas de forma correta, porém quando esse cálculo está contextualizado dentro de uma situação cotidiana, as dificuldades são maiores. Esse problema já havia sido identificado no momento em que foi realizada a pesquisa de campo nas escolas do município e pode ser justificada pela falta de contextualização no momento da aprendizagem. 
Figura 3 - Questão número 01 da atividade diagnóstica.

1) Marcelo fez a seguinte planta da sua sala de aula:

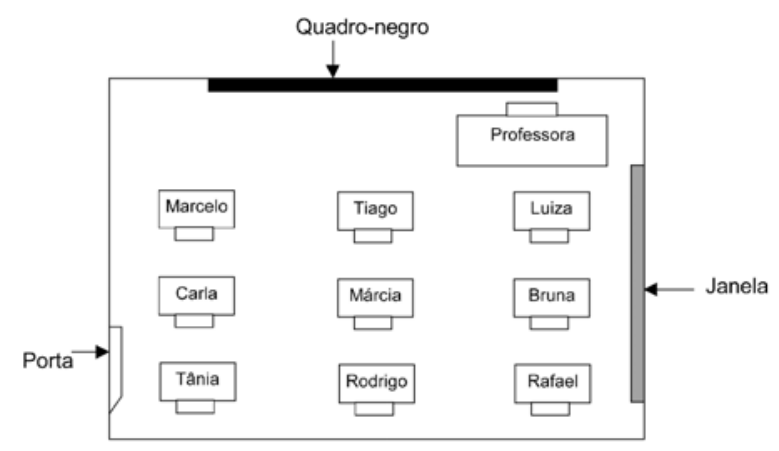

Observando o mapa de sala responda:

a) Das crianças que se sentam perto da janela, qual senta mais longe da professora?

b) Tânia quer entregar um caderno a professora, porém não quer se levantar. A quais colegas Tânia pode passar o caderno, de modo que, percorra o menor caminho até chegar a professora?

c) Rodrigo está na última fileira, quem está à direita e à esquerda de Rodrigo?

Fonte: Elaborada pelos autores.

No gráfico da Figura 4, pode-se perceber o número de alunos que acertaram cada questão proposta na atividade diagnóstica.

Figura 4 - Percentual de alunos que acertaram cada questão.

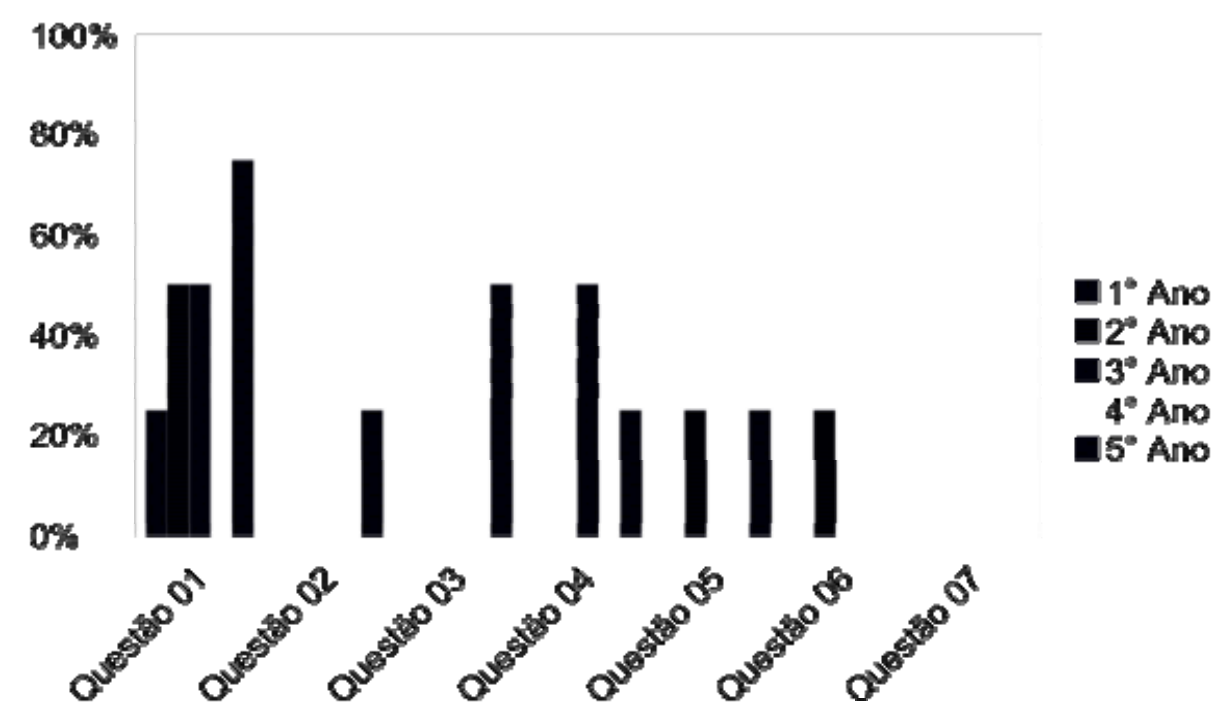

Fonte: Elaborada pelos autores. 


\section{Resultados Alcançados}

Depois que os alunos realizaram a atividade diagnóstica e foram detectados os problemas de aprendizagem, iniciou-se o trabalho com a Plataforma Matematech. A atividade foi desenvolvida de forma individual durante quatro sessões, compreendidas em um espaço de quatro semanas.

Com a aplicação da Plataforma pretendia-se ajudar no aprendizado dos alunos por meio de situações contextualizadas, conceitos referentes, por exemplo, à posição de um objeto em referência a outro objeto, dificuldade bastante visível na atividade diagnóstica e que é trabalhada nas Fases 1 e 2 da Plataforma. Outro ponto em que a Plataforma estaria contribuindo para o aprendizado dos alunos, seria em relação às operações matemáticas básicas. Através da atividade diagnóstica, foi possível observar que quando o cálculo está contextualizado dentro de uma situação cotidiana, as dificuldades dos alunos são maiores. Os cálculos que o aluno terá de realizar no uso da Plataforma, principalmente na fase 3, permitirão a ele desenvolver essa habilidade por meio de situações contextualizadas.

A partir das experimentações, foi possível fazer algumas observações. Primeiramente o uso de recursos tecnológicos para o auxílio na aprendizagem dos alunos encanta as crianças. Era perceptível a ansiedade de cada um na espera pela sua vez e o entusiasmo de cada aluno ao utilizar a Plataforma. Alguns alunos, que de acordo com a coordenadora pedagógica da escola são classificados como alunos de baixo desempenho, mostraram interesse na realização da atividade. Alunos que apresentam comportamento indisciplinar, também surpreenderam positivamente ao se interessarem em fazer uso da Plataforma. De fato, a tecnologia é uma grande aliada da educação. Os alunos do $1^{\circ}$ ano do Ensino Fundamental, testaram a Plataforma com o Nível 1

Foi possível observar que os alunos desse ano possuem dificuldades mais acentuadas na realização das propostas feita pela Plataforma, mesmo no nível mais simples. Segundo a professora responsável pela turma, os alunos nessa idade ainda não consolidaram, por exemplo, os elementos de lateralidade, como direita e esquerda.

Os alunos do $2^{\circ}$ e $3^{\circ}$ ano iniciaram o jogo com o Nível 1 . Um total de 3 alunos, a partir de várias tentativas, conseguiram chegar ao Nível 2, outros não conseguiram vencer o Nível 1 . As maiores dificuldades desse grupo de alunos também se centraram nas questões de lateralidade acrescentando a ela a ação de identificar o menor caminho percorrido.

Sobre os alunos do $4^{\circ}$ e $5^{\circ}$ ano, é possível destacar dois resultados. Os alunos apontados com baixo rendimento tiveram dificuldades semelhantes aos do $2^{\circ}$ e $3^{\circ}$ e alguns não conseguiram completar o Nível 1. Já os alunos que, de acordo com as professoras responsáveis, apresentam facilidade, realizaram as atividades de forma tranquila, chegando ao final do Nível 2. Ao comparar a atividade diagnóstica com o desempenho de cada aluno no uso da Plataforma, é possível perceber avanço, principalmente relacionada às questões de lateralidade. 
Após as semanas de testes, foi aplicada novamente a atividade diagnóstica, com o objetivo de mensurar o aprendizado adquirido com a Plataforma. Após a análise dos resultados, tem-se o seguinte cenário: dos quatro alunos do $1^{\circ}$ ano, apenas um conseguiu usar a Plataforma e ao longo da prática obteve um avanço, aumentando consideravelmente a pontuação. Os oito alunos da turma multisseriada, $2^{\circ}$ e $3^{\circ}$ ano, apresentaram resultados satisfatórios. Na atividade diagnóstica, apenas três alunos (um do $2^{\circ}$ ano e dois do $3^{\circ}$ ano), o que corresponde a menos de 50\%, conseguiram responder corretamente metade das questões. Após, o uso da Plataforma, esse valor apresentou melhoras significativas. Apesar de apresentarem alguns erros pontuais, esses alunos conseguiram vencer a dificuldade do conhecimento de lateralidade. Na turma do $4^{\circ}$ Ano, um aluno que apresentou um desempenho muito baixo, conseguiu melhorar o resultado após o uso da Plataforma. Outros dois alunos, apresentaram melhoras na resolução de questões que envolvem lateralidade. O último aluno dessa turma, não conseguiu avançar na resolução das questões propostas pela Plataforma, sendo assim não realizou essa etapa dos testes. A maioria dos alunos do $5^{\circ}$ ano conseguiu resolver de forma satisfatória as questões propostas pela atividade diagnóstica inicial, mas o resultado foi potencializado no sentido positivo após o uso da Plataforma. A Figura 5 mostra a porcentagem de alunos que acertaram cada questão após o uso da Plataforma.

Figura 5 - Percentual de alunos que acertaram cada questão.

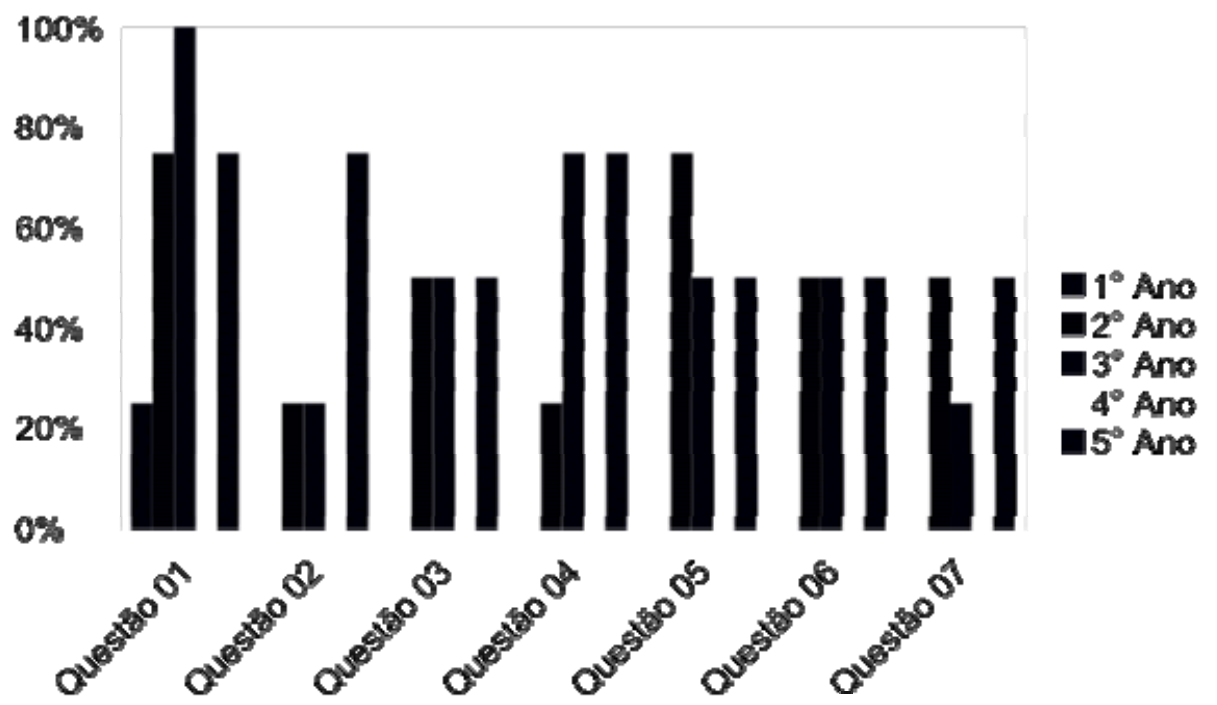

Fonte: Elaborada pelos autores.

Após a aplicação da Plataforma, foi possível observar que a mesma, além de atuar como um instrumento didático para o ensino aprendizagem de matemática, também pode ser usada como um elemento de diagnóstico. Analisando o desempenho individual de cada aluno, é possível perceber quais conhecimentos já foram consolidados e quais ainda precisam ser trabalhados. 


\section{Conclusão}

A partir do desenvolvimento desse projeto é possível fazer algumas observações. Primeiramente, foi detectado que nem toda a tecnologia desenvolvida chega ao ambiente escolar e que essa, por sua vez, ainda conserva, em pleno desenvolvimento tecnológico, práticas extremamente tradicionais e descontextualizadas com a realidade do aluno, o que acaba por desmotivar o aprendizado e acarretar resultados pouco satisfatórios no que se refere ao ensino aprendizagem nas escolas brasileiras.

De acordo com as pesquisas realizadas, a utilização de tecnologias na educação pode ajudar a fazer do aprendizado uma atividade mais lúdica e colaborar para trazer para o ambiente escolar a vivência dos alunos, tornando o ensino mais significativo.

No caso do ensino de matemática, a adoção de tecnologias na prática docente pode facilitar a visualização, transmissão e compreensão de conteúdos, enriquecendo e tornando a aula mais interessante, estimulando o aluno para o raciocínio lógico através de uma aprendizagem mais significativa e atraente.

Percebeu-se que para levar a tecnologia para dentro da sala de aula, o professor não precisa de conhecimento muito aprofundado sobre como lidar com esses equipamentos. No caso da Plataforma Matematech, ela é um recurso fácil de ser utilizado pelo docente. Além disso, a Plataforma Matematech se torna ainda mais acessível pelo fato de ser um instrumento de baixo custo e que não necessita de conexão com a internet para seu funcionamento.

A partir da aplicação da Plataforma Matematech dentro de uma escola, foi possível perceber que, assim como estudado no momento da pesquisa teórica para a construção desse artigo, a tecnologia é uma grande aliada da educação e pode colaborar de forma eficiente para melhorar os resultados no processo de ensino aprendizado.

De acordo com os dados coletados a partir da aplicação das atividades diagnósticas antes e depois do uso da Plataforma Matematech, foi possível perceber uma significativa melhora no aprendizado de conceitos básicos de matemática. Além disso, os alunos sentiram-se motivados a aprender.

J oão Paulo Pereira de Araújo Centro Federal de Educação Tecnológica de Minas Gerais - Unidade Leopoldina - CEFET-MG Engenharia de Controle e Automação GRAAL - Grupo de Pesquisa CNPq em Redes, Automação e Algoritmos Leopoldina - Minas Gerais - Brasil E-mail: junior@cefetmg.br 
Prof. Dr. José Geraldo Ribeiro J únior Centro Federal de Educação Tecnológica de Minas Gerais - Unidade Leopoldina - CEFET-MG Departamento de Computação e Mecânica GRAAL - Grupo de Pesquisa CNPq em Redes, Automação e Algoritmos Leopoldina - Minas Gerais - Brasil E-mail: jp2_araujo@yahoo.com.br

\section{Referências}

BRASIL. Plano de Desenvolvimento da Educação. Brasília, 2007. Disponível em: <http://www.mec.gov.br/pde>. Acesso em: 13 fev.2016.

BRASIL. Ministério da Educação. Saeb - Sistema de Nacional de Educação Básica. Matrizes Curriculares de Referência para o SAEB, 1997. Brasília: MEC/Inep/Daeb, 2000. Disponível em: <htpp://portaldomec.com.br>. Acesso em: 13 fev. 2016.

BRASIL. Ministério da Educação. Prova Brasil: boletim de desempenho. Brasília: MEC, SEB; Inep, 2014. Disponível em: <http://sistemasprovabrasil.inep.gov.br/provaBrasilResultados/view/boletimDesempenho/boletimDesempe nho.seam>. Acesso em: 16 fev. 2016.

BRASIL. Parâmetros Curriculares Nacionais: PCN+ Ensino Médio: Orientações Educacionais Complementares aos Parâmetros Curriculares Nacionais. Ciências da Natureza, Matemática e suas Tecnologias. Brasília: Ministério da Educação. Secretaria de Educação Média e Tecnológica, 2002.

CARVALHO, Bruno Miguel Pacheco Saraiva de. Algoritmo de Dijkstra - Universidade de Coimbra. Disponível em: < https://student.dei.uc.pt/ brunomig/cp/Artigo.pdf>. Acesso em: 20 fev. 2016.

Criamos J ogos Educativos com metodologia pedagógica sólida que prepara o aluno para a vida. Disponível em: http://www.xmile.com.br/. Acesso em: 06 mar.2016.

Educação inovadora para um mundo em transformação. Disponível em: http://www.tamboro.com.br/. Acesso em 13 mar.2016.

Instituto Nacional de Estudos e Pesquisas Educacionais Anísio Teixeira - Saeb. 2005. Disponível em: http://portal.inep.gov.br/saeb. Acesso em: em: 26 mar.2016.

INEP. Disponível em: <http://www.inep.gov.br/basica/saeb/provabrasil/matrizes/to picosdescritoresmat.htm>. Acesso em: 21 mar.2016.

INEP. História da Prova Brasil e do Saeb. Disponível em: <http: //provabrasil.inep.gov.br/index.php?option=com_content\&task=view\&id=15\&ltemid=14>. Acesso em: 13 mar. 2016.

INEP. História da Prova Brasil e do Saeb. Disponível em: <http: //provabrasil. inep.gov.br/index. php?option=com_content\&task=view\&id=15\&ltemid=14>. Acesso em: 05 mar. 2016.

INEP. O que é o PISA? Disponível em: http://portal.inep.gov.br/pisa-programa-internacional-de-avaliacaode-alunos. Acesso em: 05 mar.2016.

KENSKI, Vani Moreira. Educação e Tecnologias: O novo ritmo da informação. Papirus Editora, 3a edição, 2008.

Ludz. Disponível em: http://www.tamboro.com.br/\#!ludz/cpff. Acesso em: 03 mar.2016. 
Mistério dos Sonhos 1: o chamado dos guardiões. Disponível em:

http://www.xmile.com.br/index.php?p=misterio_sonhos1. Acesso em: 13 mar.2016.

Mistério dos Sonhos 2: a máquina do poder. Disponível em:

http://www.xmile.com.br/index.php?p=misterio_sonhos2. Acesso em: 13 mar.2016.

Mistério dos Sonhos 3: a grande jornada. Disponível em:

http://www.xmile.com.br/index.php?p=misterio_sonhos3. Acesso em: 13 mar.2016.

PERRENOUD, Philippe. Dez Novas Competências para Ensinar. Porto Alegre: Artes Médicas Sul, 2000.

PIRES, José. A questão ética frente às diferenças: uma perspectiva da pessoa como valor. In: Inclusão compartilhando saberes, Petrópolis - Rio de Janeiro, ed. Vozes, 2006.

PISA, 2014. Disponível em: http://g1.globo.com/educacao/noticia/2014/08/nobel-de-matematicacontrasta-com-baixo-indice-de-aprendizado-no-brasil.html. Acesso em: 28 mar.2016.

Programme for international student assessment (PISA) Results from PISA 2012 - Brazil. Disponível em: http://www.oecd.org/brazil/PISA-2012-results-brazil.pdf. . Acesso em 05.mar.2016. Acesso em 01 fev. 2016

QEDU. Aprendizado dos alunos: Brasil. 2016. Disponível em: http://www.qedu.org.br/brasil/aprendizado. Acesso em: 05 fev.2016.

QEDU. IDEB 2013: veja a situação da educação de cada estado. 2015. Disponível em: http://blog.qedu.org.br/blog/2015/01/12/ideb-2013/. Acesso em: 16 mar.2016.

Revista Exame CEO. Edição de Agosto/2011. Pag. 72-76. Disponível em: http://www.fundacaolemann.org.br/khanportugues/uploads/exame_201108.pdf. Acesso em: 11 mar. 2016.

RUBIN, Débora. Como encontrar o equilíbrio no uso da tecnologia da sala de aula. Revista Educação, Junho/15. Disponível em: http://www.revistaeducacao.com.br/textos/218/mudando-a-sala-de-aulaaescola-ainda-precisa-entender-que-354439-1.asp. Acesso em: 21 mar.2016.

SANTOS, Wilk Oliveira dos; SILVA, Alex Pereira da; JUNIOR, Clovis Gomes da Silva. Conquistando com o Resto: Virtualização de um Jogo para o Ensino de Matemática. XXV Simpósio Brasileiro de Informática na Educação (SBIE 2014), p. 317-321. Disponível em: http://www.br-

ie.org/pub/index.php/sbie/article/view/2957/2491. Acesso em: 22 jun.2016.

Sr. X. Disponível em: http://www.tamboro.com.br/\#!senhor-x/cahf. Acesso em: 11 mar.2016.

VEJ A. São Paulo: Abril, n. 23, 10 de Junho de 2009.

Recebido em abril de 2016

Aprovado para publicação em agosto de 2017

\section{Maria Rosangela Bez}

Programa de Pós-Graduação em Informática da Educação e Programa de Pós-Graduação em Ciência da Computação - Universidade Federal do Rio Grande do Sul - UFRGS, Brasil, bezrosangela@gmail.com

\section{Liliana Maria Passerino}

Programa de Pós-Graduação em Informática na Educação - Universidade Federal do Rio Grande do Sul UFRGS, Brasil, Ipasserino@gmail.com 


\title{
Tecnologias Móveis de Comunicação e Informação: impactos nas práticas docentes e dicentes
}

\section{Technology Mobile Communication and Information: I mpacts in Practice Teachers and Students}

\author{
Maria Aparecida de Faria Gomes \\ Centro Universitário do Leste de Minas Gerais \\ Hiolanda Ladislau Viera \\ Centro Universitário do Leste de Minas Gerais \\ Rita Alves Luna \\ Centro Universitário do Leste de Minas Gerais
}

\begin{abstract}
Resumo: Objetiva-se analisar impactos das Tecnologias Móveis Digitais de Informação e Comunicação, nos anos finais do ensino fundamental, de escolas públicas de um município do Vale do Aço. Trata-se de uma pesquisa de campo, fomentada pela FAPEMIG, aprovada pelo Comitê de Ética em Pesquisa envolvendo seres humanos do Centro Universitário do Leste de Minas Gerais. Envolveu quatrocentos e sessenta e nove participantes, professores e alunos. Utilizou-se como instrumento um questionário online e impresso. Os dados da pesquisa apontaram para o protagonismo juvenil nas redes sociais, sendo o facebook o primeiro no ranking de interesse. Os dados revelam, também, que discussões sobre o uso das tecnologias como objeto e estudo e como ferramenta para aprender estão ausentes das práticas pedagógicas. Concluiu-se que as tecnologias digitais são subutilizadas, uma vez que não há integração com o currículo, nem tampouco há propostas de atividades colaborativas e interativas para os alunos.
\end{abstract}

Palavras-chave: Tecnologias móveis. Redes sociais. Tecnologias e educação.

Abstract: We intend to anallyze the impact of Digital Mobile Technologies of information and communication in the last years of primary teaching in public school of one of $t$ he municipalities of the region of Vale do Aço. It!s about a field research encouraged by FAPEMIG, with the approval of the Comite de Ética em Pesquisa ( Ethic in Research Commitee) involving human beings of the Centro Universitario do Leste de Minas Gerais. It took four handdred and sixty nine participants, teachers and students. It was taken as instrument an on line and printed questionary. The data of the research appointed to the juvenile "protagomism" in social webs, being "face book" the first one in the ranking of preference. The data reveal, as well, that the dicussion on the use of technologies as object of study and as a tool for learning are out of the pedagogical practice. It was concluded that the digital technologies are underused, since there is neither integration with the curriculun nor proposals of collaborative and interactive activities for the students.

Keywords: Mobile technologies. Social webs. Technology and teaching. 


\section{I ntrodução}

A interação professor/aluno/objeto de aprendizagem por meios dos diversos recursos das tecnologias móveis digitais de informação e comunicação (TMDIC) pode proporcionar um salto qualitativo nas capacidades necessárias ao domínio de diversas habilidades e competências, tanto dos alunos quanto dos professores. Entre essas se destacam as habilidades para o exercício da autodidaxia, da colaboração e cooperação para realização de atividades em rede e na rede; para "ler" a rede; "escrever" a rede, ou seja, habilidades para utilizar as TMDIC como ferramenta de aprendizagem e como objeto de estudo.

Nesse sentido, derivam-se exigências importantes para a formação e o modo de trabalhar dos professores, bem como para o planejamento do currículo. Assim, muitas indagações permeiam o cotidiano educacional: Como está a integração das TMDIC na prática pedagógica? Os professores têm utilizado as tecnologias móveis como objetos de estudo? Como os alunos têm utilizado as TMDIC? Qual o impacto das tecnologias móveis de informação e comunicação no processo de aprendizagem convencional?

Dessa forma, esta pesquisa, articulada com o projeto de pesquisa "Tecnologias digitais da informação e comunicação no processo ensino-aprendizagem: linguagens, metodologias e mediação", teve como objetivos: (i) apresentar dados que permitem discutir sobre os impactos das TMDIC no processo de ensino-aprendizagem da educação dos anos finais do Ensino Fundamental de escolas públicas na região do Vale do Aço; (ii) discutir sobre as habilidades para o exercício da autodidaxia, da colaboração e cooperação em rede de alunos e professores; (ii) contribuir para disseminação da cultura da informática educativa no Vale do Aço; (iii) pesquisar sobre uso das TMDIC como objeto de estudo; estudar sobre os impactos das TMDIC nas relações sociais de professores e alunos da região do Vale do Aço.

A referida pesquisa tem uma relevância social, uma vez que contribui na conscientização de professores, pais e alunos sobre os impactos das TMDIC no processo de aprendizagem e nas relações sociais. Além disso, contribui para o processo de formação continuada dos professores sobre a necessidade do domínio de diversas habilidades e competências para o uso das TMDIC no contexto educacional; para a formação crítica do aluno em relação às tecnologias e em relação às possibilidades de ampliar interações e, consequentemente, conhecimento. $E$, ainda, por ampliar as discussões e estudos sobre essa temática.

\section{Referencial Teórico}

\subsection{Tecnologias Móveis Digitais de I nformação e Comunicação na Educação}

O termo ubíquo, definido pelo dicionário Aurélio (1995), como certo estado de onipresença, ou seja, aquele que está presente em toda a parte, de certa forma ratifica a disseminação acelerada das tecnologias móveis digitais de comunicação e informação (TMDCI). Essas tecnologias permitem exercer as mais variadas atividades em todo o tempo e lugar, como por 
exemplo: comprar na China, votar em Ipatinga, viajar de Mariana ao litoral do Espírito Santo, abraçar um amigo aniversariante em Portugal, jogar com um colega japonês, namorar entre outros.

Neste contexto de ubiquidade, acelerado pelas conexões sem fio (Wi-Fi, 3G, 4G) e acesso, cada vez maior da população, aos dispositivos móveis (tablete, smartphone, notebook), “as redes on-line ocupam atualmente o centro das atenções, especialmente a partir de 2000, quando registraram forte crescimento de adesão e utilização, especialmente por jovens em idade escolar" (ROSADO; TOMÉ, 2015, p.14).

Considera-se, assim, importante clarear o termo redes e, consequentemente, a expressão redes sociais, uma vez que "o paradigma das redes tem sido evocado como explicação estrutural para muito dos fenômenos comunicacionais, políticos, organizacionais e sociais" (DUARTE; QUANDT; SOUZA, 2008, p.13 apud SANTAELLA, 2010, p. 269).

O termo rede é definido por diversas áreas de estudo, mas é no campo da ecologia, a partir de 1920, que se torna, cada vez mais, proeminente.

\begin{abstract}
Redes são formadas por entidades e relações entre essas entidades. As entidades com números maiores do 1 são chamadas nós. Entidades e relações só formam rede quando possibilitam e são demandadas umas pelas outras. Isso quer dizer que 'um elemento não pode ser considerado um nó, a menos que haja articulações com outros nós; e ele deixa de sê-lo quando essas articulações acabam. São características das redes a agilidade e a flexibilidade para ligar (e desligar) pontos e ações distantes, o que Ihes dá uma inconstância latente'. (DUARTE; FREY, 2008, p. 156 apud SANTAELLA, 2010, p. 270).
\end{abstract}

Já sobre as redes sociais, a autora reitera, com propriedade, que essas são mais amplas do que redes sociais na Web e retoma os estudos de Duarte, Quandt e Souza (2008), afirmando que a compreensão deles sobre redes "é a que mais perto chega da caracterização das redes que emergiram nos ambientes mediados por computador" (p.27). Assim, as redes sociais na web são vistas como

Estruturas dinâmicas e complexas formadas por pessoas com valores e/ou objetivos em comum, interligadas de forma horizontal e predominantemente descentralizadas. [Com] alto fluxo de comunicação e inexistência de contratos formais reguladores do resultado das interações. (p.272).

As redes sociais na web, conforme Castells (1999), constituem a nova morfologia da organização social, sendo um conjunto de nós interconectado. O autor afirma que as "redes são estruturas abertas capazes de expandir de forma ilimitada, integrando novos nós desde que consigam comunicar-se dentro da rede, ou seja, desde que compartilhem os mesmos códigos de comunicação" (p. 565). Os conectores são assim, os detentores do saber.

As acepções de Castells (1999) dialogam com Santaella (2010) quando ela afirma que embora todos os programas das redes sociais, tais como o twitter e facebook,

existam para facilitar e mesmo encorajar a participação dos usuários, por meio de interfaces dialogáveis, podem até mesmo ser mantidos pelo sistema e não necessariamente pelas interações, o que é preciso levar em conta é que as redes são constituídas pelos participantes que delas se utilizam, pois, sem eles, as redes não poderiam existir (p.273).

Essa característica é a que determina a queda ou a permanência dos programas de redes sociais. Já assistimos a queda e ascensão de vários deles. Mais recentemente a queda e ascensão do Orkut e Facebook, respectivamente. 
O Facebook

atingiu no ano de 2012 a marca de um bilhão de pessoas inscritas, um sexto da população mundial, o que evidencia sua potencialidade de conectar enorme quantidade de sujeitos e permitir a centralização do tráfego de dados em seus servidores de informação, criando uma 'rede paralela' dentro da rede maior, que é a Internet, competindo em volume de acesso com o maior mecanismo de busca da rede, o Google. (SITE LíDER apud ROSADO; TOMÉ, 2015, p.14).

Contribui para essa aceleração exacerbada de conexões nas redes sociais, segundo os autores, as adaptações contínuas e necessárias no ramo da informática como "aplicativos (apps) para celulares, tabletes e modelos de televisão digital em inúmeros sistemas operacionais (iOS, Android, Windows Phone), que permitem a participação coletiva com edição e compartilhamento de conteúdos diversos" (p.14).

Tais considerações são corroboradas por Santaella (2010, p. 267), quanto afirma que "o traço mais característico do cibermundo encontra-se no ritmo desenfreado de sua evolução". Segundo a autora, nem bem a web1.0 com seus recursos para buscar, ter acesso e ler já havia sido absorvida chega a Web 2.0 com processos colaborativos e arquiteturas participativas de produção e já se fala na Web 3.0 com seus atributos na semântica.

Dessa forma, as mídias vão penetrando cotidianamente em todos os setores da vida humana, interferindo tanto na educação familiar quanto nas decisões globais. "A natureza ubíqua que estão adquirindo e a intensidade com que afetam nossos modos de comunicar e de viver demandam reflexões voltadas para suas implicações e para os impactos de seu uso" (SANTAELLA, 2010, p. 264).

Castells (1999) assegura que "a presença na rede ou a ausência dela e a dinâmica de cada rede em relação às outras são fontes cruciais de dominação e transformação de nossa sociedade" (p.565).

No cenário da sociedade estrutura em rede, segundo Bauman (2015)1, a educação reproduz privilégio ao invés de aperfeiçoar a sociedade. Esse filósofo e humanista polonês afirma também, que estão impregnadas a cultura Google com fragmentos de informações e a do facebook com tranquilizantes para tratar doenças que sofremos como solidão e falta de conhecimento. Dessa forma, conclui Bauman (2015), os jovens não conseguem se concentrar durante um longo tempo em uma mesma questão e a educação se torna vítima da modernidade, na qual existe uma grave crise de atenção.

Santaella (2010), também discorre sobre o efeito das tecnologias informacionais no estado mental e nos conceitos: "a nova economia da atenção". A autora inicia suas discussões com dois testemunhos opostos. O primeiro diz assim:

minha mente modificou-se notavelmente nestes últimos anos, em grande parte devido às multitarefas permitidas pela internet. [...] tornei-me mais inteligente, tenho mais clareza, mais foco, fiquei mais rápido e mais compreensivo [...]. Sou capaz de admitir de uma olhada se algo vale a pena para min ou não." (KELLY, 2009, apud SANTAELLA, 2010, p. 298).

\footnotetext{
${ }^{1}$ Entrevista concedida a Alberto Dines. São Paulo: Observatório da I mprensa em out. 2015.
} 
Já no segundo testemunho está assim disposto:

Imergir em um livro ou em um longo artigo costumara ser fácil. Agora, no entanto, minha concentração sempre começa a derivar depois de duas ou três páginas. Fico agitado, perco o fio da meada, começo a buscar algo diferente para fazer. Sinto como se tivesse que puxar meu cérebro errante de volta para o texto.(CARR apud SANTAELLA, 2010, p. 298).

A autora assegura que mesmo sendo antagônicos, os dois testemunhos convergem para a mesma questão de "estudos cognitivos a respeito dos efeitos da internet sobre a mente humana". (p.299). Alguns desses estudos são apresentados pela autora, ora reiterando o primeiro testemunho, ora o segundo. Contudo, afirma, o “cérebro é flexível e, eminentemente treinável. Uma simples tarefa de busca diária na Internet pode fortalecer os circuitos cerebrais dos mais velhos, pois o cérebro pode continuar aprendendo mesmo quando envelhecemos." (p.307). Assim conclui que

\footnotetext{
muito provavelmente, sob o influxo das tecnologias cognitivas, a inteligência humana encontra-se em processo de adaptação e acomodação devido à sobrecarga de informação, fazendo emergir, como estratégia evolucionária, mentes fluidas, hibridas, auto-organizativas em ambientes hiperconectados e ubíquos (p. 307).
}

Os estudos de Santaella, as questões de Bauman e proposições de Castells orientam e motivam a elaboração de materiais didáticos que consideram alunos como protagonistas hiperconectados em ambiente ubíquos e professores como partícipes de transformações sociais necessárias. Considera-se, assim, que a escola está diante de um dos grandes desafios que é, segundo Kenski (2010, p.25), “viabilizar-se como espaço crítico em relação ao uso e à apropriação dessas tecnologias de comunicação e informação". A autora complementa, afirmando ainda, que:

\begin{abstract}
para que todos possam ter informações que lhes garantam a utilização confortável das novas tecnologias é preciso um grande esforço educacional geral. Como as tecnologias estão permanentemente em mudança, o estado permanente da aprendizagem é consequência natural do momento social e tecnológico que vivemos. [...] Essas alterações refletem-se sobre as tradicionais formas pensar e fazer educação. (p. 26 -27).
\end{abstract}

Dessa forma considera-se importante apresentar dados estatísticos recentes sobre o uso e apropriação das tecnologias de comunicação e informação da internet, por professores e alunos. A pesquisa sobre o uso das tecnologias de informação e comunicação nas escolas brasileiras - TIC Educação 2014, do CGI - se constitui em uma referência para as discussões que serão travadas mais adiante.

\title{
2.2 Uso das tecnologias de informação e comunicação nas escolas
}

A pesquisa realizada em 2014 e publicada pelo Comitê Gestor da Internet no Brasil, em 23 de novembro de 2015, envolveu como participantes diretores, coordenadores, professores e alunos de 4a série/5o ano do Ensino Fundamental, 8a série/9o ano do Ensino Fundamental e 20 ano do Ensino Médio de escolas públicas municipais, escolas públicas estaduais e escolas particulares de todas as regiões do Brasil. 
Evidenciou-se por meio da pesquisa que

Há aumento do uso do computador e da Internet em atividades relacionadas ao cotidiano de trabalho do professor. Em 2014, 97\% utilizaram as TIC para buscar conteúdo a ser trabalhado em sala de aula, assim como $80 \%$ procuram exemplos de plano de aula na Internet. Já $70 \%$ utilizam as tecnologias para atividades administrativas, já que diversas redes públicas de ensino informatizaram seus registros escolares. (CGI 2015, p. 114).

Ficou evidente, também, que

O uso da Internet para elaboração de aulas ou atividades com os alunos continua sendo uma ação comum entre professores de escolas públicas: $96 \%$ deles afirmaram já ter utilizado algum tipo de conteúdo obtido na rede com essa finalidade. [...]. Entre os tipos de conteúdo citados por uma proporção menor de professores, estão os que envolvem um engajamento mais interativo por parte dos estudantes, tais como software educacionais (47\%) e jogos (44\%). Os dados da pesquisa também apontam que a maioria dos professores $(86 \%)$ realizou algum tipo de modificação no conteúdo obtido na Internet para preparação de aulas. (CGI 2015, p. 127, grifo nosso).

Já quanto aos alunos a pesquisa revelou que

Uma parcela importante dos alunos realiza tarefas escolares por meio das TIC em casa. Entre os alunos de escolas públicas que utilizam computador ou Internet para realizar atividades escolares, o percentual daqueles que declaram fazer projetos ou trabalhos sobre um tema, lição ou exercícios e pesquisas escolares em casa varia entre $73 \%$ e $75 \%$, ao passo que aqueles que afirmam realizá-los na escola varia entre $22 \%$ e $24 \%$. Os dados evidenciam o maior uso das TIC fora do ambiente escolar, ainda que a atividade realizada seja relacionada à educação formal. (CGI 2015, p. 111).

Segundo o Comitê Gestor da Internet

A pesquisa TIC Educação tem destacado, desde 2011, um aumento progressivo da presença de rede wireless nas escolas públicas [...], com estabilidade entre 2013 e 2014. Nos estabelecimentos de ensino em que há conexão WiFi, 96\% dos diretores afirmaram que esse recurso é de acesso restrito por meio de senha que não é disponibilizada aos alunos - revelando que o uso de equipamentos pessoais para a conexão à Internet no interior do ambiente escolar está distante de ser apropriado no cotidiano da instituição de ensino (p.112).

Os resultados da pesquisa sobre o uso das tecnologias de informação e comunicação TIC na educação realizada pelo Comitê Gestor da Internet, em 2014, revelam que “os professores brasileiros demonstram interesse em utilizar recursos educacionais digitais, mas nem sempre existem condições de infraestrutura e capacitação para o uso da Internet com propósito pedagógico" (p.29). Também, segundo o CGI (2015), “os resultados da pesquisa apontam o uso frequente de fragmentos de conteúdos disponíveis na Internet (tais como imagens e vídeos), citados com maior intensidade que o uso de materiais completos" (p.127).

\subsection{Integrar tecnologias móveis digitais de informação e comunicação ao currículo}

Reitera-se a importância de todos compartilharem "os mesmos códigos de comunicação" na sociedade do conhecimento. A escola se constitui como uma instituição fundamental para desenvolver possibilidades que permitam aos sujeitos - alunos e professores - compartilharem desses códigos. Dessa forma, é preciso, segundo Kenski (2010), dar ao professor tempo e oportunidades de familiarização com as novas tecnologias educativas para que ele possa conscientizar de suas possibilidades e seus limites. A autora enfatiza a necessidade de os cursos de formação de professores se preocuparem em lhes garantir novas competências para 
ser agente, produtor, operador e crítico das 'novas educações mediadas' pelas tecnologias de comunicação e informação, ao invés de usuário acrítico de programas e softwares pedagogicamente ruins e com conteúdos 'aculturados', ou seja, traduzidos e adaptados de outras realidades, produzidos e comercializados com baixa qualidade educativa.

Dessa forma, complementa Belloni (2012),

\begin{abstract}
Se é fundamental reconhecer a importância das TIC e a urgência de criar conhecimentos e mecanismos que possibilitem sua integração à educação, é também preciso evitar o 'deslumbramento' que tende a levar o uso mais ou menos indiscriminado da tecnologia por si e em si, ou seja, mais por virtualidades técnicas do que por virtudes pedagógicas. É importante lembrar que este deslumbramento frente às incríveis potencialidades das TIC está longe de ser uma ilusão ou um exagero 'apocalítico', mas, ao contrário, constitui um discurso ideológico bem coerente com os interesses da indústria do setor. (p.24).
\end{abstract}

A autora faz uma alerta, afirmando que a integração das tecnologias de informação e comunicação à educação faz sentido somente se realizada em dupla dimensão, sendo a primeira como objeto de estudo e a segunda como ferramenta para aprender.

Na primeira dimensão objetiva-se educar para o uso das mídias, ou seja, dominar a leitura da mídia para não ser dominado por ela. Dessa forma, com aceleração exacerbada do uso das redes sociais da internet, questionar e discutir sobre (i) a visibilidade na rede, (ii) veracidade das informações que circulam; (iii) invasão do privado; (iv) homofobia, discriminação de etnia, gênero, religião, partido político entre outros, devem ser inerentes às práticas educativas.

Já na segunda dimensão, objetiva-se utilizar as mídias para aprender. Dessa forma seus variados recursos para acessar dados, comunicar, interagir, produzir colaborativa e cooperativamente devem, também, ser inerentes às práticas educativas.

Nesse sentido, se evidencia a necessidade de exercer as habilidades para leitura e escrita na rede, em rede, da rede. Assim, antes de tudo, é preciso saber ler a rede, ou seja, "farejar" a rede para selecionar o "trigo" do "joio"; para contrastar diversas fontes (imagéticas, principalmente, os ícones; textuais e hipertextuais e as fontes sonoras) de diversos suportes de veiculação, tendo a capacidade de analisá-las criticamente. Outra necessidade, seguida à leitura da rede, não menos importante do que essa, diz respeito à leitura e à escrita em rede. Para ler e escrever em rede, se faz necessário interagir com os objetos da rede e com os diversos sujeitos em rede, trocando informações, construindo conhecimentos colaborativamente e cooperativamente. E por fim, também, não menos importante das já apresentadas, é preciso saber ler e escrever na rede, ou seja, exercitar as habilidades para realizar, atividades colaborativa e cooperativas.

Dessa forma, se fazem necessárias estratégias pedagógicas que demandam habilidades de letrados digitais tanto de professores, quanto de alunos. Essa afirmativa é corroborada por Ferreira e Dias (2005) quando asseguram que como objeto de conhecimento que é, a leitura precisa ser ensinada e aprendida, ou seja, o sujeito-leitor precisa aprender a decodificar e a usar as estratégias que levam à compreensão e ao seu controle. Dantas (2009) amplia as proposições de Ferreira e Dias (2005) ao assegurar que para ser considerado como sujeito que exercita plenamente seu conhecimento faz-se necessário que esse alguém saiba 'navegar' pelas mais diferentes formas de realização da escrita nos diferentes eventos comunicativos. Assim, 
deslocando as exposições de Dantas (2009) e Ferreira e Dias (2005) para o contexto da rede, pode-se afirmar que proporcionar oportunidades cuidadosamente estruturadas para os alunos desenvolverem as habilidades do letramento e um forte senso de ceticismo instruído é mais importante do que nunca, conforme afirma Snyder (2009). Essas, necessariamente, devem priorizar a interação, reconhecendo os interagentes, conforme afirma Primo (2008), como seres vivos pensantes e criativos na relação.

Xavier (2005) corrobora essa afirmativa, assegurando, com propriedade, que os profissionais de educação e linguagem precisam desenvolver estratégias pedagógicas eficazes em seus mais variados espaços educacionais para enfrentar os desafios que estão colocados: alfabetizar, letrar e letrar digitalmente o maior número de sujeitos para atuar adequadamente no Século do Conhecimento.

\begin{abstract}
Ser letrado digital pressupõe assumir mudanças nos modos de ler e escrever os códigos e sinais verbais e não-verbais, como imagens e desenhos, se compararmos às formas de leitura e escrita feitas no livro, até porque o suporte sobre o qual estão os textos digitais é a tela, também digital. (XAVIER, 2005, p.2).
\end{abstract}

Entretanto,

\begin{abstract}
As tentativas de inovação metodológica, por exemplo as práticas inspiradas no construtivismo, têm se chocado com a resistência dos professores que, apesar do discurso inovador ou construtivista, não transformaram em quase nada sua prática pedagógica efetiva e continuam a ser formados para repetirem velhas pedagogias, quase sempre sem novas tecnologias (BELLONI, p.92).
\end{abstract}

Nesse sentido, considera-se o letramento digital do docente como uma das demandas da esfera educacional contemporânea, uma vez que o uso das TMDIC apresentam impactos, tanto nas práticas docentes quanto nas práticas discentes.

Por essa razão, a presente pesquisa tratou de buscar dados para dialogar sobre os referidos impactos das TMDIC na educação dos anos finais do ensino fundamental nas escolas da rede pública municipal e estadual de um dos principais municípios do Vale do Aço.

\title{
3 Metodologia
}

\section{Participantes}

Participaram da pesquisa trezentos e trinta e seis alunos (336), sendo oitenta seis (86) da rede municipal e duzentos e cinquenta (250) da rede estadual, do sexto ao nono ano, com idade variando dos dez aos dezesseis anos. Participaram também cento e trinta e três professores (133) - oitenta e (81) da rede estadual e cinquenta e dois da rede municipal (52), dos anos finais do ensino fundamental. Assim, perfazendo um total de Quatrocentos e sessenta e nove (469) participantes. Deve-se ressaltar que os participantes da pesquisa são de cinco escolas estaduais e quatro escolas municipais, de diferentes localizações do município. Ambas indicadas pela Superintendência Regional de Ensino e Secretaria Municipal de Educação, respectivamente. 
A quantidade de participantes é considerada significativa uma vez que, de acordo com o cálculo amostral, apresenta uma margem de erro 5\%, conforme a seguinte fórmula:

$$
n=\frac{\mathrm{n} \cdot \mathrm{z}^{2} \cdot p \cdot(1-p)}{z^{2} \cdot p \cdot(1-p)+e^{2} \cdot(n-1)}
$$

Onde:

n - amostra calculada

$\mathrm{N}$ - população

Z - variável normal padronizada associada ao nível de confiança

$\mathrm{p}$ - verdadeira probabilidade do evento

e - erro amostral. (SANTOS, [200? ])

Instrumentos

Para a realização da pesquisa foram utilizados questionários online para os alunos e para os professores. O questionário para os alunos contém treze (13) questões, sendo onze (11) fechadas e duas (2) abertas. Essas questões identificam idade, sexo, ano escolar, rede de ensino, se faz uso da Internet, tempo de conexão diário, quais rede sociais mais utilizadas, se leva para escola as tecnologias móveis de comunicação e informação, se as utiliza na escola e para que se usa. O questionário para os professores contém onze (11) questões, sendo oito (8) fechadas e três (3) abertas, que identificam idade, sexo, formação acadêmica, tempo de magistério, rede de ensino em que atua, recursos tecnológicos móveis que utiliza no cotidiano, redes sociais que utiliza, finalidades de uso das redes sociais, os impactos das tecnologias em sua prática docente, se permite que os alunos façam uso das redes em sala de aula e por que.

Procedimentos

Inicialmente, o projeto foi submetido ao Comitê de Ética em Pesquisa envolvendo seres humanos do Centro Universitário do Leste de Minas Gerais- Unileste, sendo aprovado em 27/07/2015, conforme Parecer № 1.165.357. Durante o período de análise e adequações sugeridas do/pelo referido Comitê de Ética, foram realizadas pesquisas bibliográficas sobre a temática em questão. A pesquisa bibliográfica teve como base Livros e periódicos publicados nos sites da Capes e Scielo nos anos de 2013 à 2015. Foram utilizados argumentos de pesquisa como: aprendizagem móvel, redes sociais no ensino, tecnologias móveis, entre outros. Em um primeiro momento os artigos foram selecionados pelo título e, depois, de acordo com seu resumo.

Após aprovação no Comitê de Ética, iniciou-se a coleta de dados online, utilizando o programa Google Drive, no período de agosto a novembro de 2015. O aluno convidado para participar da pesquisa, levou um Termo de Assentimento para preenchimento e assinatura do responsável. Com apresentação do termo preenchido e assinado, o aluno respondeu às questões do instrumento. O link do referido instrumento foi disponibilizado no tablete da aluna bolsista pesquisadora e nos computadores dos laboratórios de informática das escolas envolvidas na pesquisa. 
Os professores também responderam ao questionário a partir do tablete e do notebook deles ou da pesquisadora e, ainda, a partir dos computadores da escola. O Termo de Consentimento Livre e Esclarecido (TCLE) é inerente ao instrumento aplicado para os professores, sendo condição aceitá-lo, para responder às questões.

Os dados foram tabulados conforme planilha Microsof Excel, Google Drive e Infográfico e analisados à luz do referencial.

\section{Resultados e Discussão}

Inicialmente, deve-se destacar que a imensa base de dados gerada a partir dessa pesquisa permite análise estratificada pelo tipo de rede, gênero, idade, tempo de serviço, formação, série/ano, escola etc. Entretanto para este relatório os dados são tratados sem nenhuma estratificação, ficando as demais análises para artigos futuros.

Os dados da pesquisa revelaram que a maior parte dos professores envolvidos na pesquisa, $87 \%$, é do sexo feminino; $50,5 \%$ possuem licenciatura, 49,5\%, especialização; que 5,7\% possuem curso de bacharelado e 1,9\% possuem o curso de mestrado. Esses dados demonstram que, ainda, há uma grande parte dos professores que não possui cursos de pósgraduação, constituindo-se assim, como um fator limitador de discussões e estudos referentes às questões atuais sobre o uso dos recursos da Internet como objeto de estudo e ferramenta para aprender.

Quanto ao tempo de serviço os dados demonstraram que 18,1\% professores atuam na educação até 4 anos; 27,6\% de 5 a 10 anos; 17,1\% de 11 a 15 anos e de 16 a 20 anos e 20\% mais de 20 anos. Desses professores, 50,5\% atuam na rede estadual, 22,9\% na rede municipal, 26,7\% que atuam nas duas redes de ensino.

Quanto aos recursos tecnológicos móveis e redes sociais utilizados no cotidiano dos professores, a pesquisa revelou que $99 \%$ utilizam os recursos tecnológicos móveis, conforme gráfico 1 que se segue:

Gráfico 1 - Recursos tecnológicos móveis utilizados no cotidiano docente.

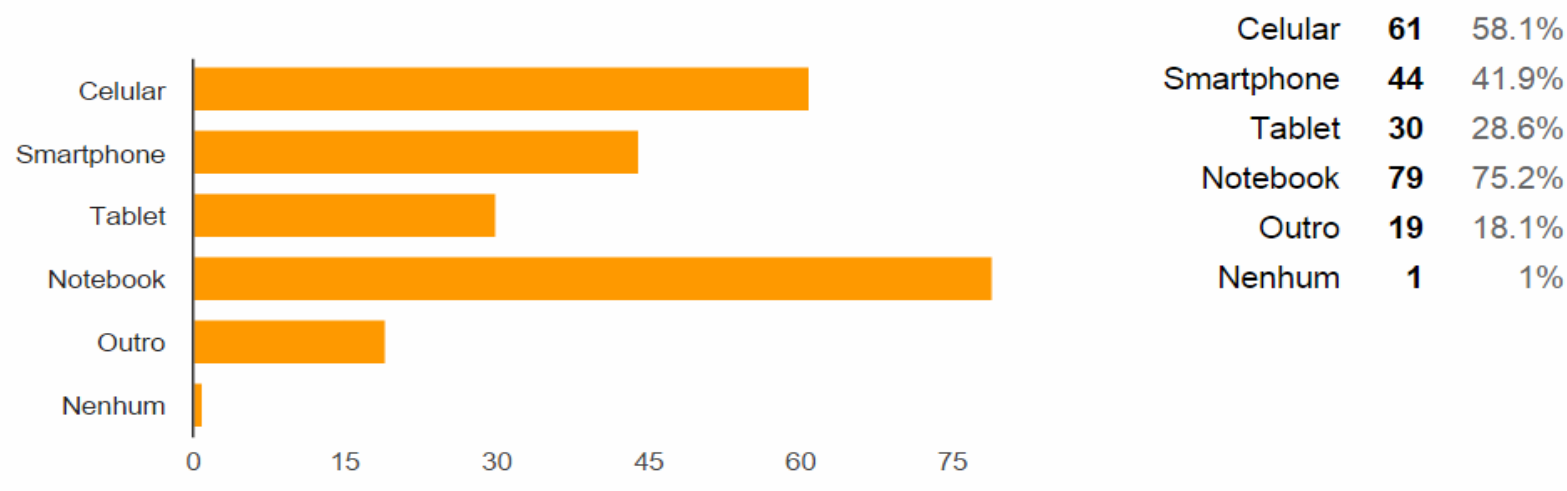

Fonte: Base de dados da pesquisa, 2015. 
Os dados revelaram que $100 \%$ dos professores envolvidos na pesquisa utilizam as redes sociais, com destaque para o email, facebook e whatsapp, conforme gráfico 2 que se segue.

Gráfico 2 - Recursos das redes sociais da Internet utilizados no cotidiano docente.

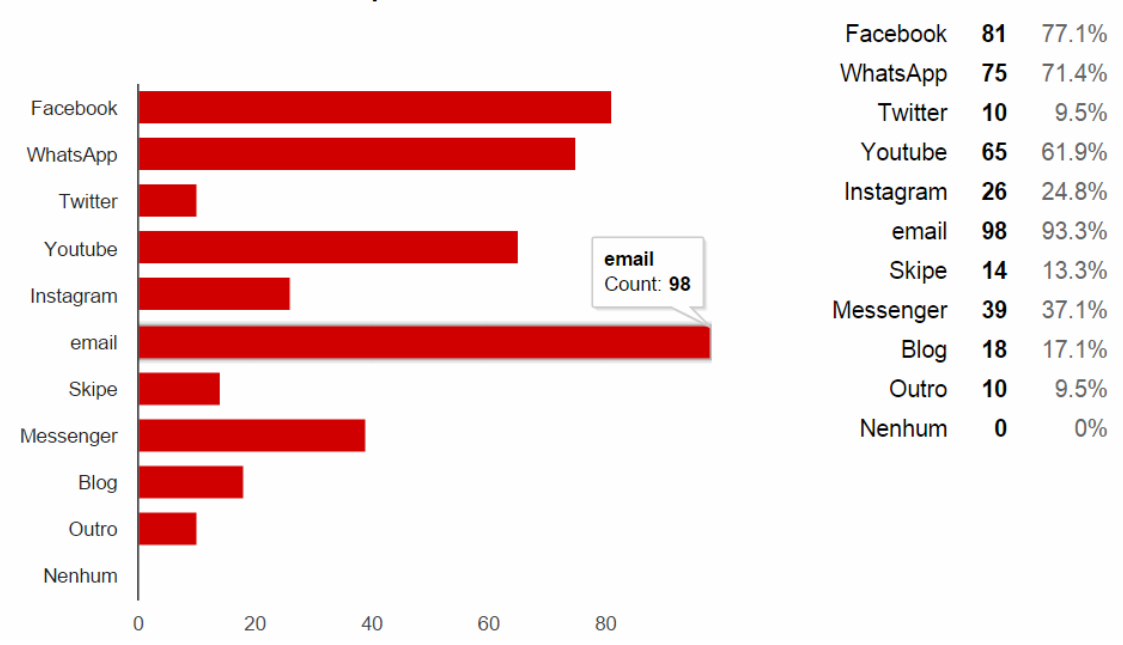

Fonte: Base de dados da pesquisa, 2015.

Tais dados convergem com as pesquisas do CGI no Brasil, revelando que os professores envolvidos nessa pesquisa fazem uso de hardware e software de última geração em seu cotidiano. Questionados sobre as finalidades de uso das redes sociais eles afirmaram, em grande maioria, que utilizam para pesquisar, comunicar, informar, trabalhar, conforme pode ser visualizado no infográfico 1 que se segue.

Infográfico 1 - Finalidade(s) de uso dos recursos das redes sociais da Internet utilizados no cotidiano docente.

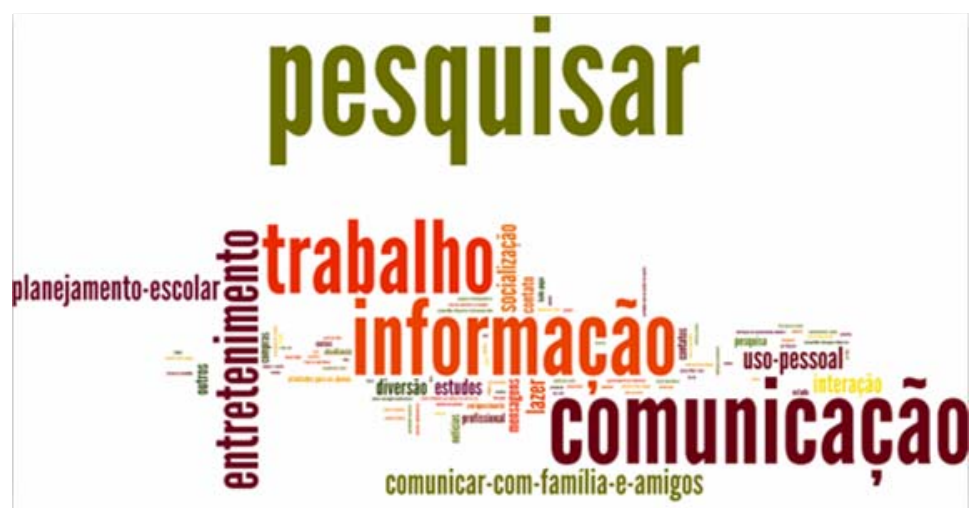

Fonte: Base de dados da pesquisa, 2015. 
Uma parcela significativa dos professores envolvidos na pesquisa - $80 \%$ - considera que as redes sociais provocam impactos em suas práticas docentes. Em contrapartida, 20\% consideram que não há impactos. Quando questionados sobre quais impactos em sua prática docente, a maioria destacou o uso indevido do celular, informações, pesquisas, busca de material didático, entre outros, conforme infográfico 2.

Infográfico 2 - Impactos da TMDIC em sua prática docente.

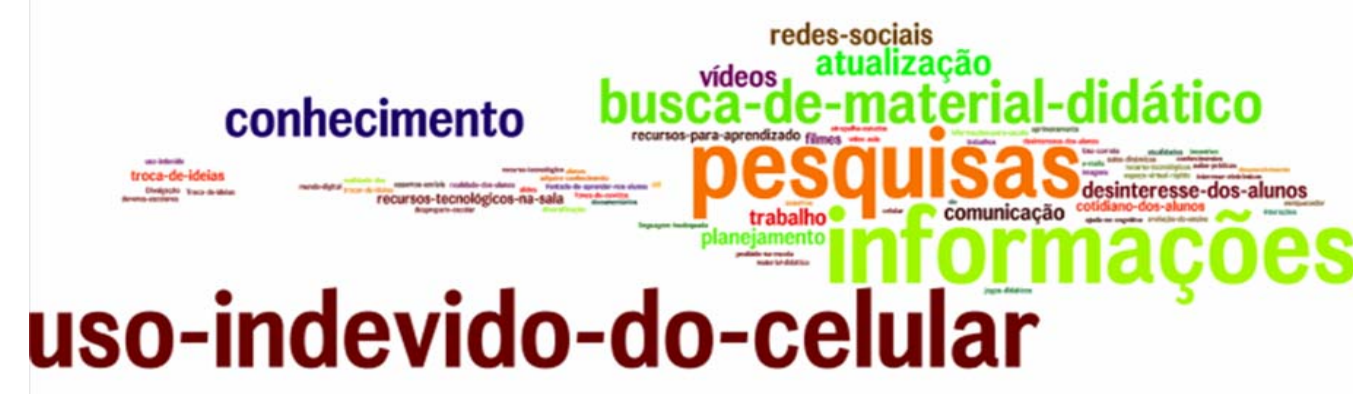

Fonte: Base de dados da pesquisa, 2015.

Os dados demonstrados acima revelam que os professores estão sintonizados com as tecnologias ubíquas, com acesso aos dispositivos móveis (tablete, smartphone, notebook), aderindo e utilizando os recursos das redes sociais para comunicar e buscar de informações, pesquisar, buscar material didático, conhecimento entre outros. Entretanto, o impacto mais destacado pelos professores foi o uso indevido do celular por parte dos alunos. Esses dados permitem inferir que tais recursos, geralmente, não são utilizados como ferramenta pedagógica - objeto de estudo ou ferramenta para aprender- conforme propõe Belloni (2010), e sim como ferramentas para facilitar o ensino.

Outro dado significativo para ampliar essa discussão foi que 79\% dos professores afirmaram que não permitem que seus alunos façam uso das $\mathrm{TMDCl}$ durante as aulas. As justificativas utilizadas por eles podem ser visualizadas no infográfico 3 que se segue: 


\title{
Proibido-por-lei Atividade-necessita-o-recurso-da-tecnologia Uso-indevido A-escola-não-permite Quando-é-pertinente-ao-planejamento Dispersa-os-alunos
}

Fonte: Base de dados da pesquisa, 2015.

Esses dados revelam que a maioria dos professores envolvidos na pesquisa, apesar de acessados, não oferecem oportunidades, por meio de estratégias pedagógicas eficazes, para seus alunos desenvolverem habilidades de letramento digital e assim poderem (i) "ler e escrever os códigos e sinais verbais e não-verbais, como imagens e desenhos", conforme Xavier (2005, p.2); (ii) exercitarem plenamente seus conhecimentos, sabendo 'navegar' pelas mais diferentes formas de realização da escrita nos diferentes eventos comunicativos, conforme Dantas (2009); (iii) exercitarem um forte senso de ceticismo, conforme Snyder (2009), diante de um dilúvio de informações distorcidas e desnecessárias que estão disponíveis na rede; (iv) se conscientizarem que se faz necessário buscar para além dos fragmentos apontados pelo motor de buscas citados Bauman (2015); (v) desenvolver senso crítico sobre as questões relativas à visibilidade na rede e para curtir, "descurtir" e compartilhar informações na rede entre outros.

Ficou demonstrado, ainda, que uma parcela significativa dos professores, considera que os alunos fazem uso indevido das tecnologias e são imaturos. Também mereceram destaque, para justificar o não uso das tecnologias em sala de aula, as questões relativas à gestão escolar tais como a proibição de seu uso e ambientes inadequados.

Dessa forma, pode se inferir, a partir dos dados apresentados até então, que as habilidades para ler e escrever em/na/a rede são inviabilizados pela

\begin{abstract}
resistência dos professores que, apesar do discurso inovador ou construtivista, não transformaram em quase nada sua prática pedagógica efetiva e continuam a ser formados para repetirem velhas pedagogias, quase sempre sem novas tecnologias (BELLONI, 2012, p.92).
\end{abstract}

Os dados apresentados nessa pesquisa não revelam que há interações entre os professores e alunos, por meio das redes sociais, para execução de atividades colaborativas e cooperativas ou da autodidaxia, confirmando-se, assim, que integração das tecnologias de informação e comunicação à educação ainda está aquém do que se deseja. Isso corrobora a afirmativa de que não há indícios de seu uso como objeto de estudo e nem tampouco como ferramenta para aprender nos anos finais do ensino fundamental das escolas envolvidas na pesquisa. 
Para dar continuidade às reflexões serão apresentados a seguir os dados referentes à pesquisa com os alunos.

A maioria dos alunos, $55.7 \%$, é do sexo feminino e tem idade que varia dos 11 aos 13 anos, sendo $30,1 \%$ com $11 ; 32.4 \%$ com $12 ; 13.7 \%$ com $13 ; 17.6 \%$ com $14 ; 4.2 \%$ com $15 ; 1.5 \%$ 16 anos e 0,6\% com mais de 16 anos. Eles estão matriculados 6o ano 50.3\%; 70 ano 19.3\%; 8ㅇ ano $14.6 \%$ e no 9 o ano $15.8 \%$, sendo que $25,6 \%$ pertencem à rede pública municipal e $74,4 \%$ à pública estadual.

Os alunos, assim como os professores, estão acessados, sendo que $91.4 \%$ afirmaram fazer uso da Internet. Já quando questionados sobre o local de uso da Internet, 79.5\% dos alunos envolvidos na pesquisa afirmaram que a utilizam em casa; apenas $5.1 \%$ acessam na escola; $5.7 \%$ na casa de parentes; $1.8 \%$ na casa de amigos; $0.6 \%$ na lan house e $7.4 \%$ reiterou que não utiliza internet. Observa-se assim que o percentual de alunos que não acessam à rede foi ainda menor. Dessa forma, a escola, locus da inclusão, não contribui para a inclusão digital dos alunos.

Já quanto ao tempo de conexão cotidiana os dados revelaram que a maioria dos alunos fica conectada de três a mais de oito horas, sendo que desses, uma parcela significativa, fica mais de oito horas na rede. Os dados dessa questão novamente confirmam que 7,4\% dos alunos envolvidos na pesquisa não utilizam a rede.

O tempo de conexão dos alunos envolvidos na pesquisa pode ser melhor visualizado no gráfico 3 que se segue.

Gráfico 3 - Tempo de conexão diária dos alunos.

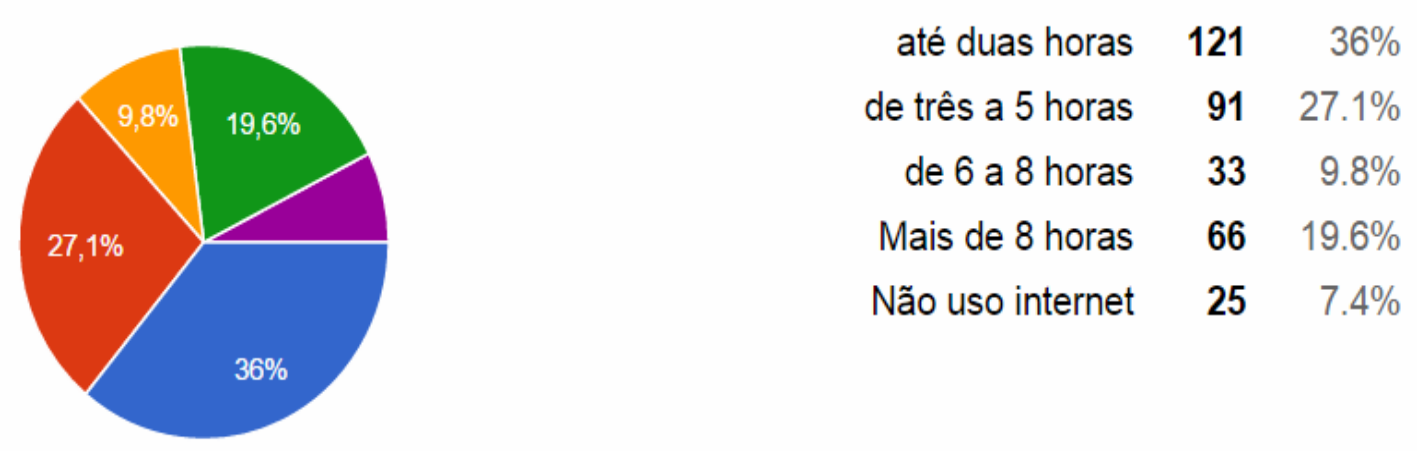

Fonte: Base de dados da pesquisa, 2015.

Outro dado significativo diz respeito aos equipamentos tecnológicos móveis dos alunos. Observa-se que o celular é o de maior incidência, sendo utilizado, mesmo que parcialmente, pelos alunos que declararam não fazer uso da Internet. Observa-se, conforme o gráfico 4, que a maioria dos alunos também tem tecnologias móveis de última geração. 


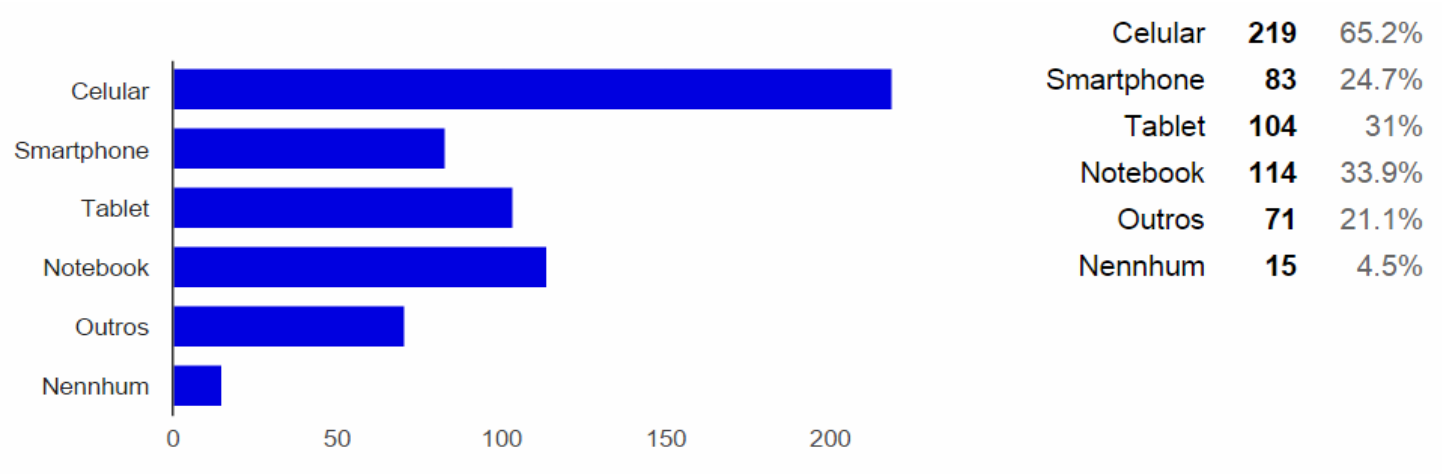

Fonte: Base de dados da pesquisa, 2015.

A seguir são apresentados os dados sobre o uso das redes sociais. Tais dados, conforme gráfico 5, evidenciam, também, a potencialidade do Facebook seguido do Youtube e WhatsApp, respectivamente.

Esses dados podem revelar questões já estudadas e mencionadas por Bauman (2015) sobre a cultura Google com fragmentos de informações e a do facebook com tranquilizantes para tratar doenças como solidão e falta de conhecimento. Doentes, os jovens não conseguem se concentrar durante um longo tempo em uma mesma questão e a educação se torna vítima da modernidade, na qual existe uma grave crise de atenção.

Gráfico 5 - Recursos das redes sociais da Internet utilizados pelos alunos.

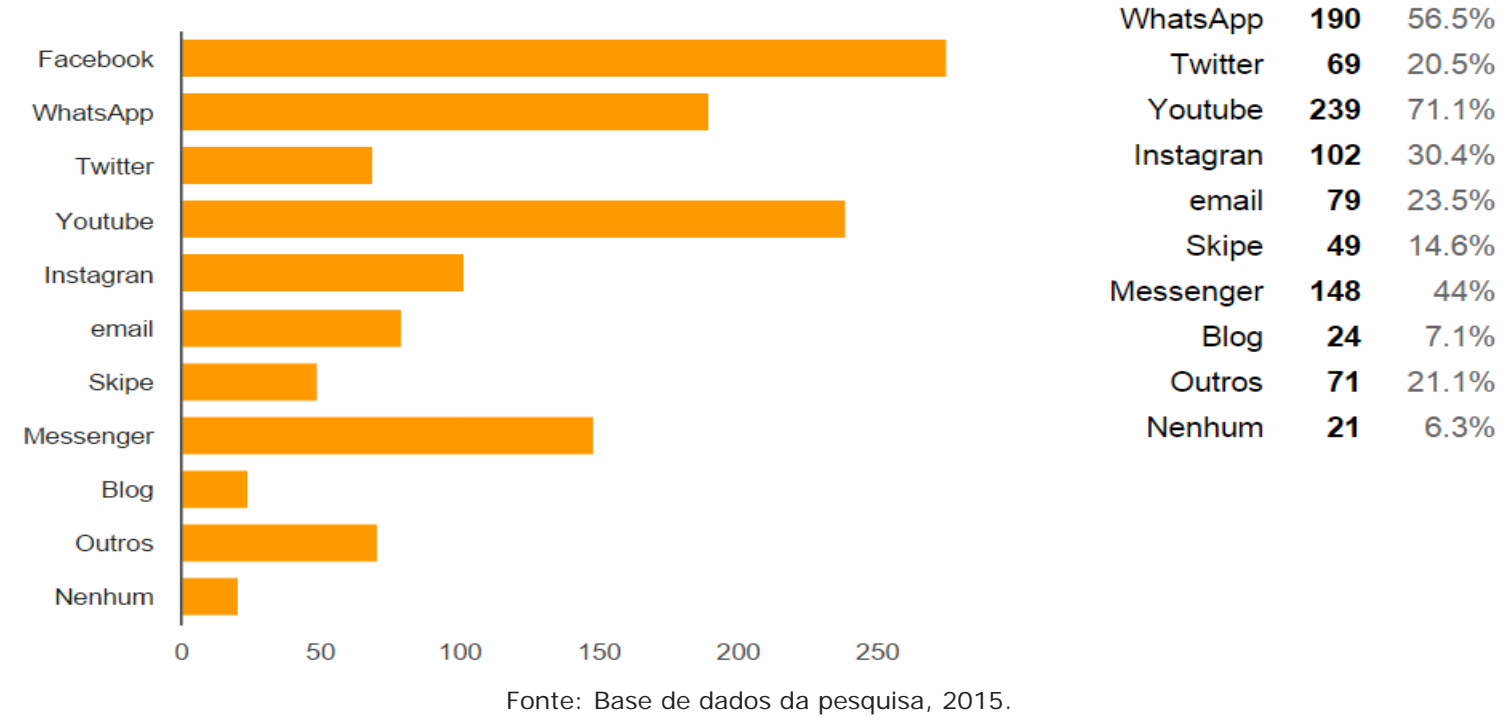

$\begin{array}{rrr}\text { Facebook } & \mathbf{2 7 5} & 81.8 \% \\ \text { WhatsApp } & \mathbf{1 9 0} & 56.5 \% \\ \text { Twitter } & \mathbf{6 9} & 20.5 \% \\ \text { Youtube } & \mathbf{2 3 9} & 71.1 \% \\ \text { Instagran } & \mathbf{1 0 2} & 30.4 \% \\ \text { email } & \mathbf{7 9} & 23.5 \% \\ \text { Skipe } & \mathbf{4 9} & 14.6 \% \\ \text { Messenger } & \mathbf{1 4 8} & 44 \% \\ \text { Blog } & \mathbf{2 4} & 7.1 \% \\ \text { Outros } & \mathbf{7 1} & 21.1 \% \\ \text { Nenhum } & \mathbf{2 1} & 6.3 \%\end{array}$

As proposições de Bauman(2015) articuladas ao resultados apresentados nessa questão parecem dialogar com o exposto pelos professores ao afirmarem que as tecnologias "desviam a atenção dos alunos" e "imaturos". 
Podem, também, evidenciar conforme Santaella (2010), uma economia de memória uma vez que a concentração sempre começa a derivar depois de duas ou três páginas, perdendo o fio da meada ou pode fortalecer os circuitos cerebrais. Isso porque

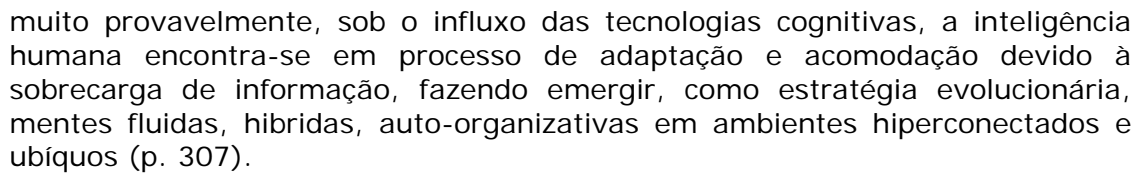

Considera-se ainda, que os dados interrogam sobre o papel da escola, do professor, da família, da sociedade, uma vez que todos os alunos envolvidos na pesquisa são menores de idade, e dessa forma não poderiam, por exemplo, ter uma conta no Facebook. No que diz respeito à escola, conforme já tratado por Belloni (2010), os dados dialogam com a necessidade de integrar as tecnologias à educação nas duas dimensões - objeto de estudo e ferramenta para aprender - e assim aprofundar mais sobre essas questões. Dessa forma, se faz necessário dar ao professor tempo e oportunidades de familiarização com as novas tecnologias educativas para que ele possa desenvolver competências para ser agente, produtor, operador e crítico das 'novas educações mediadas', ao invés de usuário acrítico de programas e softwares e ou fragmentos de conteúdos, conforme proposto por Kenski (2010).

Os dados que se seguem ratificam a necessidade de formação continuada dos professores. Dos alunos envolvidos na pesquisa, 96,1\% declararam que os professores não permitem uso das tecnologias móveis de comunicação e informação durante as aulas. E 88,6\% afirmaram que utilizam os equipamentos tecnológicos durante as aulas, mesmo sem a permissão dos professores, mas quando questionados sobre as finalidades de uso deles na escola a maioria afirmou que não usa na escola ou não usa, uma parcela significativa dos alunos afirmou que usa para jogar, pesquisar e acessar facebook, conforme pode ser visualizado no infográfico 4.

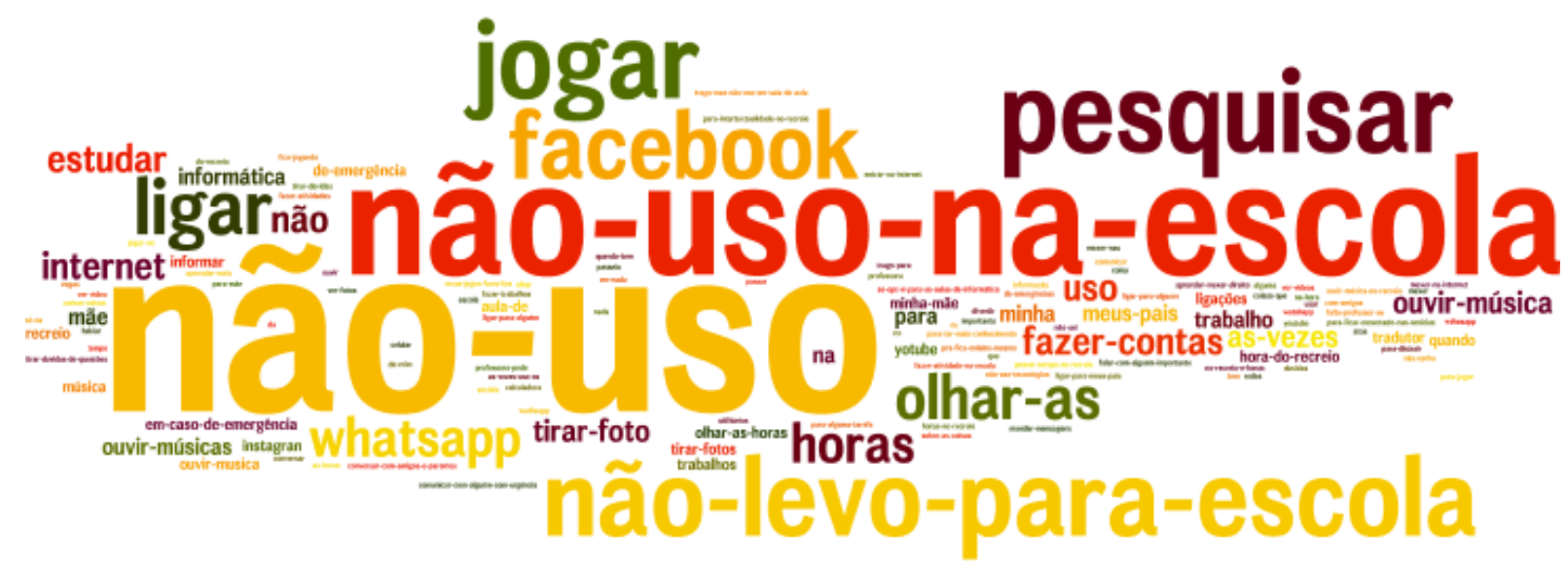

Fonte: Base de dados da pesquisa, 2015.

Como já exposto, os dados revelaram que os crescentes efeitos das redes sociais virtuais e da mobilidade no acesso à Internet são incontestáveis. Dentre esses efeitos foi constatado que 
os notebooks, tablets e celulares fazem parte do cotidiano de uma parcela significativa de crianças e adolescentes e de professores que atuam no ensino fundamental. Os dados da pesquisa, apontaram para o protagonismo juvenil nas redes sociais, sendo o facebook a rede social que ocupa o primeiro lugar no ranking de interesse. Os dados revelaram, também, que discussões sobre o uso das TMDIC como objeto e estudo e como ferramenta para aprender, interesse desta pesquisa, estão ausentes das práticas pedagógicas, e seus impactos na educação ainda carecem de mensuração.

\section{Considerações Finais}

Conclui-se a partir dos dados disponibilizados nessa pesquisa, que as TMDIC promovem impactos tanto na prática docente quanto na prática discente. Tanto professores quanto os alunos têm acesso ao que há de mais atual em termos de hardware e software, mas esses recursos ainda são subutilizados. Os professores os utilizam para melhorar sua capacidade de exposição, para buscar materiais já prontos na rede. Eles não declararam nenhum tipo de produção em rede ou elaboração de estratégias pedagógicas para utilizá-los e, nem tampouco, permitem que seus alunos façam uso das $\mathrm{TMDCl}$ em sala de aula ou propõem atividades integradas ao currículo para serem realizadas fora da sala.

Os alunos, em sua grande maioria, passam muito tempo conectados nas redes sociais para jogar e conversar, não apresentando indicativos que utilizam as redes sociais para a construção de conhecimentos escolares. Também, não há estudos ou discussões, envolvendo alunos e professores, quanto às finalidades de uso, à realização de atividades colaborativas e cooperativas e ou estudos sobre as informações acessadas, as leituras realizadas bem como o que se curte e ou compartilha em rede. Portanto, há um distanciamento entre o uso efetivo, consciente e reflexivo e o uso que se faz das redes sociais integradas à educação.

Conclui-se, também, que essa pesquisa contribui para identificar os avanços alcançados e as barreiras a serem enfrentadas para a inclusão e letramento digital de professores e alunos. A pesquisa contribui, ainda, para estudos de gestores e professores e futuras ações para a integração das TMDC à educação de maneira mais efetiva.

Conclui-se, ainda, que a presente pesquisa tem uma relevância social, por conscientizar gestores, professores, familiares e alunos sobre os impactos das TMDIC no processo de aprendizagem e nas relações sociais. Além disso, contribui para o processo de formação continuada dos professores e para a formação crítica do aluno em relação às tecnologias.

\section{Referências}

BAUMAN, Zygmunt: entrevista [out. 2015]. Entrevistador: Alberto Dines. São Paulo: Observatório da Imprensa. Disponível em: <http://observatoriodaimprensa.com.br/oitv/entrevista-com-zygmuntbauman/>. Acesso em: 20 nov. 2015.

BELLONI, Maria Luiza. O que é mídia e educação. 3. ed. Campinas: Autores Associados, 2012.

CASTELLS, Manuel. A sociedade em rede. São Paulo: Paz e Terra, 1999. 
COMITÊ GESTOR DA INTERNET NO BRASIL (CGI). Pesquisa sobre o uso das tecnologias de informação e comunicação nas escolas brasileiras - TIC Educação 2014. 2015. Disponível em: <http://www.cgi.br/media/docs/publicacoes/2/TIC_Domicilios_2014_livro_eletronico.pdf >. Acesso em 30 nov. 2015.

DANTAS, Hallysson Oliveira. Wikipédia e dicionário escolar: links entre o letramento digital e o letramento lexicográfico. In: ARAÚJ O, Júlio César; DIEB, Messias. Letramentos na web: gêneros, interação e ensino. Fortaleza: Edições UFC. 2009. p. 210-234.

FERREIRA, Aurélio Buarque de Hiolanda. Novo Dicionário Aurélio da Lingua Portuguesa. São Paulo: Nova Fonteira, 1995. p.656.

FERREIRA, Sandra Patrícia Ataíde; DIAS, Maria da Graça B. B. Leitor e leituras: considerações sobre gêneros textuais e construção de sentidos. Psicologia: reflexão e crítica, vol.18, n.3, Porto Alegre, 2005. Disponível em: < http://www.scielo.br/pdf/prc/v18n3/a05v18n3.pdf>. Acesso em: 20 nov. 2015.

KENSKI, Vani Moreira. Tecnologias e ensino presencial e a distância. Campinas: Papirus, 2010.

PRIMO, Alex. Interação mediada por computador: comunicação, cibercultura, cognição. Porto Alegre: Sulina, 2008.

ROSADO, Luiz Alexandre da Silva; TOMÉ, Vítor Manuel Nabais. As redes sociais na internet e suas apropriações por jovens brasileiros e portugueses em idade escolar. Revista Brasileira de Estudos Pedagógicos, Vol. 96, No 242 (2015). Disponível em: <

http://rbep.inep.gov.br/index.php/RBEP/article/view/3246/0 >. Acesso em: maio 2015.

SANTAELLA, Lúcia. A ecologia pluralista da comunicação: conectividade, mobilidade, ubiquidade. São Paulo: Paulus, 2010.

SANTOS, Glauber Eduardo de Oliveira. Cálculo amostral: calculadora on-line. Disponível em: <http://www.calculoamostral.vai.la>. Acesso em: [data do acesso].

SNYDER, Ilana. Ame-os ou deixe-os: navegando no panorama de letramentos em tempos digitais. In: ARAÚJO, Júlio César; DIEB, Messias. Letramentos na web: gêneros, interação e ensino. Fortaleza: Edições UFC. 2009. p. 23-46.

XAVIER, Antônio Carlos dos Santos. Letramento digital e ensino. 2005. Disponível em: <https://www.ufpe.br/nehte/artigos/Letramento\%20digital\%20e\%20ensino.pdf>. Acesso em: 21 mar. 2015.

Maria Aparecida de Faria Gomes

Centro Universitário do Leste de Minas Gerais - UNILESTE-, Brasil, mafgomes@unilestemg.br

Hiolanda Ladislau Vieira

Centro Universitário do Leste de Minas Gerais - UNILESTE-, Brasil, hiolandalv@gmail.com

Rita Alves Luna

Bolsista BicJ r - FAPEMI G - ritalunaal@gmail.com 


\title{
Avaliação da utilização de Recursos de Ensino On-line Relacionados a Diferentes Estilos de Aprendizagem
}

\section{Evaluation of the Use of Online Resources Related to Different Learning Styles}

\author{
Anderon Amendoeira Namen \\ Universidade Veiga de Almeida / Universidade do Estado do Rio de Janeiro \\ Cassia Mousinho de Figueredo \\ Universidade Veiga de Almeida \\ Danielle Spada Tavares \\ Universidade Veiga de Almeida \\ Elisa Troian Rodrigues \\ Universidade Veiga de Almeida \\ Paulo Marcos Figueiredo de Andrade \\ Universidade Veiga de Almeida \\ Reynaldo Gomes Lopes \\ Universidade Veiga de Almeida
}

Resumo: O presente trabalho apresenta os resultados de uma pesquisa que objetivou a criação de recursos on-line para apoio ao ensino de uma disciplina presencial de cursos de engenharia, com foco na criação de objetos de aprendizagem que pudessem atender aos diferentes estilos de aprendizagem dos estudantes. A partir da identificação dos estilos de aprendizagem de cada aluno, realizou-se a avaliação do seu comportamento com relação aos diferentes objetos. Mais do que avaliar o comportamento dos estudantes, o principal foco do trabalho foi desenvolver recursos de ensino que pudessem responder aos diferentes perfis de aprendizagem, de modo a contribuir para a melhoria do processo de ensino-aprendizagem.

Palavras-chave: Educação. Estilos de Aprendizagem. Ambiente On-line. Práticas Pedagógicas.

Abstract: This paper presents the results of a research aimed at creating online resources to support the teaching of a classroom discipline in engineering courses. The focus was on creating learning objects that could meet the different students' learning styles. From the identification of the students' learning styles, an evaluation of their behavior was made with respect to different learning objects. More than evaluating the students' behavior, the main focus of this work was to develop learning resources that could respond to different learning profiles, in order to contribute to the improvement of the teaching-learning process.

Keywords: Education. Learning Styles. Online Environment. Pedagogic Practices. 


\section{I ntroducão}

O ensino das diferentes ciências ainda se caracteriza pela utilização de métodos convencionais, baseados na transmissão de conhecimento por intermédio de aulas expositivas, onde a participação dos alunos, na maioria das vezes, ocorre de forma passiva e individual. A atuação do professor, de uma forma geral, tende à homogeneização discente, o que significa, na maioria das vezes, não atingir a todos os estudantes. Alunos com diferentes perfis acabam sendo excluídos do processo educativo, implicando em reprovações e abandono, justificados, muitas vezes de forma limitada, devido à insatisfação com o curso escolhido (SENRA, 2009).

Segundo Houghes (2004), o foco central do processo educacional é o aprendizado, sendo possível alcançar a excelência somente por meio do conhecimento das necessidades individuais e coletivas, utilizando a consciência a favor da escolha de um estímulo, material ou método adequados. Conforme Ferraz (2008), deve se ter a percepção de que quanto mais forem satisfeitas as necessidades e preferências por estímulos específicos de aprendizagem, melhor será a efetividade do processo. Esse cuidado com a satisfação das preferências educacionais presentes em um grupo heterogêneo de aprendizes é fundamental durante o planejamento e a implementação de materiais instrucionais.

Myers e Myers (1997) afirmam que existe uma diferença natural e previsível entre os tipos de personalidade dos estudantes e suas respostas aos diferentes métodos de ensino. Os autores afirmam que o entendimento das diferentes personalidades e, em paralelo, dos diferentes estilos de aprendizagem, pode explicar as razões para a rejeição de certos estudantes a um determinado método educativo, ao mesmo tempo em que outros se sentem confortáveis com o mesmo. Para Felder e Brent (2005), estratégias e metodologias mais adequadas devem ser definidas com o propósito de aumentar a eficácia das aulas e reduzir a insatisfação dos estudantes, o que poderia reduzir o alto índice de repetência e a evasão nos cursos superiores.

Nesse sentido, aplicar a teoria dos estilos de aprendizagem, conforme preconizado por Gardner (1994), pode ser uma alternativa válida quando o objetivo buscado se refere à melhoria do desempenho escolar, reconhecendo-se as diferenças e as singularidades dos sujeitos aprendizes. Segundo Bordenave e Pereira (2001), essa teoria contempla a maneira pela qual os indivíduos interagem com as condições de aprendizagem, abrangendo aspectos ambientais, afetivos e cognitivos, que podem favorecer o processamento de informações, tanto na busca de alternativas facilitadoras para o desencadear do próprio processo de aprendizagem, quanto na investigação dos mecanismos das práticas educativas que produzem o sucesso ou o chamado fracasso escolar.

Dentro dessa perspectiva, o presente trabalho apresenta os resultados de uma pesquisa que objetivou a criação de recursos on-line para apoio ao ensino presencial de uma disciplina pertencente ao ciclo básico dos cursos de engenharia da Universidade Veiga de Almeida, na cidade do Rio de Janeiro. Mais especificamente, o foco da pesquisa foi o desenvolvimento de objetos de aprendizagem on-line que pudessem atender aos diferentes estilos de aprendizagem dos estudantes. Adicionalmente, avaliou-se o comportamento dos alunos no ambiente de ensino a distância (nível e tempo de interação com os objetos e resultados das respostas aos questionários de avaliação de cada objeto), de acordo com os diferentes perfis dos alunos.

Esse artigo está organizado da seguinte maneira. Na Seção 2, é apresentada uma visão geral sobre os estilos de aprendizagem, dando-se enfoque ao modelo de Felder e Silverman. A seção 3 apresenta a metodologia utilizada no trabalho, envolvendo a criação de recursos de aprendizagem para os diferentes estilos. Em seguida, na seção 4, são apresentados os resultados da análise do comportamento dos alunos diante dos diferentes objetos de aprendizagem, de acordo com os diferentes perfis. Finalmente, são apresentadas as conclusões do presente trabalho. 


\section{Estilos de Aprendizagem}

A conceituação de Estilos de Aprendizagem (EAs) não é um consenso entre os pesquisadores do assunto, porém as diferenças conceituais não se contrapõem aos conceitos centrais. Dunn, Dunn e Price (1979) afirmam que EAs correspondem às diferentes maneiras pelas quais os indivíduos respondem aos estímulos ambientais, emocionais, sociológicos e físicos. Para Hunt (1979), a definição de EA se baseia nas condições educativas e/ou estruturas adequadas com as quais os aprendizes se encontram mais confortáveis para um melhor aprendizado. Keefe (1982), por sua vez, afirma que os EAs são constituídos por traços cognitivos, afetivos e fisiológicos, que funcionam como indicadores, relativamente estáveis, das formas que os alunos percebem, interagem e respondem ao ambiente de aprendizagem. Para Smith (1988), EAs são como os modelos característicos pelos quais um indivíduo processa a informação, sente e se comporta nas situações de aprendizagem. Outra definição de Dunn (1989), indica que EAs se relacionam às condições através das quais os aprendizes começam a concentrar-se, absorver, processar e reter informações e habilidades novas e difíceis, sendo que a interação entre esses elementos ocorre de modo diferente para cada pessoa em particular.

Independentemente das diferentes conceituações, sabe-se que cada indivíduo possui habilidades, preferências, peculiaridades e maneiras próprias de pensar e agir. Essa premissa também é válida sob a ótica do processo de aprendizagem, ou seja, cada sujeito possui um ritmo e forma diferenciada de receber e processar as informações. Essas diferentes formas de perceber e trabalhar as informações no âmbito da aquisição de novos conhecimentos podem ser caracterizadas como estilos de aprendizagem.

Diferentes modelos de EAs são apresentados na literatura, como os modelos de Dunn, Dunn e Price (1979), Honey e Mumford (1982), Schemeck (1983), Kolb (1984), e Felder e Silverman (1988). Ainda que existam aspectos específicos em relação aos diferentes modelos de EAs, em todos eles compartilha-se a opinião de que os aprendizes possuem diferentes preferências relacionadas ao processo de aprendizagem (GRAF; KINSHUK; LIU, 2008). Quando existem incompatibilidades entre os estilos de aprendizagem dos alunos e o estilo de ensino do professor, os primeiros podem se tornar insatisfeitos e desatentos em classe, perdendo o estímulo em relação às atividades, obtendo resultados insatisfatórios nas avaliações, e, até mesmo, abandonando os estudos. Para dirimir estes problemas, os professores devem se esforçar por um equilíbrio entre métodos de ensino que considerem os diferentes estilos. De acordo com Felder e Brent (2005), quanto maior a compreensão dos professores em relação a essas diferenças, maior a chance de atendimento às diferentes demandas relacionadas ao processo de ensino-aprendizagem.

Esta pesquisa toma por base o modelo de Felder e Silverman (1988). Os autores enumeram quatro dimensões relacionadas aos EAs. Uma dessas dimensões é denominada Processamento. Nessa dimensão os alunos podem ser classificados como ativos ou reflexivos. Os primeiros tendem a processar e reter a informação participando ativamente de alguma atividade (discutindo, aplicando e explicando para colegas); são rápidos, mas podem ser precipitados, e gostam de trabalhar em grupo. Os reflexivos, por sua vez, refletem mais sobre a informação, são mais lentos mas tendem a ser mais cuidadosos, e gostam de trabalhar individualmente.

A dimensão Entrada, por sua vez, se refere ao tipo de entrada mais efetivo para os aprendizes, caracterizando-os como verbais ou visuais. Alunos verbais preferem explicações escritas ou faladas à demonstração visual, enquanto os visuais preferem lidar com as representações visuais (gráficos, diagramas, vídeos, quadros). 
Quanto à dimensão Percepção, observa-se a existência de estudantes sensoriais e intuitivos. Estes últimos gostam de desafios, preferem descobrir inter-relações entre elementos, sentindo-se confortáveis com abstrações e desconfortáveis com cálculos rotineiros. Os sensoriais, por outro lado, gostam de resolver problemas através de procedimentos bem estabelecidos, tendem a ser práticos e memorizam fatos com facilidade.

Finalmente, a dimensão Progresso está relacionada ao modo como o estudante progride na construção de seu entendimento. Aprendizes sequenciais, por exemplo, obtém entendimento em passos lineares, de forma sequencial, tendendo a seguir caminhos lógicos e graduais na solução de um problema. Os globais, por outro lado, privilegiam o contexto, o grande quadro, tendo foco na síntese, no pensamento sistêmico.

Cabe ressaltar que cada indivíduo possuirá diferentes comportamentos nas quatro dimensões, não necessariamente possuindo características dominantes em cada uma delas. Por exemplo, um determinado aprendiz poderia possuir um forte perfil visual (dimensão Entrada) e intuitivo (dimensão Percepção), sem ter comportamento dominante nas outras duas dimensões - Processamento (ativo ou reflexivo) e Progresso (sequencial ou global). Convém salientar que o perfil de cada aluno não reflete a sua adequação ou inadequação a determinada carreira e não faz qualquer sentido apresentar recomendações de currículos de estudo com base nos EAs dos estudantes (FELDER; BRENT, 2005).

Ao responder a diversos questionamentos relacionados aos EAs, Felder (2010) afirma que no lugar de ensinar de acordo com o EA de cada sujeito, a grande questão é alcançar o equilíbrio, assegurando que cada estilo seja trabalhado em um nível mínimo ao longo do processo ensino-aprendizagem. Segundo o autor, para obter sucesso em sua vida profissional, os estudantes precisam de atributos associados a todas as categorias dos EAs. Relembrando Bauman (2001), no mundo mutável da modernidade líquida, onde dificilmente as figuras conseguem manter a sua forma por tempo suficiente para dar confiança e solidificar-se de modo a oferecer garantia a longo prazo, não basta privilegiar exclusivamente o estilo preferencial dos aprendizes; estes não desenvolveriam a destreza mental e não alcançariam a "solidez" necessária para a sua realização acadêmica e profissional.

\section{1 Í ndice de Estilos de Aprendizagem}

O Índice de Estilos de Aprendizagem (Index of Learning Styles - ILS) é um instrumento desenvolvido para identificar as preferências de aprendizagem nas quatro dimensões anteriormente mencionadas. Trata-se de um questionário contendo 44 perguntas, sendo cada dimensão abordada por onze questões; as respostas a estas fornecem dois escores que correspondem aos dois estilos da respectiva dimensão abordada (visual ou verbal, ativo ou reflexivo, sensorial ou intuitivo, sequencial ou global). O questionário pode ser respondido online em http://www.engr.ncsu.edu/learningstyles/ilsweb.html.

Após responder a todas as 44 perguntas, é feito o cômputo dos escores finais que variam na escala de 1 a 11 para cada estilo. Analisando-se o resultado para cada dimensão, a obtenção de uma pontuação entre 1 e 3 indica leve preferência por determinado estilo, significando que há praticamente um equilíbrio entre as duas categorias pertencentes à respectiva dimensão; escores entre 5 e 7 indicam moderada preferência por uma das categorias; finalmente, pontuação entre 9 e 11 caracteriza forte preferência por determinada categoria na dimensão. A Figura 1 apresenta um exemplo relacionado à dimensão Entrada, com a escala variando de 1 a 11 entre os estilos de aprendizagem verbal e visual e a classificação do suposto aluno, com pontuação 7, na direção da categoria visual, indicando um estilo moderadamente visual. 
Figura 1 - Exemplo de classificação indicando um estilo de aprendizagem visual moderado (Dimensão Entrada)

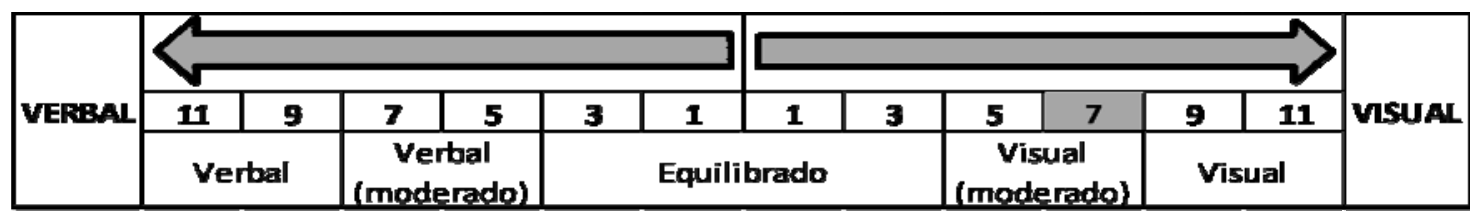

Fonte: Elaborado pelos próprios autores.

Felder e Spurlin (2005) examinam o ILS, apresentando conclusões sobre a validade e confiabilidade de várias pesquisas desenvolvidas a partir do instrumento. Esses autores concordam com os trabalhos desenvolvidos por Livesay et al. (2002) e Zywno (2003), que afirmam que o instrumento é confiável e adequado para a identificação dos EAs, recomendando que as pesquisas com tal instrumento continuem a ser realizadas.

\subsection{EAs e análise da interação com ambiente on-line}

Jonhson et al. (2013) indicam a tendência de aumento de projetos visando à análise da interação dos estudantes com o ambiente on-line. Segundo os autores, a consolidação e amadurecimento de experimentos que efetuam a análise do comportamento dos alunos no ambiente on-line pode contribuir para a melhoria dos resultados no processo de ensinoaprendizagem.

Abordando, mais especificamente, a questão dos EAs, algumas pesquisas identificaram relações entre o comportamento dos alunos no ambiente virtual e suas preferências de aprendizagem. Desse modo, para identificar o EA de determinado aprendiz, não somente o ILS é passível de ser aplicado, podendo-se utilizar recursos computacionais para registro e análise da interação dos alunos com os objetos de aprendizagem no ambiente de ensino a distância.

Trabalhos como o de Graf (2007), Graf, Kinshuk e Liu (2008) e Hoehstein et al. (2011) apresentam dados que inter-relacionam o comportamento dos alunos no ambiente virtual e as suas preferências em relação à aprendizagem. A título de ilustração, alunos ativos, por exemplo, costumam postar mais informações em fóruns on-line e executar mais testes de autoavaliação, respondendo-os em menos tempo que os alunos reflexivos. Alunos sensoriais, por sua vez, tendem a fazer mais visitas e gastar mais tempo em recursos on-line que apresentam exemplos concretos, do que os alunos intuitivos, que, por outro lado, costumam gastar mais tempo e fazer mais visitas em objetos de aprendizagem que apresentam conceitos e teorias. Os Quadros 1 a 4 apresentam um sumário relacionando comportamento e EA de cada aluno, com base nos trabalhos acima listados.

Quadro 1 - Comportamento dos estudantes - Dimensão Processamento

\begin{tabular}{|l|l|}
\hline \multicolumn{1}{|c|}{ Ativos } & \multicolumn{1}{|c|}{ Reflexivos } \\
\hline $\begin{array}{l}\text { Fóruns: postam mais informação } \\
\text { (perguntam, discutem, falam sobre algo) }\end{array}$ & $\begin{array}{l}\text { Fóruns: lêem os posts, raramente } \\
\text { postam informação }\end{array}$ \\
\hline $\begin{array}{l}\text { Respondem mais aos testes de } \\
\text { autoavaliação, acessando diversas vezes os } \\
\text { questionários }\end{array}$ & $\begin{array}{l}\text { Gastam mais tempo para responder aos } \\
\text { testes de autoavaliação }\end{array}$ \\
\hline $\begin{array}{l}\text { Primeiro fazem os exercícios e depois olham } \\
\text { os exemplos }\end{array}$ & $\begin{array}{l}\text { Primeiro olham os exemplos e depois } \\
\text { fazem os exercícios }\end{array}$ \\
\hline Gastam menos tempo olhando exemplos & $\begin{array}{l}\text { Gastam mais tempo olhando os exemplos } \\
\text { e fazem mais visitas aos mesmos }\end{array}$ \\
\hline
\end{tabular}




\begin{tabular}{|l|l|l|}
\hline $\begin{array}{l}\text { Muitas vezes erram a mesma questão (que } \\
\text { erraram na 1a. vez) na 2a. tentativa }\end{array}$ & $\begin{array}{l}\text { Geralmente acertam a mesma questão } \\
\text { (que erraram na 1a. vez) na 2a. tentativa }\end{array}$ \\
\hline Melhores em questões que envolvem fatos & $\begin{array}{l}\text { Gastam mais tempo refletindo sobre os } \\
\text { resultados de testes e exercícios }\end{array}$ \\
\hline $\begin{array}{l}\text { Acessam menos os sumários e as as as } \\
\text { conclusões }\end{array}$ & $\begin{array}{l}\text { Acessam mais os sumários e as } \\
\text { conclusões }\end{array}$ \\
\hline $\begin{array}{l}\text { Gastam menos tempo interagindo com os os } \\
\text { objetos de conteúdo }\end{array}$ & $\begin{array}{l}\text { Gastam mais tempo interagindo com os } \\
\text { objetos de conteúdo }\end{array}$ \\
\hline
\end{tabular}

Fonte: Elaborado pelos próprios autores.

Quadro 2 - Comportamento dos estudantes - Dimensão Progresso

\begin{tabular}{|l|l|}
\hline \multicolumn{1}{|c|}{ Sequenciais } & \multicolumn{1}{|c|}{ Globais } \\
\hline Favorecem os detalhes & Olham o “quadro inteiro" e as conexões \\
\hline $\begin{array}{l}\text { Navegam no curso "passo a passo" de modo } \\
\text { linear }\end{array}$ & $\begin{array}{l}\text { Navegam pulando objetos de } \\
\text { aprendizagem e indo para material mais } \\
\text { complexo }\end{array}$ \\
\hline $\begin{array}{l}\text { Primeiro acessam o conteúdo e depois } \\
\text { fazem o exercício }\end{array}$ & $\begin{array}{l}\text { Podem fazer o exercício antes de ver } \\
\text { todo o conteúdo }\end{array}$ \\
\hline $\begin{array}{l}\text { Visitam exemplos antes de objetos de } \\
\text { conteúdo }\end{array}$ & $\begin{array}{l}\text { Fazem mais visitas e gastam mais tempo } \\
\text { nos sumários e nas conclusões }\end{array}$ \\
\hline
\end{tabular}

Fonte: Elaborado pelos próprios autores.

Quadro 3 - Comportamento dos estudantes - Dimensão Entrada

\begin{tabular}{|l|l|}
\hline \multicolumn{1}{|c|}{ Visuais } & \multicolumn{1}{|c|}{ Verbais } \\
\hline Gráficos & Palavras \\
\hline Imagens & $\begin{array}{l}\text { Se comunicam e discutem mais com os } \\
\text { colegas }\end{array}$ \\
\hline Flowcharts & $\begin{array}{l}\text { Participam mais com } \\
\text { posts/visitas/discussões em fóruns) }\end{array}$ \\
\hline Vídeos e demonstrações & Material com conteúdos escritos/falados \\
\hline
\end{tabular}

Fonte: Elaborado pelos próprios autores.

Quadro 4 - Comportamento dos estudantes - Dimensão Percepção

\begin{tabular}{|l|l|}
\hline \multicolumn{1}{|c|}{ Sensoriais } & \multicolumn{1}{|c|}{ I ntuitivos } \\
\hline $\begin{array}{l}\text { Favorecem materiais concretos (dados, } \\
\text { fatos, etc) }\end{array}$ & $\begin{array}{l}\text { Favorecem materiais abstratos (teorias, } \\
\text { mensagens implícitas, etc) }\end{array}$ \\
\hline $\begin{array}{l}\text { Fazem mais visitas e gastam mais tempo } \\
\text { observando exemplos }\end{array}$ & $\begin{array}{l}\text { Fazem menos visitas e gastam menos } \\
\text { tempo observando exemplos }\end{array}$ \\
\hline
\end{tabular}




\begin{tabular}{|l|l|l|}
\hline $\begin{array}{l}\text { Fazem menos visitas e gastam menos } \\
\text { tempo estudando teorias e conceitos }\end{array}$ & $\begin{array}{l}\text { Fazem mais visitas e gastam mais tempo } \\
\text { estudando teorias e conceitos }\end{array}$ \\
\hline $\begin{array}{l}\text { Resolvem exemplos/problemas com base } \\
\text { em procedimentos padronizados }\end{array}$ & Resolvem problemas com mais desafios \\
\hline $\begin{array}{l}\text { Preferem testes/exercícios “conduzidos” de } \\
\text { autoavaliação } \\
\text { surpresas/complicações) }\end{array}$ & $\begin{array}{l}\text { Preferem testes/exercícios com busca de } \\
\text { novas soluções (demanda conhecimento } \\
\text { sobre teorias/conceitos) }\end{array}$ \\
\hline $\begin{array}{l}\text { Mais pacientes com detalhes } \\
\text { Fazem maior número de revisões antes de ir } \\
\text { para os testes de avaliação }\end{array}$ & $\begin{array}{l}\text { Gostam de encontrar conexões por conta } \\
\text { própria }\end{array}$ \\
\hline $\begin{array}{l}\text { Primeiro fazem os testes de avaliação e } \\
\text { depois olham o conteúdo }\end{array}$ \\
\hline
\end{tabular}

Fonte: Elaborado pelos próprios autores.

\section{Metodologia}

O presente trabalho foi desenvolvido junto a alunos de três turmas da disciplina Laboratório de Criatividade e Inovação, disciplina presencial ministrada no segundo período dos cursos de engenharia da Universidade Veiga de Almeida. Três professoras lecionavam para essas turmas e 64 alunos estiveram envolvidos na análise.

A pesquisa foi desenvolvida em três etapas:

1) Aplicação do questionário, traduzido para a língua portuguesa pelos pesquisadores, para identificação dos EAs dos estudantes (ILS);

2) Criação e aplicação dos recursos de aprendizagem on-line, atendendo aos diferentes EAs, para apoiar o ensino presencial;

3) Análise do comportamento e dos registros de interação dos alunos com os recursos on-line, e comparação com os resultados do ILS (item 1).

\subsection{Aplicação do questionário}

O questionário foi disponibilizado on-line utilizando-se a ferramenta Google Forms, recurso para criação de formulários na Web. Uma vez respondidas as questões pelos alunos, o respectivo cálculo dos escores relacionados aos EAs foi realizado, sendo esses dados armazenados em uma base de dados para posterior comparação com os resultados obtidos a partir dos registros de interação dos estudantes com os recursos on-line (etapa 3 da pesquisa).

\subsection{Elaboração e aplicação dos recursos de aprendizagem}

Foram desenvolvidos recursos de aprendizagem acessíveis pela Internet para três dimensões de EAs: Processamento (Ativo/Reflexivo), Percepção (Sensorial/Intuitivo) e Entrada (Visual/Verbal). Esses recursos englobavam parte do conteúdo programático da disciplina e foram aplicados visando complementar os conteúdos vistos em sala de aula. A presente pesquisa não considerou a dimensão Progresso (Sequencial/Global), não obtendo quaisquer conclusões relacionadas a essa dimensão.

Para a dimensão Processamento foi desenvolvido um texto em pdf denominado "A Criatividade e Seu Papel na Formação do Engenheiro", bem como um questionário de avaliação, contendo 5 questões de múltipla escolha, a ser respondido pelo aluno no ambiente on-line. Conforme mencionado, alunos ativos possuem comportamento distinto em comparação 
aos reflexivos no que se refere ao número de vezes em que respondem aos questionários de avaliação e ao tempo de resposta. Desse modo, o objetivo buscado foi analisar os resultados de interação com os questionários aplicados ao texto, resultados estes apresentados mais adiante, na Seção 4.

Em relação à dimensão Percepção, foram desenvolvidos 2 vídeos que abordavam o tema "Modelos Mentais". O primeiro deles foi elaborado pensando-se em aprendizes intuitivos. Esse vídeo (Figura 2) apresentava dois professores utilizando massas de modelar para criar diferentes formas geométricas e, a partir da elaboração desses diferentes objetos, deixava-se aberta, para os alunos, a possibilidade de descobrir as relações e influências dos modelos mentais nas ações e percepções dos indivíduos. Cabe ressaltar que todos os professores que participaram da produção dos materiais didáticos, assinaram um Termo de Consentimento Livre e Esclarecido, autorizando a divulgação dos materiais produzidos, vídeos e imagens, assim como dos resultados da pesquisa.

Figura 2 - Vídeo sobre Modelos Mentais - alunos intuitivos

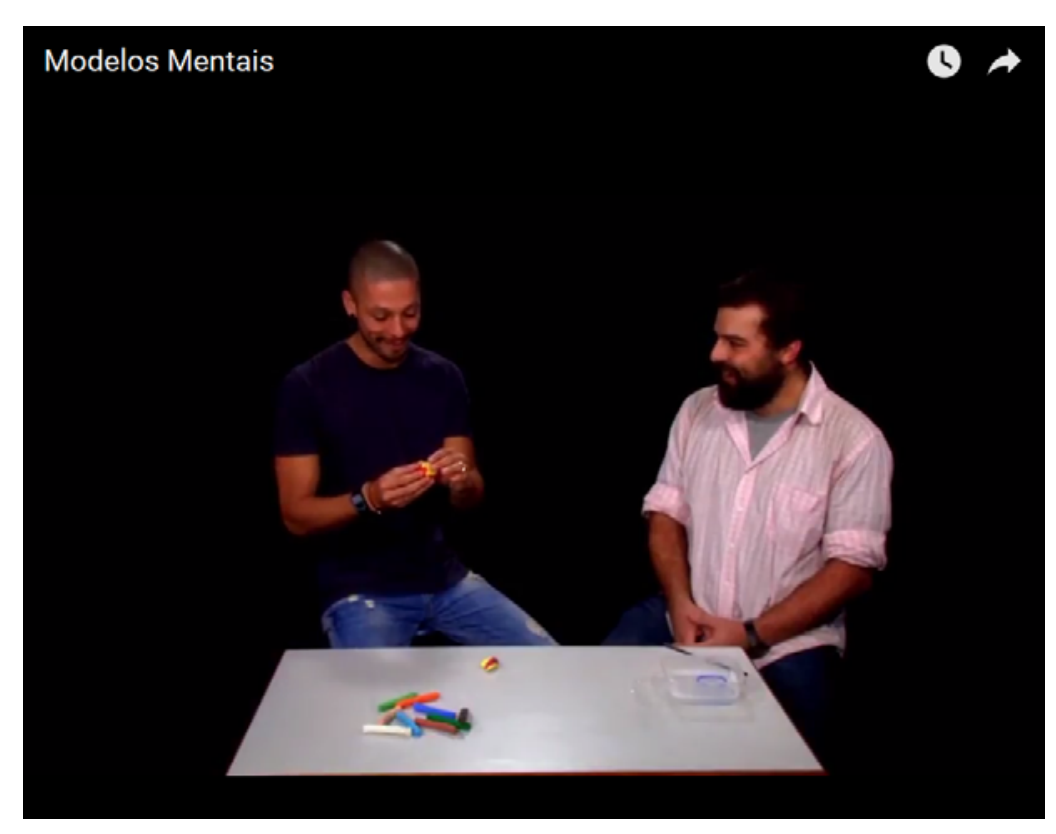

Fonte: Elaborado pelos próprios autores.

O segundo vídeo (Figura 3) tinha como foco estudantes sensoriais. Uma professora discorria sobre o mesmo tema (Modelos Mentais), mas com uma abordagem muito mais concreta, apresentando fatos e exemplos concretos sobre modelos mentais e suas aplicações. 


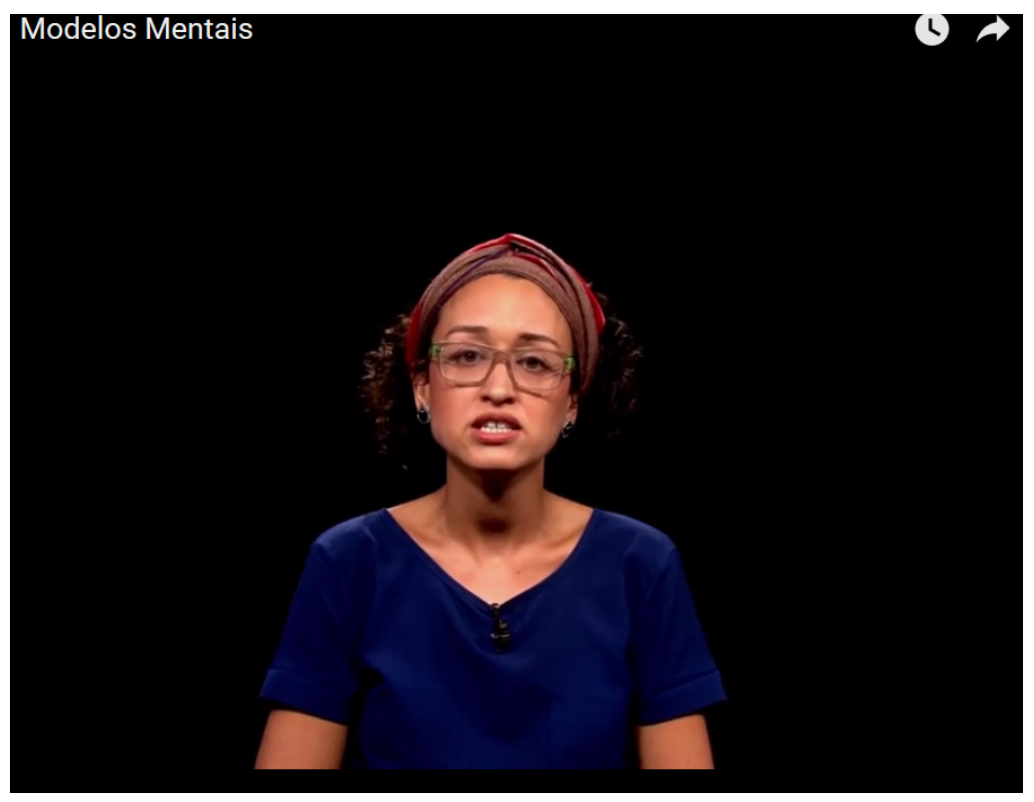

Fonte: Elaborado pelos próprios autores.

Para cada vídeo foram elaboradas questões de múltipla escolha, que o aluno deveria responder após assisti-lo. O objetivo do questionário foi o de permitir a avaliação dos resultados das respostas dos alunos, de acordo com o seu EA, visando avaliar o aprendizado dos alunos em relação a cada objeto de aprendizagem.

Pressupunha-se que alunos intuitivos obteriam mais acertos do que alunos sensoriais ao responder o questionário do primeiro vídeo mencionado (massas de modelar); alunos sensoriais, por sua vez, obteriam melhores resultados nas respostas aos questionários relacionados ao vídeo sensorial (segundo vídeo mencionado). Essa análise será apresentada na Seção 4.

Finalmente, foram elaborados quatro objetos de aprendizagem abordando o tema "Ferramentas de Criatividade" e relacionados à dimensão Entrada, dois com foco em alunos visuais e os outros dois em alunos verbais. Estes últimos foram desenvolvidos utilizando-se a técnica de animação tipográfica (mais detalhes em LEE; FORLIZZI; HUDSON, 2002). Foram utilizados e manipulados elementos tipográficos com a adição de elementos sonoros, mas sem a utilização de figuras. A Figura 4 apresenta trecho de um dos dois vídeos onde foi aplicada essa técnica. 


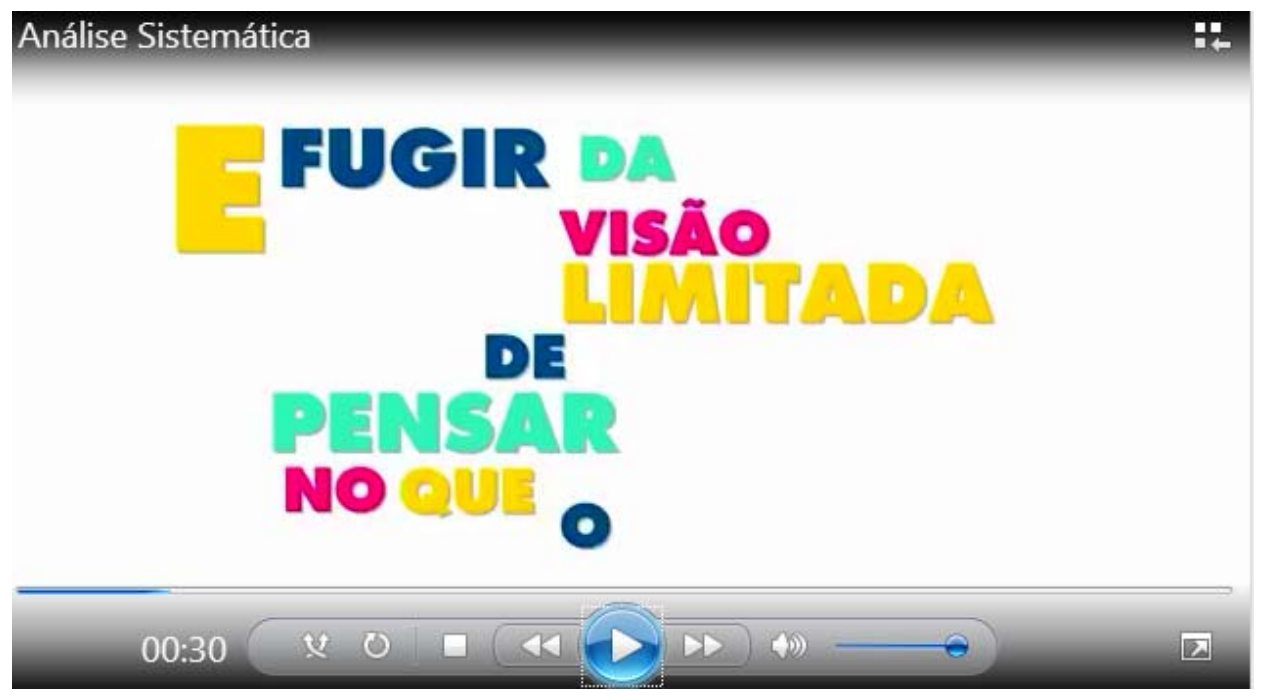

Fonte: Elaborado pelos próprios autores.

A Figura 5 ilustra uma cena de um dos vídeos criados para atendimento ao EA voltado para o aluno visual. Nos dois vídeos desenvolvidos para esse estio, buscou-se trabalhar com animações repletas de desenhos e figuras que ilustravam o conteúdo, com o acompanhamento, em paralelo, de respectiva narração.

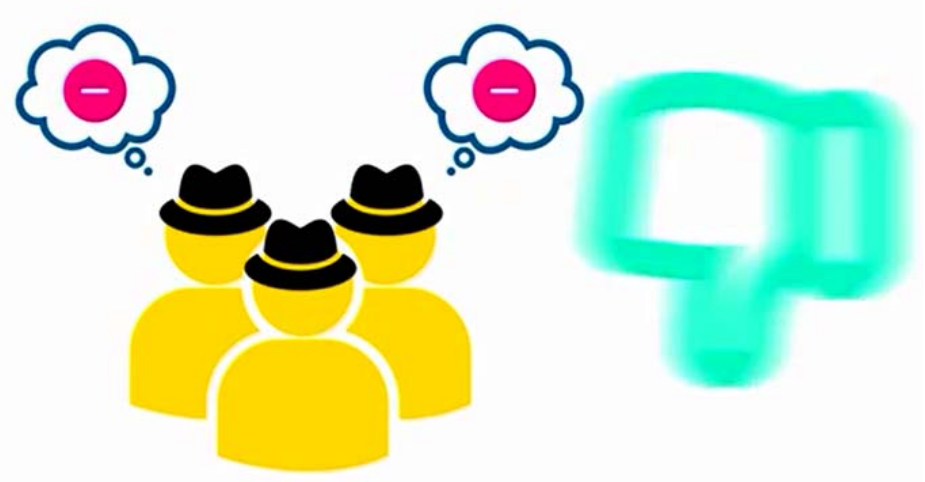

Fonte: Elaborado pelos próprios autores. 
Assim como nos outros objetos relacionados às outras duas dimensões envolvidas na presente pesquisa, utilizou-se a estratégia de aplicação de questionários de avaliação para cada um dos quatro objetos de aprendizagem desenvolvidos para a dimensão Entrada. Com base no índice de acertos dos alunos nas respostas aos questionários, bem como nos seus diferentes EAs, tornou-se viável realizar uma avaliação do comportamento dos estudantes frente aos diferentes objetos desenvolvidos.

\section{Resultados}

Conforme mencionado, foi avaliado apenas o comportamento dos estudantes com relação às dimensões de EAs Processamento, Entrada e Percepção, já que não foram desenvolvidos recursos de aprendizagem relacionados à dimensão Progresso (Sequencial/Global).

A avaliação da dimensão Processamento (Ativo/Reflexivo) foi feita a partir da análise da interação dos alunos com o objeto de aprendizagem disponibilizado (texto em pdf) e com os questionários de avaliação. O foco foi identificar o perfil dos aprendizes, obtido por intermédio do questionário com o índice de EA (ILS), e avaliar o número de acessos aos objetos e o tempo médio de interação, tudo isso com base nos registros de acesso aos recursos armazenados no ambiente on-line. Cabe ressaltar que o foco se concentrou nos alunos com escores maiores ou iguais a 5 (em uma escala de 1 a 11), tanto na classificação ativa como na reflexiva, já que escores inferiores caracterizavam certo equilíbrio na respectiva dimensão.

O Quadro 5 apresenta alguns dados relacionados à interação dos alunos com os recursos (texto em pdf e questionário de avaliação) disponibilizados para a dimensão Entrada. Pode ser observado que, dos 64 alunos que eram objeto da pesquisa, apenas 34 se encontravam nas faixas mais extremas relacionadas aos EAs da dimensão Processamento. No quadro são listados dados como o número médio de acessos ao texto e ao questionário, bem como o tempo médio para a conclusão das respostas ao questionário.

Quadro 5 - Dados da interação dos alunos ativos e reflexivos

\begin{tabular}{|c|c|c|c|c|}
\hline Perfil & $\begin{array}{c}\text { Número de } \\
\text { alunos }\end{array}$ & $\begin{array}{c}\text { Número médio } \\
\text { de acessos ao } \\
\text { texto }\end{array}$ & $\begin{array}{c}\text { Número médio de } \\
\text { acessos ao } \\
\text { questionário }\end{array}$ & $\begin{array}{c}\text { Tempo médio para } \\
\text { conclusão do } \\
\text { questionário } \\
\text { (minutos) }\end{array}$ \\
\hline ATIVO (5 a 11) & 23 & 1,48 & 1,17 & 15,73 \\
\hline REFLEXIVO (5 a 11) & 11 & 1,45 & 1,09 & 16,65 \\
\hline
\end{tabular}

Fonte: Elaborado pelos próprios autores.

Os padrões apresentados no quadro se mostraram condizentes com o esperado, ou seja, os alunos ativos tiveram um número maior de interações (acessos ao texto e questionário) e um menor tempo de resposta em relação aos alunos reflexivos.

A análise da dimensão Entrada tomou como base a quantidade de acertos nas respostas aos questionários de avaliação referentes aos dois vídeos visuais e aos dois vídeos verbais. Assim como efetuado na análise da dimensão Processamento, foram considerados apenas os alunos posicionados nas faixas mais extremas (escores maiores ou iguais a 5), o que englobou 
um número de 30 estudantes, sendo apenas quatro com perfil verbal. O Quadro 6 apresenta os resultados.

Quadro 6 - Dados da interação dos alunos visuais/verbais

\begin{tabular}{|c|c|c|c|c|c|}
\hline Perfil & $\begin{array}{c}\text { Número } \\
\text { de } \\
\text { alunos }\end{array}$ & $\begin{array}{c}\text { Nota média } \\
\text { vídeo visual } \\
\mathbf{1}\end{array}$ & $\begin{array}{c}\text { Nota média } \\
\text { vídeo visual } \\
\mathbf{2}\end{array}$ & $\begin{array}{c}\text { Nota média } \\
\text { vídeo verbal } \mathbf{1}\end{array}$ & $\begin{array}{c}\text { Nota média } \\
\text { vídeo verbal } \mathbf{2}\end{array}$ \\
\hline VERBAL (5 a 11) & 4 & 6,66 & 6,67 & 5 & 5,6 \\
\hline VISUAL ( 5 a 11 ) & 26 & 6,66 & 7,74 & 5,28 & 6,08 \\
\hline
\end{tabular}

Fonte: Elaborado pelos próprios autores.

Analisando os dados do quadro, pode-se concluir que os alunos visuais obtiveram melhor desempenho nos questionários referentes aos objetos visuais (médias 6,66 e 7,74), comparando-se com os resultados obtidos para os objetos verbais (médias 5,28 e 6,08), atendendo ao padrão esperado. Essa informação pode ser considerada nas análises, pois o número de alunos abrangido de alunos visuais é bastante razoável. Contudo, conclusão análoga não pode ser obtida dos alunos verbais, já que a quantidade limitada de alunos nesse perfil (apenas 4 alunos), prejudica qualquer avaliação estatística.

A estratégia utilizada para avaliação dos resultados da interação dos alunos da dimensão Percepção (Intuitivos/Sensoriais) foi comparar as médias de acertos dos questionários de avaliação referentes aos objetos focados nos EAs intuitivo e sensorial. Cabe ressaltar que, considerando-se todos os alunos envolvidos, independentemente do EA, a quantidade geral de acertos referente aos questionários do recurso de aprendizagem focado no perfil intuitivo ( édia $=6,72$ ) foi bem maior que a quantidade para o recurso com foco nos alunos sensoriais (média $=4,31$ ). Em outras palavras, os índices de proficiência relacionados ao objeto do EA sensorial foram bem menores que os relacionados ao objeto referente ao EA intuitivo. Uma possível explicação para o fato é que o vídeo relacionado a este último objeto trabalhava com a ludicidade, a partir do uso e da manipulação de massas de modelar, o que pode ter despertado maior interesse e atenção dos alunos, independentemente de seu EA. Ou seja, apesar do vídeo não abordar diretamente a questão dos modelos mentais, e buscar a criação de uma interrelação entre a manipulação de massas de modelar com o conceito de modelos mentais, o que, teoricamente, não atenderia diretamente aos alunos de perfil sensorial, acredita-se que a abordagem utilizada, a partir de uma atividade lúdica (no lugar de uma explanação do professor, caso do vídeo de perfil sensorial), pode ter despertado maior interesse e atenção dos alunos, inclusive os sensoriais. Essa conclusão corrobora as visões de Vygotsky (2009) e Piaget (1964) de que as relações entre desenvolvimento e aprendizagem resgatam a importância das atividades lúdicas na formação da inteligência, a partir da reprodução de situações vividas no cotidiano do estudante.

Apesar do fato acima exposto, ainda foi efetuada a comparação dos índices de proficiência dos alunos sensoriais e intuitivos, equivalente a um total de 32 alunos posicionados nas faixas mais extremas (escores maiores ou iguais 5). Estes resultados são apresentados no Quadro 7. 
Quadro 7 - Dados da interação dos alunos sensoriais/intuitivos

\begin{tabular}{|c|c|c|c|}
\hline Perfil & $\begin{array}{c}\text { Número de } \\
\text { alunos }\end{array}$ & $\begin{array}{c}\text { Nota média vídeo } \\
\text { Sensorial }\end{array}$ & $\begin{array}{c}\text { Nota média vídeo } \\
\text { I ntuitivo }\end{array}$ \\
\hline INTUITIVO (5 a 11) & 8 & 3,33 & 6,25 \\
\hline SENSORIAL (5 a 11) & 24 & 5,00 & 7,09 \\
\hline
\end{tabular}

Fonte: Elaborado pelos próprios autores.

Conforme mencionado anteriormente, pode-se constatar que todos os alunos, independentemente de seu EA, obtiveram melhores resultados nas respostas aos questionários relacionados ao vídeo com foco no perfil intuitivo. Nota-se também que os alunos sensoriais obtiveram melhores resultados para ambos os recursos de aprendizagem. Por outro lado, para os alunos de perfil sensorial, a diferença entre as notas médias obtidas para os dois vídeos foi de 2,09 (i.e., 7,09 - 5,00), inferior à diferença obtida entre os alunos de perfil intuitivo $(2,92=$ 6,25 - 3,33). Isso poderia indicar uma melhor adequação dos alunos sensoriais ao recurso de aprendizagem relacionado ao EA sensorial em comparação com os alunos intuitivos, confirmando o padrão de comportamento esperado para a respectiva dimensão de EA.

\section{Conclusões}

O presente trabalho objetivou a criação de recursos on-line para apoio ao ensino presencial de uma disciplina dos cursos de engenharias, com foco no desenvolvimento de objetos de ensino que pudessem atender aos diferentes estilos de aprendizagem dos estudantes. Ademais, foi avaliado o comportamento dos alunos no ambiente de ensino a distância, de acordo com os seus diferentes perfis.

Dentro do universo de alunos pesquisados, observou-se maior incidência de estudantes com perfil ativo (dimensão Processamento), visual (dimensão Entrada) e sensorial (dimensão Percepção). Independentemente dessa constatação, buscou-se um balanceamento na criação de recursos de ensino, visando responder a todos os diferentes perfis relacionados aos EAs. No lugar de atender às preferências individuais dos alunos, o objetivo principal foi assegurar que todos os estilos fossem trabalhados equilibradamente, de modo a enriquecer a jornada dos estudantes ao longo do processo de ensino-aprendizagem.

A avaliação da interação dos alunos com o ambiente on-line identificou, a partir da análise do número de acessos, bem como o tempo de interação com os recursos, coerência no comportamento dos alunos ativos e reflexivos em relação ao esperado. Em relação a essa dimensão, a análise da participação dos alunos em fóruns on-line, listas de discussão ou nas redes sociais também poderia ser aplicada, com vistas a identificar alunos com perfil ativo (mais atuantes) ou reflexivos, sugerindo-se o uso desta abordagem em futuros trabalhos.

Em relação à dimensão Entrada, foi identificada melhor resposta dos alunos visuais aos objetos relacionados ao perfil visual, em comparação aos objetos referentes ao perfil verbal. Não foi obtida conclusão relevante com relação aos alunos verbais, devido ao universo muito restrito de alunos, prejudicial para uma análise mais ampla.

Finalmente, para a dimensão Percepção, apesar de melhor resposta de todos os alunos, independente do seu EA, ao recurso de aprendizagem ligado ao perfil intuitivo, o que pode ter sido resultado da abordagem lúdica utilizada, verificou-se que os alunos sensoriais tiveram melhores índices de proficiência relacionados ao objeto do estilo sensorial, quando comparados com alunos de perfil intuitivo.

Piaget afirma que "o exame escolar não é objetivo, antes de mais nada porque implica sempre um certo contingente de sorte; além disso, e sobretudo, porque está mais voltado para a memória do que para as capacidades construtivas do aluno" (PIAGET, 2011, p.71). Essa 
perspectiva, de alguma forma, pode gerar questionamentos quanto aos resultados obtidos na análise da interação dos alunos e seus perfis, com relação às dimensões Entrada e Percepção, análise esta, realizada com base nos índices de acertos às respostas dos questionários de avaliação relacionados aos objetos de aprendizagem. Afinal, simples resultados de testes poderiam ser questionados quanto a sua real eficácia na identificação do efetivo aprendizado dos alunos. Por outro lado, o principal objetivo da criação dos diferentes recursos on-line, adequados aos diferentes EAs foi, em última instância, dispor de mecanismos que pudessem contribuir para a melhoria do processo ensino-aprendizagem (e não para o processo de avaliação dos alunos em si). Coadunando com essa visão, as professoras das turmas envolvidas foram unânimes ao afirmar que, em sala de aula, os alunos espontaneamente abordaram conceitos que assimilaram, a partir dos objetos on-line, de forma muito mais sólida que nas outras turmas da mesma disciplina, que não fizeram uso desses recursos. Os docentes concluíram que houve um aprofundamento nos debates em sala de aula, o que pode ser percebido como resultado efetivo da aplicação equilibrada de recursos de ensino envolvendo os diferentes EAs.

Reitera-se que quanto maior o volume de alunos envolvidos em pesquisas desse monte, maior a precisão da análise e a possibilidade de detecção de padrões de comportamento relevantes. Na presente pesquisa, em diversas situações a base de dados continha um número muito pequeno de registros de alunos de determinado perfil, o que pode ter prejudicado a avaliação dos dados. Nesse sentido, espera-se o desenvolvimento de pesquisas futuras que abranjam volume maior de estudantes. Ademais, trabalhos futuros devem considerar também a dimensão Progresso, que envolve alunos de perfil sequencial e global, dimensão essa não avaliada na presente pesquisa.

Enfim, este trabalho visa contribuir para a conscientização da importância do desenvolvimento de estratégias pedagógicas que possam promover a evolução dos alunos de maneira personalizada, respeitando os estilos de aprendizagem que lhes são próprios, segundo diferentes dimensões. Acredita-se que o professor deve ter consciência de suas potencialidades, ao fazer uso de diferentes recursos de ensino: permitindo a percepção de relações entre teoria e aplicações (estilo intuitivo); apresentando demonstrações e exemplos concretos (estilo sensorial); fazendo uso de imagens e diagramas (estilo visual) para suplementar a informação escrita/narrada (estilo verbal); propondo a realização de trabalhos experimentais (estilo sensorial) para que os alunos possam fazer inter-relações (estilo intuitivo); disponibilizando recursos visando à participação (estilo ativo) e reflexão do material apresentado (estilo reflexivo); ou ainda apresentando conceitos relacionados com o cotidiano dos alunos de forma global e/ou sequencial. Desta forma, o estudante desenvolverá formas particulares de interação com o ambiente de aprendizagem, de modo a alcançar plenamente o seu potencial de assimilação do conhecimento.

\section{Referências}

BAUMAN, Z. Modernidade líquida. trad. Plínio Dentzien. Rio de Janeiro: Jorge Zahar Editor, 2001.

BORDENAVE, J.D., PEREIRA, A.M. Estratégias de ensino - aprendizagem. 22. edição. Petrópolis: Vozes, 2001.

DUNN, R. Teaching gifted students through their learning style strengths. International Education, 1989.

DUNN, R., DUNN, K., PRICE, G. E. Productivity Environmental Preference Survey. Obtainable from Price Systems, Box 1818, Lawrence, KS 66044, 1979.

FELDER, R.M., SILVERMAN L.K, Learning and teaching styles in engineering education, Engineering Education, 78, 1988, pp. 674-681. 
FELDER, R.M., BRENT, R. "Understanding Student Differences." J. Engr. Education, 94(1), 57-72, 2005.

FELDER, R.M., SPURLIN, J.E. "Applications, Reliability, and Validity of the Index of Learning Styles." Intl. Journal of Engineering Education, 21(1), 103-112, 2005.

FELDER, R.M. ARE LEARNING STYLES INVALID? (HINT: NO!). On-Course Newsletter, September, 27, 2010. Disponível em http://www4.ncsu.edu/unity/lockers/users/f/felder/public/Papers/LS_Validity\%280nCourse\% 29. pdf. Acessado em 25-mar-2016.

FERRAZ, A.P.C.M. Diretrizes para o planejamento de materiais instrucionais para educação a distância. Tese de Doutorado do Programa de Pós-Graduação em Engenharia de Produção. Escola de Engenharia de São Carlos da Universidade de São Paulo, 2008.

GARDNER, H. Estruturas da Mente - Teoria das Inteligências Múltiplas. São Paulo: Artmed, 1994.

GRAF, S. Adaptivity in Learning Management Systems Focussing on Learning Styles. Ph.D. Thesis. Vienna University of Technology Faculty of Informatics. Vienna, 2007.

GRAF, S., KINSHUK, LIU, T. Identifying Learning Styles in Learning Management Systems by Using Indications from Students' Behaviour. In: Eighth IEEE International Conference on Advanced Learning Technologies, 2008.

HOEHSTEIN, G., KEMCZINSKI, A., GASPARINI, I., PIMENTA, M.S. Diagnóstico do estilo de aprendizagem do aluno a partir de ferramentas de comunicação. Cadernos de Informática. Volume 6, Número 1, 2011.

HONEY, P., MUMFORD, A. The Manual of Learning Styles. Peter Honey, Maidenhead, 1982.

HOUGHES, J.A. Supporting the online learner. In: ANDERSON, T.: ELLOUMI, F. Theory and practice of online learning. Athabasca: Athabasca University, 2004, pp. 307-388.

HUNT, J. Distúrbio da Aprendizagem: Uma Rosa com Outro Nome. Psicóloga Diretora do "The Natural Child Project", 1979. Disponível em http://helenab.tripod.com/jan_hunt/distapr.htm. Acesso em 24/09/2016.

JOHNSON, L., ADAMS BECKER, S., CUMMINS, M., ESTRADA, V., FREEMAN, A., LUDGATE, H. NMC Horizon Report: 2013 Higher Education Edition. Austin, Texas: The New Media Consortium, 2013.

KEEFE, J.W. Learning Style: An Overview. In Keefe, J.W. (Ed.), Student Learning Styles: Diagnosing and Prescribing Programs. Reston, Va.: National Association of Secondary School Principals, 1982.

KOLB, D.A. Experiential Learning: Experience as the Source of Learning and Development, Prentice-Hall, Englewood Cliffs, New Jersey, 1984.

LEE, J.C., FORLIZZI, J., HUDSON, S.E. The Kinetic Typography Engine: An Extensible System for Animating Expressive Text, In Proceedings of UIST02, 2002, pp 81-90.

LIVESAY, G., DEE, K., FELDER, R., HITES, L., NAUMAN, E., O'NEAL, E. Statistical evaluation of the index of learning styles. Session, 2430, 16-19, 2002.

MYERS, I.B., MYERS, P.B. Ser Humano é ser diferente: valorizando as pessoas por seus dons especiais. Tradução de Eliana Rocha; Ilda Schulter. São Paulo: Gente, 1997.

PIAGET, J. A formação do símbolo na criança: imitação, jogo e sonho; imagem e representação. Tradução de Álvaro Cabral e Cristiano Monteiro Oiticica 3.ed. Rio de Janeiro: LTC, 1964.

PIAGET. J. Para onde vai a educação? 20ạ ed. Rio de Janeiro: José Olympio, 2011.

SCHMECK, R. Learning styles of college students en Dillon y Schmeck In: Dillon, R.; Schmeck, R. (Eds.), Individual differences in cognition, pp. 233-279, New York: Academic Press, 1983. 
SENRA, C.M.S. Os estilos de aprendizagem de Felder a partir de Jung. Dissertação de Mestrado em Educação tecnológica. CEFET - MG, Belo Horizonte - MG, 2009.

SMITH, R. E. Effects of coping skills training on generalized self-efficacy and locus of control. Journal of personality and social psychology, 1988.

VYGOTSKY, L.S. I maginação e criação na infância: ensaio psicológico. Apresentação e comentários de Ana Luiza Smolka. Tradução de Zoia Prestes. São Paulo: Ática, 2009.

ZYWNO, M.S. A contribution to validation of score meaning for Felder Soloman's Index of Learning Styles. Proceedings of the 2003 American Society for Engineering Education Annual Conference \& Exposition, 2003.

Recebido em maio de 2016

Aprovado para publicação em agosto de 2017

\section{Anderson Amendoeira Namen}

Programa de Mestrado Profissional em Ciências do Meio Ambiente - Universidade Veiga de Almeida - UVA, Brasil e Programa de Pós-Graduação em Modelagem Computacional - Instituto Politécnico - UERJ, Brasil, anamen@uva.br.

\section{Cassia Mousinho de Figueiredo}

Pró-Reitoria de Pós-Graduaçao, Pesquisa e Extensão - Universidade Veiga de Almeida - UVA, Brasil, cassia.figueiredo@uva.br

\section{Danielle Spada Tavares}

Pró-Reitoria de Pós-Graduaçao, Pesquisa e Extensão - Universidade Veiga de Almeida - UVA, Brasil, danielle.spada@uva.br

\section{Elisa Troian Rodrigues}

Pró-Reitoria de Pós-Graduaçao, Pesquisa e Extensão - Universidade Veiga de Almeida - UVA, Brasil, elisa.rodrigues@uva.br

\section{Paulo Marcos Figueiredo de Andrade}

Pró-Reitoria de Pós-Graduaçao, Pesquisa e Extensão - Universidade Veiga de Almeida - UVA, Brasil, pandrade@uva.br

\section{Reynaldo Gomes Lopes}

Pró-Reitoria de Pós-Graduaçao, Pesquisa e Extensão - Universidade Veiga de Almeida - UVA, Brasil, reynaldo@uva.br 


\title{
Ensino de BIM no Brasil: Análise do Cenário Acadêmico
}

\section{Teaching BIM in Brazil: Analysis of the Academic Scenario}

HENRIQUE BENEDETTO

Universidade Federal do Rio Grande do Sul

\section{MAURÍCIO MOREIRA E SILVA BERNARDES}

Universidade Federal do Rio Grande do Sul

ROBERTO WANNER PIRES

Universidade Federal do Rio Grande do Sul

Resumo: BIM - Building I nformation Modelling, ou modelagem das informações da construção, tem recebido atenção do mercado de Arquitetura, Engenharia, Construção e Operação pelo seu potencial de integração da informação e pelo ganho da produtividade proporcionado. Todavia, a demanda por profissionais qualificados expõe uma realidade que tem pressionado as universidades, que é a falta do ensino de BIM na graduação. Essa pesquisa trata de levantamento em artigos focando o ensino de BIM no Brasil. Vários trabalhos foram analisados sob a classificação de "discussão sobre estratégia para inclusão do ensino de BIM" e "aplicação de estratégia para inclusão do ensino de BIM" nos currículos. Um pouco fora do eixo tratado pela pesquisa, mas ainda assim relevante, é abordado o ensino de BIM e a sua relação com o ensino de desenho. Pela avaliação dos artigos, foi observado que muito tem sido estudado a respeito da introdução de BIM no ensino, porém, pouco tem sido reportado a sobre implementação do paradigma na área acadêmica.

Palavras-chave: BIM, Modelagem da Informação da Construção, Ensino de BIM no Brasil

\begin{abstract}
BIM - Building Information Modeling, has received attention from the Architecture, Engineering, Construction and Operation markets for its information integration potential and for the productivity gain provided. However, the demand for qualified professionals exposes a reality that has put pressure on universities, which is the lack of teaching of BIM in undergraduate courses. This research deals with a literature search on articles focusing on the teaching of BIM in Brazil. Several papers were analyzed under the classification of "discussion on strategy for inclusion of teaching of $\mathrm{BIM}$ " and "application of strategy for inclusion of teaching of BIM" in curricula. A little off the axis treated by the research, but still relevant, is addressed the teaching of BIM and its relation with the teaching of drawing. By the evaluation of the articles, it was observed that much has been studied regarding the introduction of BIM in teaching, but little has been reported on the implementation of the paradigm in the academic area.
\end{abstract}

Keywords: BIM, Building Information Modelling, Teaching BIM in Brazil. 


\section{I ntrodução}

BIM - Building Information Modelling, ou modelagem das informações da construção, tem recebido atenção do mercado de Arquitetura, Engenharia, Construção e Operação (AECO) pelo seu potencial de integração da informação nas várias dimensões do negócio e pelo ganho da produtividade ( $\mathrm{LI}$ et al., 2014) proporcionado nesse contexto. Todavia, a demanda por profissionais qualificados, pela crescente exigência de práticas baseadas em BIM (EASTMAN et al., 2011), expõe uma realidade que tem pressionado as universidades do país, que é a falta do ensino de BIM nos cursos de Arquitetura, Engenharia, Design e outros cursos afins.

A introdução do BIM no currículo tem sido reportada como um processo mais complexo do que se possa inicialmente considerar (BARISON \& SANTOS, 2010), principalmente por que BIM estabelece um paradigma que envolve um conjunto de políticas, processos e tecnologia na gestão de todo um empreendimento (SUCCAR, 2009). Isso exige que os cursos de graduação coordenem a transferência do conhecimento de forma holística e integrada, tomando por base o ciclo de vida do empreendimento. Ainda, tal complexidade se caracteriza pela condição de BIM ter potencial de ser parte intrínseca dos programas de graduação (BARISON \& SANTOS, 2010).

Avaliando os métodos utilizados para inclusão do paradigma BIM no contexto de ensino das universidades brasileiras, observa-se que dois modelos vêm sendo aplicados para sua adoção nos currículos do ensino de Arquitetura e Engenharia Civil, são eles: a adoção integrada, envolvendo as disciplinas técnicas, e a adoção pontual, que considera somente algumas disciplinas do currículo (BARISON \& SANTOS, 2010; MENEZES et al., 2012; CHECCUCCl et al., 2013; RUSCHEL et al., 2013; CHECCUCCI, 2014). Cada modelo apresenta um conjunto de vantagens e desvantagens e, principalmente, um volume de demanda por adaptações diferenciado para os currículos dos cursos. O que se percebe, de acordo com Checcucci et al. (2013), é que poucas experiências relatam o modelo de implantação integrado, especialmente junto à graduação. Qualquer que seja a estratégia de implementação, adaptações se mostram necessárias porque o modelo de ensino atual, em grande escala, está edificado sobre disciplinas isoladas onde em cada uma delas são tratados assuntos específicos e especializados, mas de forma fragmentada (CHECCUCCl et al., 2013) sem que haja, também na grande maioria dos casos, integração e colaboração, características que reforçam a complexidade do conceito contemplado pelo paradigma BIM. Os autores ainda ponderam que dever-se-ia levar em consideração que o objeto que se propõe a desenvolver, uma edificação, se caracteriza por ser uma unidade única.

A implementação de BIM no currículo sofre um aumento em sua complexidade pela condição desta tecnologia favorecer a interdisciplinaridade, condição não presente na maioria dos currículos de graduação e tão pouco entre departamentos, uma vez que as instituições, tradicionalmente, não desenvolvem essa prática (MENEZES et al., 2012; ROMCY et al., 2013). Essa dificuldade se estabelece muito mais fortemente quando se observa a necessidade de integração dos docentes, o que é apontado por Taylor et al. (2008)como um dos maiores obstáculos à implementação de BIM no ensino. Esse cenário não favorece a implementação de 
BIM e exige das instituições uma estratégia que considere essas condições desde o princípio do processo, como reportado por Checcucci et al. (2013).

Este trabalho objetiva apresentar as atividades que estão sendo desenvolvidas quanto ao ensino de BIM no Brasil e busca servir de guia para a identificação dos autores e suas pesquisas.

\section{Metodologia da Pesquisa}

Para esta pesquisa foi feito um levantamento bibliográfico focado em artigos técnicos publicados a partir de 2010 com foco no cenário de ensino de BIM em instituições de ensino brasileiras. Essa data foi fixada levando em consideração que a mudança de paradigma estabelecida com a introdução de BIM nas instituições americanas foi abordada em 2006 durante o BIM Symposium ocorrido na Universidade de Minnesota, muito embora as primeiras experiências de implantação do ensino de BIM nos currículos de Arquitetura e Engenharia Civil nos Estados Unidos datem de 2003, com algumas poucas exceções na década de 1990. No simpósio de 2006, como reportado por Barison e Santos (2010), muitas questões foram levantadas e somente seriam respondidas efetivamente quando as instituições de ensino começassem a implantação de BIM em seus currículos. Nos anos subsequentes, reportado até 2009, uma série de outras conferências davam conta de que em 2008, nos Estados Unidos, ainda não havia um procedimento pedagógico consolidado para o ensino de BIM (CASEY, 2008). Finalmente, o período de cobertura da pesquisa tomou como referência o trabalho de Checcucci et al. (2011) que, ainda que com poucos casos reportando experiências práticas do ensino de BIM no Brasil, cobriu o período anterior.

Artigos eventualmente anteriores a 2010, fora do período da pesquisa, portanto, foram consultados para complementação de alguma ideia sendo desenvolvida. A Erro! Autoreferência de indicador não válida. apresenta os artigos objeto dessa pesquisa e os classifica em "discussão sobre estratégia para inclusão do ensino de BIM no currículo" e “aplicação de estratégia para inclusão do ensino de BIM no currículo".

Quadro 1- Artigos trabalhados na pesquisa

\begin{tabular}{|l|c|c|}
\hline Autor(es) & Discussão & Aplicação \\
\hline Barison e Santos (2010) & X & \\
\hline Menezes et al. (2012) & X & \\
\hline Menezes e Pontes (2012) & X & \\
\hline Ruschel, Andrade e Morais (2013) & X \\
\hline Godoy, Cardoso e Borges (2013) & X \\
\hline Romcy, Cardoso e Miranda 2013) & & $X$ \\
\hline Checcucci, Amorim e Pereira (2013) & $X$ & $X$ \\
\hline Checcucci (2014) & $X$ & $X$ \\
\hline Pereira e Ribeiro (2015) & & \\
\hline
\end{tabular}

Fonte: os autores 


\section{Estratégias de Ensino de BI M}

De grande contribuição para o ensino de BIM, no tocante a identificação das melhores práticas e diretrizes para a introdução do conteúdo de BIM no ensino de Arquitetura, Engenharia Civil e Gestão da Construção é a pesquisa desenvolvida por Barison e Santos (2010). Os autores apresentaram uma avaliação de estratégias utilizadas nas instituições americanas, consideradas de ponta, e culminaram com a proposta de uma estratégia de ensino aprendizagem para viabilizar a introdução de BIM nos currículos, incluindo uma classificação dos cursos de BIM, como: introdutórios, intermediários e avançados. Essa classificação está relacionada com o nível de especialidade que o aluno deve possuir para prática profissional usando BIM.

O trabalho de Barison e Santos (2010) foi desenvolvido com base nos critérios que devem ser considerados quando se está planejando um novo curso, tais como: pré-requisitos, objetivos e metas, conteúdo, metodologia do ensino e avaliação. A esses, os autores acrescentaram mais três critérios, a saber: atividades, modelos BIM e recursos de ensino.

Barison e Santos (2010) chamaram atenção para o fato de que colaboração é um elemento que não pode faltar nas atividades desenvolvidas pelos estudantes, assim como a prática em ferramentas BIM diversas. Concluindo, os autores frisam que é altamente recomendado que as instituições identifiquem qual o tipo de especialista BIM será formado. O que pode ser alcançado através de uma maior aproximação com o mercado que irá absorver esses especialistas, através de entrevistas com profissionais, por exemplo (BARISON \& SANTOS, 2010), dentre outras maneiras.

Finalizando, Barison e Santos (2010) comentam da crescente demanda por profissionais proficientes em BIM e atribuem a responsabilidade pela formação destes às universidades, sem deixar de reconhecer que essa é uma tarefa complexa e que, sobre a qual, ainda há pouco conhecimento disponível.

Ainda com caráter investigativo, Menezes et al. (2012) buscaram o entendimento do impacto da tecnologia BIM no ensino de projetos de edificações na região de Minas Gerais tanto no âmbito profissional quanto acadêmico. Para essa pesquisa foi levantada a hipótese de que com a tecnologia BIM, existam avanços reais no universo da construção civil, mas também inadequações quando contraposta ao processo contemporâneo de ensino e de concepção de projetos.

Em meio a análises de modelos convencionais, sequenciais e fragmentados de desenvolvimento de projeto e planejamento da construção, os autores observam que os resultados, na maioria das vezes, trazem consigo uma carga de retrabalho, desperdício, alto custo de produção e baixa qualidade do produto final. Na busca por uma metodologia que viesse valorizar a integração dos agentes e o trabalho colaborativo e simultâneo das equipes, bem como a valorização de uma visão abrangente do binômio projeto-execução, chegou-se na engenharia simultânea. Todavia, com a chegada da tecnologia BIM, esta se estabelece como uma alternativa, uma vez que potencializa o trabalho simultâneo e introduz uma nova maneira de manipulação da informação. 
Preocupados com o isolamento profissional em relação a outras empresas que utilizam outros tipos de recursos, o alto custo de equipamento e treinamento, os autores citam que a escassez de profissional treinado e proficiente se caracteriza como um dos principais desafios para a implantação de um sistema BIM (MENEZES et al., 2012). Consideram também que o paradigma BIM acena para uma revolução no modo de operar e pensar as atividades acadêmicas, todavia o que se percebe na prática acadêmica é uma simplificação ou redução de sua potencialidade, sendo tratado como um simples modelador e em alguns casos, sem a devida e necessária integração das disciplinas envolvidas no processo de produção dos projetos.

Continuando na vertente de avaliação de estratégias, Ruschel et al. (2013) fazem uma análise de vários relatos de implementação de BIM no cenário brasileiro, mas primeiro passam por uma avaliação das estratégias usadas no mundo a fora. Para a pesquisa os autores se utilizam do modelo de análise apresentado por Succar (2009) para definição de estágio de adoção de BIM. Nesse modelo Succar (2009) identifica, para cada um dos três estágios (primeiro estágio, segundo estágio e terceiro estágio), fases do processo de projeto e disciplinas envolvidas, produtos esperados, caracterização do processo e consequentes níveis de mudança em políticas, processos e tecnologia.

Ruschel et al. (2013) utilizam-se também da classificação proposta por Barison e Santos (2010) para avaliar o nível de competência que é possível de se obter com a estratégia de ensino aprendizagem adotada na implementação de BIM pelas instituições que foram por eles avaliadas: introdutório, intermediário e avançado. Com base nesses critérios, o Quadro 1 foi elaborado para servir de referência para as avaliações da pesquisa.

Aplicando os critérios de avaliação nos projetos de ensino de BIM considerados, os autores ressaltaram a existência de uma diversidade de casos de ensino que abordavam BIM no Brasil envolvendo cursos de Arquitetura e Urbanismo e Engenharia Civil com a adoção do modelo de implementação deste em disciplinas isoladas. A constatação dos autores foi que o processo de implementação do ensino de BIM no Brasil abrange os níveis de competência introdutório e intermediário e acontecem de forma gradual. Nenhuma experiência relatou resultado compatível com o nível de competência avançado - direcionamento o aluno para as competências gerenciais - focando, portanto, a integração entre ferramentas de gerenciamento e ferramentas BIM, simulações de custo (5D), contratos, etc. Ruschel et al. (2013) também apontaram a falta de relato de experiência que abordasse todo o ciclo de vida da edificação projeto, construção e operação - caracterizando o terceiro estágio de adoção (RUSCHEL et al., 2013).

Preocupados com a adoção de BIM no contexto da indústria de AEC - Arquitetura, Engenharia e Construção, no Brasil, Godoy et al. (2013) desenvolveram uma revisão bibliográfica buscando identificar os principais motivos que se colocavam como barreira à sua formalização como principal ferramenta de trabalho no processo de projeto. Para esse estudo lançaram como hipótese que a não vinculação de BIM ao currículo dos cursos de graduação poderia se caracterizar como uma das principais causas. Para o desdobramento, os autores desenvolveram uma pesquisa com alunos. 
Quadro 2 - Parâmetros de Classificação das experiências didáticas de ensino de Bı M

\begin{tabular}{|c|c|c|c|c|c|}
\hline \multirow[b]{2}{*}{$\begin{array}{c}\text { Nível de } \\
\text { Competência }\end{array}$} & \multirow[b]{2}{*}{$\begin{array}{c}\text { Parâmetros } \\
\text { de } \\
\text { Classificação }\end{array}$} & \multirow[b]{2}{*}{$\begin{array}{l}\text { Estágio } \\
\text { de } \\
\text { Adoção } \\
\text { de BI M }\end{array}$} & \multicolumn{3}{|c|}{ Parâmetros de Classificação } \\
\hline & & & $\begin{array}{l}\text { Modelo de } \\
\text { I nformação }\end{array}$ & \begin{tabular}{|c|} 
Fases do \\
Ciclo de \\
Vida \\
(Projeto, \\
Construção, \\
Operação) \\
\end{tabular} & $\begin{array}{c}\text { Produtos } \\
\text { Gerados na } \\
\text { Experiência } \\
\text { Didática }\end{array}$ \\
\hline Introdutório & $\begin{array}{l}\text { Habilita } \\
\text { Modelador }\end{array}$ & Primeiro & $\begin{array}{l}\text { Modelagem e } \\
\text { produtividade }\end{array}$ & Uma fase & $\begin{array}{l}\text { Modelagem } \\
\text { paramétrica, } \\
\text { quantitativos, } \\
\text { documentação }\end{array}$ \\
\hline Intermediário & $\begin{array}{l}\text { Habilita } \\
\text { Analista }\end{array}$ & Segundo & $\begin{array}{l}\text { Integração de } \\
\text { modelos e uso } \\
\text { aplicado dos } \\
\text { modelos de } \\
\text { informação }\end{array}$ & Duas fases & $\begin{array}{l}\text { Simulações } \\
\text { (dimensionamento, } \\
\text { ambientais, 4D, } \\
\text { 5D...), } \\
\text { compatibilização e } \\
\text { planejamento } \\
\text { (caminhos críticos, } \\
\text { linha de balanço) }\end{array}$ \\
\hline Avançado & $\begin{array}{l}\text { Habilita } \\
\text { Gerente }\end{array}$ & Terceiro & $\begin{array}{l}\text { Desenvolvimento } \\
\text { compartilhado e } \\
\text { holístico do } \\
\text { modelo de } \\
\text { informação }\end{array}$ & Três fases & $\begin{array}{l}\text { Introdução IPD. } \\
\text { Colaboração } \\
\text { envolvendo } \\
\text { múltiplos agentes. } \\
\text { Criação } \\
\text { compartilhada. }\end{array}$ \\
\hline
\end{tabular}

Fonte: Adaptado de Ruschel et al. (2013)

Os autores ressaltaram como resultado que o entendimento de a tecnologia atual ser suficiente para atender às demandas era motivado pela falta de conhecimento do novo paradigma BIM, principalmente por este não estar incluído na formação do aluno. Ao observarem a irreversibilidade da adoção da tecnologia BIM, ponderam que o tempo necessário para mudança de tecnologia e de processos projetuais seja, também, um grande empecilho.

Embora, ao abordarem o paradigma BIM, Godoy et al. (2013) estivessem focados nos estágios iniciais do ciclo de desenvolvimento da edificação, em suas conclusões, quando mencionam a necessidade de que a interoperabilidade seja considerada, ressaltam que BIM deve ser tratado de forma integrada na grade curricular dos cursos de Arquitetura, Engenharia e Construção simultaneamente (GODOY et al., 2013). Os autores afirmam que a fragmentação no ensino impede que a tecnologia BIM seja explorada em sua plenitude, não só como ferramenta de projeto, mas também como integrador, o que colaboraria no planejamento e gestão de todo o processo de desenvolvimento da edificação (GODOY et al., 2013).

Checcucci (2014), corroborando a opinião de que a fragmentação do ensino vai contra os conceitos trabalhados em BIM, elaborou um modelo para identificar componentes curriculares junto aos quais, BIM pode ser discutido e trabalhado para auxiliar a introdução desse paradigma nos cursos. Essa análise proporciona um mapeamento que direciona o processo de reforçar os conceitos de integração entre as disciplinas, e colaboração entre os professores para que os mesmos venham a desenvolver componentes curriculares multidisciplinares. Conceitos estes, de alta relevância no trabalho com BIM. 
Antes de inserir BIM nos cursos de graduação, Checcucci (2014) aponta que várias decisões devem ser tomadas, tais como:

1) Analisar as possíveis dificuldades: falta de professores, laboratórios, bibliografias de referência, espaço na matriz curricular, dentre outros.

2) Nível de formação que o curso promoverá: introdutório sobre conceitos básicos ou aprofundado em uma ou mais áreas de interesse. Vale aqui resgatar os conceitos de proficiência que se espera para o aluno - Modelador BIM, Analista BIM ou Gerente BIM (BARISON \& SANTOS, 2010).

3) A estratégia de organização do currículo: decidir se BIM será integrado aos componentes curriculares ou se serão criadas disciplinas específicas sobre o tema.

4) O método de ensino-aprendizagem a ser utilizado: Metodologias ativas se mostram adequadas para tratar do tema, pois lidam com o desenvolvimento de competências, além da construção do conhecimento e do estímulo da autonomia dos alunos (CHECCUCCl, 2014).

5) Atividades que serão propostas e mecanismos de avaliação da inserção são também questões a serem avaliadas.

Alguns outros fatores menos específicos também devem ser avaliados e foram citadas pela autora como: capacidade de investimento, planejamento das etapas, tempo, recursos didáticos, dentre outros (CHECCUCCI, 2014). A autora conclui que dentre as estratégias de implantação de BIM, a adoção integrada é a mais vantajosa, pois se apresenta mais abrangente e possibilita uma formação mais consistente, contando com o envolvimento de vários professores ao longo da formação do aluno. Sacks e Pikas (2013) oferecem base para esse ponto de vista quando comentam que um só professor não será competente para tratar os aspectos relacionados com BIM porque eles englobam todo o ciclo de vida da edificação.

Atentos às condições atuais da formação universitária do aluno em Engenharia Civil no que diz respeito à capacitação em BIM no Brasil, Pereira e Ribeiro (2015) desenvolveram uma pesquisa para levantar as estratégias pedagógicas para a abordagem do novo paradigma. Os autores levaram em consideração a Resolução CES/CNE no 11 (MEC, 2002), referência para a elaboração dos currículos dos cursos de graduação em engenharia, e observaram que a estratégia deve considerar a inserção do BIM nos três núcleos de formação do aluno, ou seja: núcleo de conteúdos básicos, núcleo de conteúdos profissionalizantes e núcleo de conteúdos específicos (PEREIRA \& RIBEIRO, 2015).

A pesquisa de Pereira e Ribeiro (2015) foi desenvolvida inicialmente com base em levantamento bibliográfico para nivelamento do conhecimento sobre a tecnologia BIM e sobre o ensino de BIM, tanto no Brasil como no exterior. A segunda etapa considerou a aplicação de um questionário estruturado abordando o conhecimento da comunidade acadêmica sobre BIM. Finalizando, foi feita uma análise qualitativa sobre as respostas do questionário com vistas a analisar a viabilidade de inserção de conceitos BIM nas disciplinas de desenho e projeto de forma integrada e multidisciplinar (PEREIRA \& RIBEIRO, 2015). 
Com base em 48 respostas completas, dentre 400 docentes que foram inicialmente convidados para participar (12\%) os autores identificaram que a tecnologia BIM ainda é muito pouco abordada e sua utilização muito restrita no meio acadêmico. Os autores consideram que tal resultado deveu-se a esta ser uma tecnologia recente sobre a qual o conhecimento ainda é incipiente.

Ao analisar o estágio de adoção de BIM, Pereira e Ribeiro (2015) buscaram os estágios definidos por Succar (2009) e corroborado por outros autores, como segue:

- Estágio 1 - BIM 1.0: Foca a modelagem paramétrica. A tecnologia é utilizada como ferramenta, pois o processo de trabalho ainda é individualizado, sem envolvimento e colaboração de outras disciplinas;

- Estágio 2 - BIM 2.0: Foca a colaboração. A tecnologia é expandida para outras disciplinas (multidisciplinar) e a interoperabilidade surge como termo essencial para que no novo paradigma BIM se torne um processo continuado;

- Estágio 3 - BIM 3.0: Foca na prática integrada. Amplia as possibilidades de interoperabilidade através de protocolos abertos e ambientes de trabalho virtuais, na busca de que todos os agentes envolvidos no empreendimento possam contribuir coletivamente, dentro das especificidades de suas disciplinas.

Com base nessa classificação, para os docentes que abordam BIM em suas atividades acadêmicas, 40\% dos respondentes, os resultados encontrados por Pereira e Ribeiro (2015) sugerem que o principal enfoque de BIM se encontra no Estágio 1 (58\%), seguido pelo Estágio $2(26 \%)$ e finalmente o Estágio $3(16 \%)$. Fechando a pesquisa os autores questionaram sobre os fatores que influenciam a implantação da tecnologia BIM nas instituições de ensino e concluíram que o aspecto mais influente é a infraestrutura de ensino (94\%). De relevante importância foi identificada a necessidade de uma maior integração entre as disciplinas (81\%) e a resistência à adoção de BIM, por julgar ser um tecnologia ainda não consolidada no meio acadêmico (69\%) (PEREIRA \& RIBEIRO, 2015).

Os autores concluem, dentre outras abordagens, que o conhecimento de BIM ainda é restrito, mesmo na área acadêmica e que isso deve-se ao fato de a tecnologia ser recente e ainda não consolidada, sendo inserida, tanto no meio acadêmico quanto no mercado de trabalho a passos lentos.

\section{Estratégias de Ensino de BIM nas I nstituições de Ensino no Brasil}

Através de um estudo de caso que permeou 3 semestres (2011/2, 2012/1 e 2012/2), Romcy et al. (2013) introduziram a tecnologia BIM no ensino de Arquitetura pela disciplina Desenho Arquitetônico II (DA II), que passou a se chamar Desenho Arquitetônico Auxiliado por Computador (DAC), após a contemplação dos conceitos pertinentes ao novo paradigma.

Os autores, para fixarem o objetivo de desenvolvimento do curso, consideraram as definições de estágios de implantação de BIM desenvolvidos por Succar (2009), e para o desenvolvimento da estratégia de implantação, lançaram mão da classificação dos níveis de competência desejadas para o aluno, apresentadas por Barison e Santos (2010), considerando os níveis introdutório, intermediário e avançados. Por fim, buscaram entendimento dos 
obstáculos à implementação de BIM no currículo através do entendimento dos três tipos possíveis, postulados por Barison e Santos (2010), como segue:

- Ambiente Acadêmico: tempo, motivação, recursos, regras, currículo;

- Conceitos BIM: ensino individualizado, ensino tradicional, pouco trabalho em equipe, falta de colaboração;

- Ferramentas BIM: criatividade, aprendizagem, ensino, conhecimento.

O projeto, motivado por mudança ocorrida no Programa Político Pedagógico, abordou a inclusão dos conteúdos de BIM divididos em três unidades:

Unidade 1: Conceitos e estudos de casos, com a realização de seminários;

Unidade 2: Aplicativos BIM, com atividades de modelagem em ArchiCAD (Graphisoft) e Revit (Autodesk);

Unidade 3: Concepção e modelagem de edifício proposto para uma outra disciplina.

O projeto sofreu adequação de carga horário durante a implementação e as unidades foram concluídas contando com 8 horas, 32 horas e 24 horas-aula respectivamente. Embora considerando a necessidade de BIM ser implementado ao longo de todo o ciclo de vida da edificação, o estudo na Universidade Federal do Ceará se manteve restrito à disciplina de arquitetura, no nível BIM 1.0. Considerando o nível de competência para os alunos, conforme objetivado pelo estudo, a disciplina manteve-se como introdutório, com ensino de ferramentas BIM, fundamentação de conceitos, estudo básico de modelagem e de como comunicar diferentes tipos de informação (ROMCY et al. 2013).

Os autores, através de questionário veiculado entre os alunos participantes da terceira turma do curso, fizeram uma avaliação da experiência e levantaram pontos de consideração sobre o que foi implementado e oportunidades para futuras ações. Avaliaram que o projeto desenvolvido se caracteriza pela introdução de BIM de forma gradual com base em uma disciplina, caracterizando o processo como introdução pontual (CHECCUCCl et al., 2013), conforme explorado no início desse artigo. Ainda que tivesse sido objetivo da disciplina atingir o nível de implementação BIM 2D, o conceito de multidisciplinaridade não foi explorado, porque ficou restrito à disciplina de Arquitetura.

Considerando a inclusão de BIM em estágios mais avançados, foi alertado que desafios precisam ser superados no tocante a práticas de colaboração e integração entre disciplinas e cursos. Para tal foi sugerida a aplicação de trabalhos interdisciplinares (ROMCY et al., 2013). Este trabalho apresenta um conteúdo valioso no tocante às considerações e ponderações durante um processo de implementação, pois, além da contextualização sobre BIM, os passos da implementação são apresentados e discutidos de forma clara, seguidos de uma avaliação através de uma dinâmica em três estágios - relato, incluindo a descrição do programa inicial; análise, incluindo a definição de critérios para verificar como o BIM foi apreendido a partir da disciplina e as dificuldades recorrentes; e crítica, apresentando uma reflexão sobre os 
resultados, considerando que experiências permitiram avanços na disciplina e quais desafios precisam ser superados (ROMCY et al., 2013).

Objetivando a implantação de BIM de modo integrado sempre que essa estratégia se justificasse e representasse ganho de competência para os alunos, Checcucci et al. (2013) trabalharam a implementação de BIM no curso noturno de Arquitetura e Urbanismo da FAUFBA nos períodos 2011/2 e 2012/2. Tal experimento favoreceu a estratégia de implantação integrada por ser este um curso novo, onde cada ano seriam implantadas as novas disciplinas. Assim, a introdução de BIM no currículo seria de forma gradual e incremental, permitindo avaliação constante e reduzindo o risco de insucesso.

Embora não tendo sido a implementação em um programa de graduação vigente, os autores ponderam que a estratégia de adoção integrada, provavelmente demanda uma menor alteração na estrutura da matriz curricular, o que, provavelmente, facilitaria a introdução do tema na formação do aluno. Essa observação considera que o aluno teria contato com vários professores em diversas especialidades, tendo acesso a diferentes formas de utilização da modelagem da informação da construção nas várias etapas do ciclo de vida da edificação (CHECCUCCl et al., 2013).

Como o novo curso já nasceu sob a orientação do paradigma BIM, a contratação de professores se deu também dentro do perfil, apresentando, portanto, competências calcadas na multidisciplinaridade, integração e colaboração. Na busca por capacitação em BIM, os autores reportam que os professores contratados foram submetidos a um período de formação complementar.

A implantação teve início no Laboratório de Computação Gráfica aplicado à Arquitetura e ao Desenho (LCAD) na FAUFBA através das disciplinas associadas ao ensino de Desenho e de Representação Gráfica e seus conteúdos relacionados com desenho geométrico, desenho projetivo, perspectiva, geometria descritiva, desenho técnico básico, desenho arquitetônico e o desenho de observação. Essas disciplinas foram distribuídas e organizadas para que se formassem quatro componentes curriculares distribuídos em semestres distintos. O ensino de BIM foi incorporado à disciplina Informática e Desenho II ligada ao quarto componente, que é ministrado no sexto semestre letivo ( $\mathrm{CHECCUCCl}$ et al., 2013).

Através desses componentes foi concluído o primeiro ciclo de ensino de BIM com abordagem do modelo da edificação e exploração das informações nele contidas. As demais aplicações do paradigma foram previstas para expansão através das disciplinas voltadas para a gestão, como projeto de arquitetura e construção e planejamento de obras, por exemplo. Por não serem contempladas no curso de graduação de arquitetura, ficou fora do escopo da pesquisa a fase de operação e manutenção da edificação, por não serem contempladas no curso de graduação de arquitetura. Todavia, os autores comentam que há a expectativa dessas disciplinas virem a ser oferecidas como optativas, complementando, assim, o ensino de BIM ao longo de todo o ciclo de vida de uma edificação.

Checcucci et al. (2013) concluem comentando do sucesso da implementação, mas chamam atenção que os conhecimentos adquiridos nessas duas oportunidades, no grupo de disciplinas trabalhadas, precisam ser utilizados nas demais, principalmente naquelas que envolvem a 
concepção e o desenvolvimento de projetos. Os autores reforçam a necessidade de se expandir o projeto para as disciplinas de instalação, estruturas e construção, e chamam atenção para a capacitação dos professores em BIM como um ponto crucial ( $\mathrm{CHECCUCCI}$ et al., 2013).

Delatorre et al. (2015) apresentaram um relato detalhado da implantação do BIM no curso de Arquitetura e Urbanismo e uma avaliação do processo que contou, dentre outros métodos de pesquisa, com um questionário aplicado a alunos. Sem uma clara definição do porquê, foi reportado que a inserção de BIM se deu pelas disciplinas correntes do curso e não como uma disciplina específica, como poderia ser, alternativamente. Toda a estratégia foi estruturada com base em relatos de experiência de casos no Brasil e no exterior (DELATORRE et al., 2015).

Os autores chamaram atenção para o cuidado que se deve ter nas primeiras experiências com implantação para que o não se caracterize a implementação de BIM como sendo somente a introdução de mais uma ferramenta. Para que essa percepção não se estabeleça, os autores sugerem que deve haver um acompanhamento constante durante todo o processo (DELATORRE et al., 2015), possivelmente para assegurar que a comunicação entre os envolvidos se dê da maneira mais clara e objetiva possível.

Como o processo limitou-se a implementar BIM até a geração do modelo 3D, dentre várias considerações pertinentes a esse nível de implementação, os autores concluem que o processo favoreceu o desenvolvimento de um pensamento projetivo tridimensional e uma maior análise crítica dos alunos (DELATORRE et al., 2015).

\section{O Papel do Desenho no Ambiente de Ensino de BI M}

Um pouco fora do eixo tratado por essa pesquisa, mas de grande relevância para a base profissional dos autores, Menezes e Pontes (2012) trazem à baila o ensino de BIM analisando a pertinência do desenho como ferramenta de aprendizado, concepção, desenvolvimento e representação do objeto arquitetônico, além do papel dos processos digitais neste contexto. Os autores abordam o ensino do desenho, no curso de Arquitetura, dividido em três etapas: a primeira aborda o desenho livre, a segunda trata dos conhecimentos de geometria espacial e sistemas projecionais e a terceira dedicada à representação técnica do objeto arquitetônico.

Focando a terceira etapa do ensino, Menezes e Pontes (2012) abordam a ênfase que é dada à representação dos elementos arquitetônicos específicos - telhados, escadas, rampas, e outros - que precisam ser entendidos no detalhe para que se alcance sua correta representação. No momento da representação gráfica, o aluno desenvolve o conhecimento específico quanto às características construtivas, aprendendo gradativamente sobre o elemento. Esse conhecimento é de certa forma abrangente, pois passa por questões construtivas, geométricas e de representação. Os autores observam que no momento do desenho são trabalhadas características específicas dos elementos, sob vários aspectos, que são muito importantes na formação do aluno.

Menezes e Pontes (2012) também abordam uma questão que, segundo eles, está exaustivamente discutida, que é o papel dos softwares como substituto do desenho técnico em sala de aula. Consideram a utilização de régua, esquadro, etc., uma ferramenta anacrônica, o que corrobora a estratégia de ensino dos autores deste artigo. Todavia, Menezes e Pontes 
(2012) citam que o ensino do desenho através de software traz uma redução na prática do desenho e a consequente perda quanto ao entendimento dos diversos elementos arquitetônicos em seus aspectos construtivos.

Essa lacuna que se estabelece pela aplicação de software para o ensino do desenho técnico encontra no ensino de BIM uma nova condição, uma vez que o processo de modelagem deixa de ser focado na parte geométrica e passa a ser focado na modelagem dos elementos construtivos ou arquitetônicos (MENEZES \& PONTES, 2012). Embora focados somente na parte da modelagem da tecnologia BIM, portanto trabalhando em um nível de competência introdutório (BARISON \& SANTOS, 2010), os autores a reconhecem como uma ferramenta efetiva para a mudança no ensino do desenho técnico/arquitetônico, pois resgata a possibilidade de se ampliar as possibilidades do ensino sobre a construção, abordando a modelagem de elementos construtivos ou arquitetônicos.

Menezes e Pontes (2012) concluem que com a aplicação da tecnologia BIM é possível resgatar a prática tradicional ligada ao ensino do desenho técnico/arquitetônico associado à prática do desenho de elementos construtivos específicos. Essa abordagem, na opinião dos autores, se mostra de grande potencial pois permite trabalhar a representação da edificação através de seu modelo com inteligência oferecida pela tecnologia BIM. Corroborando esse ponto de vista, Ruschel et al. (2013) apontam que com a tecnologia BIM é possível promover a aproximação do aluno com os processos de projeto, processos usados em canteiros de obras e processos de operação e manutenção, o que passa a ser um conhecimento fundamental para a elaboração do modelo do edifício no uso da tecnologia.

\section{Considerações Finais}

Pela avaliação dos artigos contemplados por essa pesquisa, observa-se que muito tem sido estudado a respeito de estratégias para introdução de BIM no ensino de Arquitetura e Engenharia Civil no Brasil, porém, muito pouco tem sido reportado a respeito da implementação do paradigma na área acadêmica. Os relatos de experiência com implementação têm mostrado um processo desenvolvido muito lentamente e apresenta indícios de que este acompanha a velocidade com a qual a tecnologia está sendo adotada no mercado Brasileiro, o que, de certa forma, reproduz o que aconteceu em outros países também.

Observa-se que o ensino assume um ritmo mais acelerado à medida que o mercado e os governos imprimem um nível superior de demanda e, eventualmente, de incentivos. Essa observação corrobora a importância de se avaliar a relação entre o estágio de desenvolvimento de BIM no mercado e seu reflexo no ensino, conforme abordado por Ruschel et al. (2013). Embora os autores deste artigo concordem com o ponto de vista apresentado por Ruschel et al. (2013), há de se considerar que essa relação de causa e efeito pode não estar totalmente correta e a adoção de BIM sofrer um acréscimo assim que mais profissionais estejam preparados e disponíveis no mercado, conforme defendido por Delatorre et al. (2015). Todavia, independentemente da precedência, iniciativas de implantação adotadas pela iniciativa privada e/ou pelo governo, podem, sim, contribuir para a inserção mais rápida de BIM no ensino, assim como no cenário de mercado nacional (WONG et al., 2011). 
Avaliando os modelos de implementação discutidos, não se percebe as vantagens e desvantagens, de um ou de outro método - integrado ou pontual, como determinantes para a implantação de BIM no ensino, mas o pleno atendimento das demandas e a necessária adequação dos currículos para receberem as adaptações necessárias para a completa adoção do paradigma BIM ao longo dos cursos de graduação. Condições como, a multidisciplinaridade: que promove a aproximação de disciplinas diferentes do mesmo curso; a integração: que aborda o desenvolvimento de disciplinas diferentes, porém afins, em um mesmo eixo dentro de um curso; e a colaboração: que busca o trabalho compartilhado e colaborativo entre os vários professores de uma ou mais disciplinas, são a espinha dorsal do ensino de BIM e se apresentam como os pontos de maior complexidade na adoção do ensino do novo paradigma nos currículos de Engenharia Civil e Arquitetura.

Por não se ter um modelo consagrado para inserção de BIM no currículo de graduação de Arquitetura e Engenharia Civil, dentre outras áreas afins, a análise das experiências reportadas, passa a impressão de que se está buscando, de forma empírica, o método que proporcionará os melhores resultados. Essa percepção se estabelece diante da falta de padrão apresentado pelas implementações, a despeito de todos os modelos e análises discutidas e disponibilizadas na literatura pertinente.

Como um efeito positivo da implantação de BIM no ensino de graduação de Arquitetura e Engenharia Civil, pode-se citar a aproximação dos alunos, ainda que em etapas iniciais dos cursos, a conhecimentos técnicos sobre os elementos modelados (DELATORRE et al., 2015) tais como, processos produtivos, estudo de materiais, estruturas construtivas, etc. Essa prática resgata um procedimento que se tinha quando as disciplinas de desenho eram ministradas utilizando-se de instrumental manual e que se perdeu, ainda que parcialmente, com a adoção de sistemas CAD - Computer Aided Design.

Finalmente observa-se que o ensino de BIM está se estabelecendo nas universidades com o intuito de entregar ao mercado, profissionais com conhecimento sobre o paradigma e com isso acelerar a sua aplicação no ambiente de AECO. Com a aplicação de BIM espera-se proporcionar que as empresas trabalhem sobre uma base de dados comum, com mais integração e obtenham com isso um acréscimo em produtividade.

Este trabalho, ainda que resumidamente, apresentou as atividades que estão sendo desenvolvidas quanto ao ensino de BIM no Brasil e estabelece como um guia para a identificação dos autores e suas pesquisas, no período compreendido entre 2010 e 2015.

\section{References}

BARISON, M. B.; SANTOS, E. T. Review and analysis of current strategies for planning a BIM curriculum. Proc., CIB W78 2010 27th International Conference. Anais, 2010a

BARISON, M. B.; SANTOS, E. T. BIM teaching strategies: an overview of the current approaches. Proc., ICCCBE 2010 International Conference on Computing in Civil and Building Engineering. Anais. In: ICCCBE2010. Nottingham, UK: W Tizani, 2010b

CASEY, M. J. BIM in education: focus on local university programs. Building Smart Alliance national Conference Engineering \& Construction. Anais...Washington D.C.: 2008 
CHECCUCCI, É. DE S. Ensino-aprendizagem de BIM nos cursos de graduação em Arquitetura e Engenharia Civil. Arquitetura, Cidade e Projeto: uma construção coletiva. Anais... In: III ENCONTRO DA ASSOCIAÇÃO NACIONAL DE PESQUISA E PÓS-GRADUÇÃO EM ARQUITETURA E URBANISMO. São Paulo, SP: 2014

CHECCUCCI, É. DE S.; PEREIRA, A. P. C.; AMORIM, A. L. DE. A DI FUSÃo DAS TECNOLOGI AS BI M POR PESQUISADORES DO BRASIL. TIC 2011. Anais... In: TIC 2011 - ENCONTRO NACIONAL DE TECNOLOGIA DE INFORMAÇÃO E COMUNICAÇÃO NA CONSTRUÇÃO CIVIL. Salvador / BA: 2011

CHECCUCCI, É. DE S.; PEREIRA, A. P. C.; AMORIM, A. L. DE. Modelagem da I nformação da Construção (BIM) no Ensino de Arquitetura. Proceedings of the XVII Conference of the Iberoamerican Society of Digital Graphics: Knowledge-based Design. Anais... In: SIGRADI 2013. Valparaiso, Chile: 2013

DELATORRE, V.; PEREIRA, A. T. C.; MIOTTO, J. BIM: Relatos de aplicação no ensino de arquitetura. Blucher Design Proceedings, v. 2, n. 3, p. 30-37, 2015.

EASTMAN, C. et al. BIM Handbook: A Guide to Building Information Modeling for Owners, Managers, Designers, Engineers and Contractors. 2nd. ed. [s.I.] J ohn Wiley \& Sons, 2011.

GODOY, V. H.; CARDOSO, C. F.; BORGES, M. M. BIM: DESAFIOS PARA UM CONCEITO EM CONSTRUÇÃO NO ENSINO DE ARQUITETURA E ENGENHARIA. COBENGE 2013. Anais... In: XLI CONGRESSO BRASILEIRO DE EDUCAÇÃO EM ENGENHARIA. Gramado, RS: 2013

$\mathrm{LI}$, J. et al. Benefits of building information modelling in the project lifecycle: Construction projects in asia. I nternational J ournal of Advanced Robotic Systems, v. 11, n. 1, 2014.

MENEZES, A. M. et al. O IMPACTO DA TECNOLOgIA BIM NO ENSINO DE PROJetos DE EDI FI CAÇõES. XL Congresso Brasileiro de Educação em Engenharia. Anais... In: COBENGE. Belém / PA: 2012

MENEZES, A. M.; PONTES, M. M. BIM e o ensino: possibilidades na instrumentação e no projeto. SIGRADI 2012 Anais. Anais. In: SIGRADI 2012 - FORMA (IN) FORMAÇÃO. Fortaleza, CE: 2012

PEREIRA, P. A. I.; RIBEIRO, R. A. A Inserção de BIM no curso de graduação em Engenharia Civil. Revista Eletrônica Engenharia Viva, v. 1, n. 2, p. 17-30, 2015.

ROMCY, N. M. E S.; CARDOSO, D. R.; MIRANDA, N. M. BIM e Ensino: Experiência Acadêmica Realizada na Universidade Federal do Ceará. Simpósio Brasileiro de Qualidade do Projeto no Ambiente Construído. Anais... In: III SIMPÓSIO BRASILEIRO DE QUALIDADE DO PROJETO NO AMBIENTE CONSTRUÍDO VI ENCONTRO DE TECNOLOGIA DE INFORMAÇÃO E COMUNICAÇÃO NA CONSTRUÇÃO. Campinas / SP: 2013

RUSCHEL, R. C.; ANDRADE, M. L. V. X. DE; MORAIS, M. DE. O ensino de BIM no Brasil: onde estamos? Ambiente Construído, v. 13, n. 2, p. 151-165, jun. 2013.

SACKS, R.; PIKAS, E. Building information modeling education for construction engineering and management. I: Industry requirements, state of the art, and gap analysis. J ournal of Construction Engineering and Management, v. 139, n. 11, p. 04013016, 2013.

SUCCAR, B. Building information modelling framework: A research and delivery foundation for industry stakeholders. Automation in Construction, v. 18, n. 3, p. 357-375, 2009.

TAYLOR, J.; LIU, J.; HEIN, M. I ntegration of building information modeling (BIM) into an ACCE accredited construction management curriculum. Proceedings of the 44th ASC National Conference. Anais...2008

WONG, K. A.; WONG, K. F.; NADEEM, A. Building Information Modelling for Tertiary Contruction Education in Hong Kong. J ournal of I nformation Technology in Construction, ITcom. v. 16, p. 467-476, 2011. 


\section{Henrique Benedetto}

Programa de Pós-Graduação em Design - Universidade Federal do Rio Grande do Sul - UFRGS, Brasil, henrique.benedetto@ufrgs.br

\section{Maurício Moreira e Silva Bernardes}

Programa de Pós-Graduação em Design - Universidade Federal do Rio Grande do Sul - UFRGS, Brasil, bernardes@ufrgs.br

\section{Roberto Wanner Pires}

Programa de Pós-Graduação em Design - Universidade Federal do Rio Grande do Sul - UFRGS, Brasil, eng.arq@gmail.com 


\title{
Considerando Estilos de Aprendizagem, Emoções e Personalidade em Informática na Educação
}

\author{
Considering Learning Styles, Emotions and \\ Personality in Computers in Education
}

\author{
Janderson Jason Barbosa Aguiar \\ Universidade Federal de Campina Grande
}

\begin{abstract}
Resumo: Muitas vezes tratam-se turmas homogeneamente e as TDIC (Tecnologias Digitais de Informação e Comunicação) são utilizadas pelos alunos desconsiderando que eles possuem particularidades (tais como: estilos de aprendizagem, emoções e traços de personalidade) que influenciam em sua aquisição de conhecimento. Neste trabalho, são apresentados conceitos e reflexões visando incentivar discussões e estudos teóricos ou empíricos que considerem essas particularidade dos alunos durante o processo de ensino e aprendizagem. É apresentada também uma breve análise de dados de alunos de computação, em diferentes níveis de ensino, os quais responderam a questionários visando identificar perfis referentes a seus estilos de aprendizagem e a seus traços de personalidade. A análise corrobora com a ideia da heterogeneidade de perfis, mesmo considerando alunos da mesma área/nível de ensino. Percebe-se que ainda há várias possibilidades de pesquisas sobre aliar as TDIC e as particularidades de alunos objetivando a melhoria do processo de ensino e aprendizagem.
\end{abstract}

Palavras-chave: Informática na educação. Estilos de aprendizagem. Emoções. Personalidade. Computação afetiva.

\begin{abstract}
It is common to treat classes homogenously and use DICT (Digital Information and Communication Technologies) disregarding that students have special features (such as learning styles, emotions and personality traits) that influence in their acquisition of knowledge. This paper presents concepts and reflections to encourage discussion and theoretical or empirical research on student's peculiarities during the teaching and learning process. This paper also presents a brief analysis of student data (computing students at different levels of education). These students answered questionnaires to identify profiles related to their learning styles and personality traits. The analysis supports the idea that there is heterogeneity of student profiles, even students from the same area/level of education. One can see that there are several possibilities for research on combining the DICT and particularities of students aiming at the improvement of the teaching and learning process.
\end{abstract}

Keywords: Computers in education. Learning styles. Emotions. Personality. Affective computing. 


\section{I ntrodução}

As Tecnologias Digitais de Informação e Comunicação (TDIC) são constantemente utilizadas no processo educativo como meio facilitador do processo de ensino e aprendizagem (COSTA, AGUIAR e MAGALHÃES, 2013). Uma vez que essas TDIC fazem parte do cotidiano de muitos alunos, especialmente em cursos de área tecnológica, é interessante intensificar os estudos sobre como usar essas tecnologias na educação, de forma a prover cada vez mais estratégias motivadoras, tais como a personalização do ambiente, a fim de maior desempenho por parte dos alunos.

Independente da área do curso, na modalidade a distância, é necessário que os alunos interajam constantemente com as TDIC. Em relação à modalidade presencial, apesar de haver cursos (especialmente em áreas não tecnológicas) que não fazem uso constante dessas tecnologias, há também cursos (principalmente na área tecnológica), a exemplo dos cursos de computação, nos quais os alunos são frequentemente submetidos à interação com as TDIC, além de geralmente apresentarem maior facilidade de manejo (sendo, portanto, relevante e de fácil aceitação/adaptação, por parte de tais alunos, usar as TDIC para viabilizar meios para facilitar sua aprendizagem).

Ao comentar sobre alunos de área tecnológica, é importante destacar que ainda é comum ouvir comentários sobre estereótipos, considerando homogeneamente os aprendizes dessa área. Entretanto, observa-se que, embora estejam na mesma área, ou até no mesmo curso, esses indivíduos apresentam particularidades - e essas particularidades podem influenciar veementemente no processo de ensino e aprendizagem.

Dentre as particularidades a considerar, é possível citar conceitos como Estilos de Aprendizagem, Emoções e Traços de Personalidade. Segundo Valaski, Malucelli e Reinehr (2011), a identificação dos estilos de aprendizagem dos alunos é uma das formas para a obtenção de suas preferências, propiciando materiais de aprendizagem mais efetivos no processo de ensino e aprendizagem. Segundo Nunes (2012), os aspectos psicológicos, tais como emoções e personalidade, têm importância e influenciam o processo de tomada de decisão dos humanos.

Jaques e Nunes (2012) afirmam que a Computação Afetiva - área de pesquisa interessada em investigar como os computadores podem inferir e expressar emoções e personalidade (JAQUES et al., 2012) - pode contribuir na formação da presença social dos alunos em Ambientes Virtuais de Aprendizagem (AVA), tendo em vista que os seres humanos vivem em grupos de pessoas com características similares e/ou complementares às suas. Além disso, Jaques e Nunes (2012) defendem que inferir estados afetivos do aluno pode auxiliar a prever aspectos como evasão e baixo desempenho.

A adoção de aspectos psicológicos humanos na educação mediada por TDIC não está consolidada. Como é exposto por Nunes (2012), ainda há dificuldade em extrair intencionalmente esses aspectos. Entretanto, há pesquisas emergentes que vêm demonstrando a importância crescente desses aspectos, como as que são citadas ao longo deste artigo. 
A partir do exposto, percebe-se que conceitos como Estilos de Aprendizagem, Emoção e Personalidade são pertinentes para se considerar em Informática na Educação, especialmente no sentido de personalização de ambientes educacionais.

Neste trabalho, são apresentados conceitos e reflexões visando incentivar estudos teóricos ou empíricos que considerem empregar esses conceitos durante o processo de ensino e aprendizagem. Na Seção 2, são apresentados alguns trabalhos relacionados. Os fundamentos sobre Estilos de Aprendizagem, Emoções e Personalidade são detalhados, respectivamente, nas Seções 3, 4 e 5. Por fim, na Seção 6 são realizadas algumas considerações.

Ressalta-se que, uma vez que os Estilos de Aprendizagem e a Personalidade são características mais estáveis nos indivíduos (bem menos mutáveis que, por exemplo, Emoções), nas Seções 3 e 5 são também apresentados resultados de uma breve análise de dados empíricos, a fim de demonstrar que, mesmo alunos de um mesmo curso e do mesmo nível de ensino (nível técnico, graduação, mestrado, doutorado), possuem características diferentes relativas a estilos de aprendizagem e traços de personalidade.

\section{Trabalhos Relacionados}

Uma vez que este artigo apresenta aspectos e discussões a fim de fomentar o debate acadêmico de linhas de pesquisa envolvendo Estilos de Aprendizagem, Emoções e Personalidade em Informática na Educação - e, portanto, proporcionar reflexões para direcionamento teórico/empírico - é possível encontrar trabalhos similares que abordem reflexões sobre esses conceitos.

Na pesquisa de Silva et al. (2013), ao serem investigados cursos de especialização para identificar se os estilos de aprendizagem impactam o desempenho acadêmico nas atividades de avaliação on-line e presencial na Educação a Distância (EAD), são realizados comentários e apresentados conceitos importantes relativos a estilos de aprendizagem. Aguiar, Fechine e Costa (2014) apresentaram um estudo mapeando as iniciativas brasileiras em Informática na Educação que utilizaram os conceitos de Estilos Cognitivos e Estilos de Aprendizagem.

Özyurt e Özyurt (2015) realizaram uma análise do conteúdo de trabalhos recentes (entre 2005 e 2014) sobre hipermídia educacional adaptativa com base em estilos de aprendizagem, discutindo os potenciais tópicos de investigação, e analisando as tendências e as lacunas existentes na literatura. Nesse contexto, Truong (2016) também realizou uma revisão na literatura sobre como estilos de aprendizagem estão sendo integrados em sistemas e-learning adaptativos, fornecendo recomendações e orientações para pesquisas futuras.

Nunes et al. (2010) apresentaram aspectos relacionados à Computação Afetiva e sua influência na personalização de ambientes educacionais, com enfoque na geração de equipes compatíveis em AVA na EAD. Na pesquisa de Nunes (2012), são apresentadas pesquisas científicas e tecnológicas realizadas no âmbito da Computação Afetiva relacionada à personalização de interfaces, interações e recomendações de produtos, serviços e pessoas em ambientes computacionais. No documento elaborado como base de um minicurso ministrado por Jaques e Nunes (2012), é provida uma visão geral teórica e prática relativa à Computação 
Afetiva aplicada em ambientes computacionais de aprendizagem. No trabalho de Jaques et al. (2012), além de ser abordada a Computação Afetiva, foi realizada uma associação com Sistemas Tutores Inteligentes, apresentando desafios e perspectivas de investigações futuras nessas áreas.

Longhi (2011), ao abordar vários conceitos importantes sobre aspectos afetivos, confirmou a hipótese de que os estados de ânimo de um aluno podem ser reconhecidos em um AVA por meio de um modelo computacional que inter-relacione fatores de personalidade $e$ comportamento. Komulainen et al. (2014) realizaram um estudo objetivando apresentar em que as características de personalidade representam na vida diária, investigando o efeito dos traços de personalidade sobre diferentes processos emocionais diários, utilizando, para isso, informações de estudantes universitários. Faquin, Falci e Araújo (2016) realizaram considerações relativas à personalidade ao apresentar os resultados de seu trabalho, cujo objetivo foi compreender como perfis de personalidade distintos podem se relacionar a diferentes desempenhos acadêmicos e níveis de habilidade em alunos de Sistemas de Informação.

Ao indicar resultados revelando que agentes pedagógicos animados têm impactos diferentes no comportamento do aluno segundo a sua personalidade, Nunes e J aques (2014) realizaram, em seu trabalho, considerações relativas a emoções e personalidade. Reis et al. (2015) publicaram um trabalho relativo ao estado da arte sobre afetividade na formação de grupos em ambientes colaborativos de aprendizagem; dentre os resultados, foi indicado que a maioria dos estudos selecionados considerou os traços de personalidade na formação de grupos em ambientes de aprendizagem colaborativa com suporte computacional.

Li e Armstrong (2015) investigaram a relação entre estilos de aprendizagem e personalidade em gestores internacionais. No contexto de examinar como emoções de adultos afetam em seus estilos de aprendizagem, Samsudin e Ch'ng (2015) verificaram que esses dois conceitos estão inter-relacionados e afetam as atividades de aprendizagem diárias.

Destaca-se que, além desses trabalhos, é possível encontrar vários outros que, apesar de não necessariamente realizarem reflexões enfatizando os conceitos de Estilos de Aprendizagem, Emoções e/ou Personalidade, usaram pelo menos um desses conceitos como parte de sua pesquisa. Para isso sugere-se que, assim como realizado no desenvolvimento deste trabalho, sejam realizadas buscas por artigos recentes via Portal de Periódicos CAPES/MEC (vislumbrando pesquisas em âmbito internacional), além de realizar buscas de tais conceitos nos seguintes veículos brasileiros de publicação científica: Revista Informática na Educação: Teoria \& Prática (IETP), Revista Brasileira de Informática na Educação (RBIE), Revista Novas Tecnologias na Educação (RENOTE), Anais do Workshop de Informática na Escola (WIE), Anais do Simpósio Brasileiro de Informática na Educação (SBIE).

No Quadro 1, em síntese, estão listados os trabalhos citados nesta seção, sendo indicados quais trabalhos estão relacionados com quais conceitos. $O$ símbolo $\checkmark$ indica que determinado trabalho apresentou considerações relacionadas a determinado conceito; por outro lado, o 
símbolo X indica que determinado trabalho não está intrinsecamente relacionado a determinado conceito.

Quadro 1 - Comparação entre trabalhos relacionados.

\begin{tabular}{|c|c|c|c|}
\hline Trabalho & Estilos de Aprendizagem & Emoções & Personalidade \\
\hline Aguiar, Fechine e Costa (2014) & $\checkmark$ & $X$ & $X$ \\
\hline Faquin, Falci e Araújo (2016) & $X$ & $X$ & $\checkmark$ \\
\hline Jaques e Nunes (2012) & $X$ & $\checkmark$ & $\checkmark$ \\
\hline Jaques et al. (2012) & $X$ & $\checkmark$ & $\checkmark$ \\
\hline Komulainen et al. (2014) & $X$ & $\checkmark$ & $\checkmark$ \\
\hline Li e Armstrong (2015) & $\checkmark$ & $\checkmark$ & $\checkmark$ \\
\hline Longhi (2011) & $X$ & $\checkmark$ & $\checkmark$ \\
\hline Nunes (2012) & $X$ & $\checkmark$ & $\checkmark$ \\
\hline Nunes et al. (2010) & $X$ & $X$ & $\checkmark$ \\
\hline Nunes e Jaques (2014) & X & $\checkmark$ & $\checkmark$ \\
\hline Özyurt e Özyurt (2015) & $\checkmark$ & $\checkmark$ & $\checkmark$ \\
\hline Reis et al. (2015) & $\checkmark$ & $X$ & $X$ \\
\hline Samsudin e Ch'ng (2015) & $\checkmark$ & $X$ & $X$ \\
\hline Silva et al. (2013) & $\checkmark$ & $X$ \\
\hline Truong (2016) & & & \\
\hline
\end{tabular}

Fonte: elaborado pelo autor.

A diferença básica desses trabalhos, em relação a este, consiste principalmente no fato que, neste artigo, são reunidos os três conceitos (Estilos de Aprendizagem, Emoções e Personalidade), sendo referenciados vários trabalhos importantes que podem servir de base para os leitores. Além disso, este trabalho difere de outros citados por realizar uma breve análise de dados de alunos de computação em diferentes níveis de ensino (referentes a seus Estilos de Aprendizagem e seus Traços de Personalidade), sendo também comentadas algumas perspectivas de uso dos conceitos de Estilos de Aprendizagem, Emoções e Personalidade na área de educação em computação.

\section{Estilos de Aprendizagem}

Embora não seja algo consensual na educação, há docentes e pesquisadores preocupados com as formas com que os aprendizes lidam particularmente com as informações, sendo o conceito de Estilos de Aprendizagem levado em consideração em muitas pesquisas atualmente.

No âmbito de Informática na Educação, muitos autores usam o termo Estilos Cognitivos como sinônimo de Estilos de Aprendizagem, e outros ainda usam o termo Estilos Cognitivos de Aprendizagem, sendo sugerido, por Aguiar, Fechine e Costa (2014), o uso do termo "Estilos de Aprendizagem" ou "Estilos Cognitivos de Aprendizagem" quando o foco for relativo à aprendizagem e à aquisição de informação - enquanto "Estilos Cognitivos" foca no controle e na organização dos processos cognitivos.

Há vários modelos teóricos empregados em relação à forma como o aluno aprende (COFFIELD et al., 2004), sendo o de Felder e Silverman (1988) um dos mais populares. Ao 
adotar esse modelo, é comum a utilização do questionário ILS (Index of Learning Styles) para extração dos estilos de aprendizagem (FELDER e SOLOMAN, 1999). Esse questionário identifica estas quatro dimensões para formas de aprendizado: 1-Ativo/Reflexivo, 2-Sensorial/Intuitivo, 3-Visual/Verbal e 4-Sequencial/Global. No Quadro 2, são apresentadas características de ambas as categorias dessas quatro dimensões.

Quadro 2 - Características dos Aprendizes de acordo com seus Estilos de Aprendizagem.

\begin{tabular}{|c|c|}
\hline Dimensão & Características dos Aprendizes \\
\hline $\begin{array}{c}\text { Ativo } \\
\text { Reflexivo }\end{array}$ & $\begin{array}{l}\text { Ativos: tendem a reter e compreender melhor a informação participando ativamente de } \\
\text { alguma atividade, discutindo, aplicando ou explicando para outros; gostam do trabalho em } \\
\text { grupo; são rápidos, mas podem ser precipitados. } \\
\text { Reflexivos: preferem refletir calmamente sobre a informação; podem ser mais lentos para } \\
\text { iniciar uma atividade; gostam do trabalho individual ou em dupla. }\end{array}$ \\
\hline $\begin{array}{l}\text { Sensorial } \\
\text { Intuitivo }\end{array}$ & $\begin{array}{l}\text { Sensoriais: gostam de resolver problemas por meio de procedimentos bem estabelecidos e } \\
\text { não apreciam complicações e surpresas; são pacientes com detalhes; memorizam fatos com } \\
\text { facilidade; apreciam trabalhos de manipulação, experimentais, repetitivos (laboratório); } \\
\text { tendem a ser práticos e cuidadosos; não gostam de disciplinas que não têm uma conexão } \\
\text { aparente com o mundo real. } \\
\text { I ntuitivos: frequentemente preferem descobrir possibilidades e inter-relações; gostam de } \\
\text { inovação e não apreciam a repetição; sentem-se confortáveis com abstrações e formulações } \\
\text { matemáticas; são rápidos e criativos; não apreciam as disciplinas que envolvem muita } \\
\text { memorização e cálculos rotineiros; apreciam a variedade. }\end{array}$ \\
\hline $\begin{array}{l}\text { Visual } \\
\text { Verbal }\end{array}$ & $\begin{array}{l}\text { Visuais: lembram-se mais do que viram; substituem as palavras por símbolos; preferem as } \\
\text { representações visuais - diagramas, quadros, cronogramas, gráficos, filmes e } \\
\text { demonstrações; reconstroem imagens de diferentes modos. } \\
\text { Verbais: tiram mais proveito das explanações escritas e faladas; gostam de ouvir e de } \\
\text { tomar notas; materiais de apoio impressos são úteis para eles; repetem as palavras, } \\
\text { falando ou escrevendo; fazem a leitura de suas notas em silêncio; transformam diagramas } \\
\text { em palavras. }\end{array}$ \\
\hline $\begin{array}{c}\text { Sequencial } \\
\text { Global }\end{array}$ & $\begin{array}{l}\text { Sequenciais: avançam com entendimento parcial; ganham entendimento em passos } \\
\text { lineares, com cada passo derivado do anterior; tendem a seguir caminhos lógicos e graduais } \\
\text { na solução de um problema; têm facilidade para explicar; enfatizam a análise, os detalhes. } \\
\text { Globais: aprendem em grandes saltos, absorvendo o material quase que aleatoriamente, } \\
\text { sem enxergar conexões, e repentinamente compreendem tudo; precisam do contexto, do } \\
\text { grande quadro; são hábeis para resolver rapidamente problemas complexos; têm facilidade } \\
\text { para juntar elementos, de maneiras novas, uma vez que tenham enxergado o grande } \\
\text { quadro, mas podem ter dificuldade para explicar como fizeram isso; o foco está na síntese, } \\
\text { no pensamento sistêmico, holístico. }\end{array}$ \\
\hline
\end{tabular}

Fonte: Silva et al. (2013), p. 4, adaptado de Felder e Silverman (1988).

Ressalta-se que há estudos que reforçam que o ILS é um instrumento confiável, válido e adequado para identificação dos estilos de aprendizagem (FELDER e SPURLIN, 2005; LITZINGER et al., 2007; ZYWNO, 2003). Todavia, nesses estudos é recomendado que continuem a ser realizadas pesquisas para avaliar a aplicação de tal instrumento.

Como exemplo, utilizando a teoria de Felder e Silverman (1988), a partir do questionário ILS, são ilustrados em gráficos, na Figura 1, alguns perfis de alunos de computação, em diferentes níveis, com base em seus estilos de aprendizagem.

Na Figura 1(a) são apresentados dois perfis bem diferentes de alunos em um curso técnico. Destaca-se o percentual alto para o estilo Reflexivo do Tecnolando B e, por outro lado, o baixo índice desse estilo para o Tecnolando A (ou seja, o Tecnolando A possui predominantemente o estilo Ativo). Outra diferença acentuada é o percentual alto para o estilo Verbal do Tecnolando 
A e, por outro lado, o baixo índice desse estilo para o Tecnolando B (ou seja, o Tecnolando B possui predominantemente o estilo Visual).

Na Figura 1(b), em relação a graduandos em computação, são vistos novamente dois perfis distintos. Destaca-se o percentual maior para o estilo Global do Graduando B em relação ao Graduando A (ou seja, o Graduando A possui predominantemente o estilo Sequencial).

Na Figura 1(c), é apresentada uma comparação similar considerando mestrandos em computação. Na Figura 1(d), perfis de doutorandos em computação.

Figura 1 - Exemplos de perfis de alunos de computação, com Estilos de Aprendizagem distintos, em diferentes níveis de ensino: (a) técnico; (b) graduação; (c) mestrado; (d) doutorado.

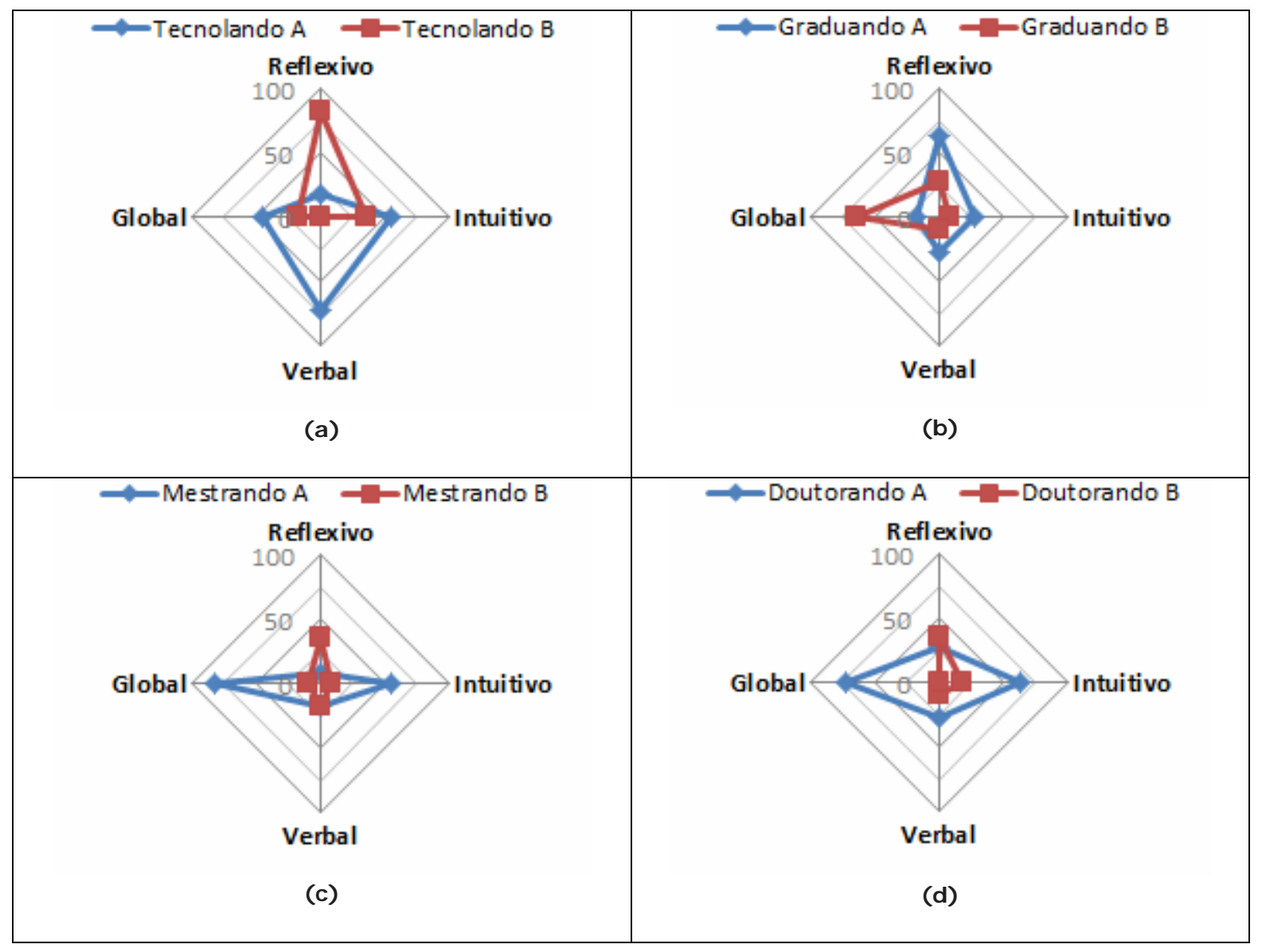

Fonte: elaborada pelo autor.

Os dados apresentados na Figura 1 foram obtidos com base na participação de 118 alunos de computação (61 alunos em nível técnico, 36 alunos de graduação e 21 pós-graduandos mestrandos ou doutorandos), os quais responderam às questões do ILS, via formulário on-line. A partir das respostas, foi definido, para caracterizar cada aluno, um vetor com 4 elementos (dados numéricos entre 0 a 100) indicando o percentual dos estilos de aprendizagem em cada uma das dimensões de Felder e Silverman (1988). Por exemplo: 0 para a dimensão 1Ativo/Reflexivo indicaria 0\% para o Estilo Reflexivo e, consequentemente, 100\% para o Estilo 
Ativo; 34 para a dimensão 2-Sensorial/Intuitivo indicaria 34\% para o Estilo Intuitivo e, consequentemente, 66\% para o Estilo Sensorial; 57 para a dimensão 3-Visual/Verbal indicaria $57 \%$ para o Estilo Verbal e, consequentemente, $43 \%$ para o Estilo Visual; e 86 para a dimensão 4-Sequencial/Global indicaria $86 \%$ para o Estilo Global e, consequentemente, $14 \%$ para o Estilo Sequencial. Uma vez que cada aluno foi representado por um vetor, foi utilizada, para a comparação entre esses vetores, a Medida de Similaridade dos Cossenos (quanto mais próximo de zero for essa medida, mais baixa é a similaridade); assim, foram identificados os pares de alunos menos similares, ilustrando-se na Figura 1 seus perfis.

Os gráficos da Figura 1 ilustram como é possível observar a ideia de heterogeneidade de perfil relativa aos estilos de aprendizagem, entre os alunos de computação, independente do nível de ensino. Ressalta-se que os gráficos não são apresentados a fim de delinear um perfil de estilos de aprendizagem para tais cursos, mas para destacar a diferença de perfis de alunos em uma mesma área/nível de ensino.

É possível citar também iniciativas de uso do modelo de Felder e Silverman (1988) que não utilizam o ILS, utilizando métodos para inferir os estilos baseando-se em analisar como o estudante se comporta (por exemplo, que tipos de atividades realiza) em sistemas de aprendizagem (DORÇA et al., 2013; GRAF, KINSHUK e LIU, 2008; POPESCU, TRIGANO e BADICA, 2007). Além da obtenção dos estilos, alguns pesquisadores apresentam a possibilidade de atualizações dinâmicas dos perfis relativos aos estilos de aprendizagem dos alunos (DORÇA et al., 2013; POPESCU, TRIGANO e BADICA, 2007).

\section{Emoções}

Segundo Reis et al. (2015), pesquisas em Informática na Educação usam as terminologias "estados afetivos" e "aspectos afetivos" para caracterizar o estado mental afetivo (emoção, estado de ânimo) e as características de personalidade de um aluno, nas diversas situações vivenciadas no processo de ensino e aprendizagem.

Em relação à afetividade, Longhi (2011) indica que há diferentes conceituações, com base em abordagens filosóficas e psicológicas, sendo o modelo de Scherer (2000) vantajoso ao evidenciar as diferenças entre emoções, estados de ânimo e traços de personalidade.

Scherer (2000) baseia-se em fatores como intensidade, duração, sincronização, impacto comportamental, entre outros, para diferenciar as emoções dos outros estados afetivos. Enquanto emoções são caracterizadas como estados afetivos de curta duração (minutos ou horas), alta intensidade e disparadas/ativadas por um estímulo (por exemplo: alegria, medo, raiva, tristeza e vergonha), os estados de ânimo (humor) caracterizam-se como estados afetivos difusos, de baixa intensidade, longa duração e sem causa aparente, e os traços de personalidade são definidos como estados afetivos que tendem a ser estáveis e característicos de um indivíduo (LONGHI, 2011; REIS et al., 2015).

As emoções podem ser classificadas em primárias/básicas (inatas e de segurança individual) e secundárias/sociais (estabelecidas a partir das primárias). Para mais detalhes sobre os 
conceitos dos diferentes estados afetivos, sugere-se a leitura da fundamentação teórica da tese de doutorado de Longhi (2011).

Gil et al. (2015) afirmam que aplicações para reconhecer emoções estão recebendo muita atenção como um meio para melhorar a experiência do usuário com a tecnologia. Esses autores indicam que há proliferação de projetos envolvendo a coleta de dados de usuários relativos a emoções, como, por exemplo, estudos relativos a análises de sentimento em fóruns de discussão de MOOCs (Massive Online Open Courses - Cursos On-line Abertos e Massivos) visando descobrir antecipadamente prováveis situações de abandono (WEN, YANG e ROSÉ, 2014 apud GIL et al., 2015); assim, além de realizar essa descoberta, pode-se tentar considerar as emoções dos alunos para realizar adaptações no ambiente - usando-se, por exemplo, agentes pedagógicos animados (NUNES e JAQUES, 2014) - com o objetivo de mantê-los engajados nesses cursos, reduzindo, consequentemente, as taxas de evasão.

O reconhecimento de emoções do usuário geralmente requer dispositivos específicos, uma vez que podem ser reconhecidas pelas seguintes fontes: (i) voz (prosódia) ou diálogo; (ii) comportamento observável, isto é, as ações do usuário na interface do sistema (por exemplo, opções escolhidas e velocidade de digitação); (iii) expressões faciais; e (iv) sinais fisiológicos (batimentos cardíacos, eletromiograma - tensão muscular, condutividade da pele, respiração) (JAQUES E NUNES, 2012).

Um modelo afetivo que se enquadra como uma abordagem multidimensional de emoção é o PAD - Pleasure, Arousal e Dominance (MEHRABIAN, 1996). A dimensão Pleasure trata a valência da emoção sentida (variando de "agradável" a "desagradável"), a dimensão Arousal trata o grau de excitação (variando entre "excitado" e "relaxado") e a dimensão Dominance trata o grau de controle do usuário (variando de "dominante" até "submisso"). Ressalta-se que, além do PAD, há outros modelos para representar emoções, como o modelo OCC ${ }^{1}$ (ORTONY, CLORE e COLLINS, 1988), por meio do qual é explicada a origem de 22 tipos de emoções, sendo descritos os processos cognitivos que ativam cada um deles.

Para definir os valores de cada dimensão do modelo PAD, Bradley e Lang (1994) apresentaram o Self-Assessment Manikin (SAM), um instrumento orientado a figuras. Broekens e Brinkman (2009) apresentaram o AffectButton, uma ferramenta para a detecção do estado afetivo do usuário a partir de feedback explícito, construída de formar similar ao SAM, na qual o usuário pode informar dinamicamente o seu estado. Na ferramenta (Figura 2), é exibida uma face que muda de expressão a partir do movimento do mouse e, a partir disso, são medidos os valores para cada dimensão do modelo PAD.

Considerando, por exemplo, que, ao tentar solucionar determinados problemas, o ato de programar computadores gera diferentes emoções ao programador aprendiz, este cenário é um possível caso para aplicar o conceito de emoções visando à melhoria da educação na área da computação. A identificação das emoções poderia ser útil em diversas pesquisas a fim de

\footnotetext{
${ }^{1}$ De acordo com Longhi (2011), o modelo OCC (ORTONY, CLORE e COLLINS, 1988) - provavelmente o mais utilizado para avaliar/sintetizar emoções de usuários em sistemas computacionais - pressupõe que as percepções emocionais de um agente são valoradas a partir de seus objetivos, padrões e preferências. Neste modelo, considera-se que uma emoção é derivada a partir da sua avaliação sob três dimensões: (i) consequência dos eventos, (ii) ação dos agentes e (iii) aspectos dos objetos, permitindo, além de inferir uma emoção, verificar a experiência subjetiva e a valência emocional.
} 
sugerir meios facilitadores para o desenvolvimento de alguns programas, com base em escolhas/caminhos seguidos anteriormente por outros usuários/programadores que, ao final da realização de tarefas similares, indicaram uma emoção indicativa de sucesso, a exemplo de alegria.

Um exemplo de estudo considerando emoções é descrito por Pereira (2012), no qual se utilizou o contexto afetivo do usuário para propor um Sistema de Recomendação que faz uso das emoções do usuário para selecionar e sugerir itens durante o processo de recomendação: o Affective-Recommender, que utiliza o modelo PAD e o instrumento SAM (a partir do AffectButton).

Figura 2 - AffectButton (de esquerda para a direita, de cima para baixo, faces geradas para os estados: Feliz, Com medo, Surpreso, Triste, Bravo, Relaxado, Contente, Frustrado).

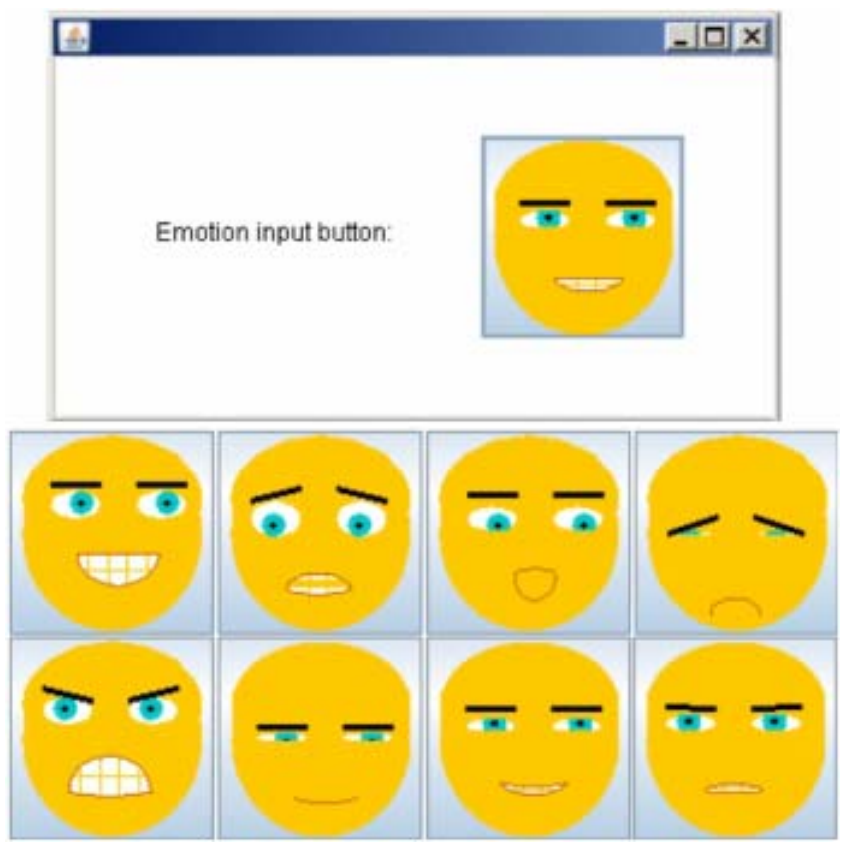

Fonte: Broekens e Brinkman (2009), p. 3.

A recomendação de itens no Affective-Recommender é realizada baseada em usuários com preferências similares. A preferência de um usuário para um item é vista como sua reação estado afetivo detectado após o contato - ao item. Os resultados indicaram que os alunos conseguiram informar seus estados afetivos, e que houve uma mudança neste estado baseado no item acessado (PEREI RA, 2012).

O uso de um Sistema de Recomendação baseado em Emoções, como o AffectiveRecommender, é um exemplo de iniciativa que poderia ser adotada em cursos na modalidade a distância, e até mesmo em cursos presenciais, contanto que utilizassem o Moodle como ambiente virtual de apoio ao processo de ensino e aprendizagem. 
Uma vez que emoções são mais breves/momentâneas, variando em curto período de tempo (diferentemente dos Estilos de Aprendizagem e da Personalidade de um indivíduo), não são apresentados nesta seção diagramas (como feito nas Seções 3 e 5 - Figuras 1 e 3 ) com perfis de alunos de computação relativos a emoções.

\section{Personalidade}

A Personalidade pode ser definida como padrão consistente do comportamento originado internamente no indivíduo (BURGER, 2000), embora não haja um consenso na Psicologia para sua definição.

Nunes (2012) afirma que a Teoria do Traço (ALLPORT e ALLPORT, 1921) tem sido a mais comumente aplicada para representação de personalidade, por ser mais facilmente mensurável de forma explícita em humanos por meio de computadores.

O modelo dos Cinco Grandes Fatores (CGF) da personalidade, ou Big Five (JOHN e SRIVASTAVA, 1999), é uma versão moderna da Teoria do Traço. Os CGF, em português, podem ser definidos como: Extroversão, Socialização (ou Amabilidade), Realização (ou Conscientização), Neuroticismo (ou Instabilidade Emocional) e Abertura (ou Abertura à mudança). No Quadro 3, são apresentados adjetivos característicos do Big Five.

Quadro 3 - Adjetivos característicos do Big Five.

\begin{tabular}{|c|c|c|c|c|c|}
\hline & Extroversão & Socialização & Realização & Neuroticismo & Abertura \\
\hline & Ativo & Altruísta & Confiável & Ansioso & Artístico \\
& Aventureiro & Amigável & Consciente & Apreensivo & Curioso \\
& Barulhento & Carinhoso & Eficiente & Emotivo & Engenhoso \\
& Energético & Confiante & Minucioso & Instável & Esperto \\
& Entusiástico & Cooperativo & Organizado & Nervoso & Imaginativo \\
& Exibido & Gentil & Prático & Preocupado & Inteligente \\
& Sociável & Sensível & Preciso & Temeroso & Original \\
& Tagarela & Simpático & Responsável & Tenso & Sofisticado \\
\hline \multirow{4}{*}{ Polo dótulo oposto } & Acanhado & Antipático & Desatento & Calmo & Comum \\
& Introvertido & Brigão & Descuidado & Contido & Simples \\
& Quieto & Bruto & Desorganizado & Estável & Superficial \\
& Reservado & Crítico & Distraído & Indiferente & Tolo \\
& Silencioso & Frio & Imprudente & Sereno & Trivial \\
& Tímido & Insensível & Irresponsável & Tranquilo & Vulgar \\
\hline
\end{tabular}

Fonte: Nunes (2012), p. 119.

Para extrair informações relativas à personalidade humana, é comum utilizar inventários de personalidade. Dentre os validados, há o NEO-IPIP (Neo-International Personality Item Pool), que permite medir as 5 dimensões do Big Five, incluindo mais 6 facetas para cada dimensão, propiciando maior precisão na representação da personalidade. O NEO-IPIP é um inventário com 300 itens que possuem afirmativas, aos quais o respondente atribui um valor de concordância do quanto essas afirmativas o representam em uma escala tipo Likert de cinco pontos. Uma alternativa ao NEO-IPIP é o inventário TIPI (Ten I tem Personality Inventory), com apenas 10 itens (NUNES, 2012). 
Um exemplo de iniciativa em Informática na Educação utilizando Personalidade é a ferramenta Group Recommender (NUNES et al., 2010), que possibilita a criação de equipes de trabalho eficientes coordenadas por tutores, considerando as características do tutor e a similaridade de Traços de Personalidade de seus alunos. Para utilização do sistema, é necessário que os usuários/alunos respondam ao Personality Inventory PV1.0 (NUNES, MORAES e REINERT, 2010) - uma interface para o NEO-IPIP e TIPI, com versão em português -, do qual se extrai o modelo de personalidade e, por meio deste, são gerados os dados necessários para a criação das equipes (NUNES, 2012).

Segundo Gosling (2008), a melhor forma de obtenção dos Traços de Personalidade dos usuários seria a utilização de abordagens que não exigissem esforço cognitivo (como, por exemplo, padrão de digitação) se comparado aos tradicionais inventários de personalidade. Neste contexto, há pesquisas, tais como a de Bachrach et al. (2012), a de Markovikj et al. (2013) e a de Schwartz et al. (2013), que descrevem que Traços de Personalidade possuem correlação com padrões de uso da rede social Facebook (https://www.facebook.com/), podendo facilitar a detecção de personalidade com a mineração dos dados dos usuários dessa rede social.

Na Figura 3, são ilustrados em gráficos alguns perfis de alunos de computação, a partir de seus Traços de Personalidade, extraídos via ferramenta Five Labs (FIVE, 2015), que se baseia no estudo de Schwartz et al. (2013).

Figura 3 - Exemplos de perfis de alunos de computação, com Traços de Personalidade distintos, em diferentes níveis de ensino: (a) técnico; (b) graduação; (c) mestrado; (d) doutorado.

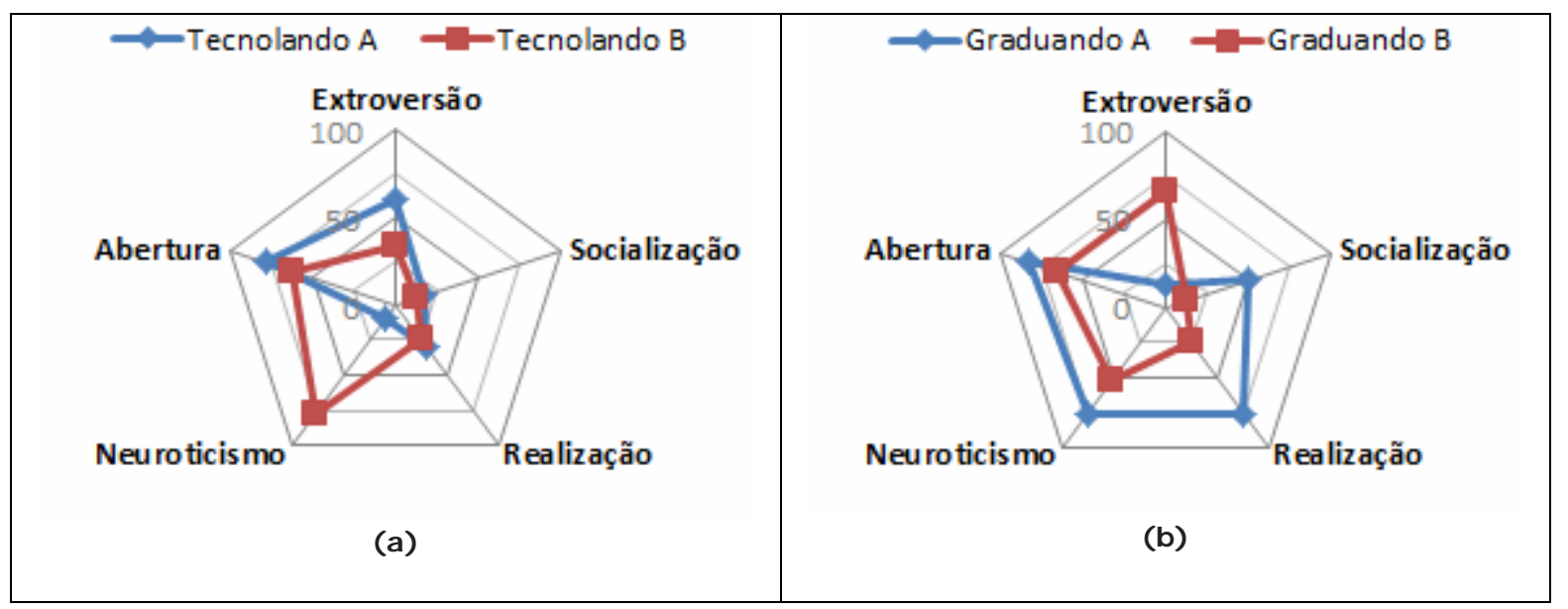




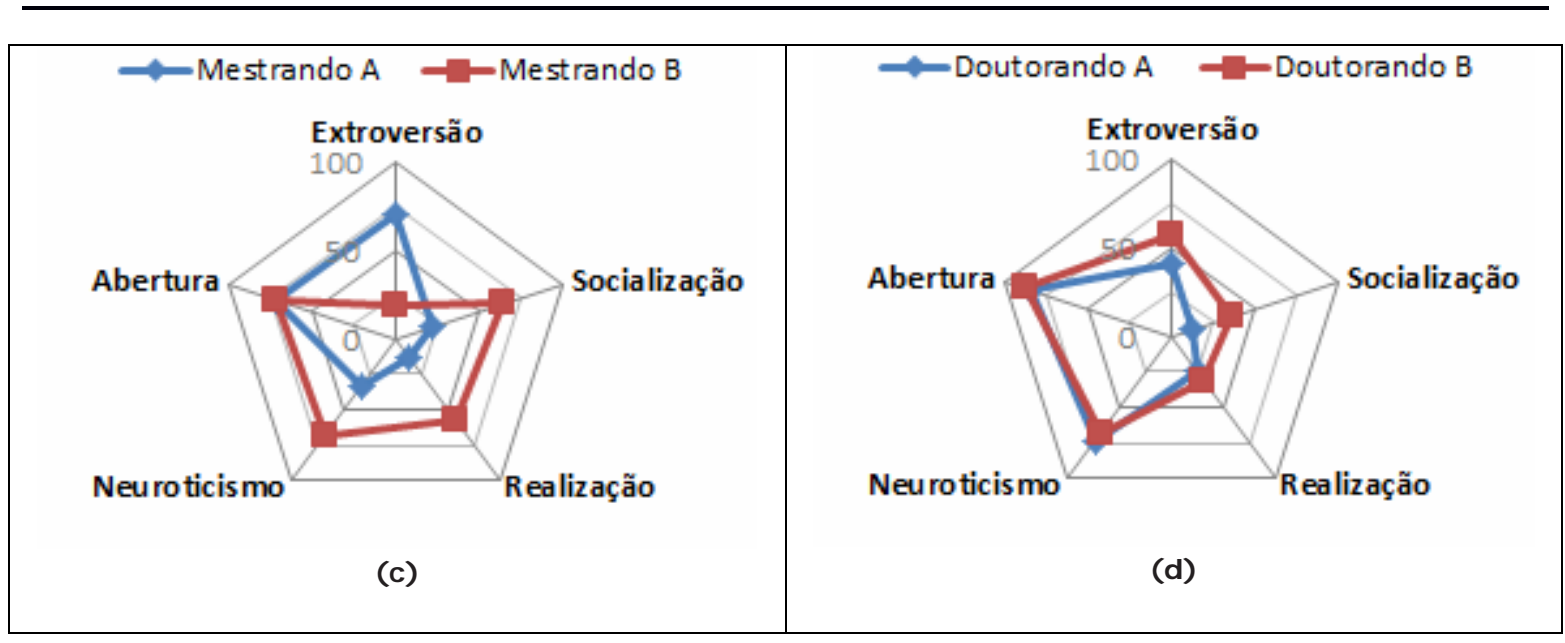

Fonte: elaborada pelo autor.

Similarmente à comparação relativa a estilos de aprendizagem (Figura 1), nota-se, a partir da Figura 3, diferenças entre perfis de alunos em um curso técnico, na graduação, no mestrado e no doutorado. Com base nos gráficos 3(a), 3(b), 3(c) e 3(d), é possível observar, entre os alunos de computação, a não homogeneidade de perfil relativa aos Traços de Personalidade, independente no nível de ensino. Destaca-se, por exemplo, o alto nível de Neuroticismo no Tecnolando B em relação ao Tecnolando A, e o baixo nível de Extroversão do Graduando A em relação ao Graduando B.

Os dados apresentados na Figura 3 foram obtidos com base na participação de 81 alunos de computação (38 alunos em nível técnicos, 23 alunos de graduação e 20 - mestrandos ou doutorandos), os quais informaram, via formulário on-line, os resultados da ferramenta Five Labs. A partir das respostas, foi definido, para caracterizar cada aluno, um vetor com 5 elementos (dados numéricos entre 0 a 100) representando o valor percentual de cada um dos traços do Big Five (Extroversão, Socialização, Realização, Neuroticismo e Abertura). Uma vez que cada aluno foi representado por um vetor, foi utilizada a Medida de Similaridade dos Cossenos para identificar os pares de alunos menos similares (assim como no estudo relativo a Estilos de Aprendizagem - Seção 3), ilustrando-se na Figura 3 seus perfis.

Assim como comentado na Seção 3 (sobre a Figura 1, relativa a estilos de aprendizagem), ressalta-se que os gráficos da Figura 3 não são apresentados com o objetivo de delinear um perfil de Personalidade dos alunos de tais cursos. O objetivo consiste em destacar, a partir desses exemplos, a diferença na personalidade dos alunos em uma mesma área/nível de ensino.

Considerando que pessoas com personalidades similares podem ter preferências similares, a utilização de sistemas de recomendação educacionais, utilizando a estratégia de recomendação baseada em personalidade (NUNES e HU, 2012), consiste em outro interessante cenário possível para aplicar aspectos psicológicos em Informática na Educação.

Voltando-se à área da computação para exemplificar o uso de personalidade em I nformática na Educação, é interessante citar que, em uma recente revisão sistemática de pesquisas sobre 
personalidade em engenharia de software (CRUZ, DA SILVA e CAPRETZ, 2015), foi percebido que pesquisas relacionadas a programação em pares, educação, eficácia da equipe, alocação de processo de software, características de personalidade dos engenheiros de software e performance individual concentraram mais de $88 \%$ dos estudos selecionados. Acredita-se que, além da computação, várias outras áreas podem se beneficiar de estudos relativos à formação de equipes, além de aspectos relacionados à execução de tarefas específicas nas variadas áreas do conhecimento humano.

\title{
6 Considerações Finais
}

A partir dos fundamentos apresentados, é possível notar que há várias formas de expandir o uso de aspectos psicológicos em Informática na Educação, a exemplo de pesquisas no âmbito da personalização de ambientes virtuais de aprendizagem, que tende a impactar positivamente no desempenho individual dos aprendizes. A personalização é uma característica importante em sistemas para EAD devido às diferentes experiências dos alunos adultos, foco principal desse tipo de modalidade de ensino (KERKIRI, MANITSARIS e MAVRIDOU, 2007).

Como afirmado anteriormente, os aspectos psicológicos - tais como Emoções e Traços de Personalidade - influenciam processos de tomada de decisão. Uma vez que tomar decisões é algo cotidiano para os indivíduos, tais conceitos apresentam-se potencialmente úteis para a melhoria do processo de ensino e aprendizagem. Compete, neste ponto, expor esta consideração de J aques e seus colaboradores:

\begin{abstract}
Ainda, embora existam importantes trabalhos que apontem a importância de considerar as emoções na aprendizagem, não existem teorias compreensíveis e validadas que identifiquem quais emoções são mais importantes para aprendizagem e como especificamente estas interferem na aprendizagem. Dessa forma, devido também a sua natureza multidisciplinar, essa área se mostra ao mesmo tempo um campo de pesquisa desafiador e promissor. (J AQUES et al., 2012, s/p.)
\end{abstract}

É notável, portanto, que a Computação Afetiva consiste em um campo propício para a realização de investigações científicas que possibilitem ainda mais o uso das TDIC para a melhoria da educação. Aliado a isso, considerar os Estilos de Aprendizagem é essencial para dar suporte às diferenças diretamente relacionadas ao modo particular de aprender dos alunos.

O desenvolvimento de iniciativas nessa linha de pesquisa apresenta-se como algo desafiador, uma vez que a forma de extrair esses aspectos psicológicos e unir esses conceitos, para proporcionar um desempenho maior no processo de ensino e aprendizagem, requer reflexões e implementações não triviais.

A relevância de trabalhos nessa temática volta-se ao aspecto da preocupação com as características humanas dos estudantes. A educação é uma área cujos aspectos psicológicos influenciam diretamente devido à psicologia também se preocupar em como um indivíduo adquire conhecimento. 
Destaca-se também que, além dos conceitos em foco nesta pesquisa, há outros fatores afetivos que têm influência na aprendizagem, como os estados de ânimo (SCHERER, 2000) conceito brevemente comentado na Seção 4.

Finalizando com comentários relativos à computação (área escolhida neste artigo para exemplificar a aplicação dos conceitos expostos nas Seções 3 a 5), é possível dizer, por exemplo, que a aprendizagem de programação é um problema extremamente relevante, mas é diferente de aprender engenharia de software (que envolve, dentre outros aspectos, o trabalho em equipes, gerenciamento de recursos e pessoas etc.); além disso, aprender computação teórica é mais similar com a aprendizagem de matemática e mais diferente de, por exemplo, aprender sobre redes, sistemas operacionais e arquitetura de computadores. Ou seja, dentro de uma mesma área, é possível encontrar uma variedade grande de contextos que poderiam se beneficiar dos conceitos de estilos de aprendizagem, emoções e/ou personalidade.

\section{Agradecimento}

À Coordenação de Aperfeiçoamento de Pessoal de Nível Superior (CAPES), pelo apoio financeiro, e aos alunos que responderam aos questionários.

\section{Referências}

AGUIAR, J. J. B.; FECHINE, J. M.; COSTA, E. Estilos Cognitivos e Estilos de Aprendizagem em Informática na Educação: um mapeamento sistemático focado no SBIE, WIE e RBIE. In: Anais do 25o Simpósio Brasileiro de Informática na Educação, Dourados, p. 441-450, 2014.

ALLPORT, F. H.; ALLPORT, G. W. Personality Traits: Their Classification And Measurement. Journal Of Abnormal And Social Psychology, 16, p. 6-40, 1921.

BACHRACH, Y.; KOSINSKI, M.; GRAEPEL, T.; KOHLI, P.; STILLWELL, D. Personality and patterns of Facebook usage. In: Proceedings of the 3rd Annual ACM Web Science Conference (WebSci '12), ACM, New York, NY, USA, p. 24-32, 2012.

BRADLEY, M. M.; LANG, P. J. Measuring emotion: the self-assessment manikin and the semantic differential. Journal of Behavior Therapy \& Experimental Psychiatry, v.25, n.1, p. 49-59, 1994.

BROEKENS, J.; BRINKMAN, W.-P. AffectButton: Towards a Standard for Dynamic Affective User Feedback. In: Affective Computing and Intelligent Interaction and Workshops. p. 1-8, 2009.

BURGER, J. M. Personality. Wadsworth, fifth edition, 2000.

COFFIELD, F.; MOSELEY, D.; HALL, E.; ECCLESTONE, K. Should we be using learning styles? What research has to say to practice. London, Learning and Skills Research Centre, Learning and Skills Development Agency. 2004. Disponível em:

<http://www. itslifejimbutnotasweknowit.org.uk/files/LSRC_LearningStyles.pdf>. Acesso em: 09 jun. 2016.

COSTA, E.; AGUIAR, J.; MAGALHÃES, J. Sistemas de Recomendação de Recursos Educacionais: conceitos, técnicas e aplicações. In: II Congresso Brasileiro de Informática na Educação - J ornada de Atualização em Informática na Educação (J AlE), p. 57-78, 2013.

CRUZ, S.; DA SILVA, F. Q. B.; CAPRETZ, L. F. Forty years of research on personality in software engineering: A mapping study. Computers in Human Behavior, v. 46, p. 94-113, 2015. 
DORÇA, F. A.; LIMA, L. V.; FERNANDES, M. A.; LOPES, C. R. Comparing strategies for modeling students learning styles through reinforcement learning in adaptive and intelligent educational systems: An experimental analysis. Expert Systems with Applications, v. 40, n. 6, p. 2092-2101, 2013.

FAQUIN, G. S.; FALCI, M. L. F.; ARAÚJO, M. A. P. Uma Metodologia de Avaliação da Relação entre Perfis de Personalidade e Desempenho Acadêmico em Alunos de Sistemas de Informação. In: Proceedings of the XII Brazilian Symposium on Information Systems, Florianópolis, p. 285-292, 2016.

FELDER, R. M.; SILVERMAN, L. K. Learning and Teaching Styles in Engineering Education. Journal of Engineering Education, v. 78, n. 7, p. 674-68, 1988.

FELDER, R.; SOLOMAN, B. A. Index of Learning Styles (ILS). 1999. Disponível em: <http://www4.ncsu.edu/unity/lockers/users/f/felder/public/ILSpage.html>. Acesso em: 09 jun. 2016.

FELDER, R.; SPURLIN, J. Applications, Reliability, and Validity of the Index of Learning Styles. International Journal of Engineering Education, v. 21, p. 103-112, 2005.

FIVE. Five Labs - See the personality behind your posts. Product of Five.com. 2015. Disponível em: <http://labs.five.com/>. Acesso em: 24 abr. 2015.

GIL, R.; VIRGILI-GOMÁ, J.; GARCÍA, R.; MASON, C. Emotions ontology for collaborative modelling and learning of emotional responses. Computers in Human Behavior, v. 51, p. 610-617, 2015.

GOSLING, S. Psiu, Dê Uma Espiadinha: O Que As Suas Coisas Dizem Sobre Você; Tradução Marcio De Paula S. Hack. Rio De Janeiro: Elsevier. 2008.

GRAF, S.; KINSHUK; LIU, T-C. I dentifying Learning Styles in Learning Management Systems by Using Indications from Students' Behaviour. In: ICALT '08 - Eighth IEEE International Conference on Advanced Learning Technologies, p. 482-486, 2008.

JAQUES, P. A.; NUNES, M. A. S. N. Ambientes Inteligentes de Aprendizagem que inferem, expressam e possuem emoções e personalidade. In: Isotani, S.; Campos, F. C. A. (Org.). Jornada de Atualização em Informática na Educação - JAIE 2012. 1 ed. Porto Alegre: SBC, v. 1, p. 32-71, 2012.

J AQUES, P. A.; NUNES, M. A.; ISOTANI, S.; BITTENCOURT, I. Computação Afetiva aplicada à Educação: Dotando Sistemas Tutores Inteligentes de Habilidades Sociais. In: Anais do CSBC 2012 - DesafIE, Curitiba, 2012.

JOHN, O. P.; SRIVASTAVA, S. The Big Five Trait taxonomy: History, measurement, and theoretical perspectives. In: PERVIN, L. A.; JOHN, O. P. (Org.), Handbook of Personality: Theory and research, v. 2, p. 102-138. Guilford Press, New York. 1999.

KERKIRI, T.; MANITSARIS, A.; MAVRIDOU, A. Reputation Metadata for Recommending Personalized eLearning Resources. In: International Workshop on Semantic Media Adaptation and Personalization, Los Alamitos, CA, USA, v.0, p. 110-115, 2007.

KOMULAINEN, E.; MESKANEN, K.; LIPSANEN, J.; LAHTI, J.; JYLHÄ, P.; MELARTIN, T.; WICHERS, M.; ISOMETSÄ, E.; EKELUND, J. The Effect of Personality on Daily Life Emotional Processes. PLoS ONE, v. 9, n. 10 , p. 1-9, 2014.

LI, M.; ARMSTRONG, S. J. The relationship between Kolb's experiential learning styles and Big Five personality traits in international managers. Personality and Individual Differences, v. 86, p. 422-426, 2015.

LITZI NGER, T. A.; LEE, S. H.; WISE, J. C.; FELDER, R. M. A Psychometric Study of the Index of Learning Styles. Journal of Engineering Education, 96(4), p. 309-319, 2007.

LONGHI, M. T. Mapeamento de aspectos afetivos em um ambiente virtual de aprendizagem. Tese (Doutorado) - Instituto de Informática, Universidade Federal do Rio Grande do Sul, Porto Alegre, 2011. Disponível em: <http://hdl.handle.net/10183/39578>. Acesso em: 30 jul. 2016. 
MARKOVIKJ, D.; GIEVSKA, S.; KOSINSKI, M.; STILLWELL, D. Mining Facebook Data for Predictive Personality Modeling. Proc of Workshop on Computational Personality Recognition, AAAI Press, Melon Park, CA. 2013.

MEHRABIAN, A. Pleasure-arousal-dominance: A general framework for describing and measuring individual differences in Temperament. Current Psychology, v. 14, p. 261-292, 1996.

NUNES, M. A. S. N. Computação Afetiva personalizando interfaces, interações e recomendações de produtos, serviços e pessoas em Ambientes computacionais. In: NUNES, M. A. S. N.; OLIVEIRA, A. A.; ORDONEZ, E. D. M. (Org.). Projetos e Pesquisas em Ciência da Computação no DCOMP/PROCC/UFS: São Cristóvão, p. 115-151, 2012.

NUNES, M. A. S. N.; BeZERRA, J. S.; REINERT, D.; MORAES, D.; PEREIRA, E.; PEREIRA, A. J. S. Computação Afetiva e sua influência na personalização de Ambientes Educacionais: Gerando equipes compatíveis para uso em AVAs na EaD. In: Glaucio J osé Couri Machado. (Org.). Educação e Ciberespaço: Estudos, Propostas e Desafios. Aracaju: Virtus Editora, v. 1, p. 308-347, 2010.

NUNES, M. A. S. N.; HU, R. Personality-based recommender systems: an overview. In: Proceedings of the sixth ACM conference on Recommender systems (RecSys '12). ACM, New York, NY, USA, p. 5-6, 2012.

NUNES, M. A. S. N.; MORAES, D.; REINERT, D. Personality Inventory - Pv 1.0 (Portuguese Version). Registrado no Inpi. 2010. Disponível em: <http://personalityresearch.ufs.br/pt/produtos/softwares/personality-inventory/versao-10>.

NUNES, T. M.; JAQUES, P. A. Utilizando Agentes Pedagógicos Animados como uma abordagem não restritiva ao Gaming The System. Revista Brasileira de Informática na Educação, v. 22, n. 1, p. 147-163, 2014.

ORTONY, A.; CLORE, G.; COLLINS, A. The cognitive structure of emotions. Cambridge, UK. 1988.

ÖZYURT, Ö.; ÖZYURT, H. Learning style based individualized adaptive e-learning environments: Content analysis of the articles published from 2005 to 2014. Computers in Human Behavior, v. 52, p. 349-358, 2015.

PEREIRA, A. Affective-Recommender: Um Sistema de Recomendação Sensível ao Estado Afetivo do Usuário. Dissertação de Mestrado, Universidade Federal de Santa Maria - Centro de Tecnologia, Santa Maria, Rio Grande do Sul, Brasil. 2012.

POPESCU, E.; TRIGANO, P.; BADICA, C. Adaptive Educational Hypermedia Systems: A Focus on Learning Styles. In: EUROCON 2007 - The International Conference on "Computer as a Tool”, p. 2473-2478, 2007.

REIS, R. C. D.; RODRIGUEZ, C. L.; LYRA, K. T.; JAQUES, P. A.; BITTENCOURT, I. I.; ISOTANI, S. Estado da Arte sobre Afetividade na Formação de Grupos em Ambientes Colaborativos de Aprendizagem. Revista Brasileira de Informática na Educação, v. 23, n. 3, p. 113-130, 2015.

SAMSUDIN, Z.; CH'NG, L. The Learning Styles And Learning Emotions Of Adult Learner In E-Learning Environment. International Educational Technology Conference (IECT), Istanbul - Turkey, 2015.

SCHERER, K. Psychological models of emotion. In: BOROD, J. (Ed.). The neuropsychology of emotion. Oxford/New York: Oxford University Press. p. 137-162, 2000.

SCHWARTZ, H. A.; EICHSTAEDT, J. C.; KERN, M. L.; DZIURZYNSKI, L.; RAMONES, S. M.; AGRAWAL, M.; SHAH, A.; KOSINSKI, M.; STILLWELL, D.; SELIGMAN, M. E. P.; UNGAR, L. H. Personality, Gender, and Age in the Language of Social Media: The Open-Vocabulary Approach. PLoS ONE, 8(9), e73791, 2013.

SILVA, D. M.; LEAL, E. A.; PEREIRA, J. M.; OLIVEIRA NETO, J. D. Estilos de Aprendizagem na Educação a Distância: Uma Investigação em Cursos de Especialização. In: EnANPAD 2013, Rio de Janeiro. 2013.

TRUONG, H. M. Integrating learning styles and adaptive e-learning system: Current developments, problems and opportunities. Computers in Human Behavior, v. 55, p. 1185-1193, 2016. 
VALASKI, J.; MALUCELLI, A.; REINEHR, S. Revisão dos Modelos de Estilos de Aprendizagem Aplicados à Adaptação e Personalização dos Materiais de Aprendizagem. In: XXII Simpósio Brasileiro de Informática na Educação - SBIE, p. 844-847, 2011.

ZYWNO, M. S. A Contribution to Validation of Score Meaning for Felder-Soloman's Index of Learning Styles". In: Proceedings of the 2003 American Society for Engineering Education Annual Conference \& Exposition. Nashville, Tennessee. 2003. Disponível em:

<http://www4.ncsu.edu/unity/lockers/users/f/felder/public/ILSdir/Zywno_Validation_Study.pdf>. Acesso em: 09 jun. 2016.

Recebido em junho de 2016

Aprovado para publicação em agosto de 2017

\section{Janderson Jason Barbosa Aguiar}

Programa de Pós-Graduação em Ciência da Computação - Universidade Federal de Campina Grande UFCG, Brasil, janderson@copin.ufcg.edu.br 


\title{
Formação em Tecnologia Assistiva Através de um Curso Aberto, Massivo, Online e de uma Biblioteca Virtual de Soluções Assistivas
}

\author{
Assistive Technology Training Through an Open, Mass \\ Online Course and a Virtual Library of Assistive \\ Solutions
}

\author{
Rosana Wagner \\ Instituto Federal Farroupilha - Campus Panambi \\ Roberto Franciscatto \\ Universidade Federal de Santa Maria - Campus Frederico Westfalen \\ Liliana Maria Passerino \\ Universidade Federal do Rio Grande do Sul \\ José Valdeni de Lima \\ Universidade Federal do Rio Grande do Sul \\ Sidnei Renato Silveira \\ Universidade Federal de Santa Maria
}

\begin{abstract}
Resumo: Este trabalho descreve a formação em tecnologias assistivas, através da utilização de um Massive Open Online Course (MOOC) estruturado para este fim, bem como, uma biblioteca virtual de soluções assistivas projetada e desenvolvida, como ferramenta de apoio. O artigo apresenta os principais conceitos acerca das tecnologias educacionais e assistivas, seguido dos trabalhos relacionados a MOOC e as bibliotecas virtuais assistivas. O principal objetivo desta pesquisa é estruturar um MOOC de TA que apoie o processo de formação de professores do Ensino Profissionalizante que atuam na preparação para a inclusão de pessoas com deficiência (PCD) no mercado de trabalho. Desenvolveu-se uma pesquisa quanti-qualitativa a partir do método estudo de caso. Os dados foram coletados através de questionários, fóruns e tarefas realizados pelos participantes durante a realização do MOOC. A biblioteca virtual de soluções assistivas (Solassist) integra esta pesquisa como forma de repositório de tecnologias assistivas que são apresentadas no MOOC desenvolvido.
\end{abstract}

Palavras-chave: MOOCs, Tecnologia Assistiva, Solassist, Biblioteca Virtual, Acessibilidade.

\begin{abstract}
This work describes training in assistive technologies through the use of a Massive Open Online Course (MOOC) structured for this purpose, as well as a virtual library of assistive solutions designed and developed as a support tool. The article presents the main concepts about educational and assistive technologies, followed by work related to MOOC and assistive virtual libraries. The main objective of this research is to structure a MOOC of TA to support the process of training teachers of Vocational Education that work in the preparation for the inclusion of people with disabilities (PCD) in the labor market. Quantitative-qualitative research was developed from the case study method. Data were collected through questionnaires, forums and tasks performed by the participants during the MOOC. The virtual library of assistive solutions (Solassist) integrates this research as a repository of assistive technologies that are presented in the developed MOOC.
\end{abstract}

Keywords: MOOCs, Assistive Technology, Solassist, Virtual Library, Accessibility.

BEZ, Maria Rosangela; PASSERINO, Liliana Maria; VALDENI, J osé Valdeni de. Instruções para Autores da Revista de Informática na Educação: teoria \& prática. Informática na Educação: teoria \& prática, Porto Alegre, v. 20, n. 2, p. 103123, mai./ago. 2017. 


\section{I ntrodução}

A Educação a Distância (EAD) evoluiu desde a década de 90, passando para Ambientes Virtuais de Aprendizagem (AVAs) muito populares como o Moodle, Teleduc, Rooda, entre outros. No final de 2011 surgem os Massive Open Online Courses (MOOCs), os quais compreendem um tipo de Curso Aberto desenvolvido por meio da utilização de AVAs e de ferramentas como a Web 2.0. Estes, apresentam um novo cenário para a EAD, no que se refere à transição da lógica da transmissão para a lógica da comunicação (interatividade) entre os mais diversos perfis de usuários. Têm seus pilares fundamentados na democratização do acesso a conteúdos educacionais.

Os MOOCs têm sua oferta concentrada no cenário educacional americano, tendo como principais expoentes: Coursera, Udacity, EDX (Mcfedries, 2012)

No que se refere ao panorama educacional brasileiro em EAD, os MOOCs representam uma mudança nos processos de aprendizagem online, intensificando a aprendizagem, colaboração e interação, troca de ideias, dúvidas, compartilhamento de experiências e construção coletiva entre os estudantes. A interatividade e a utilização de mídias educativas são fundamentais nos MOOCs.

A proposta apresentada neste trabalho visa juntar o poder de interação e colaboração dos MOOCs com a capacitação destes usuários junto as Tecnologias Assistivas (TA) utilizando como ferramenta de apoio a este objetivo uma biblioteca virtual de soluções assistivas própria, desenvolvida pelos autores deste trabalho de pesquisa, denominada SolAssist.

O principal objetivo desta pesquisa é estruturar um MOOC de TA que apoie o processo de formação de professores do Ensino Profissionalizante que atuam na preparação para a inclusão de pessoas com deficiência ( $P C D$ ) no mercado de trabalho. A biblioteca Solassist é parte integrante deste MOOC no sentido de ampliar as possibilidades de acesso a recursos de tecnologia assistivas pelos participantes do MOOC.

A integração destes recursos tecnológicos, bem como, a originalidade da ideia, provê um sistema hierárquico dinâmico e prático ao aprendizado sobre as TAs e suas múltiplas utilizações no dia-a-dia.

Desta forma este trabalho encontra-se organizado da seguinte forma: no segundo capítulo apresenta-se as tecnologias educacionais e assistivas que dão suporte a este artigo, através das quais foi possível organizar um MOOC de Tecnologia Assistiva. O conceito de MOOCs é apresentado, bem como, quais são as principais características de criação de um MOOC.

O terceiro compõe trabalhos relacionados que estão sendo realizados através da utilização de diferentes plataformas e tecnologias.

A metodologia de desenvolvimento desta pesquisa é apresentada no quarto capítulo, e a seguir, no quinto apresenta-se o projeto piloto realizado através da integração do MOOC Solassist Learning com a biblioteca de soluções assistivas (Solassist). Os resultados do projeto 
piloto estão apresentados no capítulo 6 e os trabalhos futuros no capítulo 7.

\section{Tecnologias educacionais e assistivas}

Apesar de ser um assunto largamente discutido e aprimorado na atualidade, a acessibilidade vem sendo desenvolvida desde os primórdios da humanidade, quando as pessoas resolviam dificuldades relativas à deficiência utilizando os recursos que possuíam. Muito antes do surgimento do termo TA, as práticas de acessibilidade já existiam, efetivamente, sob a forma de simples instrumentos que melhoravam a autonomia da pessoa deficiente.

Segundo Manzini (2005), pode-se denominar de tecnologia assistiva desde uma bengala, utilizada por nossos avós, como forma de proporcionar conforto e segurança no momento de seu caminhar, bem como, um aparelho de amplificação usado por uma pessoa com surdez ou mesmo um veículo adaptado para uma pessoa com deficiência.

O conceito de Tecnologia Assistiva vem sendo aprimorado, contudo, devido à infinidade de recursos que hoje são abrangidos por essa área. De acordo com Passerino e Pereira (2014), a TA é um termo utilizado para identificar "todo o arsenal de recursos e serviços que contribuem para proporcionar ou ampliar habilidades funcionais de pessoas com deficiência", promovendo vida independente, autonomia e inclusão. Tais recursos e serviços propostos pela Tecnologia Assistiva são respostas para qualquer incapacidade do indivíduo e podem ser compreendidos como soluções na área da acessibilidade. A partir desta análise, tem-se, então, a expressão "Soluções Assistivas", que compreendem casos de sucesso na inserção da acessibilidade nos diversos meios sociais.

As soluções assistivas não necessariamente precisam de tecnologia para serem efetivas, tendo como base estratégias a serem implantadas na sociedade em geral para promover a inclusão. Verifica-se, contudo, uma carência de soluções assistivas por parte de empresas e demais ambientes sociais, estimulada pela falta de informação e suporte na implantação e no gerenciamento destas tecnologias (Manzini, 2005).

Dentro deste contexto, estuda-se a vantagem que as bibliotecas virtuais apresentam na divulgação de informação e troca de experiências acerca das práticas acessíveis, visto que o conteúdo nelas inserido é disponibilizado para qualquer usuário, em qualquer lugar e a qualquer momento. Juntamente com uma biblioteca virtual de soluções assistivas pensou-se na articulação de um curso (disponibilizado via MOOC) voltado ao treinamento sobre tecnologias assistivas, tema deste trabalho e relatado de forma mais detalhada nas seções subsequentes.

\subsection{MOOCs: Massive Open Online Courses}

Um MOOC (Massive Open Online Courses) nada mais é do que um tipo de curso aberto (permite o livre acesso, sem restrições, a oportunidades de aprendizagem) ofertado por meio de ambientes virtuais de aprendizagem (AVAs) ou outras tecnologias correlatas, objetivando disponibilizar a uma grande quantidade de alunos a oportunidade de ampliar seus conhecimentos em um processo de coprodução. 
As características que configuram os MOOCs são a de serem cursos abertos e que permitem escalabilidade. Sobre a primeira, significa que mesmo estudantes que não estão regularmente registrados na instituição promotora podem participar. No entanto, é preciso lembrar que uma limitação ao aberto está associada à exigência de habilidades mínimas por parte dos participantes, o letramento digital, além da infraestrutura tecnológica com acesso à internet e preferencialmente com uma banda larga de qualidade que permita a navegação sem muitas frustrações. Sobre escalabilidade, o desenho do curso é apropriado para atender crescimento exponencial de matrículas, podendo chegar a centenas de milhares de estudantes participando em cada oferta de curso (Mota, Inamorato 2012).

A ideia dos MOOCs é, de fato, precedida pelo movimento global de Recursos Educacionais Abertos (REA) e que vem ganhando espaço no cenário nacional e internacional. REA, termo cunhado em evento da Unesco em 2002, são materiais educacionais ou de pesquisa, incluindo cursos completos, objetos de aprendizagem, textos, vídeos, livros e software, disponíveis em qualquer formato ou mídia, que estejam em domínio público ou que tenham uma licença de uso aberta, permitindo o reuso e adaptação por terceiros (Mota, Inamorato 2012) .

Neste contexto, os Recursos Educacionais Abertos (REA) são imprescindíveis, no sentido de permitir que as informações sejam livremente acessadas, reusadas, remixadas e redistribuídas. Quanto mais um curso emprega licenças restritivas em seus conteúdos, mais barreiras surgem, e assim restringem o fluxo e acesso das informações e portanto, se distanciam-se da essência de um MOOC (Santana, Rossini, Pretto, 2014)

A integração dos MOOCs com recursos tecnológicos, como as mídias digitais, visa facilitar e disseminar a utilização destes, porém ao mesmo tempo representa uma forma de prérequisitos para utilização desta metodologia. Ainda que a maior parte dos MOOCs possam ser considerados como em caráter de experiências piloto, em sua dinâmica atual aparece duas correntes distintas, as quais divergem-se, com baixas chances de reencontro posterior, o que difere em objetivos e métodos (Eastin, 2015). No que diz respeito aos ramos derivados dos MOOCS, podem ser associados dois tipos que são o cMOOCs e os xMOOCs, tais como Coursera e edX.

Os cMOOCs são baseados no Conectivismo, uma teoria da era digital que parte da premissa que o conhecimento está no mundo e não apenas no indivíduo, como afirmam outras correntes de aprendizagem, tais como o Cognitivismo e o Construtivismo (Eastin, 2015). Alguns elementos que ajudam a caracterizar o Conectivismo são, de acordo com Siemens (2012):

i. Aprendizagem e conhecimento estão diretamente associados à máxima diversidade de opiniões, ii. Aprendizagem passa por um adequado processo de conexão a fontes especializadas de informação, iii. Desenvolvimento da capacidade de saber mais é mais relevante do que o que momentaneamente se sabe, iv. Capacidade de enxergar conexões entre os campos de conhecimentos, ideias e conceitos constitui uma habilidade central, e v. Aprendizagem, nesta modalidade, depende de máquinas conectadas, de mais infraestrutura tecnológica associada e facilidades de conexão como elementos essenciais para facilitar uma aprendizagem que possa 
fluir sem dificuldades.

Assim, os cMOOCs se caracterizam pela utilização do conteúdo como ponto de partida e os estudantes são encorajados a expandir e criar conhecimentos a partir de seus próprios interesses e buscas na rede. Via os processos de agregação, mixagem, customização e compartilhamento, os cursos evoluem. Agregação significa que, diferentemente dos cursos tradicionais nos quais o conteúdo é estático e definido preliminarmente, durante o curso, após o seu início, novos conteúdos são permanentemente agregados ao ecossistema do curso, baseado na interatividade entre os professores responsáveis e os estudantes participantes, todos entendidos como contribuintes ao cMOOC (Mota, Inamorato, 2012)

Mixagem porque é fortemente estimulado associar o material específico preparado para o curso com outros conteúdos que forem tornados disponíveis ao longo do curso. Customização, desde que o material resultante da mixagem seja permanentemente redesenhado em uma forma customizada tal que seja apropriadamente utilizado pelos participantes, viabilizando que eles atinjam seus objetivos específicos. Compartilhamento é associado ao fato que o material redesenhado deve ser distribuído a todos os demais participantes do curso. Ou seja, um CMOOC utiliza múltiplas plataformas (blogs, wikis, websites e redes sociais as mais variadas), além de priorizar a interatividade entre os participantes. O cMOOC, portanto, não é todo planejado desde o início, a experiência evolui conforme o curso se desenvolve (Mota, Inamorato, 2012)

Os xMOOCS, diferentemente dos cMOOCS, são mais recentes ainda e se baseiam num formato estruturado e tradicional, que segue um fluxo, a partir de conhecimento pré-definido pelo professor, compartilhado de um para muitos. Neste modelo a figura do professor é central e em geral professores doutores de universidades renomadas são os responsáveis, os conteúdos são definidos a priori pela instituição e não se prioriza a interatividade entre os participantes (Mota, Inamorato, 2012)

Com base no contexto deste capítulo, após a apresentação de um dos mais tradicionais ambientes de aprendizagens, o MOODLE, insere-se o contexto dos MOOCs que possibilitam uma nova metodologia de formação, a qual busca integrar conteúdos mais interativos e dinâmicos, como conexão com servidores hospedeiros de ambientes de realidade virtual, a utilização de plataformas diferenciadas e de OAs interativos. A metodologia dos MOOCs visa a utilização de interação através de mídias interativas.

\subsection{Processo de desenvolvimento de um MOOC}

O processo de desenvolvimento de um MOOC, inicialmente pode ser considerado semelhante ao de um curso de EAD. Os cursos de EAD geralmente utilizam AVAs. Os MOOC também podem utilizar os AVAs, porém geralmente os MOOCs são desenvolvidos sob plataformas desenvolvidas especificamente para a criação do mesmo.

Outra característica dos MOOCs é terem recursos educacionais abertos ou objetos de 
aprendizagem, estes diminuem a quantidade de leitura que o aluno deve realizar, bem como tornam o aprendizado mais dinâmico e atrativo.

Os MOOCs, como seu próprio nome diz, são desenvolvidos para um grupo massivo de estudantes, ou seja, não há tanta interação com o professor, os alunos trocam experiências entre si, bem como, não ocorrem correções de atividades descritivas e longas.

Por esse motivo, os MOOCS não são utilizados para cursos de longa duração, como cursos de graduação ou pós-graduação, mas sim para cursos de 30 a 200 horas aproximadamente e são destinados a pessoas que desejam saber um pouco mais sobre um assunto, porém não constituem uma formação completa.

Para que seja possível desenvolver um MOOC, primeiramente é necessário ter um assunto bem desenvolvido e com bastante material didático (de preferência dinâmico), planejar uma carga horária que seja possível o desenvolvimento do conteúdo previsto e um ambiente tecnológico capaz de hospedar os conteúdos e que permita que os usuários realizem cadastros e possam interagir no ambiente com outros colegas.

Para o desenvolvimento destes MOOCs uma vasta gama de tecnologias pode ser utilizada. A seguir são apresentados alguns dados a respeito da EAD e dos MOOCs e as tecnologias que podem ser adotadas para o desenvolvimento desta modalidade

\section{Trabalhos relacionados}

Nesta seção são apresentados alguns dos principais trabalhos relacionados, com relação ao objetivo proposto para este artigo. A ferramenta exposta na seção 3.1 corresponde a um ambiente de MOOC voltado ao ensino de tecnologia assistiva em geral, enquanto que na seção 3.2, são apresentados os principais portais de tecnologias assistivas, na ideia de ferramentas que podem ser utilizadas para descrever, expor e caracterizar tecnologias assistivas na prática, fazendo um contraponto com a biblioteca virtual de soluções assistivas (SolAssist) desenvolvida para este fim.

\subsection{Plataforma SiestaTV Learning}

A SiestaTV Learning é uma plataforma desenvolvida de acordo com o conceito de AVA, porém com o conceito voltado para cursos dinâmicos e que utilizem mais recursos didáticos, como vídeos interativos. Esta plataforma é desenvolvida pela empresa GetitCorp (GetitCorp, 2016).

A SiestaTV Learning visa desenvolver cursos de acordo com o formato de MOOCs. É uma plataforma com tecnologia acessível, simples, interativa, móvel utilizando recursos 3D, a qual é possível acessá-la através da televisão, computador, notebook, tablet ou smartphone (GetitCorp, 2016). 
Esta plataforma tem grande interatividade uma vez que pode ser utilizada através de interação com Unit (realidade virtual) onde são desenvolvidos jogos e perguntas de interação. Atualmente esta plataforma é utilizada basicamente para a formação de professores em mídias interativas.

O ambiente é desenvolvido com base em vídeos, cuja estrutura sequencial pode remeter a diferentes tipos de mídias, ressaltando que esse avanço na estrutura de conteúdo somente poderá ocorrer após o término da visualização do vídeo. Entre cada vídeo há uma atividade, baseada no conteúdo que foi demonstrado no vídeo. A Figura 1 apresenta a tela inicial do ambiente desenvolvido, onde é possível acessar a canais de TV, fóruns, chats, mensagens e aos cursos nos quais está cadastrado.

Figura 1 - Tela inicial da plataforma SiestaTv Learning. Fonte: (GetitCorp, 2016).

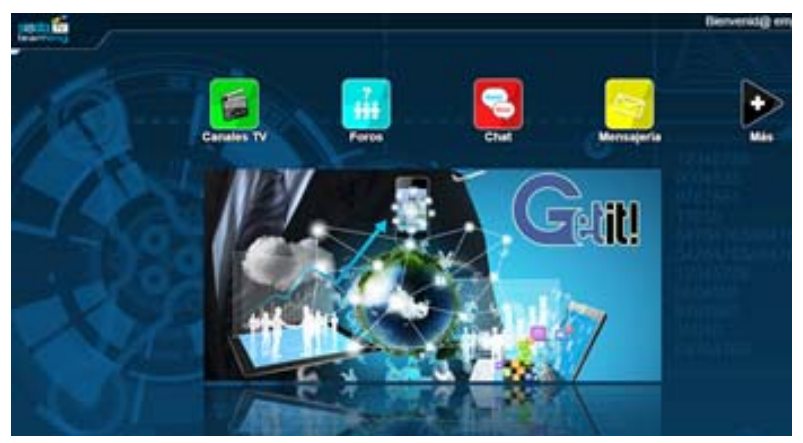

FONTE: autor.

Este ambiente é considerado muito interessante ao se tratar de cursos como MOOCs, que contenham conteúdos mais dinâmicos e que necessitam de uma maior interação e interatividade com os usuários. Considera-se que seja um ambiente que visa a interação entre o usuário e a plataforma, estando assim de acordo com o conceito de MOOCS.

\subsection{Portais de Tecnologias Assistivas como alternativa de apoio a MOOCs}

Existentes atualmente diversos portais de tecnologia assistiva que podem ser mostrar úteis quando pretende-se utilizar estes, como ferramenta de suporte e apoio ao ensino e exemplificação de tecnologias assistivas. As ferramentas apresentadas abaixo, são exemplos de portais sobre tecnologias assistivas espalhados pelo mundo.

A. AAATE (Association for the Advancement of Assistive Technology in Europe)

A AAATE (em português, Associação para o Avanço da Tecnologia Assistiva na Europa), é uma associação pan-europeia interdisciplinar dedicada aos aspectos da tecnologia assistiva, como o uso da mesma, pesquisa, desenvolvimento, manufatura, suprimentos e políticas.

Possui atualmente mais de 250 membros e tem como missão estimular o avanço da tecnologia assistiva para o benefício das pessoas com deficiência, incluindo pessoas idosas. Entre as principais atividades desenvolvidas pela AAATE estão: organização de conferências 
internacionais sobre tecnologia assistiva; revista científica da AAATE; seminários, workshops e eventos de informação (AAATE, 2015)

\section{B. EASTIN (European Assistive Technology Information Network)}

O EASTIN (http://www.eastin.eu) é um motor de buscas europeu que fornece acesso a recursos de Tecnologia Assistiva. São mais de 50.000 produtos disponibilizados no portal, 5.000 empresas produtoras e distribuidoras, permitindo ao usuário realizar buscas completas e navegar por entre notícias, estudos de caso e demais informações relativas à acessibilidade.

Através do EASTIN, pessoas que utilizam a tecnologia assistiva, profissionais de saúde, gestores e demais interessados podem encontrar sugestões que auxiliem na resolução de problemas de autonomia no cotidiano de pessoas portadoras de deficiência (Eastin, 2015).

C. Portal Nacional de Tecnologia Assistiva

Portal brasileiro mantido pelo Instituto de Tecnologia Social (ITS http://www.assistiva.org.br/), criado com o objetivo de oferecer informações para o incentivo de políticas públicas que promovam a inclusão social e melhoria de vida dos cidadãos.

Este portal concentra material sobre inúmeros tipos de deficiência, além de notícias, legislação e catálogo de produtos relacionados à acessibilidade, permitindo tornar as soluções mais acessíveis para o benefício de todas as pessoas que delas necessitam ( Portal Nacional de Tecnologia Assistiva, 2015)

D. SIVA

O SIVA (http://portale.siva.it/) é um portal italiano que fornece orientações ao público acerca dos benefícios que a tecnologia traz na qualidade de vida e participação de pessoas com deficiência. Através de cadastros de produtos assistivos realizados neste portal, os usuários podem ter acesso a informações consistentes que auxiliam nas práticas de inclusão social e digital.

O SIVA faz parte da rede EASTIN, citada anteriormente e é dedicado a qualquer pessoa interessada na área da Tecnologia Assistiva, seja profissional, portador de deficiência ou pesquisador. (Portale SIVA, 2015).

Vale salientar que a principal diferença entre as soluções apresentadas nesta seção e o protótipo desenvolvido neste trabalho (SolAssist) como suporte ao curso proposto via MOOC, se dá pela proposta da biblioteca virtual de soluções assistivas que é de coletar soluções assistivas que são utilizadas na prática laboral no dia-a-dia de pessoas com deficiência. Estas soluções podem ser inseridas na biblioteca tanto por pessoas físicas, quanto empresas que fazem uso ou desenvolveram soluções assistivas para determinado contexto, colaborando para a inclusão de pessoas com deficiência no mercado de trabalho de forma efetiva. Outro diferencial são os recursos de acessibilidade, usabilidade e design responsivo que garantem a biblioteca ser 
acessada por pessoas com diferentes necessidades especiais, bem como, sua disponibilização a diferentes dispositivos eletrônicos em que a mesma pode ser acessada e utilizada.

\section{Metodologia}

O artigo aqui descrito é originário de um projeto de pesquisa intitulado Solassist Learning. Este por sua vez, caracteriza-se como um subprojeto do Projeto Solassist (principal). Com início em julho de 2012, o Solassist é o mais recente projeto de Pesquisa do Grupo TEIAS ${ }^{1}$.

O objetivo principal do projeto Solassist é desenvolver uma Biblioteca Virtual de Soluções Assistivas, com acesso livre e gratuito, que possibilite, além da consulta por parte de usuários e comunidade, atender questões de formação continuada e servir de base para tomada de decisões na implantação e implementação de políticas públicas. Este projeto está alicerçado no entendimento de que a sistematização e divulgação das tecnologias assistivas poderá facilitar e socializar as soluções de pessoas com deficiência ou dificuldades diversas, nas tarefas do cotidiano, principalmente no trabalho. Desta forma, o projeto Solassist tem por objetivo identificar, organizar, categorizar e divulgar soluções de tecnologias assistivas em uso, além de formar gestores para o atendimento destas necessidades nas organizações produtivas do país.

A pesquisa realizada no projeto Solassist Learning, conforme já apresentado anteriormente, tem como problema de investigação: como estruturar/organizar um MOOC de TA que apoie o processo de formação de professores do Ensino Profissionalizante que atuam na preparação para a inclusão de PCD no mercado de trabalho.

Trata-se de uma pesquisa quanti-qualitativa a partir do método estudo de caso.

A pesquisa qualitativa, visa à "análise de casos concretos em suas peculiaridades locais e temporais, partindo das expressões e atividades das pessoas em seus contextos locais" (AAATE, 2015). Justifica-se a pesquisa qualitativa neste trabalho por obtermos dados descritos por meio de sentimentos e conhecimentos expressados pelos participantes no envolvimento com as atividades propostas no decorrer do curso. Dentre as técnicas possíveis a serem realizadas na pesquisa qualitativa, será utilizado o método estudo de caso exploratório e descritivo.

Esta pesquisa utilizou como base os principais autores e pesquisadores de cada uma das áreas apresentadas. A ampla pesquisa bibliográfica desenvolvida torna capaz a realização de um estudo exploratório descritivo, tornando possível confrontar os dados obtidos com base nas teorias previamente estudadas.

O Grupo de Pesquisa TEIAS - Tecnologias em Educação para Inclusão e Aprendizagem em Sociedade, coordenado pela Profa. Dra. Liliana Maria Passerino vem se dedicando sistematicamente ao ensino, extensão e à pesquisa sobre a tecnologia, linguagem e comunicação de pessoas com deficiência, em especial, com autismo, deficiência intelectual, paralisia cerebral e deficiência motora. 
Os instrumentos de coleta de dados utilizados são fóruns, entrevistas e questionários.

A pesquisa quantitativa também é utilizada neste trabalho e tem por finalidade computar alguns dados de questionários elaborados. A pesquisa quantitativa foi utilizada como suporte à pesquisa qualitativa e como forma de obtenção de alguns dados da pesquisa que puderam ser observados por meio deste método de pesquisa.

A triangulação entre os dados obtidos por meio das pesquisas qualitativas e quantitativas permite representar as diferentes perspectivas metodológicas para a análise de um tema, sendo este processo compreendido como a compensação complementar das deficiências e dos pontos obscuros de cada método isolado. A base desta concepção é o insight lentamente estabelecido de que "métodos qualitativos e quantitativos devem ser vistos como campos complementares e não rivais" (Flick, 2009).

A seguir apresentamos o projeto piloto que foi desenvolvido. Através do projeto piloto foi possível analisar dados positivos e negativos que puderam ser mantidos ou alterados para a versão final do projeto.

\section{DESENVOLVI MENTO}

Os MOOCs representam cursos de curta duração, os quais não visam uma formação completa ao cursista, mas sim possibilitam uma formação inicial sobre algum assunto específico. A principal característica é ter conteúdos dinâmicos e possibilitar uma formação através de recursos digitais. Com base nisso desenvolveu-se o MOOC Solassist Learning, exposto em maiores detalhes na seção 5.1 e também projetou-se e desenvolveu-se a biblioteca virtual de soluções assistivas (denominada SolAssist) descrita de forma mais clara na seção 5.2, bem como, sua arquitetura de funcionamento, sendo ambas tecnologias perfeitamente "casadas" para o entendimento e compreensão acerca das TAs.

\subsection{SOLASSI ST LEARNI NG}

O projeto piloto teve início em setembro de 2014 e término em janeiro de 2015, atingindo uma carga horária de 100 horas. O público alvo foi profissionais que atuam em cursos profissionalizantes e com pessoas com deficiência matriculadas.

Os participantes foram indicados pela Auditora Fiscal do Trabalho - Ministério do Trabalho e Emprego e Coordenadora do Projeto Inclusão de Pessoas com Deficiência no Trabalho - SRTE/RS, Ana Maria Machado da Costa. Após a indicação de quais seriam as empresas e projetos mais indicados para realização do estudo, foram selecionados interessados que se manifestaram por meio de uma inscrição prévia. Na inscrição prévia, além de dados básicos dos participantes, foi solicitado também um atestado da instituição de trabalho comprovando que o interessado atua no ensino profissionalizante e que há pessoas com 
deficiência na sua turma ou meio de atuação. Esta seleção visou garantir que as vagas fossem destinadas especificamente para o público alvo de nosso interesse. Foram selecionados 34 participantes.

Os pré-requisitos estabelecidos para os participantes foram ser usuário das TIC (uso de editores de texto e ferramentas de imagem básicas); dispor de computador com acesso à internet (banda larga); e possuir uma conta de e-mail. O curso foi organizado em sete módulos, por meio dos quais foi possível organizar os conteúdos previstos, conforme tabela 01:

Tabela 01. Organização do curso Solassist Learning

Unidade 1: INCLUSÃO: perspectivas históricas e atuais

\begin{tabular}{l|l}
\hline Duração: & 1 semana/7dias \\
\hline Carga Horária: & 07 hs \\
\hline
\end{tabular}

Unidade 2: MARCO POLÍTICO-LEGISLATIVO

\begin{tabular}{l|l}
\hline Duração: & 1 semana/7dias \\
\hline Carga Horária: & 07 hs \\
\hline Unidade 3: TECNOLOGIA ASSISTIVA E \\
ACESSIBI LIDADE \\
\hline Duração: & 4 semanas/28dias \\
\hline Carga Horária: & 28 hs \\
\hline
\end{tabular}

Unidade 4: PAPEL SOCIAL DA TECNOLOGIA ASSISTIVA

\begin{tabular}{l|l}
\hline Duração: & 1 semana/7dias \\
\hline Carga Horária: & 07 hs \\
\hline Unidade 5: EDUCAÇÃO PROFISSI ONAL E \\
INCLUSÃO \\
\hline Duração: & 2 semana/14dias \\
\hline Carga Horária: & 14 hs \\
\hline Unidade 6: PRÁTICAS PEDAGÓGICAS E INSERÇÃO \\
LABORAL COM APOIO DE TECNOLOGIAS
\end{tabular}

\begin{tabular}{l|ll}
\hline Duração: & 4 semanas/28dias \\
\hline Carga Horária: & 28hs & \\
\hline $\begin{array}{l}\text { Unidade 7- AVALIAÇÃO } \\
\text { produção escrita }\end{array}$
\end{tabular}

\begin{tabular}{l|l}
\hline Duração: & 1 semana/7dias \\
\hline Carga Horária: & 09 hs \\
\hline
\end{tabular}

Fonte: AUTOR

O curso foi desenvolvido na modalidade EAD, por meio do ambiente virtual de aprendizagem Wikispaces. Outras ferramentas, como o PbWorks e o Google Drive foram utilizadas.

A Figura 2 apresenta a aba "home" do curso, onde consta o logotipo do curso, bem como, informações iniciais. Quando apresentada aos participantes as abas e os conteúdos laterais foram sendo disponibilizadas conforme o andamento dos conteúdos previstos. 
Figura 2 - Aba Home do Solassist Learning

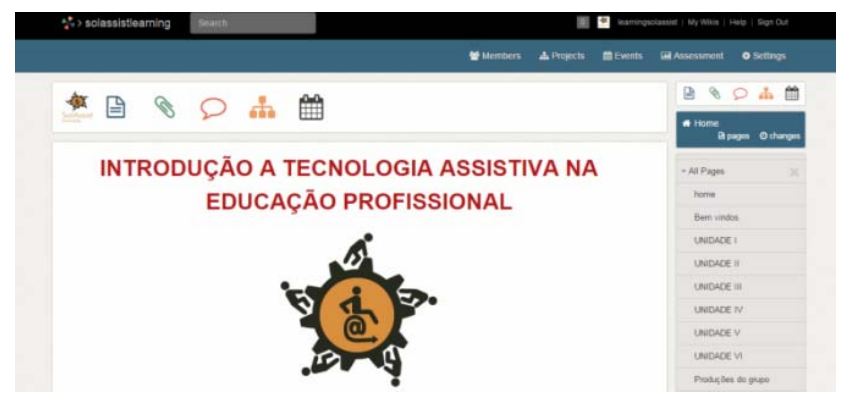

Fonte: AUTOR

A Figura 3 apresenta a aba "Bem Vindos", na qual constam informações acerca do curso, bem como, instruções iniciais de questionários a serem respondidos antes de iniciar o curso.

Nesta aba também constam informações sobre as datas e módulos a serem estudados. Foi disponibilizado um tutorial com os passos principais para acesso ao PbWorks.

Figura 3 - Aba Bem Vindos do Solassist Learning

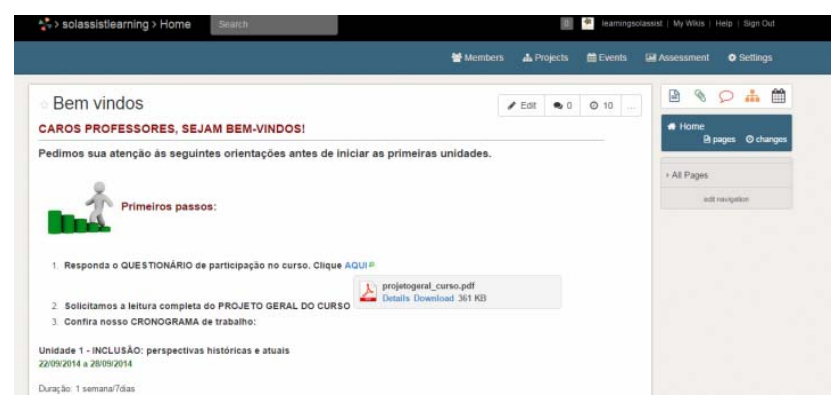

Fonte: AUTOR

As Figuras 4 e 5 apresentam respectivamente as Unidades I e II, com a apresentação dos conteúdos e das atividades. O curso foi dividido em 7 unidades, cada uma com seus respectivos conteúdos e atividades. A maior parte das atividades foram desenvolvidas no próprio ambiente de trabalho dos participantes, possibilitando assim que tivéssemos acesso aos dados da instituição e dos procedimentos que estavam sendo aplicados. 
Figura 4 - Unidade I

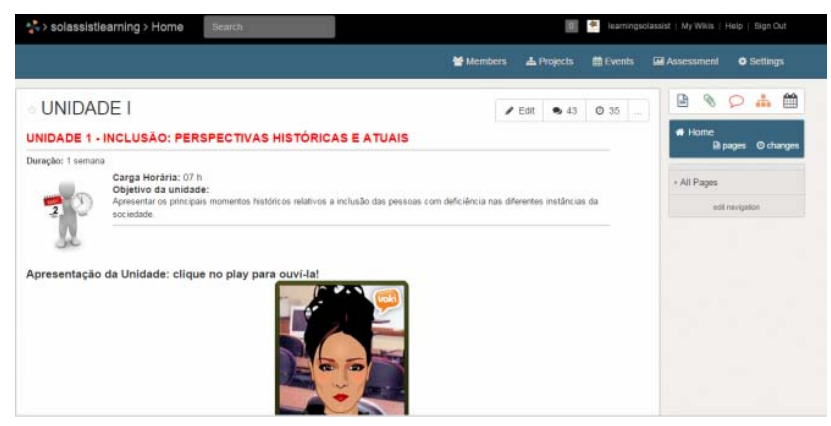

Fonte: AUTOR.

Figura 5 - Unidade II

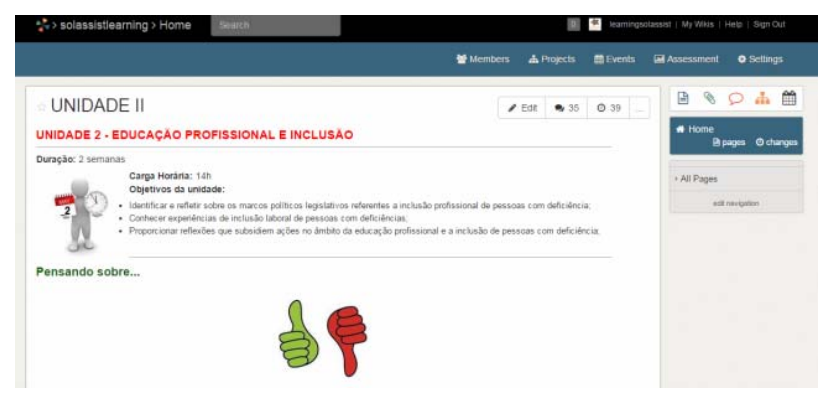

Fonte: AUTOR.

Para que os participantes pudessem interagir, bem como, aprender uns com os outros, foi criada uma aba "produções do grupo", conforme figura 6, local onde divulgou-se todos os links dos Pbworks pessoais, possibilitando assim que todos pudessem visualizar os conteúdos dos colegas, tornando assim a aprendizagem mais dinâmica e completa, por meio da interação entre os participantes.

No Wikispaces é possível restringir o acesso, desta forma foi possível controlar que todas as informações apenas pudessem ser acessadas pelos próprios participantes e pelos administradores, mantendo assim a identidade dos participantes preservada.

Figura 6 - Aba produções do grupo

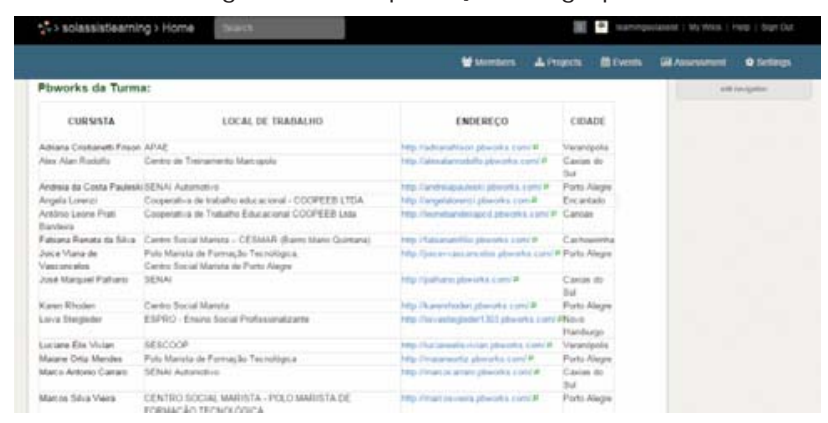

Fonte: AUTOR. 
As atividades relacionadas ao desenvolvimento de alguma atividade no ambiente escolar e após a apresentação de dados das atividades foram disponibilizadas/entregues como resposta as atividades por meio do PbWorks. Atividades relacionadas a questionários e enquetes foram realizadas por meio do Google Drive, os fóruns de participação foram realizados por meio de recursos do próprio Wikispaces.

\subsection{Arquitetura da Biblioteca Virtual de Soluções Assistivas}

A biblioteca virtual de soluções assistivas (ferramenta de apoio ao curso oferecido via MOOC), foi projetada conforme os passos definidos abaixo.

Como estágio inicial, foram analisados e identificados os requisitos básicos necessários ao desenvolvimento da biblioteca virtual. A ideia de funcionamento geral baseou-se em uma biblioteca de soluções composta por contribuições dos usuários previamente cadastrados no sistema, sejam eles pessoas físicas ou jurídicas. Os usuários, após efetuarem seu registro pessoal, podem incrementar a biblioteca cadastrando soluções assistivas, que passam a ser disponíveis para qualquer pessoa que busque informações no sistema.

A partir dos requisitos levantados para o desenvolvimento da biblioteca virtual, foi realizada a modelagem de dados, como forma de avaliar como o banco de dados deveria ser moldado para receber todas as informações necessárias ao funcionamento do website. Verificou-se, então, a necessidade do sistema apresentar interfaces para cadastro e login de usuário, cadastro de soluções assistivas e principalmente, um mecanismo de busca para retornar informações de acordo com a pesquisa realizada.

As páginas da biblioteca começaram a ser produzidas com auxílio do framework Bootstrap, para que todo o conteúdo pudesse ser adaptável a diferentes dispositivos de acesso. Foram projetados os formulários para cadastro de pessoa física e jurídica, seguidos pelo formulário de login. A página inicial da biblioteca virtual de soluções assistivas, pode ser visualizada, conforme Figura 7.

Figure. 7. Página inicial da biblioteca virtual de soluções assistivas

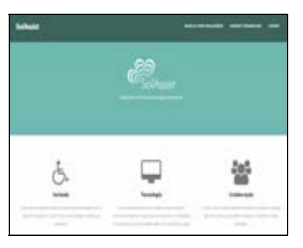

Fonte: AUTOR.

Uma vez realizado o cadastro, as informações do usuário armazenadas no banco de dados foram utilizadas para uma personalização de seu perfil, apresentado após autenticação na biblioteca. Neste perfil, o usuário pode visualizar suas informações pessoais, pode acessar o formulário de cadastro de soluções assistivas, bem como, as soluções por ele cadastradas. 
Ao terminar o desenvolvimento do cadastro de soluções, deu-se início a uma segunda etapa de desenvolvimento, na qual os cadastros de soluções realizados já reuniam informação suficiente para que fosse implementado um mecanismo de busca na biblioteca. A busca de soluções, então, foi subdividida em uma busca simples (por palavra chave digitada) e uma busca avançada (o usuário procura solução por características específicas). Ao acessar qualquer solução, são apresentadas em tela informações como contexto de uso, categoria em que se enquadra, sua utilização, além de arquivos de mídia explicativos (vídeos, documentos ou imagens) sobre a mesma.

A biblioteca virtual também contou com uma área administrativa, onde são apresentados relatórios de usuários e soluções cadastradas. Nesta área, o administrador pode visualizar informações presentes na biblioteca, publicar notícias e controlar tarefas a serem desenvolvidas no sistema. Ainda, lhe é permitido ver estatísticas acerca dos cadastros realizados, sua quantidade e classificação.

Concluídas todas as páginas que compuseram a biblioteca virtual e após verificar seu devido funcionamento, deu-se início à construção de um protótipo para o Sistema Operacional Android, planejado com o intuito de oferecer acesso a informações cadastradas no sistema web. Neste aplicativo, o usuário pode acessar seu perfil, visualizar soluções assistivas que cadastrou e realizar busca dentre as soluções existentes na biblioteca, digitando um termo ou palavra chave. A figura 8 exemplifica o funcionamento da versão móvel da biblioteca virtual.

Figure. 8. Tela inicial e perfil do usuário na versão móvel da biblioteca virtual

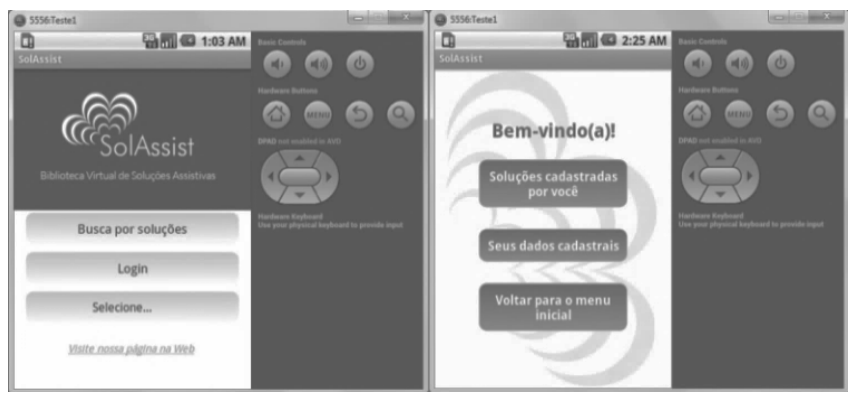

Fonte: AUTOR.

A biblioteca virtual de soluções assistivas foi implementada de forma responsiva com a utilização do banco de dados MySQL, linguagem de Programação PHP e Javascript. Para o desenvolvimento das interfaces, foi utilizada a linguagem de estruturação HTML5 e folhas de estilo em CSS3. Já o protótipo para o sistema operacional Android foi construído no ambiente de desenvolvimento integrado (IDE) Eclipse, com utilização da linguagem de programação Java. A figura 9 demonstra a arquitetura completa posta em prática para a construção e funcionamento da biblioteca virtual de soluções assistivas.

Figure. 9. Arquitetura da biblioteca virtual de soluções assistivas 


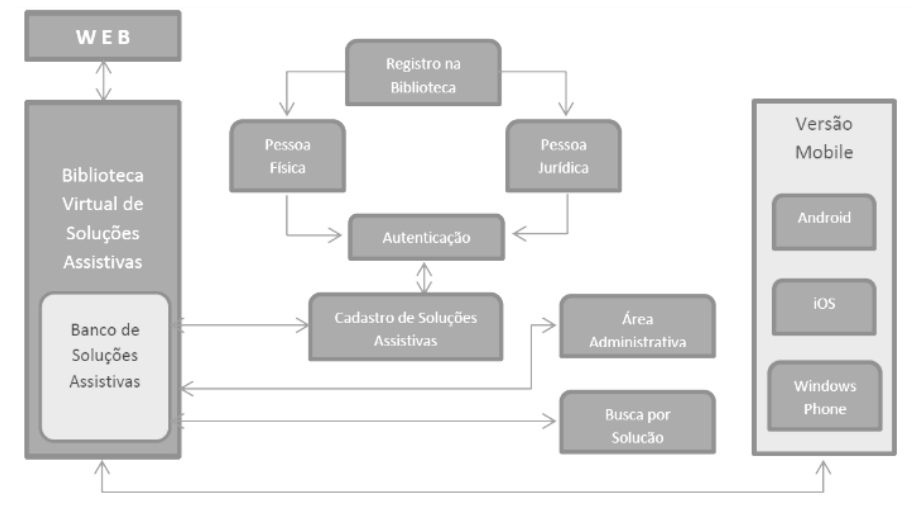

Fonte: AUTOR.

O projeto da Biblioteca Virtual de Soluções Assistivas, denominado SolAssist, é resultado de atividades de pesquisa em conjunto com a Universidade Federal do Rio Grande do Sul - UFRGS e sua versão atual encontra-se disponível na Web através da URL: http://www. ufrgs.br/teias/solassistv2/principal/index. php.

\section{RESULTADOS OBTI DOS}

Durante o desenvolvimento do projeto piloto diversos questionários foram enviados com a finalidade de obtenção de dados acerca dos participantes e dos conteúdos apresentados. Dos 34 participantes que iniciaram o curso, 10 finalizaram cumprindo a carga horária necessária (no mínimo 75\% de participação) para a obtenção da certificação pela UFRGS como Curso de Extensão.

Um questionário foi disponibilizado antes do início do curso, o que possibilitou a obtenção dos dados a respeito dos referidos participantes relacionados com escolaridade, interesse no curso, local de trabalho, deficiências com as quais atuam, tempo de experiência, área de atuação, classificação do conhecimento em TA. O resultado está apresentado na tabela 02.

Tabela 02. Formulário de dados a respeito dos participantes no MOOC Solassist Learning

\begin{tabular}{|c|c|c|c|}
\hline \multicolumn{4}{|c|}{$\begin{array}{l}\text { PARTI CI PANTES DO MOOC - SOLASSI ST } \\
\text { LEARNI NG - PERFI L }\end{array}$} \\
\hline Idade & Sexo & $\begin{array}{l}\text { Grau de } \\
\text { Instrução }\end{array}$ & $\begin{array}{l}\text { Carga } \\
\text { horária de } \\
\text { trabalho }\end{array}$ \\
\hline $\begin{array}{l}{[21-30]:} \\
06 \% \\
{[31-40]:} \\
45 \% \\
{[41-50]:} \\
35 \% \\
{[51-60]:} \\
14 \%\end{array}$ & $\begin{array}{l}\text { Fem.: } 91 \% \\
\text { Mas.: } 09 \%\end{array}$ & $\begin{array}{l}\text { Curso } \\
\text { técnico 6\% } \\
\text { Graduação } \\
: 39 \% \\
\text { Pós } \\
\text { Graduação } \\
: 55 \%\end{array}$ & $\begin{array}{l}31 \text { a } 40 \\
\text { horas: } 77 \% \\
\text { Mais de } 41 \\
\text { horas: } 23 \%\end{array}$ \\
\hline
\end{tabular}




\begin{tabular}{|c|c|c|c|}
\hline $\begin{array}{l}\text { Horas diárias } \\
\text { de acesso a } \\
\text { internet }\end{array}$ & $\begin{array}{l}\text { Possui } \\
\text { conhecime } \\
\text { nto em } \\
\text { tecnologias } \\
\text { assistivas }\end{array}$ & $\begin{array}{l}\text { Possui } \\
\text { algum tipo } \\
\text { de } \\
\text { deficiência }\end{array}$ & $\begin{array}{l}\text { Onde você } \\
\text { utiliza } \\
\text { acesso } \\
\text { internet }\end{array}$ \\
\hline $\begin{array}{l}\text { Menos de } 01 \\
\text { hora: } 3 \% \\
\text { Entre } 01 \text { e } \\
03 \text { horas: } \\
52 \% \\
\text { Entre } 04 \text { e } \\
05 \text { anos: } \\
29 \% \\
\text { Mais de } 05 \\
\text { anos: } 16 \%\end{array}$ & $\begin{array}{l}\text { Sim: } 19 \% \\
\text { Não: } 81 \%\end{array}$ & $\begin{array}{l}\text { Sim: } 0 \% \\
\text { Não: } \\
100 \%\end{array}$ & $\begin{array}{l}\text { Em casa: } \\
\text { 30\% } \\
\text { Trabalho: } \\
37 \% \\
\text { Ambos: } \\
29 \%\end{array}$ \\
\hline $\begin{array}{l}\text { Dispositivo } \\
\text { de acesso }\end{array}$ & $\begin{array}{l}\text { Finalidade } \\
\text { de acesso }\end{array}$ & \multicolumn{2}{|c|}{ Rede social que utiliza } \\
\hline $\begin{array}{l}\text { Computador } \\
58 \% \\
\text { Notebook: } \\
85 \% \\
\text { Celular: } \\
58 \% \\
\text { Tablet: } 16 \%\end{array}$ & $\begin{array}{l}\text { Lazer: } \\
26 \% \\
\text { Trabalho: } \\
84 \% \\
\text { Estudo: } \\
81 \%\end{array}$ & \multicolumn{2}{|c|}{$\begin{array}{l}\text { Facebook: } 94 \% \\
\text { Instagran: } 13 \% \\
\text { Whatsapp: } 16 \% \\
\text { Twitter: } 10 \% \% \\
\text { Linkedin: } 16 \% \\
\text { Outros: } 13 \%\end{array}$} \\
\hline
\end{tabular}

Fonte: AUTOR.

Ao término do curso foi aplicado outro questionário, que tornou possível analisar a eficácia do curso. Todos os participantes trabalhavam, o que tornou um pouco difícil a continuação de todo o grupo. Um total de 34 pessoas foram selecionadas para a realização do curso. A seleção priorizou pessoas que atuassem no ensino profissionalizante e pessoas com deficiência. Algumas destas antes de acessar o ambiente do curso já haviam desistido. Alguns participantes relataram dificuldade em trabalhar com as ferramentas tecnológicas utilizadas bem como o ambiente Wikispaces. Ao acessar o ambiente, antes de estar logado no curso é necessário criar um login e senha e estas instruções estão em inglês. Alguns participantes relataram grandes dificuldades com a língua estrangeira. Um total de 10 participantes finalizaram o curso com a carga horária necessária para certificação.

A respeito do tempo dedicado aos estudos, $89 \%$ dos participantes disseram que conseguiram dedicar tempo suficiente para a realização do curso. As principais dificuldades encontradas estão representadas na figura 10. 


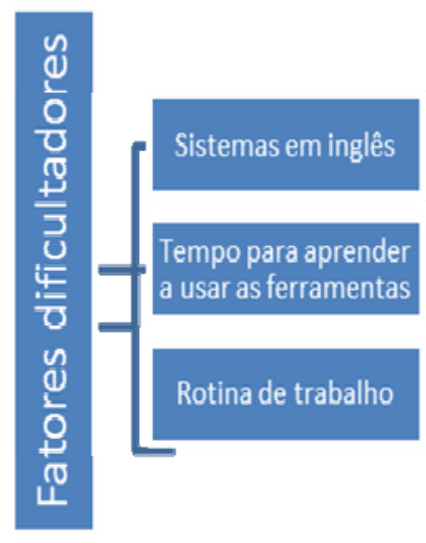

Fonte: AUTOR.

Um total de $33 \%$ dos participantes afirmou que após o curso sugeriu a implantação e utilização de recursos de Tecnologia Assistiva e que realmente puderam ser implantados. Os demais $67 \%$ afirmaram que através do curso puderam perceber onde se aplica os recursos de TA, porém ainda não foram implantados. A figura 11 apresenta os recursos que puderam ser implantados pelos participantes com base nos conhecimentos adquiridos no decorrer do curso.

Figura 11 - TA's implantadas

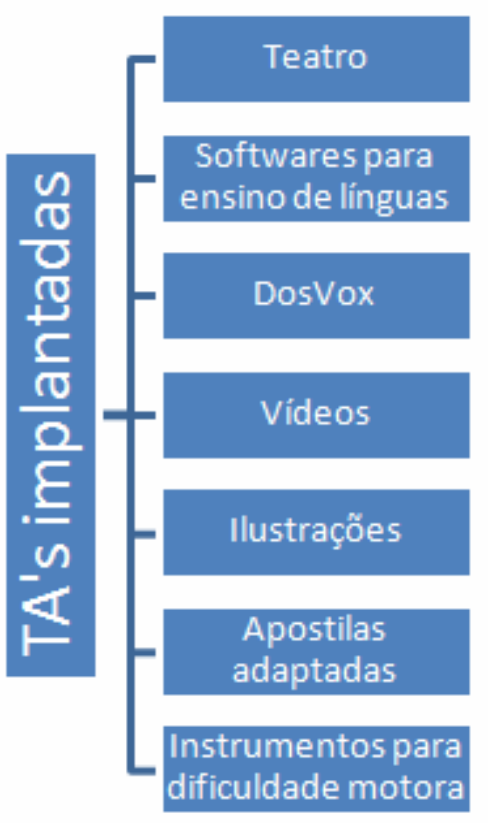

Fonte: AUTOR.

Por meio das respostas aos questionamentos foi possível gerar um panorama geral sobre o público alvo do curso, suas dificuldades e sobre as demandas que foram apresentadas 
de acordo com as necessidades de adaptações de ambientes de trabalhos e adaptações a serem realizadas.

Neste momento análises detalhadas estão sendo feitas por meio da utilização do software NVIVO a respeito das participações em fóruns, possibilitando assim a análise de outros dados que se tornaram evidentes durante a participação dos participantes. Os alunos desistentes foram identificados e estão sendo aplicados questionários com o intuito de identificar o motivo das desistências. Alguns dos participantes que finalizaram também estão sendo selecionados para que entrevistas sejam realizadas com intuito de identificar os pontos fortes e as fragilidades do projeto piloto realizado.

Os participantes que finalizaram o curso com a carga horária mínima para obtenção do certificado, receberam um certificado expedido pela UFRGS, como forma de curso de extensão.

A realização deste projeto piloto possibilitou a obtenção de um panorama geral. Para que o projeto seja desenvolvido será fundamental a utilização dos dados obtidos até o momento como forma de possibilitar uma formação mais completa aos participantes.

\section{TRABALHOS FUTUROS}

O MOOC Solassist Learning representa um projeto piloto realizado através da plataforma Wikispaces e de recursos educativos disponíveis na Web. A realização deste projeto piloto possibilitou a obtenção de dados que servirão para melhorias do projeto final. Os resultados dos questionários aplicados durante o curso foram analisados e neste momento está sendo desenvolvido um projeto final.

Dentre as principais alterações necessárias para o projeto final é a utilização de conteúdos mais dinâmicos, como vídeos e objetos de aprendizagem e também a utilização de uma plataforma com maior usabilidade e que tenha idioma em português.

\section{CONSI DERAÇÕES FI NAIS}

Através da notável expansão da Educação a Distância tornam-se necessárias novas metodologias, conceitos e tecnologias que possibilitem o crescimento desta modalidade de estudo, bem como tornem possível o desenvolvimento desta forte demanda.

O MOOCs apresentado neste trabalho tem como principal objetivo auxiliar neste desenvolvimento, possibilitando a realização de pesquisas e novos estudos sobre este conceito. A utilização de diferentes plataformas, como o Wikispaces, integrado com a biblioteca de Tecnologia Assistiva visa apoiar o desenvolvimento do que conceituamos como MOOC, por utilizar materiais dinâmicos e, mesmo sendo um curso de baixa carga horária, possibilitar links que possam ser explorados mais amplamente de acordo com o interesse de cada estudante.

Os resultados apresentados possibilitaram o conhecimento do público cursista, das dificuldades apresentadas no decorrer do curso e das fragilidades do ambiente que podem ser melhoradas para a próxima versão do curso. 
Por fim, os resultados apresentados pelos questionários realizados ao término do curso, demonstram que a integração realizada dos diversos materiais, incluindo um ambiente dinâmico e a integração de diferentes plataformas, como a biblioteca Solassist possibilitaram uma formação bastante ampla sobre Tecnologia Assistiva aos cursistas.

\section{REFERÊNCIAS}

AAATE. Association for the Advancement of Assistive Technology in Europe. 2003. Disponível em: <http://www.atireland.ie/aaate/>. Acesso em: 13 de agosto de 2015.

BERSCH, Rita. (2008) Introdução à Tecnologia Assistiva. CEDI - Centro Especializado em Desenvolvimento Infantil. Porto Alegre - RS.

EASTIN. (2015) O que é EASTIN? Disponível em: <http://www.eastin.eu/pt-pt/whatl sEastin/index>. Acesso em: 16 abr. 2015.

FLICK. Introdução à pesquisa qualitativa. 3 ed. Porto Alegre: Artmed, 2009.

GETITCORP. Disponível em: https://www.getitcorp.tv/. Acesso em março de 2016.

MANZINI, E. J. (2005) Tecnologia assistiva para educação: recursos pedagógicos adaptados. Brasília - DF: Ensaios pedagógicos: construindo escolas inclusivas, p. 82-86.

MCFEDRIES, P. "I'm in the Mood for MOOCs". IEEE SpEctrum. p.30. 2012.

MOTA, INAMORATO(2012) MOOC, uma revolução em curso. Jornal da Ciência. Publicado em 26/11/12

PASSERINO, Liliana Maria ; PEREIRA, A. C. C. Educação, Inclusão e Trabalho: um debate necessário. Educação e Realidade, v. 39, p. 831-846, 2014.

Portal Nacional de Tecnologia Assistiva. (2015) Conheça o Portal. Disponível em: <http://www.assistiva.org.br/conheca-o-portal>. Acesso em: 16 abr. 2015.

Portale SIVA. (2015). Quem somos nós. Disponível em: <http://portale.siva.it/it-IT/home/aboutUs>. Acesso em: 16 abr. 2015.

SANTANA, B.; ROSSINI, C.; PRETTO, N. L. (Org.). Recursos Educacionais Abertos: práticas colaborativas e políticas públicas. São Paulo/Salvador: Casa da Cultura Digital/EDUFBA, 2012. p. 17-32. Disponível em: <http://www. artigos. livrorea. net. br/2012/05/educacao-aberta-configurando-ambientes-praticas-erecursos-educacionais/ >. Acesso em: 01 jan. 2014.

SIEMENS, G. MOOCs are really a platform. Elearnspace, July 25, 2012.

Recebido em jumho de 2016

Aprovado para publicação em agosto de 2017

\section{Rosana Wagner}

Professora no Instituto Federal Farroupilha- Campus Panambi. Doutora pelo Programa de Pós-Graduação em Informática da Educação - Universidade Federal do Rio Grande do Sul - UFRGS, Brasil, rosanawagner@gmail.com

\section{Roberto Franciscatto}

Professor na Universidade Federal do Rio Grande do Sul - Campus Frederico Westfalen. Doutor pelo Programa de Pós-Graduação em Informática na Educação - Universidade Federal do Rio Grande do Sul UFRGS, Brasil, roberto.franciscatto@gmail.com

\section{Liliana Maria Passerino}

Professora Doutora no Programa de Pós-Graduação em Informática na Educação - Universidade Federal do Rio Grande do Sul - UFRGS, Brasil, Ipasserino@gmail.com 
José Valdeni de Lima

Professor Doutor no Programa de Pós-Graduação em Informática na Educação - Universidade Federal do Rio Grande do Sul - UFRGS, Brasil, valdeni@inf.ufrgs.br

\section{Sidnei Renato Silveira}

Professor Doutor na Universidade Federal de Santa Maria, sidneirenato.silveira@gmail.com 


\title{
A Acessibilidade de Pessoas com Daltonismo: A Construção de um Protótipo de AVA Inclusivo
}

\author{
The Accessibility People with Color Blindness: \\ Construction of a Prototype AVA Inclusive
}

RITA DE CASSIA MIRANDA DA COSTA Universidade do Oeste Paulista (UNOESTE)

ADRI ANA APARECIDA DE LIMA TERÇARIOL Universidade Nove de Julho (UNINOVE)

FERNANDA SUTKUS DE OLIVEIRA MELLO Universidade do Oeste Paulista (UNOESTE)

SIDINEI DE OLIVEIRA SOUSA Universidade do Oeste Paulista (UNOESTE)

\author{
ELISANGELA APARECIDA BULLA IKESHOJ I \\ Instituto Federal de Educação, Ciência e Tecnologia de São Paulo (IFSP)/Câmpus Birigui
}

\begin{abstract}
Resumo: O presente estudo teve como finalidade desenvolver um protótipo de módulo digital que pudesse melhorar e/ou adequar o acesso de pessoas com daltonismo ao Ambiente Virtual de Aprendizagem (AVA) "Aprender Unoeste". A pesquisa assumiu um caráter qualitativo. Os principais resultados evidenciam caminhos que podem ser utilizados para que ambientes virtuais adotados em atividades presenciais e/ou a distancia por instituições de ensino superior possam ser enriquecidos com recursos que propiciem o pleno acesso de todos, em especial, das pessoas com daltonismo. Considerar determinadas especificidades para se promover o acesso efetivo de pessoas com daltonismo aos AVA, propiciando condições mais eficientes de leitura e visualização das informações gerais, incluindo dos materiais didáticos disponíveis.
\end{abstract}

Palavras-chave: Acessibilidade. Inclusão. Daltonismo. Ambiente Virtual de Aprendizagem.

Abstract: The present study aimed to develop a prototype digital module that could improve and / or adapt the access of people with color blindness to the Virtual Learning Environment (VLE) "Learning Unwest". The research assumed a qualitative character. The main results highlight the ways in which virtual environments adopted in face-to-face and / or distance learning activities by higher education institutions can be enriched with resources that provide full access for all, especially those with color blindness. Consider certain specificities to promote the effective access of people with color blindness to VLE, providing more efficient conditions for reading and visualizing the general information, including the available didactic material.

Keywords: Accessibility. Inclusion. Color Blindness. Virtual Learning Environment. 


\section{I ntrodução}

A Educação a Distância $(\mathrm{EaD})$, caracteriza-se pela educação mediada por suportes técnicos de comunicação entre pessoas em tempo e lugares diferentes, conforme pontua o decreto $\mathrm{n}^{\circ}$ 5.622, de 19 de dezembro de 2005:

[...] caracteriza-se a educação a distância como modalidade educacional na qual a mediação didático-pedagógica nos processos de ensino e aprendizagem ocorre com a utilização de meios e tecnologias de informação e comunicação, com estudantes e professores desenvolvendo atividades educativas em lugares ou tempos diversos. (BRASIL, 2005, p. 1).

Nos dias atuais inúmeros são os meios e as Tecnologias de Informação e Comunicação (TIC) articuladas à viabilização da EaD. A oferta de cursos online, por exemplo, coexiste com cursos ofertados por correspondência. Isso sinaliza que as instituições estão buscando diversas possibilidades de interação em escala mundial e a total queda das barreiras de tempo e espaço. Isso leva a EaD a um novo patamar, no qual modelos pedagógicos precisam ser repensados para os novos processos cognitivos das pessoas inseridas no ciberespaço. O ciberespaço é entendido aqui como "espaço de comunicação aberto pela intercomunicação mundial dos computadores e das memórias dos computadores" (LÉVY, 1999, p. 92).

O desenvolvimento desses espaços interativos com fins educacionais e as comunidades de e-learning propiciaram o surgimento de Ambientes Virtuais de Aprendizagem (AVA), definidos por Behar et al. (2008, p. 29) como:

[...] espaço na internet formado pelos sujeitos e suas interações e formas de
comunicação que se estabelecem por meio de uma plataforma, tendo como
foco principal a aprendizagem [...]. Dentre as funcionalidades da plataforma
podem ser citadas as de comunicação síncrona e assíncrona, entre elas o bate-
papo (ou chat), MSN, fórum de discussão, diários de bordo, base de dados,
funcionalidades que dão suporte ao trabalho em grupo, publicações de
arquivos.

São novas formas de apreender conteúdos e construir novos conhecimentos, o que demanda a necessidade de reformulação dos aspectos pedagógicos, bem como das interfaces dos ambientes virtuais nos quais esses cursos são desenvolvidos. Somente dessa maneira, será possível ampliar as oportunidades de espaços educativos acessíveis a todos, independente de suas condições geográficas, sociais, intelectuais, físicas, entre outras.

Para tanto, torna-se importante usufruir ao máximo das potencialidades das TIC, suprindo as necessidades de um mundo não só mais globalizado, como também inclusivo. Além disso, a implementação de um curso a distância implica o planejamento de uma arquitetura pedagógica que contemple: aspectos organizacionais (objetivo do projeto, local, duração, atribuição de tarefas etc), o conteúdo (materiais utilizados para propiciar a "apropriação do conhecimento"), aspectos metodológicos e aspectos tecnológicos (ambientes virtuais de aprendizagem e suas ferramentas), conforme pontua Behar et al. (2008).

A partir disso, o conteúdo, enquanto "qualquer tipo de material e/ou elemento(s) utilizado(s) com a finalidade de apropriação do conhecimento" (BEHAR et al., 2008, p. 27) 
precisa ser pensado e adequado para a modalidade a distância, bem como dentro dos preceitos da educação inclusiva e das questões legais relativas à acessibilidade, de modo que possa cumprir seu propósito educativo. Ao ser disponibilizado para alunos com deficiência visual, por exemplo, o conteúdo precisa estar em mídia acessível, como o som e o texto, em ambientes igualmente acessíveis.

É importante que um ambiente que abarque as necessidades das pessoas se adeque às dimensões da acessibilidade e à premissa do desenho universal, conceito criado pelo americano Ron Mace. Ao tornar-se signatário da Convenção sobre Direito das Pessoas com Deficiência, o Brasil corrobora da seguinte definição de desenho universal:

\begin{abstract}
"Desenho universal" significa a concepção de produtos, ambientes, programas e serviços a serem usados, na maior medida possível, por todas as pessoas sem necessidade de adaptação ou projeto específico. O "desenho universal" não excluirá as ajudas técnicas para grupos específicos de pessoas com deficiência, quando necessárias. (BRASIL, 2009, p. 3).
\end{abstract}

Enquanto o desenho universal não se torna prática comum são necessários ajustes para atender aos quesitos de acessibilidade, em especial à dimensão comunicacional, objeto de estudo deste trabalho. A riqueza de ferramentas dos AVA evoca interatividade. No entanto, o entusiasmo oriundo dos recursos interativos finda quando constatado que muitos usuários não conseguem sequer acessá-los, muito menos utilizá-los para interagir com outras pessoas.

No tocante às pessoas com deficiência visual, o problema não fica restrito à navegação pela interface, pois uma vez tendo acesso à ferramenta, geralmente, ainda faltam informações sobre os conteúdos visuais, ou seja, falta acessibilidade. Sonza, Conforto e Santarosa (2008, p. 135) propõem a seguinte definição de acessibilidade à web:

Entende-se por acessibilidade à rede a possibilidade de qualquer indivíduo, utilizando qualquer tipo de tecnologia de navegação (navegadores gráficos, textuais, especiais para cegos ou para sistemas de computação móvel), poder visitar qualquer site e obter um total e completo entendimento da informação contida nele, além de ter total e completa habilidade de interação.

Infere-se da definição supracitada que a criação de páginas na web específicas para pessoas com deficiência visual, como alternativa aos conteúdos de um site qualquer, não é uma proposta de acessibilidade, pois os usuários continuarão impossibilitados de acessar, interagir ou compreender a página original. Os AVA e os demais web sites utilizam-se dos mesmos suportes tecnológicos, diferenciando-se, essencialmente, de acordo com a proposta e ferramentas disponíveis (MACHADO JÚNIOR, 1998 apud BESSANI et al., 2010). Portanto, a discussão dos quesitos de acessibilidade em AVA, norteia-se pelas mesmas diretrizes recomendadas para qualquer página da web.

Nesse sentido, a fim de orientar desenvolvedores quanto aos recursos necessários para prover acessibilidade, alguns documentos foram publicados. Em 1999, a World Wide Web Consortium - mais conhecida como W3C, divulgou as Diretrizes para Acessibilidade do Conteúdo Web 1.0 (em inglês, Web Contente Acessibility Guidelines - WCAG 1.0). Esse documento é tido como o mais completo e relevante documento já criado, não tendo sido 
superado nem pelo WCAG versão 2.0, produzido pela mesma organização (SONZA; CONFORTO; SANTAROSA, 2008). Outros autores, como Bessani et al. (2010), passaram a adotar o WCAG 2.0. No Brasil, foi criado o Manual de Acessibilidade do Governo Eletrônico (eMAC), em 2005.

As diretrizes, além de orientações para o desenvolvimento e análise dos ambientes virtuais alocados na web, contribuem para a aplicação de outros dois conceitos, introduzidos aqui por Sonza, Conforto e Santarosa (2008): usabilidade e comunicabilidade, aplicados à web.

No que se refere à usabilidade, compreende-se que indica a navegação confortável dos web sites. Segundo Kulpa, Teixeira e Silva (2010 apud NOBREGA, 2011, p. 16), "uma interface com qualidade de usabilidade está na sua adequação às necessidades do usuário, sem que o mesmo tenha que se adaptar ao sistema através da interface". De acordo com Sonza, Conforto e Santarosa (2008), os pontos essenciais para assegurar a usabilidade são: as cores, o redimensionamento, o contraste, os atalhos, o contexto, orientação e auxílio para navegação.

Quanto à comunicabilidade, trata-se da qualidade das interfaces compreendidas pelos seus usuários, do modo desejado pelos seus projetistas, pois a compreensão da lógica de interação, por parte do usuário facilitará seu relacionamento com o sistema (PRATES; BARBOSA, 2016). Aplicada à web, entende-se que a comunicabilidade reflete sobre a clareza dos elementos visuais como ilustrações, fotos e botões, por exemplo (SONZA; CONFORTO; SANTAROSA, 2008).

Diante desse cenário, no que se refere ao acesso de pessoas com deficiência visual, em especial, o daltonismo, aos ambientes virtuais de aprendizagem, torna-se de extrema relevância que se considere suas necessidades especiais e se promova a concepção e criação desses espaços educativos, respeitando o que as diretrizes da área sinalizam quanto à usabilidade e à comunicabilidade.

Nesse cenário, a presente pesquisa apresentou como principal finalidade propor o desenvolvimento de um protótipo de módulo que melhore e/ou adeque o acesso de pessoas com daltonismo aos ambientes virtuais de aprendizagem, favorecendo assim, a inclusão dessas pessoas a cursos oferecidos na modalidade a distância, propiciando condições mais eficientes de leitura das informações gerais e dos materiais didáticos, disponíveis nesses ambientes.

A pesquisa assumiu um caráter qualitativo, uma vez que a proposta de investigação focou o estudo a respeito da acessibilidade de pessoas com daltonismo aos ambientes virtuais de aprendizagem, adotando como plataforma de referência o Aprender Unoeste, ambiente virtual de aprendizagem desenvolvido pela Universidade do Oeste Paulista - Unoeste - Presidente Prudente/SP.

Sendo assim, este artigo tem como objetivo discutir os principais eixos temáticos que circundam a pesquisa realizada, bem como apresentar o protótipo criado a partir dos estudos desenvolvidos, destacando os avanços obtidos e as perspectivas para a sua continuidade.

\section{Daltonismo e suas especificidades}

É preciso compreender que um grande número de pessoas em todo o mundo tem algum tipo de deficiência, física, mental ou sensorial, que limita sua habilidade para as atividades 
diárias. Não existem dados exatos sobre a quantidade de pessoas nesse contexto, apenas percentuais estimados. No Brasil, tais percentuais revelam que quase ${ }^{1 / 4}$ da população (23\%) possui algum tipo de deficiência, o que significa cerca de 45,6 milhões de pessoas (COLOR BLIND AWARENESS, 2014).

Pesquisas realizadas pelo Color Blind Awareness (2014) indicam que o daltonismo afeta aproximadamente 1 em cada 12 homens (8\%) e 1 em cada 200 mulheres (0,005\%) no mundo. Na Grã-Bretanha, isso significa que existem cerca de 2,7 milhões de pessoas daltônicas (cerca de $4,5 \%$ de toda a população), a maioria dos quais são do sexo masculino.

O daltonismo tem causa genética. Está relacionado a um gene recessivo localizado no cromossoma X e ocorre com maior frequência entre os homens. A mulher pode ter visão normal, mas ser portadora do gene recessivo e passar aos filhos. Existem diferentes causas de daltonismo. Para a grande maioria das pessoas com deficiência de visão de cores, a condição é genética e foi herdada de sua mãe, embora algumas pessoas fiquem cegas para cor como resultado de outras doenças, como diabetes e esclerose múltipla ou ainda adquirem a condição ao longo do tempo devido ao processo de envelhecimento, medicação, entre outros (COLOR BLIND AWARENESS, 2014).

O daltonismo não é considerado um distúrbio de grande dificuldade, não ao ponto de atrair a atenção para que sejam realizados ajustes e melhorias nos elementos do cotidiano em que a distinção de cores é fundamental.

As pessoas com Monocromacia enxergam em tons pastel ou acinzentado quando possuem $100 \%$ desse distúrbio, se ocorrer em menor porcentagem, confundem verde e vermelho ou enxergam em tons mais claros e é nestes casos que ocorre a confusão de cores semelhantes. 0 daltonismo não tem cura e este é um grande incentivo para a preocupação com a acessibilidade para as pessoas com este distúrbio.

I magine-se nesta situação: você está em um restaurante, bar ou qualquer ambiente do gênero, e necessite ir ao banheiro, esta é uma situação comum, corriqueira do dia a dia, algo como andar, não pensamos, apenas seguimos o rumo do nossa intenção já determinada. Porém, ao chegarmos ao banheiro, nos deparamos com as opções apresentadas na Figura 1.

Figura 1 - Visão da pessoa com 100\% de daltonismo.

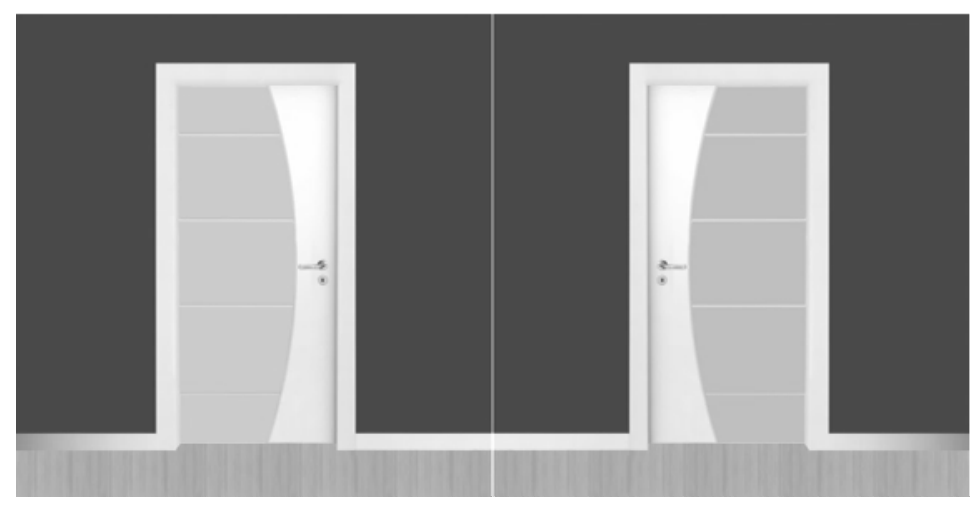

Fonte: Elaborado pelos autores. 
Qual seria sua escolha? Esse pequeno desconforto e confusão ao qual nos submetemos nessa situação proposta é algo que as pessoas com esse distúrbio enfrentam todos os dias. Esse, simples ato para alguns, causa constrangimento.

É preciso ver além do tamanho da dificuldade, pois conforme apresentado, na situação acima, pode ocorrer "apenas" um desconforto, porém se for o caso de uma prova de concurso público em que se exija a visualização de cores, a leitura de um mapa ou gráfico, será uma desvantagem. E se a pessoa nessa situação se deparar com a necessidade de desenvolver uma atividade em um ambiente virtual de aprendizagem? É preciso antes de tudo, compreender que não é somente um simples desconforto, é questão de igualdade, adaptar para tornar justo ou ao menos, igualitárias as oportunidades.

\section{Ambientes virtuais de aprendizagem e acessibilidade}

Cerca de $15,8 \%$ dos alunos matriculados em faculdades em todo o país optaram por cursos de graduação a distância. Em torno de 1,15 milhão de estudantes, segundo o censo da educação superior divulgado pelo Ministério da Educação em 2014 (BRASI L, 2014).

A grande procura por esta modalidade estimulou também a preocupação com a acessibilidade nos ambientes virtuais de aprendizagem. De acordo com o pensamento de Nóbrega (2011) a educação a distância já é uma ação inclusiva, por oportunizar processos formativos àqueles que necessitam de flexibilidade de tempo e/ou distância. É nesse contexto que emerge a preocupação com a acessibilidade de pessoas com daltonismo aos ambientes virtuais de aprendizagem.

Entende-se por acessibilidade, de acordo com a definição proposta pelo Decreto Federal noㅡ 5.296/2004, artigo $8^{\circ}$ :

I - Acessibilidade: condição para utilização, com segurança e autonomia, total ou assistida, dos espaços, mobiliários e equipamentos urbanos, das edificações, dos serviços de transporte e dos dispositivos, sistemas e meios de comunicação e informação, por pessoa portadora de deficiência ou com mobilidade reduzida. (BRASIL, 2004, grifo nosso).

Segundo Sassaki (2005), existem seis dimensões da acessibilidade necessárias para a criação de ambientes educacionais inclusivos, sendo elas: a arquitetônica, a metodológica, a instrumental, a pragmática, a atitudinal e a comunicacional. Esta última refere-se também à acessibilidade digital. Esse autor apresentou uma sucinta definição de cada dimensão a qual segue:

- Acessibilidade arquitetônica: refere-se ao ambiente físico, o qual é previsto que não haja limitações do espaço tanto nas locações internas quanto externas da escola, incluso também o transporte por ela ofertado.

- Acessibilidade metodológica: neste caso trata dos métodos e técnicas de estudo de ação comunitária e de educação dos filhos, no qual é preciso sair dos padrões e buscar formas atualizadas e mais interativas. 
- Acessibilidade instrumental: refere-se à preocupação com os instrumentos e utensílios utilizados nas atividades da vida diária, no estudo, no lazer, esporte e recreação, são dispositivos que atendam às barreiras sensoriais, físicas e mentais entre outras.

- Acessibilidade pragmática: diz respeito às restrições ou limitações definidas por políticas públicas, por meio de leis e similares ou mesmo em regulamentos e/ou em normas em geral.

- Acessibilidade atitudinal: aborda a divulgação por mídia e/ou movimentos de conscientização e sensibilização de todos e da convivência na diversidade humana, com isso busca-se superar paradigmas, preconceitos, estereótipos e principalmente as discriminações.

- Acessibilidade comunicacional: versa sobre a não limitação da comunicação interpessoal, na escrita e na comunicação virtual. Essa última pode ser associada à acessibilidade digital, abordada no presente artigo.

A preocupação com a acessibilidade nos ambientes virtuais está presente em todos os textos selecionados para embasar o pensamento aqui abordado. Behar et al. (2008, p. 4) defende que “o conteúdo das páginas e as ferramentas devem ser acessíveis porque muitas pessoas podem, total ou parcialmente, não ver, ouvir, mover ou mesmo processar com dificuldade algum tipo de informação."

Porém, é preciso observar que, há uma crescente preocupação com relação à acessibilidade, de um modo geral, nas várias esferas da sociedade. Essa preocupação se manifesta na forma de ações reguladas por lei, tais como: a criação de rampas de acesso para cadeirante, elaboração de provas de concursos/vestibular específicas a cada deficiência, entre tantos outros exemplos. Todavia, apesar desse fato, que representa um salto positivo para a qualidade de vida das pessoas com necessidades, a acessibilidade no meio virtual não possui igual foco até o presente momento.

Nesse sentido, Torres, Mazzoni e Alves (2002, p. 85), citam a falta de mecanismos intergovenamentais que possam promover a acessibilidade dos conteúdos encontrados na internet e ainda ressaltam: "A não-observância da acessibilidade no espaço digital, pelos autores dos materiais disponibilizados, nessa forma pode ser considerada como uma discriminação feita a milhares de usuários".

Após a discussão aqui apresentada a respeito do daltonismo e suas especificidades e compreendermos as dimensões da acessibilidade, incluindo a comunicacional que se associa aos ambientes virtuais de aprendizagem, apresentar-se-á o percurso metodológico adotado para o desenvolvimento deste estudo e construção do protótipo acessível ao usuário daltônico, adotando como parâmetro o AVA Aprender Unoeste.

\section{Percurso metodológico}

A construção deste artigo é resultado de estudos desenvolvidos a partir de um trabalho de revisão da literatura, bem como da elaboração de uma proposta que prevê a possibilidade de construção de recursos de acessibilidade, considerando as necessidades especiais de um daltônico ao acessar um AVA, especificamente, o ambiente virtual Aprender Unoeste.

A revisão bibliográfica possibilitou aos pesquisadores o contato com estudos já realizados na área de "Acessibilidade e Educação a Distância", assim como a identificação de suas ideias 
principais. Essa aproximação com o tema ocorreu a partir da análise de publicações disponíveis nas seguintes bases de dados: Capes, Google Acadêmico e Scielo.

Esses acervos foram selecionados devido ao fato de estarem disponíveis, ou seja, com acesso aberto e online aos usuários, tornando possível a análise de trabalhos completos publicados em periódicos brasileiros. Por meio desse procedimento, iniciou-se a busca e levantamento de publicações científicas, produzidas no Brasil, entre 2000 e 2016, que abordassem temáticas próximas desta investigação, tais como: Inclusão; Daltonismo; Educação a Distância; Ambiente Virtual de Aprendizagem.

Nesse sentido, os descritores utilizados foram os seguintes: "Acessibilidade", "Ambiente Virtual de Aprendizagem" e "Daltonismo". A busca foi realizada, de forma individual, com cada descritor, e depois utilizando a junção entre eles. O Quadro 1, apresentado a seguir, demonstra o levantamento realizado.

QUADRO 1 - Busca inicial dos artigos científicos.

\begin{tabular}{|l|c|c|}
\hline Base de pesquisa & Artigos disponibilizados & Artigos selecionados \\
\hline Capes & 70 & 2 \\
\hline Google Acadêmico & 5629 & 7 \\
\hline Scielo & 378 & 15 \\
\hline Total & 6077 & \\
\hline
\end{tabular}

Fonte: Elaborado pelos autores.

Após selecionar os artigos que condiziam com a temática, realizou-se a leitura de todos os resumos, o objetivo era identificar a abordagem de cada artigo para que fosse possível demarcar qual texto obteria melhor aproveitamento para o desenrolar dos tópicos/subtítulos distribuídos ao longo deste estudo. Enfatiza-se aqui então que os artigos selecionados, a partir do levantamento bibliográfico realizado, foram utilizados para fundamentar as ideias sistematizadas pelos pesquisadores neste artigo.

Além dos procedimentos adotados para o encaminhamento da revisão sistemática da literatura, vale destacar ainda os principais encaminhamentos, ou seja, as etapas gerais contempladas para a criação do protótipo, apresentado como produto nesta pesquisa:

\subsection{Etapa 1 - Levantamento e estudo dos tipos de daltonismo}

Por meio dessa etapa foi possível identificar a existência de vários tipos de daltonismo, compreendendo suas características principais, a saber:

Tricromacia: tipo de visão de cores normal, usa todos os três tipos de cones luz corretamente, e é conhecido como tricromacia. Pessoas com visão normal das cores são conhecidas como tricomatas (COLOR BLIND AWARENESS, 2014). As diferentes condições anômalas são protanomalia, que é uma reduzida sensibilidade à luz vermelha, deuteranomalia 
que é uma reduzida sensibilidade à luz verde e é a forma mais comum de cegueira e cor tritanomalia que é uma reduzida sensibilidade à luz azul e é extremamente rara (COLOR BLIND AWARENESS, 2014).

Dicromacia: pessoas com visão Dicromatica têm apenas dois tipos de cones que são capazes de perceber a cor, ou seja, eles têm uma total ausência de função de um tipo de cone (COLOR BLIND AWARENESS, 2014). Pessoas que sofrem de protanopia são incapazes de perceber qualquer luz "vermelha", aqueles com deuteranopia são incapazes de perceber a luz "verde" e aqueles com tritanopia são incapazes de perceber a luz "azul" (COLOR BLIND AWARENESS, 2014).

Monocromacia (Acromatopsia): pessoas com visão monocromática enxergam seu mundo composto de diferentes tons de cinza que variam do preto ao branco, como se "assistissem" ao mundo por meio de uma velha televisão com um conjunto de tonalidade entre o preto e o branco. Acromatopsia é extremamente rara, ocorrendo apenas em cerca de 1 pessoa em 33.000 e seus sintomas podem tornar a vida muito difícil. Normalmente alguém com acromatopsia terá de usar óculos escuros dentro das condições normais de luz.

Enfim, compreendeu-se que daltonismo é um distúrbio da percepção visual caracterizado pelo não funcionamento dos cones oculares responsáveis por diferenciar todas ou algumas cores. Sua origem está, principalmente, relacionada à hereditariedade e sua incidência é em média vinte vezes mais comum em homens.

\subsection{Etapa 2 - Análise do “Aprender Unoeste”}

A análise do ambiente virtual de aprendizagem Aprender Unoeste foi realizada com o propósito de se verificar as cores desse AVA, adotado nesta pesquisa, para identificar quais poderiam prejudicar a visibilidade dos estudantes daltônicos.

\subsection{Etapa 3 - Escolha da melhor localização para inserir o recurso}

A partir da análise da plataforma Aprender Unoeste identificou-se que seria necessário acrescentar o botão "Acessibilidade", conforme apresentado na Figura 2. Nela seriam descritos os meios de acessibilidade fornecidos pela Unoeste, tanto no espaço físico, quanto no virtual. 

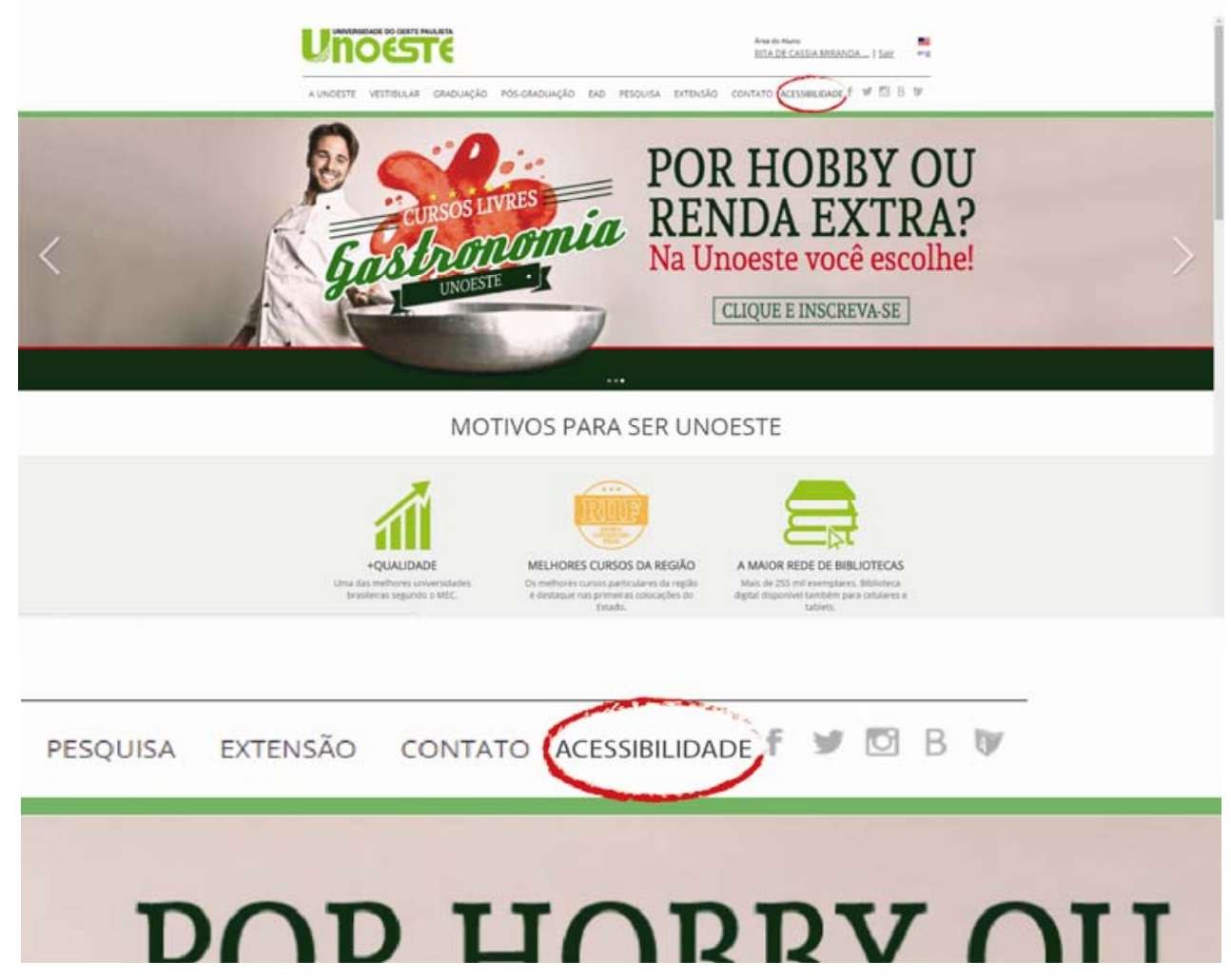

Fonte: Elaborado pelos autores.

Nesse ambiente verificou-se ainda a necessidade de, posteriormente, adicionar uma explicação do que é e como funciona a acessibilidade para daltonismo. Essa explicação poderá ser feita por meio de vídeo autoexplicativo, infográfico ou sequência de imagens, descrevendo os passos para ativar o ícone e como o ambiente ficará, de forma semelhante à explicação contida neste.

O estudante ainda terá a opção de escolher a forma de visualizar a legenda que mostra a escrita da cor, ao passar o mouse sobre a imagem, ou optar pela forma de ícone, no qual é apresentado o ícone correspondente a cor.

Essa ideia será apresentada a um programador junto ao setor de Tecnologia da Informação (TI) da Unoeste, para ser avaliada a possibilidade da aplicação desse modelo para todo o ambiente virtual Aprender Unoeste, ou se seria relevante a sua aplicação, focada apenas nos ambientes das atividades das disciplinas e cursos ofertados.

\subsection{Etapa 4 - Construção do protótipo}

A partir dos estudos realizados, foi construída uma proposta de protótipo adaptando o ambiente virtual de aprendizagem “Aprender Unoeste" para uma versão acessível aos usuários daltônicos.

Inicialmente, foi pensado na técnica de converter cores para daltônicos, por meio do tratamento e acentuação das tonalidades de cores em imagens, recolocando-as na web, 
contudo foi levado em consideração o pensamento de Gomes e Ribeiro (2012, p. 2), o qual segue: “não obstante o já elevado número de investimento nesta área, não existe ainda um sistema integrado que possibilite recoloração global das páginas web, sendo essa perspectiva constituiria uma notória melhoria na acessibilidade, para daltônicos."

Com isso, chegou-se a conclusão que este não é o objetivo, até porque já existem ferramentas para esta função, as quais podem ser aplicadas na imagem selecionada.

O intuito do protótipo desta pesquisa é fazer com que a informação apresentada pela cor fique evidente para o daltônico, ou seja, a intenção é deixar o conteúdo tão aparente quanto para uma pessoa que não possua este distúrbio. Antes de apresentá-lo, é preciso levantar de antemão duas variáveis encontradas em sua construção e conclusão, essas variáveis serão solucionadas ao término da apresentação, do projeto a seguir.

Essas variáveis implicam algumas limitações, as quais é preciso dedicar atenção. Com relação à primeira variável, o daltonismo interfere na distinção das cores de fotografias ou imagens, e mesmo que o daltônico consiga identificar variações de cores na imagem, é possível que ainda não enxergue o que a imagem representa, pois, nesse caso, as cores visualizadas podem ter tonalidades bastante semelhantes, resultando em confusão perceptiva por não enxergarem detalhes importantes para a total identificação das imagens. No que se refere à segunda variável, há casos em que alguns textos estão organizados dentro de caixas, nesses casos, é comum o texto ter uma determinada cor e a caixa (fundo do texto), possuir outra cor. Nessa situação, é possível que ocorra a mesma confusão citada na visualização da imagem pelo daltônico, porém essa confusão irá interferir na leitura do texto dentro da caixa.

Garcia et al. (2013, p. 2), apresenta tal preocupação e chama a atenção para a necessidade de estarmos atentos aos diferentes graus de daltonismo.

Para atender e proporcionar satisfação aos usuários é de vital importância que as interfaces sejam desenvolvidas de acordo com as necessidades de cada um e que gerem o menor desconforto possível, seja na disposição de ícones e botões, vocabulários impróprios ou na combinação das cores.

A partir desse entendimento, foi possível chegar a dois modelos de adaptação: Legenda em Escrita e Legenda ColorAdd, conforme apresenta-se a seguir.

\section{Legenda em escrita}

O primeiro modelo de adaptação, conforme mostra a Figura 3 e 4, consiste na apresentação para o daltônico do nome da cor, assim que ele passa o mouse sob qualquer elemento que tenha cor. O uso do mouse para essa finalidade é para promover a interface do daltônico quando ele estiver usando computadores, notebooks ou similares. No caso de dispositivos móveis, como, por exemplo, smartphones ou tabletes, a visualização do nome da cor será conseguida por meio do touch-screen sob a imagem ou palavra em questão. Para ambos os tipos de dispositivos, aparecerá para o daltônico o nome da cor de forma escrita. É importante ressaltar que o nome da cor atenderá a um contraste que possibilitará a correta identificação e leitura do texto com o nome da referida cor. 
Figura 3 - Modelo do Protótipo “Legenda em escrita” - Cor azul claro.

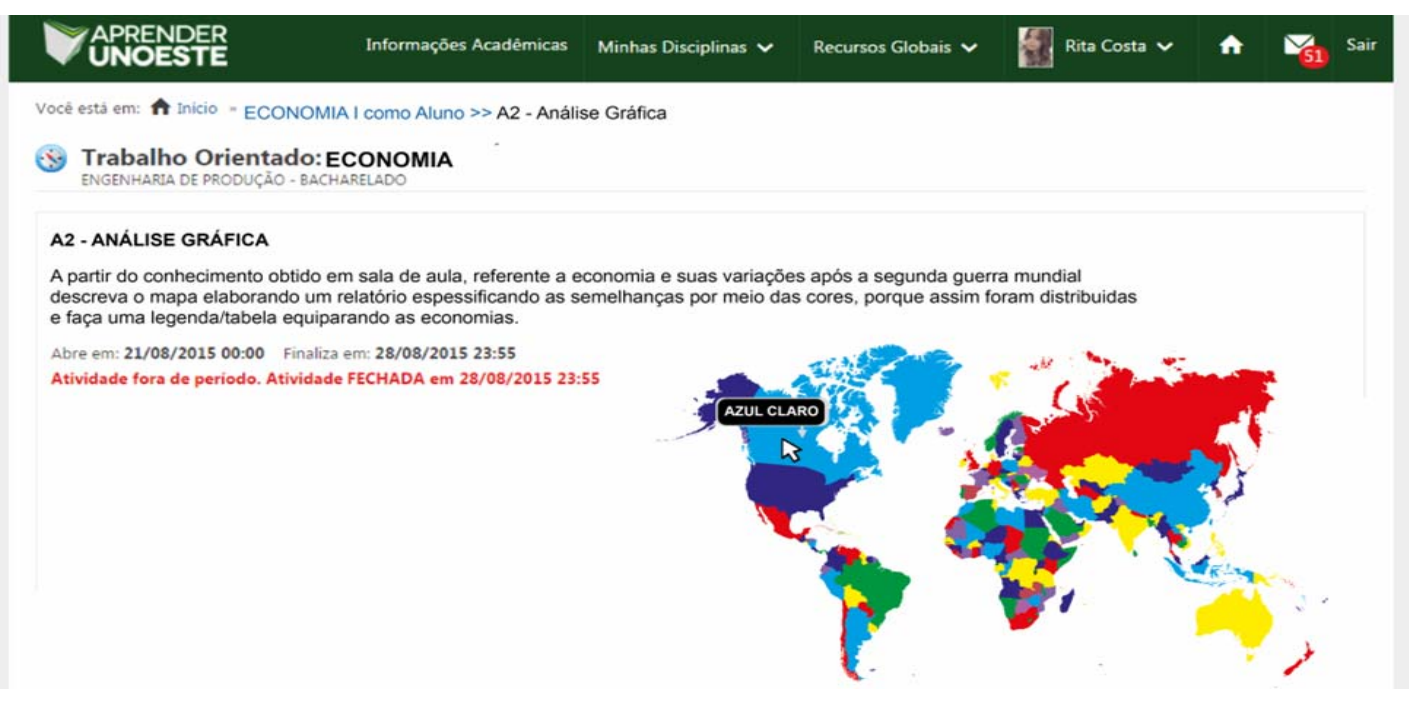

Fonte: Elaborado pelos autores.

Figura 4 - Modelo do Protótipo “Legenda em escrita” - Cor vermelho.

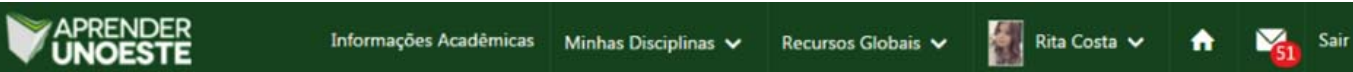

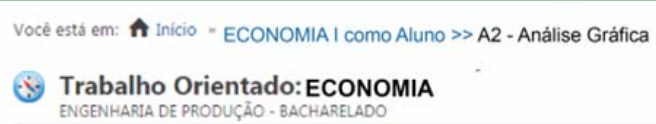

\section{A2 - ANÁLISE GRÁFICA}

A partir do conhecimento obtido em sala de aula, referente a economia e suas variaçōes após a segunda guerra mundial

descreva o mapa elaborando um relatório espessificando as semelhanças por meio das cores, porque assim foram distribuidas

e faça uma legenda/tabela equiparando as economias.

\section{Abre em: 21/08/2015 00:00 Finaliza em: 28/08/2015 23:55}

Atividade fora de periodo. Atividade FECHADA em 28/08/2015 23:55

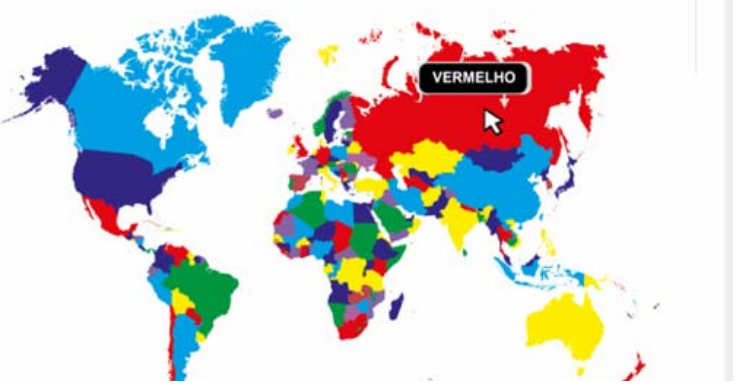

Fonte: Elaborado pelos autores.

Garcia et al. (2013), orienta sobre a importância de colocar-se no lugar daqueles que possuem alguma limitação, a fim de compreender o que se espera de um sistema com acessibilidade. Dessa maneira, é premente que desenvolvedores de sistemas online ou desktop ampliem a empatia pelas pessoas que passam por algumas limitações ou dificuldades para 
acessar esses sistemas, para, a partir daí, fazer uso de mecanismos técnicos com o intuito de promover melhorias de acessibilidade.

Os avanços tecnológicos e todas as vantagens que eles nos proporcionam são abordados por Nóbrega (2011) no sentido de levantar um questionamento sobre a validade desses avanços no contexto da inclusão. Quando um sistema não é acessível a todos, não só o conteúdo se torna limitado, mas também toda a interação com as demais pessoas que utilizam os sistemas e que possuam contato com o conteúdo. Assim, de certa forma, um sistema falho no tocante à acessibilidade é também excludente socialmente.

Nesse sentido, o recurso "legenda escrita" possibilita o acesso e a segurança para compreensão do conteúdo, tornando possível ao daltônico executar uma atividade e colaborar nas tarefas junto aos seus colegas de sala, sem passar por algum tipo de constrangimento ou mesmo manter-se calado por receio da reação dos demais alunos.

\section{Legenda ColorAdd}

As cores possuem uma adaptação própria para as pessoas com daltonismo por meio de ícones, conforme apresentado na Figura 5:

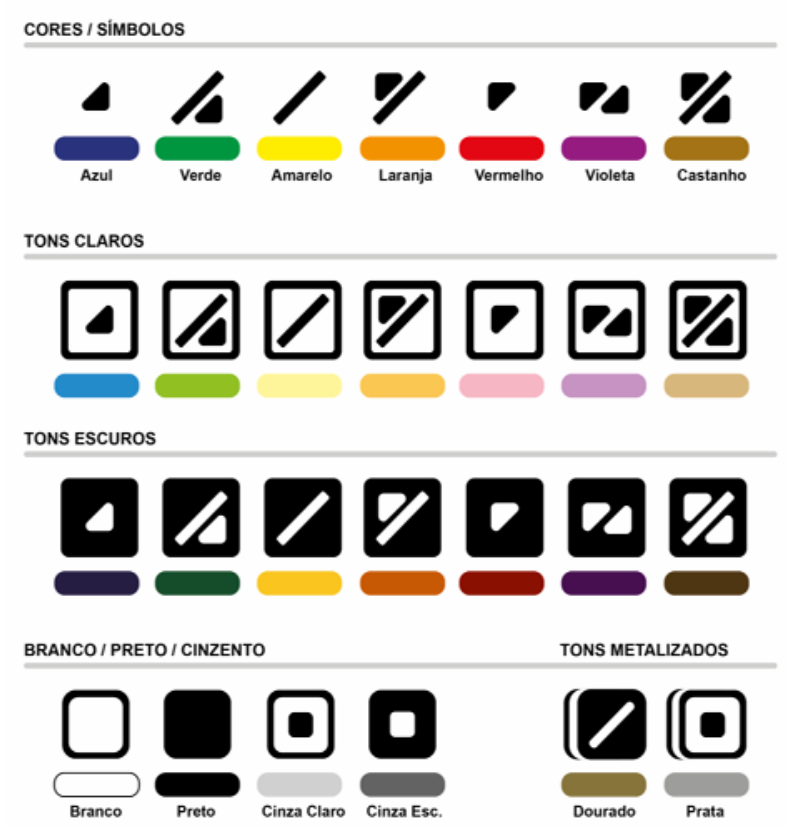

Fonte: Color identification system for colorblind people.

Esse código ColorADD é:

[...] um Sistema de Identificação das Cores premiado com a Medalha de Ouro da Comemoração da Declaração Universal dos Direitos do Homem. Uma ferramenta que procura garantir a plena integração de um público daltônico 
sempre que a Cor é fator determinante na comunicação e na aprendizagem. Estima-se que 350 milhões de indivíduos (cerca 10\% da população masculina mundial e $0,5 \%$ da população feminina) sejam daltônicos. (COLORADD, 2016, p.3).

Este modelo é vantajoso para quem já possui familiaridade com tais ícones. A forma como será utilizado segue o padrão do primeiro modelo, porém, o nome da cor será substituído pelo ícone, tendo como vantagem a economia de área de visualização ocupada. O Modelo ColorAdd pode ser visualizado na Figura 6 e 7

Figura 6 - Modelo do Protótipo "ColorAdd" - Ícone cor azul.

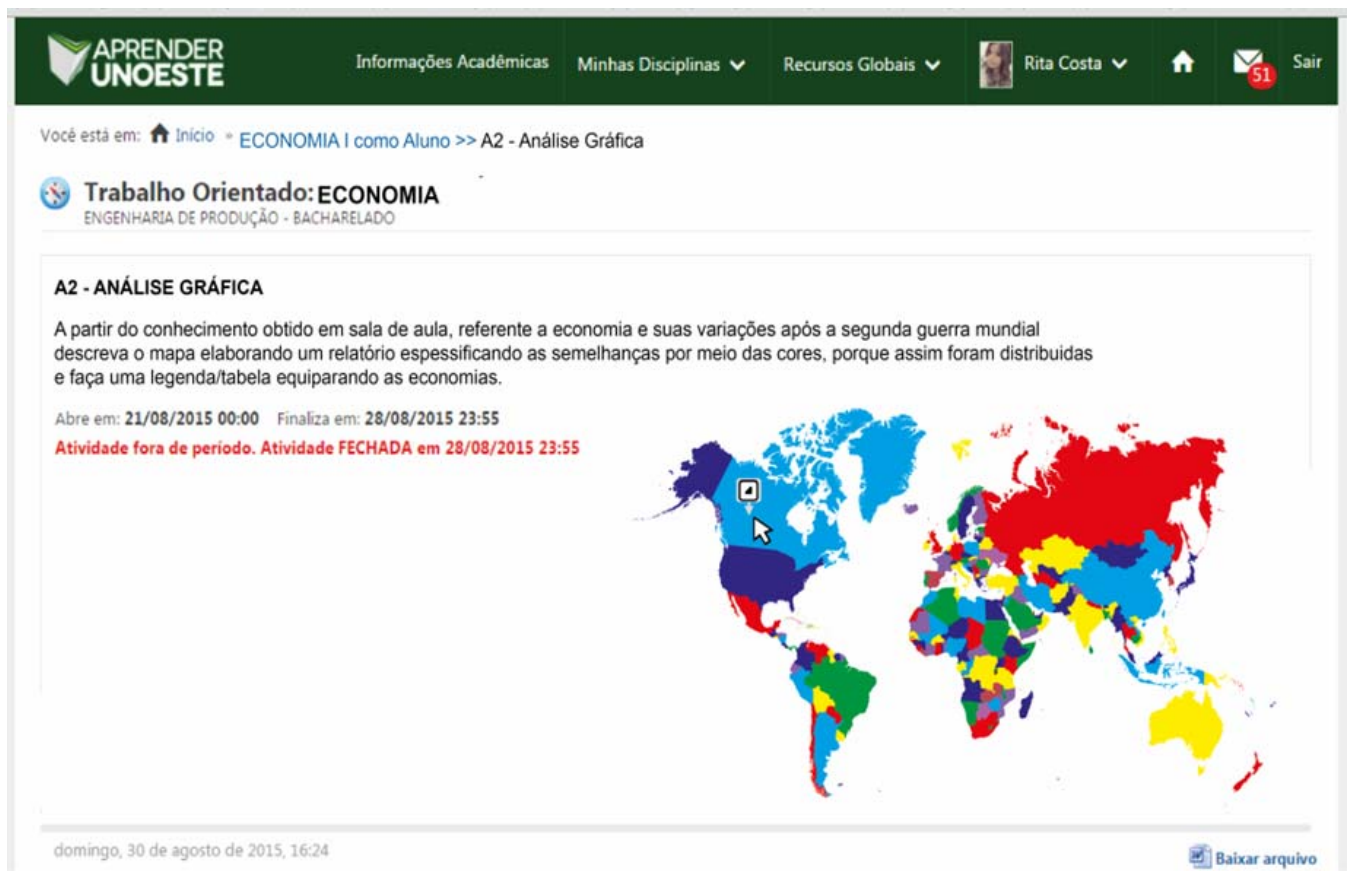

Fonte: Elaborado pelos autores. 


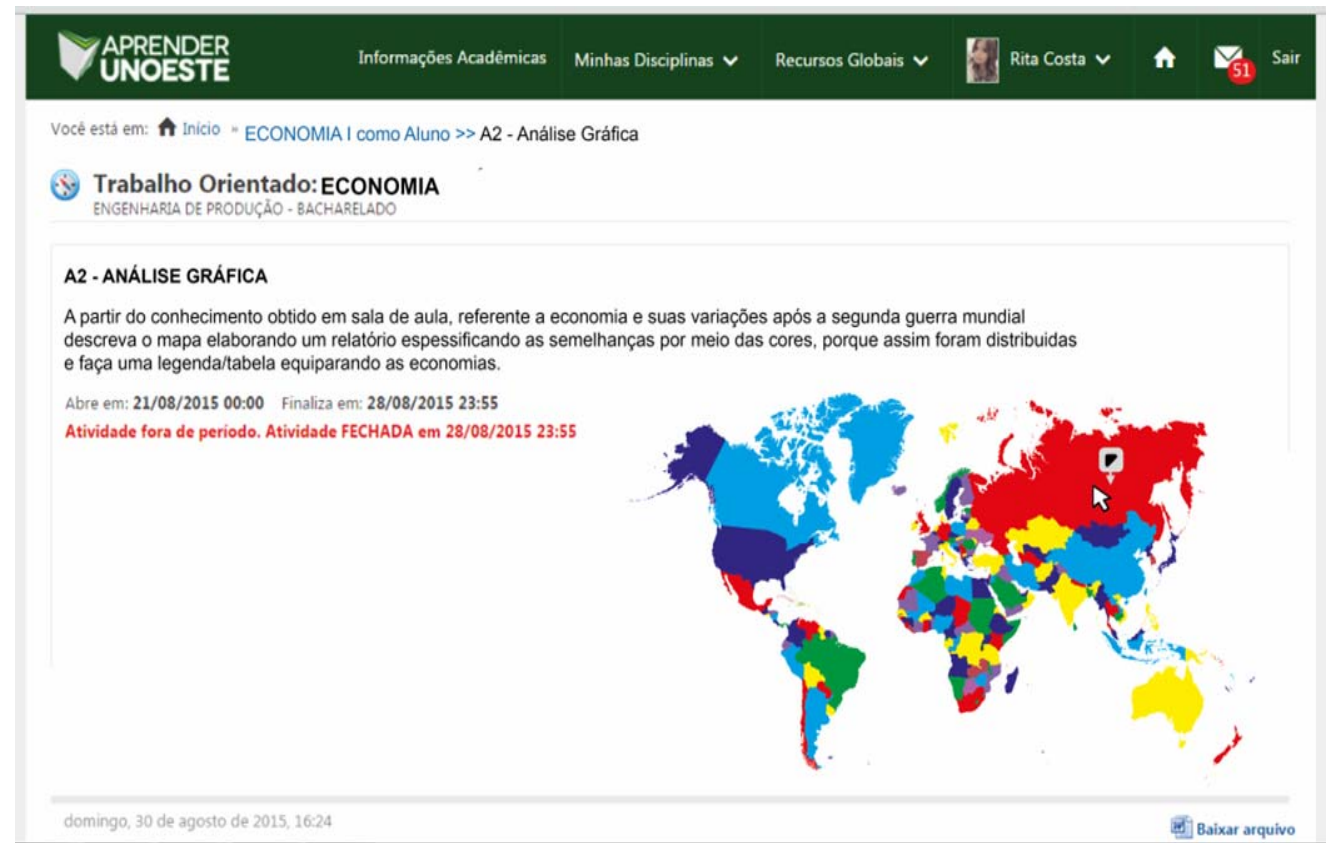

Fonte: Elaborado pelos autores.

Assim como as cores contribuem para a representação simbólica de algo, os ícones potencializam na compreensão quando as cores não são identificáveis por alguma razão. Nessa direção, Fontanella, Galon e Melo (2014, p. 1231), chamam a atenção para importância das cores na comunicação:

A cor é parte fundamental dos planos comunicacionais. A significação da cor pode abranger aspectos denotativos e conotativos. No sentido denotativo, é comum usar a cor como referência direta na qualificação de objetos (por exemplo, "o carro vermelho", "a camisa verde", etc.). Os significados conotativos referem-se às associações sugeridas pela cor (por exemplo, num sinal de trânsito a cor verde informa que o cruzamento está livre para passagem).

Dessa maneira, com o recurso "Legenda ColorAdd", por meio do qual os ícones auxiliam na visualização das cores, a familiaridade com o significado de cada símbolo, torna, além de eficiente, mais rápido a compreensão das cores, de uma forma que se compara a percepção de cores de um não daltônico, favorecendo a interação com o conteúdo e com outras pessoas. Nesse contexto, Santana, Almeida e Baranauskas (2008, p. 74) chamam a atenção para o seguinte pensamento: “No entanto, o papel da tecnologia como fator de integração entre pessoas, quando não consciente dos cuidados a se ter com relação à acessibilidade, pode ser distorcido, levando em certos casos, à separação entre pessoas sem ou com deficiência ou a exclusão desse segundo grupo."

Todavia, como ativar? Ambos possuem a mesma forma de ativação: na aba superior no Aprender haverá o ícone referente a acessibilidade para daltônicos, ao clicar no ícone aparecerá às opções: Legenda, ColorAdd e Conheça o ColorAdd. 
O ícone antes colorido passa a ficar cinza desta forma é possível constatar quando a ferramenta estará ativada ou desativada. As Figuras 7, 8, 9, 10, 11 e 12, indicam como seria a visualização dessa ferramenta no ambiente virtual - Aprender Unoeste.

Figura 8 - ícone de acessibilidade para daltônicos.

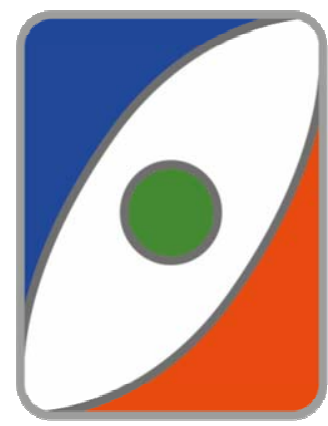

Fonte: Duarte, 2016

Figura 9 - Modelo do Ícone de ativação da ferramenta.

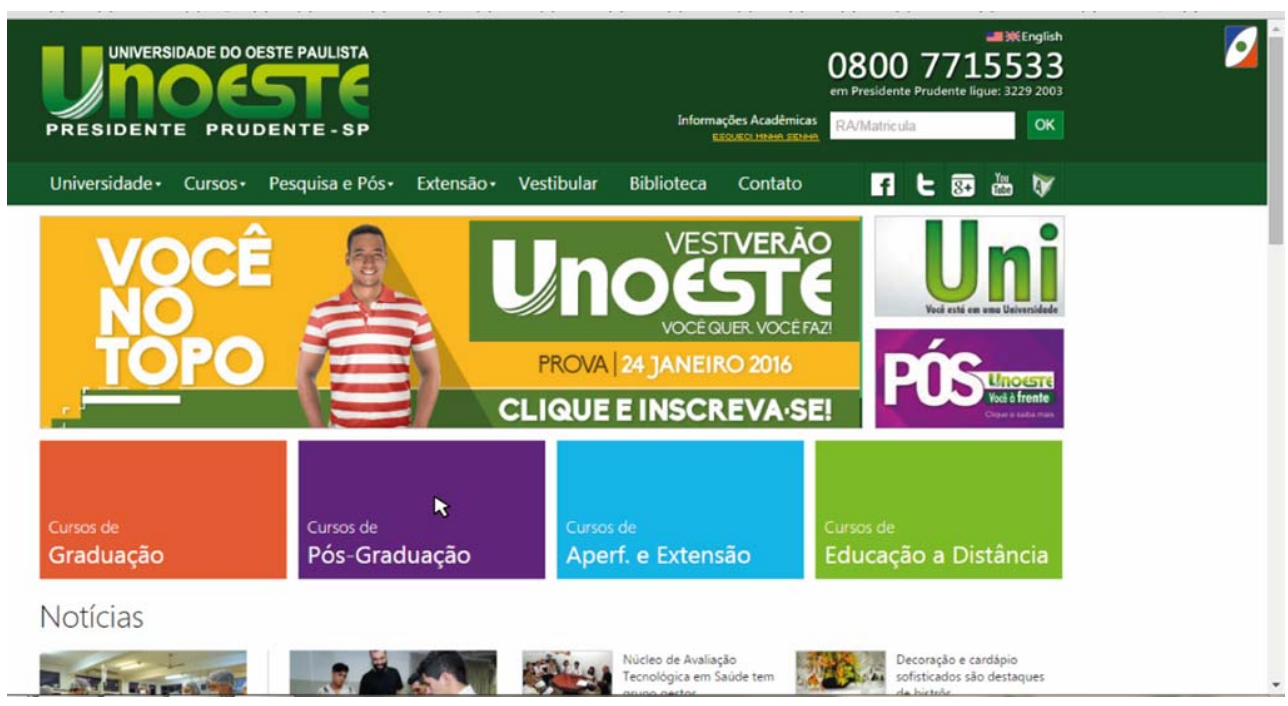

Fonte: Elaborado pelos autores. 
Figura 10 - Modelo do Ícone de ativação da ferramenta.

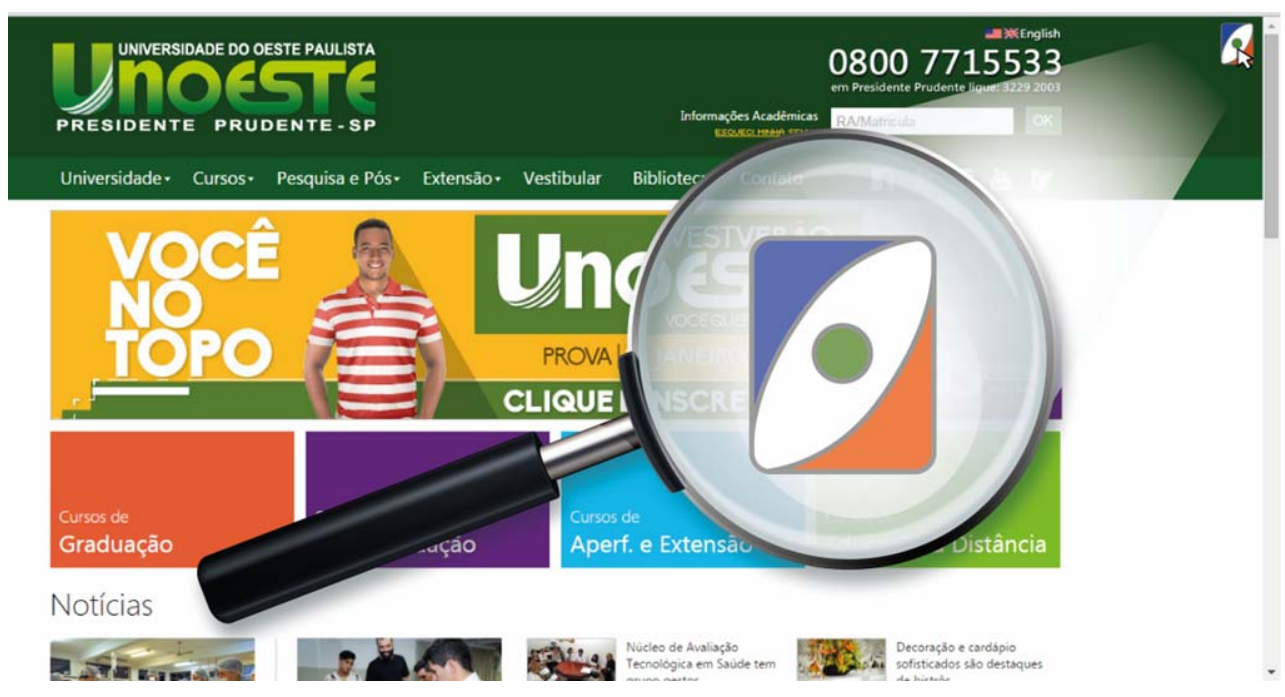

Fonte: Elaborado pelos autores.

Figura 11 - Opções ao clicar no ícone de acessibilidade.

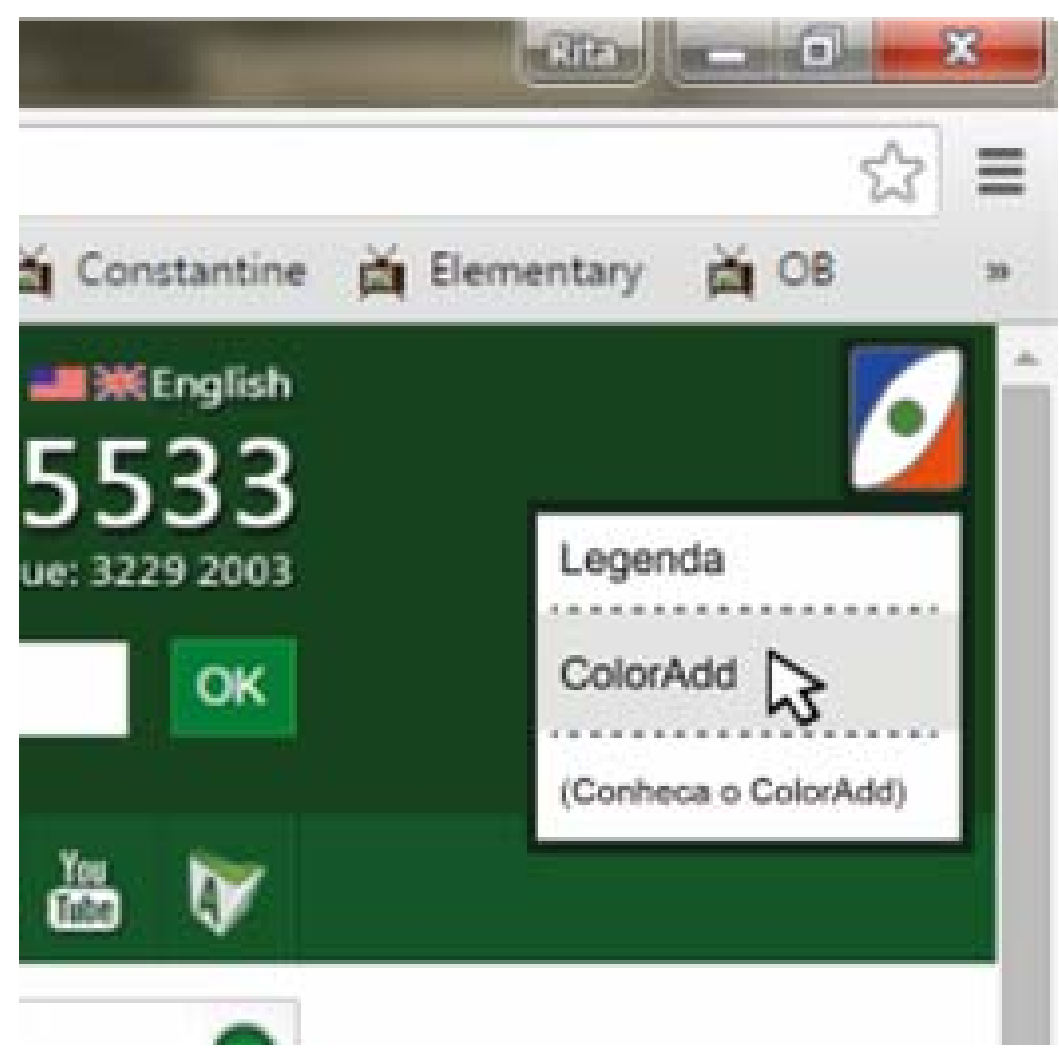

Fonte: Elaborado pelos autores. 


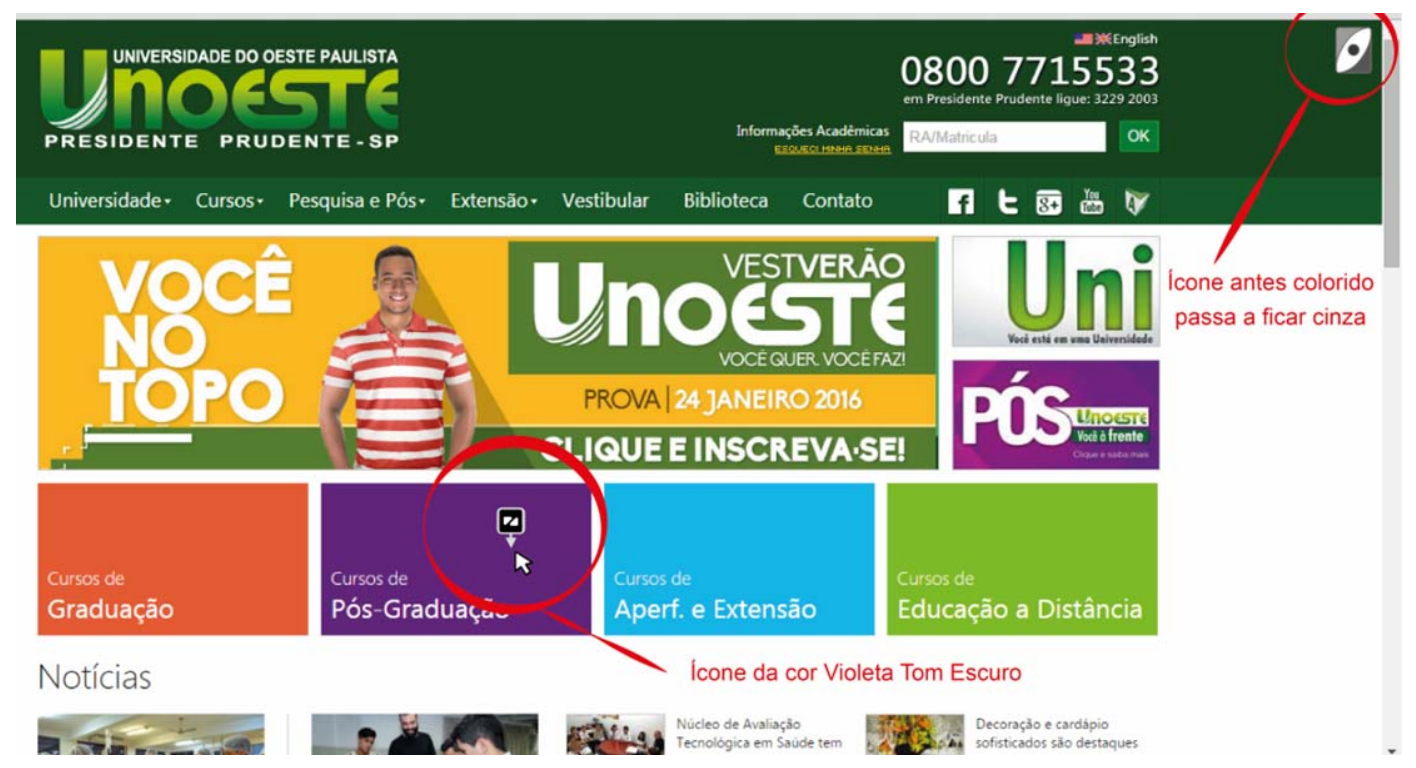

Fonte: Elaborado pelos autores.

Como mencionado, anteriormente, existem duas variáveis relevantes. Com relação à primeira variável, na qual a identificação de imagens/fotografias é prejudicada pelo grau de daltonismo do usuário, nesse caso, a separação e nomeação de cada cor pode não auxiliar na sua visualização, é preciso, nessas situações específicas, a recoloração da imagem.

Gomes e Ribeiro (2012) propõem uma técnica realizada para recolorir imagens em ambientes virtuais após tratá-las, manuseando-as ao nível de cada pixel que compõe a imagem (com o auxílio da linguagem de programação javascript). Gomes e Ribeiro (2012, p. 472), apresentam a solução da seguinte forma: "esta inovação possibilita a aplicação dos algoritmos de correcção de cor, às imagens, de forma directa, durante o carregamento da página nos browsers, sem recorrer a aplicações externas."

Convém salientar que, a recoloroção de imagem não é 100\% efetiva, já que existem diferentes tipos de daltonismo, e, em alguns casos, a recoloração pode acabar piorando a identificação da imagem.

No caso do protótipo apresentado neste artigo, ao ativar qualquer uma das opções: Legenda ou ColorAdd, será também ativado a recoloração que levará em consideração a forma mais comum de daltonismo, na qual o daltônico não consegue diferenciar a cor verde do vermelho.

A segunda variável diz respeito ao fato de algumas aplicações organizarem o Layout das páginas por meio de textos dentro de caixas, quadros ou tabelas. Dependendo do grau de daltonismo do usuário e das cores usadas, pode ser que a cor da escrita acabe se misturando com a cor aplicada ao fundo do texto. Nesse sentido, Nóbrega (2011, p. 23), considera que,

a utilização de uma cor no texto que contraste com a coloração do fundo auxilia os usuários com baixa visão, desde que a combinação de cores seja adequada às pessoas com daltonismo: não recomenda-se o uso da combinação vermelho/verde, vermelho/marrom ou azul/verde, por exemplo. 
Em relação aos impactos desta variável, em uma próxima etapa desta pesquisa será realizada uma orientação quanto ao uso adequado das cores, junto aos profissionais que trabalham com o Design de Interface da plataforma Apender Unoeste, orientando-os sobre esta questão e como proceder evitando as combinações citadas por Nóbrega (2011).

O protótipo aqui apresentado possui outras limitações que precisam ser aprofundadas em pesquisas futuras. Por exemplo, no caso da recoloração de imagens, poderiam ser trabalhadas subclassificações, uma vez que não há benefício $100 \%$ eficaz no tratamento de cores em imagens, devido ao fato de que cada daltônico as enxerga de maneiras diferentes, pois o grau de daltonismo depende da quantidade de cones e também de determinar quais deles possuem defeitos na retina.

Além disso, outros testes serão realizados com o intuito de validarmos a solução junto a usuários com daltonismo. Para isso, em uma próxima etapa deste estudo a solução projetada será efetivamente implementada no AVA Aprender Unoeste com o apoio da equipe de TI desta instituição. Na sequência serão convidados alguns estudantes da universidade que sejam daltônicos para realizarem o acesso ao AVA na versão adaptada para emitirem suas opiniões e nos auxiliarem na depuração da solução ilustrada no protótipo aqui apresentado. Somente após essa etapa de aplicação e testes serão sistematizados os resultados alcançados diante dos experimentos realizados com o público-alvo desta investigação.

Acredita-se assim que os avanços obtidos até o presente momento são essenciais para essa e outras instituições que almejam desenvolver ações, articulando ambientes virtuais nas modalidades presenciais e a distância se conscientizem da necessidade de repensar e buscar diferentes alternativas para que todos os seus usuários, sejam eles estudantes, docentes e equipe técnico-administrativa tenham condições de usufruir da melhor forma possível de todos os recursos tecnológicos que lhes forem ofertados.

Por fim, vale enfatizar que a implementação do protótipo, de forma efetiva no AVA, objeto desta análise, constituir-se-á o foco de uma pesquisa futura, ainda a ser realizada pelos pesquisadores envolvidos nesta investigação. O desenho do protótipo neste estudo limitou-se à descoberta de um caminho a ser seguido para adicionar um dispositivo no AVA Aprender Unoeste que possa torná-lo acessível a pessoas daltônicas. Esse objetivo foi atingido, conforme evidenciam as informações aqui apresentadas.

\section{Considerações finais}

Por meio desta pesquisa, concluiu-se que é possível a inclusão de recursos adicionais nos AVA, visando à melhoria de acesso de pessoas com daltonismo nesses espaços de aprendizagem. O protótipo construído evidencia que existem possibilidades para que tecnicamente o AVA de uma instituição que se diz "inclusiva", possa ser readequado, pensando no acolhimento, permanência e sucesso de estudantes daltônicos.

A legislação é clara quando se refere ao acesso a todos nos estabelecimentos de ensino de qualquer nível, etapa ou modalidade, públicos ou privados, e que estes devem proporcionar condições de acesso e utilização de todos os seus ambientes ou compartimentos para pessoas 
com deficiência ou com mobilidade reduzida, inclusive salas de aula, bibliotecas, auditórios, ginásios e instalações desportivas, laboratórios, áreas de lazer e sanitários.

Com o nítido avanço da tecnologia e das redes sociais interligadas pela internet ampliam-se também as possibilidades de educação inclusiva, tanto no acesso a ilimitadas informações, quanto na criação de práticas metodológicas alternativas. A partir dessa premissa, é possível criar oportunidades de acesso à educação para pessoas com necessidades que possam vir a comprometer a aprendizagem (ALMEIDA et al., 2011). Nesse sentido, se bem trabalhado, organizado e orientado aos responsáveis pela interface e customização do AVA utilizado na instituição é possível torná-lo acessível aos daltônicos, conforme evidenciado neste estudo.

O daltonismo é muitas vezes tratado como um assunto de pouca importância, devido à concepção de que pouco interfere no cotidiano dos daltônicos, porém é uma limitação para a execução de tarefas simples. Desse modo, entendemos que qualquer necessidade de acessibilidade em qualquer nível deva ser contemplada pelas várias esferas da sociedade, ou seja, há que se empregar esforços para garantir a acessibilidade e inclusão às pessoas que por alguma limitação, congênita ou adquirida, Ihes é vedado, considerando todas as modalidades de ensino.

\section{Referências}

ALMEIDA, A. C. F. de. et al. Acessibilidade para pessoas com deficiência visual no Moodle. Linhas Críticas, Brasília, DF, v. 17, n. 33, p. 327-348, dez. 2011. Disponível em: <http://periodicos.unb.br/index.php/linhascriticas/article/view/5697/4709>. Acesso em: 15 abr. 2015.

BEHAR, P. A. et al. A importância da acessibilidade digital na construção de objetos de aprendizagem. RENOTE, Rio Grande do Sul, v. 6, n. 1, 2008. Disponível em: <http://seer.ufrgs.br/index. php/renote/article/view/14459/8381>. Acesso em: 10 mai. 2015.

BESSANI, P. B. S. et al. Usabilidade e acessibilidade no desenvolvimento de interfaces para ambientes de educação à distância. In. RENOTE, v. 8, n. 1, 2010. Disponível em: <http://seer.ufrgs.br/renote/article/view/15180>. Acesso em: 10 mai. 2015.

BRASIL. Decreto n. o 5.296, de 02 de dezembro de 2004. Regulamenta as Leis nos 10.048 , de 8 de novembro de 2000, que dá prioridade de atendimento às pessoas que especifica, e 10.098, de 19 de dezembro de 2000, que estabelece normas gerais e critérios básicos para a promoção da acessibilidade das pessoas portadoras de deficiência ou com mobilidade reduzida, e dá outras providências. Diário Oficial da União, Brasília, DF, 03 dez. 2004. Disponível em: <http://www.planalto.gov.br/ccivil_03/_ato2004-2006/2004/decreto/d5296.htm>. Acesso em: 13 dez. 2015.

Decreto no 5.622, de 19 de dezembro de 2005. Regulamenta o art. 80 da Lei no 9.394, de 20 de dezembro de 1996, que estabelece as diretrizes e bases da educação nacional. Diário Oficial da União, Brasília, DF, 20 dez., 2005. Disponível em:

<http://www2.camara.leg.br/legin/fed/decret/2005/decreto-5622-19-dezembro-2005-539654normaatualizada-pe.pdf>. Acesso em: 10 abr. 2015.

Decreto no 6.949, de 25 de agosto de 2009. Promulga a Convenção Internacional sobre os Direitos das Pessoas com Deficiência e seu Protocolo Facultativo, assinados em Nova York, em 30 de março de 2007. Diário Oficial da União, Brasília, DF, 26 ago. 2009. Disponível em: <http://www.planalto.gov.br/ccivil_03/_ato2007-2010/2009/decreto/d6949.htm>. Acesso em: 10 abr. 2015. 
Ministério da Educação Instituto Nacional de Estudos e Pesquisas Educacionais Anísio Teixeira. Notas Estatísticas Censo da Educação Superior, 2014. Disponível em: <http://download.inep.gov.br/educacao_superior/censo_superior/documentos/2015/notas_sob re_o_censo_da_educacao_superior_2014̄.pdf>. Acesso èm: 10 dez. 2015.

DUARTE, A. Acessibilidade para Daltônicos na Web. Disponível em:

http://www.daltonicos.com.br/daltonico/index.html. Acesso em: 18 abr. 2016.

GARCIA, F. E. A. S. et al. Aplicação da Interação Humano-Computador no Desenvolvimento de Interfaces Gráficas Destinadas a Daltônicos. Revista E-f@tec, Garça, v. 3, n. 2, 2013.

Disponível em: <http://www.fatecgarca.edu.br/revista/Volume3/artigos_vol3/Artigo_19.pdf>. Acesso em: 23 jan. 2016.

GOMES, A; RIBEIRO, M.M.G. Recoloração de web conteúdos para daltónicos: recoloração de imagens. In: Conferência Internacional em Design e Artes Gráficas, 2, 2012, Tomar. Desafios conceptuais para o design e a produção gráfica: livro de actas. Lisboa: ISEC. p. 470-473. Disponível em:

<http://gcd.isec.universitas.pt/anexos/miolo_\%20Livro_\%20Actas_CIDAG2012_Julho\%202013 .pdf>. Acesso em: 10 abr. 2015.

COLORADD: Color identification system. Disponível em:

<http://www.coloradd.net/imgs/ColorADD-Sobre-Nos_0315.pdf>. Acesso em: 19 jan. 2016.

COLOR IDENTIFICATION SYSTEM FOR COLORBLIND PEOPLE. Disponível em:

<http://www.coloradd.net/>. Acesso em: 19 jan. 2016.

COLOUR BLIND AWARENESS. 2014. Disponível em: <http://www.colourblindawareness.org/>. Acesso em: 19 jan. 2016.

LÉVY, P. Cibercultura. São Paulo: Editora 34, 2009.

MELO, D. G.; GALON, J. E. V.; FONTANELLA, B. J. B. Os "daltônicos" e suas dificuldades: condição negligenciada no Brasil? Physis: Revista de Saúde Coletiva, v. 24, n. 4, p. 1229-1253, dez. 2014. Disponível em: <http://www. scielosp.org/scielo. php?script=sci arttext\&pid=S0103$73312014000401229 \&$ lng=pt\&nrm=iso $>$. Acesso em: 10 jan. 2016.

NÓBREGA, G. C. Acessibilidade aos conteúdos visuais em ambientes virtuais de aprendizagem. Revista Brasileira de Tradução Visual, Recife, PE, v. 9, n. 9, 2011. Disponível em: <http://rbtv.associadosdainclusao.com.br/index. php/principal/article/viewFile/114/184>. Acesso em: 15 jan. 2016.

PRATES, R. O.; BARBOSA, S. D. J. Avaliação de interfaces de usuário: conceitos e métodos. Disponível em: <http://homepages.dcc.ufmg.br/ rprates/ge_vis/cap6_vfinal.pdf>. Acesso em: 10 jan. 2016.

SASSAKI, R. Inclusão: o paradigma do século 21. Revista Inclusão, vol. 1, n. 1, p. 19-23, out. 2005. Disponível em: <http://portal.mec.gov.br/seesp/arquivos/pdf/revistainclusaol. pdf>. Acesso em: 10 jan. 2016.

SANTANA, V. F.; ALMEIDA, L. D. A.; BARANAUSKAS, M. C. C. Aprendendo sobre acessibilidade e construção de websites para todos. Revista Brasileira de Informática na Educação, v. 16, n. 03, dez. 2008. Disponível em: <http://www.br-ie.org/pub/index.php/rbie/article/view/45/39>. Acesso em: 14 dez. 2015.

SONZA, A. P.; CONFORTO, D.; SANTAROSA, L. Acessibilidade nos portais da educação profissional e tecnológica do Ministério da Educação. In: Revista Brasileira de Educação Profissional e Tecnológica, Brasília, v. 1, n. 1, p. 131-146, jun. 2008. Disponível em: <http://www2.ifrn.edu.br/ojs/index.php/RBEPT/article/view/2874>. Acesso em: 14 dez. 2015.

TORRES, E. F.; MAZZONI, A. A.; ALVES, J. B. da M. A acessibilidade à informação no espaço digital. Ciência da Informação, Brasília, v. 31, n. 3, p. 83-91, set. 2002. Disponível em: 
<http: //www.scielo.br/scielo.php?script=sci_arttext\&pid=S0100-

19652002000300009\&lng=en\&nrm=iso>. Acesso em: 19 jan. 2016.

Recebido em agosto de 2016

Aprovado para publicação em agoto de 2017

\section{Rita de Cassia Miranda da Costa}

Programa de Pós-Graduação em Educação - Universidade do Oeste Paulista - UNOESTE, Presidente Prudente/SP, Brasil, rita.cmc92@gmail.com

\section{Adriana Aparecida de Lima}

Programa de Pós-Graduação em Educação - Universidade Nove de Julho - UNINOVE, São Paulo/SP, Brasil, atercariol@gmail.com

\section{Fernanda Sutkus de Oliveira Mello}

Docente do Programa de Graduação em Sistemas para Internet, Publicidade, Jornalismo e Design Gráfico Universidade do Oeste Paulista - UNOESTE, Presidente Prudente/SP, Brasil, fernanda_mello@unoeste.br

\section{Sidinei de Oliveira Sousa}

Docente do Programa de Pós-Graduação em Educação - Universidade do Oeste Paulista - UNOESTE, Presidente Prudente/SP, Brasil, sidinei@unoeste.br

\section{Elisangela Aparecida Bulla I keshoji}

Professora do Ensino Básico, Técnico e Tecnológico - Instituto Federal de Educação, Ciência e Tecnologia de São Paulo/Câmpus Birigui - IFSP, Birigui/SP, Brasil, elisangela.bulla@gmail.com 


\title{
Acesso ao Computador: Comparação do Desempenho de Jovens com Diferentes Dispositivos de Entrada
}

\section{Computer Access: Comparison of Youth Performance with Different Input Devices}

\author{
GLÁUCIA SANCHES GUIMARÃES \\ Universidade Estadual Paulista - UNESP - Campus Marília \\ MARCELO GRANDINI SPILLER \\ Universidade Estadual Paulista - UNESP -Campus Marília \\ LÍGIA MARIA PRESUMIDO BRACCIALLI \\ Universidade Estadual Paulista - UNESP - Campus Marília
}

\begin{abstract}
Resumo: Há diferentes dispositivos para facilitar o acesso ao computador, porém, poucos estudos para verificar a eficácia dos mesmos. O objetivo deste estudo foi comparar o desempenho de jovens ao utilizarem dispositivos de acesso ao computador. Participaram do estudo cinquenta jovens saudáveis com idades entre 15 e 25 anos. Para a coleta de dados foi utilizado computador com tela sensível ao toque, mouse e o Camera Mouse. Foram utilizados três softwares para avaliar tempo de reação e acurácia dos participantes: Discrete Aiming Task, Tracking Task e Single Switch Performance Test. Os resultados demonstraram que nas atividades de precisão e tempo de reação, o mouse e a toque na tela foram os dispositivos que geraram os melhores desempenhos. Conclui-se que, o Camera Mouse foi o dispositivo que gerou os piores desempenhos.
\end{abstract}

Palavras-chave: Recursos para computador; Acesso; TIC.

\begin{abstract}
There are different types of devices to facilitate access to a computer, however, only few studies are aimed at verifying their efficacy. The objective of this study is to compare the performance of young subjects while using different computer access devices. Fifty healthy youngsters, aging between 15 and 25, took part in the study. Three softwares were used to evaluate the participants' reaction time and accuracy: Discrete Aiming Task v.2.0, Tracking Task v.2.0 and Single Switch Performance Test (SSPT). Results attested that in precision and time reaction activities, the mouse and the touch-screen were the devices generating the best performances. It is concluded that, within the devices used, the Camera Mouse software was the one generating the worst performances.
\end{abstract}

Keywords: Resources to computer; Acess; TIC. 


\section{I ntrodução}

O uso de computadores no ambiente escolar tem se popularizado, e as escolas têm procurado se adequar para a implantação de laboratórios de informática.

Nesse sentido, a legislação brasileira prevê escolas inclusivas que tenham como concepção a implantação de projetos de tecnologias da informação e comunicação que tenham como base os princípios do desenho universal (BRASIL, 2015).

Desenho universal é definido como concepção de produtos, ambientes, programas e serviços a serem utilizados
por todas as pessoas, sem necessidade de adaptação ou projeto específico,
incluindo os recursos de tecnologia assistiva. O conceito de desenho universal
tem como pressupostos: equiparação das possibilidades de uso, flexibilidade no
uso, uso simples e intuitivo, captação da informação, tolerância ao erro,
mínimo esforço físico, dimensionamento de espaços para acesso, uso e
interação de todos os usuários (ABNT, 9050,2015, p.4)

O conceito de desenho universal tem sete princípios que são adotados mundialmente: 1) uso equitativo; 2) uso flexível; 3) uso simples e intuitivo; 4) informação de fácil percepção; 5) tolerância ao erro; 6) baixo esforço físico; 7) dimensão e espaço para acesso e uso (CONNELL et al., 1997).

Como uso equitativo entende-se que o produto ou ambiente pode ser utilizado por todos com segurança e conforto, elimina qualquer forma de segregação ou estigma e tenha um design atraente para todos. Quanto ao uso flexível o design deve abranger uma gama de preferencias e habilidades individuais do usuário. Deve atender indivíduos com habilidades diferentes e oferecer diferentes maneiras de uso, por destros ou canhotos, além de propiciar precisão, destreza e respostas eficazes para indivíduos com tempos de reação diferentes a estímulos. Em relação ao uso simples e intuitivo quando se elimina a complexidade desnecessária, é fácil de entender independente da capacidade linguística e escolaridade do usuário, fornece sugestões e feedback adequado durante e após a execução da tarefa. Informação de fácil percepção: essa característica do ambiente ou elemento espacial faz com que seja redundante e legível quanto a apresentações de informações vitais. As informações são consideradas de fácil percepção quando são apresentadas de diferentes formas (pictórico, verbal, tátil), de forma a ser compreendida por pessoas com diferentes habilidades (cegos, surdos, analfabetos, entre outros). O design comunica eficazmente a informação necessária para o usuário, independentemente das condições ambientais ou habilidades sensoriais do usuário. Em relação à tolerância de erro deve-se minimizar perigos e as consequências adversas de ações acidentais ou não intencionais. Quanto ao baixo esforço físico o projeto pode ser utilizado de forma eficiente e confortável, com um mínimo de fadiga. O usuário deve manter uma posição corporal neutra, minimizar ações repetitivas e sustentação do esforço físico. No último princípio, dimensão e espaço para aproximação e uso, é ressaltado que o ambiente ou produto deve ter dimensão e espaço apropriado para aproximação, alcance, manipulação e uso, independentemente da estatura, postura e mobilidade do usuário (ABNT, 2015; CONNELL et al., 1997). 
Nessa perspectiva, as novas ferramentas digitais devem superar a exclusão ao engendrar um movimento de inovação rumo à construção de uma sociedade verdadeiramente inclusiva (CONFORTO; SANTAROSA, 2002).

Novos dispositivos de entrada têm sido desenvolvidos com o intuito de tornar mais dinâmico e natural a interação homem/ máquina. Recentemente, tela sensível ao toque, acionador pela interação corporal e dispositivos de acesso por voz tem sido incorporado em telefones celulares e outros dispositivos baseados em tecnologia como Microsoft Kinect (CHOU; HUANG; TSAI, 2015).

Uma das interfaces comumente utilizada nos dias atuais é a touchscreen ou tela sensível ao toque, que é feita por meio do toque dos dedos na área de exibição. Este recurso tem sido aplicado em vários dispositivos, tais como computadores, caixas eletrônicos, aparelhos celulares e tablets (PARK; LEE; KIM, 2011). A tela sensível ao toque é capaz de decodificar milhares de pontos, passando informações do toque, como o arraste, o toque simples ou duplo, ao sistema eletrônico do dispositivo (WILKIE; MAK; SAKSIDA, 1994).

Os dispositivos mais recentes de acesso ao computador são baseado em webcams ou sensores infravermelhos. Esse tipo de interface parece ser uma forma mais natural de apontar, da mesmo forma como as pessoas tendem a olhar para o objeto que deseja interagir e não exigem que do usuário qualquer contato com o corpo (RAYA et al., 2010).

Por intermédio da webcam é possível substituir o mouse e o teclado. O método de controle do cursor baseado na câmera pode ser realizado das seguintes formas: por meio do rastreamento ocular do usuário, com um ponto fixado em uma região de sua face, por meio de movimentos da cabeça, pelos gestos das mãos e, ainda, por meio de óculos especiais com ponteira a laser (ARAI; MARDIYANTO, 2010).

O Camera Mouse, é um software gratuito que se utiliza da webcam para auxiliar o usuário no controle do cursor do mouse. A partir de um ponto fixado na face do indivíduo, torna-se possível a detecção do movimento de sua cabeça e, consequentemente, o controle do cursor. O clique do mouse é acionado quando o usuário permanece por alguns segundos com o cursor parado em uma determinada região da tela que deseja operar. Este tempo de espera pode ser alterado nas configurações do programa. O software foi desenvolvido para facilitar o acesso ao computador de pessoas com paralisia cerebral, atrofia muscular, esclerose lateral amiotrófica, esclerose múltipla, traumatismo cranioencefálico, entre outros distúrbios neurológicos. Normalmente, é utilizado por indivíduos que não possuem controle das mãos, mas que conseguem mover a cabeça de forma voluntária e com maior coordenação. Esse software pode ser utilizado com programas de entretenimento, educação, comunicação, navegadores da web, porém funciona melhor com aplicativos que exijam apenas um clique esquerdo no mouse e que não tenham alvos muito pequenos que dependam de grande precisão (CAMERA MOUSE, 2015).

No estudo de Betke; Gips e Fleming (2002) foi testada a eficiência do Camera Mouse com um grupo de vinte pessoas sem deficiências. Em primeiro lugar, para cada usuário foi feita uma breve explicação de como o software funcionava, e, em seguida, eles passaram a praticar a movimentação do cursor durante um minuto. Após este período, foi solicitado que cada usuário jogasse um jogo. Depois destas atividades, cada usuário digitou frases em um programa de 
teclado ortográfico. No final do estudo, concluiu-se que o grupo aprendeu rapidamente como utilizar o Camera Mouse para construir frases ou jogar jogos.

Alguns estudos com indivíduos adultos sem deficiência indicam desvantagens no uso de rastreadores oculares devido à sensibilidade aos movimentos da cabeça do usuário, por serem barulhentos, por terem a precisão do apontar limitada devido ao tamanho da fóvea humana, por dependerem de calibração e por terem o efeito toque Midas ${ }^{1}$ (VERTEGAAL, 2008), além de custo mais elevado.

Apesar de atualmente haver diferentes dispositivos para facilitar o acesso ao computador, observa-se que existem poucos estudos que verificam a eficácia de uso dessas ferramentas.

No presente estudo, pretende-se avaliar o desempenho, em relação a acurácia e tempo de atividade, de adolescentes e jovens adultos durante o uso de três dispositivos de entrada: mouse, tela sensível ao toque e o software Camera Mouse.

\section{Método}

O projeto foi encaminhado ao Comitê de Ética da Faculdade de Filosofia e Ciências da UNESP de Marília/SP e teve parecer favorável n 957/2014. Todos os participantes assinaram o Termo de Consentimento Livre e Esclarecido.

O estudo tem um delineamento metodológico de pesquisa quase-experimental, tipo de estudo com rigor científico semelhante a pesquisa experimental, porém não apresenta grupo controle e a amostra não é definida de forma aleatória. Nesse tipo de estudo, a comparação pode ser realizada com o mesmo grupo de sujeitos, considerando o antes e depois da intervenção (PORTNEY; WATKINS, 2008).

\subsection{Participantes}

Participaram do estudo 50 adolescentes e jovens adultos saudáveis de ambos os sexos, sendo 9 do sexo masculino e 41 do sexo feminino, com média de idade de $21,36( \pm 2,25)$ anos. Foram excluídos do estudo aqueles indivíduos que apresentavam qualquer tipo de deficiência diagnosticada.

\subsection{Local}

O estudo foi desenvolvido no Laboratório de Análise de Desempenho Motor (LADEMO) do Departamento de Educação Especial da Faculdade de Filosofia e Ciências de Marília.

\footnotetext{
${ }^{1}$ Toque de Midas= Efeito causado pela sobrecarga da função de entrada visual do olho com a tarefa de saída motora, que provoca, por parte dos usuários, a seleção inadvertida ou ativa qualquer alvo que ocorra a fixação dos olhos.
} 


\subsection{Equipamentos e materiais}

Para a coleta de dados foi utilizado computador com tela sensível ao toque, mouse e o software Camera Mouse 2 .

Para avaliar tempo de reação e acurácia dos participantes foram utilizados três softwares: Discrete Aiming Task v.2.0 ${ }^{3}$, Tracking Task v.2.04 e Single Switch Performance Test (SSPT) ${ }^{5}$. O Discrete Aiming Task v.2.0 é um software desenvolvido pelo Prof. Dr. Victor Hugo Alves Okazaki que possui recursos para analisar cinematicamente o cursor do mouse e avalia a acurácia. O Tracking Task v.2.0, também desenvolvido pelo Prof. Dr. Victor Hugo Alves Okazaki foi utilizado para analisar a tarefa de rastreamento associada ao tempo de reação a tarefa e acurácia. O software Single Switch Performance Test (SSPT), é um software livre desenvolvido na University of Pennsylvania que avalia o tempo necessário para ativar um alvo, para liberar o clique do mouse e a velocidade de repetição da ativação.

\subsection{Procedimentos de coleta de dados}

Cada participante foi posicionado sentado em uma cadeira, com postura e mobiliário ergonomicamente adequados para realização da atividade proposta no computador alocado em uma mesa a sua frente.

O monitor do computador utilizado foi posicionado de forma que o centro da tela ficasse posicionado a uma distância correspondente ao alcance máximo de cada participante. O alcance máximo é uma forma de mensuração antropométrica que consiste em determinar um eixo hipotético do membro superior centrado na articulação do ombro e a partir desse ponto desenha-se um raio que é igual ao comprimento do membro superior (NOWAK, 1996; JAROSZ, 1996). Essas medidas foram necessárias para garantir que todos os participantes tivessem acesso ao alvo quando fizessem o uso da tela sensível ao toque.

Para este estudo foram adotados três dispositivos de entrada: mouse, tela sensível ao toque e o software Camera Mouse, que foram utilizados durante a realização de atividades nos softwares Discrete Aiming Task v.2.0, Tracking Task v.2.0 e Single Switch Performance Test (SSPT).

Inicialmente, cada participante praticou uma vez as atividades propostas utilizando os três tipos de dispositivos. Durante o treino e coleta com o Camera Mouse, o ponto que substituiu o cursor do mouse foi fixado na região da glabela do participante. Posteriormente ao treino, realizou-se sorteio para determinar a ordem de cada dispositivo e atividade que o participante deveria seguir.

Para realizar a calibração do Camera Mouse, o participante era posicionado adequadamente em frente ao computador, e em seguida a câmera embutida era ativada para que por meio da imagem pudéssemos fixar o ponto na glabela que se transformaria em cursor. O Camera Mouse

\footnotetext{
${ }^{2}$ http://www.cameramouse.org/

${ }^{3}$ http://okazaki.webs.com/softwaresdownloads.htm

${ }^{4}$ http://okazaki.webs.com/softwaresdownloads.htm

${ }^{5}$ https://aacinstitute.org/sspt/
} 
foi programado para fazer o clique a cada 1 segundo em que o participante permanecesse com o cursor fixado no alvo desejado.

No software Discrete Aiming Task o participante realizou a tarefa de clicar dentro de duas placas finas alternadamente. Foi estipulado o número total de dois cliques para realizar a tarefa, e foram computados os acertos e erros nos alvos. Durante a utilização do software Tracking Task o participante teve como tarefa manter o cursor do mouse dentro de um círculo azul que muda diversas vezes de direção na tela do computador durante 10 segundos. Ao final, foi computada a porcentagem de tempo que o indivíduo conseguiu manter o cursor dentro do círculo. Para o software Single Switch Performance Test (SSPT) o participante deveria realizar o clique todas as vezes que aparecesse uma tela amarela no computador. No final da atividade foi obtido o tempo médio que cada participante levou para fazer o clique nas 10 telas.

\subsection{Procedimentos de análise de dados}

Foram avaliadas três situações problemas: mouse, tela sensível ao toque e o software Camera Mouse. Durante atividades com os softwares Discrete Aiming Task v.2.0, Tracking Task v.2.0 e Single Switch Performance Test (SSPT) foi possível avaliar a acurácia e tempo de reação para realizar o clique do computador.

Com o Discrete Aiming Task v.2.0 a medida do tempo para a realização da tarefa foi dada em segundos e em número de acertos no alvo. Na realização da atividade com o Tracking Task v.2.0 foi considerada a porcentagem de tempo dentro do círculo durante a atividade proposta.

No teste com o Single Switch Performance Test (SSPT), foi coletado o tempo médio de resposta de cada participante ao realizarem os cliques solicitados. Foram utilizados segundos como unidade de medida para a análise dos dados de tempo médio de resposta no Single Switch Performance Test (SSPT).

\subsection{Análise estatística}

Foi realizada análise estatística descritiva por meio de mediana, média, desvio-padrão ( $\mathrm{dp}$ ), valor mínimo, valor máximo para as variáveis tempo total de resposta (s), número de acertos, tempo-círculo (\%) e tempo médio de resposta (s). Para a comparação das variáveis estudadas verificou-se a similaridade entre os grupos por meio do teste Friedman para amostras dependentes. Quando houve diferença estatisticamente significante, procedeu-se à comparação de dois a dois por meio do teste de comparação de Dunn. A verificação da normalidade dos dados foi realizada por meio do teste de Kolmogorov-Smirnov.

Adotou-se, para todos os testes, o nível de significância de $5 \%$ de probabilidade para a rejeição da hipótese de nulidade. 


\section{Resultados}

Os resultados foram apresentados separadamente por software utilizado: 1) Discrete Aiming Task v.2.0; 2) Tracking Task v.2.0 e 3) Single Switch Performance Test (SSPT).

\subsection{Discrete Aiming Task v.2.0}

$\mathrm{Na}$ Tabela 1 encontram-se os dados referentes ao tempo total para realizar a atividade de clicar nas duas placas durante a utilização de cada recurso. Observa-se que houve diferença estatística entre os três recursos.

Comparando-se as médias durante a utilização da tela sensível ao toque, os indivíduos obtiveram o menor tempo para a realização da atividade, enquanto que com o uso do Camera Mouse apresentaram o maior tempo.

Tabela 1 - Resultados obtidos para a variável tempo total de resposta (s) durante o acionamento do Discrete Aiming Task v.2.0 com os diferentes recursos de acesso ao computador.

\begin{tabular}{cccc}
\hline & $\begin{array}{c}\text { Mouse } \\
(\mathrm{s})\end{array}$ & $\begin{array}{c}\text { Tela sensível ao toque } \\
(\mathrm{s})\end{array}$ & $\begin{array}{c}\text { Camera Mouse } \\
(\mathrm{s})\end{array}$ \\
\hline Mínimo & 0.73 & 0.29 & 2.19 \\
Máximo & 2.66 & 1.55 & 11.79 \\
Média & 1.40 & 0.87 & 4.20 \\
Mediana & 1.42 & 0.84 & 3.72 \\
Desvio Padrão & 0.40 & 0.27 & 1.75 \\
\hline \multicolumn{4}{r}{ *Teste Friedman $p<0.0001$}
\end{tabular}

Fonte: Elaborada pelos autores.

Por meio do teste de comparação de Dunn, houve diferença significante quando se comparou Mouse e Tela sensível ao toque, Mouse e Camera Mouse e Tela sensível ao toque e Camera Mouse, com valor de $\mathrm{p}<0.001$.

Na Tabela 2 encontra-se o número de acertos entre os recursos utilizados. Pode-se observar que o Mouse foi o recurso que obteve maior média de acertos.

Tabela 2 - Acertos durante o acionamento do Discrete Aiming Task v.2.0 com os diferentes recursos de acesso ao computador

\begin{tabular}{cccc}
\hline & Mouse & Tela sensível ao toque & Camera Mouse \\
\hline Mínimo & 0 & 0 & 0 \\
Máximo & 2 & 2 & 2 \\
Média & 2 & 1 & 1 \\
Mediana & 2 & 2 & 1 \\
\hline
\end{tabular}

Fonte: Elaborada pelos autores. 
Por meio do teste de comparação de Dunn, foi observado que o Mouse demonstrou ter mais precisão para acertar o alvo quando comparado ao Camera Mouse, com p<0.001. Nas comparações Mouse e Tela sensível ao toque e Tela sensível ao toque e Camera Mouse não houve significância estatística.

\subsection{Tracking Task v.2.0}

Na Tabela 3, encontram-se os dados referentes a porcentagem de tempo do cursor dentro do círculo durante a atividade com o Tracking Task v.2.0 utilizando os diferentes recursos de acesso ao computador. Observa-se que houve diferença estatística entre os recursos utilizados.

O Mouse foi o recurso que obteve maior porcentagem de tempo dentro do círculo, enquanto - Camera Mouse foi o recurso que obteve o pior desempenho, com a média de apenas 23,9\% do tempo dentro do círculo.

Tabela 3 - Resultados obtidos para a variável \% tempo-círculo durante a utilização do Tracking Task v.2.0 com diferentes recursos de acesso ao computador

\begin{tabular}{cccc}
\hline & $\begin{array}{c}\text { Mouse } \\
(\%)\end{array}$ & $\begin{array}{c}\text { Tela sensível ao toque } \\
(\%)\end{array}$ & $\begin{array}{c}\text { Camera Mouse } \\
(\%)\end{array}$ \\
\hline Mínimo & 58 & 15.2 & 1.5 \\
Máximo & 84.6 & 82 & 43.2 \\
Média & 76.4 & 67.7 & 23.9 \\
Mediana & 77.7 & 71.9 & 24.6 \\
Desvio Padrão & 5.8 & 15.1 & 10.6 \\
\hline
\end{tabular}

Fonte: Elaborada pelos autores.

Por meio do teste de comparação de Dunn, houve grande significância para as comparações entre Mouse e Camera Mouse e Tela sensível ao toque e Camera Mouse, com valor de $p<0.001$. A comparação Mouse e Tela sensível ao toque obteve $p<0.05$.

\subsection{Single Switch Performance Test (SSPT)}

Na Tabela 4, observam-se os resultados obtidos para a variável tempo médio de resposta. As menores médias de tempo foram obtidas durante a o acionamento com o uso do Mouse, seguido da Tela sensível ao toque e Camera Mouse. 
Tabela 4 - Resultados obtidos para a variável tempo médio de resposta (s) durante o acionamento do SSPT com os diferentes recursos de acesso ao computador

\begin{tabular}{cccc}
\hline & $\begin{array}{c}\text { Mouse } \\
(\mathrm{s})\end{array}$ & $\begin{array}{c}\text { Tela sensível ao toque } \\
(\mathrm{s})\end{array}$ & $\begin{array}{c}\text { Camera Mouse } \\
(\mathrm{s})\end{array}$ \\
\hline Mínimo & 0.24 & 0.36 & 0.63 \\
Máximo & 0.40 & 0.68 & 1.60 \\
Média & 0.30 & 0.46 & 1.12 \\
Mediana & 0.30 & 0.44 & 1.09 \\
Desvio Padrão & 0.04 & 0.07 & 0.22 \\
\hline \multicolumn{4}{c}{ *Teste Friedman $p<0.0001$} \\
\end{tabular}

Fonte: Elaborada pelos autores.

Por meio do teste de comparação de Dunn, observa-se que houve significância para as comparações entre Mouse e Tela sensível ao toque, Mouse e Camera Mouse e Tela sensível ao toque e Camera Mouse, com valor de $\mathrm{p}<0.001$.

\section{Discussão}

O estudo avaliou-se o desempenho de jovens adultos sem deficiência no uso de três dispositivos de entrada: mouse, tela sensível ao toque e o software Camera Mouse. Desta forma, foi possível identificar quais são as dificuldades e facilidades dos participantes no uso de diferentes dispositivos de entrada para o computador o que poderá contribuir para o desenvolvimento de recursos com base no pressuposto do desenho universal.

o Camera Mouse foi o recurso que obteve a maior média de tempo para ativação do clique durante a tarefa no Single Switch Performance Test (SSPT). Apesar de o pior desempenho ter ocorrido com Camera Mouse, o estudo indica que qualquer pessoa pode utilizar essa ferramenta para acessar o computador, porém deve ser considerada a necessidade de treinamento para melhorar a performance do usuário. Durante a análise do tempo médio de resposta dos participantes, o mouse foi o recurso que apresentou menor média de tempo, em segundo lugar a tela sensível ao toque e por último o Camera Mouse, sendo o recurso mais lento ao cumprir a tarefa.

Durante as atividades de precisão, tanto o mouse quanto a tela sensível ao toque se sobressaíram em relação ao Camera Mouse.

Estudo realizado com o Camera Mouse com pessoas sem deficiência corrobora com nossos resultados, pois mostrou que após explicação sobre o funcionamento e treinamento durante 1 minuto os participantes aprenderam rapidamente como utilizar o software para construir frases ou jogar jogos (BETKE; GIPS; FLEMING, 2002). Apesar de alguns autores afirmarem que esse tipo de interface parece ser uma forma mais natural de apontar (RAYA et al., 2010), os dados do estudo indicam que esse tipo de tecnologia ainda não foi incorporada no cotidiano das pessoas. A aquisição de habilidades no uso de uma nova ferramenta de acesso ao computador exige dos usuários treino e sistematização de uso.

O mouse foi o dispositivo em que os participantes apresentaram o melhor desempenho. Deve ser considerado que apesar do uso do mouse exigir movimentos precisos e treino 
(ALMANJI; DAVIES; AMOR, 2015), essa é a ferramenta mais comum e que se encontra inserida no cotidiano das pessoas para acesso ao computador. Os participantes desse estudo são nativos tecnológicos, que provavelmente tem uma prática diária com o mouse que deve ter refletido na acurácia para clicar em ícones na tela.

A tela sensível ao toque é mais recente que o mouse, porém, não menos presente, pois, atualmente, a maioria dos celulares possui esta tecnologia. Uma vez que se tem que fazer o toque em ícones por meio de um recurso tão pequeno que é o celular, pode-se ter maior facilidade no momento de realizar o toque na tela de um computador que possui dimensões muito maiores da qual estão acostumados no dia a dia.

Possivelmente, o fato de a pesquisa ter sido realizada com jovens entre 15 e 25 anos, que nasceram em uma época em que o mouse já era muito utilizado e que presenciaram a crescente utilização da tela sensível ao toque, torna-os muito mais hábeis no momento de executar a tarefa de clique com estes recursos, porém o estudo indica que outros dispositivos, como o Camera Mouse, podem ser utilizados desde que haja treinamento e uso rotineiro. A proposta de dispositivos de entrada que não se faça necessário o uso das mãos traz vantagens no que se refere a uma interação homem-máquina mais natural, e a liberação das mãos para execução de outras tarefas. O acesso ao computador sem o uso das mãos permite que um maior número de pessoas, mesmo aquelas com limitações em membros superiores, possa realizar as atividades de forma independente e autônoma.

\section{Conclusão}

Nas atividades de precisão com o Discrete Aiming Task, a tela sensível ao toque foi o recurso que obteve maior agilidade para completar a tarefa. Entretanto, durante a atividade com o Tracking Task v.2.0, que também avalia precisão, o recurso que obteve melhor desempenho foi o mouse ao apresentar maior porcentagem de tempo com o cursor dentro o círculo. O mouse foi o recurso com menor tempo médio de resposta e o Camera Mouse o maior tempo médio de resposta. Constatou-se que em todas as atividades realizadas, o Camera Mouse foi o recurso que demonstrou pior desempenho quanto ao tempo de reação e precisão durante as tarefas propostas. No entanto, os resultados obtidos indicam que o uso de dispositivo de entrada com controle do acionamento por alguma estrutura do corpo é viável, podendo ser mais eficaz com o treino. Para isso esse tipo de dispositivo poderia ser disponibilizado rotineiramente em laboratório de informática no ambiente escolar.

\section{Referências}

ALMANJI, A.; DAVIES, C.; AMOR, R. Examining Dynamic Control-Display Gain Adjustments to Assist MouseBased Pointing for Youths with Cerebral Palsy. International J ournal of Virtual Worlds and Human Computer Interaction, v. 3, n. 1, 2015. Disponível em: <http://vwhci.avestia.com/2015/001.html>. Acesso em: 05 jun. 2016.

ASSOCIAÇÃO BRASILEIRA DE NORMAS TÉCNICAS. NBR 9050: acessibilidade a edificações, mobiliário, espaços e equipamentos urbanos. Rio de Janeiro, 2015. 
ARAI, K.; MARDIYANTO, R. Camera as Mouse and Keyboard for Handicap Person with Troubleshooting Ability, Recovery, and Complete Mouse Events. International J ournal of Human Computer Interaction (IJ HCl), v.1, n.3, p. 47, 2010.

BETKE, M.; GIPS, J.; FLEMING, P. The Camera Mouse: visual tracking of body features to provide computer access for people with severe disabilities. IEEE Transactions on Neural Systems and Rehabilitation Engineering, v.10, n.1, 2002.

BRASIL. Lei Brasileira de Inclusão No 13.146, de 6 de julho de 2015. Institui a Lei Brasileira de Inclusão da Pessoa com Deficiência (Estatuto da Pessoa com Deficiência). Brasil, 2015.

CAMERA MOUSE. About Camera Mouse, 2015. Disponível em:<http://www.cameramouse.org/about.html>. Acesso em: 18 abr. 2016.

CHOU, C.-J.; HUANG, W.-N.; TSAI, M.-H. Browsing without Clicking - Two Proposals of Web Interface Design for Universal Accessibility. Procedia Manufacturing, v. 3, n. Ahfe, p. 6290-6297, 2015. Elsevier B.V. Disponível em: <http://www.sciencedirect.com/science/article/pii/S2351978915008100>. Acesso em: 02 abr. 2016.

CONFORTO, D.; SANTAROSA, L. M. C. Acessibilidade à Web: Internet para Todos. Revista de Informática na Educação: Teoria, Prática - PGIE/UFRGS, v.5, n. 2, p.87-102, 2002

CONNELL, B. R.; J ONES, M.; MACE, R.; MUELLER, J.; MULLICK, A.; OSTROFF, E.; ET AL. (1997). Principles of Universal Design. Disponível in: <https://www.ncsu.edu/ncsu/design/cud/about_ud/udprinciplestext.htm>. Acesso em: 20 jun. 2016.

JAROSZ, E. Determination of the workspace of wheelchair users. International J ournal of Industrial Ergonomics, v.17, p. 123-33, 1996.

PARK, D.; LEE, J.; KIM, S. Investigating the affective quality of interactivity by motion feedback in mobile touchscreen user interfaces. International J ournal Human-Computer Studies, n.69, p.839-853. Elsevier: 2011.

PORTNEY, L.G.; WATKINS, M.P. Foundations of Clinical Research: Applications to Pratice. 3rd edition. New Jersey: Prentice Hall, 2008.

RAYA, R.; ROA, J. O.; ROCON, E; CERES, R.; PONS, J.L. Wearable inertial mouse for children with physical and cognitive impairments. Sensors and Actuators, v. 162, p. 248-259, 2010.

NOWAK, E. The role of anthropometry in desing of work and life environments of disabled population. International J ournal of Industrial Ergonomics, v.17, p. 113-21, 1996.

VERTEGAAL, R. A Fitts' Law comparison of eye tracking and manual inputin the selection of visual targets. ICMI'08, p. 241-248, 2008.

WILKIE, D. M.; MAK, T.; SAKSIDA, L. M. Pigeons' landmark use as revealed in a 'feature-positive', digitized landscape, touchscreen paradigm. International J ournal of Behavioural Processes, n.32, p. 87-100, 1994.

Recebido em agosto de 2016

Aprovado para publicação em agosto de 2017

\section{Gláucia Sanches Guimarães}

Bolsista do Programa de Aprimoramento Profissional em Fisioterapia - Universidade Estadual Paulista - UNESP - Campus de Marília, SP, Brasil, galsg@hotmail.com

\section{Marcelo Grandini Spiller}

Doutorando do Programa de Pós-graduação em Educação - Universidade Estadual Paulista - UNESP Campus de Marília, SP, Brasil, m_grandini@yahoo.com.br

\section{Lígia Maria Presumido Braccialli}

Docente do Departamento de Educação Especial - Universidade Estadual Paulista - UNESP - Campus de Marília, SP, Brasil, bracci@marilia.unesp.br 


\title{
Nova Interface de Usuário Baseada no Conceito de uma Única Cela Braille
}

\author{
New User Interface Based on a Single Braille Cell \\ Approach
}

\author{
Marcelo Bernart Schmidt \\ Universidade do Vale de Itajaí \\ Luiz Gustavo Metzger \\ Universidade do Vale de Itajaí \\ Robert Mortimer \\ Associação Brasileira de Assistência ao Deficiente Visual \\ Alejandro Rafael Garcia Ramirez \\ Universidade do Vale de Itajaí
}

\begin{abstract}
Access to information is usually a challenge for visually impaired people. Auditory and the Braille systems become an ally for them, allowing access to knowledge, identification of products and places, among others uses. However, technologies for printing and reading in Braille are expensive, constraining its dissemination and use. This work presents a Braille reading system, based on a single cell' approach, designed for computer interactions. The single Braille cell concept is closely related to fingertip's physiology and it is based on a static reading. The designed computer interface took into account accessibility standards preconized by IBM. The system features voice recognition, auditory feedback and provides two operation modules: training and reading. The system was evaluated by three blind participants with different kinds of Braille' knowledge and different computer's skills. The results promises an efficient way to learn Braille using the single Braille cell concept.
\end{abstract}

Keywords: Accessibility. Assistive technology. Braille. Human-Computer interface. Visually impaired people.

Palavras-chave: Acessibilidade, Tecnologia Assisitiva. Braille. Interface Homem-Computador. Pessoa deficiente visual. 


\section{I ntroduction}

Braille method, also known as the white writing, had become the reading and writing alphabet most used by blind people worldwide (COOK; POLGAR, 2015). However, nowadays, the cost and dimensions of printing and reading Braille technologies are expensive. This is the case of new Braille displays and the Braille books, for instance.

On the other hand, there are technologies that allow access to information other than the Braille. Those technologies generally employ auditory (i.e. screen readers) and/or tactile feedback as a substitute for vision. However, when information is based on a spatial dimension, expressions or illustrations, feedback is often lost, or would be tedious to articulate it verbally (XU et. al, 2011). Braille emerges as a solution, allowing interaction between the reader and texts in a unique way, because of the sense of the touch (ROSEN, 1997).

It is fact that people with visual impairments, who have not learned Braille before, have more difficulty writing and communicating their thoughts. In addition, students that were alphabetized in Braille write texts better, while those who only use a keyboard and auditory systems write texts and stories in a very disorganized and disarticulated way (BARANAUSKAS; MANTOAN, 2001).

The work in (MUNRO; MUNRO, 2013) explores the backgrounds and training of teachers who work with students with visual impairments. Authors showed the necessity of developing print literacy skills in Braille, including decoding, morphology, fluency, vocabulary and comprehension. Those issues could led to improve literacy outcomes for students who are visually impaired and for them who use Braille as their primary learning tool.

Numerous commercial solutions enable reading and writing Braille, like the Perkins Machine and the Braille tactile displays, for example (COOK; POLGAR, 2015). Tactile displays have important applications in areas such as virtual reality, teleoperation, telepresence, vision-tactile substitution, fundamental haptic science research, video games and online shopping (XU et. al, 2011).

From a hardware point of view, Braille devices are electromechanical devices, having between eight and eighty of piezoelectric cells (HERSH; JOHNSON, 2008). This sort of technology is expensive and the number of cells tends to increase as the more information contained on the computer's screen will be represented.

Another important aspect is associated to the reliability of the hardware mechanisms. A simple malfunctioning of a single point of one cell, caused by an electrical or mechanical failure, for instance, would essentially turn the Braille display useless, since symbols recognition will be impossible with a faulty point.

From a software point of view, available solutions do not provide totally accessible interfaces to the users, i.e. the visually impaired individual does not interact freely with texts, since they are only sequentially reproduced in Braille (or by the auditory feedback). It is easy to imagine how difficult reading an entire book would be.

In this work, a single Braille cell was designed to contribute in the learning processes of the Braille alphabet, looking for a simpler hardware solution. In addition, a human-Braille-computer 
interface was designed to interact with texts and alphanumeric characters, based on accessibility standards. The results promised an accessible solution for visually impaired individuals. This work in started in 2006 thanks to the project entitled "Development of a Braille printing system", supported by FAPESC. Then, a new project was developed thanks to the "University Merit Award", in 2007, also from FAPESC. After a long period of study and maturation, a master's degree thesis was carried out, leading to the current proposal.

\section{Bibliographical review}

Braille cell is composed by a single rectangle with 6 or 8 points, Figure 1. Cell points are numbered as follows: left column 1, 2 and 3 -from top to the bottom, and right column 4, 5 and 6 , from top to the bottom.

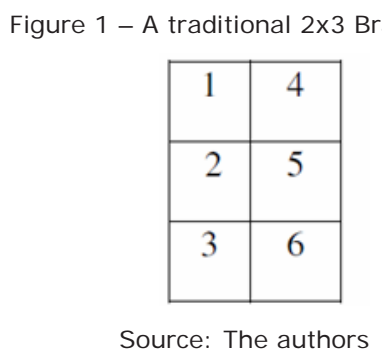

These dots represent embossed characters, which can be read by using the sense of touch. Each dot combination represents certain symbol or letter (COOK; POLGAR, 2015).

Braille displays usually have something between eight and eighty cells, allowing the user to read the alphabet by using the fingers. In particular, it is necessary to slide the fingers to recognize the Braille characters. This is known as active reading (LINDEN, 2016). Generally, a primary finger has to be moved through the cells, in a linear way, differently to the reading using the eyes. Looking to a forty cells display, for instance, while the user reads a character, the other thirty-nine are idle. Which means that they are not being read with the other fingers.

On the other hand, Braille recognition is intrinsically related to the sensory nerves perception. When Louis Braille designed his writing system, he had no prior knowledge of the properties of mechanosensors in the fingertip, like the Merkel endings. He just used his own tactile experience to careful set the spacing of the dots (LINDEN, 2016). Years after, Kenneth Johnson and his colleagues at the Johns Hopkins University School of Medicine, demonstrated that Merkel fibers faithfully represented the Braille dots' pattern. In (GIBSON, 1962) the impression made on the skin involves the excitation of nerve endings, known as receptors, resulting in a sensation, which is known as passive touch.

Nowadays researchers had begun to develop displays composed by a single Braille cell, based on how Braille is read, which means, one character at a time. Within this new approach, it would be enough to lay the finger on the cell, or the cell upon the finger, for immediate recognition.

From the software point of view, existing solutions for the single cell approach do not provide fully accessible interfaces. For example, users do not interact with texts freely, so they 
are reproduced sequentially. This fact motivated this question: Is it possible to improve this interaction?

This research aims to investigate the design of a single Braille cell for reading. In addition, a software based on accessibility recommendations, analyzes the impact of this approach on visually impaired users.

\subsection{Related works}

This section presents a brief review related to Braille cells designs.

In 2005, Jun Su Lee and Stepan Lucyszyn presented the design of a new refreshable Braille cell (LEE; LUCYSZYN, 2005). A micromachined refreshable Braille cell, actuated by using hydraulic pressures from the volumetric expansion of a paraffin wax, was successfully done and tested.

In ( $\mathrm{CHO}$ et. al, 2006) authors propose the use of piezoelectric technology in portable devices. They designed a Braille cell, consisting of six piezoelectric linear motors. The details of the Braille cell were discussed and evaluated.

In 2009, Supriya and Senthilkumar designed a device that reads computer files and translates text characters to a six Braille cells. Each Braille cell was actuated by 36 Volts solenoids, with fast magnetization and demagnetization properties. Visual Basic was used as a front-end tool with a variety of specialized user interaction features such as, cursor location, routing buttons, file selection and increment and decrement of reading speed. The system complements tactile information with sounds, in order to improve the learning of less experienced Braille users (SUPRIYA; SENTHILKUMAR, 2009).

In (RANTALA et. al, 2010) a Braille prototype using piezoelectric active principles to create a tactile feedback under the cell screen, was developed. An evaluation of three input gestures (moving, squeezing and stroking) was conducted, identifying preferred methods for creating haptic messages using a hand-held device. Two output methods, using one or four haptic actuators, were also investigated.

In (MATSUDA; ISOMURA, 2011), authors presents a system designed for teaching Braille to deaf blind users. The system converted the speech of a non-disabled person to Braille, improving the learning process.

In (KENJIRO et. al, 2011) authors present a sheet-type Braille display by integrating organic thin-film transistors (TFT) and soft polymer actuators using low voltage for driving actuators.

A refreshable Braille cell as a tactile display prototype, based on a $2 \times 3$ pneumatic microbubble actuator array and an array of commercial valves, has been developed in (WU et. al, 2012). The device has also been designed to meet the criteria of lightweight and compactness to facilitate portable operation.

A new design and fabrication of a tactile display array was presented in (LEE et. al, 2014). It was based on dielectric elastomer actuators. The display stimulates the Merkel cells as well as the Meissner corpuscles.

Finally, in (ROS, 2014) it was discussed the design, implementation and test of a new dynamic tactile display for reconfigurable Braille. The display features a high-resolution tactile 
stimulation area allowing for customization of the Braille layout, as well as the timing of the braille rendering, offering a flexible solution to match user's skills.

\section{Materials and Methods}

In this work, a single Braille cell based on six Pulse Width Modulation (PWM) servos, was designed. The cell dimension is bigger than common Braille cells, in order to properly recognize Braille characters by using the passive touch.

In the standalone Braille cell concept, differently of Braille displays, the cell should be large enough. Therefore, that it would be far enough laying the finger on the cell, or the cell upon finger, for immediate recognition. Furthermore, each point would be clearly remarkable from the others because each one touches in the same part of the finger. In this new Braille display concept, the finger would remain static in the cell, and the dots are triggered depending on the character that will be displayed.

Figure 2 shows the Braille cell. Six steel's needles was attached to the servos axes. The spacing between columns is $8 \mathrm{~mm}$, and between each row is $3 \mathrm{~mm}$. Each needle has a diameter of $1.0 \mathrm{~mm}$. The pins displacement is around $0.8 \mathrm{~mm}$ and each one vibrates at $50 \mathrm{~Hz}$.

Figure 2. Braille cell.

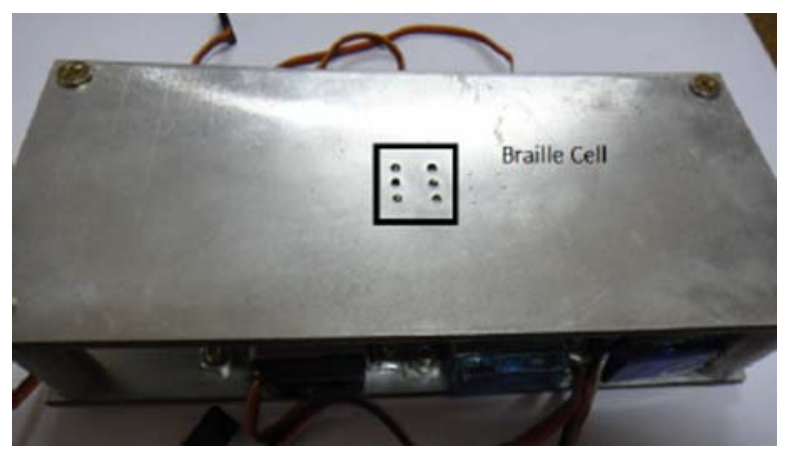

Source: The authors

An embedded system, based on the Arduino Uno board, was linked to the serial port of a computer. The microcontroller generates the appropriate PWM signal to actuate each servo after decoding the characters sent by the software. Figure 3 shows the picture of the system.

Figure 3. The elements of the system.

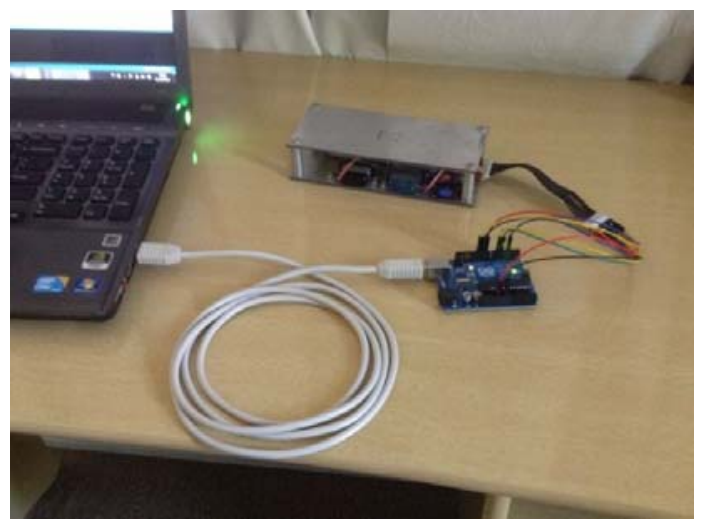

Source: The authors 
The software is featured in two modules. The first one is the training module and its goal is to familiarize the user with the system. The second one is the reading module, which allows reading entire text files stored in the computer, Figure 4.

Figure 4. Software interface.

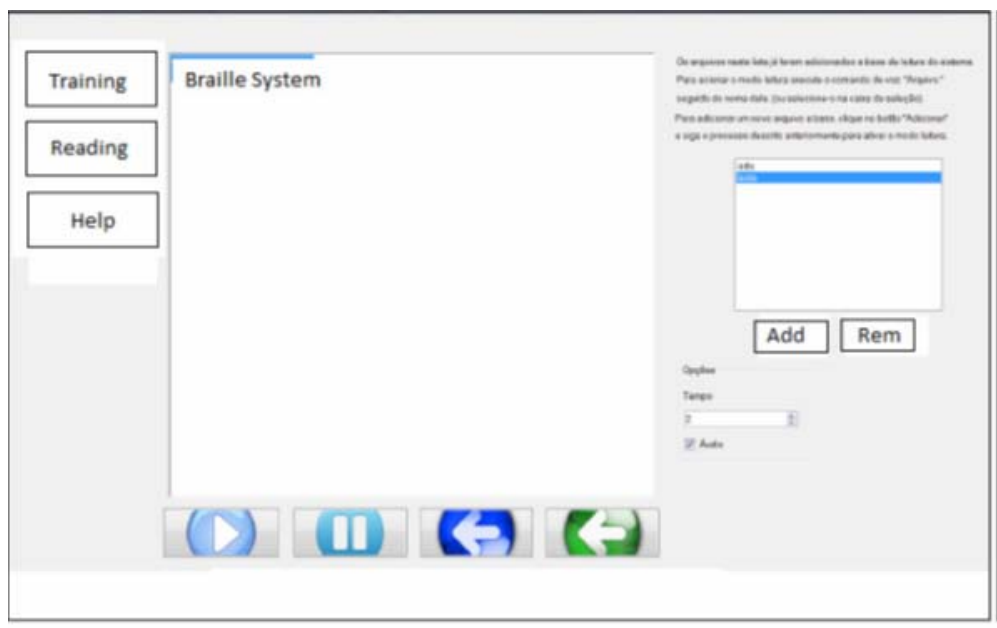

Source: The authors

The training module was divided into three operation modes: sequential, random and demand.

In the sequential mode, alphabet characters $(\mathrm{a}-\mathrm{z})$ and some special symbols, i.e. : ,.!?", are sent to the Braille cell in a conventional order by using the time rate configured for the user, Figure 5. For example, characters can be sent to the cell every 2 seconds. This is the ideal mode for those who are not yet familiarized with Braille.

Figure 5. Training module.

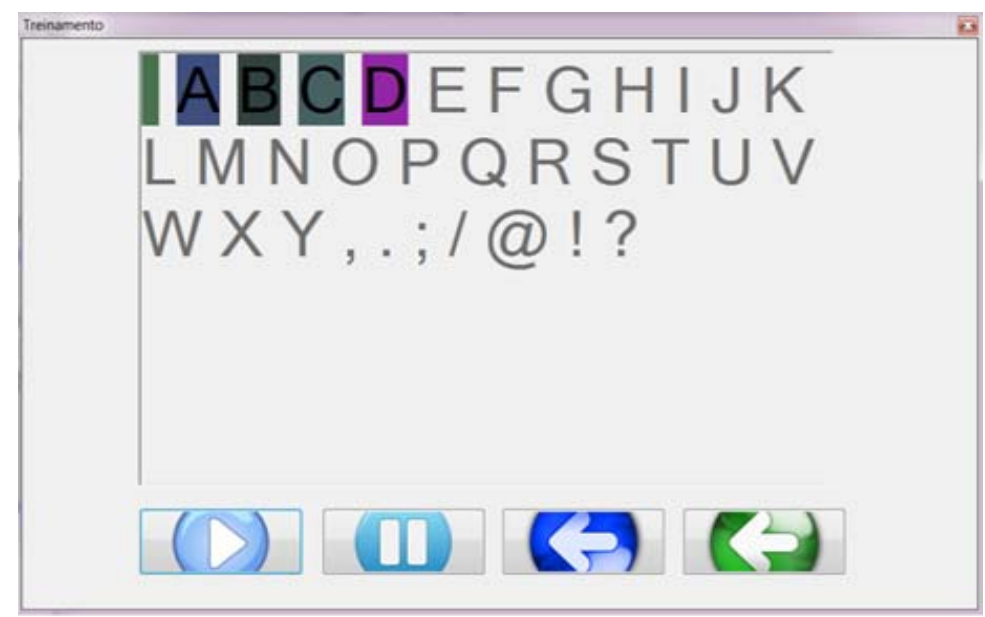

Source: The authors 
In the random mode, alphabet characters $(\mathrm{a}-\mathrm{z})$ and special symbols $(, .$. ? ") are sent to the Braille cell like in the sequential mode, but, randomly.

In those two operation modes, the user can interact with the software by using speech commands, like: start, stop, restart or going back to the previous character.

On the other hand, the demand mode allows the user recognizing a Braille character by pressing any key of the computer keyboard. This mode is particularly important to users less familiarized with the computer resources and unfamiliar with the keyboard layout.

The reading module allows the user to load files from the computer memory and start to read them. The user can start reading from the last character read, if the file has been opened and paused, for instance.

The software uses voice recognition engine avoiding the user having to remove the finger of the Braille cell. In addition, voice synthesis is used to provide auditory feedback to the user about the current state of the application, facilitating the interaction.

\section{Methodology}

The study was performed with three blind volunteers, involving the following activities:

a) Explanation of the Braille cell characteristics and its relationship with the computer, as well as the goal of the system designed.

b) Explanation on how to get access to the system resources, like navigating through reading and training modules, verifying the user interaction using voice recognition and voice synthesizer and computer keyboard access to perform the modes described previously.

c) Perform the sequential mode, adjusting the speed rate, stopping, returning to the previous character and restarting the sequence.

d) Perform the random mode, making the same operations like in the sequential mode.

e) Perform the demand mode. In the demand mode the user presses any key and guess the character represented in the Braille cell, speaking aloud what character it believes it is. The hit rate and the required time to identify each character were computed for the subsequent analysis.

f) Perform the reading module using the same procedures cited in item c, but alternating between different files.

\subsection{Participants}

Users manipulate the system by alternating between voice recognition and keyboard commands. They find out the character printed on the Braille cell.

Participant $A$ is an engineer. He was 73 years old. He was born with a rare case of hyperopia. Over the years, the hyperopia has been getting worse and, when he reached the age of 40 , remained only with $5 \%$ of vision. This user is very smart and has a good knowledge of Braille. He is a university professor and had former experience as a programmer. He used the Dosvox system, later replacing it by Jaws.

Participant B is 11 years old and is blind. He partially knows the Braille system and up to date, he has not regular contact with computers and do not have a good knowledge of the standard QWERTY, having minimal affinity with those resources. Therefore, he showed some difficulties when using the keyboard.

Participant $\mathrm{C}$ is 28 years old and born blind. He is one of the greatest experts of Braille system in the state of Santa Catarina. He is an employee of the Santa Catarina Foundation for Special Education (FCEE). He acts in the pedagogy area, giving support to users who are also 
educators. He is a computer expert, knows the QWERTY keyboard layout and uses the Jaws system. He is independent and lives alone. His opinion was of a great value to this study.

The participants' interaction with the system was oriented and observed through the tests performed. When the tests were concluded, a questionnaire was applied in order to register the benefits and the negative points of the system.

\subsection{Experiments}

This section discusses the experiments performed and the main results obtained. In this work, we were concerned about the accuracy and completeness of the goals, as in (OSGOOD; SUCI; TANNENBAUM, 1957) under the scope of the usability ISO standard 9241:11. On the other hand, we are also concerned about the satisfaction using the system.

The training module was selected as the starting point, knowing the system. Each user could select the training mode via keyboard shortcut ( $T$ key). In addition, each user could use the voice command "Training". It was verified the need to create new voice commands, such as: repeat phrase, repeat word, back phrase or next line.

Figure 6 shows the results of the demand mode. It was possible to store some quantitative information, such as:

a) Detection Time: The detection time was measured, in seconds, from the moment the key was pressed until the user recognized it.

b) Characters recognition: In this test, each character was sent twice, by using a random sequence. Time, characters recognition and errors were computed for each user.

Figure 6. Results of the Demand mode.

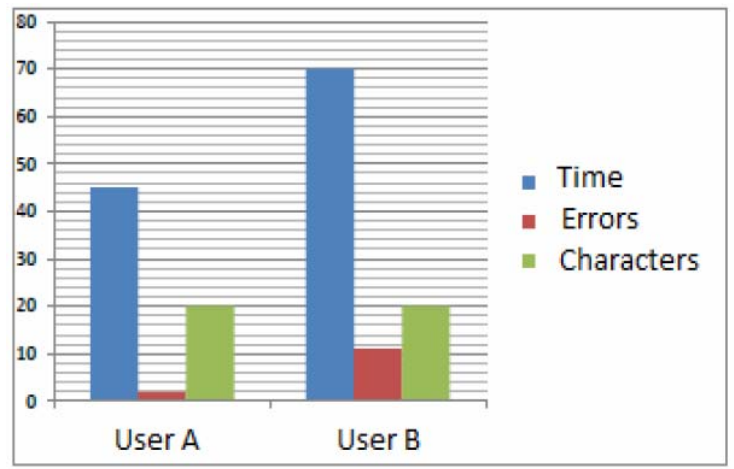

Source: The authors

By analyzing Figure 6, user B spent more time (70 seconds) to recognize the same quantity of characters (20) as User A. User B also made more mistakes (10). On the other hand, user A took 45 seconds to perform this activity and made only two errors.

In addition, the missing characters rate of user $A$ is only $10 \%$. This means that the character recognition rate is $90 \%$. According to (LEE et. al, 2004) a suitable average recognition rate could reaches up to $60 \%$ or higher.

On the other hand, user A read 2.25 characters per second, which is a slow rate. According to (MUNRO; MUNRO, 2013), previous work with fluent and experienced Braille readers suggests that readers prefer to move their reading fingers from, approximately, five Braille cells per 
second, up to eleven cells per second. It is important to remark that each Braille cell prints one character at a time.

By selecting the $L$ key, or by using the voice command "Reading" the user could select the reading module. This module makes use of a files repository.

\subsection{Evaluation}

The first step consisted in identifying the user characteristics. Important things, like which is the level of knowledge of Braille and the expertise on computer uses, was noticed. Such information allowed the system configuration with standard values. In this collaborative process, the system was improved by taking into account the users' opinions and the answers to the next questionnaire:

a) Is a sound feedback necessary after sending the characters?

b) Which are the commands you would like to add in order to enhance interaction with the Braille cell?

c) Which is the greatest difficulty when using the system?

d) Is necessary to add new modules/modes? If yes, which new resources would be interesting?

e) In your opinion, which are the system's advantages and disadvantages compared to traditional Braille reading?

All the process was monitored, registering eventually anomalies on the system or the benefices. It should be remarked that participant's skills were used to continuously adjust the defaults values of the system.

The analysis was started with the study of the hardware, where a problem related to the fixed distance between the columns, was detected. According to User C, standard Braille sheets have less separated cells, which difficult the identification of the character being printed. According to this user, each visually impaired individual must discover his own tactile field. Some more expertise people would feel the Braille points with the most external side of the finger, while others, possibly for having shorter fingers, would find it more difficult. With the current Braille columns' separation, User A was able to identify the Braille character without the necessity of moving the finger, while User $C$ needed to move the finger throw every dot identifying the pattern. So a mechanical analysis would be required, adjusting cell columns' width.

A point well accentuated by the three users was the need of some identification for the right finger position. According Users $A$ and $C$, the creation of some static mark identifying the boundary points of each column would be interesting. That way, fingers' initial position could be easily understood.

In relation to the software, its use, commands, system timing and modes, was evaluated as easy. However, according to the User C, existing modes have low relevance to more experienced users. The main point strengthening this statement is the fragility of the reading system based on a single cell. The need of reading the characters, one by one, to form a complete word, to make sense in the context of an entire phrase, is not very practical. 
On the other hand, according to the users, the training mode could be extremely useful for learning processes, as it reduces the monotony of current approaches. User C perceives their great passion for computers. According to him, children find the classical learning methods boring and less motivating. In addition, users positively evaluates the reading module.

Many challenges emerges, as for instance, gamifying. User $\mathrm{C}$ suggests developing a game to unravel the greater number of characters as fast as possible.

\section{Conclusions}

This article presents a hardware and software solution to assist the Braille reading process. In particular, a single Braille cell approach was adopted bringing advantages and disadvantages to the solution. The system featured accessibility based on recommended standards. It uses low cost technologies. The software features two modules and three different operation modes, which were developed to interact with the system, including speech recognizing and auditory feedback.

Between the positive features, were founded: the device's costs reduction, because of the use of the one single cell approach; the inexistence of the break line problems, which are typically found in the traditional systems; and the lesser effort when compared to the use of traditional Braille displays. On the other hand, the difficulty of reading large texts (partially resolved with auditory commands) and the impossibility of reading using both hands, which is a feature of more advanced users, were noticed.

The system evaluation was made by case studies involving three users with different knowledge of Braille and different computers' skills. The experiments were concerned with users' behavior and their evolution using the system. The software interface was considered friendly, even though in case of the less experienced users. In addition, it was observed that the success of the hardware approach was closely related to the success of the computer's interface.

The character recognition rate of one of the users was 90\%. According to (LEE et. al, 2004) a suitable average recognition rate could reaches up to $60 \%$ or higher, showing a good result. On the other hand, user A read 2.25 characters per second, which could be considered a slow rate, according to (MUNRO; MUNRO, 2013).

This is an applied research, which aims to promote an affordable solution for Braille reading.

\section{Acknowledgements}

Authors would like to thank to Fundação de Amparo à Pesquisa e Inovação no Estado de Santa Catarina (FAPESC), for the financial support. Authors would also thanks to the Santa Catarina Foundation for Special Education (FCEE), for the partnership.

\section{References}

COOK; A. M.; POLGAR. J. M. Assistive technologies: principles and practices. St. Louis: Mosby Elsevier, 2015. 472 p. 
XU, Cheng; ISRAR, A.; POUPYREV, I.; BAU, O.; HARRISON, C. Tactile Display for the Visually Impaired Using TeslaTouch. In: CHI 2011 Interactivity. Vancouver, BC. Canada. 2011.

ROSEN, S. Kinesiology and sensorimotor function. In: BLASCH, B. B.; WIENER, W. R.; WELSH, R. L. (Ed.). Foundations of orientation and mobility. $2^{\text {nd }}$ Ed. New York: AFB Press. 1997. P. 170- 199.

BARANAUSKAS, M. C.; MANTOAN, M. T. Acessibilidade em ambientes educacionais: para além das guidelines. Rev Online da Biblioteca Prof. Joel Martins, v. 2, n. 2, p. 13-23. 2001.

MUNRO, Michel P.; R. MUNRO, Heather. Infusion of Print Literacy Methodology into Braille Instruction for Students with Visual Impairments. Journal of Blindness Innovation and Research, v. 3, n. 2. 2013.

HERSH, Marion; JOHNSON, Michael A. Disability and Assistive Technology Systems. In: HERSH, Marion; JOHNSON, Michael A. (Ed.). Assistive Technology for Visually Impaired and Blind People. Springer. 2008. P 1- 50.

LINDEN, David J. Touch: the Science of hand, heart and mind. Penguin. 2016. 250 p.

GIBSON, J. J. Observations on active touch. Psychological Review, v. 69, n. 2, p. 477-491. 1962.

LEE, Jun Su; LUCYSZYN, Stepan. A Micromachined Refreshable Braille Cell. Journal of Microelectromechanical Systems, v. 14, n. 4, August. 2005.

CHO, H. C.; KIM, B. S.; PARK, J. J.; SONG. J. B. Development of a Braille Display using piezoelectric linear motors. International J oint Conference SICE-ICASE. 2006. P. 1917-1921.

SUPRIYA, S.; SENTHILKUMAR, A. Electronic Braille pad. International Conference on Control, Automation, Communication and Energy Conservation. 2009. P. 1-5.

RANTALA, J.; RAISAMO, R.; LYLYKANGAS, J. et al. The role of gesture types and spatial feedback in haptic communication. In: IEEE Transactions on Haptics, v. 4. n. 4, pp. 295-306. 2010.

MATSUDA, Y.; ISOMURA, T. I mprovement of Interfaces for Finger Braille Teaching System. In: J ournal of Computer and Information Technology, v.1, n. 2, pp.19-28, 2011.

KENJIRO F., SEKITANI, T.; ZSCHIESCHANG, U. et. all. A 4V Operation, Flexible Braille Display Using Organic Transistors, Carbon Nanotube Actuators, and Organic Static Random-Access Memory. In: Advances Functional Materials. v. 21, pp. 4019-4027. 2011.

WU, X.; KIM, S-H.; ZHU, H.; JI, C-H.; ALLEN, M. A. A Refreshable Braille Cell Based On Pneumatic Microbubble Actuators. In: J ournal of Microelectromechanical Systems, v. 21, n. 4, pp. 908 - 916. 2012.

LEE, H. S.; PHUNG, H.; LEE, D-H.; KIM, U. K. et. al. Design analysis and fabrication of arrayed tactile display based on dielectric elastomer actuator. In: Sensors and Actuators. A: Phys., v. 205, pp. 191-198. 2014.

ROS, Paolo Motto, DANTE, Vittorio, Mesin, Luca ; PETETTI, Erminio; GIUDICE, P. Del; PASERO, E. A new dynamic tactile display for reconfigurable Braille: implementation and tests. In: Frontiers in Neuroengineering, v. 7. n. 6. 2014.

OSGOOD, Charles Egerton, SUCI, George J.; TANNENBAUM, Percy H. The measurement of meaning. University of Illinois Press, 1957. 342 p.

LEE, Sangwon; JUNG, Kwangmok; KOO, Jachoon; LEE, Sungil; CHOI, Hoogon; JEON, Jaewook; NAM, Jaedo; CHOI, Hyoukryeol. Braille display device using soft actuator. In: Proc. SPIE 5385 Smart Structures and Materials 2004: Electroactive Polymer Actuators and Devices (EAPAD), v. 368. 2004.

ROSSETO, E. Recuperação Histórica das Políticas de Inclusão no Ensino Superior. In: SEMINÁRIO NACIONAL DE ESTUDOS E PESQUISAS HISTEDBR, 8, 2009, Campinas, SP. História, Sociedade e Educação no Brasil. Campinas, SP: UNICAMP, 2009. P. 1-16. 
Recebido em março de 2016

Aprovado para publicação em agosto de 2017

\section{Marcelo Bernart Schmidt}

Programa de Pós-Graduação em Computação Aplicada. Universidade do Vale de Itajaí - UNIVALI, Brasil, marcelo.bernart@gmail.com.

\section{Luiz Gustavo Metzger}

Ciências da Computação. Universidade do Vale de Itajaí - UNIVALI, Brasil, luizgustavo.Igm@gmail.com.

\section{Robert Mortimer}

Centro de Tecnologia Assistiva - LARATEC. Associação Brasileira de Assistência ao Deficiente Visual LARAMARA, Brasil, rmortimer@laramara.org.br.

\section{Alejandro Rafael Garcia Ramirez}

Programa de Pós-Graduação em Computação Aplicada. Universidade do Vale de Itajaí - UNIVALI, Brasil, ramirez@univali.br 


\title{
Integração de Objetos de Aprendizagem em Matemática Utilizando SCORM em Ambiente Virtual de Aprendizagem
}

\author{
Mathematics Learning Objects I ntegration Using \\ SCORM in Learning Virtual Environment
}

\author{
Paulo J osé Evaristo da Silva \\ Instituto Federal de Educação, Ciência e Tecnologia de São Paulo \\ Thais de Oliveira \\ Instituto Federal de Educação, Ciência e Tecnologia de São Paulo \\ Rodrigo Palucci Pantoni \\ Instituto Federal de Educação, Ciência e Tecnologia de São Paulo
}

\begin{abstract}
Resumo: O objetivo deste trabalho é apresentar uma metodologia para integração do aplicativo GeoGebra no Ambiente Virtual de Aprendizagem (AVA) utilizando a tecnologia SCORM. Mais especificamente, visa a integração de Objetos de Aprendizagem (OA) ao AVA voltado para o ensino de Matemática. Para garantir os requisitos funcionais dos objetos, a metodologia utilizada contou com o empacotamento e integração dos OAs no AVA Moodle de acordo com as normas e especificação do SCORM, através de uma configuração de software. Como resultado, o trabalho apresenta a ampliação de possibilidades de interação do software nos processos educacionais de Matemática. Contudo, conclui-se que a interoperabilidade dos componentes ainda é um desafio na prática, devida as várias versões de sistemas operacionais, navegadores e componentes.
\end{abstract}

Palavras-chave: Learning Object. LMS. SCORM. GeoGebra.

\begin{abstract}
The objective of this research is to present a methodology for integration GeoGebra application in the Learning Management System (LMS) using SCORM technology. More specifically, it aims to integrate learning objects (LO) to LMS focused the teaching of Mathematics. To ensure the functional requirements of the objects, the methodology used included the packaging and integration of LOs in LMS Moodle according to the rules and SCORM specification through a software configuration. As a result, the work presents the expansion of software possibilities of interaction in the educational processes of mathematics. However, concluded that the interoperability of components is still a challenge in practice due to various versions of operating systems, browsers and components.
\end{abstract}

Keywords: Learning Object. LMS. SCORM. GeoGebra. SILVA, Paulo José Evaristo da; OLIVEIRA, Thais de; PANTONI, Rodrigo Palucci. Integração de Objetos de Aprendizagem em Alegre, v. 20, n. 2, p. 169-187, mai./ago. 2017. 


\section{I ntrodução}

No âmbito do ensino da Matemática, Belfort (2002 apud CYRINO e BALDINI, 2012) ${ }^{1}$, destaca queas Tecnologias da Informação e Comunicação (TICs) podem favorecer a compreensão de conceitos, o desempenho na resolução de problemas e no raciocínio lógicodedutivo do estudante. Nesta perspectiva, o GeoGebra apresenta-se como um software adequado para uso em todos os níveis de ensino, porque combina a construção, experimentos e demonstração de conceitos aprendidos na matemática. Além destas possibilidades apresentadas, o GeoGebra permite, inclusive, que se exporte e disponibilize os aplicativos para serem usados na internet (GEOGEBRA, 2013a).

Estas características do GeoGebra o colocam como recurso potencial para uso em diferentes situações de ensino aprendizagem na Matemática, especialmente, no caso da Educação a Distância (EaD) como destacam Oliveira, Guimarães e Andrade (2012). A EaD é uma modalidade em que a mediação didático-pedagógica nos processos educacionais ocorre com a utilização de meios e TICs, com os estudantes e professores desenvolvendo atividades educativas em lugares ou tempos diversos (BRASIL, 2005).

Ainda que o ensino da Matemática na EaD seja um promissor espaço para a utilização de recursos como o GeoGebra, é possível que sua integração com o ambiente virtual seja realizada de forma padronizada, inclusive para utilização de outros aplicativos com o mesmo propósito, independente da área aplicada. Para isso é necessário que se considere alguns requisitos técnicos, bem como, a necessidade de algumas adequações técnicas, considerando assim, as características dos Objetos de Aprendizagem (OAs).

Os OAs contam com o Modelo de Referência para Objetos de Conteúdo Compartilhável, do inglês Sharable Content Object Reference Model (SCORM). Este modelo é capaz de trazer resultados em termos de reusabilidade, acessibilidade e interoperabilidade (ADL, 2009), permitindo que o ambiente possa utilizar objetos de aprendizagem, independentemente da plataforma de hardware e software. O SCORM, conta com especificações e normas, que permitem a reutilização de conteúdos de aprendizagem baseados na internet de forma padrão (ADL, 2009).

Neste contexto, o trabalho apresenta a articulação teórico-prática dos estudos de Oliveira (2010) e de Silva (2013), sendo o primeiro uma dissertação de mestrado sobre a Trigonometria e a mudança na prática docente mediante novos conhecimentos e o segundo, um estudo com a integração dos aplicativos GeoGebra e Moodle apoiados pelo SCORM.

Mais especificamente, o objetivo deste trabalho é apresentar uma metodologia para integração do aplicativo GeoGebra num Ambiente Virtual de Aprendizagem (AVA) utilizando o SCORM. As possibilidades de integração e utilização do GeoGebra com o padrão SCORM visam fomentar a construção de OAs que possam ser reutilizados em diversas plataformas com suporte ao SCORM.

Para apresentar o estudo, este artigo se organiza a partir de quatro seções, sendo que na primeira é detalhado e articulado o referencial teórico que embasou o estudo, inclusive, contribuições teóricas de trabalhos apresentados na temática. $\mathrm{Na}$ segunda seção são apresentados os aspectos metodológicos desenvolvidos no processo de integração do GeoGebra com o SCORM que vão refletir na terceira seção, onde são apresentados os resultados e propostas de utilização da integração contexto do ensino da Matemática, com base nos fundamentos teóricos presentes no estudo. Na quarta e última seção são apresentadas as conclusões (considerações) sobre as diferentes possibilidades de uso da integração proposta, bem como aspectos relevantes que permitam a ampliação do estudo e trabalhos futuros.

\footnotetext{
${ }^{1}$ BELFORT, E. Utilizando o computador na capacitação de professores. In: CARVALHO, L. M.; GUIMARÃES, L.C. (Org.).
} História e tecnologia no ensino da matemática. Rio de J aneiro: IME-UERJ, 2002, cap. 3, p. 39-50. 


\section{Referencial Teórico}

Nesta seção são descritos os conceitos e concepções advindos de outros trabalhos e estudos sobre os temas que envolvem o presente trabalho, como as definições e concepções sobre objetos de aprendizagem, uso do GeoGebra no ensino da matemática e integração de tecnologias.

A construção de OA possui características para garantir a acessibilidade, reusabilidade e interoperabilidade. Tarouco, Fabre e Tamusianas (2003) apresentam resultados alcançados numa fase preliminar de criação de um repositório de $\mathrm{OA}$, a estrutura dos metadados ${ }^{2}$ na categorização e o ambiente do sistema de cadastramento dos objetos educacionais. Essa pesquisa assemelha-se em termos de necessidade de categorizar os OA por meio de metadados e a possibilidade de disponibilizá-los para reutilização em outros contextos ou pessoas.

Para a construção de OA podem ser usadas algumas ferramentas de autoria, mas quase sempre exigem conhecimentos avançados em informática. Em função disso, foi proposto a modelagem e desenvolvimento de uma ferramenta, que possa facilitar a construção de OA para usuários não "experts" em informática, como pode ocorrer entre os profissionais da saúde e do ensino (NIENOW; BEZ, 2009). São apresentadas ferramentas de autoria que suportam a criação de OA, inclusive para SCORM, mas salienta a dificuldade encontrada por profissionais com pouca experiência em informática para construção desses objetos.

A pesquisa de Dutra, Tarouco e Passerino (2010) buscou identificar critérios a serem considerados para o encapsulamento e a utilização de OA SCORM em AVA, com o intuito de apoiar o processo de Avaliação Formativa. O trabalho aborda o registro da interação do aluno com o OA SCORM por meio do livro de Ambiente de Execução (RTE), que é usado nessa pesquisa para acompanhar o acesso dos alunos aos conteúdos de Trigonometria. Essa pesquisa serve de apoio para construção dos OA por suas recomendações no encapsulamento dos objetos.

Sampaio e Almeida (2010) mostram a influência do uso das TICs na aprendizagem por meio do uso de OA na área da Matemática. A pesquisa utiliza dois grupos de crianças, sendo que doze crianças trabalharam em dupla e treze individualmente. Sabendo da contribuição das TICs na educação, a pesquisa mostrou o aproveitamento dos alunos quando interagiram individualmente e em duplas nos computadores, mesmo o SCORM não permitindo a interação em grupos online, mostrou-se possível essa interação para uma prática presencial. Os resultados revelaram uma nítida diferença entre os dois grupos investigados, apontando o trabalho em dupla como uma alternativa eficiente para aprendizagem em busca dos objetivos propostos.

González e Ruggiero (2009), apresentam uma pesquisa ampliando a utilização dos OA em SCORM para permitir a aprendizagem colaborativa, considerando uma definição mais ampla de $\mathrm{OA}$, válida para o modelo instrucional a distância, orientado à aprendizagem em grupo. Porém, como mostra a pesquisa o modelo SCORM não oferece soluções para atividades em grupo. Uma solução para essa restrição é oferecida no Modelo Conceitual para Aprendizagem Colaborativa Baseada no Método de Projeto construído pelos pesquisadores.

\subsection{Objetos de Aprendizagem: definições}

Objetos de Aprendizagem (OA) são definidos por Tarouco, Fabre e Tamusianas (2003) como qualquer recurso suplementar ao processo de aprendizagem e que possa ser reutilizado no apoio à aprendizagem. O termo Learning Object (LO), objeto educacional sinônimo de OA, normalmente é aplicado para materiais construídos em pequenos conjuntos com intenção de ampliar as situações de aprendizagem onde o recurso pode ser utilizado. 
Baseado neste conceito, esta pesquisa trata de dois conjuntos de OAs: os aplicativos do GeoGebra e os conteúdos SCORM criados para o AVA Moodle.

No documento IEEE (2013) Learning Object Metadata Standard é definido que um objeto de aprendizagem pode ser utilizado para aprendizagem, educação ou treinamento. Neste contexto, a ideia básica defendida é que os OA são elementos mediadores do processo de aprendizagem.

Wiley (2002) apresenta um OA como qualquer recurso digital que pode ser reutilizado para apoiar a aprendizagem. Esta definição inclui qualquer recurso independente de seu tamanho. Recursos menores podem ser dados, textos, imagens, trechos de áudio, vídeos, animações e pequenas aplicações. Exemplos maiores de recursos reutilizáveis incluem páginas da internet combinando texto, imagens e outras mídias ou aplicações que ofereçam experiências completas, como um evento instrucional completo.

Polsani (2003) descreve o amplo entendimento entre os membros das comunidades de OA sobre os requisitos funcionais dos objetos:

- Acessibilidade: o OA deve ser anotado com metadados2, permitindo o armazenamento e a referência em bases de dados;

- Reutilização: o OA deve funcionar em diferentes contextos de ensino;

- Interoperabilidade: o OA deve ser independente dos meios de comunicação de entrega e dos sistemas de gestão do conhecimento.

Esses requisitos funcionais dos OAs assemelham-se aos benefícios derivados de um objeto em programação orientada a objetos (POLSANI, 2003). No paradigma da orientação a objetos, onde o mundo real é organizado como um conjunto de objetos compostos de dados e procedimentos - os dados representam o estado do objeto e os procedimentos conhecidos como métodos, manipulam os dados representando o comportamento do objeto (BUDD, 1991 apud GONZÁLEZ; RUGGIERO, 2009) ${ }^{3}$.

Partindo das diferentes concepções e definições apresentadas, neste trabalho, objetos são definidos pelas especificações SCORM segundo a equação I proposta por González e Ruggiero (2009).

$$
\text { OBJETO = DADOS }(\text { Estado })+\text { MÉTODO }(\text { Comportamento })
$$

\subsection{EaD e SCORM: os diferentes ambientes e as implicações técnicas}

O uso de recursos das TICS na educação por meio do computador pode ser chamado de elearning, uma forma de Educação a Distância (EaD), que é diferenciada em aprendizado via internet, do inglês Web Based Training, (WBT) e aprendizado baseado no computador sem internet, do inglês Computer Based Training, (CBT) (FRANCO; BRAGA; RODRIGUES, 2011).

O WBT é cada vez mais utilizado com o crescimento da internet, que possibilita aos alunos e professores flexibilidade nos horários de acordo com suas necessidades, sem perder a interação.

Para disponibilizar aos alunos um curso em e-learning via internet com OAs, faz-se necessário a utilização de um AVA, que são aplicativos computacionais que possibilitam a administração do oferecimento de um curso, o desenvolvimento do conteúdo de aprendizagem e o acompanhamento de cada aluno nas atividades propostas (FRANCO; BRAGA; RODRIGUES, 2011).

Esses aplicativos funcionam em um servidor de internet e são acessados por um navegador (browser). A equipe envolvida no projeto e os alunos podem acessar o aplicativo através de um computador com conexão à internet.

\footnotetext{
${ }^{2}$ Metadados são as informações utilizadas para descreverem os dados do OA.

${ }^{3}$ BUDD, T. An Introduction to Object-Oriented Programming. Published by Addison-Wesley. Pearson, 1991.
} 
Os AVAs podem possuir níveis de acesso com funções específicas de visitante, aluno, tutor, professor e administrador. Uma das vantagens é que apenas os alunos do curso têm acesso ao ambiente.

Existem várias ferramentas disponíveis em um AVA, que permitem compartilhar materiais, manter discussões, realizar tarefas, testes e avaliações registrando notas dos participantes. Algumas dessas ferramentas possibilitam inclusão de textos, imagens, sons, vídeos entre outros materiais de estudos. Os alunos também podem ser agrupados para realização de atividades. Testes e avaliações podem ser utilizados, questões de múltipla escolha que permitem a correção instantânea, garantindo aos alunos um retorno rápido do seu desempenho. As tarefas solicitadas podem ser comentadas após a correção, fornecendo um feedback para os alunos. Finalmente um quadro de notas possibilita aos alunos consultarem apenas suas notas (PULINO FILHO, 2007).

A existência de vários AVAs permite a escolha que atenda melhor às necessidades, considerando custos de implantação e manutenção, ferramentas disponíveis, utilização por outras instituições e compatibilidade com as teorias de aprendizagem também interferem nessa escolha. São exemplos de ambientes o Blackboard ${ }^{\circledR}{ }^{4}$, TelEduc ${ }^{\circledR}{ }^{5}$ e Moodle ${ }^{\circledR}$ (Modular ObjectOriented Dynamic Learning Environment) ${ }^{6}$. Para este trabalho, o AVA utilizado foi o Moodle por sua possibilidade de integração com objetos no padrão SCORM que compõe um acervo de especificações e normas, que admitem um conjunto de funcionalidades integradas como a interoperabilidade, a acessibilidade, durabilidade e a reutilização de conteúdos de aprendizagem baseados na internet (ADL, 2009).

Essas características possibilitam aos AVAs encontrar, importar, compartilhar, utilizar, exportar e reutilizar conteúdos de aprendizagem de uma forma normalizada. Os conteúdos devem ser construídos, armazenados e distribuídos sem relevar a importância das plataformas, e sim, permitindo o desenvolvimento de bibliotecas digitais, facilitando a classificação e "empacotamento" desses objetos (ADL, 2009).

\subsection{Aplicativos do GeoGebra}

O GeoGebra é um software de matemática dinâmica gratuito e multiplataforma para todos os níveis de ensino, que combina geometria, álgebra, tabelas, gráficos, estatística e cálculo em um único sistema (GEOGEBRA, 2013a). No início de 2012, Cyrino e Baldini (2012) selecionaram trabalhos no banco de dados da CAPES que continham a palavra "GEOGEBRA", foram encontrados uma tese de doutorado, oito dissertações de mestrado acadêmico e vinte sete dissertações de mestrado profissional, todos publicados no período de 2008 a 2010. Após a leitura dos resumos, verificaram que um deles não utilizou o GeoGebra e foi desconsiderado. Identificaram que a maioria dos trabalhos discutiam como os professores analisavam potencialidades pedagógicas do GeoGebra em sala de aula. De modo geral, os temas abordados apontam para contribuições do software no processo de ensino e aprendizagem de conteúdos matemáticos.

Além disso, recomendaram entre outros pontos que nos cursos de formação de professores, ao atuar com o apoio das TICs, incluam momentos nos quais eles tenham a oportunidade de:

- Analisar um software como uma ferramenta que permite ao aluno construir novos conhecimentos matemáticos, tendo em conta seus

\footnotetext{
${ }^{4}$ Disponível em http://www. blackboard.com/.

${ }^{5}$ Disponível em http://www.teleduc.org.br/.

${ }^{6}$ Disponível em http://www.moodle.org.
} 
conhecimentos prévios, aspectos históricos e sociais da evolução desses novos conhecimentos;

- Investigar diferentes formas de utilizar o software para dinamizar as aulas, promovendo a interação entre o aluno e o objeto matemático, a realização de simulações, a validação de ideias prévias, a experimentação, a criação de soluções e a construção de novas formas de representação mental;

- Analisar e reconhecer diferentes formas de pensamento e de registros, provocadas pelo uso do software, para que se possam aceitar, valorizar e utilizar as formas de pensamento de seus alunos nas interações em sala de aula (CYRINO e BALDINI, 2012 p.59-60).

Oliveira (2010) investiga uma abordagem no ensino de Trigonometria. Sua hipótese de trabalho baseia-se na oportunidade de alunos experimentarem novas aprendizagens por meio de novos conhecimentos do professor. O autor encontrou por meio da pesquisa, formas diferentes de trazer o assunto Trigonometria. Dentre elas, explorou o dinamismo, cor e movimento proporcionados pelo GeoGebra e construiu uma sequência de aplicativos contextualizando os conceitos estudados em Trigonometria de forma detalhada e dinâmica.

A tela inicial de um dos aplicativos, o dos Triângulos Semelhantes, é apresentado na

\section{Erro! Fonte de referência não encontrada.Erro! Nenhum nome foi dado ao indicador.}

Neste aplicativo, foi objetivado verificar que a razão entre dois lados do triângulo, calculadas em triângulos semelhantes, garantem o mesmo resultado. Com isso, conclui que é possível estudar essas razões em um triângulo acessível, tabular esses valores (e construir as Tábuas Trigonométricas) e utilizá-las para quaisquer triângulos semelhantes. Além disso, visa compreender a relação de dependência dessa razão com o ângulo agudo do triângulo retângulo.

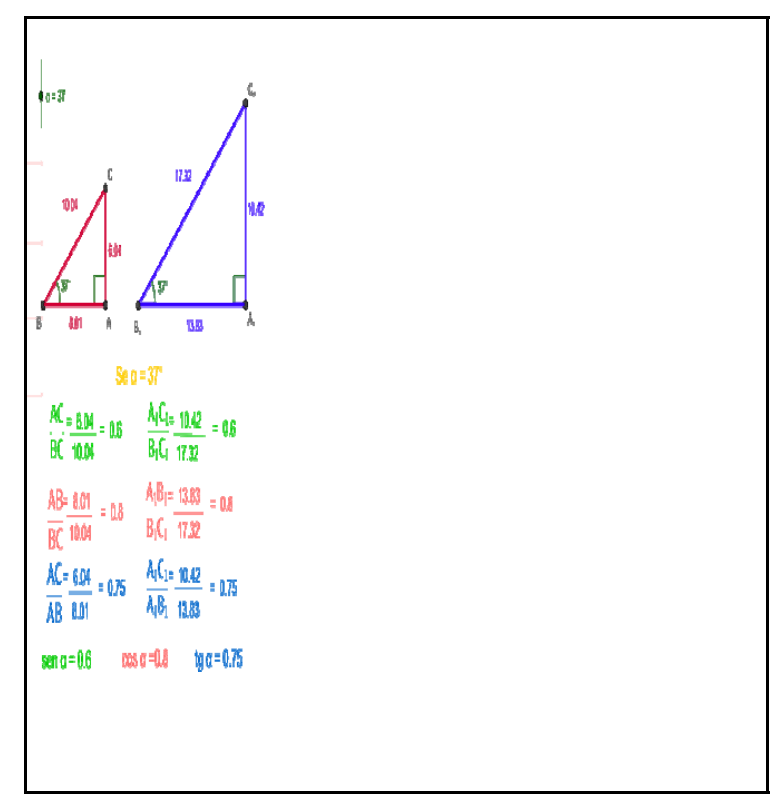

Figura 1 - Aplicativo de triângulos semelhantes. Fonte: Oliveira (2010). 
Os aplicativos construídos por Oliveira (2010) foram disponibilizados no Portal do Professor $^{7}$, o que permite que alunos e professores possam ter acesso ao material sem a necessidade de contato com quem os criou.

Para a pesquisa apresentada neste texto foram escolhidos seis desses aplicativos para a construção dos OA, por meio dos Applets GeoGebraWeb também disponíveis no GeoGebra.

Segundo Deitel e Deitel (2010), os applets são programas Java incorporados nas páginas Web, que são baixados no navegador e executados por meio do plug-in Java instalado. Alguns navegadores não possuem o plug-in por padrão e necessitam da intervenção do usuário para instalá-lo.

Esse processo de instalação de plug-ins pode gerar uma sobrecarga de trabalho para o usuário, antes mesmo de exibir o conteúdo desejado no navegador. Preece, Rogers e Sharp (2005) apresentam as reações emocionais do usuário ao utilizar os computadores e apontam que essa necessidade de instalação poderá frustrar o usuário. Essa tarefa deveria ser automatizada pelo navegador ou os plug-ins deveriam ser substituídos por tecnologias no navegador que interpretassem esses arquivos diretamente.

\section{Metodologia}

A proposta metodológica que envolve a integração do GeoGebra com o padrão SCORM se organiza a partir de quatro etapas. Após o levantamento do referencial teórico e estudo dos trabalho de Oliveira (2010) e Silva (2013), foram realizados os seguintes procedimentos metodológicos: (A) na primeira etapa foi necessário estudar o funcionamento do software GeoGebra e suas contribuições no apoio ao ensino de Matemática, os modelos de interoperabilidade, o SCORM, e as formas de licenciamento e distribuição dos objetos educacionais; (B) em uma segunda etapa foi proposto uma recomendação para exportar os aplicativos criados no GeoGebra; (C) na terceira etapa foram definidas as recomendações para o encapsulamento dos materiais em SCORM; (D) uma vez definido esse modelo, foi necessário testar a conformidade dos pacotes SCORM e incluí-los em pelo menos um AVA, no caso desta pesquisa, o Moodle.

Especificamente na quarta etapa, partindo das características do SCORM e as funcionalidades no Moodle, buscou-se validar o funcionamento dos OA. Para isso, optou-se por uma pesquisa exploratória, com a análise dos registros na ferramenta de teste disponibilizada pela ADL e inclusão dos OAs na plataforma Moodle.

\subsection{Detalhamentos técnicos}

A realização das etapas $B, C$ e D envolvem o trabalho de exportação dos aplicativos criados no GeoGebra, implementação do SCORM e inserção dos OAs no Moodle para testar seu funcionamento.

\footnotetext{
${ }^{7}$ Disponível em http://portaldoprofessor.mec.gov.br/
} 
Do ponto de vista técnico, o GeoGebraWeb, é um conjunto de arquivos que podem gerar applets on-line ou off-line. No entanto, esses arquivos não são destinados aos usuários finais. Esses applets estão em um documento HTML5 que podem conter vários documentos GeoGebraWeb (GEOGEBRA, 2013b).

Na Erro! Fonte de referência não encontrada. estão omitidos o início, entre outras partes de um arquivo HTML5, concentrando-se apenas nas partes do GeoGebraWeb. Primeiramente, a fonte do GeoGebraWeb é carregada, nos documentos online o "src" é igual ao da linha 2, para documentos off-line sua configuração correta é "web/web.nocache.js". As definições de "data-param-width" e "data-param-height" (linha 3) definem o tamanho do applet apresentado no navegador. Os outros parâmetros são as configurações diretas para GeoGebraWeb. Finalmente, a configuração “data-paramggbbase64" (linha 7) possui o arquivo, conforme gerado pelo GeoGebra.

$\mathbf{1}$ | <script type="text/javascript" language="javascript"

2 | src="http://www.geogebra.org/web/4.2/web/web.nocache.js" $></$ script $>$

3 | <article class="geogebraweb" data-param-width="600" data-param-height="400"

4 | data-param-showResetIcon="false" data-param-enableLabelDrags="false"

$\mathbf{5}$ | data-param-showMenuBar="false"

6 | data-param-showToolBar="false" data-param-showAlgebraInput="true"

7 | data-param-ggbbase64="UEsDBBQACAAIAHOOh0AAAAAAAAAAAAAAAAAWAA...==">

Figura 2 - Exemplo de código de um applet GeoGebraWeb. Fonte: GEOGEBRA (2013b).

As implementações realizadas nas etapas B, C e D, tiveram como material base os OAs que tratam de Trigonometria e foram construídos com o GeoGebra para propor um tratamento diferente do assunto, como tratado nos livros didáticos, discutindo a Trigonometria no Triângulo Retângulo, no Ciclo Trigonométrico e, ainda, nas Funções Trigonométricas (Oliveira, 2010). Considerando que o material didático foi entendido para construção do OA, é importante conhecer a estrutura do arquivo SCORM e como poderá suportar essa tarefa. A

apresenta uma típica abordagem para navegação e criação compatível com SCORM que será usada nesta pesquisa. 


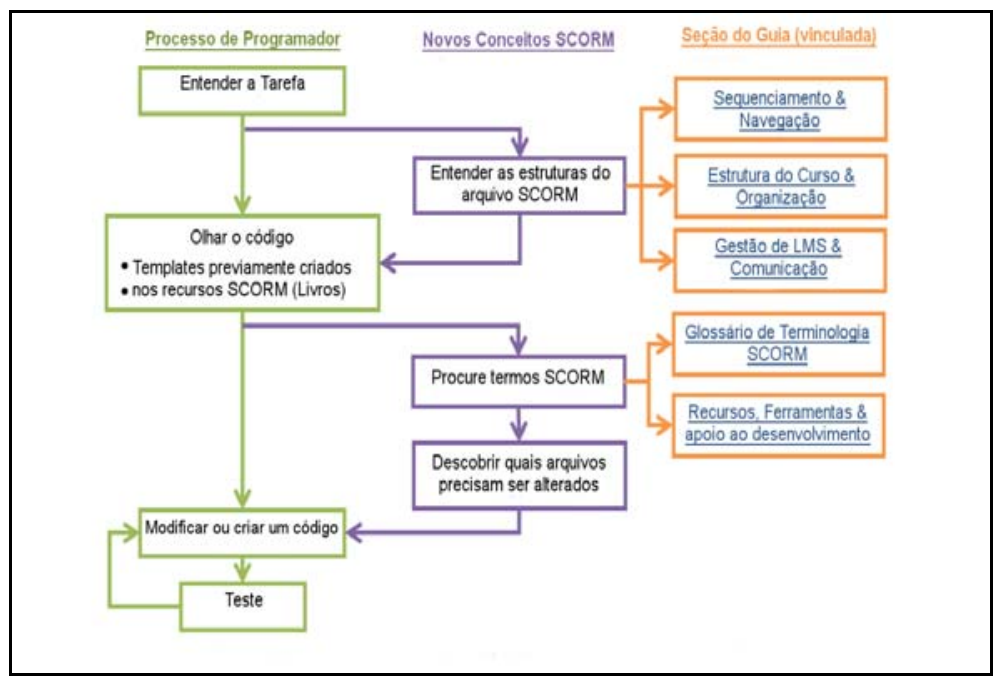

Figura 3 - Processo de programador para o desenvolvimento SCORM.

$$
\text { Fonte: ADL (2011). }
$$

A maneira mais fácil e recomendada no SCORM é usar um Template, ou seja, um modelo, por ser uma estrutura simples com arquivos que podem ser modificados e ampliados para criar o OA.

Os modelos são geralmente fornecidos pela comunidade e podem implementar padrões de projeto. Para efeitos nesta seção, utilizaram um modelo de partida simples fornecida por ADL (2009). A Tabela 1 lista alguns termos SCORM e a maneira como relacionam-se com o Design Instrucional.

Tabela 1 - Termos SCORM e sua relação com o Design Instrucional

\begin{tabular}{|c|c|c|}
\hline $\begin{array}{c}\text { Termo comum no Design } \\
\text { Instrucional }\end{array}$ & Termo comum SCORM & Termo Oficial SORM \\
\hline $\begin{array}{c}\text { Vídeos, arquivos de texto, } \\
\text { imagem ou outras mídias, } \\
\text { também chamados de Ativos } \\
\text { (Asset) }\end{array}$ & Ativo (Asset) & SCO \\
\hline $\begin{array}{c}\text { Objeto Educacional ou } \\
\text { Aprendizagem (OA) }\end{array}$ & Objeto de Conteúdo Compartilhável (SCO) & Activity \\
\hline & $\begin{array}{c}\text { Atividade; um SCO ou agrupamento lógico de SCOs } \\
\text { com sequenciamento associado, pode-se referir a } \\
\text { uma estrutura organizacional. }\end{array}$ & Activity Tree / \\
\hline $\begin{array}{c}\text { Estrutura Organizacional } \\
\text { ativos, ramificação, estrutura } \\
\text { para um curso) }\end{array}$ & $\begin{array}{c}\text { Uma árvore de atividade representa os dados que o } \\
\text { LMS implementa para refletir uma hierarquia. }\end{array}$ \\
\hline & Pacote de Conteúdo (pasta compactada com o \\
& conteúdo do curso) & Content Package \\
\hline
\end{tabular}




\begin{tabular}{|c|c|c|}
\hline $\begin{array}{c}\text { Termo comum no Design } \\
\text { I nstrucional }\end{array}$ & Termo comum SCORM & Termo Oficial SORM \\
\hline Ramificação & Sequenciamento & Sequencing \\
\hline Marcação & $\begin{array}{c}\text { Objetivo (Nota: Não está relacionado com o termo } \\
\text { do Design Instrucional, Objetivo de Aprendizagem) }\end{array}$ & Objective \\
\hline $\begin{array}{c}\text { Ramificação para o } \\
\text { programador, fluxograma }\end{array}$ & Rollup e regras de sequenciamento & Interações \\
\hline $\begin{array}{c}\text { Dados da interatividade do } \\
\text { aluno (qualquer interação com } \\
\text { o conteúdo, normalmen Data / } \\
\text { utilizado para avaliação) }\end{array}$ & & cmi.interactions \\
\hline
\end{tabular}

Fonte: adaptado de ADL (2011).

Um pacote de conteúdo SCORM contém duas partes principais: (a) o arquivo de manifesto que descreve todos os SCOs do pacote, a representação do diagrama de estrutura de conteúdo criado (chamado de organização), as regras de sequenciamento, os metadados para os SCOs, as agregações, e o próprio pacote; (b) todos os arquivos SCO e ativos para o pacote de conteúdo, no caso dessa pesquisa são os aplicativos em HTML5 exportados do GeoGebra.

$\mathrm{O}$ arquivo de manifesto é sempre nomeado de "imsmanifest.xml" e sempre aparece no nível superior de um pacote de conteúdo compactado, independentemente da estrutura do resto do pacote. É um arquivo de Linguagem de Marcação Estendida (XML), que organiza o conteúdo do pacote. Esse manifesto é um conjunto detalhado de instruções, estruturado de forma especificada pelo SCORM, que organiza o conteúdo do pacote e diz ao LMS quando, como e qual o conteúdo será oferecido aos alunos. A estrutura básica de um arquivo de manifesto é apresentada na 


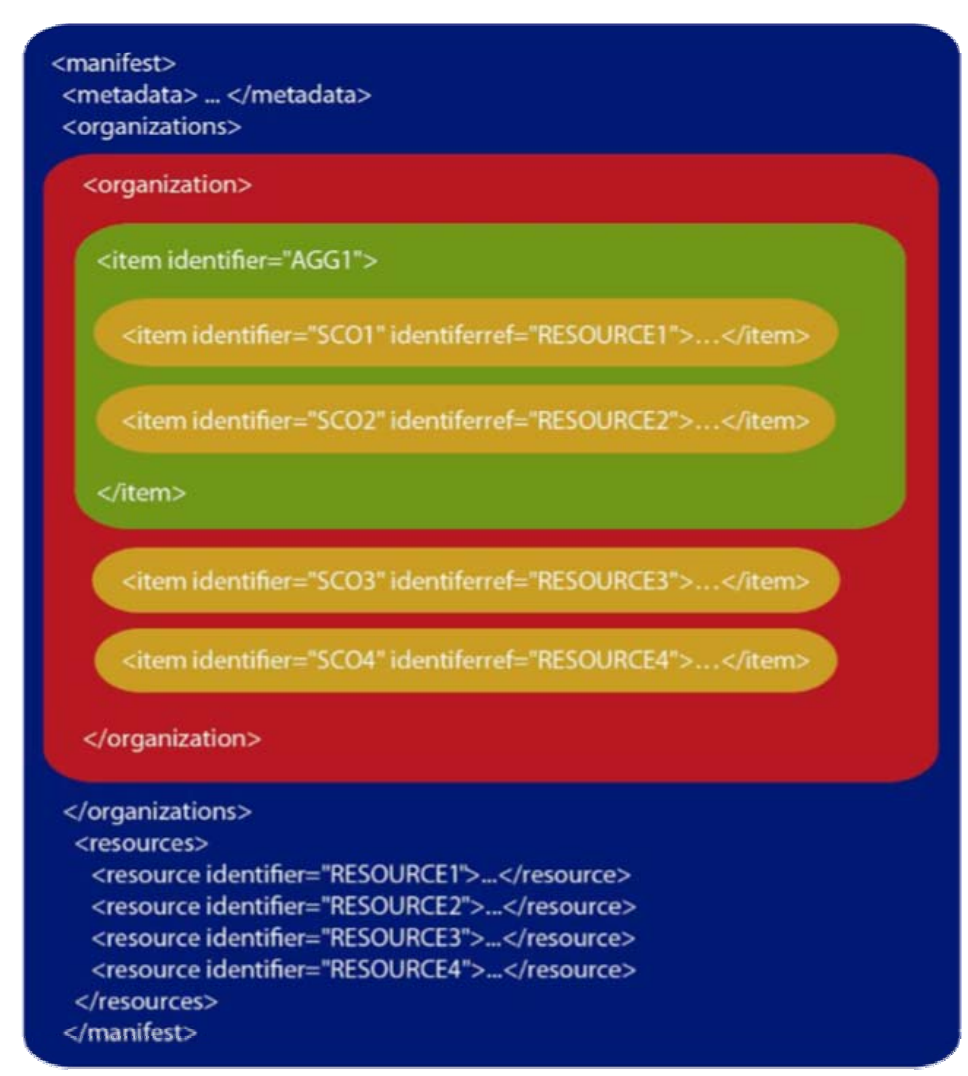

Figura 1 - Exemplo de manifesto (imsmanifest.xml) Fonte: ADL (2011).

Seguindo o processo de desenvolvimento descrito na

, foi iniciada a etapa de modificação dos arquivos e criação dos códigos. Optou-se primeiramente pela edição do arquivo de manifesto, podendo ser criado por ferramentas de autoria, embora alguns programadores preferem criá-los a partir do zero usando um editor de XML, sendo este, o caso da pesquisa.

Os arquivos de manifesto foram criados com base na construção de OAs com um SCO para cada aplicativo construído por Oliveira (2010) e um outro OA, contendo todos os SCOs. A estrutura disponível na Figura 2 contempla o pacote que contém todos os aplicativos, sendo cinco SCOs seguidos por uma agregação com outro SCO. A agregação foi intitulada de "Gráficos", por conter o aplicativo das Variações dos Gráficos das Funções Trigonométricas que agrupa três aplicativos com a mesma proposta, porém, para funções diferentes, um do seno, do cosseno e outro para a tangente (OLIVEIRA, 2010). 


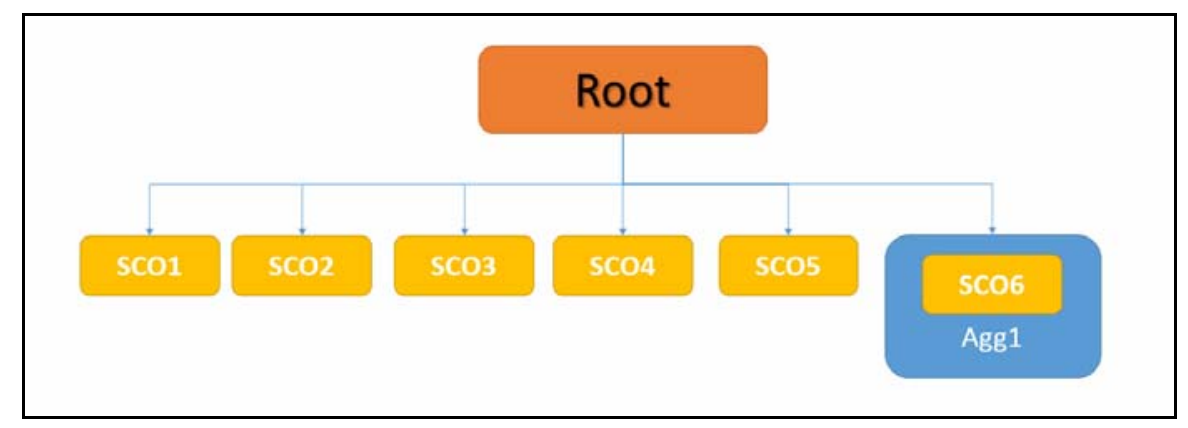

Figura 2 - Estrutura do pacote com seis aplicativos Fonte: Elaborado pelos autores

Definida a primeira parte do pacote de conteúdo, iniciou-se a construção dos SCOs a partir dos applets GeoGebraWeb. Os arquivos gerados estão em HTML5, para cada página existe um applet criado por Oliveira (2010). Esses applets puderam ser abertos no navegador e permitiram a interação com o conteúdo matemático. São os arquivos mais reutilizáveis, pois, eles podem ser redistribuídos, reorganizados e reaproveitados em muitos contextos. Esses arquivos em HTML5 foram modificados para tornarem-se os SCOs do modelo SCORM.

O SCORM define as regras para que as informações sejam trocadas entre o LMS e os SCOs. A definição do Modelo de Dados do RTE é baseada no padrão IEEE 1484.11.1-2004 ${ }^{8}$ Standard for Learning Technology - Data Model for Content Object Communication e a comunicação ocorre por meio da SCORM Application Programming I nterface (API) descrito no padrão IEEE 1484.11.2-2003 ${ }^{9}$ Standard for Learning Technology - ECMAScript Application Programming Interface for Content to Runtime Services Communication. A API do SCORM é um método padronizado para um SCO comunicar-se com o LMS, enquanto os alunos interagem com o conteúdo, permitindo recuperar e registrar alguns elementos no LMS (ADL, 2009).

Alguns elementos do Modelo de Dados do RTE precisam ser programados dentro dos SCOs, por meio de chamadas na linguagem JavaScript ${ }^{10}$. O SCO no LMS deve encontrar uma instância do SCORM. Isto é realizado por meio de um arquivo chamado de API Wrapper (ADL, 2011). Nesta pesquisa foi utilizada a API Wrapper, disponível no Template citado anteriormente. Essa API Wrapper irá encontrar a instância do SCORM e dispõe das funções escritas em JavaScript, necessárias para o conteúdo comunicar-se com o LMS: dolnitialize(); doTerminate(); doGetValue(); doSetValue(); doCommit(); doGetLastError(); doGetErrorString(); doGetDiagnostic(); ErrorHandler(); getAPIHandle(); findAPI(); getAPI(); findObjective(); findDataStore() e message(). O SCO necessita realizar no mínimo duas chamadas. A primeira, dolnitialize(), usado para iniciar a comunicação e a segunda, doTerminate(), que deve ser chamada antes de sair do SCO (ADL, 2011).

\footnotetext{
${ }^{8}$ Disponível em: http://ieeexplore. ieee.org/servlet/opac?punumber $=9661$

${ }^{9}$ Disponível em: http://ieeexplore. ieee. org/servlet/opac?punumber $=8972$

10 JavaScript é uma linguagem de programação interpretada.
} 


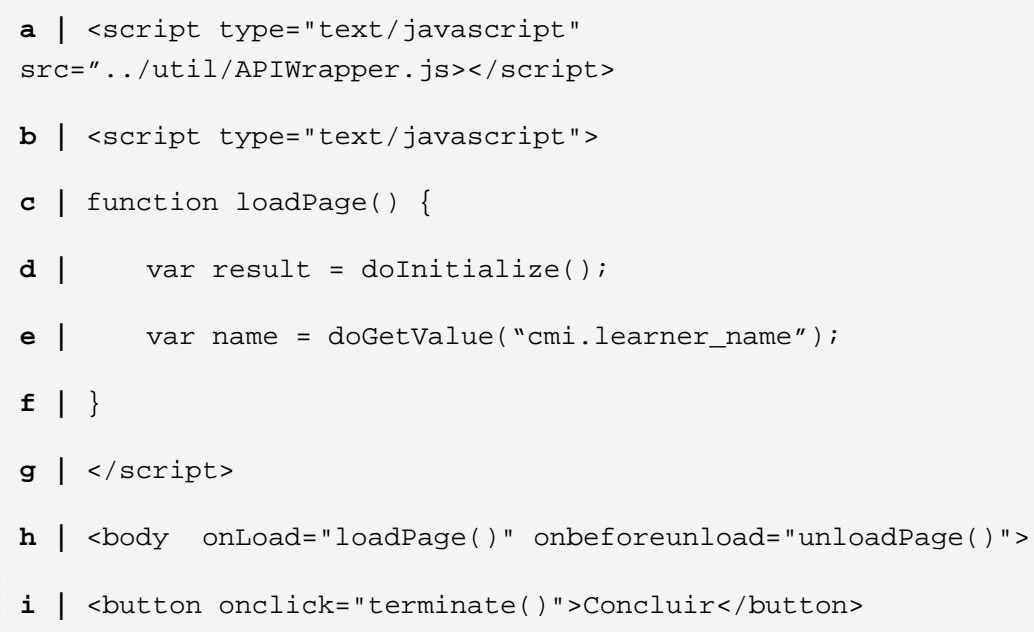

A Erro! Fonte de referência não encontrada. mostra alguns trechos de código de um SCO desta pesquisa, vale ressaltar, que este não é o arquivo em sua totalidade e as letras de (a) até (i) não indicam as linhas em sequência, foram incluídas apenas na figura para auxiliar nas citações. $O$ atributo de evento onload ${ }^{11}$ foi utilizado para iniciar a comunicação com o LMS. O onload definido no elemento body, descrito na linha (h), dentro do HTML5 executa um JavaScript, após o conteúdo ter sido completamente carregado, incluindo imagens, arquivos de script, arquivos de estilos, etc. Além deste, o atributo de evento onbeforeunload, descrito na linha (h), foi utilizado para finalizar a comunicação por executar uma chamada JavaScript antes que o documento HTML5 fosse descarregado do navegador. Adicionalmente, cada SCO contou com um botão "Concluir", descrito na linha (i), que dispara uma chamada JavaScript que também permite registrar alguns dados no LMS.

Estes dados são consultados posteriormente no LMS, podendo ser utilizados para acompanhar o progresso do aluno e indicar sua interação com o OA. A Tabela 2 indica os elementos utilizados nos OAs construídos.

Tabela 2 - Elementos utilizados nos OAs construídos

\begin{tabular}{|l|l|}
\hline Notação & Descrição \\
\hline cmi.learner_name & Obtém o nome do aluno registrado no LMS. \\
\hline cmi.progress_measure & Registra o progresso do aluno no SCO. \\
\hline cmi.success_status & Define a situação do aluno em relação ao SCO. \\
\hline cmi.objectives & Define os objetivos do SCO. \\
\hline cmi.session_time & Define o tempo de sessão do aluno durante seu acesso ao SCO. \\
\hline
\end{tabular}

A ADL (2009) disponibiliza uma ferramenta que permite às organizações a realização de testes em LMS, SCOs e pacotes de conteúdo para verificar sua conformidade com o SCORM. Cada teste contempla as instruções para execução e os registros de cada ação de teste e seus respectivos resultados.

${ }^{11}$ Disponível em: http://www.w3schools.com/tags/ev_onload.asp 


\section{Resultados}

De acordo com a metodologia aplicada, foi possível gerar os applets GeoGebraWeb. Os arquivos gerados estão em HTML5, para cada página existe um applet criado por Oliveira (2010). Esses applets puderam ser modificados e transformados em SCOs permitindo a interação com o conteúdo de Trigonometria.

Algumas falhas ocorreram no processo de "empacotamento", como por exemplo, a implementação da navegação entre os SCOs do mesmo pacote e o controle dos dados no RTE.

Os elementos do RTE foram manipulados pelas chamadas na linguagem JavaScript, permitindo acompanhar alguns registros da interação do aluno com o OA.

Os testes de conformidade foram realizados a partir da organização dos SCOs para se tornar pacotes de conteúdo SCORM.

Após correções dos tipos de falhas supracitadas, visualizações e refatorações dos códigos, foi possível alcançar pacotes de conteúdo em conformidade com o SCORM.

Apresenta-se, nas Figuras 7 a 12, as telas dos seis aplicativos concebidos por Oliveira (2010), "empacotados" nesta pesquisa e incluídos no AVA. Destaca-se que os objetivos foram extraídos da pesquisa de Oliveira (2010).

A Figura 7 - SCO dos Triângulos semelhantes apresenta a tela inicial do SCO dos Triângulos semelhantes que foi estruturado com o objetivo de dar significado às razões trigonométricas no triângulo retângulo por meio da verificação das regularidades obtidas em triângulos semelhantes. Pode-se comparar com O OA inicial apresentado na Erro! Fonte de referência não encontrada., nota-se que há possibilidade de interação com o objeto diretamente no navegador, sem a necessidade de instalar novos softwares nos dispositivos dos alunos.

Figura 7 - SCO dos Triângulos semelhantes 

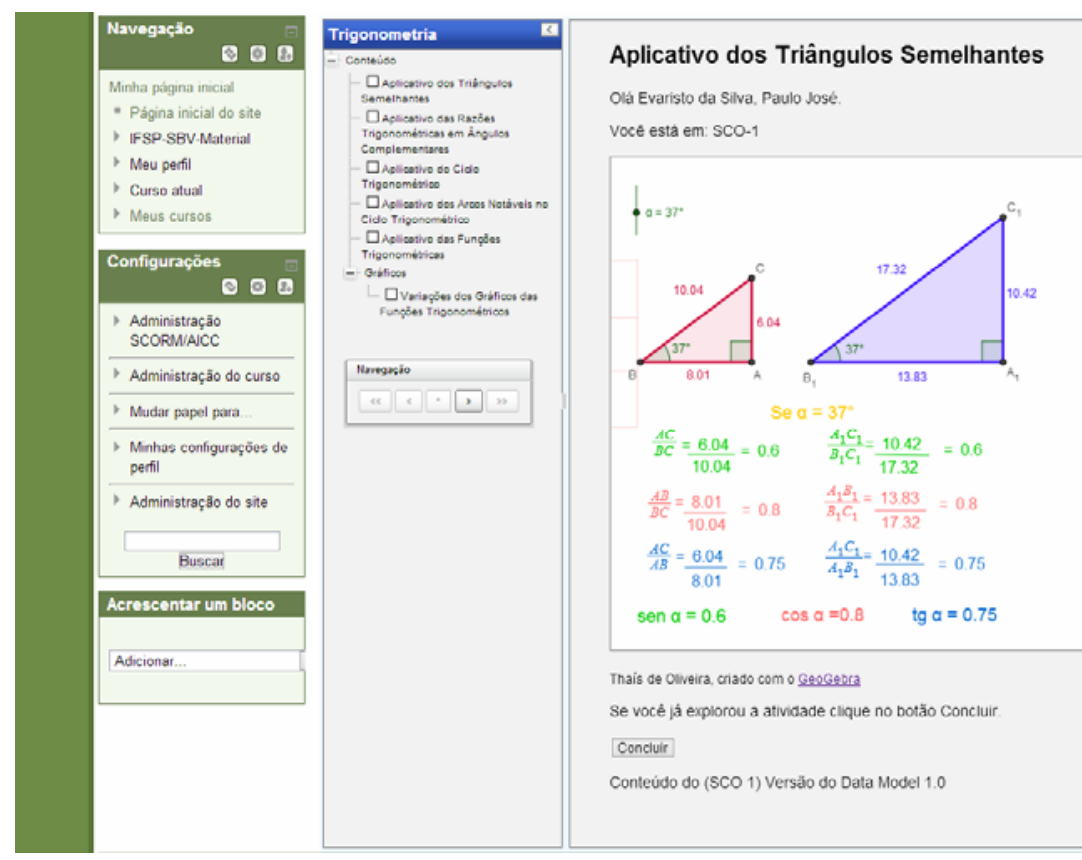

Thais de Oweira, crado com o gengerera

Se vocé já explorou a atividade clique no botăo concluir.

Concluir

Conteưdo do (SCO 1) Versăo do Data Model 1.0

Fonte: Elaborado pelos autores

A Figura 3 apresenta a tela inicial do SCO das Razões trigonométricas em ângulos complementares que foi estruturado com o objetivo de fazer correspondência aos valores do seno e cosseno de ângulos complementares.
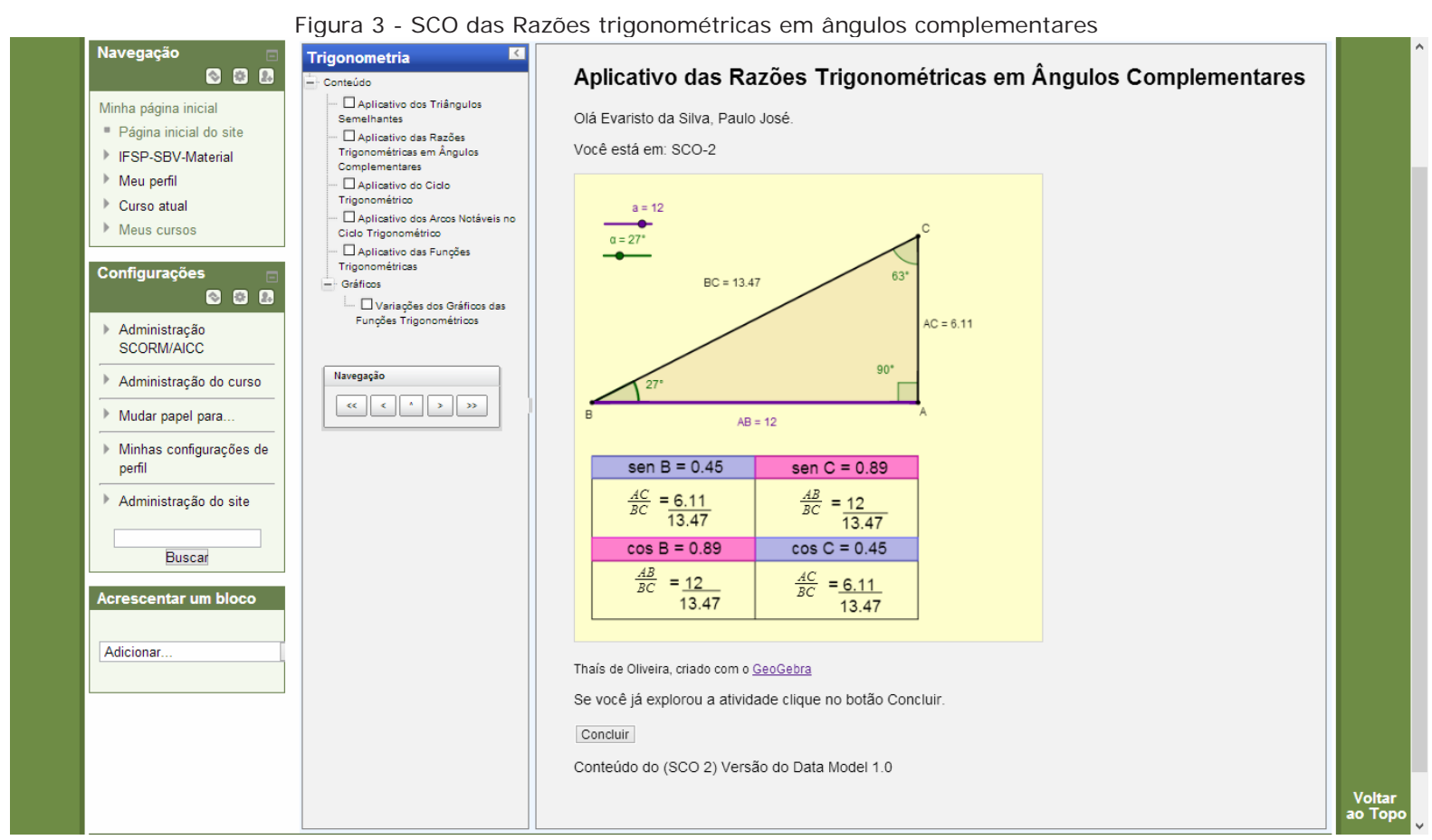

Fonte: Elaborado pelos autores

A Figura 4 apresenta a tela inicial do SCO do Ciclo trigonométrico que possui o objetivo de evidenciar detalhes de forma parcial sobre esse círculo. 

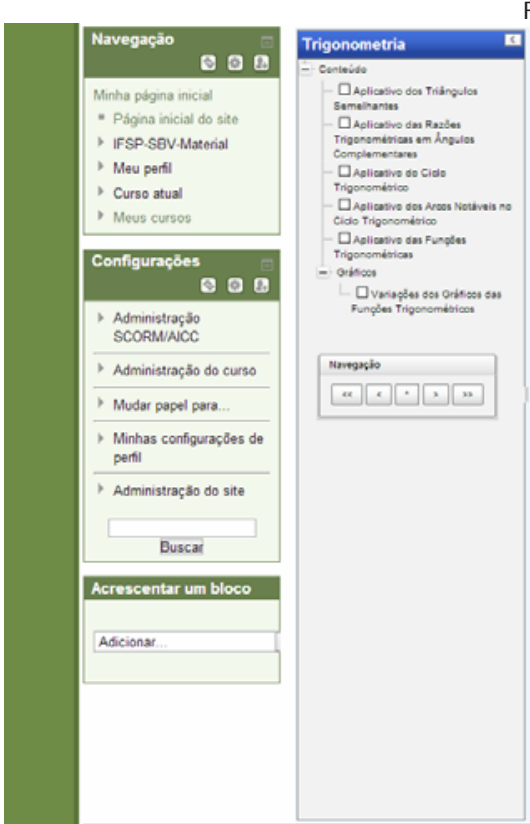

Figura 4 - SCO do Ciclo trigonométrico

\section{Aplicativo do Ciclo Trigonométrico}

Olà Evaristo da Siviva. Paulo José.

vocé está em: Sco-3

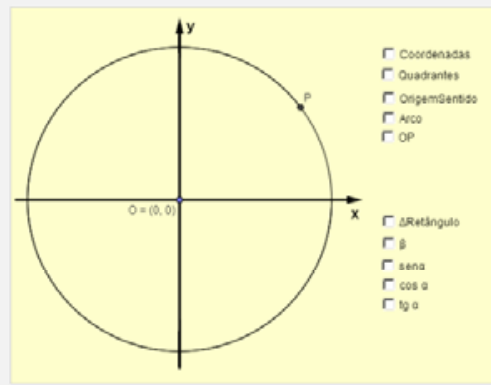

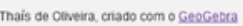

se vocé já explorou a atividade clique no botăo concluit

Conduir

Conteúdo do (sco 3) Versăo do Data Model 1.0

Elaborado pelos autores

A Figura 5 apresenta a tela inicial do SCO dos Arcos notáveis no ciclo trigonométrico que tem por objetivo a relação de simetrias entre os quadrantes, usando como referência os ângulos notáveis.

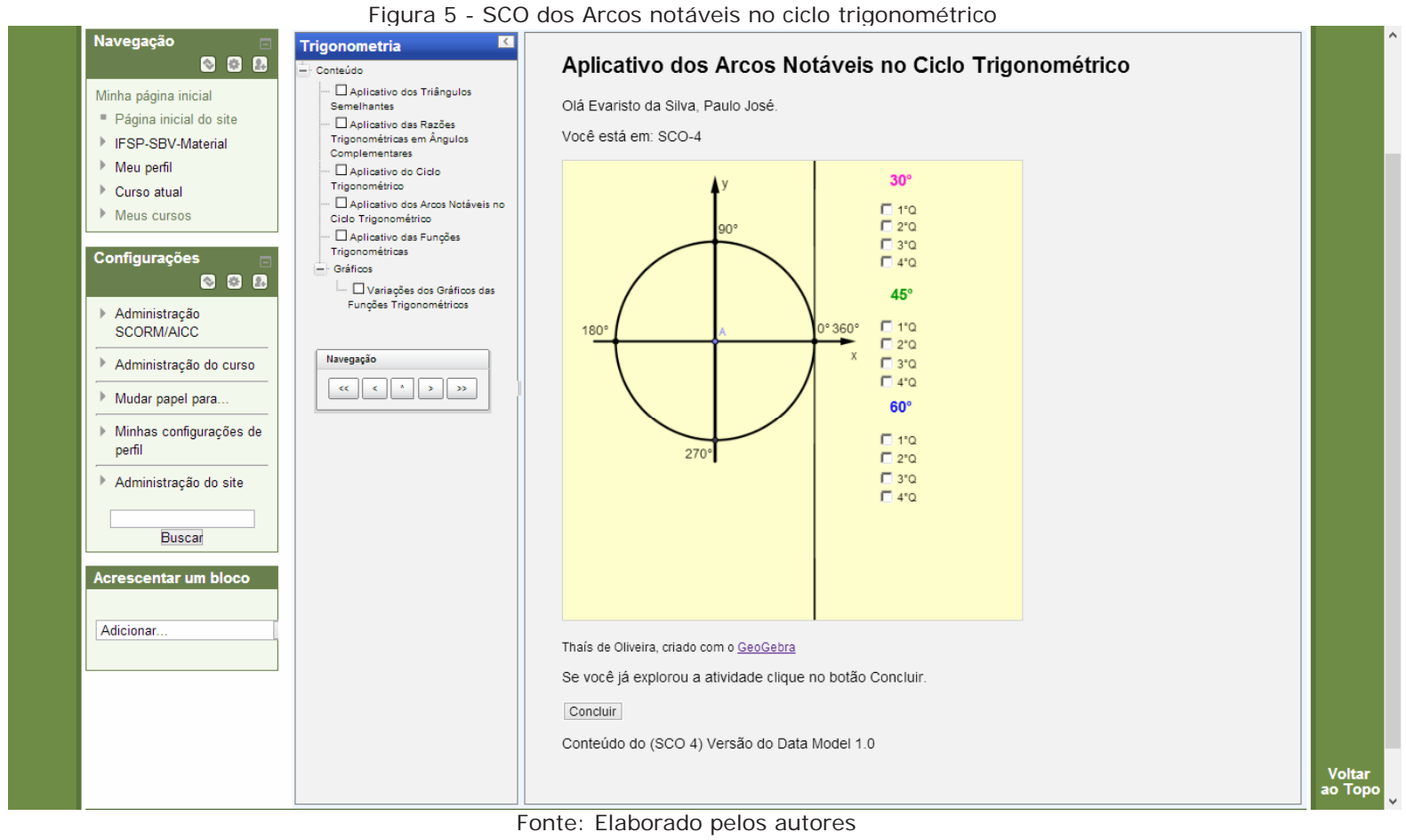

A

Figura 6 apresenta a tela inicial do SCO das funções trigonométricas que possui o objetivo de relacionar simultaneamente o ciclo trigonométrico com os gráficos das funções trigonométricas geradas no plano cartesiano. 

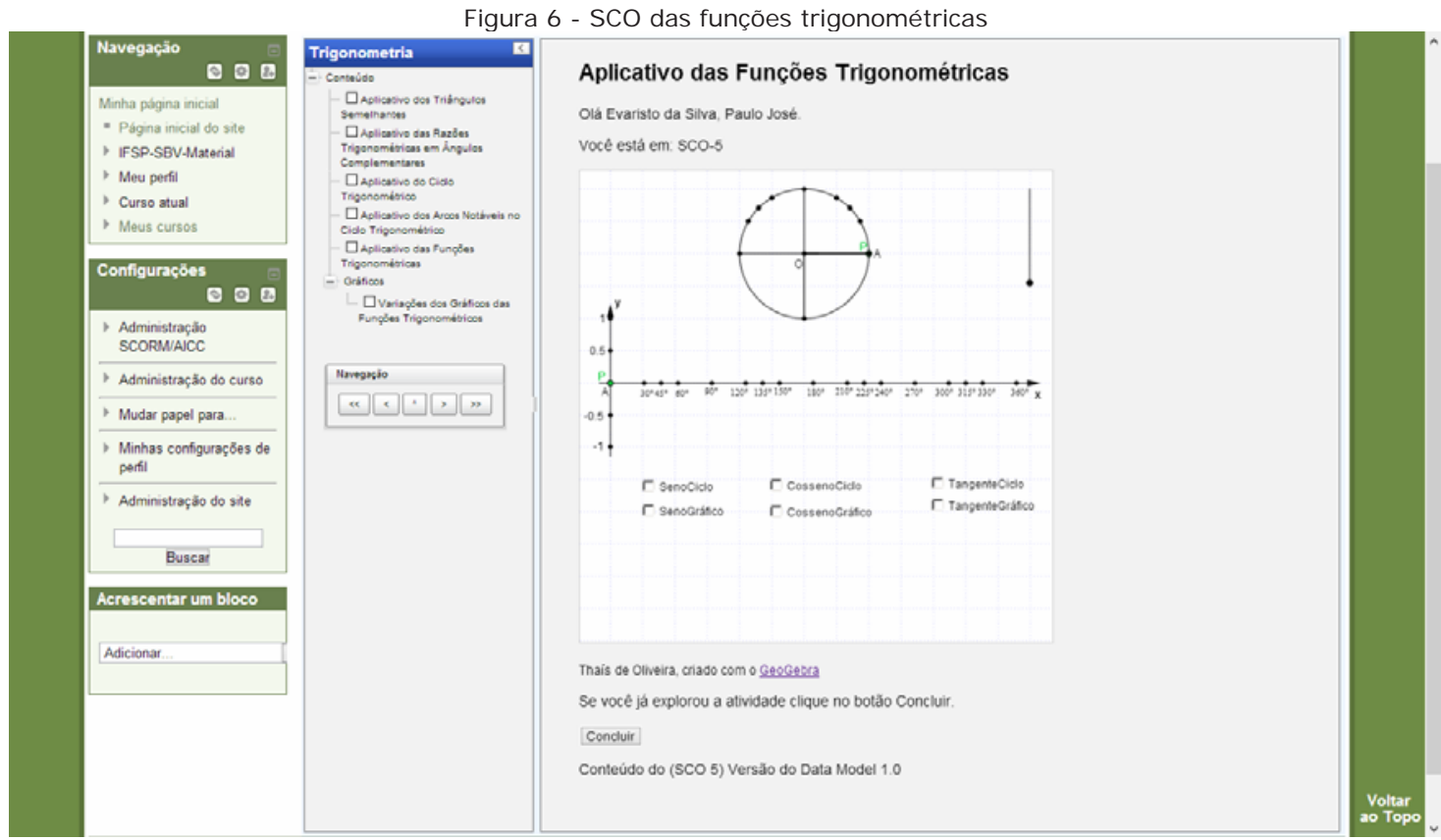

Fonte: Elaborado pelos autores

A Figura 7 apresenta a tela inicial do SCO com as variações dos gráficos das funções trigonométricas, o objetivo definido para esse SCO está na exploração da variação gráfica das funções trigonométricas.

Figura 7 - SCO com as variações dos gráficos das funções trigonométricas
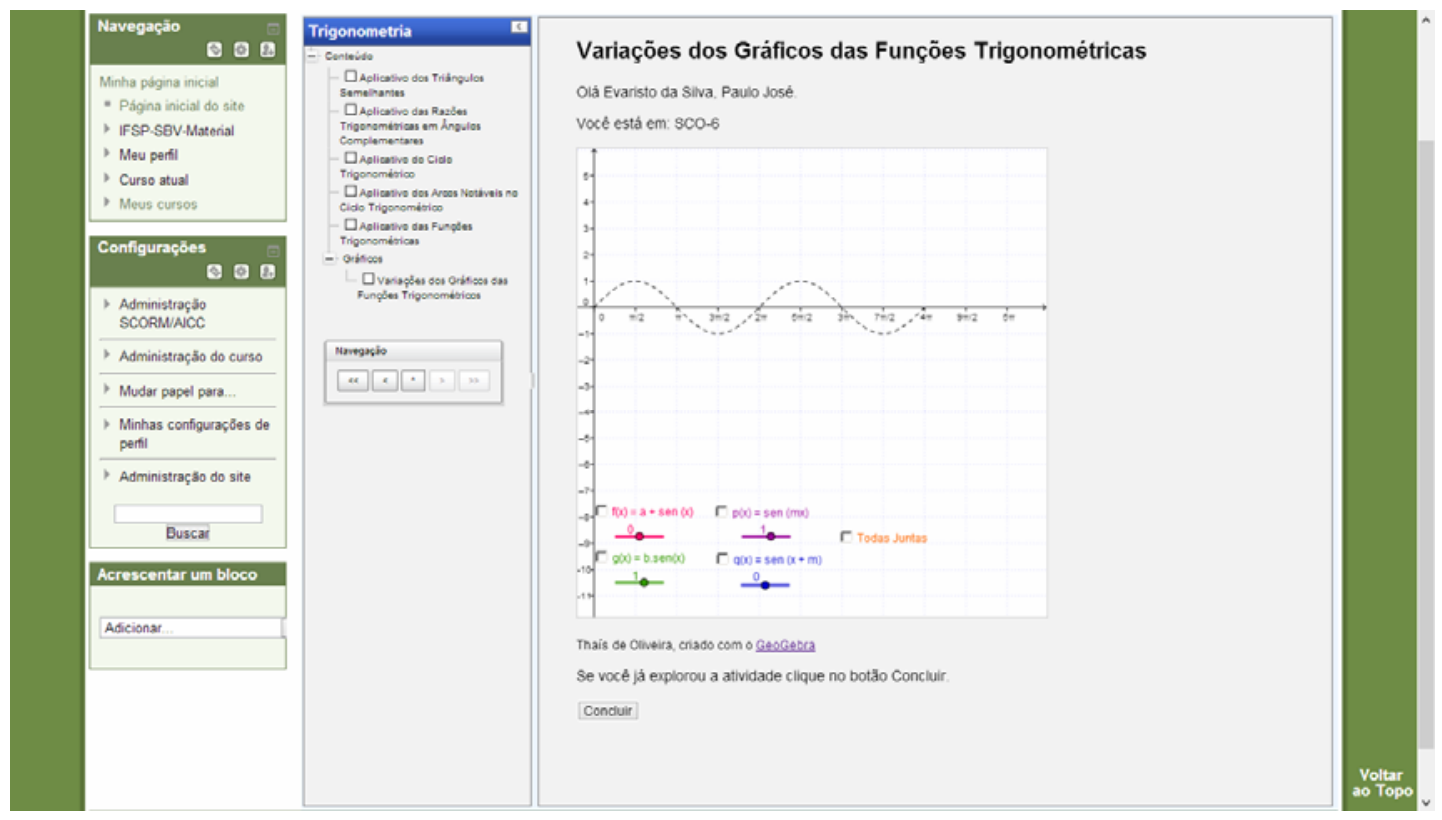

Fonte: Elaborado pelos autores

\section{Conclusões}

Neste trabalho, assim como nos trabalhos citados no referencial teórico é perceptível a contribuição do SCORM para construção de OAs que adaptem materiais disponíveis, por permitir a interoperabilidade, acessibilidade, reusabilidade inerentes aos OA. Além disso, é um 
modelo que adota padrões de conhecimento internacional, permite o compartilhamento dos conteúdos em diversos países, e para diversas áreas do conhecimento.

A emergência de se ampliar as possibilidades de uso remoto sem instalação de softwares no contexto da EaD faz-se necessário. No caso do presente estudo, dada a importância do GeoGebra no contexto do ensino da Matemática, permitir que o estudante interaja com os OAs diretamente do navegador foi um dos resultados mais interessantes do presente estudo.

Segundo os resultados apresentados, percebe-se que a interoperabilidade de software para os OAs, é uma característica ainda difícil de ser alcançada. Contudo, o uso do modelo SCORM auxilia na busca da interoperabilidade de software. A reusabilidade pode ser conquistada na utilização dos pacotes de conteúdo em diversos cursos e por repetidas vezes. A acessibilidade fica condicionada às descrições dos OAs, armazenamento e disponibilização em bases de dados que permitam sua busca e utilização.

Foram empacotados com sucesso seis aplicativos do GeoGebra, originalmente concebidos por Oliveira (2010). Contudo, conclui-se que a interoperabilidade dos componentes ainda é um desafio na prática, devida as várias versões de sistema operacionais, navegadores e componentes.

Além destes resultados iniciais, é possível ampliar estudos no sentido de garantir outras implementações técnicas para ampliar o potencial pedagógico do GeoGebra no processo de ensino-aprendizagem da Matemática, tendo várias possibilidades de estudos futuros.

\section{Referências}

ADL. Advanced Distributed Learning. SCORM 2004 4rd edition. Version 1.1. 2009. Disponível em: <http://www.adlnet.org>. Acesso em: 15 abr. 2013.

ADL. Advanced Distributed Learning. SCORM users guide for programmers. Version 10. 2011. Disponível em: <http://www.adlnet.org>. Acesso em: 03 jun. 2013.

BRASIL. Decreto no 5.622, de 19 de dezembro de 2005. Regulamenta o art. 80 da Lei no 9.394, de 20 de dezembro de 1996, que estabelece as diretrizes e bases da educação nacional. Disponível em http://www.planalto.gov.br/ccivil_03/_Ato2004-2006/2005/Decreto/D5622.htm>. Acesso em: 03 ago. 2009.

CYRINO, M. C. C. T.; BALDINI, L. A. F. O software GeoGebra na formação de professores de matemática: uma visão a partir de dissertações e teses. Revista Paranaense de Educação Matemática, Campo Mourão, v. 1, n. 1, p.42-62, jul./dez. 2012. Semestral.

DEITEL, P. J.; DEITEL, H. Java: como programar. 8. ed. São Paulo: Pearson Prentice Hall, 2010.

DUTRA, R. L. S.; TAROUCO, L. M. R.; PASSERINO, L. Utilização de objetos de aprendizagem abertos SCORM para dar suporte à avaliação formativa. Revista Brasileira de I nformática na Educação, Porto Alegre, v. 18, n. 3, p.59-70, 2010.

FRANCO, L. R. H. R.; BRAGA, D. B.; RODRIGUES, A. EaD virtual: entre teoria e prática. 2. ed. Assis: Triunfal Gráfica e Editora, 2011.

GEOGEBRA. Geogebra. Disponível em: <http://geogebra.org>. Acesso em: 15 abr. $2013 a$.

GEOGEBRA. Tutorial: Creating HTML5 documents with GeoGebraWeb. Disponível em: <http://wiki.geogebra.org/en/Tutorial:Creating_HTML5_documents_with_GeoGebraWeb>. Acesso em: 15 abr. 2013b. 
GONZÁLEZ, L. A. G.; RUGGIERO, W. V. Collaborative e-learning and learning objects. I EEE Latin America Transactions, New York, v. 7, n. 5, p.569-577, set. 2009.

IEEE. Draft standard for learning object metadata. Disponível em: http://Itsc.ieee.org/wg12/files/LOM_1484_12_1_v1_Final_Draft.pdf. Acesso em 01 jun. 2013.

NIENOW, A. L.; BEZ, M. L. Ferramenta de autoria para construção de objetos de aprendizagem para a área da saúde. In: VIII SEMINÁRIO DE INFORMÁTICA, 8., 2009, Torres, Anais... Torres: ULBRA, 2009. Disponível em: <http://www.seminfo.com.br/anais/2009/pdfs/WEl_Tche/63504_1.pdf>. Acesso em: 03 jun. 2013.

OLIVEIRA, T. Trigonometria: a mudança da prática docente mediante novos conhecimentos. 2010.177 f. Dissertação (Mestrado) - Departamento de Matemática, Universidade Federal de São Carlos, São Carlos, 2010.

OLIVEIRA, I. L. L. de; GUIMARÃES, S. U.; ANDRADE, J. A. A.. As potencialidades do GeoGebra em processos de investigação matemática: uma análise do desenvolvimento de objetos de aprendizagem da EaD no ensino presencial. In: CONFERêNCIA LATINO AMERICANA DE GEOGEBRA, 1., 2012 , São Paulo. Anais... . São Paulo: Puc-sp, 2012. p. 265 - 279. Disponível em: <http://www4. pucsp.br/geogebrala/submissao/pdfs/10potencialidades.pdf>. Acesso em: 09 abr. 2016.

POLSANI, P. Use and abuse of reusable learning objects. In: Journal of Digital Information, Texas, v. 3, n. 4., 2003. Disponível em: <http://journals.tdl.org/jodi/index.php/jodi/article/view/89/88\%3Cbr>. Acesso em: 01 jun. 2013.

PREECE, J.; ROGERS, Y.; SHARP, H. Design de interação: além da interação homem-computador. Porto Alegre: Bookman, 2005.

PULINO FILHO, A. R. Livro do moodle: um sistema de gerenciamento de cursos. Brasília: Universidade de Brasília. 229 p. 2007.

SAMPAIO, R. L.; ALMEIDA, A. R. S. Aprendendo matemática com objetos de aprendizagem. Ciências e Cognição: Revista interdisciplinar de estudos da cognição, Rio de Janeiro, v. 15, n. 1, p.64-75, 20 abr. 2010.

SILVA, P. J. E. Construção de Objetos de Aprendizagem em SCORM para Apoio ao Ensino de Matemática. Trabalho de Conclusão de Curso (Graduação em Tecnologia em Sistemas para Internet). Instituto Federal de Educação Ciência e Tecnologia de São Paulo-Câmpus São João da Boa Vista, São João da Boa Vista, 2013.

TAROUCO, L. M. R.; FABRE M. J. M.; TAMUSIUNAS, F. R.. Reusabilidade de objetos educacionais. Revista Novas Tecnologias na Educação, Porto Alegre, v. 1, p. 1-11, fev. 2003. Disponível em: < http://seer.ufrgs.br/renote/article/view/13628/7697>. Acesso em: 01 jun. 2013.

WILEY, D. A. Conectando objetos de aprendizagem de teoria do design instrucional: a definição, uma metáfora, e uma taxonomia. O uso instrucional de objetos de aprendizagem (Bloomington, IN: Agência de Tecnologia Educacional). 2002.

Recebido em abril de 2016

Aprovado para publicação em agosto de 2017

Paulo J osé Evaristo da Silva

Professor do Instituto Federal de Educação, Ciência e Tecnologia de São Paulo, Câmpus São J oão da Boa Vista, São João da Boa Vista - SP, Brasil, pauloevaristo@ifsp.edu.br

\section{Thais de Oliveira}

Professora do Instituto Federal de Educação, Ciência e Tecnologia de São Paulo, Câmpus São J oão da Boa Vista, São J oão da Boa Vista - SP, Brasil, thaisoliveira@ifsp.edu.br

\section{Rodrigo Palucci Pantoni}

Professor do Instituto Federal de Educação, Ciência e Tecnologia de São Paulo, Câmpus Sertãozinho, Sertãozinho- SP, Brasil, rpantoni@ifsp.edu.br 


\title{
Desenvolvimento do Pensamento Computacional com Valores da Ética Hacker
}

\section{Computational Thinking with Hacker's Ethics}

\author{
FLÁVIA LINHALIS ARANTES \\ Universidade Estadual de Campinas (UNICAMP)
}

PAULA EDUARDA JUSTINO RIBEIRO

Universidade Estadual de Campinas (UNICAMP)

Resumo: A introdução de conceitos de computação aos jovens é importante pelo seu caráter transversal às demais áreas do conhecimento. Com o objetivo de estimular o desenvolvimento do pensamento computacional, este artigo apresenta o design e a avaliação de uma oficina com a utilização do software livre Scratch realizada no Projeto J ovem Hacker. O Projeto busca maneiras de auxiliar na formação de jovens tendo como base a ética hacker, importante para orientar os alunos a ter um senso crítico e uma ética mais voltada ao compartilhamento de ideias e soluções de software. A oficina descrita poderá ser replicada em outros contextos em que o Scratch for utilizado e o material produzido poderá ser reutilizado e remixado em projetos similares.

Palavras-chave: Pensamento Computacional. Ética Hacker. Scratch.

\begin{abstract}
The introduction of computing concepts to young people is important because of its interdisciplinary character to other areas of knowledge. With the aim of stimulating the development of computational thinking, this article presents the design and evaluation of a Scratch course in the Jovem Hacker Project. The project studies ways to assist in the training of young people on the basis of the hacker ethic, important to guide the students to have a critical sense and a more openness to sharing ideas and software solutions. The workshop can be replicated to other contexts where the Scratch is used and the material produced can be reused and remixed in similar projects.
\end{abstract}

Keywords: Computational Thinking. Hacker Ethics. Scratch. 


\section{I ntrodução}

Atualmente, muitos referem-se aos jovens como "nativos digitais" devido a uma aparente fluidez com a tecnologia. De fato, a maioria deles sente-se confortável ao usar dispositivos diversos - mandam mensagens, usam jogos online, navegam na Internet. Mas isso os torna realmente fluentes com as novas tecnologias? Apesar de interagirem muito com mídias digitais, poucos são capazes de criar seus próprios jogos, animações ou simulações. É como se pudessem "ler", mas não "escrever". De acordo com Resnick e colegas (2009), fluência digital não se trata apenas de trocar mensagens, navegar e interagir usando o computador, mas também de ter a habilidade de imaginar, projetar e criar com novas mídias (RESNICK et al., 2009).

Mas para fazer isso é preciso aprender a programar. Com o intuito de contribuir com a formação de uma geração que seja mais capacitada tecnologicamente, surgiu o Projeto J ovem Hacker $^{1}$, que investiga maneiras de auxiliar na formação de uma geração mais autônoma tecnologicamente e se empodere dos rumos da nossa sociedade, tendo como base a ética hacker e o software livre (ARANTES et al., 2014; AMIEL et al., 2015).

O objetivo não é necessariamente preparar os jovens para carreiras profissionais da programação e da computação, mas nortear uma geração que seja mais criativa, com um pensamento mais sistemático, que se sinta confortável para expressar suas ideias (RESNICK et al., 2009).

O desenvolvimento do pensamento sistemático que a programação proporciona é chamado de "pensamento computacional". Cuny, Snyder e Wing (2010) definem pensamento computacional como sendo "os processos de pensamento envolvidos na formulação de problemas e suas soluções, sendo que as soluções são representadas de modo a serem efetivamente realizadas por um agente de processamento de informações". Uma ferramenta que tem se destacado nessa direção é o software livre Scratch ${ }^{2}$. De acordo com Brennan e Resnick (2012), ao programar e compartilhar projetos interativos em Scratch, crianças e adolescentes aprendem conceitos computacionais, além de aprenderem a pensar de maneira criativa e a trabalhar colaborativamente - habilidades importantes atualmente. Programar com Scratch, portanto, pode oferecer um contexto e um conjunto de oportunidades para contribuir com o desenvolvimento do pensamento computacional.

$\mathrm{Na}$ literatura, existem vários relatos do uso do Scratch com alunos do ensino fundamental e médio iniciantes em programação (AURELIANO e TEDESCO, 2012; SCAICO et al., 2013; FRANÇA e AMARAL, 2013; RODRIGUES et al., 2015). No entanto, além de ensinar programação, é preciso orientar os alunos a ter um senso crítico e uma ética que nortearão a maneira como irão lidar com o software e a tecnologia. Neste artigo, apresentamos o design de uma oficina de Scratch, no contexto do Projeto Jovem Hacker, o qual busca maneiras de auxiliar na formação de jovens considerando a ética hacker. Além de mostrar o design da oficina, consideramos importante também ter a avaliação da aprendizagem como uma prática

\footnotetext{
1 Sítio oficial: http://jovemhacker.org.

2 Sítio oficial: http://scratch.mit.edu.
} 
contínua que busca nortear a orientação aos aprendizes durante o processo de formação, bem como servir de elemento balizador para futuras edições do Projeto J ovem Hacker.

Dois assuntos são abordados neste artigo: (1) o design de uma oficina de Scratch com conceitos da ética hacker e (2) uma abordagem avaliativa para a oficina, que pode ser adaptada a outros contextos de formação com Scratch.

\section{Projeto J ovem Hacker}

De acordo com Amiel e colegas (2015), o projeto Jovem Hacker, fazendo jus ao seu nome, é fortemente alicerçado em uma cultura de partilha, busca do conhecimento e valorização da liberdade, pilares essenciais da cultura hacker.

Os hackers não programam necessariamente por ganhos financeiros, mas porque sentem prazer em fazê-lo. Linus Torvalds costuma dizer que "para um hacker, o computador por si só já é uma diversão" (HIMMANEN, 2001, p. 19). Muitos bons projetos podem ser resultado desse tipo de atividade, como ocorreu com o sistema operacional Linux, a World Wide Web e tantas outras criações relevantes (HIMMANEN, 2001).

No projeto Jovem Hacker, criamos uma estrutura de curso focada na apropriação tecnológica que perpassa o hardware e o software. Com base em uma noção emancipatória da tecnologia, uma ética hacker fundamentada no software livre e no pensamento computacional, o Projeto propõe a estrutura de um curso através das seguintes oficinas modulares (ARANTES et al., 2014; AMIEL et al., 2015):

i) Arquitetura básica de computadores e de software.

ii) Lógica de programação ou introdução ao pensamento computacional com Scratch.

iii) Desenvolvimento web com HTML, CSS e JavaScript.

iv) Introdução de uma linguagem de programação para web (e além) utilizando Python.

v) Como momento final da formação é definido, em conjunto com os alunos, um projeto de interesse coletivo ou individual, desenvolvido com base nas atividades apresentadas nas oficinas.

Em 2015, o Projeto J ovem Hacker aconteceu em paralelo em duas cidades e dois contextos diferentes, enriquecendo nossas bases para pesquisa e melhoria da proposta - Edição Cultura Campinas e Edição IFSP Capivari. Mais informações sobre as edições do Projeto e sobre o currículo podem ser obtidas em Amiel e colegas (2015).

Neste artigo, apresentamos e discutimos a oficina de Scratch que aconteceu na Edição Cultura Campinas, entre maio e dezembro de 2015. O material produzido nessa edição está disponível no sítio do Projeto ${ }^{3}$.

\section{Trabalhos Relacionados}

Quando os computadores foram introduzidos nas escolas, na década de 80 , houve um entusiasmo para ensinar crianças e adolescentes a programar. Papert apresentou a linguagem Logo como uma nova maneira de pensar a educação e o aprendizado (PAPERT, 1980). O

\footnotetext{
${ }^{3}$ Material disponível no sítio do Projeto em http://wiki.jovemhacker.org/index.php/Material
} 
construtivismo de Papert colocava o computador como uma ferramenta que a criança podia controlar e programar, a linguagem Logo tornou-se uma poderosa aliada na construção do conhecimento.

Entretanto, aquele entusiasmo inicial durou pouco. A maioria das escolas passou a utilizar o computador para outras tarefas, tais como criar textos e navegar na Internet. Desde então, a tecnologia evoluiu muito e os computadores diminuíram ainda mais de tamanho - dispositivos móveis tornaram-se parte da rotina de crianças e adolescentes.

Nos últimos anos, as tentativas de introduzir programação para crianças e adolescentes têm voltado à tona. Algumas iniciativas surgiram nos Estados Unidos, com projetos como code.org ${ }^{4}$, pois estima-se que em poucos anos faltará mão de obra qualificada para atuar no mercado de trabalho americano na área de programação.

No Brasil surgiram algumas iniciativas que são basicamente extensões de projetos dos Estados Unidos. Um exemplo é o Projeto Code Club ${ }^{5}$, cujo objetivo é oferecer a oportunidade para crianças aprenderem a programar. Para isso, o projeto oferece material de ensino para uma rede de voluntários apoiar a realização de atividades extracurriculares ligadas à programação de computadores. A primeira parte do projeto utiliza Scratch para estimular o desenvolvimento do pensamento computacional.

Alguns projetos introduzem a programação por meio de oficinas como forma complementar ao ensino. No trabalho de França e Amaral (2013), os autores descrevem a realização de uma oficina em Scratch para estimular o pensamento computacional em estudantes do ensino básico de uma escola pública de Pernambuco. Os autores aplicam e avaliam conceitos computacionais propostos por Brennan e Resnick (2012) e apresentam resultados positivos que podem ser explorados com o uso do Scratch para disseminar o pensamento computacional, em conjunto com avaliação contínua.

O trabalho desenvolvido por Scaico e colegas (2013) utilizou Scratch com o intuito de ensinar programação a alunos do ensino médio do interior da Paraíba. O artigo relata uma olimpíada de programação, onde os alunos foram estimulados a enfrentar diversas situações que envolviam conceitos computacionais e exigiam esse conhecimento para a solução de problemas.

No trabalho de Rodriguez e colegas (2015), os autores descrevem um projeto com o objetivo de desenvolver noções básicas do pensamento computacional junto a sete alunos do primeiro ano do ensino médio de uma escola pública, por meio dos recursos do Scratch, no âmbito de um programa de Pré-Iniciação Científica. Como resultado, os autores destacam três jogos desenvolvidos pelos alunos que permitiram verificar como se apropriaram dos recursos cognitivos inerentes ao pensamento computacional.

O Projeto Jovem Hacker não tem como objetivo necessariamente ensinar a programar. Seu diferencial é justamente entender as diferentes metodologias e objetivos do "aprender a programar". O projeto procura despertar no jovem a habilidade de partir de algo que existe, para então fuçar, remixar e alterar para outros propósitos (AMIEL et al., 2015). Aliado a isso, o

\footnotetext{
${ }^{4}$ Sítio oficial: https://code.org.

5 Sítio oficial: http://codeclubbrasil.org.
} 
projeto também está fortemente alicerçado a uma ética hacker, que acreditamos contribuir com uma geração tecnologicamente mais independente e que possa fazer parte de um futuro com mais compartilhamento e abertura tecnológica.

$\mathrm{Na}$ próxima seção, abordaremos o conceito de ética hacker, sua relação com o Projeto J ovem Hacker e, consequentemente, com a oficina de Scratch apresentada neste artigo.

\section{A Ética Hacker}

No mundo da tecnologia, muito se ouve falar sobre hackers. Uma definição muito utilizada para o termo diz que hackers são "indivíduos que se dedicam com entusiasmo à programação, que acreditam que o compartilhamento de informações é um bem poderoso e positivo" (HIMMANEN, 2001). Muitos confundem o termo hacker com cracker. Esse segundo é o termo usado para designar quem pratica a quebra (ou cracking) de um sistema de segurança, usam seu conhecimento de forma ilegal, portanto, são vistos como criminosos ${ }^{6}$.

Ética pode ser definida como um conjunto de valores morais e princípios que norteiam a conduta humana na sociedade. Pekka Himanem (2001) descreveu a ética dos hackers através de sete valores que considerou importantes para a maioria dos hackers:

(i) Paixão: o fator gerador de alegria e motivação para o trabalho dos hackers é a paixão, o que justifica o trabalho empregado no alcance de seus objetivos.

(ii) Liberdade: a ética de trabalho dos hackers consiste em combinar paixão com liberdade.

(iii) Valor Social: os hackers não dão prioridade aos lucros, mas sim em criar soluções que sejam úteis para a sociedade como um todo. Ao mesmo tempo, também buscam destaque dentro das comunidades em que atuam e esperam reconhecimento pelas suas criações.

(iv) Abertura: muitos hackers disponibilizam suas criações gratuitamente para que outras pessoas possam utilizá-las e melhorá-las. Esse compartilhamento contribui para que as soluções fiquem mais completas e robustas, além de aumentar o alcance de suas criações.

(v) Atividade: os hackers defendem a ideia de que a comunidade deve ser participativa e auxiliar na construção dos ambientes de informação.

(vi) Consideração: os hackers defendem a ideia de que os recursos tecnológicos são como fontes públicas, motivando as pessoas a serem mais ativas na defesa da liberdade na Internet, por exemplo.

(vii) Criatividade: há um desejo dos hackers por melhorar constantemente suas criações através da criatividade.

De acordo com Araldi e colegas (2015), a definição de ética hacker usada por Pekka Himanen (2001), deixa evidente a busca pela evolução da sociedade através do compartilhamento de habilidades técnicas, o que pode contribuir para um mundo melhor e mais justo para todos.

\footnotetext{
${ }^{6}$ Consulte o sítio: http://olhardigital.uol.com.br/noticia/qual-a-diferenca-entre-hacker-e-cracker/38024.
} 
Para o Projeto Jovem Hacker, programação é uma habilidade como correr, ler, escrever e várias outras que as pessoas podem aprender. Da mesma forma, hacker não é um talento mas uma habilidade muitas vezes associada com procurar e explorar falhas em um computador ou uma rede de computadores, modificar software ou hardware de um computador pessoal e contornar limitações de forma criativa ${ }^{7}$. Nesse contexto, se a ética hacker for abordada desde o início da atividade de programação dos novatos, então há uma chance maior de enxergar a tecnologia com um olhar mais voltado à liberdade e à partilha de informação.

\section{Desenvolvimento do pensamento computacional com valores da ética hacker}

Nesta seção, relataremos a oficina de Scratch realizada no Projeto Jovem Hacker. A oficina aconteceu durante o mês de junho de 2015, foram 4 encontros, com duração de 4 horas cada, totalizando 16 horas. Quinze jovens, com idades entre 13 e 16 anos participaram da oficina, que aconteceu no espaço Minha Campinas ${ }^{8}$.

A metodologia adotada foi adaptada de Brennan e Resnick (2012), que abordam os seguintes conceitos computacionais: sequência, evento, paralelismo, loop, condicionais, operadores e dados. Além disso, essa metodologia introduz práticas comuns em programação, tais como iteratividade, teste e depuração, reuso e remix, abstração e modularização.

Acrescentamos à metodologia de Brennan e Resnick (2012) os conceitos de passagem de mensagem (sincronização), procedimentos e passagem de parâmetros, pois esses conceitos são importantes para aqueles que irão experimentar outras linguagens além do Scratch, como é o caso dos alunos do Projeto. Além disso, enfatizamos as práticas de remix e compartilhamento, importantes para estimular a ética hacker nos jovens.

Todas as oficinas do Projeto Jovem Hacker utilizaram apenas software livre. É importante diferenciar aqui software livre de software gratuito. O software gratuito (freeware) é um programa de computador que as pessoas podem utilizar sem pagar. Já o software livre (free software ou open source software) é qualquer software cuja licença garanta ao seu usuário liberdades relacionadas ao uso, alteração e redistribuição. Exemplos de licenças de software livre são GNU-GPL, Apache, BSD, MIT, dentre outras. Uma lista completa das licenças pode ser consultada em FSF (2016a).

Mais especificamente, software livre se refere à existência simultânea de quatro tipos de liberdade, definidas pela Free Software Foundation (FSF, 2016b):

1. A liberdade de executar o programa, para qualquer propósito (liberdade no 0)

2. A liberdade de estudar como o programa funciona, e adaptá-lo para as suas necessidades (liberdade $\mathrm{n}$ - 1 ). Acesso ao código-fonte é um pré-requisito para esta liberdade.

3. A liberdade de redistribuir cópias de modo que você possa ajudar ao seu próximo (liberdade no 2).

4. A liberdade de aperfeiçoar o programa, e liberar os seus aperfeiçoamentos, de modo que toda a comunidade se beneficie (liberdade no 3). Acesso ao códigofonte é um pré-requisito para esta liberdade.

\footnotetext{
${ }^{7}$ Consulte a página: http://material.jovemhacker.org/apresentacao/01-bem-vindo.html.

${ }^{8}$ Sítio oficial: http://www. minhacampinas.org.br.
} 
Para a oficina, usamos o Scratch versão 1.4, uma versão mais antiga do Scratch, mas que é totalmente livre (independente de softwares proprietários para sua execução). O Scratch 2.0 é mais recente, mas apesar de também ser livre, utiliza o software Flash ou o Adobe Air para executar, ambas tecnologias proprietárias/fechadas, apesar de gratuitas. Nas próximas subseções, apresentaremos os conceitos desenvolvidos na oficina.

\subsection{Sequência}

A sequência é a organização lógica das instruções necessárias para que um programa seja executado com êxito. A Figura 1 mostra um exemplo de programa que deixa claro que a sequência dos comandos é muito importante para o resultado final. Nesse exemplo a abelha precisa desenhar um " $X$ " na tela. Os comandos de abaixar, levantar a caneta e deslizar devem respeitar uma determinada sequência para alcançar o resultado esperado.

Figura 1 - Exemplo de programa para explorar o conceito de sequência.
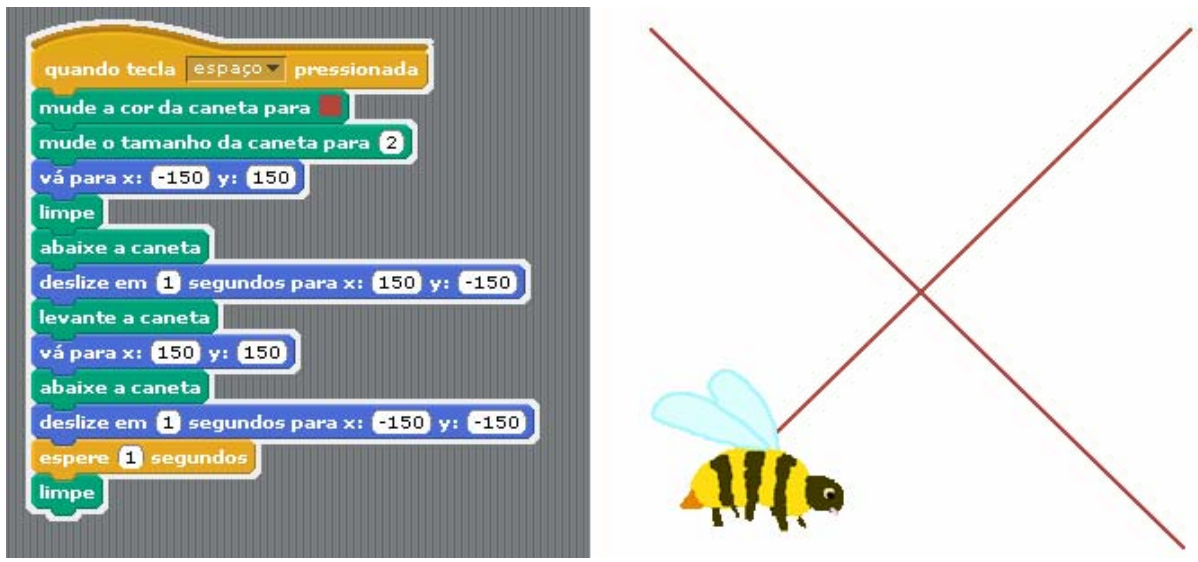

Fonte: Elaborada pelos autores.

\subsection{Eventos e Passagem de Mensagem}

O evento é um acontecimento que produz uma ação. O início de um programa normalmente está associado a um evento - um clique no mouse ou uma tecla pressionada, por exemplo.

Os eventos possuem grande utilidade em relação à sincronização das ações de mais de um objeto. Os objetos em Scratch, referidos como sprites, não podem chamar os scripts uns dos outros diretamente. Ao invés disso, o Scratch usa um mecanismo de broadcast para suportar comunicação e sincronização entre sprites (MALONEY et al., 2010). Qualquer sprite pode fazer o broadcast de uma mensagem (uma string qualquer) utilizando os comandos apresentados na Figura 2(b). Sincronização e passagem de mensagem são considerados conceitos avançados de programação, mas no Scratch eles são tratados de uma maneira muito simples, o que facilita o entendimento por parte de iniciantes em programação.

Para introduzir o conceito de eventos com passagem de mensagem, mostramos um exemplo onde havia um diálogo entre um gato e um cachorro. Primeiramente, mostramos a sincronização do diálogo usando tempo e falamos sobre as limitações dessa abordagem. Em 
seguida, o mesmo diálogo foi reconstruído usando eventos para sincronizar as falas. Por fim, foi proposto aos estudantes um exercício no qual teriam de criar uma animação com diálogo empregando os eventos para sincronizar os personagens.

\subsection{Paralelismo}

O paralelismo possibilita que sequências de instruções sejam executadas ao mesmo tempo. Esse conceito, também conhecido como multi-threading, usualmente é considerado uma técnica de programação avançada. Mas a natureza do Scratch torna o conceito fácil de ser absorvido pelos iniciantes em programação. Nosso dia a dia é altamente paralelo, então é natural para os usuários do Scratch terem seus personagens fazendo várias coisas ao mesmo tempo ou ter vários personagens na mesma cena.

Durante a oficina, os conceitos de concorrência e paralelismo foram abordados no diálogo do gato e do cachorro descrito na seção anterior, pois é um exemplo que mostra dois personagens realizando ações simultaneamente. Os exemplos a partir daqui são praticamente todos com ações simultâneas, o que contribui para o conceito ser absorvido pelos alunos.

\subsection{Laços}

O laço ou loop é um comando que tem como função repetir um trecho de sequências quantas vezes forem necessárias. No Scratch há dois tipos de laços, o laço sempre, que repetirá os comandos indefinidamente, e o laço repita, no qual é possível definir o número de vezes da repetição. Dois exercícios sobre este conceito foram apresentados, tendo como objetivo saber se os alunos escolheriam o melhor laço para cada situação e se usariam o laço corretamente. O primeiro exercício era para "tocar uma música e fazer um personagem dançar" o segundo era para "animar pelo menos quatro personagens no fundo do mar", onde cada personagem teria um laço.

\subsection{Condicionais e Operadores}

Os condicionais são blocos de comandos que permitem que decisões sejam tomadas tendo em vista condições pré-definidas. No bloco abaixo, SE a <condição> for verdadeira, ENTÃO a <açãol> é executada, SENÃO a <ação2> é executada.

SE <condição>

ENTÃO <açãol>

SENÃO <ação2>

Os blocos de condicionais devem ser utilizados em conjunto com as condições. Por sua vez, as condições podem ser criadas utilizando operadores relacionais e/ou operadores lógicos.

A instrutora explicou o conceito e, em seguida, fez um exercício junto com os alunos, onde um cachorro perseguia um gato usando as teclas de navegação. O gato, por sua vez, fugia do cachorro também usando teclas de navegação. Em seguida, cinco exercícios envolvendo condicionais foram propostos. A descrição completa dos exercícios pode ser encontrada no sítio 
do Projeto J ovem Hacker na parte de Condicionais e Operadores do material de Scratch ${ }^{9}$.

\subsection{Variáveis}

As variáveis são utilizadas para guardar valores nos programas. Por exemplo, ao fazer um jogo em que haverá contagem de pontos, é preciso que exista uma variável para guardar essa pontuação.

Na maioria das linguagens de programação textuais, as variáveis são abstratas, o que leva muitos iniciantes a terem dificuldades para compreender seu conceito. Em Scratch, as variáveis são mais concretas, isto é, os usuários podem vê-las, arrastá-las e manipulá-las como fazem com os demais comandos. Além disso, a tipagem de dados é mais simples, as variáveis podem armazenar três tipos de dados - booleanos, numéricos e strings.

O conceito de variáveis foi introduzido por meio de uma dinâmica, que trabalhava também o conceito de condicional. A dinâmica foi feita tendo como exemplo o jogo do Pong com pontos. $\mathrm{Na}$ primeira parte os alunos se dividiram em quatro grupos. Os grupos receberam tiras de tecido EVA coloridas, onde estavam escritos os comandos correspondentes ao script da bolinha do jogo. A instrutora perguntava qual comando eles achavam que deveria ser utilizado para realizar os movimentos da bolinha. O grupo que tinha o comando consigo se manifestava e juntos - alunos e instrutora - montaram o script da bolinha.

Depois dos scripts prontos, iniciamos a segunda parte da dinâmica - a simulação da execução do programa. Durante a simulação, a variável foi incrementada com pequenos pedaços de chocolate. Com isso, foi possível mostrar o que acontecia com a bolinha e com a variável a cada iteração do laço de cada thread concorrente. Foi uma maneira diferente e descontraída de mostrar conceitos importantes como variáveis, condicionais e concorrência. Mais detalhes sobre a dinâmica podem ser encontrados em Arantes e Ferreira (2015).

Em seguida, a instrutora mostrou o código do Rail Rush (trem e carro) e pediu para usar variáveis para fazer as seguintes alterações: (i) cada vez que o carro atravessar sem bater no trem, o jogador ganha 1 ponto; (ii) o jogo acaba em 30 segundos ou se o trem bater no carro.

O segundo exercício era da bruxa e do fantasma e nele havia três tarefas: (i) adicionar um ponto para cada segundo que a bruxa não tocar no fantasma; (ii) acabar o jogo em trinta segundos e (iii) perder cinco pontos toda vez que a bruxa tocar no fantasma.

\subsection{Procedimentos e Passagem de Parâmetros}

Os procedimentos e as funções são maneiras de modularizar os programas para que fiquem mais fáceis de entender e modificar. São recursos muito importantes, pois estruturam o programa e evitam repetição de código.

O Scratch 1.4 não trabalha com procedimentos nem com funções. O Scratch 2.0 suporta apenas procedimentos de uma maneira bem limitada:

- Os comandos e procedimentos operam apenas no sprite onde aparecem - um sprite não pode invocar um comando ou procedimento em outro sprite. Isto significa que o mesmo

\footnotetext{
${ }^{9}$ Material sobre operadores e condicionais em Scratch: http://wiki.jovemhacker.org/index.php/Condicionais_e_Operadores
} 
procedimento não pode ser usado em objetos diferentes daquele onde o procedimento foi declarado. Essa limitação torna os procedimentos pouco úteis no Scratch, pois uma das vantagens da sua utilização é poder reutilizar código.

- Não é possível chamar um procedimento dentro dele mesmo (não possibilita recursão).

Apesar dessas limitações no Scratch, o conceito de procedimento com passagem de parâmetro foi incluído em nossa oficina pelos seguintes motivos:

- A abstração procedural é uma das grandes ideias da ciência da computação, com grande valor para estruturar programas. Como o objetivo do projeto Jovem Hacker é abordar outra linguagem de programação depois do Scratch, achamos melhor mostrar o conceito de procedimentos.

- Ao explorar outros programas em Scratch, os alunos certamente iriam se deparar com procedimentos. Então é importante que conheçam esse conceito.

Entretanto, para praticar e ver exemplos com procedimentos foi necessário usar o Scratch 2.0. Ao justificar o uso do Scratch 2.0 para os alunos, aproveitamos para falar sobre software livre e software proprietário, pois apesar de ser um software livre, o Scratch 2.0 usa o Flash para executar, que é um software proprietário. Explicamos aos alunos que o software livre está de acordo com as quatro liberdades mencionadas no início da seção 5 . Por outro lado, o software proprietário não dá acesso ao código-fonte e, apesar de muitos serem gratuitos, não significa que são livres.

Foi importante também diferenciar código-fonte e arquivo executável. O código-fonte é o conjunto de palavras e símbolos contendo as instruções do programa, escritas em uma linguagem de programação como C, Java, Python, dentre outras. Para ilustrar, mostramos o exemplo de uma instrução condicional na linguagem C e a comparamos com uma em Scratch. A instrutora explicou que para modificar o programa é preciso ter o código-fonte e, em linhas gerais, é isso que diferencia o software livre dos softwares proprietários. Depois que o programa foi escrito usando uma linguagem de programação, é comum gerar um arquivo executável do programa para que as pessoas possam executá-lo sem precisar do código-fonte. Explicamos que, quando o programa é proprietário, o usuário tem acesso apenas ao arquivo executável, por isso não é possível alterar o programa.

Os procedimentos no Scratch 2.0 são definidos na aba Mais Blocos. O trecho da Figura 2 mostra a definição de um procedimento chamado velocidade.

Figura 2 - Exemplo de procedimento em Scratch.

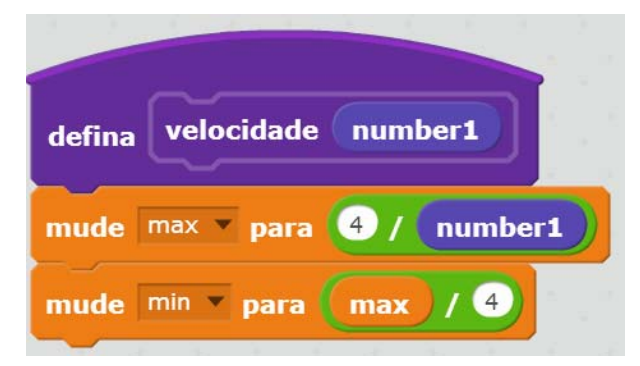

Fonte: Elaborada pelos autores. 
O procedimento velocidade recebe o parâmetro number1. O parâmetro é uma variável local, que pode ser utilizada apenas dentro desse procedimento. Nesse exemplo, o procedimento velocidade irá modificar os valores das variáveis max e min de acordo com o valor passado para o parâmetro number1.

Um exemplo completo que utiliza o procedimento acima pode ser acessado na comunidade do Scratch $^{10}$.

\subsection{Remix e Compartilhamento}

Fazer remix e compartilhamento de código é muito comum e desejado quando se trabalha com software livre. O remix consiste em utilizar partes dos programas de outras pessoas para fazer o seu programa. O compartilhamento acontece quando você mostra o código fonte do seu programa para os outros de maneira livre (usando licenças livres). Assim, outras pessoas poderão utilizar na íntegra ou remixar o seu programa.

Para fazer remix e compartilhamento de programas em Scratch, é preciso entrar na comunidade do Scratch $2.0^{11}$ e fazer um rápido cadastro. É possível examinar os projetos disponíveis na comunidade sem ter um login e uma senha, mas para fazer remix e compartilhamento é preciso tê-los.

$\mathrm{Na}$ comunidade, é possível remixar, compartilhar, discutir e receber feedback de seus projetos. Além disso, explorar projetos de outros autores pode servir como fonte de inspiração para novos projetos e aprendizado de novas técnicas de programação (Resnick et al., 2009).

Faz parte da ética hacker criar uma cultura onde o programador sente-se orgulhoso, e não aborrecido, quando seu projeto é adaptado e remixado por outros. De acordo com Resnick e colegas (2009), na comunidade do Scratch 2.0, quando alguém remixa um projeto, o sítio automaticamente adiciona um link de volta ao projeto original como uma maneira do autor ter os créditos. Além disso, cada projeto tem um link para seus "derivados" (projetos que foram remixados a partir dele) e os projetos mais remixados são destacados no sítio.

No último encontro da oficina, todos entraram na comunidade Scratch e exploraram projetos já existentes. Em seguida, a instrutora pediu que os alunos criassem um projeto para ser compartilhado - que podia ser remixado ou não. Dos 14 alunos que estavam presentes nesse encontro, 7 (50\%) compartilharam o projeto na comunidade.

Aqueles que não compartilharam, não o fizeram devido aos seguintes motivos:

- um aluno $(7,1 \%)$ achou que o projeto não ficou bom;

- três $(21,4 \%)$ gostariam de compartilhar, mas não souberam como fazê-lo;

- um $(7,1 \%)$ achou que não valia a pena compartilhar porque muitos já haviam compartilhado o mesmo projeto;

- dois (14,2\%) não concluíram o projeto no tempo disponível.

Os dois alunos que não terminaram o projeto afirmaram que concluiriam em casa e compartilhariam em seguida.

Um fato que merece destaque é que os alunos escolheram projetos pequenos e remixaram

${ }^{10}$ Exemplo completo com o procedimento velocidade: https://scratch. mit.edu/projects/67670514

${ }^{11}$ Sítio oficial da comunidade do Scratch: http://scratch. mit.edu 
pouco. Por exemplo, um aluno escolheu um projeto que gerava fractais indefinidamente. Ele remixou partes do projeto que mudavam os fractais de cor e de tamanho. Outro aluno remixou o projeto do labirinto, um dos mais populares da comunidade do Scratch, alterando os tamanhos de alguns obstáculos.

Boa parte do trabalho intelectual do remix está em ler e entender o código (ou partes dele). Os alunos encontraram programas interessantes que gostariam de remixar, mas ao abrir o código, ficaram assustados com o grande tamanho e muitos desistiram de tentar entender por falta de tempo e experiência em ler código. Acreditamos que isso se deve ao fato de não termos solicitado aos alunos para "ler código". Então, em uma próxima oficina, é bom reservar um tempo para praticar leitura de código antes de falar sobre remix e compartilhamento.

Todos gostaram muito dessa atividade de exploração e deram depoimentos como "gostei muito da comunidade e de ver como há tantos projetos e animações, gostei muito de criar o remix e mexer na comunidade", "bem empolgante", "interessante, onde posso compartilhar descobertas e ideias".

\section{Valores da ética hacker aplicados à oficina de Scratch}

O Projeto Jovem Hacker foi pensado de maneira a valorizar práticas e conceitos que são comuns na ética hacker. Durante a oficina descrita na seção anterior, conceitos e práticas da cultura hacker foram trabalhados da seguinte maneira:

- Procuramos despertar nos jovens o gosto (a paixão) pela computação e pela programação, procurando desmistificar que programar é algo difícil e acessível a uma minoria. Uma das maneiras de atingir esse objetivo foi trabalhar a programação de uma maneira divertida/lúdica e criar condições para que os jovens se interessarem pelo que estavam aprendendo e realizando. Uma atividade lúdica está relacionada ao entretenimento, que dá prazer e diverte as pessoas envolvidas. Atividades desse tipo, usualmente, estão relacionadas a jogos e ao ato de brincar. Os conteúdos lúdicos são importantes para incutir nas pessoas a noção de que aprender pode ser divertido. O uso do Scratch ajudou muito nesse sentido, pois seu ambiente oferece recursos para criar jogos e outros tipos de animações, o que favorece o aprendizado de conceitos computacionais considerados avançados de uma maneira mais lúdica e atrativa.

- $\quad$ Mostramos que o software livre é útil para a sociedade como um todo, pois empresas e órgãos públicos encontram nas soluções livres uma maneira para racionalizar seus custos e despesas, já que não há a necessidade de pagar um valor para licenças de uso.

- Mostramos que é importante dar reconhecimento e créditos para aquele que criou ou contribuiu com determinada solução. Conforme mencionado na seção 5.8, faz parte da ética hacker criar uma cultura onde o programador sinta-se orgulhoso, e não aborrecido, quando seu projeto é adaptado e remixado por outros. Trabalhamos essa questão durante a aula de remix e compartilhamento, onde cerca da metade dos alunos compartilhou suas soluções.

- Mostramos aos jovens que existem as comunidades de software livre, onde várias pessoas se envolvem em atividades para auxiliar uns aos outros na construção de 
soluções de software. Essa ideia de comunidades também vai ao encontro da concepção de que o software deve ser um recurso público, que todos podem utilizá-lo e melhorá-lo, para que as soluções fiquem mais robustas e aumentem seu alcance. Em nosso último encontro, os jovens participaram da comunidade do Scratch, explorando e remixando as soluções de outras pessoas. Procuramos mostrar que é construtivo usar sua criatividade para melhorar sua própria solução e para contribuir com a solução de outros. Também citamos as comunidades GNU/Linux, que é o sistema operacional instalado nas máquinas usadas no Projeto Jovem Hacker, mas os jovens não chegaram a entrar/participar nessas comunidades.

\section{Avaliação Formativa}

Com relação à avaliação, evitamos instrumentos como provas, pois nosso objetivo era que a oficina fosse divertida e agradável e as provas poderiam desmotivar os alunos devido ao seu sentido de cobrança. A avaliação foi feita com base nos exercícios desenvolvidos durante a oficina (conforme seção 5), o que caracteriza uma natureza formativa. Assim, foi analisada a coleção de trabalhos construídos ao longo da oficina, enfatizando a natureza evolutiva, ao invés da análise de um único projeto final, o que seria um exame somativo. Cada exercício foi avaliado considerando a correta utilização dos conceitos computacionais. Além disso, para cada exercício os alunos diziam o que acharam do nível de dificuldade. Podemos dizer, portanto, que a avaliação consistiu em 2 partes:

(i) Análise dos exercícios feitos pelos alunos: para tanto, no final de cada encontro, os instrutores gravavam em pendrives os programas que os alunos desenvolveram e analisaram seus conteúdos posteriormente. O gráfico da Figura 3 mostra os resultados da análise dos exercícios.

(ii) Impressões dos alunos com relação aos exercícios: no final de cada encontro, solicitamos resposta para a seguinte pergunta com relação ao nível de dificuldade dos exercícios: "Dê uma nota de 1 a 5 para o exercício, sendo 1-Muito difícil e 5-Muito fácil. Deixe em branco se não fez o exercício". Com essa pergunta, buscamos saber se os exercícios estão adequados para a oficina e se os alunos estão compreendendo os conceitos, pois assumimos que se estão achando os exercícios fáceis é porque estão assimilando os conceitos. O gráfico da Figura 4 mostra o resultado das impressões dos alunos com relação ao nível de dificuldade dos exercícios.

A análise dos exercícios feitos sobre o conceito de sequência (seção 5.1) mostrou que 14 dos 15 presentes $(93,3 \%)$ concluíram os três exercícios de maneira satisfatória. Cinco consideraram os exercícios fáceis $(33,3 \%)$, cinco difícil $(33,3 \%)$, quatro tiveram um pouco de dificuldade $(26,7 \%)$ e um não respondeu $(6,7 \%)$. Apesar das dificuldades relatadas por alguns, eles conseguiram realizar as atividades. Acreditamos que a dificuldade inicial deve-se ao fato do primeiro contato com Scratch ter sido algo novo, pois alguns só compreenderam conceitos de palco, mudança de trajes e animação de personagens depois da ajuda dos instrutores. Os alunos requisitaram ajuda dos instrutores para fazer o primeiro exemplo. Os outros dois exemplos, apesar de um pouco mais elaborados, foram feitos com pouca ajuda. 
Figura 3 - Gráfico mostrando o resultado da tabulação de dados dos exercícios feitos pelos alunos na oficina de Scratch.

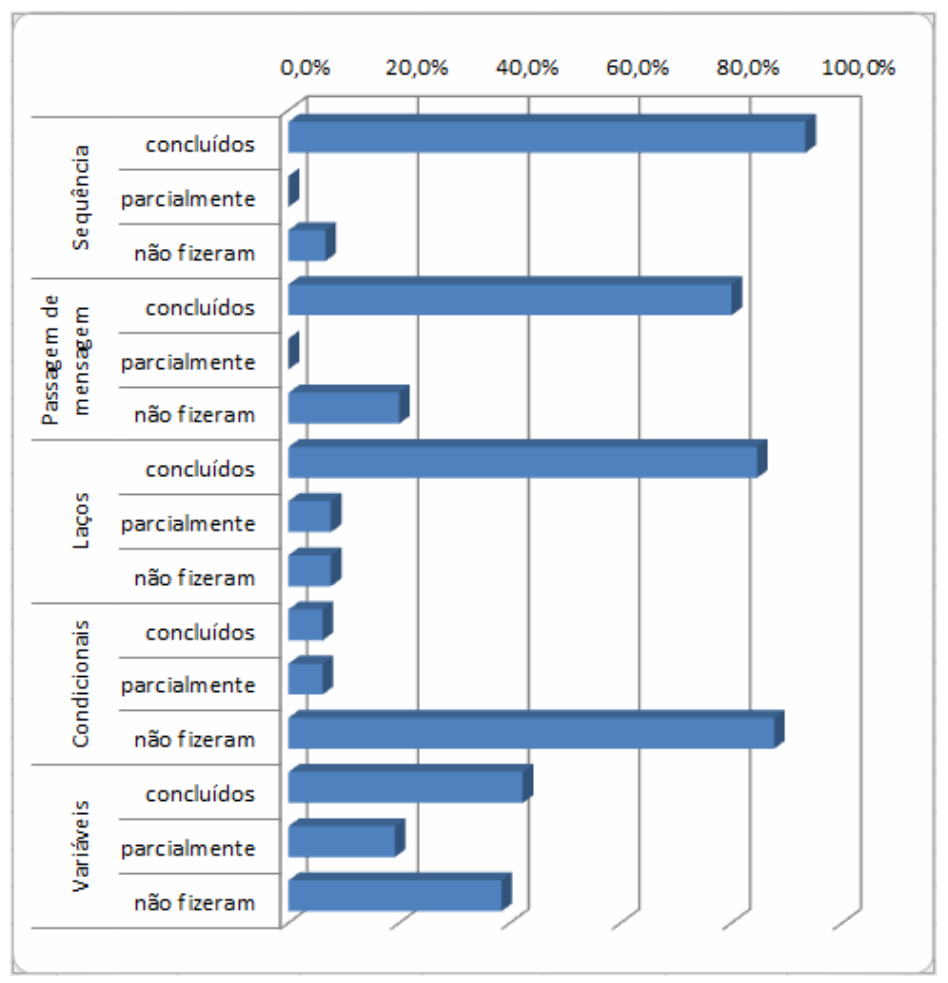

Fonte: Elaborada pelos autores.

Figura 4 - Gráfico mostrando os dados sobre as impressões dos alunos sobre o nível de dificuldade dos exercícios.

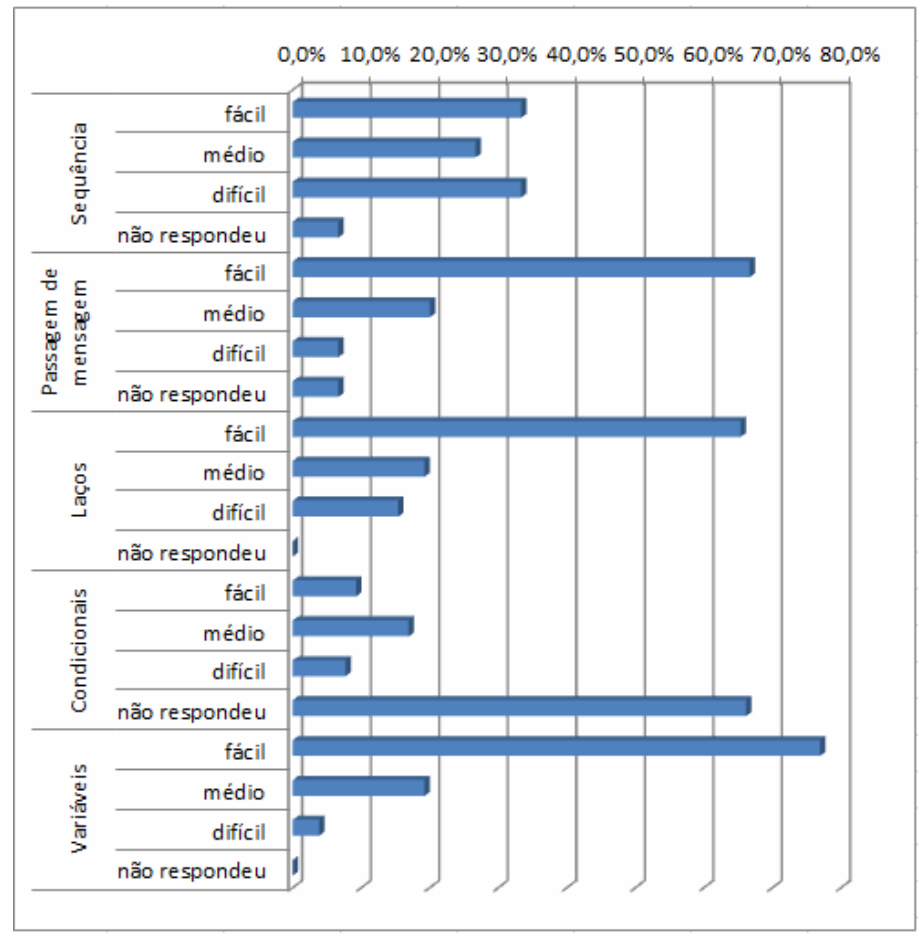

Fonte: Elaborada pelos autores. 
Com relação aos eventos e passagem de mensagem (seção 5.2), verificamos que doze dos quinze estudantes (80\%) finalizaram o exercício e a maioria $(66,7 \%)$ o classificou como fácil.

Conforme mencionado na seção 5.4, foram dois exercícios sobre laços. Doze dos treze estudantes que estavam presentes $(92,3 \%)$ concluíram o primeiro exercício com êxito. Com relação ao segundo exercício, dez estudantes concluíram com êxito (76,9\%), um concluiu de forma parcial $(7,7 \%)$ e um não fez a atividade $(7,7 \%)$ por não ter conseguido realizá-la no tempo disponível. A média dos alunos que concluíram os exercícios com êxito é $84,6 \%$. No nível de dificuldade atribuído aos exercícios sobre laços, a maioria dos alunos os classificou como fáceis (média de 65,4\%).

A instrutora solicitou cinco exercícios sobre condicionais com laços (seção 5.5 acima). Diferente dos outros exercícios, esses foram solicitados faltando pouco tempo para encerrar o encontro. Por esse motivo, a instrutora indicou para os alunos terminarem em casa. Os gráficos mostram a média dos resultados. Observe que os resultados do conceito de condicionais está discrepante, quando comparados aos outros exercícios. A maioria dos alunos fez no máximo um dos exercícios, outros fizeram apenas um exercício incompleto. Apenas um aluno fez dois exercícios em casa.

Um fato que chamou a atenção foi que alguns responderam sobre o nível de dificuldade dos exercícios sobre condicionais, mas não os fizeram. Acreditamos que isso se deve ao fato dos alunos terem explorado os exercícios e respondido às questões apenas com a primeira impressão que tiveram, pois o tempo da oficina não foi suficiente para terminarem. Isso ficou claro nas respostas sobre o exercício do fundo do mar, no qual 30,8\% classificaram o exercício como fácil, mas ninguém o concluiu com êxito. Uma possível explicação é que os alunos podem ter achado o exercício fácil, mas pouco atrativo. Podem não ter sentido motivação em fazê-lo, já que outros exercícios pareciam mais interessantes.

$\mathrm{Na}$ aula sobre variáveis (seção 5.6), alguns exercícios sobre condicionais que os alunos não fizeram em casa foram retomados e explorados. Dois deles foram solicitados como exercícios para serem feitos durante a aula, onde os alunos deviam usar as condicionais e acrescentar variáveis para contar pontos nos jogos. Para resolver o exercício do Rail Rush era preciso uma variável para o tempo e outra para a pontuação. Em relação à pontuação, nove dos treze estudantes $(69,2 \%)$ fizeram corretamente, e em relação ao tempo e finalização do jogo, sete dos treze estudantes $(53,9 \%)$ concluíram com êxito. Dez dos treze (77\%) estudantes classificaram este exercício como fácil.

Sobre o exercício da bruxa e do fantasma com variáveis, sete dos treze estudantes $(53,9 \%)$ adicionaram pontos com êxito. Sobre o tempo e finalização do jogo, sete dos treze estudantes $(53,9 \%)$ também conseguiram concluir. E em relação à perda de pontos, apenas quatro dos treze estudantes $(30,8 \%)$ conseguiram realizar corretamente. $\mathrm{Na}$ pergunta sobre as dificuldades encontradas no exercício, dez estudantes (77\%) classificaram como fácil, o que foi discrepante, já que apenas 4 alunos fizeram o exercício completo.

Ao analisar os gráficos das Figuras 3 e 4, percebemos que o Scratch apresenta-se como um ambiente que pode ser utilizado satisfatoriamente pelos jovens para o desenvolvimento de habilidades e conhecimentos relativos ao pensamento computacional. 


\section{Lições e Desafios}

Nesta seção, apresentamos as principais lições que aprendemos com a oficina de Scratch no contexto do Projeto Jovem Hacker, lições que servirão para refinarmos as próximas edições do Projeto. Apresentamos também alguns desafios que precisamos levar em consideração em edições futuras.

Uma das lições que aprendemos foi sobre deixar as aulas mais dinâmicas e participativas. Devido à aparente dificuldade que os alunos tiveram na aula sobre condicionais, o conceito de variáveis foi introduzido por meio de uma dinâmica, que trabalhava também com condicionais. A dinâmica do chocolate (ARANTES e FERREIRA, 2015) proporcionou uma maneira mais participativa e exploratória de apresentar a teoria, o que deixou a aula mais motivadora e descontraída.

Outra lição que aprendemos foi a de que solicitar muitos exercícios pode desmotivar os alunos, o ideal é solicitar um ou dois exercícios de cada vez. Na aula sobre condicionais, a instrutora solicitou muitos exercícios de uma só vez, o que não foi bom, pois os alunos não conseguiram fazer quase nenhum, porque preferiram explorar todos os exercícios ao invés de manter o foco na solução de um deles. Na ocasião, a instrutora aproveitou para incentivá-los a terminar os exercícios em casa, mas a maioria sequer tentou fazer. Para aprender uma linguagem de programação é preciso estudar, praticar, dedicar-se em casa. A oficina contou com 4 encontros com cerca de 4 horas cada - foram apenas 16 horas, pouco tempo para aprender lógica de programação, efetivamente. Então, um dos desafios deste projeto, que precisa ser levado em consideração nas próximas edições, é motivá-los a explorar e estudar fora das aulas presenciais, em casa e outros ambientes.

$\mathrm{Na}$ aula sobre laços e condicionais, notamos que alguns alunos se distraíram com joguinhos e celulares. Apesar dos instrutores terem chamado a atenção, essa distração certamente atrapalhou a realização dos exercícios e consequentemente a absorção do conceito de condicionais. Imaginamos que a distração se deve ao fato dos alunos terem percebido que não teriam tempo hábil para fazer os exercícios e/ou terem se sentido desmotivados a fazer os exercícios, por acharem difíceis ou pouco interessantes.

A aula que eles mais se interessaram e mantiveram o foco foi sobre exploração da comunidade do Scratch. Nas próximas edições, será reservado mais tempo para os alunos explorarem a comunidade, remixarem e compartilharem.

Ainda sobre a aula de remix e compartilhamento, antes de abordar propriamente o remix, consideramos que será mais adequado solicitar aos alunos que leiam o código. Boa parte do trabalho do remix está em ler e entender o código (ou partes dele). Muitos alunos encontraram programas interessantes que gostariam de remixar, mas não estavam habituados a ler o código e desistiram de tentar entender os programas que consideraram longos. Nas próximas edições, reservaremos um tempo para praticar leitura de código antes de abordar remix e compartilhamento.

A questão da avaliação e os conceitos de fácil e difícil são muito relativos, o que pode ser apontado como uma limitação desta pesquisa. Na avaliação realizada, procuramos obter 
informações dos alunos a respeito do nível de dificuldade dos exercícios. Entretanto, essa questão é muito particular. Outros alunos, de futuras edições do Jovem Hacker, poderão atribuir níveis de dificuldade diferentes, o que provavelmente levará a outros resultados.

\section{Considerações Finais}

O estudo apresentado neste artigo teve por objetivo demostrar as potencialidades do ambiente de programação Scratch na disseminação do pensamento computacional, permeado por conceitos da ética hacker.

Os resultados apontam que os jovens aprenderam diversos conceitos de Ciência da Computação através dos exercícios desenvolvidos durante a oficina - sequência, evento, passagem de mensagem, paralelismo, laços, condicionais, variáveis, procedimentos, passagem de parâmetros, variáveis, remix e compartilhamento. Mais que conteúdos, os jovens puderam conhecer e exercitar conceitos e práticas relacionados à ética hacker, tais como uso de software livre, despertar do gosto pela programação, exploração de uma comunidade, remix e compartilhamento de soluções de programação.

Considerando os resultados obtidos com a oficina, avaliamos que os objetivos inicialmente traçados foram alcançados. Com o uso do Scratch conseguimos explorar os conceitos computacionais apontados por Brennan e Resnick (2012) na disseminação do Pensamento computacional para jovens. Além disso, conseguimos explorar na prática conceitos da ética hacker, importantes para a formação de uma geração mais aberta ao compartilhamento de ideias e soluções de software. Por fim, os conteúdos puderam ser avaliados continuamente por meio de exercícios, possibilitando acompanhar a aprendizagem dos estudantes durante seu processo de formação.

A oficina para ensino e avaliação do pensamento computacional com valores da ética hacker poderá ser adaptada a outros contextos, bem como ser utilizada nas edições futuras do Projeto Jovem Hacker. O material que foi produzido na oficina, bem como os exercícios utilizados nas aulas e na avaliação, estão disponíveis sob licença pública Creative Commons no sítio do Projeto ${ }^{12}$.

\section{Agradecimentos}

Agradecemos à Secretaria de Cultura do Estado de São Paulo e ao FAEPEX da Unicamp pelo apoio financeiro ao Projeto J ovem Hacker.

Ao Raniere Silva, por ajudar a preparar o material que foi utilizado na oficina. Ao Felipe Rodrigues e ao Gabriel de Souza Fedel, pelo apoio durante as oficinas.

Por fim, agradecemos ao Minha Campinas pelo espaço físico cedido para realização das oficinas.

\footnotetext{
${ }^{12}$ Endereço com o material produzido no Projeto J ovem Hacker: http://wiki.jovemhacker.org/index.php/Material
} 


\section{Referências}

AMIEL, T.; FEDEL, G. S.; ARANTES, F. L.; AGUADO, A. G. Dominando para não ser dominado: Autonomia tecnológica com o projeto jovem hacker. In: WORKSHOP INTERNACIONAL DE SOFTWARE LIVRE, 16., 2015, Porto Alegre. Anais..., p.1-13.

ARALDI, M. L. C.; MARTINS, A. R. Q.; TEIXEIRA, A. C. Pesquisa de uso da ética hacker na formação de estudantes do ensino fundamental. In: WORKSHOP INTERNACIONAL DE SOFTWARE LIVRE, 16., 2015, Porto Alegre. Anais..., p. 1-13.

ARANTES, F. L.; AMIEL, T.; FEDEL, G. Nos rumos da autonomia tecnológica - desafios e lições aprendidas para a formação de jovens. In: WORKSHOP DE INFORMÁTICA NA ESCOLA, 20., 2014, Dourados, MS. Anais..., p.1-10.

ARANTES, F. L.; FERREIRA, J. M. L. S. Uma dinâmica para ensino de conceitos fundamentais de programação. In: WORKSHOP DE ENSINO EM PENSAMENTO COMPUTACIONAL, ALGORITMOS E PROGRAMAÇÃO (WAlgProg), 1., 2015, Maceió. Anais..., p. 1-10.

AURELIANO, V. C. O.; TEDESCO, P. C. A. R. Ensino-aprendizagem de programação para iniciantes: uma revisão sistemática da literatura focada no SBIE e WIE. In: SIMPÓSIO BRASILEIRO DE INFORMÁTICA NA EDUCAÇÃO, 23., 2012, Rio de Janeiro. Anais... , p. 1-10.

BRENNAN, K.; RESNICK, M. New frameworks for studying and assessing the development of computational thinking. In: ANNUAL MEETING OF THE AMERICAN EDUCATIONAL RESEARCH ASSOCIATION, 2012, Vancouver, Canada. Proceedings..., p. 1-25.

CUNY, J.; SNYDER, L.; WING, J. M. Demystifying computational thinking for non-computer scientists. Unpublished manuscript in progress, 2010. Disponível em: http://www.cs.cmu.edu/ CompThink/resources/TheLinkWing.pdf. Acesso em: 23 jan. 2017.

FRANÇA, R. S.; AMARAL, H. J. C. Proposta metodológica de ensino e avaliação para o desenvolvimento do pensamento computacional com o uso do Scratch. In: WORKSHOP DE INFORMÁTICA NA ESCOLA (WIE), 19., 2013, Campinas. Anais..., p. 179-188.

FREE SOFTWARE FOUNDATION (FSF 2016a). Various Licenses and Comments about Them. 2016. Disponível em: https://www.gnu.org/licenses/license-list.en.html. Acesso em: 23 de jan. 2017

FREE SOFTWARE FOUNDATION (FSF 2016b). O que é o software livre? 2016. Disponível em: https://www.gnu.org/philosophy/free-sw.html. Acesso em: 23 de jan. 2017

HIMANEN, P. A ética dos Hackers e o espírito da era da informação: a diferença entre o bom e o mau hacker. Rio de Janeiro: Editora Campus, 2001.

MALONEY, J.; RESNICK, M.; RUSK, N.; SILVERMAN, B.; EASTMOND, E. The Scratch programming language and environment. Transactions on Computers and Education, v. 10, n. 4, p.16:1-16:15, Nov. 2010.

PAPERT, S. Mindstorms: Children, Computers, and Powerful Ideas. New York: Basic Books, 1980.

RESNICK, M.; MALONEY, J.; MONROY-HERNÁNDEZ, A.; RUSK, N.; EASTMOND, E.; BRENNAN, K.; MI LLNER, A.; ROSENBAUM, E.; SILVER, J.; SILVERMAN, B.; KAFAI, Y. Scratch: Programming for all. Communications of the ACM, v. 52, n. 11, p.60-67, Nov. 2009.

RODRIGUEZ, C. L.; ZEM-LOPES, A. M.; MARQUES, L.; ISOTANI. S. Pensamento computacional: transformando ideias em jogos digitais usando o Scratch. In: WORKSHOP DE INFORMÁTICA NA ESCOLA (WIE), 21., 2015, Maceió, Brasil. Anais..., p. 1-10.

SCAICO, P.; DE LIMA, A.; AZEVEDO, S.; DA SILVA, J. B.; RAPOSO, E. H.; PAIVA, L. F.; ALENCAR, Y.; MENDES, J. P.; SCAICO, A. Ensino de programação no ensino médio: Uma abordagem orientada ao design com a linguagem Scratch. Revista Brasileira de Informática na Educação, v. 21, n. 02, p. 92-103, 2013. 
Recebido em outubro de 2016

Aprovado para publicação em agosto de 2017

Flávia Linhalis Arantes

Núcleo de Informática Aplicada à Educação (NIED) - Universidade Estadual de Campinas (UNICAMP) Campinas, SP, Brasil, farantes@unicamp.br

\section{Paula Eduarda J ustino Ribeiro}

Programa de Formação Interdisciplinar Superior (ProFIS) e Núcleo de Informática Aplicada à Educação (NIED) - Universidade Estadual de Campinas (UNICAMP) - Campinas, SP, Brasil,

rpaulaeduarda@gmail.com 


\title{
Experiência com Alunos Surdos no Ambiente Virtual de Aprendizagem do Curso de Letras/Libras/UFSC
}

\section{Experience With Deaf Students in the Virtual Learning Environment of the Letters/Brazilian Sign Language/UFSC Program}

\author{
CAMI LA GUEDES GUERRA GOES \\ Universidade Federal do Rio Grande do Sul \\ LUCILA MARIA COSTI SANTAROSA \\ Universidade Federal do Rio Grande do Sul
}

\begin{abstract}
Resumo: Este artigo apresenta um recorte da pesquisa desenvolvida sobre o primeiro curso de graduação de Licenciatura em Letras/Libras, na modalidade de Educação a Distância. O objetivo foi analisar as experiências dos alunos surdos nos aspectos da mediação da aprendizagem, a partir do referencial de Vygotsky e de considerações sobre a acessibilidade para atendimento das necessidades da comunidade surda num ambiente EaD. Os dados foram coletados, via questionário, em duas turmas de alunos. Os resultados apontam para a necessidade de maior adequação de aspectos sobre a acessibilidade das ferramentas e dos materiais utilizados para surdos, bem como pontuam necessidades no processo de mediação de professores/tutores, para o atendimento às necessidades desses alunos.
\end{abstract}

Palavras-Chave: Letras/Libras. Alunos surdos. Educação a distância. Ambiente virtual de ensino e aprendizagem. Experiências.

\begin{abstract}
This article presents part of the research developed about the first Distance Education teaching program in Letters/Brazilian Sign Language. The objective was to analyze the experiences of the deaf students in aspects concerning the mediation of learning, based on Vygotsky's theory and considerations on accessibility to meet the needs of the deaf community in a Virtual Learning Environment. Data were collected through a questionnaire in two groups of students. The results suggest the need for greater adequacy of aspects regarding the accessibility to the tools and materials used for the deaf, as well as they point out needs in the process of mediating lecturers/tutors, in order to meet the needs of these students.
\end{abstract}

Keywords: Letter/Brazilian Sign Language. Deaf students. Distance Education. Virtual Learning and Teaching Environment. Experiences. 


\section{I ntrodução}

Aspectos relacionados à surdez, ao longo da história, têm sido consolidados a partir de visões incorretas, decorrendo disso o aumento da exclusão e o não reconhecimento da capacidade dos surdos, considerados, nesta investigação, como pessoas usuárias da língua dos sinais.

Foi longa a caminhada para o reconhecimento dos direitos de todas as pessoas com deficiências. Com a Declaração Universal dos Direitos Humanos, num período pós-guerra, se inaugura uma fase de reconhecimento dos direitos de diferentes grupos sociais, luta essa iniciada pelas pessoas com deficiências, que passam a buscar um lugar de visibilidade na sociedade, de participação no espaço social, em igualdade com toda a população. Foi nesse momento que a comunidade surda iniciou sua luta política, social e de independência no tempo do ouvintismoi. Dessa forma, o surdo começou a ser o ator de sua história e, consequentemente, da trajetória da comunidade. Suas conquistas foram crescentes, mas foi com o reconhecimento de Libras como a língua oficial da comunidade surda que se abriu uma longa linha de pesquisa, principalmente, na área da linguística.

Discussões sobre a educação de surdos foram realizadas a partir dessas pesquisas, propostas novas foram surgindo centradas no bilinguismo, apontando uma mudança de paradigma. Cursos superiores com intérpretes de Libras foram surgindo e, inclusive, na Educação a Distância. Essa última, entendida como um sistema de ensino - aprendizagem diferenciado do convencional, exige uma nova metodologia, outras estratégias e, principalmente, outra postura por parte do aluno. Conforme Stumpf (2004, p. 49):

\footnotetext{
Educação a Distância (EaD) é uma forma sistematicamente organizada de autoestudo, onde o aluno se instrui a partir do material que lhe é apresentado. Pressupõe a combinação de tecnologias convencionais e modernas que possibilitam o estudo individual ou em grupo, através de métodos de orientação e tutoria à distância.
}

Stumpf (2004) esclarece que o processo de aprendizagem fica muito mais sob controle do aluno do que do professor, já que ele usa o computador à sua maneira e tem chance de explorar os recursos do jeito que Ihe convém. Sendo assim, facilita a construção de conhecimento, o que torna a EaD uma forma de ensino bastante flexível, ativa e atrativa para qualquer participante independentemente do seu estado físico, ou seja, tanto para as pessoas sem deficiência como para as pessoas com deficiência.

Porém, na EaD a relação entre os atores precisa ser outra para que ocorra o desenvolvimento dos alunos, e os professores/tutores terão que assumir uma nova postura: ser mediadores.

O conceito de Zona de Desenvolvimento Proximal (ZDP), desenvolvido por Vygotsky, é de extrema importância para a experiência educacional, inclusive na Educação a Distância, já que podemos compreender a dinâmica interna do desenvolvimento e do aprendizado como um estado em movimento. Sendo assim, propor estratégias que aproveitem a condição de autonomia da EaD, e as possibilidades de trocas entre os alunos a partir de fóruns, chats, 
postagens de análises de textos, enfim, propiciam o debate para então propor novos desafios. Santarosa (2006) propõe formas de como organizar um AVA (Ambiente Virtual de Aprendizagem) estruturado para o ambiente educacional, que busque o sucesso do aluno na sua aprendizagem. Entre elas, temos:

- A presença do diálogo/conversação síncrona/assíncrona (alunoaluno; aluno-professor) no contexto da aprendizagem em colaboração e interação social;

- Dinâmica de interação da dimensão de troca/cooperação/construção conjunta, na realização das atividades em rede;

- Apresentação de meios/ferramentas/softwares em rede, que gerem motivação intrínseca;

- Ênfase no desenvolvimento de processos mentais superiores em oposição à memorização/retenção de informação;

- Incentivo à exploração/descoberta na construção de conhecimento, na dimensão do construtivismo social no acesso/interação a ambientes virtuais.

- Ênfase na criação de conflitos cognitivos, do ponto de vista individual, e, principalmente, sócio cognitivos, do ponto de vista do grupo;

- O incentivo à interação/cooperação/construção no enfoque "todostodos", além do simples acesso à informação disponibilizada em rede.

- Criação de espaços de inclusão e oposição à segregação. (SANTAROSA, 2006, p. 9).

O papel do professor/tutor é considerado de extrema importância, já que esses sujeitos são mediadores diretos, que auxiliam nas tarefas e atividades nas quais o aluno necessita de mediação. Podemos considerar a figura do professor/tutor como a dos agentes presentes na mediação proposta por Vygotsky, como vemos na figura sugerida por Gallimore e Tharp (2002).

Figura 1 - A gênese de uma capacidade de desempenho: avanços para além da Zona de Desenvolvimento Proximal.

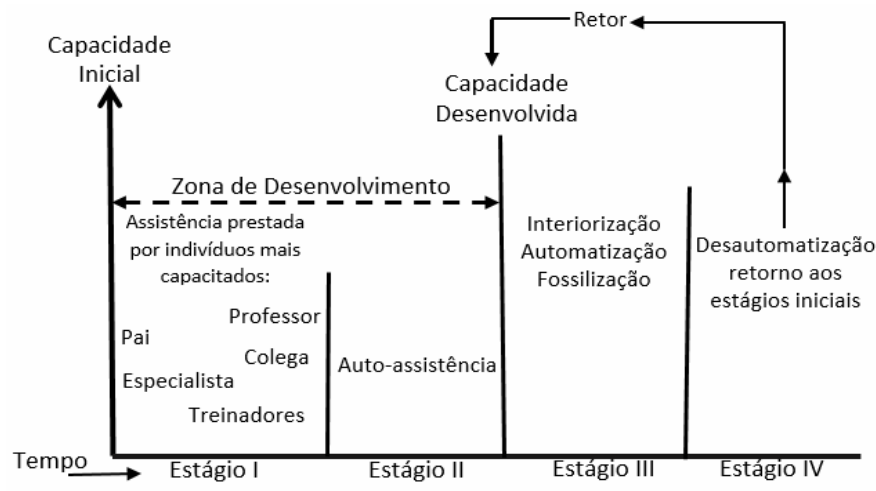

Fonte: Gallimore e Tharp (2002) 
Esta intervenção é considerada pelos autores de fundamental importância para o desempenho do aluno em direção à ZDR (Zona de Desenvolvimento Real), ou seja, aquele estágio em que ele realiza uma ação já esperada a partir de seu controle interno.

Nesse processo de mediação, não se pode esquecer que esse sujeito tem como língua materna a Língua de Sinais e sua aprendizagem apoiada na visão. As ferramentas de acessibilidade para surdos, nas quais a imagem deve estar presente, respeitando a modalidade viso-gestual da língua de sinais, estão disponíveis em alguns ambientes virtuais de ensinoaprendizagem, porém ainda encontramos muitos espaços de EaD que não contemplam essas necessidades dos alunos surdos. A utilização da webcam para gravação de arquivos de vídeo, sua postagem desses arquivos em fóruns, janelas com intérprete de Libras, videoconferências e outros recursos de acessibilidade para surdos são indicadores de qualificação de um ambiente virtual de aprendizagem, demonstrando uma preocupação real com a efetiva participação e aprendizagem destes sujeitos.

Importante salientar que as mediações têm que estar associadas à acessibilidade do ambiente virtual, já que, como colocado anteriormente, para ser efetiva a aprendizagem, a mediação tem de considerar as características dos sujeitos com os quais interage. O importante e necessário é que estes modelos de ensino-aprendizagem sejam adequados ao surdo em função da sua diversidade linguística, de seu meio visual de captação das informações e de seus canais de comunicação viso-gestuais. A língua de sinais é considerada a primeira língua para a comunidade surda e, portanto, é adequado que os ambientes de ensino-aprendizagem disponibilizem estratégias para a tradução Português/Libras.

A mediação dos tutores, o incentivo, a proposição de situações-problema que incentivem o aluno na busca de soluções, a troca de informações, enfim, toda a atitude que estimule o aluno a se movimentar em busca de aprendizagem são desafios que se apresentam na sala de aula online e responsabilidade de seus atores pedagógicos. A autonomia do aluno em sua interação com o ambiente é um dos objetivos propostos na Educação a Distância, sendo a aprendizagem colaborativa outro dos fundamentos desta modalidade e a acessibilidade em Língua Brasileira de Sinais premissa para esta efetividade.

As trocas entre os alunos, que formam uma comunidade de aprendizagem on-line, significam muito para que haja efetivação da aprendizagem, e os Ambientes Virtuais de Ensino e Aprendizagem (AVEAs) estão equipados com diferentes ferramentas e recursos onde é possível esta interação. As ferramentas de acessibilidade para surdos, nas quais a imagem deve estar presente, respeitando a modalidade viso-gestual da língua de sinais, estão disponíveis em alguns ambientes virtuais de ensino-aprendizagem, porém ainda encontramos muitos espaços de EaD que não contemplam as necessidades dos alunos surdos.

No Brasil, já encontramos mais investimentos em acessibilidade virtual para pessoas com deficiências e algumas iniciativas de concretizar a acessibilidade para os estudantes surdos, como o curso de Letras/Libras desenvolvido na Universidade Federal de Santa Catarina (UFSC), mas ainda são grandes as limitações e muito, também, tem a ser feito. 
O curso de Licenciatura em Letras/Libras iniciou quando da aprovação da lei no 10.496, e da sua regulamentação pelo decreto no 5.626 de 2005, que determinava a necessidade da implementação da disciplina de Libras nos cursos de Licenciatura, Fonoaudiologia.

Não existindo este profissional para o ensino de Libras, com formação em nível superior, a UFSC pleiteou e obteve junto ao MEC a autorização para a criação do curso, na modalidade a distância, em observância ao decreto nํ 5.626/2005. O curso de Letras/Libras busca garantir a inclusão social de surdos na sociedade por meio de formação acadêmica, abrindo espaço para a sua inserção no mercado de trabalho.

Em 2006, foram criados 9 (nove) polos e, em 2008, mais 15 (quinze) polos. Uma estrutura foi organizada para atender a necessidade da comunidade e a expectativa do mercado, bem como das normas oficiais da EaD. Os professores nos polos trabalhavam junto com os tutores surdos ou ouvintes, sendo esta uma experiência bilíngue (português e Libras), uma vez que é necessário ter formação, conhecer a área e ter contato com a comunidade surda. Também foram contratados monitores e técnicos, surdos ou ouvintes para o desenvolvimento de cada área de conhecimento. O AVEA foi construído a partir do sistema Moodle, que é gratuito.

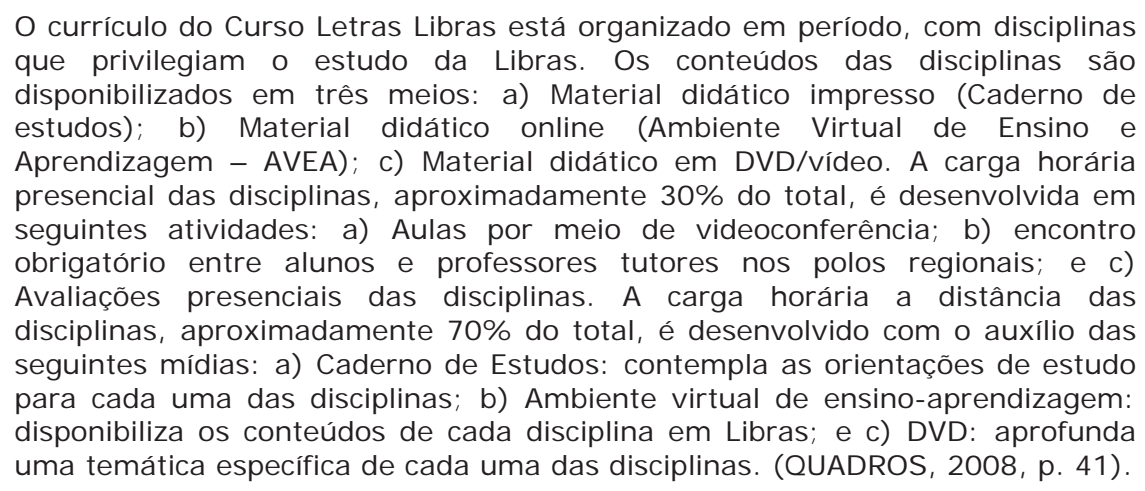

Com base no que foi exposto, nos propusemos a investigar o curso, tendo presentes os objetivos que seguem.

\section{Objetivos da pesquisa}

Como escopo geral, nossa proposta buscou analisar as experiências dos estudantes surdos no AVEA, quanto à acessibilidade do ambiente no atendimento às necessidades linguísticas da comunidade surda e ao processo de mediação relacionados à comunicação/interação/ aprendizagem entre os atores desse ambiente - alunos/professores/tutores.

Mais especificamente, procuramos:

a) Analisar os discursos dos estudantes surdos, alunos do AVEA do Letras/Libras, quanto à acessibilidade e a possibilidade de interação;

b) Analisar os aspectos ressaltados pelos estudantes surdos, quanto aos processos de mediação da aprendizagem, em relação a professores e tutores do curso;

c) Identificar os pontos positivos e negativos do AVEA no atendimento a estudantes surdos, a partir da análise das suas experiências; 
d) Avaliar a adequação das ferramentas e dos materiais para o estudante surdo, considerando sua língua de natureza viso-gestual;

e) Fazer um levantamento das sugestões feitas pelos surdos ao modelo de AVA do Letras/Libras, com vistas ao atendimento às suas necessidades relacionadas à acessibilidade e ao processo de mediação dos professores/tutores.

\section{Metodologia}

O estudo caracterizou-se como uma pesquisa qualitativa descritiva que fez a análise do curso de Licenciatura em Letras/Libras.-Foram coletados dados junto a estudantes surdos em duas turmas, através de um questionário construído para tal finalidade, nos polos de Porto Alegre - RS e Santa Maria - RS.

Esse instrumento foi disponibilizado no AVEA, os estudantes tinham acesso, através um link.

Desses questionários foram gerados dois tipos de arquivos: um deles de extensão ".doc", em português escrito, e o outro arquivo similar em vídeo "AVA", com todos os itens em Libras. O estudante fazia a escolha do arquivo preferido, tendo sido assim respeitada a sua condição de usuário de L1 ou L2. Os questionários respondidos foram devolvidos em arquivos, por email, à pesquisadora.

O questionário contemplou, entre outras, perguntas relacionadas à compreensão dos conteúdos trabalhados, à existência do intérprete ou de alguma estratégia para melhor aprendizagem e entendimento dos materiais e recursos de vídeo, bem como a acessibilidade ao ambiente e os recursos e materiais existentes no AVEA.

Os dados foram analisados de acordo com o seu formato e, organizados os resultados, serão apresentados a seguir.

\section{Resultados}

Do total de 69 alunos - 48 do polo de Santa Maria e 21 do polo do Porto Alegre - 36 responderam e retornaram os questionários.

Inicialmente, podemos verificar, no Quadro 1, que a aprendizagem pode ficar prejudicada com o entendimento parcial dos conteúdos, resultando em perdas no desenvolvimento do aluno surdo, quando não há acessibilidade para ele. A não existência de vídeos traduzidos para Libras é, em grande parte, responsável pelo pouco entendimento e, em função disso, pela pouca reflexão e crítica do aluno na disciplina, causando também descontentamento com o curso. Foi apontada a questão do português escrito, segunda língua para os surdos. Nesse sentido, a lacuna apontada foi que, para terem melhor entendimento, muitas vezes os alunos chamam intérpretes para a tradução. Também foi relatada uma situação na qual a professora auxiliou fazendo resumos dos textos, portanto, novamente apareceu a questão do acesso parcial ao conhecimento. 
Quadro 1 - Respostas dos alunos quanto ao auxílio à aprendizagem com os materiais pedagógicos disponibilizadas do AVEA.

\begin{tabular}{|l|r|r|}
\hline \multicolumn{1}{|c|}{ Categoria } & \multicolumn{2}{c|}{ TOTAL } \\
\cline { 2 - 3 } & № & $\%$ \\
\hline Sim auxiliam a compreensão e autonomia nos & 18 & $50 \%$ \\
\hline $\begin{array}{l}\text { Aprofundam a } \\
\text { estudos }\end{array}$ & 8 & $22 \%$ \\
\hline Alguns auxiliam & 4 & $11 \%$ \\
\hline Sem eles dificultaria a aprendizagem & 2 & $6 \%$ \\
\hline Facilita a aprendizagem porque os vídeos são em Libras & 3 & $8 \%$ \\
\hline Depende do professor & 1 & $3 \%$ \\
\hline
\end{tabular}

Fonte: Elaborado pelas autoras.

Quanto ao entendimento dos vídeos postados no AVEA, temos as respostas de $43 \%$ dos alunos dizendo que entendem a tradução dos vídeos para Libras. Porém, se analisarmos a soma de $57 \%$ dos itens considerados como negativos, teremos um percentual superior ao positivo (Figura 2).

Figura 2 - Respostas dos alunos quanto ao entendimento dos vídeos disponibilizados no AVEA do curso Letras/Libras.

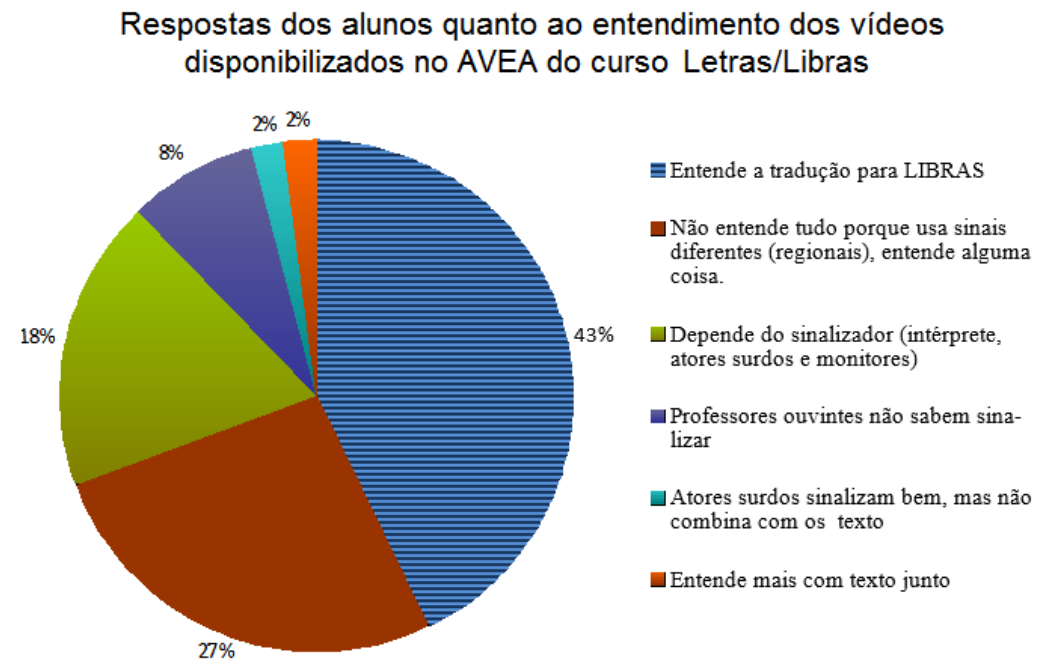

Fonte: Elaborada pelas autoras.

Aspectos como os sinais regionais, as maneiras diferenciadas de sinalizar das pessoas, a tradução para Libras que não está de acordo com o texto-base da disciplina, são apontados como dificuldades do AVEA no recurso vídeo. Estes pontos estão relacionados a questões linguísticas, como as variações regionais, sociais e estilísticas, mas que parecem estar interferindo no entendimento e na compreensão dos alunos. Entendemos que a Libras, como qualquer outra língua, apresenta estas variações, e que o processo de adaptação a este vocabulário diferenciado, inclusive por ser um discurso acadêmico, pode ser necessário, mas não impossível, pois não se trata de outra língua, apenas de outra modalidade (visual espacial).

Em relação aos aspectos da língua, outros pontos foram observados, como o problema dos professores ouvintes que não sabem sinalizar, e/ou as traduções para Libras que não acompanham os textos que, como apontado acima, são de outra classe de problemas não 
relacionados apenas aos aspectos linguísticos. Técnicas de tradução precisam ser implementadas buscando qualificar o material teórico em Libras produzido para as disciplinas. Quanto aos professores que não sabem Libras, temos uma análise importante de um dos participantes, que coloca a questão da seguinte maneira: “Depende da disciplina. O professor sabe bem sua disciplina, mas não utiliza Libras, utiliza intérprete, porém o intérprete não sabe muito bem a disciplina, então a versão fica ruim e conteúdo é perdido. Têm atores surdos que sinalizam bem, porém às vezes eles interpretam diferente um texto. Isto me deixou preocupada" (estudante do curso de Letras/Libras).

Então, novamente temos questões técnicas de tradução interferindo na aprendizagem. O professor que sabe pouco sobre Libras deve utilizar intérprete, mas este profissional tem de estar qualificado para a tradução do discurso acadêmico, bem como os profissionais envolvidos devem conhecer e se apropriar das particularidades da comunicação da Libras.

Continuando a análise e mudando nosso foco para a questão da mediação no ambiente, apresentamos dados referentes à interação tutor/aluno no AVEA. Optamos por separar os polos, já que em Santa Maria a tutora é ouvinte e, em Porto Alegre, é surda. Assim, observamos se a questão linguística teve interferência nesta situação.

Figura 3 - Respostas dos alunos relacionadas à interação com o tutor surdo do curso Letras/Libras do Polo UFRGS.

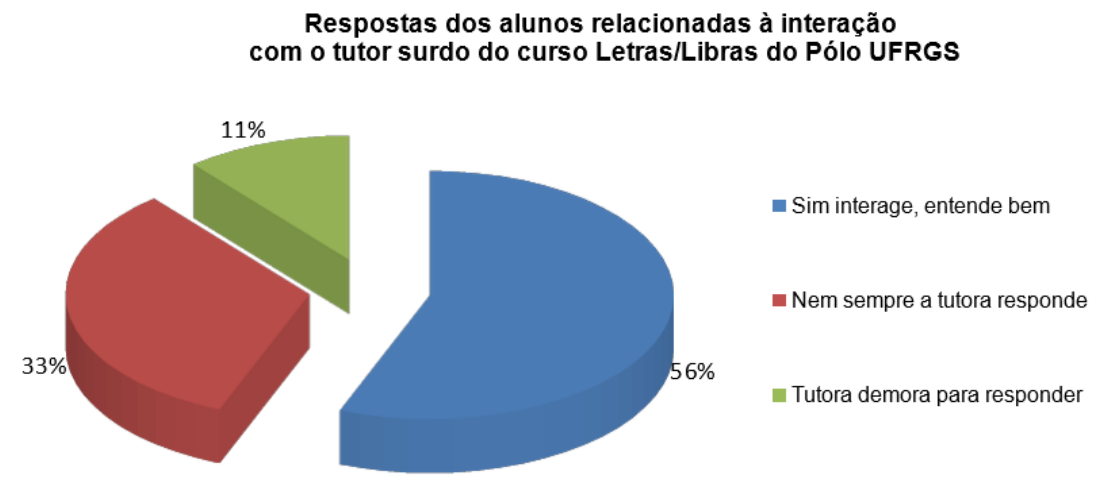

Fonte: Elaborada pelas autoras.

Nesta questão, podemos ver que, na Figura 3, encontramos a resposta de 56\% dos alunos dizendo que interagem e entendem bem a tutora surda do polo de Porto Alegre, mas um número significativo respondeu que há demora para responder, ou nem sempre há resposta da tutora. Percebemos que, mesmo a tutora sendo surda, portanto não havendo problema linguístico presente, a dificuldade aparece relacionada ao papel do tutor no AVEA, que também é responsável por mediar à aprendizagem do aluno.

O tutor é uma pessoa agregada à universidade com a função de assessorar os estudantes em diversos níveis e em questões gerais. Os temas envolvem desde assuntos relacionados com a aprendizagem, adaptação social, até conselhos de ordem mais pessoal. Cabe ao tutor: familiarizar o estudante com os temas que serão desenvolvidos no programa do curso; discutir com os alunos os prérequisitos para uma abordagem que leve a um estudo bem sucedido; analisar as questões de administração e organização do tempo e fazer com eles considerações analítico-críticas sobre os conteúdos aprendidos. O aluno recebe a orientação e se capacita para trabalhar sozinho. (SILVA; SILVA, 2009, p. 99). 
Quadro 2 - Respostas dos alunos relacionadas à integração com o tutor ouvinte do curso Letras/Libras do polo UFSM.

\begin{tabular}{|c|c|c|}
\hline \multicolumn{3}{|c|}{$\begin{array}{l}\text { Respostas dos alunos relacionadas à integração com } \\
\text { o tutor ouvinte do curso Letras/ Libras do Polo UFSM }\end{array}$} \\
\hline Categoria & $\begin{array}{l}\text { Polo } \\
\text { UFSM }\end{array}$ & $\%$ \\
\hline Sim interage, entende bem & 17 & $43 \%$ \\
\hline Nem sempre a tutora responde & 4 & $9 \%$ \\
\hline Não estimula muito alunos & 3 & $8 \%$ \\
\hline $\begin{array}{llll}\text { Tutora } & \text { precisa } & \text { responder } & \text { com } \\
\text { filmagem em Libras } & & \\
\end{array}$ & 3 & $8 \%$ \\
\hline $\begin{array}{l}\text { Aluno não interage no AVEA porque } \\
\text { não tem boa leitura e escrita no } \\
\text { português, prefere pessoalmente }\end{array}$ & 3 & $8 \%$ \\
\hline A tutora demora em responder & 2 & $5 \%$ \\
\hline $\begin{array}{l}\text { Nem sempre o aluno entende as } \\
\text { explicações }\end{array}$ & 2 & $5 \%$ \\
\hline Tutora não é fluente em Libras & 2 & $5 \%$ \\
\hline Tutora Ausente do AVEA & 1 & $3 \%$ \\
\hline Aluno prefere tutor surdo & 1 & $3 \%$ \\
\hline A relação é um pouco complicada & 1 & $3 \%$ \\
\hline
\end{tabular}

Fonte: Elaborado pela autora.

Da mesma forma, na relação com a tutora ouvinte do polo de Santa Maria, as repostas positivas foram em bom número, porém, novamente, aspectos relacionados ao papel do tutor são destacados pelos participantes, inclusive os relacionados com as questões linguísticas, por exemplo, quando 2 (dois) deles respondem que a tutora não é fluente em Libras e outro aponta sua preferência por tutor surdo.

No recurso vídeo, também encontramos percentual importante de respostas positivas. Todos os vídeos presentes no AVEA estão em Libras e, mesmo que a questão da regionalidade de alguns sinais apareça como observação, este é o recurso, de fato, adequado ao aluno surdo, no ensino a distância, pois contempla de forma integral a modalidade de língua da qual estes sujeitos são usuários. Quanto aos aspectos negativos, encontramos respostas referentes à velocidade do recurso, que está relacionada aos equipamentos dos usuários, portanto provocando interferência nos momentos de estudos. Aqui novamente nos reportamos à questão da interface do usuário, que além de ser um fator individual de conhecimento técnico, é também uma condição socioeconômica, que determina a forma de acesso ao ambiente. A Figura 4 mostra o percentual de $78 \%$ de aspectos positivos, em oposição aos $22 \%$ de aspectos negativos, como um indicador de aprovação do recurso. 
Figura 4 - Respostas dos alunos ao recurso vídeo do AVEA.

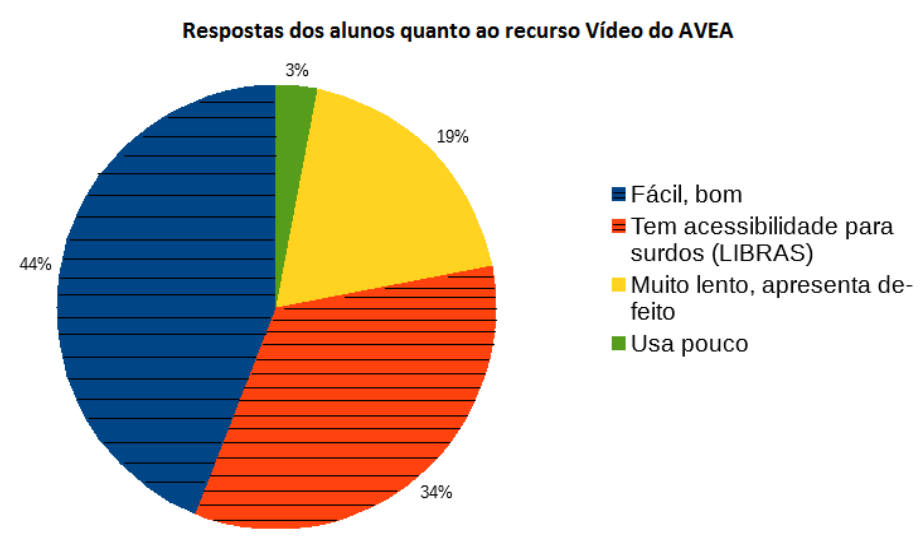

Fonte: Elaborada pelas autoras.

Como pontos negativos, temos o total de $28 \%$ de respostas conforme a Figura 5 , onde se destacam as questões relacionadas à falta de respostas dos tutores, à falta de clareza nas orientações ou informações fracas, e o não recebimento de orientações.

Figura 5 - Respostas dos alunos referentes as orientações recebidas no curso Letras/Libras.

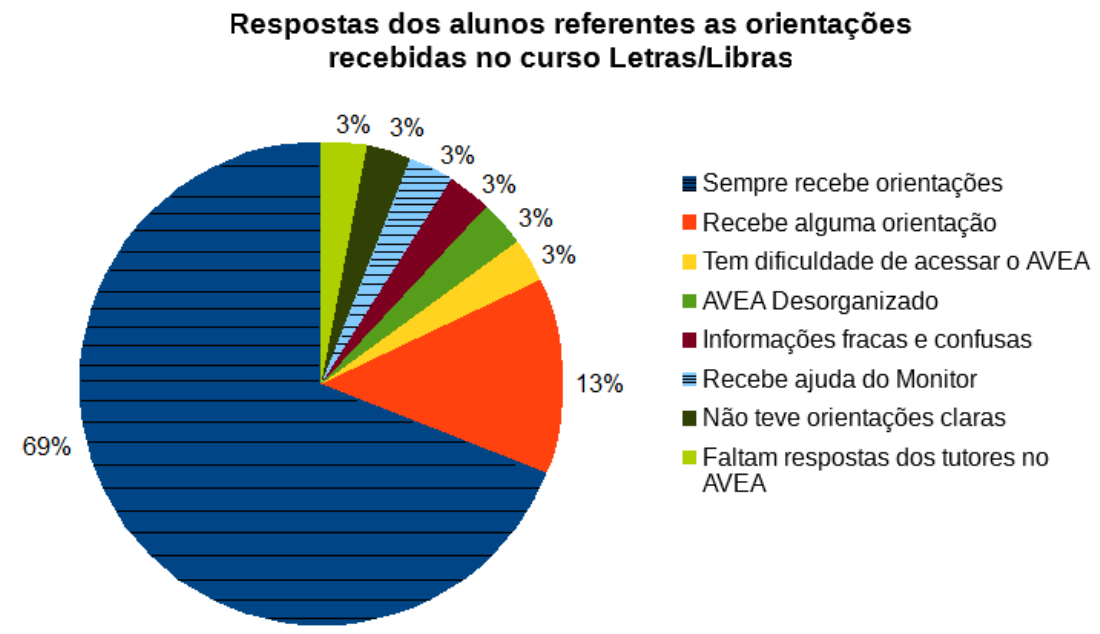

Fonte: Elaborada pelas autoras.

Na Figura 6, a maioria dos alunos respondeu positivamente (81\%) quanto ao aspecto visual do AVEA. A clareza do ambiente e o fácil acesso são pontos importantes para que haja eficiência nos ambientes virtuais de aprendizagem. A presença dos vídeos em Libras é destacada como fator de garantia de acessibilidade. Como pontos negativos, temos $19 \%$ das respostas, que se dividem entre os problemas na escolha de cores das roupas dos sinalizantes, ou das cores do próprio AVEA. Além disso, temos algumas respostas referentes à configuração e à dificuldade de visualização das imagens dos vídeos, mas acreditamos que estes problemas possam se referir ao equipamento que o aluno possui para o acesso a internet e não ao AVEA. Novamente, questões externas podem interferir no processo de interação com o ambiente, 
como o acesso a uma rede com maior velocidade, ou a um equipamento de hardware mais atualizado.

Figura 6 - Respostas dos alunos quanto à acessibilidade, relacionadas ao aspecto visual do AVEA do curso Letras/Libras.

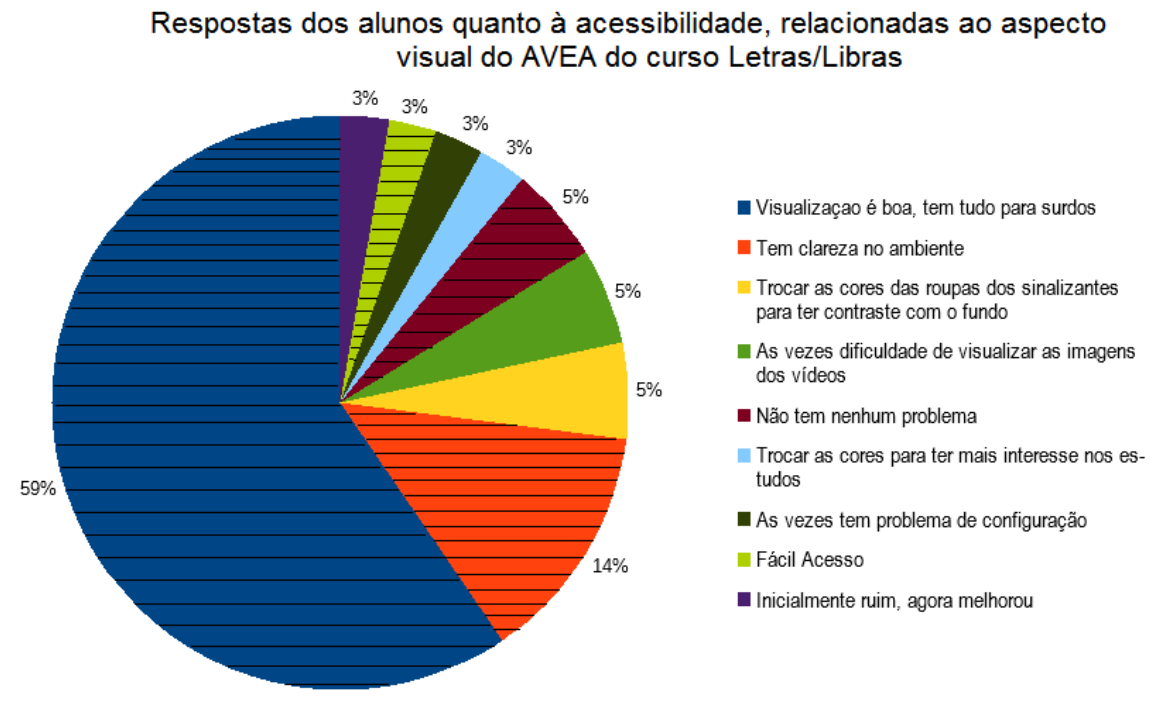

Fonte: Elaborada pela autora.

As respostas na Figura 7 são referentes às lacunas do AVEA, ou seja, ao que está faltando no ambiente. Encontrou-se o percentual de $16 \%$ dos alunos indicando a falta de comunicação (chat) através de vídeo e a falta de tradução para Libras de alguns textos em português.

Figura 7 - Respostas dos alunos relacionadas lacunas do AVEA do curso Letras/Libras.

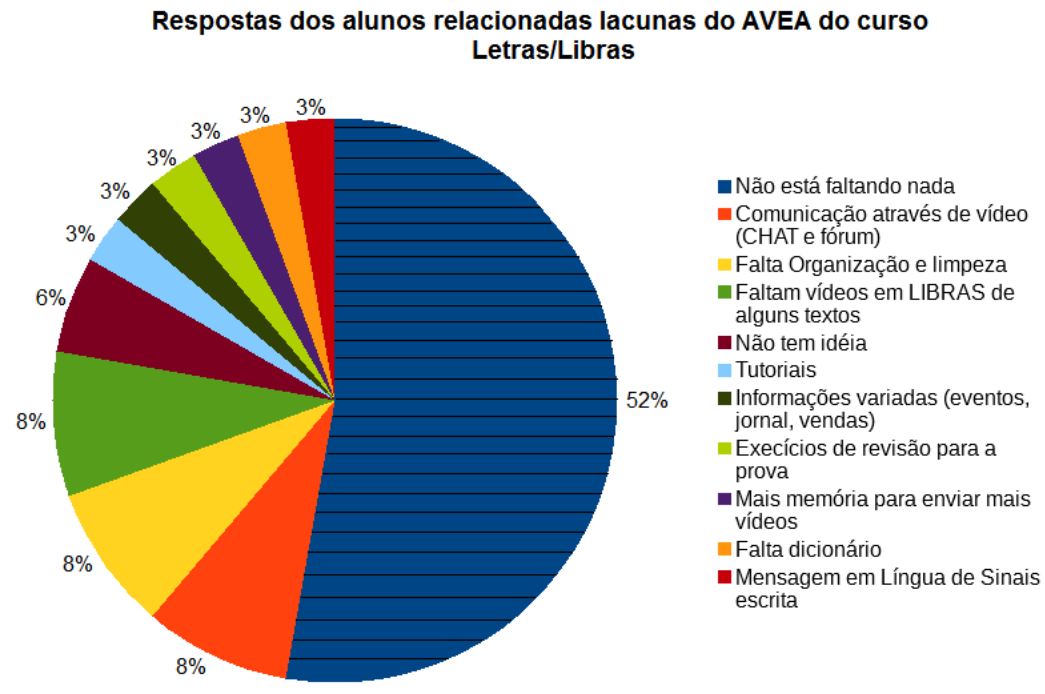

Fonte: Elaborada pela autora.

Outros itens relacionados à questão da imagem seriam: a memória não suficiente para o envio de mais vídeos no AVEA e a possibilidade do envio de mensagem em Língua de Sinais Escrita. Entendemos que estes itens estão relacionados à especificidade linguística do grupo de 
alunos, portanto, de relevância para a análise de acessibilidade para surdos no AVEA, uma vez que a proposta era analisar as condições desta estrutura AVEA para o ensino a distância de surdos.

\section{Considerações finais}

A partir dos dados coletados, podemos fazer algumas reflexões sobre as questões de acessibilidade para surdos, especificamente no AVA do curso de Letras/Libras. Inicialmente, destacamos os resultados referentes aos aspectos linguísticos envolvidos - um deles a fluência em Libras -, que interferem nos fundamentos da EaD, por exemplo, na relação com tutores e nos processos de aprendizagem. Há nos resultados uma positividade maior nas respostas dos alunos quanto às suas experiências com o tutor surdo, o que aponta o conhecimento de Libras como uma das causas de maior fluidez nessa relação. No entanto, são apontados também os aspectos quanto ao papel do tutor neste processo, quando este não responde às questões dos alunos ou, quando se ausenta do AVA por muito tempo.

Interessante observar a oposição que surge quando há o conhecimento do conteúdo - no caso do professor da disciplina - e seu pouco conhecimento de Libras, que diverge da situação do intérprete de Libras, conhecedor da língua, mas não dos conteúdos trabalhados. Há um protocolo de atuação dos intérpretes de Libras, segundo o qual esses, necessariamente, devem buscar subsídios antes de suas atuações, ou seja, estudar textos e, se possível, fazerem contato com os professores, para que compartilhem informações, diminuindo a distância entre seu trabalho e o conhecimento referente. Este pode ser um processo que interfere na aprendizagem do aluno, já que a mediação do professor, por seu desconhecimento da língua em questão, depende de uma mediação linguística; no entanto, se todos trabalharem de forma coordenada, com qualidade, este prejuízo poderá ocorrer de forma não contundente. Trata-se de uma característica de acessibilidade dos AVAs que atendem os alunos surdos, pois esta minoria linguística é usuária de Libras e, assim sendo, precisa ser atendida de forma adequada, para que a aprendizagem se efetive.

No recurso vídeo, é importante destacar que todos os materiais disponíveis estão em Libras, dado este que demonstra o ambiente bilíngue do curso, e as experiências negativas estão relacionadas a aspectos de tradução do português para Libras e, em alguns casos, dos sinais regionais utilizados, ou seja, das variações da língua. Assim como no português, a Libras tem variações regionais que não impedem a comunicação, no entanto, a plataforma do curso oferece um glossário através do qual o aluno encontra subsídios do léxico utilizado nas traduções dos textos. Esta ferramenta é um recurso que diminui distâncias entre os léxicos regionais, pois aponta para uma padronização da linguagem acadêmica e, assim sendo, reforça o entendimento comum de conceitos, aspecto fundamental na validação da linguagem específica de um campo de conhecimento.

No Ambiente Virtual de Ensino e Aprendizagem do Curso de Letras/Libras da UFSC, nos polos do Rio Grande do Sul, entendemos que a proposta atende, em boa parte, às necessidades dos alunos surdos. Quanto ao curso Letras/Libras, constatamos bons percentuais de aprovação, sendo que a procura por ele recai basicamente na busca de aprofundamento, de 
conhecimento e de formação na área de ensino de Libras. Estes dados vêm ao encontro da nossa questão de pesquisa, que sugeria a necessidade de adequação dos AVEAs para surdos, especificamente no curso de Letras/Libras da UFSC, pois desta forma, garante-se o acesso às informações e ao conhecimento com a maior plenitude possível, dos usuários surdos destes ambientes.

Em síntese, podemos destacar, com relação ao AVEA, que:

a) Há necessidade de maior espaço de armazenamento no ambiente, uma vez que os alunos surdos utilizam muitos vídeos em Libras para envio de respostas às atividades e para o processo de comunicação/interação dentro do ambiente;

b) É necessário que os recursos de equipamentos e rede de Internet contemplem maior velocidade para vídeos, bem como para o acesso ao AVEA;

c) As informações e orientações devem ser claras, tanto nos materiais como nas ferramentas do ambiente utilizado, explorando maiormente imagens e vídeos em Libras;

d) As imagens de tradução para Libras devem apresentar tamanho condizente a para uma melhor visualização pelo aluno surdo, possibilitando melhor acesso e maior clareza da língua de sinais;

e) As visualizações das imagens em vídeo devem apresentar cores adequadas de fundo e das roupas dos intérpretes, facilitando a acessibilidade aos alunos surdos;

f) Todos os textos e materiais utilizados devem ser apresentados também com tradução para Libras, através de vídeos;

g) Há necessidade de organização dos materiais e tutoriais do AVEA que facilitem a utilização pelos alunos surdos, no fluxo de interação com o ambiente.

Da mesma forma, em relação ao processo de mediação com os professores/tutores:

a) Há necessidade de os professores e tutores conhecerem Libras, para facilitar o processo de comunicação/ interação/mediação/aprendizagem;

b) Os Professores com domínio dos conteúdos e sem domínio de Libras, bem como intérpretes sem domínio do conteúdo dificultam o processo de mediação e da aprendizagem dos alunos surdos;

c) Deve existir uma dinâmica mais efetiva, por parte dos mediadores, em dar respostas claras e imediatas aos alunos surdos;

d) Deve-se ampliar alternativas de sinais em Libras, evitando usos exclusivos de sinais regionais que dificultam o entendimento do aluno surdo;

e) As traduções em Libras devem apresentar fidelidade aos textos, mostrando correspondência exata aos mesmos;

f) Deve ser priorizada, nos cursos, a presença de tutores com domínio de Libras e do conteúdo das disciplinas;

g) Os interpretes em cursos para surdos devem aprimorar o domínio do conteúdo das disciplinas, para uma tradução mais efetiva. 
Os itens destacados não esgotam os elementos apontados pelos alunos, neste estudo. Acima de tudo, sugerem que novas investigações sigam nessa linha, para possibilitar um mapeamento sempre maior e mais adequado, o qual aponte e direcione para a construção de maior acessibilidade dos AVEAs e espaço mais efetivo de interação/comunicação/mediação que atenda às necessidades desses usuários, em cursos EaD.

Finalizando, gostaríamos de reiterar nossa convicção da importância do curso de Letras/Libras da UFSC, que é responsável pela formação dos futuros profissionais surdos atuantes na área do ensino de Libras, mas também apontamos que, tendo respondido aos questionamentos aos quais essa pesquisa se propôs, se faz necessária a reformulação dos itens que se apresentaram como barreiras à aprendizagem dos alunos, contatados a partir dos usuários deste AVEA. A proposta do curso Letras/Libras é o aluno surdo e, assim sendo, deve contemplar o atendimento às suas necessidades educativas.

A importância deste curso, na modalidade EaD, recupera o tempo perdido por muitos dos sujeitos surdos, pois muitos deles não tiveram possibilidade de formação no nível superior. Com a criação dos polos do curso de Letras/Libras pelo Brasil, o reconhecimento da Libras como primeira língua para o sujeito surdo se espalhou e se multiplicou, reafirmando identidades surdas e culturas, ampliando os espaços de participação e produção de conhecimento dos sujeitos surdos no ambiente acadêmico e dando visibilidade e reconhecimento científico a esta área do conhecimento.

\section{Notas}

\section{Referências}

GALLIMORE, Ronald; THARP, Roland G. O Pensamento educativo na sociedade: ensino, escolarização e discurso escrito. In: MOLL, Luis C. Vygotsky e a Educação: implicações pedagógicas da psicologia sóciohistórica. Porto Alegre: Artes médicas, 2002. p. 171-199.

QUADROS, Ronice Müller de; CERNY, Roseli Zen; PEREIRA, Alice Theresinha Cybis. Inclusão de surdos no ensino superior por meio do uso da tecnologia. In: QUADROS, Ronice Müller de (Org.). Estudos Surdos III. 1. ed. Petrópolis: Arara Azul, 2008. p. 32-57.

SANTAROSA, Lucila Maria Costi. Paradigmas Educacionais para o desenvolvimento de ambientes digitais/virtuais, visando pessoas com necessidades especiais - PNEEs. In: CONGRESSO NACIONAL DE TECNOLOGÍA EDUCATIVA Y ATENCIÓN A LA DIVERSIDAD, 4.; CONGRESSO IBEROAMERICANO DE INFORMÁTICA EDUCATIVA ESPECIAL, 6., 2006, Murcia, España. Las tecnologias em la escuela inclusiva: nuevos escenarios, nuevas oportunidades. Murcia, España: FG Graf, 2006. Palestra da sessão de encerramento dos eventos. p. 35-42.

SILVA, Angela Carrancho da; SILVA, Christina Marília Teixeira da. Avaliação de ambientes virtuais de aprendizagem. In: SILVA, Angela Carrancho da (Org.). Aprendizagem em ambientes virtuais e educação a distância. 1. ed. Porto Alegre: Mediação, 2009. p. 73-88.

STUMPF, Marianne Rossi. Língua de sinais: escrita dos surdos na Internet. In: CONGRESSO IBEROAMERICANO DE INFORMÁTICA EDUCATIVA, 5., Viña del Mar, Chile, 2000. Anais eletrônicos... Vinã del Mar, Chile: RIEE, 2000. Disponível em: < http://www.c5.cl/ieinvestiga/actas/ribie2000/papers/248/ index.htm>. Acesso em: 30 jul. 2015. 
Recebido em julho de 2016

Aprovado para publicação em agosto de 2017

\section{Ms. Camila Guedes Guerra Goes}

Programa de Pós-Graduação em Educação - Universidade Federal do Rio Grande do Sul - UFRGS, Brasil, milagguerra@gmail.com

\section{Dra. Lucila Maria Costi Santarosa}

Programa de Pós-Graduação em Educação - Universidade Federal do Rio Grande do Sul - UFRGS, Brasil, lucilamcs@yahoo.com

Ouvintismo - termo utilizado para definir o domínio dos ouvintes sobre a surdez. 


\title{
Avaliação I nformatiza Adaptativa do ENADE Pelo MOODLE: Evidências de Validade
}

\section{Adaptive Computerization Assessment of ENADE by MOODLE: Evidence of Validity}

\section{Lucio Ferreira Santana}

Centro Universitário FIEO

\section{Daniel Bartholomeu} Centro Universitário Salesiano - UNISAL - Americana.

José Maria Montiel Centro Universitário FIEO - UNIFIEO/SP.

Gleiber Couto Universidade Federal de Goiás no Campus de Catalão - UFG/CAC.

\author{
Arthur Almeida Berberian \\ Centro Universitário FIEO \\ Fernando Pessoto \\ Centro Universitário Salesiano - UNISAL - Americana.
}

\begin{abstract}
Resumo: Testes informatizados adaptativos adquirem relevância quanto às possibilidades de estudos. Este estudo teve como objetivo relacionar dados de uma avaliação do ENADE do Curso do Direito. Participaram 92 pessoas. Foi utilizado dois instrumentos de medida de multipla escolha, um em papel e lápis e outro adaptado ao modelo informatizado adaptativo em ambiente MOODLE. Os resultados demonstraram que os itens estiveram dentro dos parâmetros de ajuste ao modelo investigado. A correlação entre os níveis de dificuldade dos itens nas duas formas, revelaram que os parâmetros dos itens se mantiveram os mesmos entre uma e outra forma de aplicação. Considera-se que estudos que se propõem a analisar os itens, recorrendo a TRI como meio de análise do modelo de Rasch, permitem aferir evidência de validade de construto. Sugere-se que novos estudos a respeito do ENADE, em modelo informatizado adaptativo, pois o ambiente MOODLE demonstrou ser um meio útil e eficaz de avaliação.
\end{abstract}

Palavras-chave: Avaliação Educacional. TRI. Modelo de Rasch.

\begin{abstract}
Adaptive computer tests acquire relevance as to the possibilities of studies. This study aimed to relate data from an ENADE evaluation of the Law Course. 92 people participated. Two multi-choice measurement instruments were used, one in paper and pencil and another adapted to the adaptive computer model in a MOODLE environment. The results showed that the items were within the fit parameters to the investigated model. The correlation between the difficulty levels of the items in the two forms, revealed that the parameters of the items remained the same between one and another form of application. It is considered that studies that propose to analyze the items, using TRI as a means of analysis of the Rasch model, allow to gauge evidence of construct validity. It is suggested that new studies regarding ENADE, in an adaptive computer model, since the MOODLE environment has proved to be a useful and effective means of assessment.
\end{abstract}

Keywords: Educational Assessment. TRI. Rasch Model.

SANTANA, Lucio Ferreira; BARTHOLOMEU, Daniel; MONTIEL, José Maria; COUTO, Gleiber; BERBERIAN, Arthur Almeida; POSSOTO' Fernando. Avaliação informatiza adaptátiva do ENADE pelo MÓODLE: evidências de validade, São Paulo, v. 20 , n. 2, p. 222-238, mai./ago. 2017 


\section{Introdução}

No que se refere especificamente ao sistema educacional brasileiro, o Ministério da Educação (MEC) tem dedicado na última década um cuidado especial ao processo de avaliação deste contexto, por exemplo as inúmeras provas desenvolvidas para se aferir a qualidade do ensino em diversos níveis, desde o ensino fundamental (Sistema de Avaliação do Ensino Básico - SAEB), médio (Exame Nacional do Ensino Médio - ENEM) e superior (Exame Nacional de Cursos - ENC). Para esse último, mais recentemente foi idealizado o Sistema Nacional de Avaliação do Ensino Superior (SINAES) (informações disponíveis em www.inep.gov.br). O objetivo fundamental do SINAES é a avaliação das Instituições de Ensino Superior (IES), integrando diferentes dimensões cujos elementos centrais são, a auto-avaliação orientada, a avaliação da instituição, avaliação dos cursos de graduação e o ENADE. Assim, é possível analisar de um ponto de vista mais extenso, a instituição como um todo, de uma expectativa mais reduzida, restringindo-se ao desempenho do estudante por meio do ENADE.

Uma qualidade peculiar desses sistemas de avaliação em larga escala para instituições educacionais incide na medida de qualidade das instituições, definida por indicadores do quanto cada instituição colaborou para o desenvolvimento de seus alunos em termos de habilidades acadêmicas, competências profissionais e conhecimento. A questão principal que radica dessa discussão é a validade das medidas utilizadas na aferição dessa qualidade ou, em outros termos, da eficácia escolar. Tal medida tem sido nomeada, na literatura científica, como medida de "valor agregado", acentuado como "uma medida do avanço médio do aluno, durante - período de tempo em que ele é exposto a determinado ambiente educativo, comparativamente com o que obteria em outras escolas da amostra" (Ferrão, 2003, p.16; Jesus \& Laros, 2004; Raudenbush, 2004b; Rubin, Stuart \& Zanutto, 2004; Soares, Ribeiro \& Castro, 2001).

A despeito de apresentar uma definição operacional, a validade de tais avaliações deve ser estabelecida para cada sistema de avaliação designado aos diferentes níveis de educação. Nesse contexto, estudos devem ser delineados no sentido de se testar as interpretações feitas com base nos instrumentos de medida, averiguando se estão funcionando adequadamente, conforme se foi planejado. Assim, não só o instrumento, mas os delineamentos de coleta de informação são testados. Na psicometria, tais estudos são abordados dentro do julgamento de validade. Além da preparação adequada de uma prova, para que essa apresente êxito na avaliação (cumpra seus objetivos), é fundamental atestar-se a qualidade científica das próprias (American Educational Research Association AERA, American Psychological Association - APA, National Council on Measurement in Education - NCME, 1999; Urbina, 2004). As informações providas por esses estudos agregam dados respeitáveis no aprimoramento dos sistemas de avaliação (nesse caso em larga escala), já que aprofundam o debate da legalidade da medida utilizada e recomendam algumas limitações das inferências feitas com base nos resultados obtidos por tal sistema, recomendando novas formas de se avaliar com vistas a aumentar sua eficácia. Apesar disso, evidenciam-se poucos trabalhos dessa natureza feitos com as provas do 
MEC, fato que se torna inquietante ao se considerar o impacto social de tais sistemas bem como de seus resultados.

Dentre as possibilidades de estudos de validade para o ENADE, a investigação de alternativas viáveis de administração e redução da prova são particularmente interessantes, pois tendem a reduzir seu custo e tornar mais fiáveis as avaliações. Neste contexto, os Testes informatizados adaptativos adquirem relevância, já que possibilitam uma avaliação reduzida e com estimativas boas das habilidades das pessoas. Os TAls são administrados via computador. Testes adaptativos (TA) são aqueles cuja aplicação dos itens se adapta ao sujeito que está respondendo ao teste, que busca encontrar um teste ótimo para cada examinando, ou seja, um teste aplicado com o mínimo de perguntas possível e que aproximar-se para o mesmo resultado de um teste comum. Para isso, é necessário estimar a proficiência do indivíduo de forma iterativamente durante a administração do teste e, assim, só precisam ser selecionados os itens que mensurem eficientemente a proficiência do examinado. A noção básica de um TA é imitar automaticamente o que um sábio examinador faria, ou seja, um TAl tem por intenção administrar itens, de um banco de itens previamente calibrados, que satisfaçam ao nível de capacidade do examinando. Geralmente, esses itens são escolhidos de acordo com o modelo da Teoria de Resposta ao Item (TRI), que é adotado para descrever o comportamento da resposta do indivíduo. Ao contrário dos testes papel-e-lapis, diferentes examinados podem receber diferentes testes de tamanhos variados. (COSTA, 2009 apud WAINER et al., 1990, p. 3).

Outra vantagem de um TAl é a flexibilidade para aplicação de baterias de testes. Ao oposto do exame tradicional, um TAI não determina que todos os examinados façam a prova ao mesmo tempo. Em uma bateria de testes, por exemplo, o examinando que finalizar a prova pode passar diretamente para a prova seguinte sem precisar esperar os outros. Além disso, o aplicador do teste pode fornecer as instruções do teste de forma virtual. Para Moreira (2011, p. 98), "a maior vantagem de um CAT em relação a um teste tradicional consiste na maior eficiência na estimação do nível de habilidade do respondente com um menor número de itens do que os testes tradicionais". Para atingir esse objetivo, dois aspectos básicos são necessários: o método de estimação das habilidades dos respondentes e o critério de seleção dos itens. Ainda Olea et al. (2004), descreve que a maioria dos CATs utiliza estratégias como, um critério de partida, para determinar o primeiro item a ser apresentado; um método estatístico (geralmente Bayesiano ou Máxima Verossimilhança) para estimar a proficiência do indivíduo e a precisão associada; um procedimento para selecionar o próximo item; um critério para finalizar o teste.

Seguindo tais apontamentos quando se opta pela utilização do TAl, deve-se primeiramente se preocupar com qual será o tipo de ambiente ou sistema gerenciador de conteúdo que devemos utilizar para nos auxiliar. Ainda é possível optar pelo Ambiente Virtual de Aprendizagem (AVA) ao qual possui diversos recursos e ferramenta, facilitadoras para a gerência centralizada de novas implementações de conteúdos, usuários, banco de questões e os já existentes de maneira automatizada; publicação de conteúdo rapidamente; permitir reuso ou duplicação desses conteúdos de maneira que não necessite a criação desse novamente a fim de favorecer a utilização mais rápida por parte dos alunos (Ellis, 2009). Ainda o mesmo autor 
descreve uma metodologia, chamada Metodologia de Avaliação de Ambientes Virtuais de Aprendizagem (MAAVA), destinada à avaliação de um ambiente configurado para um curso, fundamentado na importância de atrelar os objetivos educativos das ferramentas do AVA aos objetivos pedagógicos, dos quais se pretende que os alunos alcancem ao final de curso e/ou disciplina e; na importância de ter um AVA com boa usabilidade, comunicabilidade e sociabilidade, para não afetar o atendimento aos objetivos pedagógicos.

Em continuidade, a literatura tem apontado que para essa transição de paradigma, o surgimento de novos sistemas de gestão de conteúdos tem sido muito recorrente e pertinente, por exemplo, (CMS - content management system), em código de fonte aberta (open source), como é o caso do MOODLE (http://www.MOODLE.org), lançado em 1999, utilizado também para ambientes educativos e colaborativos online, com intuito de fomentar um espaço de colaboração, onde seus usuários poderiam intercambiar saberes, experimentando, criando novas interfaces para o ambiente em grande comunidade aberta. Quando utilizados em educação, tendem a ser designados como sistemas (ou plataformas) em linha de gestão da aprendizagem e de trabalho colaborativo (http://MOODLE.fct.unl.pt/), possui um sistema de julgamento que auxilia o profissional a configurar e a aplicar a avaliação. As questões são guardadas por categorias em uma base de dados e podem ser reutilizadas em outros questionários e avaliações e até mesmo em outros cursos ou disciplinas como no caso da educação.

PULINO (2005) menciona como vantagem, em relação a outros sistemas gerenciadores de cursos, que o MOODLE é um software livre que apresenta todas as funcionalidades e os objetivos educacionais requerido em um LMS. Com o advento da informática e a popularização dos computadores, versões informatizadas de vários testes do tipo "papel e lápis" passaram a ser desenvolvidas. Contudo, na grande maioria dos casos, o que foi feito, foi apenas uma mudança nos processos de aplicação do teste, que passou a ser disponibilizado na tela do computador, e de resolução do teste, que passou a ser efetivado por intermédio do computador. De tal modo, um teste informatizado é o mesmo teste tradicional do tipo "papel e lápis" efetivado por meio do computador. Essa foi considerada a primeira geração de testes informatizados, segundo Olea e Hontangas (1999). Uma alternativa para as avaliações do tipo “papel e lápis" tradicional ou informatizada é a emprego dos chamados TAls.

Esta alternativa é particularmente viável em investigações de competências e de larga escala, considerando a maior rapidez e eficiência desta modalidade de avaliação, bem como praticidade na forma de coletar os dados. No caso do Brasil, provas governamentais como o ENADE tendem a ter alto impacto na definição de políticas públicas educacionais no ensino superior e, apesar disso, muito ainda resta a ser feito com estas provas, sobretudo no que se refere à novos estudos de validade e de viabilidade metodológica (Bartholomeu, 2011). Na tentativa de buscas por trabalhos envolvendo metodologias de avaliação de AVAs, é notória a carência de pesquisas que venham a sugerir um formato de avaliação.

Como mencionado anteriormente bem como em decorrencia da carência de estudos com esta temática, existem vantagens de se ter um método adaptativo de avaliação do ENADE como sua praticidade, já que pode ser respondida por qualquer computador ou aparelho de 
celular, bem como que o modelo adaptativo otimiza o uso dos itens, tendo maior precisão na estimativa das habilidades reais dos estudantes e favorecendo melhores avaliações da qualidade dos cursos, melhorando estas avaliações aplicadas no contexto escolar, otimizando o tempo dos estudantes ao responder o questionário, tornando ele menos cansativo e mais preciso. Ao mesmo tempo, o uso do MOODLE para este fim pode facilitar para as IESs que desejem empregar um modelo gratuito para se obter as estimativas de habilidades dos seus estudantes nesta prova, usando de recursos gratuitos para analisar e contemplar aspectos públicos.

Seguindo tais postulados, esse trabalho se coloca no sentido de se propor uma metodologia para se estudar evidencias de validade de exames de larga escala produzidos no INEP, individualmente, o ENADE. Tal exame é mesclado por questões de formação geral e específica e tem o objetivo de aferir as habilidades acadêmicas e competências profissionais que estudantes ingressantes e concluintes de Instituições de Ensino Superior apresentam. Assim, dadas as vantagens que as TAls apresentam e a necessidade de novas investigações de validade do ENADE este trabalho se insere procurando evidências de validade para o ENADE "Direito" a partir de sua estrutura interna e fazendo a adaptação informatizada e adaptativa deste instrumento a partir do software livre MOODLE como uma alternativa barata para esta finalidade. Neste sentido, será que o sistema adaptativo do MOODLE é melhor do que a aplicação de papel e lápis do ENADE Direito? Esta é a pergunta de pesquisa que este trabalho se atém. Com isso, o objetivo deste estudo é relacionar dados de uma avaliação do ENADE do Curso do Direito, informatizada adaptativa e de papel e lápis visando evidências de validade para este teste.

\section{Método}

\subsection{Participantes}

Foram participantes 92 adultos com idade variando de 18 a 70 anos do ensino superior do 1 ㅇ e 6 o semestre do curso de Direito de um Centro Universitário da Grande São Paulo, com $64,13 \%$ dos participantes sendo do sexo feminino.

\subsection{Instrumentos}

\subsubsection{ENADE Direito - INEP}

O ENADE apresenta 40 questões que avaliam conhecimentos, competências profissionais e habilidades acadêmicas de estudantes do Ensino Superior. Desse teste, 10 questões são relativas ao componente de formação geral, e as 30 restantes são itens específicos da área do curso em avaliação. Cada questão respondida corretamente receberá um ponto. O estudo utilizou 26 questões de Competência Especifico/Múltipla Escolha, extraídas do questionário do ENADE. As demais questões, que são dissertativas e conhecimento geral, não foram utilizadas, por não contemplarem o objetivo do presente estudo. Sua aplicação foi 
realizada via "papel e lápis" definição atribuída por sistema de avaliação tradicional neste tipo de ambiente.

\subsubsection{Avaliação do ENADE Direito informatizado adaptativa}

Cabe ressaltar que este instrumento é feito em papel e lápis e suas questões foram inseridas no MOODLE como questionário adaptativo, instalado no módulo de atividade. Foi utilizado nesse estudo o ambiente MOODLE versão 2.7+ (Build:20140522), com plugin Adaptive Quiz versão:2015060900, ao qual foram adequados os questionários e disponibilizados aos respondentes no ambiente MOODLE.

O Modulo de atividade Adaptive Quiz é um novo módulo do MOODLE, que permite criar, modificar e administrar questionário no estilo adaptativo. Um algoritmo é utilizado para estimar a capacidade do participante nas escolhas das perguntas dentro de certo número de erros, do nível mais fácil até o mais difícil. Os parâmetros para utilização do algoritmo são configuráveis, dentro outros parâmetros são necessários a utilização de categorias do banco de questões e tags (marcadores), a fim de determinar as questões que serão exibidas durante a tentativa do participante individualmente. Entretanto as categorias de questões podem atribuir o conjunto de perguntas do Adaptive Quiz e as tags são utilizadas para atribuir os níveis de dificuldades as perguntas. Foi verificar a implementação deste algoritmo, nos arquivos de plugin do MOODLE ADAPTIVE QUIS, e pode ser encontrado no arquivo salvo no diretório “...MOODLE\mod \adaptivequiz\catalgo.class. php”.

O conjunto de parâmetros permite que o aplicador possa determinar os níveis de dificuldade das perguntas. Inicialmente o nível para primeira pergunta é selecionado nos parâmetros e, em seguida, o algoritmo seleciona o próximo nível de dificuldade ou retrocede o nível dependendo da resposta certa ou errada e sim por diante até o final do questionário. No início de uma tentativa o conjunto de perguntas é indeterminado. A quantidade de perguntas que serão apresentadas está entre o número mínimo e máximo de perguntas determinadas nos parâmetros. Quando o número mínimo de perguntas respondidas for atingido e para que aja a sua parada por completo, o participante do teste tem que atingir o nível de capacidade de precisão requerida ou atingir o número máximo de perguntas respondidas. Assim, atendendo a estratégia sugeria por Olea et al. (2004).

\subsection{Procedimentos}

Todos os instrumentos de avaliação anteriormente descritos foram aplicados em sessões previamente agendadas junto aos participantes e à Instituição, após consentimento dos responsáveis pela Instituição e pelos alunos, e assentimento desses últimos. Foram utilizados os laboratórios de informática da própria Instituição com agendamento prévio para a aplicação do teste informatizado e teste no papel, sendo que o pesquisador levou lápis, caneta, papéis e folhas de teste, bem como termos de consentimento. As avaliações respeitaram as atividades cotidianas, de modo que não comprometeu as atividades estabelecidas pela Instituição e foram realizadas durante o período de aulas (noturno), em horário cedido pelo 
professor, usou em média noventa minutos para aplicação. Os dois instrumentos foram aplicados um em seguida do outro, iniciando pelo teste em lápis e papel e o de computador em seguida, durando 45 minutos cada um. Cabe mencionar que o estudo foi aprovado pelo comitê de ética em pesquisa do Centro Universitário FIEO - UNIFIEO/SP.

Os procedimentos de coletas de dados ocorreram em 2 etapas; na primeira foi aplicado o instrumento de avaliação "ENADE", em formato de papel e lápis em grupo; e num segundo momento, a avaliação informatizada em computadores nos laboratórios cedidos pela Instituição. Nesse caso, ocorreu em 40 máquinas ao mesmo tempo (1 para cada avaliando). Assim, a aplicação ocorreu em grupos compostos de 40 (quarenta) pessoas cada. Ambas as etapas tiveram duração de 45 minutos cada.

\subsection{Resultados E Discussão}

Para a análise dos dados, inicialmente, os dados obtidos serão tabulados em planilha. Em seguida serão feitas as análises descritivas das variáveis obtidas no ENADE informatizado e em papel e lápis. Esses instrumentos serão submetidos a procedimentos de análise de sua estrutura interna, visando a validá-la por duas análises estatísticas a saber: análise fatorial confirmatória, e TRI pelo modelo de Rasch. Em seguida, serão submetidos a análise de correlação de Pearson, visando a identificar se as duas formas do teste (informatizada e papel e lápis) são equivalentes (paralelas). Cabe mencionar que os resultados serão apresentados em

2 (duas) etapas conforme a seguir.

\subsubsection{Etapa 1. Estimação dos parâmetros dos itens do ENADE Direito 2006}

Para estimação dos parâmetros, foram usados dados de um estudo prévio do ENADE da prova de Direito de 2006, disponibilizados no site do INEP. Esse curso contou com 4491 sujeitos com idades de 21 a 63 anos com a maioria deles (74\%) com até 23 anos. Quanto ao sexo, $57,5 \%$ eram mulheres. Ainda, $58,7 \%$ estudavam no turno noturno. O nível de escolaridade dos pais em sua maioria (cerca de 50\%) foi nível superior. A maior parte das pessoas eram provenientes de famílias que apresentavam até 9 salários. Cerca de 53\% estudaram em instituições privadas de ensino e $75 \%$ do total de instituições estudadas apresentavam incentivo para pesquisa. Em relação ao conceito das instituições que os sujeitos eram provenientes, $43 \%$ apresentou conceito 3.

Nesse estudo foi estabelecido os parâmetros ao modelo informatizado adaptativo dos itens dos componentes específicos da prova de ENADE direito de 2006, esses parâmetros podem ser observados na Tabela 1. Percebe-se o nível de dificuldade dos itens da prova, bem como índices de ajuste de infit e outfit que demonstraram bons ajustes não excedendo parâmetros estabelecidos por Linacre (2002) de 1,5. Assim, a prova demonstrou bom ajuste ao modelo de Rasch. Os níveis de dificuldade foram classificados e inseridos no MOODLE a partir da Tabela 2 seguindo a especificação deste software que não aceita valores negativos. Ainda cabe mencionar que as cores apresentadas tanto na tabela 1 , como na tabela 2 , tem como propósito a compreensão dos níveis de dificuldades ao se inserir cada questão, sendo apenas 
ilustrativa. Após a estimação dos parâmetros, estes foram incluídos na base do MOODLE pelo método adaptativo e foram rodados nessa avaliação informatizada e também foram feito escalonamentos dos paramentos, por limitação do aplicativo, por não receber valores de estimação de itens negativos. Vale ressaltar que a prova foi aplicada no formato de papel e lápis e informatizado adaptativo em estudantes deste curso para serem correlacionadas as notas no Estudo 2 e estimadas a quantidade de informação fornecida por um e outro formato visando estabelecer pontos fortes e fracos de cada modalidade de aplicação. Para maiores detalhes sobre essas estimativas veja os anexos.

Tabela 1. ENADE 2006 - DIREITO.

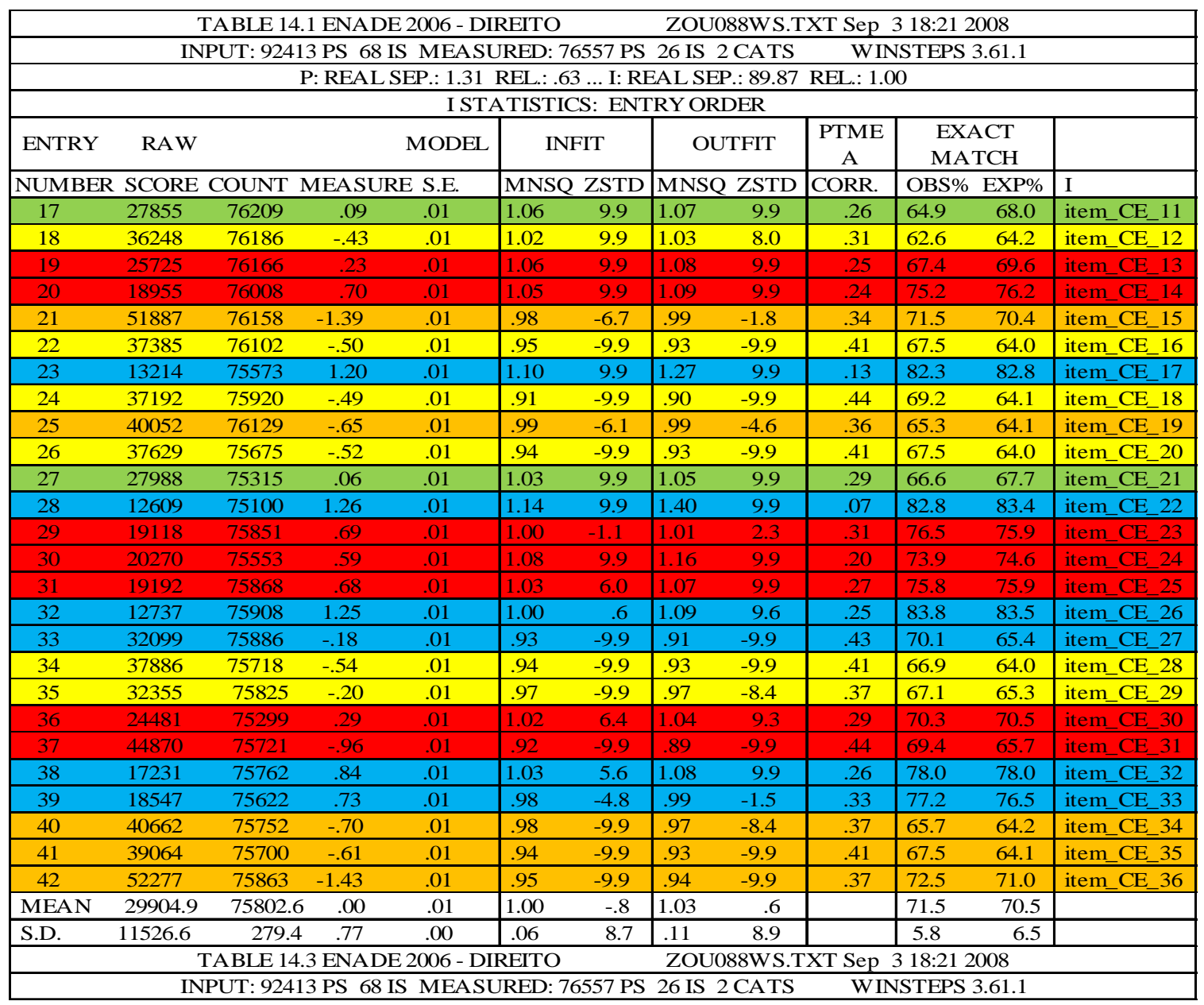

Tabela 2 Agrupamento por itens de dificuldade

\begin{tabular}{|c|c|c|c|}
\hline Level 1 & Dificuldata -2 & adpq_1 & Qtde Itens 6 \\
\hline level 2 & Dificuldata -1 & adpq_2 & Qtde Itens 6 \\
\hline Level 3 & Neutro & adpq_3 & Qtde Itens 2 \\
\hline Level 4 & Dificuldade 1 & adpq_4 & Qtde itens 6 \\
\hline Level 5 & Dificuldade 2 & adpq_5 & Qtde Itens 6 \\
\hline
\end{tabular}




\subsubsection{Etapa 2. Resultados da aplicação do ENADE - Direito em papel e lápis e informatizado adaptativo}

Os indicadores do ENADE no modelo informatizado adaptativo e papel e lápis para os Alunos do Ensino Superior foram investigados quanto à sua adequação ao modelo de Rasch. Tal modelo considera somente o parâmetro de dificuldade dos itens para se estimar a adequação deles a uma escala, partindo do pressuposto da TRI. Foram demonstrados abaixo. O ajuste do modelo leva em consideração a estrutura geral. Se você remover alguns itens "desajustados" e reprocessar a análise TRI a distribuição vai ser mais normal, mas ainda haverá itens com altos resíduos. Devido a isso, a abordagem de "modo de ajuste" não é uma boa maneira de examinar item ajustados. Em caso afirmativo, qual é a ferramenta adequada para verificar o ajuste do item? É o "IN.MSQ" e "OUT.MSQ" que significam "InFit " e "outfit." Foi utilizado nessa abordagem o "outfit".

\subsubsection{ENADE papel e lápis}

A precisão fornecida por esse modelo para os itens resultou em um coeficiente de 0,26 para os itens e 0,48 para as pessoas, o que favorece a interpretação de que as pessoas, ao responderem os itens, tendem a informar sobre os conhecimentos com maior precisão. Todavia, os itens não foram capazes de avaliar os conhecimentos dos alunos com a mesma magnitude. $\mathrm{O}$ erro médio de medida para itens e pessoas, respectivamente foi de 0,04 (DP= $0,01)$ e 0,08 ( $D P=0,01)$. Essas e outras informações constam da Tabela 3.

Tabela 3 - Parâmetros de Ajustes de Itens e das Pessoas ( $N=184)$ papel e lápis

\begin{tabular}{l|l|l|l|l|l|l|l|l}
\hline \multirow{2}{*}{ Parâmetros } & \multicolumn{9}{|l}{ Itens } & \multicolumn{2}{l}{ Pessoas } \\
\cline { 2 - 9 } & Dificuldade & I nfit & Outfit & Erro & Habilidade & I nfit & Outfit & Erro \\
\hline Média & 0,00 & 1,00 & 1,00 & 0,04 & $-1,07$ & 1,00 & 1,00 & 0,08 \\
\hline DP & 0,74 & 0,06 & 0,14 & 0,01 & 0,67 & 0,14 & 0,24 & 0,01 \\
\hline Máximo & 1,31 & 1,09 & 1.44 & & 0,36 & 1,31 & 1,68 & \\
\hline Mínimo & $-1,65$ & 0,87 & 0,79 & & $-2,72$ & 0,74 & 0,32 & \\
\hline Precisão & 0,26 & & & 0,48 & & & \\
\hline
\end{tabular}

Os itens forneceram média de outfit de 1,00 ( $D P=0,14)$, indicando um bom ajuste dos itens nesse aspecto, de forma geral. Analisando mais detidamente esses dados, observa-se que a variação de outfit esteve entre os valores $1,44-0,79$, sugerindo que todos os itens estiveram dentro dos parâmetros de ajuste ao modelo. Nenhum item apresentou índices acima de 1,50 (Bond \& Fox, 2001). O procedimento de análise empregado para se interpretar as pontuações gerais brutas produzidas com o ENADE (provenientes da soma dos escores nos fatores) foi o uso do mapa do construto ou mapa de respostas esperadas, baseado na TRI, mais especificamente, no modelo de Rasch. 


\subsubsection{ENADE Informatizado e Adaptativo}

A precisão fornecida por esse modelo para os itens resultou em um coeficiente de 0,40 para os itens e 0,81 para as pessoas, o que favorece a interpretação de que as pessoas, ao responderem os itens, tendem a informar sobre os conhecimentos com maior precisão. Todavia, os itens não foram capazes de avaliar os conhecimentos dos alunos com a mesma magnitude. $\mathrm{O}$ erro médio de medida para itens e pessoas, respectivamente foi de 0,70 ( $D P=$ $0,01)$ e $0,40(D P=0,01)$. Essas e outras informações constam da Tabela 4.

Tabela 4 Parâmetros de Ajustes de Itens e das Pessoas ( $\mathrm{N}=184$ ) adaptativo

\begin{tabular}{|c|c|c|c|c|c|c|c|c|}
\hline \multirow{2}{*}{ Parâmetros } & \multicolumn{4}{|l|}{\begin{tabular}{|l|} 
Itens \\
\end{tabular}} & \multicolumn{4}{|l|}{ Pessoas } \\
\hline & \begin{tabular}{|l} 
Dificuldade \\
\end{tabular} & Infit & Outfit & Erro & Habilidade & Infit & Outfit & Erro \\
\hline Média & 0,00 & 0,99 & 1,03 & 0,70 & $-1,05$ & 0,99 & 0,95 & 0,04 \\
\hline DP & 1,06 & 0,16 & 0,36 & 0,01 & 0,90 & 0,21 & 0,33 & 0,01 \\
\hline Máximo & 1,96 & 1,36 & 2,43 & & 1,38 & 1,50 & 2,40 & \\
\hline Mínimo & $-1,97$ & 0,25 & 0,54 & & $-3,22$ & 0,58 & 0,49 & \\
\hline Precisão & \multicolumn{4}{|l|}{0,40} & \multicolumn{4}{|l|}{0,81} \\
\hline
\end{tabular}

Os itens forneceram média de outfit de 1,03 ( $D P=0,36)$, indicando um bom ajuste dos itens nesse aspecto, de forma geral. Analisando mais detidamente esses dados, observa-se que a variação de outfit esteve entre os valores $2,43-0,54$, sugerindo que nem todos os itens estiveram dentro dos parâmetros de ajuste ao modelo. Alguns itens apresentaram índices acima de 1,50 (Bond \& Fox, 2001). Isso revela que para a análise de casos extremos há mais discordância do modelo para o dado empírico, em outras palavras, pessoas que deveriam acertar itens mais fáceis ou mais difíceis não acertam, não é tão preciso para pessoas com resultados extremos. Provavelmente isso decorre pelo fato de que nem todos os sujeitos responderam ao inventário por completo. O fato é que ele é mais preciso para avaliar pessoas com habilidades medianas. Ao mesmo tempo não houveram incrementos de precisão significativos entre as duas formas.

Em uma situação dicotômica, a variância é $p(1-p)$ enquanto $p=$ valor do parâmetro. Com base nos valores dos parâmetros do item, pode-se calcular e traçar a função das informações de teste (TIF) para os itens como mostrado na Figura 1 e 2. 
Figura 1. Test Information Funcion Teste Adaptativo.

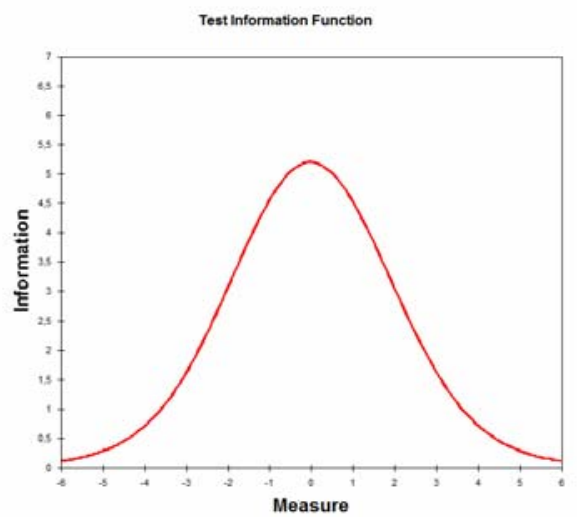

Fonte: SANTANA, 2016

Figura 2. Test Information Funcion Teste papel e lápis.

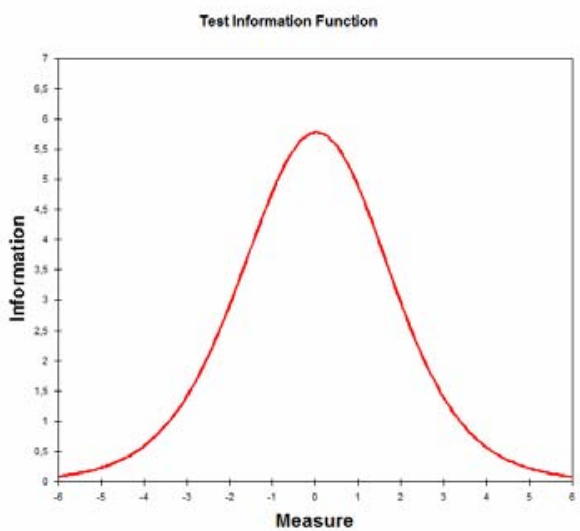

Fonte: SANTANA, 2016

Conforme apresentado, é possível observar as duas Figuras, que estas TIFs são diferem entre si. No teste adaptativo, a maioria das informações é dispersa em relação ao $\theta$ zero, isso nos indica que os itens são menos precisos, enquanto a quantidade de informação nas extremidades inferiores são as mesmas, podemos notar que cai lentamente. No teste papel e lápis, a maioria das informações é centralizada em relação ao $\theta$ zero, isso nos indica que os itens são mais precisos, enquanto a quantidade de informação nas extremidades inferiores também são as mesmas, podemos notar que cai rapidamente. A Função de Informações do Item (IIF) é um pico em algum momento que mostra a precisão desigual ao longo da escala, tal teste seria melhor para estimar a capacidade de armazenamento dos investigados cuja habilidade é cair perto do pico do teste de informação. Em alguns testes, a TIF são bastante plana na região central da escala. Tais testes estimam algum gama de capacidade de armazenamento com quase igual precisão e fora desta faixa com menos precisão.

A TIF é simplesmente a soma de todos os IIFs no teste. Enquanto IIF pode nos expor a informação e a precisão de um determinado parâmetro de item, o TIF pode nos expor a mesma coisa no nível de exame. Quando há mais de um formulário alternativo para o mesmo exame, o 
TIF pode ser usado para equilibrar formulários alternativos. O objetivo é fazer com que todas as formas alternativas tenham os mesmos valores de TIF em todos os níveis de $\theta$. A correlação entre os níveis de dificuldade dos itens nas duas formas foi 0,82 , revelando que os parâmetros dos itens se mantiveram os mesmos entre uma e outra forma de aplicação. Já a habilidade das pessoas teve correlação de 0,40 , sugerindo que os dois formatos tenderam a avaliar as pessoas de maneira diferente. Dentre os fatores que podem explicar este fato, há que se considerar que os algoritmos de parada e seleção dos itens no MOODLE são feitos desconsiderando valores negativos (mas somente categorias dos níveis de dificuldade dos itens). Além disso, a redução do erro padrão em casos extremos tardou a acontecer, elevando os valores de outfit de itens e principalmente de pessoas no modelo informatizado, sendo esta uma limitação deste modelo no MOODLE que poderia ser reavaliada, sobretudo com um banco de itens pequeno como este $(n=26)$. Apesar disso, a curva de informação do modelo informatizado apresentou maior amplitude, possibilitando uma melhor análise e interpretação das habilidades das pessoas em um intervalo maior. O aumento no número de itens favoreceria uma estimativa destas habilidades com maior precisão, melhorando níveis de precisão e problemas de outfit identificados.

Há que se ressaltar também que somente o item 13 apresentou funcionamento diferencial significativo entre formas do teste, revelando que na forma de papel e lápis ele foi mais difícil. Halkits (1993) apresenta um CAT para medir a competência dos estudantes de enfermagem em três áreas: cálculo, princípio de administração de drogas e efeitos dos medicamentos. Este modelo foi apresentado como uma possibilidade explicativa para os dados ora obtidos no MOODLE. Construiu um banco de itens para cada área de conhecimento, calibrando suas dificuldades conforme o de papel-e-lápis anterior mente administrado a 4496 examinados. Como administrar um teste-tomador, uma estimativa de capacidade inicial (pseudo-Bayesiano) é fornecido pela atribuição a cada participante em dois itens fictícios com a dificuldade média, $\mathrm{D}^{0}$, do banco de subitens. Assim estimativa de capacidade inicial de cada aluno é a dificuldade do item média.

O primeiro item para resposta é selecionado aleatoriamente perto 0,5 logits menos do que a capacidade de estimativa inicial. Isso produz uma chance de $62 \%$ de sucesso de acerto no item, ao qual o participante pode não estar familiarizado com o CAT, produzindo assim à oportunidade de exatidão de sucesso em todo o CAT. A seleção dos próximos itens por ser aleatório melhora na segurança do teste, impedindo que os participantes tenham testes idênticos. Após a resposta do primeiro item, é feito o calculo da media de competência e erro padrão são estimados. Mais uma vez, um item é selecionado entre os que estão perto de 0,5 logits mais fácil do que a competência estimada. De, pois que este item é respondido, a medida de competência é novamente revista e mais um item é selecionado e administrado, e o processo tem seu prosseguimento.

A medida de erro padrão adotada também não foi restritiva o suficiente para alguns sujeitos, sendo que estes responderam a uma quantidade maior de itens. Talvez a quantidade de itens no banco tenha sido pequena demais sendo necessária uma versão com mais itens para novas estimativas do erro padrão que sejam mais adequadas para uma parte dos 
participantes. Isso pode estar associado também à maior quantidade de desajustes das pessoas na versão informatizada em comparação à papel e lápis. Apesar disso, a versão informatizada via MOODLE foi capaz de fornecer uma quantidade maior de informação com uma quantidade menor de itens de modo geral, fato este que, se associado com a baixa correlação dos thetas estimados via informatizada e papel e lápis indicaria a viabilidade do modelo informatizado adaptativo.

Visualizando a função de erro padrão, note que depende apenas da diferença entre o número de respostas certas e erradas e o número total de respostas, não em outras características tais como que a igualdade entre as resposta certas e erradas, para um número fixo de perguntas, o erro-padrão será menor. Conforme discutido em Wright (1988), a fórmula para calcular a medida de capacidade é dada por: Medida de capacidade $=H / L+\ln (R / W)$, onde $\mathrm{H}$ é a soma de tudo questionar dificuldades respondidas, $\mathrm{L}$ é o número de perguntas respondidas, $\mathrm{R}$ é o número de respostas certas, e $\mathrm{W}$ é o número de respostas erradas.

Segundo as descrições anteriormente apresentadas é possível entender que esta medida não é afetada pela ordem de resposta, e sim pela dificuldade total e o numero de respostas certas e erradas. Esta medida é controlada pelo algoritmo de teste apresentando alternância entre as perguntas respondidas pelo usuário certo/errado e pode não ser aplicado a outros algoritmos. Na prática isso significa que a capacidade de medir não deve excepcionalmente ser afetada por um conjunto pequeno de respostas certas ou erradas. Conforme discutido por Linacre (2000), a medida da capacidade do teste-tomador pode convergir com a dificuldade da pergunta no qual o teste-tomador tem uma probabilidade de $50 \%$ de responder uma pergunta corretamente. Por exemplo, dado um teste com 10 perguntas e o teste-tomador que respondeu todas as perguntas 5 corretamente e a pergunta 6 de forma errada, medida de capacidade do teste-tomador cairia perto de 5.5.

No caso específico do MOODLE há que se considerar que as dificuldades no critério de parada identificadas estão associadas a cinco critérios, quais seja o banco de itens já atingiu sua capacidade total. (ocorre quando há pequena quantidade de itens associadas ao teste); 0 tamanho máximo é atingido. (ocorre quando atinge o numero Maximo de itens cadastrados nos parâmetros); A medida de capacidade é estimada com precisão suficiente. (ocorre quando cada resposta fornece mais informações estatísticas sobre a medida de capacidade diminuindo o desvio padrão de medida e aumentando sua precisão.); A medida da capacidade é suficientemente longe. (ocorre quando não há mais itens à esquerda); O teste-tomador esta mostrando comportamento fora-teste. (ocorre quando o algoritmo do CAT detecta respostas irrelevantes da mesma opção ou resposta padrão de opções, responder rapidamente e também muito lentamente). Assim, a quantidade de desajustes de pessoas ao modelo, bem como a quantidade de itens parecem ter sido os principais problemas identificados no modelo atual.

Por fim, de um ponto de vista psicométrico, este estudo refere-se a validade, que na opinião de Anastasi e Urbina (2000), referem-se primeiramente ao que o teste mede. Entretanto, essa definição é mais compreensiva, dizendo respeito, essencialmente ao uso específico para o qual a prova foi criada, sendo determinados seus métodos de pesquisa em razão de tais objetivos de testagem. Que vem ao encontro do que diz (Stevens, 1946) que 
medir é inserir numero para apresentar a variação de uma variável qualquer, a partir de algumas regras bem definidas, seja qual for, e este trabalho teve como objetivo evidenciar validade entre os testes, para os parâmetros de ajustes dos itens papel e lápis indicam que eles foram respondidos conforme as expectativas do modelo Rasch (Racsh, 1960), pois os valores de infit e outfit estão dentro do intervalo considerado por Linacre (2002) como de ajuste adequado, também para os parâmetros de ajustes dos itens do modelo adaptativo indicam os mesmos e a precisão fornecida por esses modelos de itens favorece a interpretação de que as pessoas, ao responderem os itens, tendem a informar sobre os conhecimentos com maior precisão.

A precisão e eficiência de um teste são preocupações primordiais e, muitas vezes, concorrentes na avaliação aplicada, havendo uma tendência para usar testes (questionários) curtos como alternativa para redução do tempo do teste e dos custos segundo (Makransky e Glas, 2013), com tudo pode ser observar pelos achados que teste informatizado adaptativos compre estes princípios, pois não é necessário que todo o questionário seja aplicado ao respondente para que obtenha uma avaliação desejada. Outro ponto importante também observado por Olea et al. (2004), a respeito de um Teste Adaptativo Computadorizado que o plugin adptive quiz do MOODLE nos trás características imprescindíveis a randomização das questões do banco de questões, a aleatoriedade entre os itens das questões, proporcionando ao respondente exclusividade em seu questionário.

\subsection{Considerações Finais}

A presente pesquisa, tendo por base as descrições observadas na literatura no que tange a hipótese que poderia haver correlação entre os testes, sendo que alguma diferença poderia ser mais comum em um ou em outro teste, foi observado que a correlação entre os itens de dificuldades dos testes foi significativa e as habilidades das pessoas teve uma correlação baixa, levantou-se o funcionamento diferencial dos itens (DIF) que compunham o teste Informatizado Adaptativo, utilizando o modelo de Rasch (1960) que permite investigar a probabilidade de acerto aos itens, por pessoas com determinada habilidade, tendo em vista suas dificuldades, observa-se que neste teste em comparação com o papel e lápis nem todos os itens são passados para os respondentes podendo haver alguma discrepância entre os resultados. Pode-se considerar que estudos que se propõem a analisar os itens, recorrendo a TRI como meio de análise, permitem aferir evidência de validade de construto ao instrumento analisado, pois evidenciam o quanto cada item estaria contribuindo para mensurar o construto.

Outro aspecto a ser mencionado é a análise do DIF, que possibilitou concluir que a medida de compreensão investigada na presente pesquisa não apresentou vieses de gênero, não havendo necessidade de modificá-la. Esses dados reforçam a confiabilidade do uso do teste Informatizado Adaptativo acerca de sua eficácia no caso do ENADE Direito, mostrando-se uma alternativa viável e de baixo custo para instituições e governo visando melhorar os sistemas de avaliação do ENADE. Todavia, não se descarta a necessidade de investigações futuras que visem aferir novas evidências de validade para o teste Informatizado Adaptativo no MOODLE. 


\section{Referências}

AAKER, ET AL Marketing Research (7th Ed.), New York: John Wiley \& Sons, Inc, 2001. Disponível em: $<$ http://www.inf.ufsc.br/ verav/Ensino_2013_2/0_uso_de_questionarios_em_trabalhos_cient\%EDficos.pdf $>$, Acesso em: 11 dez. 2015

ADAPTIVE QUIS ENGINE. Disponível em: < http://rlcommunity.remotelearner.net/mod/book/view.php?id=70\&chapterid=1030>, Acesso em: $11 \mathrm{dez}, 2015$.

AERA; APA; NCME (American Educational Research Association; American Psychological Association; National Council on Measurement in Education). Standards for Educational and Psychological Testing. Washington, DC: AERA, 1999.

AnAStasi, A., \& URBINA, S. Testagem Psicológica. Porto Alegre: Artes Médicas. Andrade, D. F., Tavares, H. R., \& Valle, R. C. Teoria da Resposta ao Item: conceitos e aplicações. São Paulo: Associação Brasileira de Estatística, 2000.

BARTHOLOMEU, D., SILVA, M. C. R., PIRES, S. D., \& PRIMI, R.. Estabelecimento de pontos de corte pela TRI para uma prova equalizada com o ENADE. Em F. C.-Capovilla. (Org.). Transtornos de aprendizagem: Progressos em avaliação e intervenção preventiva e remediativa (p. 229-238), v. 1, São Paulo: Memnon, 2011.

BOND, T. G., \& FOX, C. M. Applying the Rasch model: Fundamental measurement in the human sciences. London: Lawrence Erlbaum Associates, 2001

BRASIL. Sistema nacional de avaliação do ensino superior - sinaes. 2015. Disponível em: <www.inep.gov.br>, Acesso em: 21 abr. 2015

CHAGAS, D. A.; LISBOA, R. P.; FURTADO, E. S. Framework MAAVA Metodologia de Avaliação de Ambientes Virtuais de Aprendizagem. Anais do Simpósio Brasileiro de Informática na Educação, p. 856-859, 2011

COMPUTER-ADAPTIVE TESTING: A Methodology Whose Time Has Come. Disponível em : <http://www.rasch.org/memo69.pdf>, Acesso em: $11 \mathrm{dez} .2015$.

COSTA, D. R. Métodos estatísticos em testes adaptativos informatizados. Dissertação (Mestrado) Universidade Federal do Rio de Janeiro, Rio de Janeiro, 2009. Disponível em: <http: //www.pg.im.ufri.br/teses/Estatistica/Mestrado/121.pdf>. Acesso em: 03 Jul, 2016.

DOUGIAMAS, M. Reading and Writing for Internet Teaching, 1999. Disponível em: <http://dougiamas.com/writing/readwrite.html>, Acesso em: 11 dez. 2015.

ELLIS, R. Field Guide to Learning Management Systems, ASTD Learning Circuits, 2009. Disponível em: $<$ http://www.astd.org/NR/rdonlyres/12ECDB99-3B91-403E-9B157E597444645D/23395/LMS_fieldquide_20091.pdf>. Acessado em: 15 abril de 2016

FERRÃO, M. E. Introdução aos modelos de regressão multinível em educação. Campinas: Komedi, 2003.

FRANCISCATO, F. T. et al. Avaliação dos Ambientes Virtuais de Aprendizagem MOODLE, TelEduc e Tidia - Ae: um estudo comparativo. Novas Tecnologias na Educação, v. 6, n. 2, p. 5- 10, 2008.

HALKITIS, P. N. CAT algorithm. Rasch Measurement Transactions, v. 6:4, p.254-5, 1993.

JESUS, G. R. \& LAROS, J. A.. Eficácia escolar: regressão multinível com dados de avaliação em larga escala. Avaliação Psicológica, 3(2), 93-106, 2004.

JESUS, F. DE; JUNIOR, M.; TEZZA, R. Algoritmo de um teste adaptativo informatizado com base na teoria da resposta ao item para a estimação da usabilidade de sites de e-commerce. Produção, $v$. 23, n. 2010, p. 525-536, 2013.

LANDEIRA-FERNANDEZ, J., \& PRIMI, R. (2002). Comparação do desempenho entre calouros e formandos no Provão de Psicologia 2000. Psicologia: Reflexão e Crítica, 15(1), 219-234.

LEGOINHA, P., Brilha, J. \& Neves, L. Geologia e Internet em Portugal. Ciências da Terra (UNL), Lisboa, no especial IV, pp. 9-15, 2000. Disponível em: <http://www.geopor.pt/geotic/papers/legoinha.html>, Acesso em: 11, dez, 2015 
LEGOINHA, P. O MOODLE e as comunidades virtuais de aprendizagem The MOODLE and the virtual learning communities. SciencesNew York, v. 1, p. 1-4, 2006.

LEITE, E. A. M. et al. Avaliação Assistida , Feedbacks e Questionários do MOODLE. Anais do XXII SBIE - XVII WIE, n. Novembro 2011, p. 2303-2313, 2011.

LINACRE, J. M. Computer-Adaptive Testing: A Methodology Whose Time Has Come. Development of Computerized Middle School Achievement Test, n. 69, 2000.

LINACRE, J. M. What do infit and outfit, mean-square and standardized mean? Rasch Measurement Transactions,16(2), 887, 2002.

MAKRANSKY, G. \& GLAS, C.A.W. The Applicability of Multidimensional Computerized Adaptive Testing for Cognitive Ability Measurement in Organizational Assessment. International Journal of Testing, 13(2), 123-139, 2013.

MOODLE, 2015. Disponível em: <http://www.MOODLE.org>, Acesso em: 15 fev 2015.

MOREIRA, F. Sistemática para a implantação de testes adaptativos informatizados baseados na teoria da resposta ao item. Tese (Doutorado) - Universidade Federal de Santa Catarina, Florianópolis, 2011. Disponível em: <http://repositorio.ufsc.br/handle/123456789/95506>. Acesso em: 03 Jul, 2016.

OLEA, J. et al. Un test adaptativo informatizado para evaluar el conocimiento de inglés escrito: diseõ y comprobaciones psicométricas. Psicothema, v. 16, n. 3, p. 519-525, 2004. Disponível em: http://www.unioviedo.es/reunido/index.php/PST/article/view/8230. Acesso em: 03 jul, 2016.

PORTUGUAL, FCT (Faculdade de Ciências e Tecnologia), 2015. Disponível em: <http://MOODLE.fct.unl.pt/>. Acesso em: 15 Out, 2015

PULINO, A. R., MOODLE, um sistema de gerenciamento de cursos. Brasília/DF: Departamento de Engenharia Civil e Ambiental, Universidade de Brasília. Sob Licença da Creative Commons (2005).

RASCH, G. Probabilistic models for some intelligence and attainment tests. Copenhagen: Danish Institute for Educational Research, 1960

RAUDENBUSH, S. W. Schooling, statistics, and poverty: can we measure school Improvement? New Jersey: Educational Testing Service, 2004

RAUDENBUSH, S. W. What are value-added models of estimating and what does this imply for statistical practice. Journal of Educational and Behavioral Statistics, 29(1), 121-129, 2004b.

RUBIN, D. B. Estimating causal effects of treatments in randomized and nonrandomized studies. Journal of Educational Psychology, 66(5), 688-701, 1974

RUBIN, D. B., STUART, E. A. \& ZANUTTO, E. L. A potential outcomes view of value-added assessment in education. J ournal of Educational and Behavioral Statistics, 29, 103-116, 2004.

SANTANA, L. F. Avaliação informatiza adaptativa do ENADE pelo MOODLE: evidências de validade. Centro Universitário FIEO, 2016.

SALVADOR, JOSÉ; GONÇALVES, J. O MOODLE Como Ferramenta De Apoio a Uma Disciplina Presencial De Ciências Exatas. Anais do XXXIV Congresso Brasileiro de Ensino de Engenharia, v. 1, n. 1941, p. 7122 - 7131, 2006.

SOARES, J. F., RIBEIRO, L. \& CASTRO, C. M. Valor agregado de instituições de ensino superior em Minas Gerais para os cursos de Direito, Administração e Engenharia Civil. Dados, 44(2) 363-396, 2001.

STEVENS, S.S. On the Theory of Scales of Measurement. Science 103 (2684): 677- 680, 1946. Disponível em: doi:10.1126/science.103.2684.677. PMID 17750512. Acessado em: 16 Nov, 2016

URBINA, S. Essentials of Psychological Testing. New Jersey: John Wiley \& Sons, Inc., 2004.

WAINER, H. et al. Computerized adaptive testing: A primer. Lawrence Erlbaum Associates, Inc, 1990. Disponível em: <http://www.springerlink.com/index/M58R14228306306V.pdf>. Acesso em: 03 Jul, 2016. 
Recebido em dezembro de 2016

Aprovado para publicação em agosto de 2017

\section{Lucio Ferreira Santana}

Programa de Pós-Graduação em Psicologia Educacional - Centro Universitário FIEO - UNIFIEO, Brasil, luciolfs@gmail.com

\section{Daniel Bartholomeu}

Programa de Pós-Graduação em Psicologia - Centro Universitário Salesiano - UNISAL - Americana, Brasil, d_bartholomeu@yahoo.com.br

\section{José Maria Montiel}

Programa de Pós-Graduação em Psicologia Educacional - Centro Universitário FIEO - UNIFIEO, Brasil, montieljm@hotmail.com

\section{Gleiber Couto}

Programa de Pós-Graduação em Psicologia - Universidade Federal de Goiás no Campus de Catalão UFG/CAC, Brasil, gleibercouto@gmail.com

\section{Arthur Almeida Berberian}

Programa de Pós-Graduação em Psicologia Educacional - Centro Universitário FIEO - UNIFIEO, Brasil, arthru.berberian@gmail.com

\section{Fernando Pessoto}

Programa de Pós-Graduação em Psicologia - Centro Universitário Salesiano - UNISAL - Americana, Brasil, fpessoto@gmail.com 


\title{
Scribblenauts Unmasked: Avaliação do Jogo Digital e seus Aspectos Educativos
}

\section{Scribblenauts Unmasked: Evaluation of Digital Game and his Educational Aspects}

Fabiano Naspolini de Oliveira
Universidade Federal de Santa Catarina

Eliane Pozzebon Universidade Federal de Santa Catarina

Luciana Bolan Frigo

Universidade Federal de Santa Catarina

\begin{abstract}
Resumo: A utilização de jogos digitais, na educação, aperfeiçoa o perfil dos nativos digitais em sala de aula. Para contribuição de mais recursos didáticos, que tenham relação ao perfil deles, este artigo apresenta o jogo digital Scribblenauts Unmasked. O objetivo geral é apresentar o potencial educativo de jogos digitais mediante diversão e aprendizado. Estão expostos aspectos técnicos e demais propriedades do jogo, tais como: gráficos, jogabilidade, música, mecanismos e a diversão aplicada. Realiza-se uma relação entre esses aspectos e a diversão, juntamente aos elementos que o caracterizam como ferramenta educativa. Apresenta-se a experiência do jogo, com alunos, com aplicação dos conceitos de substantivos e adjetivos. O experimento demonstra o potencial educativo do jogo digital em questão, confirmando a hipótese inicial de que é possível utilizá-lo na educação com intuito de uma aprendizagem mais ativa do conteúdo proposto.
\end{abstract}

Palavras-chave: Jogo digital. Scribblenauts Unmasked. Educação. Diversão.

\begin{abstract}
Using digital games in education it's aligned to the new student's profile who are in classrooms. So, to give an appropriated didactic resource to these students, this article presents the Scribblenauts Unmasked game. The objective is to present the educational potential of the game before fun and learning. The research shows the game objectives, and technical aspects like graphics, gameplay, music, mechanics and the fun. A connection among all these aspects and the main characteristics of education tool is described. Finally, this article explains about how students experience the game to learn concepts of substantives and adjectives and it shows the educative potential of digital game.
\end{abstract}

Keywords: Digital game. Scribblenauts Unmasked. Education. Fun. OLIVEIRA, Fabiano Naspolini de; POZZEBON, Eliane; FRIGO, Luciana Bolan. Scribblenauts Unmasked: Avaliação do Jogo
Digital e seus Aspectos Educativos. Informática na Educaçăo: teoria \& prática, Porto Alegre, v. 20, n. 2, p. 239-257, mai./ago. 2017 


\section{I ntrodução}

Ao se utilizar uma ferramenta didática em sala de aula, é importante analisar a sua aplicabilidade para o contexto educacional específico do assunto a ser ensinado. Em caso de utilização de jogos comerciais, segundo Gee (2007), ele precisa ter bons princípios de aprendizagem construídos em seu projeto. Quando o autor menciona princípios construídos em seu projeto, ele se refere ao aprendizado que o jogo oferece do jeito que foi criado, não necessariamente que a aplicação foi pensada para esse propósito (jogos educativos). Portanto, é importante discutir essas boas práticas para se ter subsídios e segurança ao analisar um jogo que poderá ser aplicado com alunos em sala de aula e também ser indicado para que outros professores possam utilizá-lo.

O Scribblenauts (figura 1) na primeira versão traz um jogo digital comercial desenvolvido primeiramente em 2009 pela empresa 5th Cell e distribuído pela Warner Bros. Interative Entertainment. O jogo possui 22.802 palavras disponíveis ao jogador. Com essa quantidade de palavras, diversos objetos para a interação ao longo do game podem ser criados. O jogo inicia sua história com um garoto que escreve uma palavra no caderno e com essa ação, o que foi escrito torna-se realidade de forma a auxiliá-lo na resolução dos problemas propostos no game. Há múltiplas escolhas, o jogador pode salvar um gato em cima de uma árvore com uma escada ou usar um propulsor a jato para voar e capturar o felino. Ao escrever a palavra, surge o objeto para interagir. Desta fase, cabe destacar, apenas o recurso de substantivo atende aos objetivos propostos neste artigo.

O sucesso do jogo trouxe uma série de outros games oriundos dessa primeira versão, dentre eles está o Scribblenauts Unmasked. Nesse jogo, o garoto do jogo novamente tem que ajudar as pessoas com suas habilidades, escrevendo as palavras no seu caderno e criando coisas, porém, contam com o adicional dos heróis da DC Comics, que inclusive, agregam o vocabulário próprio desse mundo dos quadrinhos. Exemplos de heróis são Super-Homem, Batman, Mulher Maravilha, Flash, etc. Outro recurso novo é a permissão de adicionar adjetivos aos itens do jogo, que também será um recurso que atenderá o objetivo deste artigo.

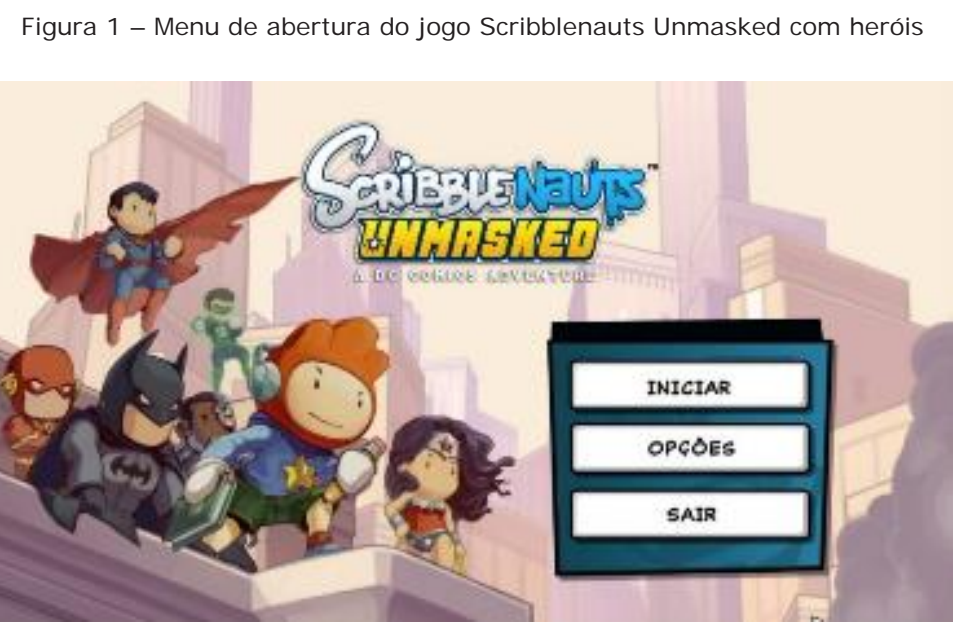

Fonte: elaborada pelos autores.

Em 2013 é criado o Scribblenauts Unmasked: A DC Comics Adventure, com mais opções e recursos. Este jogo possui característica e potencial dentro do contexto da educação, perante análise na aplicação de diversão e aprendizado. Esse tema torna-se relevante, pois, tanto os 
jovens quanto os adultos que cresceram interagindo com games, são um público significativo em quantidade de usuários. Inclusive, Mattar (2010) ressalta que os jovens, os nativos digitais, cresceram jogando videogames, sendo um elemento que faz parte do cotidiano deles. Contudo, este público não está recebendo a devida atenção quanto aos aspectos educativos.

Para contextualizar, apresentam-se os conceitos de jogos educativos avaliados no presente trabalho. Estão descritos os detalhes técnicos de Scribblenauts Unmasked para que se entendam seus objetivos e missões, e o que o torna um jogo de entretenimento divertido com vários recursos. Depois são abordados os aspectos educacionais que esse game possui sob o ponto de vista de conhecimentos, habilidades e atitudes que podem ser trabalhados nele. São apresentadas algumas sugestões de abordagens em sala de aula com esse game.

É importante ressaltar que a versão avaliada foi para computador, haja vista que existem outras para videogames.

Também é apresentado um experimento feito com alunos da rede pública da cidade de Araranguá - SC com o intuito de verificar a aprendizagem dos conceitos de substantivo e adjetivo por meio da utilização do jogo, que é foco desse artigo. Discute-se o procedimento adotado no experimento e referencial teórico para criação das perguntas realizadas, além dos resultados obtidos na aplicação com os alunos.

Pretende-se com a análise desse jogo, sob o ponto de vista técnico e educacional, contribuir para o entendimento dessas plataformas digitais como potencial para a educação e demonstrar que aprender e se divertir é uma possibilidade diferente de outros meios convencionais.

É importante ressaltar que nesse artigo, ambos os termos, jogo e game, se referem a jogos digitais já que a aplicação proposta está em meio digital e não serão discutidos aspectos de jogos analógicos.

\section{J ogos Educativos}

Conforme, Clua e Bittencourt (2004), todos os jogos possuem potencial educativo. A diferença está em que alguns foram desenvolvidos desde o início com este propósito. Já outros, foram produzidos para entretenimento, mas, com a devida adaptação, também podem ser usados no contexto educacional. Essa divisão é abordada na figura 2, demonstrando que os jogos com exclusividade de entretenimento também são educativos. Os jogos didáticos são aqueles comumente chamados de educativos por terem em seu design a preocupação de ensino de algum conteúdo.

Figura 2 - Jogos educativos e suas vertentes

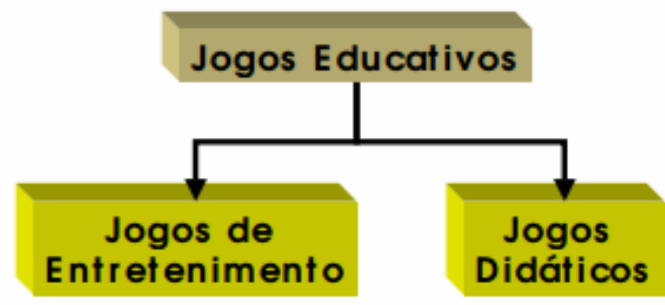

Fonte: Clua e Bittencourt (2004).

Outros autores como Koster (2005), Gee (2007), Mattar (2010) e Prensky (2012) vem reafirmando esse conceito. Eles citam e analisam jogos originários do entretenimento dentro da abordagem educativa, demonstrando benefícios de os utilizarem com os aprendizes. 
Jogos têm potencial e são poderosos com suas complexas ferramentas e abrangentes temas e recursos, podendo atuar como campo de aprendizagem. Neles, estão combinadas várias mídias como som, vídeo, imagem, texto, informações, simulações e tudo integrado a bases de dados (MORRIS, 2016).

Clua e Bittencout (2004) também apontam que os jogos podem "desenvolver habilidades cognitivas importantes para o processo de aprendizagem" como criatividade, resolução de problemas, raciocínio rápido, percepção entre outras.

Além desses benefícios, segundo Damian (2013), há as relações dos jogos com filmes, livros e outras mídias, entendendo o jogo como arte. Ou seja, indicadores de outras percepções e possibilidades de uso dos jogos na educação.

Mesmo com todos estes benefícios, é importante compreender como combinar jogos com aprendizagem. Prensky (2012) afirma que isso pode ocorrer de diversas formas e não há uma resposta padrão. Afinal, depende de alguns fatores como: público, assunto a ser trabalhado, contexto político da instituição, tecnologia disponível, recursos e experiência possíveis de serem aplicadas e a distribuição do jogo.

Portanto, é a análise desses fatores que determina o grau de envolvimento e aprendizado dos estudantes pelo jogo.

\subsection{Características de Jogos Digitais Didáticos}

Os jogos digitais didáticos possuem muitas variações em termos de características. Para entendê-las melhor, Queiroz (2011) realizou um levantamento desses atributos com diversos autores. Ele descobriu as seguintes características: estímulo à cognição e participação, exigência de concentração, estímulo de criatividade, espontaneidade e imaginação, possibilidade de repetição e capacidade intensa de imersão por parte do jogador.

Contudo, mais recentemente, Panosso et al (2015), fez uma revisão bibliográfica de várias pesquisas que usaram a terminologia jogos educativos. Com base nelas e após uma seleção, elencaram-se características desse tipo de jogo com foco nos trabalhos mais relevantes perante análise comportamental, são elas: reforço, controle por regras, resolução de problemas e generalização de estímulos.

O jogo Scribblenauts Unmasked possui essas características e serão apresentadas no decorrer de sua análise no presente artigo.

\section{Trabalhos Relacionados}

Existem diversas aplicações de jogos de entretenimento comerciais nas mais variadas áreas do conhecimento. A seguir estão apresentados três trabalhos escolhidos, que contribuem para organizar a proposta deste artigo.

No trabalho de Kikuchi (2014), ele utilizou o jogo SimCity 3000 para o ensino de urbanização na disciplina de geografia. Seus resultados indicam que a aplicação do mesmo é “realmente viável no processo de ensino-aprendizagem por evocar a participação mais ativa dos alunos em uma linguagem que eles assimilam com facilidade". A organização demonstrada para apresentar ao aluno o jogo e como utilizá-lo didaticamente em sala de aula foi a contribuição do trabalho para a presente pesquisa.

$\mathrm{Na}$ abordagem de Evangelista et al. (2012), os autores aplicaram o jogo Age of Empires com o intuito de ensino-aprendizagem de História Antiga. Segundo conclusões da prática realizada, eles perceberam que "os alunos se divertiam muito jogando e que boa parte deles pôde fazer uma relação com o que foi estudado, podendo-se concluir que efetivamente o jogo pode ser aplicado como ferramenta didática". A forma de validação da proposta usando questionário foi a ferramenta de coleta de dados que serviu como base à pesquisa deste artigo. 
Por último, Santos (2011) utilizou o Second Life para o ensino de física, principalmente na simulação de fenômenos físicos diferentes das leis Newtonianas. O resultado apresentado foi viável para o ensino. Para este artigo, a proposta contribuiu quanto ao entendimento de como se aplicar um jogo comercial em um assunto pertinente às aulas.

Destaca-se que os jogos mencionados, já estão prontos e foram apenas utilizados como ferramenta didática para as aulas dos professores. A única exceção é o Second Life porque permite personalização de todo o jogo por parte dos jogadores.

Portanto, vale destacar que é necessário, ao docente, compreender a linguagem própria da mídia game para melhor adequação de jogos. Também saber o que existe no mercado para poder trazer à realidade de uma sala de aula e analisar como ele pode ser útil para as aulas do docente.

\section{Análise Técnica do J ogo Scribblenauts Unmasked}

Para se realizar a análise técnica do jogo, é necessário conhecer os recursos disponíveis e como se interage com eles, pois isto facilita a compreensão do seu potencial educativo. Dessa forma, os recursos educativos podem ser identificados, criando estratégias para o uso em sala de aula.

Para tal, este jogo será avaliado com base em seis itens principais: roteiro, mecanismos, banco de palavras, arte, música e diversão.

\subsection{Roteiro}

Em resumo, Scribblenauts Unmasked inicia com o personagem de Maxwell (figura 3), fã dos quadrinhos da DC Comics. Ele discute com sua irmã Lily sobre qual herói seria o mais poderoso. A menina é detentora de um globo que permite viajar para onde desejar. No decorrer da discussão, o globo ativa sua funcionalidade e os irmãos são transportados ao universo dos heróis da DC Comics.

Figura 3 - A disputa de Maxwell e Lily sobre qual herói é mais poderoso em Scribblenauts Unmasked
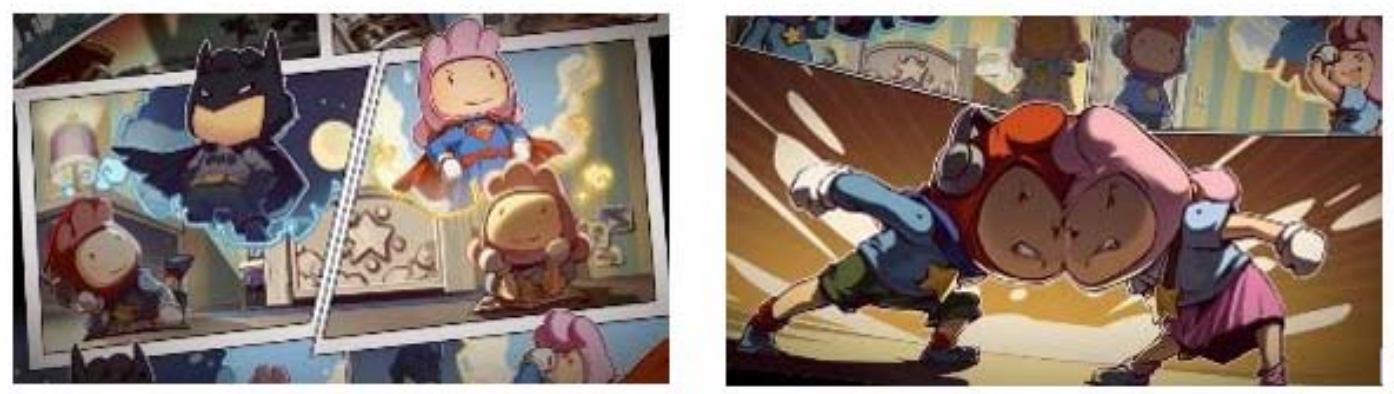

Fonte: Clua e Bittencourt (2004)

Na viagem conturbada, o globo da irmã de Maxwell se parte em dois e eles não podem mais voltar para casa. Para consertar o globo, é preciso reunir as "starites", estrelas com o poder de restaurar esse item. Eles as conseguem ajudando as pessoas nos universos dos heróis da DC Comics. Como rival, Doppelganger surge com os mesmos poderes de Maxwell, ajudando vilões como Coringa, Sinestro e outros, dificultando a jornada do herói. E como aliados, os heróis contam com Batman no início do jogo e depois outros do lado do bem surgem para ajudá-los nessa história. 
Em detalhes, o roteiro está estruturado em três atos, nas etapas narrativas de Vogler (2006) e Skolnick (2014) de acordo com a figura 4. No Primeiro Ato é apresentado o "Mundo Comum" representado pela casa dos personagens, seguido do "Chamado à Aventura" que ocorre quando os personagens quebram o globo e vão para o universo da DC Comics. Com isso, os personagens entram no Segundo Ato: um mundo especial enfrentando desafios, fazendo aliados e confrontando inimigos. Então, ao enfrentar todos os perigos, retornam ao mundo comum em seus lares, transformados pela experiência vivida na história, ou seja, o "Retorno com o Elixir" que faz parte do Terceiro Ato.

Figura 4 - A jornada do herói com suas etapas divididas em três atos.

\section{O modelo da Jornada do Herói}

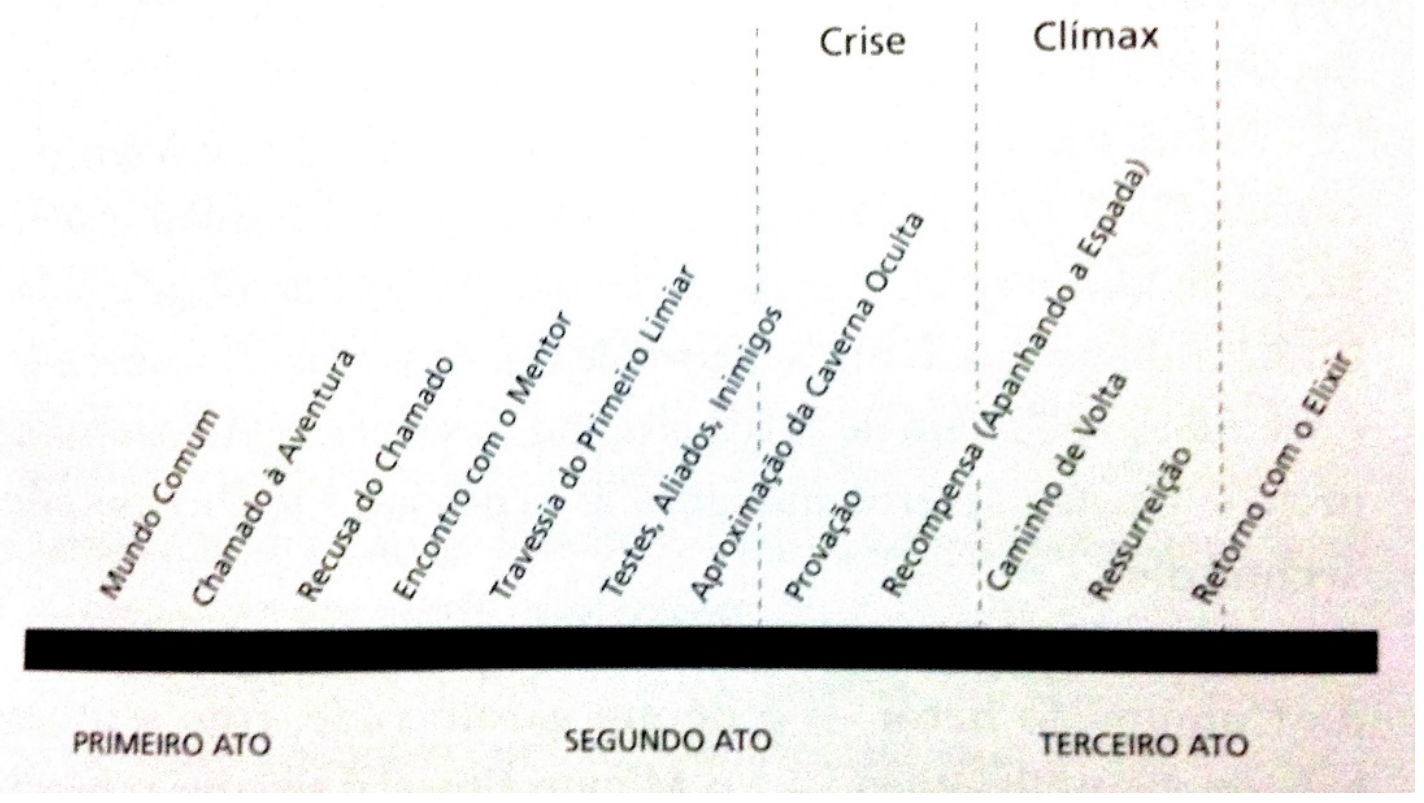

Fonte: Morro do Olimpo (2017) baseado em Vogler (2006) e Skolnick (2014).

Quanto aos detalhes, também é necessário comentar que, no jogo, ficam bem claros os arquétipos que Vogler (2006) e Skolnick (2014) criam quanto aos personagens. Há o herói, Maxwell, depois, Batman, Lily, Flash e Super-Homem, mentores auxiliadores do jogador com informações, Coringa e Doppelganger, sombra como vilões da história dentre outros.

Apesar de o jogo apresentar uma estrutura comum e sólida de roteiro, há um diferencial com a característica da não linearidade. O jogador pode escolher entre duas cidades, ou a cidade de Metrópoles ou Gotham, e mesmo assim ser chamado a todo instante para perigos que ocorrem nelas. Esse conceito de escolha utiliza melhor a mídia game, no que diz respeito a não linearidade. Corroborando Aguiar (2014), aponta que uma narrativa não linear oferece ao jogador a possibilidade de escolher qual caminho narrativo deseja seguir. Isso possibilita vários finais para a história e muda a experiência. Diferente de ler um livro ou assistir um filme, a narrativa pode ser manipulada em diferentes níveis.

\subsection{Mecanismos do J ogo}

Em todo o início de jogo, o jogador espera uma forma de conhecer o objetivo, as regras e as instruções de como jogar, ou seja, o mecanismo do jogo. Nesse sentido, o tutorial de 
Scribblenauts Unmasked é preciso, contendo no início explicações sobre como usar as palavras para criar objetos, como resolver os problemas propostos, jogar no lixo itens criados e acrescer adjetivos conforme demonstra a figura 5. Essas funções são o que Salen e Zimmerman (2012) chamam de regras operacionais do jogo. Isso proporciona clareza ao jogador já no inicio do jogo com informações de como ele deverá interagir dentro daquele contexto. Inclusive, é desenvolvido de forma prática e contextualizada a história do game, sem necessitar de leituras de manuais para sua compreensão.

Figura 5 - Tutorial prático que ensina a adicionar adjetivos a um personagem

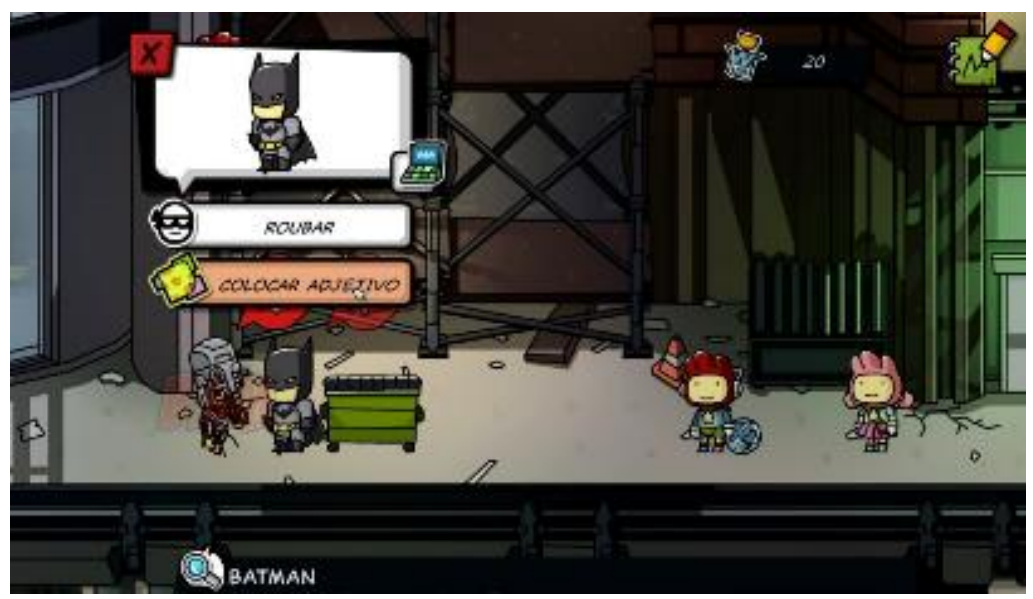

Fonte: elaborada pelos autores.

Analisando os mecanismos em geral, é importante comentar outro conceito que o jogo traz, conforme as regras de Salen e Zimmerman (2012) que é a regra da forma "elegante", que em termos de game, significa: fácil de aprender, mas difícil de dominar. Isso favorece a diversão, pois o jogador aprende facilmente os mecanismos de como interagir com o jogo.

Os comandos podem ser realizados basicamente com o mouse e com alguns atalhos pelo teclado. Estes comandos usados já seguem padrões de outros jogos para controle de personagem (teclas A, S, D, por exemplo). Considerar o padrão e adequar isso para uma melhor interação do jogador na plataforma em que está atuando, é o que Rogers (2012) chama de ergonomia.

Além da adequação a esse critério, quando se trata de digitar palavras (figura 6), há a possibilidade de sugestões para o que o jogador está tentando escrever. Isso ajuda, pois muitas vezes o jogador não se lembra da grafia correta da palavra ou o jogo não a tem, mas ele possui uma alternativa próxima.

Figura 6 - Escrita da palavra "medico" no caderno para criá-lo

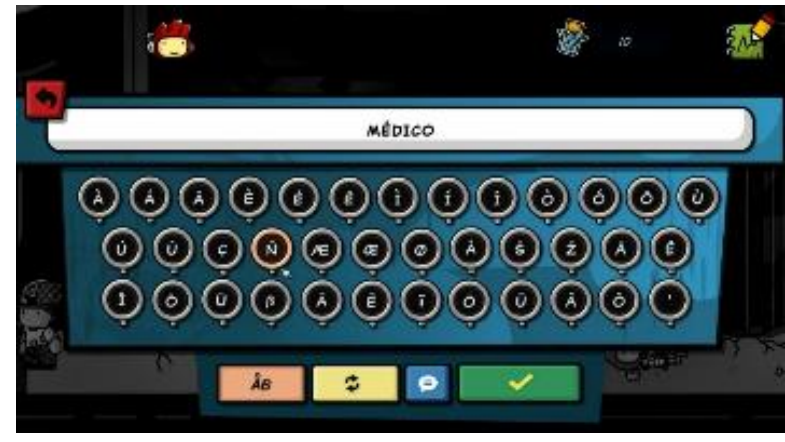

Fonte: elaborada pelos autores. 
As missões (figura 7), por exemplo, estão disponíveis por meio do símbolo "W" como mecanismo de ajuda. Elas podem ser cumpridas de diversas maneiras, mas existe uma regra que, naquele universo, se o jogador repetir as mesmas palavras, há desconto nos pontos de reputação. Esses pontos são ganhos ao cumprir missões ou usar palavras. Esse tipo de balanceamento é o que Schell (2011) chama de punição, um tipo de equidade ao jogo. Nesse caso, é muito pertinente o uso do recurso, pois obriga o jogador a usar novas estratégias e aumentar o seu vocabulário. Como recompensa, ganha pontos de reputação que podem liberar outros itens, estágios e continuar na jornada.

Há mudança também nos objetivos menores que alteram quando se revisita a fase (critério de replay), tornando o jogo mais interessante e não levando o jogador ao tédio.

Há um adendo quanto ao mecanismo geral que define desavio versus sucesso, conceito defendido por Schell (2011). Como o jogo oferece muitas possibilidades nas soluções propostas, não se percebe com clareza o aumento da dificuldade a cada vitória do jogador. Ele é relativo à estratégia que o jogador utilizará para resolver o problema. Dessa forma, não há a certeza de que cada etapa do jogo foi desenvolvida de um nível mais fácil até outro desafiante.

Figura 7 - Surgimento de missão para o jogador (símbolo W)

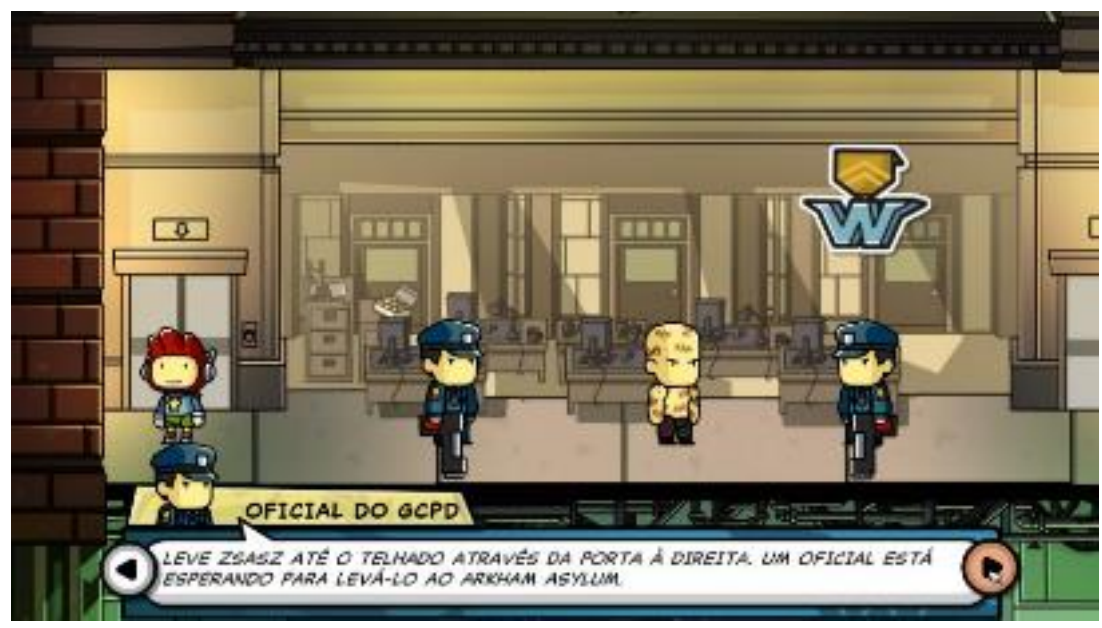

Fonte: elaborada pelos autores.

Referente as resoluções, podem-se criar objetos, pessoas, chamar heróis, fazer conexões entre eles ou ainda atribuir adjetivos para o que o jogador quiser. Um exemplo de resolução é a de um carro muito sujo. Neste caso o objetivo é claro: limpá-lo. No entanto o jogador pode escolher entre jogar uma nuvem de chuva nele e lavá-lo ou atribuir a qualidade de "limpo". A estratégia de solução adotada fica a critério do jogador.

O jogador também pode visitar outras regiões da DC Comics, mas para isso precisa acumular pontos de reputação para poder acessar os lugares. Starites conquistadas também o levam a ser conduzido pela história para chegar ao final. Em alguns momentos, ele pode estar em uma região e receber um chamado de socorro. Ele pode atendê-lo ou continuar na missão atual. Esse senso de urgência que o jogo propõe é interessante, porque leva à sensação de superpoder. É o que Sallen e Zimmerman (2012) chamam de "experiência lúdica significativa".

Outro mecanismo importante é a evolução que se pode notar no jogo. Um exemplo são os heróis e itens que podem ser obtidos durante o jogo, visto que alguns são bloqueados no início. Essa é uma forma de coleção oferecida ao jogador, semelhante aos antigos álbuns de figurinhas da infância. Esses itens, sejam utilizáveis ou não, são o que Rabin (2011) chama de inventários e coleções. Segundo o autor, eles "irão acrescentar complexidade ao seu jogo". E, 
na verdade, os dois conceitos possuem relações, pois o jogador pode colecionar novos heróis, armas, mas também usá-los durante o game.

Quanto ao mecanismo que trabalha a parte lúdica. As opções de uso dos adjetivos, para obtenção de mudança de cenários e situações, sem acarretar perdas quanto as missões propostas, são uma forma de se brincar com as palavras. Em muitas formas a sua aplicação trabalha o senso de diversão na forma educativa. Esse tipo de experimentação dá autonomia ao jogador para que ele possa fazer o que quiser. Testar opções, criar possibilidades, liberdade de escolha e outras formas de interação, são mais formas de se incrementar o aprendizado de forma lúdica.

\subsection{Banco de Palavras, Arte e Música}

O jogo tem muitas opções e ferramentas a serem exploradas. Quanto as palavras armazenadas no jogo, há um numero significativo e empolgante que são adotados para itens e seres comuns e também outros novos da DC Comics que só existem dentro desse universo. "Arlequina", "Batmóvel" e "Anel do Poder" são alguns deles, por exemplo. O jogo também disponibiliza um editor para que o jogador possa criar o seu super-herói ou item especial. Isso possibilita a criação de termos próprios, conforme a figura 8.

Figura 8 - Construção ou personalização de personagens e itens do jogo

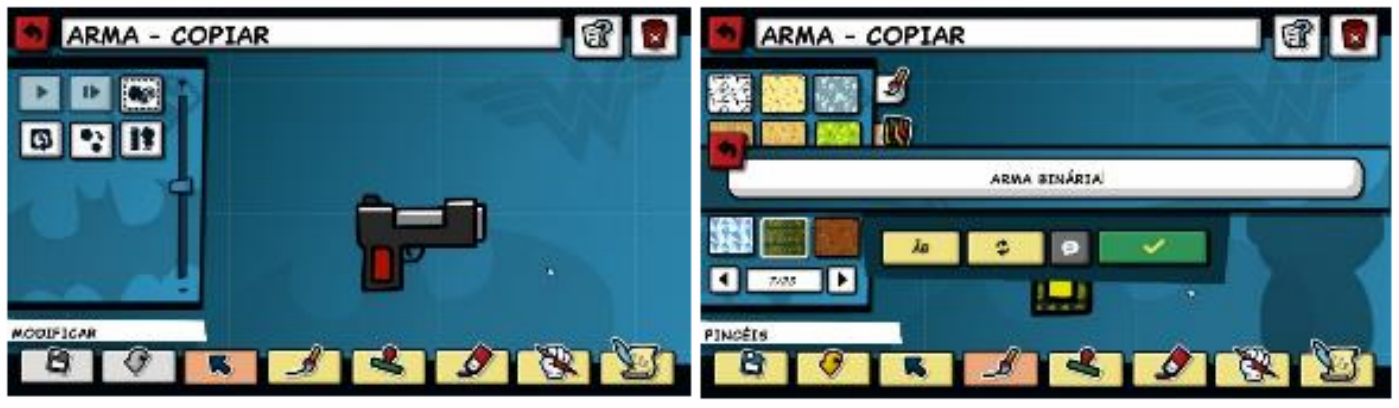

Fonte: elaborada pelos autores.

Na arte, o estilo de Scribblenauts Unmasked é o mesmo para todas as versões. O foco está em uma arte simples, sem muitos detalhes e bastante lúdica. De fato, o jogo é muito voltado para a criatividade e é bem notável esse conceito.

Os ícones e imagens remetem rapidamente às ações que o jogador deve realizar ou qual função assumir. Um exemplo é quando criado um item e o jogador deseja descartá-lo. Rapidamente, surge um lixo no canto superior direito da tela como possibilidade de função.

As músicas foram produzidas para ambientar os mundos especiais de super-heróis, aventuras e perigos que estão para surgir, coerentes a cada um desses momentos. Também há sons de feedback perante ações certas ou infrações que o jogador comete. Por exemplo, são emitidos sons de notificação ou avisos ao se tentar colocar um objeto em local impossível ou ao se digitar uma palavra que não existe no banco de dados do jogo.

\subsection{Fatores de diversão e aprendizagem}

Em Scribblenauts Unmasked, a diversão está muito relacionada à resolução de problemas, ajudando os jogadores nas mais diversas situações. Koster (2005) define os jogos como quebra-cabeças a serem resolvidos. Com isso, o jogador reconhece padrões de como funciona 
o game, resgata estratégias anteriores aprendidas para resolver o mesmo problema em outras abordagens. Ou seja, o jogo sempre implicará em resolução de algo para se seguir a outra etapa. E no estudo deste artigo, a diversão foi aplicada no jogo coerente a esse conceito. Um exemplo é o uso de asas (figura 9). Usar personagens alados é muito comum no game para alcançar regiões de difícil acesso. Essa estratégia pode ser usada para o Maxwell voar ou para dar esse poder a outro personagem. Também se pode criar uma entidade que voa como, por exemplo, o Pégaso, o cavalo alado das lendas gregas. Dessa forma, o jogador aprende com o jogo e vai ganhando experiência para ter um desempenho superior nas próximas missões. Ele se mantém resolvendo problemas com soluções diferentes, mas em situações similares.

Figura 9 - Uso do Pégaso para voar no jogo Scribblenauts Unmasked

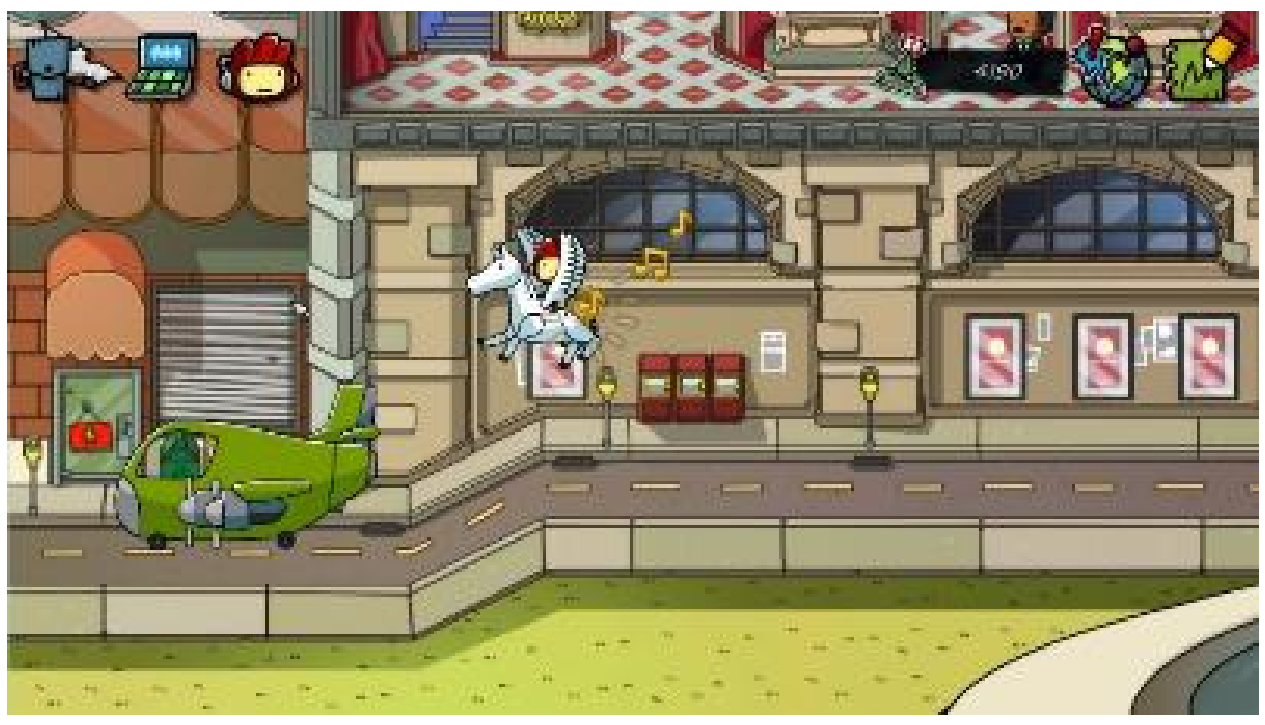

Fonte: elaborada pelos autores.

Quanto ao ensino-aprendizado, Koster (2005) também aborda o conceito de diversão como uma liberação química em um momento de vitória no game. Corroborando com isso, esse instante ocorre quando o jogador aprende algo ou domina uma tarefa específica apresentada. Percebe-se que o jogo, naturalmente, já se refere a aprendizagem como ato de algo que fornece diversão. Logo, se o jogador aprende com o jogo, o professor pode abordar um assunto específico ou conteúdo, se valendo dessa referência e adaptando-a para esse aprendizado. Um exemplo, quanto a Scribblenauts Unmasked, é quanto ao aprendizado da aplicação de adjetivos. Em uma aula de língua portuguesa, o professor geralmente explicaria o conceito e o relacionaria com o jogo. Depois, poderiam praticar e observar que, se tentassem colocar substantivo ou outra classe gramatical não teriam êxito. O jogo impediria tal ação. Já quanto aos adjetivos, eles seriam aceitos. Sem citar que todo esse ensino estaria contextualizado com o universo do jogo, realizando uma aprendizagem de forma efetiva. Em suma, ele aprende com o jogo e esse conhecimento vai sendo utilizado nas próximas etapas e novos conceitos também serão aprendidos.

Outro conceito encontrado em Scribblenauts Unmasked e trazido por Koster (2005) é o de que o jogador só continua ativo até continuar aprendendo. Uma vez que já o aprendeu, precisa de algo novo. Isso tem bastante relação com as pesquisas de Csikszentmihalyi (1990). Essa forma de manter o interesse do jogador na busca por aprendizado contínuo é caracterizada pelo autor como um estado de fluxo (flow). De acordo com a figura 10, o ideal é sempre manter o jogador aprendendo algo novo durante o jogo, no caso, novas experiências ou utilizações de habilidades que já possui, mas aplicadas de maneira diferente. Quando se 
consegue manter o jogador interessado e motivado, ele estará no canal de flow. Caso não esteja nele, podem ter ocorrido duas situações: o desafio proposto foi maior que a habilidade que ele tinha no momento (frustração) ou o contrário (tédio): o game está muito fácil ou repetitivo e o jogador não aprende mais com ele.

Figura 10 - Gráfico demonstrando o canal de flow

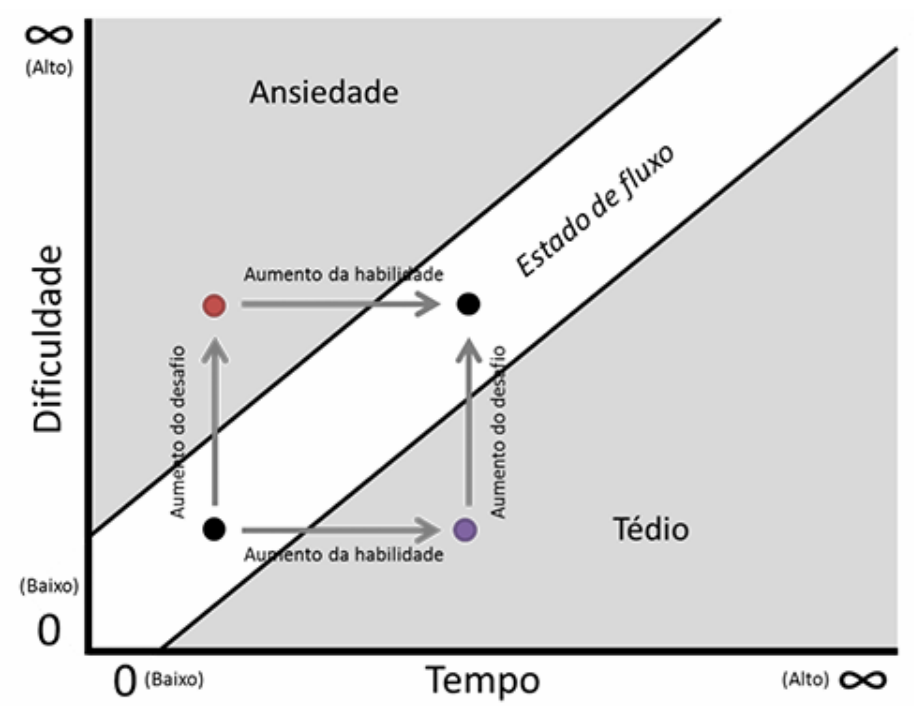

Fonte: Paula (2017).

Em Scribblenauts Unmasked, o conceito de flow está muito presente, porque mesmo o jogador dominando as regras operacionais, ele nunca sabe qual será a missão a realizar e de que forma irá agir. Ele sempre aprenderá com ela e resolverá novos quebra-cabeças. Até porque o jogo penaliza se ele tentar usar uma mesma palavra no mesmo mundo que está presente. Isso o faz mudar a estratégia na solução do problema para aprender a lidar com novos recursos diante dos desafios propostos.

Portanto, ao se entender o jogo e seu funcionamento, além da relação entre diversão e aprendizado, podem-se perceber diversos aspectos educativos.

\section{Aspectos Educacionais do J ogo Digital Scribblenauts Unmasked}

É possível elencar diversos aspectos educacionais quanto ao que se é proposto em Scribblenauts Unmasked, neste artigo. Especificamente por meio dos mecanismos do jogo, que são a aplicação de conceitos de substantivo, adjetivo, resolução de problemas e outros.

Nesse contexto, é importante lembrar, que o fato da utilização do jogo deve estar relacionado diretamente com a junção da função aprendizagem por meio da diversão, com o cuidado e garantia de se obter o fator aprendizado com seriedade no que se deseja. E com utilização de alguns games é possível. Costa (2010) defende esta tese ressaltando que, "nos jogos de entretenimento, existe pelo menos uma estrutura similar à do objeto de conhecimento". E mais, o autor também acredita no sucesso de alguns fatores por haver a possibilidade de ligação entre a experiência do jogo e o cotidiano. Um exemplo, em Scribblenauts Unmasked, é a utilização dos adjetivos. A ação implicada pelo jogador quando qualifica os personagens e objetos no jogo, tende a ser absorvida no aprendizado como conhecimento da função dessa classe gramatical que servirá para seu dia a dia, para a vida. 
Outros autores defendem e enumeram pontos positivos para a utilização de um jogo digital no processo de ensino-aprendizagem. Prensky (2012) diz que essa, é uma estratégia usada com bons resultados. O autor comenta que essa estratégia atinge êxito por três razões: 1) 0 envolvimento que o jogo promove com a aprendizagem dentro daquele contexto; 2) o processo de interação da aprendizagem aplicada naquele contexto; e 3) a relação desses dois aspectos.

Para Gee (2007) a utilização de jogos também é relevante por seguir princípios de aprendizado que o caracterizam como potencial educativo. São alguns deles:

- Aprendizado de forma ativa com análise crítica da situação e resolução de quebra-cabeças propostos;

- Percepção de princípios semióticos no jogo e as relações entre as partes dele, como palavras que criam imagens, tendo interação e resolvendo problemas, por exemplo;

- O jogador pode correr riscos em um espaço com consequências baixas. Ele pode criar uma fogueira e, se algo pegar fogo, o risco real será nulo;

- Os princípios de entrada no jogo - uma palavra - aumentam para diversas saídas. A interação com o objetivo da missão, como ele resolverá o problema e quais consequências ele traz ao jogo são fatores de saída que vem dessa entrada do jogador;

- Gradativamente no jogo são possíveis conquistas para indicar o caminho certo e o tornando experiente para avançar na aventura;

- A forma de aprendizado do conhecimento é intuitiva;

- Pode-se seguir por múltiplos caminhos dentro da aventura, quais atividades vai fazer;

- Incentiva a descoberta e exploração, ao tentar novas palavras, outras soluções e navegar em outros universos do jogo;

- Permite a dispersão ao compartilhar com outros o que está fazendo no jogo, suas obras criadas via internet;

- O significado e conhecimento está distribuído, ou seja, estão nos objetos do jogo, símbolos, descrições de forma que a sua exploração vai permitindo compreender as relações e o desbravando;

- A informação explícita sobre o conteúdo é sob demanda. Ela só aparece quando realmente é necessária dentro do jogo;

- O aprendizado é incremental, visto que ele vai aprendendo ao longo do jogo, avançando para níveis mais difíceis e o seu aprendizado e experiência conquistada é usado a todo o instante. A experiência ao longo do processo é considerada;

- O texto não é puramente verbal, mas incorporado ao contexto do jogo;

- Estabelecer hipóteses, refletir, testar e examinar são possibilidades que o jogo permite que o aluno possa fazer;

- O jogador estabelece identidades ao jogar, relacionando sua identidade virtual com ações que realiza com o mundo real, identidades anteriores que assumiu e que projetou;

- Permite o auto-conhecimento, pois o jogador vai conhecendo suas competências ao longo do jogo e aprendem com a experiência vivenciada;

Observe que esses são apenas alguns dos trinta e seis princípios abordados pelo autor, mas se demonstra a relação com a aprendizagem.

Concluindo, são muitas as justificativas para uma boa prática e utilização de jogos com finalidade de aprendizado. E sob essa análise e descrição, Scribblenauts Unmasked possui características, conteúdo, aspectos educacionais e potencial educativo para tal, basta conhecêlo para descobrir sugestões de aplicação.

\section{Sugestões de como Aplicar o Jogo Scribblenauts Unmasked na Educação}

Scribblenauts Unsmaked não foi criado para fins didáticos, mas claramente possui elementos dentro do contexto que, ao se interagir, podem trabalhar diversos conhecimentos, 
habilidades e atitudes. Como proposta, algumas abordagens de uso são listadas nos mais diversos temas. São elas:

- Conceitos de substantivos e adjetivos: na criação do ambiente é necessário que os substantivos sejam digitados, para que surjam os itens, as pessoas e outros mais; dada a função dessa classe gramatical. Então, o jogador precisa dominar esse conceito ou não conseguirá realizar a ação. Se tentar um adjetivo, por exemplo, ocorrerá um erro e receberá uma notificação. Assim, o jogador passa a interagir indiretamente por meio da experimentação com a língua portuguesa de uma maneira visual e prática.

- Prática da leitura e interpretação de textos: o jogo traz uma história interativa que vai sendo desvendada ao longo do processo. A leitura é indispensável para entendimento de fatos e tomada de ações. E a interpretação será necessária para que se justifiquem as escolhas e tomada de decisão quanto ao que se é proposto naquele contexto.

- Prática do idioma: o jogo pode ser jogado em outros idiomas. Pode ser um complemento para aprendizado de inglês, por exemplo.

- Desenvolvimento de vocabulário, sinônimos, antônimos dentro de um contexto: não somente em outros idiomas, mas também na linguagem materna. O jogador pode ir testando novas palavras e significados, além de sinônimos, pois, se repetir palavras, sofre perda de pontos. Antônimos podem vir para resolver problemas simples como por exemplo em: “Ele é muito alto e não consegue passar por ali", é preciso usar o adjetivo "baixo" para resolver problema;

- Conceitos de arte: esse tema implica em duas funções muito notórias para aplicação em educação. Primeiramente, tanto na parte visual quanto na musical, a própria arte do jogo pode ser estudada, afinal no jogo há a influência e o estilo do artista. Podem-se estudar quais sensações e objetivos ele teve em retratar o jogo daquela forma. Relações da obra com outros artistas e jogos, etc. Como segunda opção, no editor de itens e personagens, o jogador pode fazer edições em tudo e aprender cores, escalas, contraste e outros conceitos para um design digital interessante, pensando em um público infantil, por exemplo.

- Histórias em quadrinhos: como o jogo têm personagens da DC Comics, podem-se fazer relações com outros meios tais como: desenhos animados, quadrinhos, filmes e a aplicação disto no jogo;

- Resolução de problemas: baseado em sistema de quebra-cabeças, o jogador precisa resolver, encaixar situações. É necessário criatividade, estratégia e tomada de ação. E tudo isso funciona como experiência para outros desafios;

- Trabalhar sob pressão: há momentos em que jogo exige rapidez na tomada de decisão e o jogador fica sob pressão. Por exemplo, o jogador corre o risco de perder uma missão com a morte do personagem, que estava sendo ajudado;

- Riscos calculados: o jogador precisa avaliar o risco do que vai realizar dentro do jogo para evitar perdas. Por exemplo, se o jogador não utilizar uma arma correta em tal ação ele pode acabar destruindo o objeto que pretendia levar para alguém;

- Estabelecimento de prioridades e metas: o jogo tem um foco principal: meta de buscar starites para ir embora daquele universo. Mas também tem metas menores e chamadas urgentes. Portanto, o jogador vai ter que estabelecer prioridades, por exemplo: focar nas missões principais ou ajudar a população para mais pontos de reputação?

- Criatividade: o jogo permite essa característica por meio da criação de objetos, resolução de situações e seguimento do jogo. Tanto na resolução de problemas, quanto na sequencia do jogo, é possível criar, ou seja, a criatividade não tem limite. E ainda, há o editor de itens e personagens para se personalizar o que quiser e como desejar;

Para este artigo especificamente, utilizamos o conteúdo de substantivos e adjetivos com os alunos, na busca de realizar o objetivo e potencial do jogo em relação ao aprendizado, mas após todas estas indicações citadas, pode-se concluir que há muitos outros potenciais, habilidades e atitudes a serem aplicados como aprendizagem quando se trata desse jogo. 


\section{Aplicação do Scribblenauts Unmasked com Alunos para o Ensino dos Conceitos de Substantivos e Adjetivos}

Para analisar o potencial do jogo, na prática em sala de aula, foi realizado um experimento com 26 alunos que frequentam escolas públicas de Araranguá - SC. Os alunos têm idade, na maior parte, entre 11 e 16 anos. Todos já jogaram jogos digitais para computador e todos estavam familiarizados com esse tipo de entretenimento e controles (mouse e teclado), exceto com o jogo a ser avaliado.

Os conteúdos que são fundamentais para o conhecimento testado serão apresentados a seguir, bem como o processo adotado para aplicar com os alunos o jogo da pesquisa.

\subsection{Conceitos de substantivo e adjetivo}

A elaboração das perguntas e padronização dos conceitos de substantivos e adjetivos teve como base teórica a definição de Cunha (2014) que para substantivo o define: como "a palavra com que designamos ou nomeamos os seres em geral". Como categorias, Cunha (2014) lista os seguintes tipos:

- Nomes de pessoas, lugares, instituições, gênero, espécie ou de um de seus representantes. Exemplos: cidade, homem, Brasil, Maria, Senado, cavalo, etc;

- Nomes de ações, noções, qualidades e estados, estes tomados como seres. Exemplos: justiça, viagem, ira, otimismo, doença, opinião, etc.

O adjetivo, Cunha (2014) define como "um modificador do substantivo" de várias formas:

- uma qualidade (ou defeito). Exemplos: homem perverso, inteligência lúcida etc;

- modo de ser. Exemplos: pessoa simples, rapaz delicado etc;

- aspecto ou aparência. Exemplos: céu azul, vidro fosco etc;

- estado. Exemplos: casa arruinada, laranjeira florida etc;

- estabelecer junto ao substantivo uma relação de tempo, espaço, matéria, finalidade, propriedade etc. Exemplos: nota mensal, casa paterna, vinho português etc.

Perante estas definições, as perguntas para os alunos foram elaboradas considerando o contexto do jogo e conceitos gerais.

\subsection{Experimento com alunos do jogo Scribblenauts Unmasked}

Primeiramente, fez-se duas perguntas aos alunos para se avaliar o conhecimento prévio que tinham do assunto: "O que é substantivo? Dê exemplos" e "O que é adjetivo? Dê exemplos". Nessa primeira etapa, onze alunos não sabiam o conceito de substantivo e cinco desconheciam o conceito de adjetivos.

Após essa pergunta prévia, os alunos foram submetidos a prática do jogo em uma sessão média de 15 minutos, previamente estipulados, pois não havia certeza de quanto tempo levariam para cumprir todo o tutorial do game, vivenciando os dois conceitos apresentados.

Ao final da interação no jogo, eles voltavam ao formulário inicial e respondiam cinco perguntas de múltipla escolha, referente as ações desempenhadas por eles no jogo, e já relacionadas aos conceitos em questão. As questões seguem na Figura 11. Ainda, neste caso, as questões foram cuidadosamente analisadas e elaboradas, como por exemplo, o item "Não sei", para evitar que os alunos chutassem nas questões. Todas as questões eram baseadas em ações que eles fizeram no jogo. Nessa etapa, observou-se que o acerto das quatro primeiras questões foi por parte de $70 \%$ dos alunos. O objetivo destas questões era verificar se o aluno percebia a diferença entre substantivo e adjetivo durante as interações no jogo.

Já na última questão, apenas $20 \%$ acertaram. Houve muita pergunta para esta questão durante o experimento, acredita-se que isso ocorreu devido a complexidade de alternativas maiores e itens parecidos, o que pode ter confundido os alunos e dificultado a interpretação. 
Depois, novamente respondiam mais 5 questões de múltipla escolha, porém focadas apenas no conceito de substantivos e adjetivos. As frases eram inspiradas nos contextos usados no jogo, no entanto estavam mais relacionadas ao aprendizado tradicional em sala de aula. Essas perguntas se encontram na Figura 12. Nessa etapa, observou-se que novamente as questões mais simples ( 1 a 4) levaram a mais acertos por parte dos alunos (entre 70 a $80 \%$ deles acertaram). Já na última questão, apenas 50\% acertaram.

Figura 11 - Perguntas sobre Scribblenauts Unmasked quanto aos conceitos de substantive e adjetivo

O jogador criou o Batman para defender uma pessoa de um criminoso. Ele digitou "Batman" e ele surgiu. Ele usou um substantivo ou adjetivo para criar?*

Substantivo

Adjetivo

Não sei (marque essa caso realmente não saiba ou deseja chutar)

Quando o jogador clica em um cavalo da cena, adicionando a ele a palavra "alado", esse cavalo ganha asas. Ele usou um substantivo ou adjetivo para criar as asas?"

Substantivo

Adjetivo

Não sei (marque essa caso realmente não saiba ou deseja chutar)

Quando o jogador clica em um carro defeituoso, adicionando a ele a palavra "consertado", esse carro volta a funcionar perfeitamente. Ele usou um substantivo ou adjetivo para deixar o carro arrumado?:

Substantivo

Adjetivo

Não sei (marque essa caso realmente não saiba ou deseja chutar)

Quando o jogador cria um médico para curar um ferido, ele digita a palavra "Médico" e ele surge. Ele usou um substantivo ou adjetivo para criar?*

Substantivo

Adjetivo

Não sei (marque essa caso realmente não saiba ou deseja chutar)

Qual dos itens é uma solução válida para resolver o seguinte problema no jogo: "Uma baleia pede para que seja limpa, pois está muito suja de lama".

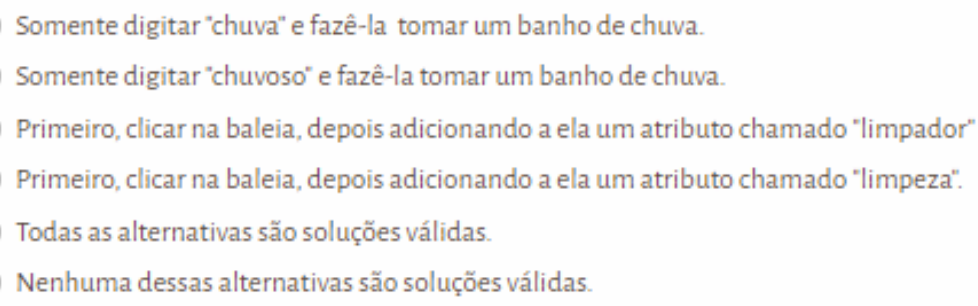

Fonte: elaborada pelos autores. 
Figura 12 - Perguntas sobre os conceitos de substantivo e adjetivo

Marque apenas aquela palavra que for um adjetivo.

Carro

Batman

Arrumado

Mecânico

Marque apenas aquela palavra que for um substantivo.

Coringa (vilão do Batman)

Inflamável

Forte

Gigante

Qual frase abaixo é VERDADEIRA? *

Liga da Justiça é um substantivo.

Leve é um substantivo.

Doente é um substantivo

Balão é um adjetivo.

\section{Qual frase abaixo é VERDADEIRA?*}

Alado e Asas são substantivos.

Inflar é um substantivo.

Inflável é um adjetivo.

Alado e Asas são adjetivos.

\section{Qual frase abaixo é VERDADEIRA?"}

$\mathrm{Na}$ frase "Shazam está voando" temos a presença de um adjetivo.

Na frase "Mulher Maravilha usa o seu laço da verdade", laço é um adjetivo.

$\mathrm{Na}$ frase "Lex Luthor usou criptonita contra o Super-Homem", tanto Lex Luthor quanto Super-Homem são substantivos.

Na frase "Zatana adora fazer mágicas deslumbrantes" năo temos a presença de um adjetivo.

Fonte: elaborada pelos autores.

Após terminarem os questionários, eles novamente voltaram a responder as duas perguntas feitas no diagnóstico "O que é substantivo? Dê exemplos" e "O que é adjetivo? Dê exemplos". Nessa etapa, a mesma pergunta tinha mais respostas corretas, sendo que apenas 1 aluno manteve a resposta "Não sei", tanto antes quanto no pós-jogo.

Nessa fase, é possível detectar que as respostas deles refletem as ações e exemplos que eles vivenciaram no jogo, não necessariamente um conceito de fato. Por exemplo, muitos responderam substantivos do jogo que eles criaram durante a interação como "carro", "Batman", "moto", "médico" e outros. O mesmo ocorreu com os adjetivos como "forte", "alado", "inflado" etc. Com esse efeito, observou-se que os alunos que não sabiam o conceito anteriormente, pelo menos sabiam quais palavras pertenciam àquele conceito. Os que já 
tinham acertado antes do jogo, apenas complementaram o conceito correto que já tinham dado com exemplos do game.

Todos os alunos foram questionados sobre a diversão enquanto jogavam. Todos relataram terem se divertido, além de gostarem da forma como o conteúdo foi abordado. Eles ficaram tão imersos que foi necessário avisar do tempo encerrado para a sessão.

O experimento, com esse grupo, demonstra que um jogo pode trazer conceitos abstratos de uma maneira mais prática e vivencial. Também, que o jogo pode ser usado como um reforço ou complemento ao que o professor está trabalhando em sala de aula, principalmente porque o entendimento deles sobre o conceito apresentado ocorreu com a prática do jogo. Afinal, devido a isso, a maior parte das respostas estão relacionadas as ações feitas durante o game.

Tendo em vista o experimento apresentado, pode-se atestar a utilização do jogo dentro do ensino de língua portuguesa, principalmente pelos seus mecanismos serem ligados ao conteúdo desta aula. O professor terá uma ferramenta didática mais ativa em seu processo de ensino do português. A compreensão de substantivos e adjetivos foi mais marcante para os alunos, pois relacionaram as ações realizadas durante a interação com o jogo com os dois conceitos avaliados.

O professor, mediando essa atividade, pode fazer relações do jogo com conteúdos da aula e trazer mais interesse pelo aprendizado dos alunos. É importante frisar a necessidade da mediação do docente nessa atividade, pois o direcionamento dele e o elo entre conteúdo e jogo são fundamentais para que o aluno entenda a proposta a ser realizada com o game.

Concluindo, a pesquisa contribui efetivamente para demonstrar uma abordagem de jogos de entretenimento na educação e sua aplicação em sala de aula, com resultados positivos e pertinentes.

\section{Conclusão}

Este trabalho apresentou a utilização do game Scribblenauts Unmasked em aula prática, com foco em seu potencial de diversão e aprendizado, ligados ao conteúdo da Língua Portuguesa; em específico: substantivos e adjetivos, dentro do contexto. Como resultado, percebe-se nos alunos um estímulo diferente quando se entendia na prática o que eram essas palavras. Houve maior interesse por parte do aluno quando percebe o que acontecia e como estas palavras se apresentavam por meio da brincadeira na tela de um computador.

A associação de escrita, imagem e resultado permitiu um melhor entendimento do tema, despertando o interesse do aluno para tentar outras possibilidades. Durante a aplicação, muitos dos alunos queriam continuar na experimentação das alternativas que o jogo oferecia, quanto aos substantivos e adjetivos, não necessariamente para continuar no jogo, mas para continuar explorando e experimentando as possibilidades. Dessa forma, percebeu-se que a descoberta foi incentivada e também a brincadeira (play).

É fundamental ressaltar que se deve conhecer o jogo profundamente antes de utilizá-lo com os alunos, além de se ter claramente uma estratégia metodológica de como ele será apresentado e aplicado dentro de um contexto escolar. Isso é necessário para que o recurso didático seja eficaz quanto ao que o professor pretende abordar na aula, e para que o aluno consiga ser orientado por ele, para realizar as funções básicas no jogo, e justificar o investimento da escola na aquisição desse game.

Outro benefício, é que os jogos de entretenimento contêm conhecimentos que, se analisados, podem trazer ferramentas didáticas prontas aos professores. É uma facilidade ao docente, pois nem sempre ele domina conceitos de game design e programação de computadores para fazer os seus próprios jogos digitais. Mas necessita de análise para aplicar em sala de aula.

Também é necessária uma análise financeira da viabilidade de se aplicar esses tipos de jogos na escola. Seja a própria instituição de ensino investindo ou o governo, deve-se justificar 
o uso do recurso didático, apresentando benefícios, conteúdos que irá abordar e se a escola possui recursos tecnológicos que viabilizem o funcionamento correto dos jogos.

Como continuidade do trabalho, poderão ser avaliadas as outras versões de Scribblenauts para se observar se os aprendizados são os mesmos, mas também se tem mais liberdade de criação que essa versão focada nos personagens da DC Comics.

Sugere-se também a aplicação do jogo, com mais turmas de alunos, além de outros tipos de perguntas formuladas para se verificar se é possível manter a compreensão dos conceitos apresentados no experimento: substantivos e adjetivos. Ou expandir a experiência dentro da língua portuguesa ao se desenvolver vocabulário e grafia correta de palavras, por exemplo.

Por último, é importante uma avaliação e conhecimento de outros jogos de entretenimento, haja vista que muitos professores desconhecem esse recurso didático. Logo, essa pode ser uma forma de se demonstrar como os jogos podem ser abordados em sala de aula, e da relação do jogo com o conteúdo que o docente quer trabalhar. É fato que muitas vezes o docente tem vontade de usar tal recurso para seus alunos, mas falta a informação de como ele pode utilizálo dentro do seu contexto.

Concluindo, Scribblenauts Unmasked como jogo digital, possui aspectos educativos. Todo o trabalho desenvolvido e teoria estudada corroboram com a aplicação de jogos digitais para se alcançar objetivos de ensino aprendizagem. Portanto, a proposta deste artigo e sua aplicação demonstraram que é viável a utilização de um jogo de entretenimento em atividades de cunho educativo ou com conteúdo e contexto educacional.

\section{Referências}

AGUIAR, Michele Pereira de. Narrativa para Jogos Digitais. Curitiba: Universidade Positivo, 2014.

CLUA, E. W. G.; BITTENCOURT, J. R. Uma nova concepção para a Criação de Jogos Educativos. Simpósio Brasileiro de Informática na Educação - SBIE. Disponível em: http://www.joinville.udesc.br/portal/professores/marcelo/materiais/Clua_e_Bittencourt_2004___Cria__o_d e_Jogos_Educativos__minicurso.pdf . Acesso 12 setembro 2016.

COSTA, Leandro Demenciano. O que os jogos de entretenimento têm que os educativos não têm: 7 princípios para projetar jogos educativos eficientes. Rio de Janeiro: Editora PUC-Rio, 2010.

CSIKSZENTMIHALYI, Mihaly. Flow: the psychology of optimal experience. Nova Iorque: Harper Perennial, 1990.

CUNHA, Celso. Gramática do português contemporâneo. Rio de Janeiro: Lexikon, 2014.

DAMIAN, Davi S. Menezes. Games: contemporâneo, subjetividade e utopia. Informática na Educação: teoria e prática, Porto Alegre, v. 16, n. 1, p. 173-190, jan./jun. 2013.

EVANGELISTA, J ean Lúcio Santos; ANDRADE, Willams Silva; BITENCOURT, Ricardo Barbosa; OLIVEIRA, Edivânia Granja da Silva. Utilização do jogo para PC "Age of Empires" como ferramenta didática para aulas de História Antiga. Revista Semiárido De Visu v.2 n.3 mai/ago. 2012.

GEE, James Paul. What videogames have to teach us about learning and literacy - Revised and Updated Edition. Nova Iorque: Palgrave Macmillan, 2007.

KIKUCHI, Thiago Kiyoschi Igarashi. Uma alternativa na prática docente: ensinando a urbanização com o jogo SimCity 3000. In: SEMINÁRIO INTERNACIONAL DE EDUCAÇÃO SUPERIOR, 2014, Sorocaba. Anais do Seminário Internacional de Educação Superior. Sorocaba: Uniso, Sorocaba, SP, 2014.

KOSTER, R. Theory of Fun for Game Design - 10th Anniversary. Arizona: Paraglyph Express, 2013.

MATTAR, J oão. Games em Educação: como os nativos digitais aprendem. São Paulo: Prentice Hall, 2010. 
MORRIS, Christine Ballengee. Games, Pedagogy and Art Education. Revista Informática na Educação: Teoria e Prática. Porto Alegre, v. 19 n. 1, p. 61-68, jan./maio 2016.

MORRO DO OLIMPO. Morro do Olimpo Explica! - A Jornada do Herói \#02. Disponível em: <http://morrodoolimpo.com.br/podcast/morro-olimpo-explica-jornada-heroi-02/> Acesso 29 março 2017.

PANOSSO, Mariana Gomide; SOUZA, Silvia Regina de; HAYDU, Verônica Bender. Características atribuídas a jogos educativos: uma interpretação Analítico-Comportamental. Psicol. Esc. Educ., Maringá, v. 19, n. 2, p. 233-242, ago. 2015 . Disponível em < http://dx.doi.org/10.1590/2175-3539/2015/0192821>. acesso em: 30 mar. 2017.

PAULA, Heller de. Projetar para a emoção e para o fluxo (flow) - Travor van Gorp. Disponível em: <http://hellerdepaula.com/br/projetar-para-emocao-e-para-o-fluxo-flow-travor-van-gorp/> Acesso 05 junho 2017.

PRENSKI, Marc. Aprendizagem baseada em jogos digitais. São Paulo: Editora Senac São Paulo, 2012.

QUEIRÓZ, Renato Almeida de. Aplicando tecnologias sociais no desenvolvimento de jogos educativos digitais. 2011. TCC (Graduação) - Curso de Sistemas de Informação, Universidade Federal do Ceará, Quixadá, 2011. Disponível em: <http://www.repositoriobib.ufc.br/000012/00001232.pdf>. Acesso em: 30 mar. 2017.

RABIN, Steve. Introdução ao desenvolvimento de games: vol. 1: entendendo o universo dos jogos. São Paulo: Cengage Learning, 2011.

ROGERS, Scott. Level UP: um guia para o design de grandes jogos. São Paulo: Blucher, 2012.

SALEN, Katie. ZIMMERMAN, Eric. Regras do jogo: fundamentos do design de jogos: volume 2 - regras. São Paulo: Blucher, 2012.

SANTOS, Renato P. dos. O Second Life como plataforma para micromundos físicos para o ensino de Física. Revista Novas Tecnologias na Educação, CINTED, UFRGS, v. 9, n. 1, jul 2011.

SCHELL, Jesse. A arte de game design: o livro original. Rio de Janeiro: Elsevier, 2011.

SKOLNICK, Evan. Videogame Storytelling: What every developer needs to know about narrative techniques. Berkeley: Watson-Guptill Publications, 2014.

VOGLER, Christopher. A jornada do escritor: estruturas míticas para escritores. Rio de Janeiro: Nova Fronteira, 2006.

Recebido em setembro de 2016

Aprovado para publicação em agosto de 2017

Fabiano Naspolini de Oliveira

Programa de Pós-Graduação em Tecnologias da Informação e Comunicação - Universidade Federal de Santa Catarina - UFSC, Brasil, fabiano@fabricadejogos.net

\section{Eliane Pozzebon}

Programa de Pós-Graduação em Tecnologias da Informação e Comunicação - Universidade Federal de Santa Catarina - UFSC, Brasil, eliane.pozzebon@ufsc.br

\section{Luciana Bolan Frigo}

Programa de Pós-Graduação em Tecnologias da Informação e Comunicação - Universidade Federal de Santa Catarina - UFSC, Brasil, luciana.frigo@ufsc.br 


\title{
Tecnologias e Saúde Mental: uma Plataforma de Jogos Digitais para Jovens com Transtorno de Desenvolvimento
}

\section{Technology and Mental Health: a Digital Game Platform for Young People with Developmental Disorders}

FRANCISCO MILTON MENDES NETO Universidade Federal Rural do Semi-Árido

KARLA ROSANE DO AMARAL DEMOLY Universidade Federal Rural do Semi-Árido

EVERTON J ALES DE OLIVEIRA Universidade Federal Rural do Semi-Árido

MARIZA SOUZA MOURA Universidade Federal Rural do Semi-Árido

RAFAEL DE ALMEIDA RODRIGUES Universidade Federal Rural do Semi-Árido

RAMIRO DE VASCONCELOS DOS SANTOS JUNIOR Universidade Federal Rural do Semi-Árido

\begin{abstract}
Resumo: Esta pesquisa apresenta o percurso de implementação de uma plataforma de jogos digitais junto a oficinas que fazemos com jovens atendidos no CAPSi - Centro de Atenção Psicossocial da Infância e da Adolescência de Mossoró. O aporte teórico que sustenta o trabalho considera os estudos de Gilbert Simondon sobre os processos de individuação dos seres vivo, físico e técnico e as construções de Francisco Varela sobre o modo de funcionamento da cognição. A metodologia empregada é qualitativa integrando a tessitura de diários de bordo nas oficinas, a análise de dispositivos presentes em jogos e a escolha de tecnologias para a construção da plataforma. Utilizamos como ferramenta de desenvolvimento a Unity. Como resultados do trabalho, indicamos as mudanças cognitivas e afetivas que pudemos distinguir como recorrentes no percurso dos jovens autistas nas oficinas de jogos e o estágio de desenvolvimento da plataforma que será validada em ambientes de saúde mental e educação.
\end{abstract}

Palavras-chave: Plataforma de jogos. Jovens. Autismo. Cognição. Saúde mental.

\begin{abstract}
This paper presents the accomplishment process of a digital gaming platform through workshops developed among youth in psychic suffering, treated at CAPSi - Psychosocial Care Center for Children and Adolescents in Mossoró. The theoretical framework that supports this work especially considers Gilbert Simondon studies on the individuation process of living beings in a physical and technical intersection and the production of Francisco Varela on cognition function. The implemented methodology is qualitative integrating the interweave of logbooks during workshops, games devices overview and the choice of appropriate technologies for the development of the digital gaming platform. As results of this research, we present cognitive and affective transformations that we could distinguish as recurrent on autistic youth during the gaming workshops and the final stage of the platform completion, which will be validated in mental health and education environments.
\end{abstract}

Keywords: Gamming Platform. Young. Autism. Cognition. Mental health.

MENDES NETO, Francisco Milton; DEMOLY, Karla Rosane do Amaral; OLIVEIRA, Everton Jales; MOURA, Mariza Souza; RODRIGUES, Rafael de Almeida; SANTOS JUNIOR, Ramiro Vasconcelos. Tecnologias e Saúde Mental: uma plataforma de jogos digitais para jovens com transtorno de desenvolvimento. Informática na Educação: teoria \& prática, Porto Alegre, v.20, n. 2, p. 258-271, mai./ago. 2017. 


\section{I ntrodução}

Neste artigo discutimos a implementação de uma plataforma de jogos digitais para favorecer a experiência de jovens com transtorno de desenvolvimento que são atendidos em um Centro de Atenção Psicossocial de Mossoró. O quadro teórico que subsidia nossa análise é composto pelos conceitos de individuação dos seres vivo, físico e técnico, desenvolvido por Gilbert Simondon (1958, 1989; 2009) e pelo conceito de enação construído por Francisco Varela e seus colaboradores Evan T. Thompson e Eleanor Rosch (2001). O trabalho destes cientistas favorece nosso entendimento sobre as circunstâncias do viver humano na relação com as tecnologias e, no caso de nossa pesquisa, a experiência de jovens com transtorno de desenvolvimento - autismo, deficiências mentais, depressão - em oficinas de jogos digitais. A metodologia que utilizamos neste percurso de invenção de uma plataforma digital de jogos envolve a pesquisa intervenção, com o emprego de oficinas semanais de jogos digitais propostas por estudantes e pesquisadores do Programa Rede de Oficinandos na Saúde ${ }^{1}$ em um ambiente de saúde mental. A plataforma está sendo desenvolvida em jogos multiplataforma utilizando a Unity ${ }^{2}$. A escolha se deu pela compatibilidade com outras tecnologias e aceitação em diversos dispositivos.

Nesta escrita apresentamos o percurso de construção e conceitos que operam na arquitetura e dispositivos da plataforma. Estamos propondo artefatos modelados a partir de oficinas semanais em um ambiente de saúde mental, oficinas de jogos que favorecem a observação e análise de modos de coordenar condutas: gestos, ideias e emoções na experiência.

Escritas em diários de bordo de estudantes e pesquisadores durantes as oficinas no CAPSi permitem aceder ao "en-atuar" dos jovens e aos dispositivos presentes nos jogos que fazem disparar processos cognitivos, como modos de interagir, formas de funcionamento da atenção e de exercício de autoria. As oficinas na pesquisa intervenção são concebidas como tecnologias sociais que permitem observar e distinguir pistas, o percurso dos jovens e as características que se destacam nos jogos, compondo informações essenciais que levamos em conta na implementação da plataforma.

Iniciaremos com a explicitação de como conceitos centrais do trabalho - individuação psíquica e coletiva e en-ação operam na experiência em que jogamos e aprendemos com os jovens no CAPSi de Mossoró/RN, um fazer que acontece semanalmente, desde janeiro do ano de 2012. Em seguida trazemos dois recortes: as ações dos jovens no jogar e as características dos jogos já instalados no ambiente do Programa Rede de Oficinandos na Saúde. Os diários de bordo permitiram observar o en-agir dos jovens, contando com os dispositivos presentes nos jogos - sons, imagens, vídeos, animação, tempo, cenário ou design, personagens,

\footnotetext{
${ }^{1}$ O programa Rede Oficinandos na Saúde é uma experiência que reúne projetos de extensão através de uma parceria entre a Universidade Federal Rural do Semi-Árido e o Centro de Atenção Psicossocial da Infância e da Adolescência (CAPSi). O programa utiliza tecnologias da informação e comunicação com o propósito de produzir modos de inserção social, cuidado e formação em saúde mental. A experiência conta com o apoio e colaboração de pesquisadores das universidades UFRGS, UFC, UNISC e UFAL e, desde o ano de 2011 é financiada pelo Ministério da Educação - PROEXT/MEC/SESU.

2Informações sobre a Unity estão disponíveis no endereço: https://unity3d.com/pt/unity.
} 
interatividade, inatividade. Estes dispositivos favorecem a observação de circunstâncias em que manifestam medo, sofrimento, por exemplo, quando um jovem tampa os ouvidos e fecha os olhos diante de luzes e sons. Estas são apenas algumas das pistas que, na experiência direta com os jovens, levamos em consideração na proposta da implementação de uma plataforma de jogos digitais.

Para finalizar o texto, apresentaremos as definições para a plataforma e a atualidade de sua implementação, trabalho este que é realizado por uma equipe transdisciplinar que integra pesquisadores e estudantes das ciências humanas e da ciência da computação. Ao final desta construção, apresentaremos alguns resultados importantes que decorrem da experiência de interação de jovens com transtorno de desenvolvimento em oficinas de jogos digitais.

\section{As experiências humana e técnica}

Ao interagir em oficinas, inicialmente nós nos colocamos a seguinte questão: - Como jovens deslocam e/ou transformam processos cognitivos e afetivos na experiência e interação com jogos digitais? A pergunta desencadeou a reflexão sobre como acontece a experiência humana nas dimensões cognitiva, técnica e social e recorremos aos estudos de Gilbert Simondon e Francisco Varela.

\subsection{Gilbert Simondon e a individuação humana, física e técnica}

Simondon é considerado o filósofo da técnica por ter se dedicado a estudos sobre os processos de individuação psíquica e coletiva e sobre a individuação dos objetos técnicos, esclarecendo sobre a estreita relação entre a configuração dos objetos técnicos e as diferentes sociedades que vamos construindo.

A operação de individuação descrita na obra do autor é importante no trabalho de implementação de uma plataforma de jogos, pois permite distinguir um modo de olhar e explicar os encontros que acontecem entre os jovens e os artefatos técnicos nas oficinas.

Equipamos um ambiente de saúde mental do município de Mossoró no ano de 2012 onde temos oito computadores conectados à Internet, oito tablets, oito câmeras fotográficas, papeis, tintas, lápis de cor, tesouras, entre outros artefatos que favorecem o linguajar. Para Maturana, tudo o que nós os humanos fazemos ocorre enquanto rede de conversações e estas se tecem no contínuo entrelaçamento de linguagens e emoções. As ações na linguagem o autor distingue como "linguajar" e jogar é um modo de linguajar.

Interagimos nas oficinas no CAPSi com grupos de oito jovens, nas quintas e sextas feiras, perfazendo um coletivo de cerca de sessenta e quatro jovens. Os diagnósticos feitos pela equipe interdisciplinar que os atende na instituição indicam circunstâncias, como: autismo, deficiência mental e/ou depressão. Precisávamos construir um caminho para compreender as ações, os sofrimentos, as alegrias, saberes dos jovens que observávamos no percurso das oficinas. 
Em sua tese, Simondon oferece algumas pistas para compreender o modo de existência dos seres humanos em seus processos de individuação psíquica e coletiva. Ao problematizar a gênese do indivíduo, o autor esclarece de que é preciso deslocar-se da noção de "forma" para a de "informação", quando queremos compreender processos de individuação. Assim, o indivíduo físico, vivo ou técnico experimenta atualizações nos processos de individuação que acontecem no percurso de existência dos mesmos.

Ao analisar a história da Filosofia Ocidental, Simondon (2009) pensa a problemática do sujeito na análise que faz dos sistemas metaestáveis, que são irredutíveis à ordem da identidade. O indivíduo, nesta perspectiva, é resultante da operação de individuação, seja na dimensão dos seres vivos físicos ou técnicos. De acordo com o autor:

\begin{abstract}
Existem duas vias segundo as quais a realidade do ser como indivíduo pode ser abordada: uma via substancialista, considerando o ser como consistindo em sua unidade, dado a si mesmo, fundado sobre si mesmo, engendrado, resistindo àquilo que não é ele mesmo; uma via hilemórfica considerando o indivíduo como engendrado pelo encontro de uma forma e de uma matéria (SIMONDON, 2009, p.23).
\end{abstract}

Simondon questiona a ambas as vias, pois acabam definindo o propósito de busca por um "princípio de individuação" que as sustenta no sentido de que este princípio explica uma realidade encontrada. (SIMONDON, 2009, p.26). As visões substancialista e /ou hilemórfica, tomadas como explicação para o modo de existir dos seres humanos, consideram como ponto de partida "o indivíduo constituído e dado", em um esforço "para remontar às condições de sua existência" (SIMONDON, 2009, p.23). O autor sustenta a perspectiva da ontogênese que focaliza as fases do ser, designando seu caráter de devir, o qual precede à tomada de forma, visibilizando os regimes pelos quais o sujeito passa a existir.

Assim, no contexto do nosso trabalho, os jovens em circunstância de transtorno de desenvolvimento, assim como cada um de nós com nossas potências e fragilidades, surgem em decorrência de um sistema em tensão metaestável (energia potencial), sempre em devir. Ao contrário de processos estáveis, da afirmação de identidades cristalizadas em um modo de ser que definiria como somos e porque assim o somos, o que se passa é uma "[...] comunicação permanente, mantendo uma metaestabilidade que é condição de vida" (SIMONDON, 2009, p. 25)

Enquanto examinarmos apenas os limites da aparência (forma e conteúdo), o que nos ambientes de saúde mental e de educação aparecem na forma de escritas - diagnósticos, registros sobre estudantes -, estaremos reforçando uma perspectiva que cristaliza uma posição para o sujeito - jovem com transtorno de desenvolvimento -, enfatizando as fragilidades no lugar das potências do vir a ser, tornar-se no transcurso da experiência, o que implica devir humano.

[...] o devir não é uma moldura na qual o ser existe; ele é dimensão do ser, modo de resolução de uma incompatibilidade inicial rica em potenciais. A individuação corresponde ao surgimento de fases no ser que são as fases do ser; ela não é uma consequência depositada no limiar do devir e isolada, mas esta própria operação se realizando. 
O propósito de nosso trabalho é construir uma plataforma de jogos digitais contando com a observação e análise de mudanças cognitivas e afetivas na experiência de oficinas com jovens em circunstâncias de transtornos mentais. Levamos em conta a energia potencial dos processos de individuação nos quais nos fazemos humanos.

Sobre o modo como compreendemos as circunstâncias de jovens com transtornos de desenvolvimento, tornamos visíveis em diários de bordo construídos nas oficinas as potencialidades dos jovens em situações de jogo, pois nossa atenção está deslocada para as operações de individuação que experimentam ao se defrontarem com problemas e produzirem soluções/atualizações. As oficinas de jogos digitais acontecem em grupos, o que se apresenta como uma novidade no CAPSi onde os atendimentos são preponderantemente individuais. Sobre a dimensão subjetiva que integra a vida humana, Simondon chama nossa atenção para o coletivo:

\begin{abstract}
O psiquismo e o coletivo são constituídos por individuações que sucedem a individuação vital. O psiquismo é a perseguição da individuação vital em um ser que, para resolver sua própria problemática, é obrigado a intervir ele mesmo como elemento do problema, por sua ação, como sujeito; o sujeito pode ser concebido como a unidade do ser enquanto ser vivo individuado e enquanto ser que representa sua ação para si mesmo através do mundo como elemento e dimensão do mundo; os problemas vitais não são fechados sobre si mesmos; sua axiomática aberta só pode ser saturada por uma sequência indefinida de individuações sucessivas que empregam sempre mais realidade préindividual e a incorporam na relação ao meio; afetividade e percepção se integram em emoção e em ciência que supõem um recurso a dimensões novas (SIMONDON, 2009, p. 30).
\end{abstract}

Como recurso a dimensões novas, o autor discute a potência da ação sobre si mesmo e no coletivo, o que ajuda a pensar sobre a tecnologia social que empregamos na pesquisa intervenção - as oficinas - em que os jovens são convidados a uma experiência de jogar com o outro, interagir. Simondon segue sua reflexão sobre a ação sobre si mesmo, a busca de resolução de problemáticas vitais nesta dimensão psíquica e também coletiva.

\begin{abstract}
Entretanto o ser psíquico não pode resolver em si mesmo sua própria problemática; sua carga de realidade pré-individual; ao mesmo tempo em que se individua como ser psíquico que ultrapassa os limites do ser vivo individuado e o incorpora em um sistema do mundo e do sujeito, permite a participação sob forma de condição de individuação do coletivo; a individuação sob forma de coletivo faz do indivíduo um indivíduo de grupo, associado ao grupo pela realidade pré-individual que ele traz em si e que, reunida à dos outros indivíduos, se individua em unidade coletiva. As duas individuações, psíquica e coletiva, são recíprocas uma com relação à outra; elas permitem a definição de uma categoria do transindividual que tende a dar conta da unidade sistemática da individuação interior (psíquica) e da individuação exterior (coletiva) (SIMONDON, 2009, p. 30)
\end{abstract}

Neste ponto, é por intermédio de um corpo que experimenta processos de individuação que a informação se atualiza. Assim, o corpo passa a ser compreendido como plano de inscrição da experiência no encontro dos jovens com jogos digitais. Passamos a compreender que a individuação não envolve captação de uma realidade, mas sim deslocamentos e atualizações que emergem como efeito do encontro de um corpo com um sinal perceptivo (visual, sonoro, 
olfativo, sensorial, gustativo ou abstrato), o qual possibilita o ser vivo individuado interagir com o mundo em uma relação de coprodução.

No contexto desta pesquisa, compreender o campo problemático que se instaura com o desafio do desenvolvimento de uma plataforma de jogos digitais para a saúde mental requer a explicitação dos nossos entendimentos sobre como o dispositivo jogo pode favorecer a experiência de jovens com transtorno de desenvolvimento. E, neste ponto, é importante distinguir que os seres humanos se individuam mediante uma ação encarnada, corpórea, tal como indica Francisco Varela (2003), outro pesquisador com o qual interagirmos na construção de nossa pesquisa.

\title{
2.2 Francisco Varela e a Enação
}

Podemos afirmar, inspirados em Varela, Thompson e Rosch (2001) que o ser humano configura o conhecimento e as realidades em que vive em processos que conceituam como enação, fazendo a cognição diferenciar-se permanentemente de si mesma.

\begin{abstract}
[...] a cognição não é a representação de um mundo preestabelecido elaborada por uma mente pré-definida, mas é antes a atuação de um mundo e de uma mente com base numa história da variedade das ações que um ser executa no mundo (p. 32).

[...] primeiro, que a cognição depende dos tipos de experiência que surgem do fato de se ter um corpo com várias capacidades sensório-motoras e, segundo, que estas capacidades sensório-motoras individuais se encontram elas próprias mergulhadas num contexto biológico, psicológico e cultural muito mais abrangente (VARELA, THOMPSON e ROSCH, 2001, p. 226).
\end{abstract}

Ao indicarem o que implica os processos em que nos tornamos humanos e seguimos atualizando modos de conhecer, viver, sentir, fazer nos movimentos da cognição, podemos aproximar os estudos dos autores da perspectiva de Simondon, pois em ambas as teorias temos que os indivíduos humanos se transformam em congruência, nos processos que articulam potências, energias, modos de agir na linguagem, tornando visíveis emoções como alegria e/ou dor nos percursos de vida e conhecimento.

A criação de novos mundos implica uma diferenciação de si próprio e uma transformação estrutural, de acordo com a própria definição de "mente corporificada".

[...] a cognição depende dos tipos de experiência que surgem do fato de se ter um corpo com várias capacidades sensório-motoras e, segundo, [...] estas capacidades sensório-motoras individuais se encontram elas próprias mergulhadas num contexto biológico, psicológico e cultural muito mais abrangente (VARELA; THOMPSON; ROSCH, 2001, p. 226).

Ao analisarmos como os jovens coordenam suas ações no ambiente equipado com jogos já disponíveis, percebemos que atualizam modos de sentir, fazer, interagir nas oficinas e vamos definindo pistas para produzir uma plataforma de jogos pertinentes aos seus percursos de vida e conhecimento. Temos, ao mesmo tempo, o trabalho de observar e distinguir modos perceptivos sensórios motores, isto é, como jogam, onde pousam a atenção, que jogos mais os atraem (considerando aqui aqueles jogos já disponíveis no ambiente das oficinas). Outro 
trabalho necessário foi distinguir características presentes nos jogos e os efeitos que estes dispositivos produzem na experiência dos jovens: agradam, assustam, alegram, entristecem. Diferentes mídias, como sons, imagens, personagens, cenários, escritas, enfim, estes elementos e as operações, desafios que os jogos colocam aos jogadores, precisariam integrar a plataforma de modo a expandir as potencialidades dos jovens no transcurso da experiência.

\section{Oficinando com jovens e jogos digitais em um ambiente de saúde mental}

Organizamos oficinas em um ambiente equipado com diferentes tecnologias que favorecem a interação, como jogos de computador e tablets. O ambiente onde nossa pesquisa se desenvolve é o CAPSi que atende em média cento e cinquenta jovens com transtornos mentais de Mossoró e vindos de cidades circunvizinhas.

O programa Rede de Oficinandos na Saúde intensificou a experiência com a tecnologia jogos digitais a partir de janeiro de 2013, quando bolsistas de extensão e de pesquisa passaram a organizar oficinas de jogos no CAPSi. Temos atualmente participando das oficinas jovens com autismo, depressão e/ou deficiência mental e acompanhamos a experiência compondo diários de bordo. O Programa envolve sessenta e quatro jovens nas oficinas, divididos em pequenos grupos de oito, durante uma hora, em dois momentos nas quintas-feiras e sextas-feiras, turnos da manhã e da tarde.

Para esta escrita consideramos as escritas dos diários de bordo referidas a oito jovens que estudam nos anos iniciais do ensino fundamental e, ao mesmo tempo, participam de terapias e das oficinas do Programa Rede de Oficinandos na Saúde.

Os jogos instalados em computadores e tablets inicialmente estão disponíveis na internet. Crawford (1982) esclarece que temos diferentes tipos de jogos e, baseados nos estudos de Monte (2014) descrevemos na Tabela 1 características dos jogos utilizados nas oficinas.

Tabela 1. Descrição de tipos de Jogos

\begin{tabular}{|c|l|}
\hline Tipo de Jogo & \multicolumn{1}{|c|}{ Descrição da forma de jogo e exemplo } \\
\hline Jogos de ação & $\begin{array}{l}\text { Enfatizam a reação instantânea e precisam de intensa concentração do } \\
\text { jogador: Mario Word }{ }^{3}, \text { Chicken Invaders }^{4} \text {. }\end{array}$ \\
\hline Jogos de Simulação & $\begin{array}{l}\text { Procuram reproduzir com fidelidade um fenômeno ou acontecimento, } \\
\text { buscando aproximações com aspectos da realidade vivida em um } \\
\text { contexto/cenário: rally de carros }{ }^{5} \text {, passeio e resgate de helicóptero }\end{array}$ \\
\hline Jogos de Aventura & $\begin{array}{l}\text { Procuram fazer o jogador pensar para seguir no jogo, muitas vezes contam } \\
\text { com a solução de um problema ao longo da ação: Subway Surfers }\end{array}$ \\
\hline
\end{tabular}

3 Mario World disponível em <http://nintendo.wikia.com/wiki/Super Mario World>.

4Chicken Invaders disponível em <https://www.interactionstudios.com/chickeninvaders.php>.

5 Rush Rally disponível em <https://play.google.com/store/apps/details?id=brownmonster.app.game. rushrally\&hl=pt-br> 6 Gunship Battle disponível em <https://play.google.com/store/apps/details?id=com.theonegames.gunshipbattle\&hl=ptbr>

7 Subway Surfers disponível em <https://play.google.com/store/apps/details?id=com.kiloo.subwaysurf> 


\begin{tabular}{|c|l|}
\hline $\begin{array}{c}\text { Jogos de Interpretação de } \\
\text { Personagens }\end{array}$ & $\begin{array}{l}\text { O jogador deve interpretar um personagem que pode ser da vida real. Uma } \\
\text { possibilidade deste jogo é ajudar o jogador a resolver questões do } \\
\text { personagem, a interagir, brincar e fazer falar os personagens, por } \\
\text { exemplo, os gatinhos no Tablet }{ }^{8} \text {. }\end{array}$ \\
\hline Jogos de estratégia & $\begin{array}{l}\text { Requerem que o jogador gerencie um conjunto limitado de recursos para } \\
\text { atingir um objetivo predefinido. Geralmente, gerenciar estes recursos } \\
\text { envolve decidir que unidade criar e onde colocá-la em ação. Outros jogos } \\
\text { de estratégia são baseados em turnos, onde o jogador utiliza o tempo para } \\
\text { tomar as decisões e o computador age quando o jogador indicar que está } \\
\text { pronto. Mário Word, Chickens, Resgate de helicóptero. }\end{array}$ \\
\hline
\end{tabular}

Fonte: elaborada pelos autores.

Apresentaremos a seguir recortes do percurso de alguns jovens que chamaremos por nomes fictícios, preservando suas identidades. Indicaremos características que os jogos precisam considerar quando propostos para um trabalho na saúde mental. Os recortes foram produzidos a partir de escritas de diários de bordo que são tecidos a cada encontro/oficina onde interagimos e jogamos juntos, oferecendo no ambiente uma diversidade de jogos digitais.

\subsection{Coordenações de condutas na experiência de jovens com jogos digitais}

As ações no jogo provocam mudanças nas coordenações de ações, coordenações de sentido, coordenações de gestos, coordenações de emoções. Levamos em conta estas operações cognitivas na experiência dos jovens e refletimos sobre as circunstâncias de suas vidas, no caso do presente texto, as circunstâncias do autismo, da deficiência mental e da depressão.

É sempre delicado pensar em características que remetem a todos, pois a perspectiva com a qual trabalhamos aponta para as singularidades, as circunstâncias de cada jovem, sujeito de sua vida e história. Cada sujeito é único em seu modo de viver-conhecer-sentir, portanto nas oficinas buscamos este olhar atento em que aprendemos com cada jovem sobre como interage com os jogos. Jamais será do mesmo modo que se apresentam as circunstâncias do autismo, da deficiência mental e/ou da depressão. Então, em meio a este alerta, apontamos alguns elementos que nos parecem necessários de considerar no trabalho de desenvolvimento de uma plataforma de recomendação de jogos digitais, um quadro que tecemos com base na experiência direta e imediata com os sujeitos nas oficinas.

Jogar implica produzir modos interagir nas oficinas, trabalho este importante na promoção da saúde mental. Observamos e distinguimos mudanças afetivas e cognitivas como modos de coordenar condutas nas oficinas de jogos.

Novas coordenações de ações em oficinas de jogos digitais produzem deslocamentos nos modos de composição das experiências sensoriais, estéticas, afetivas e cognitivas. Os jovens que participaram dessa observação estão em circunstâncias como o autismo, a deficiência mental e/ou a depressão, como já indicamos, mas nesse artigo serão apresentadas apenas

8 Talking Tom disponível em <https://play.google.com/store/apps/details?id=com.outfit7.talkingtom> 
nossas construções referidas às circunstâncias de jovens com autismo, devido à necessidade de um recorte para composição da escrita.

A Tabela 2 apresenta ações recorrentes que nos permitem distinguir mudanças nas coordenações de ações na experiência: coordenações de gestos, coordenações de ideias, coordenações de emoções. As oficinas de jogos favorecem a observação e análise de mudanças afetivas e cognitivas, os movimentos da cognição inventiva em que mundo e sujeitos se constroem mutuamente. Aqui recortamos nesta escrita a análise de nossa experiência com jovens autistas.

Tabela 2. Tabela contendo modos de coordenar condutas recorrentes na experiência, dispositivos presentes nos jogos já conhecidos e dispositivos a estarem presentes na plataforma.

\begin{tabular}{|c|c|c|}
\hline $\begin{array}{l}\text { Coordenações } \\
\text { oficinas }\end{array}$ & de Ações iniciais na experiência das & $\begin{array}{l}\text { Dispositivos presentes em jogos } \\
\text { conhecidos dos jovens }\end{array}$ \\
\hline $\begin{array}{l}\text { Coordenação } \\
\text { de gestos }\end{array}$ & $\begin{array}{l}\text { No coletivo, inicialmente podem } \\
\text { procurar estabelecer vínculos. } \\
\text { Pode acontecer ausência ou pouco } \\
\text { contato visual, o mesmo para expressão } \\
\text { facial e expressão de emoções. } \\
\text { Modos de comunicar podem } \\
\text { acontecer sem a fala. Repetição de ações, } \\
\text { palavras (quando já iniciam a falar) e na } \\
\text { escolha de objetos. } \\
\text { Podem abrir e fechar os jogos } \\
\text { inicialmente, sem explorar. A alegria pode } \\
\text { vir na forma de bater com as pontas dos } \\
\text { dedos no alto da cabeça, como a comemorar } \\
\text { o que fazem, ou ainda no olhar } \\
\text { alegre/sorridente, ou ainda com sons, são } \\
\text { modos de linguajar. } \\
>\quad \text { medo pode vir na forma de tapar os } \\
\text { ouvidos, chorar, afastar-se, esconder-se } \\
\text { embaixo das mesas. } \\
>\quad \text { Inquietações podem acontecer e, em } \\
\text { alguns casos, temos o sentar no chão, } \\
\text { repetição de gestos com um objeto, ficar a } \\
\text { correr pelo ambiente, esconder-se atrás da } \\
\text { porta. }\end{array}$ & $\begin{array}{l}\text { Elementos contidos nos jogos: } \\
\text { interatividade. } \\
\text { Situações nos jogos mobilizam a } \\
\text { atenção durante o jogar, como: sons, } \\
\text { imagens vídeos e animações. } \\
\text { Condutas acontecem como o choro, } \\
\text { repetições de gestos com determinado } \\
\text { objeto. Observamos que em muitas } \\
\text { situações esta inquietude acontecia devido } \\
\text { o volume dos sons no jogo. Nesse caso, o } \\
\text { controle do volume, de acordo com cada } \\
\text { jovem, deve ser implementado. } \\
\text { Outras ações manifestando agitação e } \\
\text { inquietude aconteciam e podiam estar } \\
\text { relacionadas a circunstâncias presentes no } \\
\text { viver cotidiano. }\end{array}$ \\
\hline $\begin{array}{l}\text { Coordenação } \\
\text { de ideias }\end{array}$ & $\begin{array}{l}\text { Podem mostrar o interesse por objetos } \\
\text { específicos, vídeos, jogos e podem } \\
\text { permanecer neles durante longo período. } \\
\text { p interesse se mostra através do pedido } \\
\text { para jogar, por vezes apontando para } \\
\text { aqueles dispositivos, puxando os oficineiros } \\
\text { pelas mãos para mostrar o que vem } \\
\text { experimentando, ou na forma de palavras, } \\
\text { pequenas frases. }\end{array}$ & $\begin{array}{l}\text { Elementos contidos nos jogos: } \\
\text { personagens conhecidos por eles. } \\
\text { São atraídos pela jogabilidade, o ato } \\
\text { de jogar com praticidade utilizando um } \\
\text { dispositivo como o tablet. }\end{array}$ \\
\hline $\begin{array}{l}\text { Coordenação } \\
\text { de Emoções }\end{array}$ & $\begin{array}{l}\text { Observamos um estranhamento na } \\
\text { interação com elementos que podem } \\
\text { provocar sustos, tensões, medos no } \\
\text { ambiente, assim como podem alegrar. } \\
>\text { Observa-se em algumas situações o } \\
\text { receio, o temor e o medo. Estas emoções } \\
\text { têm relação com diferentes elementos para } \\
\text { cada jovem: sons, cores, imagens de } \\
\text { objetos, processos que se transformam no } \\
\text { transcurso da experiência. } \\
>\text { Observamos a vibração e alegria desde } \\
\text { o encontro com um fazer que parece }\end{array}$ & $\begin{array}{l}\text { O momento inicial dos jogos que foram } \\
\text { inseridos nas oficinas pode de certa forma } \\
\text { causar um estranhamento. Mas depois do } \\
\text { primeiro contato, observamos interesse e } \\
\text { envolvimento com jogos. } \\
>\text { As emoções de receio, temor, medo, } \\
\text { quando causadas por dispositivos dos } \\
\text { jogos, podem ser auxiliadas com a função } \\
\text { em que o próprio jogador passa a controlar } \\
\text { a iluminação da imagem, o volume do } \\
\text { som, ou ainda a contar com o apoio afetivo } \\
\text { do oficineiro jogador durante o jogar. }\end{array}$ \\
\hline
\end{tabular}




\begin{tabular}{|c|c|c|}
\hline & $\begin{array}{l}\text { possível, a fase de um jogo, o simples iniciar } \\
\text { a jogar, mas estas emoções podem se } \\
\text { alterar na relação com as circunstâncias do } \\
\text { ambiente e do sujeito. }\end{array}$ & \\
\hline \multicolumn{2}{|c|}{$\begin{array}{l}\text { Transformações nas coordenações de ações } \\
\text { Coordenações de ações novas e emergentes }\end{array}$} & $\begin{array}{l}\text { Dispositivos a estarem presentes na } \\
\text { Plataforma de J ogos Digitais }\end{array}$ \\
\hline $\begin{array}{l}\text { Coordenação } \\
\text { de Gestos }\end{array}$ & $\begin{array}{l}\text { Atenção pode estar endereçada a } \\
\text { imagens e a movimentos presentes nos } \\
\text { jogos. } \\
\text { quando engloram diferentes jogos no ambiente, } \\
\text { quados nas oficinas de jogos. } \\
>\text { Podem sair das cadeiras e lançar o olhar } \\
\text { para o que os outros fazem. } \\
>\text { Temos a ampliação das ações em que } \\
\text { passam a experimentar o jogar com o outro. }\end{array}$ & $\begin{array}{l}\text { Elementos da plataforma, Animação do } \\
\text { jogo. } \\
>\text { Variedade de jogos em um único } \\
\text { ambiente. } \\
>\text { Interatividade de forma adaptativa. } \\
>\text { Várias fases no jogo aumentando os } \\
\text { desafios e possibilidades de exploração de } \\
\text { cenários, situações. }\end{array}$ \\
\hline $\begin{array}{l}\text { Coordenação } \\
\text { de Ideias }\end{array}$ & $\begin{array}{l}\text { Podem estabelecer novos modos de } \\
\text { comunicação, através da escrita ou mesmo } \\
\text { através de gestos no ambiente. } \\
>\quad \text { Em algumas situações manifestam a } \\
\text { necessidade da presença do outro. } \\
>\text { São capazes de aceder, pouco a pouco a } \\
\text { fala e podem tornar fluentes este modo de } \\
\text { comunicação. } \\
>\text { Potencialidades lógicas estão em } \\
\text { destaque, por exemplo, no vencer fases de } \\
\text { jogos mais complexos, em alguns casos, de } \\
\text { modo brilhante. } \\
>\text { Temos aqui a multisensorialidade, pois } \\
\text { se ampliam os modos sensório-motores de } \\
\text { acoplamento com diferentes mídias no } \\
\text { ambiente de jogos digitais, o que favorece o } \\
\text { encontro com o outro. }\end{array}$ & $\begin{array}{l}\text { Variedade de estilos de jogos } \\
\text { (estratégia, multiplayer, jogos de } \\
\text { plataforma, casuais, etc.). } \\
\text { Interatividade e Jogos multiplayer. } \\
\text { Comunicação (fala, escrita, gestos) no } \\
\text { mesmo jogo. } \\
\text { Elementos para comemorar de forma } \\
\text { adaptativa. } \\
\text { Observação: Aprendemos com crianças } \\
\text { autistas que elas podem vibrar quando } \\
\text { perdem, o que pode estar associado a } \\
\text { outros elementos que não pontuações, } \\
\text { como luzes que aparecem e são lançadas, } \\
\text { ou outros dispositivos que surgem no final } \\
\text { das fases de um jogo. } \\
>\text { Diferentes mídias áudio, vídeo, imagem } \\
\text { e animações, favorecendo a interatividade. }\end{array}$ \\
\hline $\begin{array}{l}\text { Coordenação } \\
\text { de Emoções }\end{array}$ & $\begin{array}{l}\text { Alguns jovens experimentam fruição } \\
\text { estética no jogar. Temos uma maleabilidade } \\
\text { e fluidez que se mostram como processos } \\
\text { que produzem prazer. } \\
\text { d Interação pode mostrar-se serena com } \\
\text { diferentes mídias, sons, imagens e escritas } \\
\text { no ambiente, a partir da descoberta de que } \\
\text { podem modelar estes usos nos jogos } \\
\text { digitais: aumentar e baixar sons, ampliar ou } \\
\text { reduzir a tela, entre outras ações. } \\
\text { Circunstâncias de sofrimento podem } \\
\text { emergir e interagem com problemáticas que } \\
\text { dizem respeito a cada jovem no percurso do } \\
\text { viver. }\end{array}$ & $\begin{array}{l}\text { Gráfico, design, áudio e vídeo, unidos } \\
\text { durante o jogo de forma atrativa. } \\
>\text { Adaptabilidade nos controles de } \\
\text { dificuldade, som, imagem, vídeo e diversos } \\
\text { outros elementos do jogo. }\end{array}$ \\
\hline
\end{tabular}

Fonte: elaborada pelos autores.

A metodologia que utilizamos para o desenvolvimento da pesquisa compreende a produção de diários de bordo em que os oficineiros acompanham as ações dos jovens no ambiente.

A tabela acima foi organizada levando em conta as ações recorrentes que pudemos identificar com o propósito de construir as informações necessárias para o desenvolvimento da plataforma. Os resultados dessa tabela se colocam como uma base para entender e elencar quais elementos dos jogos são atrativos para os jovens inseridos no CAPSi que participam das oficinas. E então, damos continuidade ao desenvolvimento e nossa reflexão se situa nesta 
relação entre modos de coordenar condutas dos jovens, os estudos que realizamos sobre o autismo e sobre os dispositivos capazes de potencializar processos cognitivos e afetivos de jovens em situações de jogo.

\subsection{A construção da plataforma}

Segundo Andrade et al. (2004), os jogos podem ser desenvolvidos a partir de objetivos psicopedagógicos consolidados e serem utilizados na relação com extensa gama de processos cognitivos, como também, a partir de sistemas inteligentes adaptativos que forneçam recursos adaptáveis às necessidades de cada jogador.

A proposta de uma plataforma contendo jogos com funções adaptativas surge a partir da necessidade de desenvolver ferramentas que tomam como base as singularidades, interesses e problemáticas de jovens em situações e circunstancias de transtorno no desenvolvimento.

Conforme já referimos, a construção da plataforma ocorre em jogos multiplataforma utilizando a Unity, e, dentro das linguagens as quais ela dá suporte, utilizamos as linguagens C\# e JavaScript.

A plataforma propõe a utilização de jogos em uma linguagem simples e com uma interface que convida os jovens a pousarem a atenção e se engajarem em situações de jogo, ao mesmo tempo, permite aos profissionais e/ou oficineiros observarem e acompanharem as ações que coordenam no ambiente.

Entre as técnicas de adaptabilidade existentes, tem sido utilizada a técnica de Balanceamento Dinâmico de Dificuldade, que, de acordo com Siebel (2011), em jogos acontece de forma automática, ou seja, os parâmetros, cenários e comportamentos de um jogo são alterados em tempo real e isso acontece de acordo com as habilidades do jogador.

Aplicamos a técnica de balanceamento de dificuldade para que os jogos atuem com a adaptação dos elementos neles contidos. Um exemplo na experiência das oficinas foi quando um jogador em circunstância de autismo estava jogando e uma característica que o mobilizou para o jogo foi o som. O elemento som pode afastar ou engajar jovens autistas na experiência das oficinas de jogos, portanto, à medida que o jogador avança ou não nas fases, o elemento som é habilitado ou desabilitado, promovendo a adaptabilidade na relação com as ações dos jogadores.

Tendo por base os elementos contidos na Tabela 1, sobre as coordenações de ações observadas e analisadas no transcurso da experiência do Programa Rede de Oficinandos na Saúde, catalogamos alguns elementos que são mais atrativos para eles. Os jogos vão sendo adaptados de acordo com as ações dos jogadores e a adaptação durante o jogo atua alterando os elementos do jogo. Um exemplo acontece no jogo "Estellar", no qual a cada vitória ou derrota, os elementos como som, velocidade da aeronave e cor do plano de fundo vão sendo modificados.

A Figura 1 apresenta alguns jogos que estão inseridos na plataforma, os mesmos estão sendo finalizados para adicionar técnicas adaptativas. 
Figura 1 - Jogos em desenvolvimento contidos na plataforma.
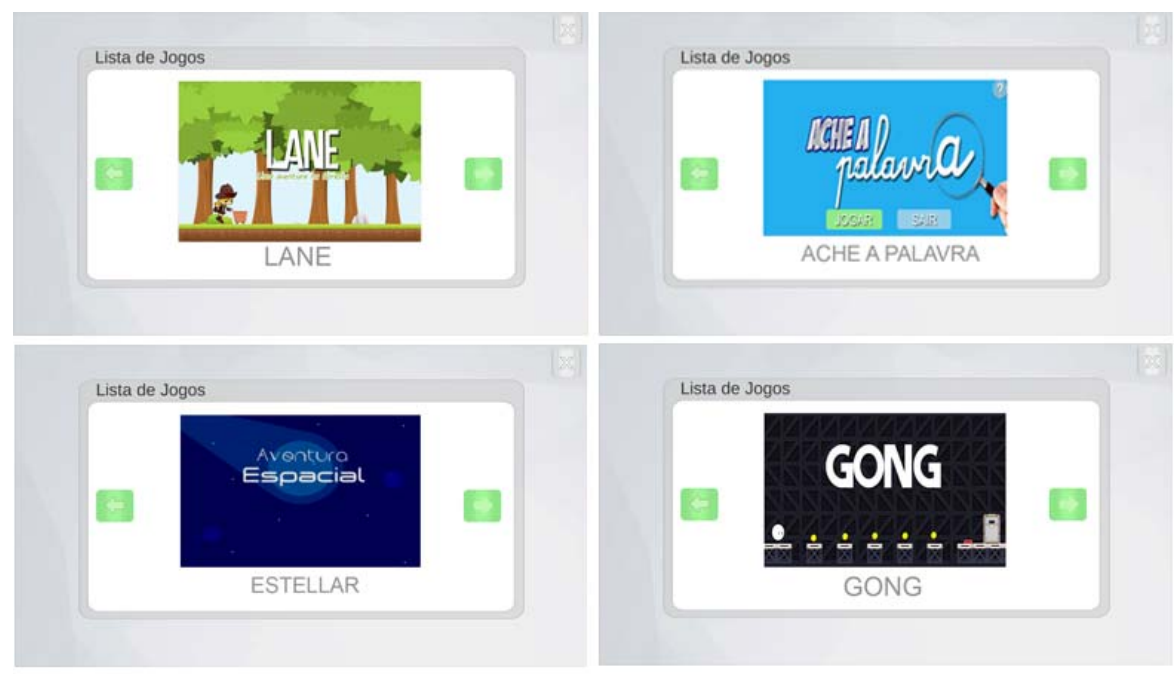

Fonte: elaborada pelos autores.

Planejamos realizar a validação com os jovens inseridos no CAPSi na utilização da plataforma com a participação da equipe de profissionais que atuam na instituição e integram o Programa Rede de Oficinandos na Saúde. Através de oficinas e testes com a plataforma, serão acompanhadas as interações que acontecem no modo de coordenar condutas na experiência dos jovens com a plataforma. Neste momento da pesquisa, tomaremos novamente os diários de bordo para produzir entendimentos sobre como a plataforma de jogos faz disparar processos afetivos e cognitivos na experiência dos jovens autistas, assim como junto aos demais jovens nas oficinas, pois consideramos também os processos vividos pelos jovens que apresentam deficiência mental e/ou depressão.

\section{Considerações Finais}

A pesquisa que realizamos acontece a partir de um trabalho semanal de oficinas de jogos digitais em um CAPSi de Mossoró. Para a equipe de pesquisa esta experiência é essencial porque permite a produção de saberes, entendimentos sobre como operam os sujeitos em circunstâncias de transtorno de desenvolvimento. Priorizamos o trabalho sobre os diários de bordo de estudantes e pesquisadores. Nas oficinas sempre temos dois colegas responsáveis, então vamos alternando as situações em que um joga com os jovens e o outro se dedica no ato de escrever. Temos um conjunto de redes de escritas, estas se referem a cada jovem e ao coletivo, pois cada grupo das oficinas é composto por oito jovens.

A proposta para a escrita do artigo fez com que organizássemos a tabela em que as ações recorrentes foram destacadas, mas pousamos também a nossa atenção para as ações que se diferenciam, pedidos de ajuda na manifestação do sofrimento, momentos de alegria e festa, enfim, o que compõe a experiência, os processos do viver-conhecer. 
Como ações da pesquisa que segue seu curso de desenvolvimento, temos a finalização da plataforma, de forma que atue com a recomendação durante a aplicação no ambiente; a validação junto aos jovens do CAPSi e a expansão da plataforma para outros dispositivos, além da inclusão de outras técnicas adaptativas em pesquisa.

O trabalho traz junto da operacionalização a alegria e potência no encontro entre pesquisadores das ciências humanas e da ciência da computação com estudantes de mestrado e de graduação destas duas grandes áreas. Quando nossa atenção está dirigida a inventar novas formas de cuidar e aprender nos ambientes onde estamos, estes encontros tornam-se motivo de alegria na experiência universitária e fortalecem, em nosso entendimento, o sentido de estarmos na universidade pública, a inventar dispositivos necessários para o trabalho em saúde mental e em educação.

\section{Referências}

ANDRADE, G. et al. Extending reinforcement learning to provide dynamic game balancing. En Proceedings of the Workshop on Reasoning, Representation, and Learning in Computer Games, 19th International J oint Conference on Artificial Intelligence (IJCAI), 2005.

ANDRADE, L. C. et al. Mapa do Zoológico - Captura Cognitiva para Disfunção Executiva. XV SBIE - Simpósio Brasileiro de informática na Educação, Manaus, 2004.

CRAWFORD, Chris. The art of computer game design. Washington State University Vancouver, 1984. $81 \mathrm{p}$.

KOSTER, R. Theory of fun for game design. O'Reilly Media, Inc., 2010.

MATURANA, H; VARELA, F. A árvore do conhecimento: as bases biológicas da compreensão humana. São Paulo: Editora Palas Athena, 2001.

MONTE, W. S. do. Oficinando com jovens: análise de processos de atenção na experiência com jogos digitais. Dissertação (Mestrado em Ambiente, Tecnologia e Sociedade) Universidade Federal Rural do Semi-Árido. Mossoró/RN, 2014.

SILVA, A. S. Desvelando o sentido da deficiência mental: uma leitura psicanalítica. Mental, Barbacena, v.3, n.4, jun. $2005 . \quad$ Disponível em: <http://pepsic.bvsalud.org/scielo.php?script=sci_arttext\&pid=S167944272005000100009\&lng=pt\&nrm=iso>. Acesso em 27 dez. 2015.

SILVA, M. P. Inteligência Artificial Adaptativa para Ajuste Dinâmico de Dificuldade em Jogos Digitais. Dissertação (Mestrado) -- Universidade Federal de Minas Gerais, 2015.

SIMONDON, G. Du mode d'existence des objets techniques. Paris: Aubier, 1958; 1989. Millon, 2009.

L'individuation à la lumière des notions de forme et d'information. Grenoble: Jérôme VARELA, F. Conhecer: as ciências cognitivas tendências e perspectivas. Lisboa: Instituto Piaget, 1988. 
VARELA, F.; J. THOMPSON, E. T.; ROSCH, E. A mente corpórea: ciência cognitiva e experiência humana. Lisboa: Instituto Piaget 1991.

VON FOERSTER, H. Las semillas de la cibernética. Barcelona: GEDISA, 1996.

WATZLAWICK, P; KRIEG, P (Orgs). El ojo del observador: contribuciones al constructivismo. Barcelona: Gedisa, 2009.

Recebido em setembro de 2016

Aprovado para publicação em agosto de 2017

\section{Francisco Milton Mendes Neto}

Programa de Pós-Graduação em Ciência da Computação, Programa de Pós-Graduação em Cognição,

Tecnologias e Instituições e Programa de Pós-Graduação em Ensino - Universidade Federal Rural do Semi-

Árido - UFERSA, Brasil, miltonmendes@ufersa.edu.br

\section{Karla Rosane do Amaral Demoly}

Programa de Pós-Graduação em Cognição, Tecnologias e Instituições - Universidade Federal Rural do Semi-Árido - UFERSA, Brasil, karla.demoly@ufersa.edu.br

\section{Everton Jales de Oliveira}

Graduação em Ciência da Computação - Universidade Federal Rural do Semi-Árido - UFERSA, Brasil, verto.jales@gmail.com

\section{Mariza Souza Moura}

Programa de Pós-Graduação em Ciência da Computação - Universidade Federal Rural do Semi-Árido UFERSA, Brasil, marizasouzamoura@gmail.com

\section{Rafael de Almeida Rodrigues}

Programa de Pós-Graduação em Ciência da Computação - Universidade Federal Rural do Semi-Árido UFERSA, Brasil, rafael_allx@hotmail.com

\section{Ramiro de Vasconcelos dos Santos J unior}

Programa de Pós-Graduação em Cognição, Tecnologias e Instituições - Universidade Federal Rural do Semi-Árido - UFERSA, Brasil, ramirovsjunior@gmail.com 


\title{
O Webfólio como Procedimento Avaliativo no Processo de Aprendizagens: Sentidos, Significados e Desafios
}

\author{
The Webfolio as Assessment Procedure in the Process \\ of Learning: Senses, Meaning and Challenges
}

\section{JOSEVAL DOS REIS MIRANDA}

Universidade Federal da Paraíba

\begin{abstract}
Resumo: Este artigo tece reflexões sobre a utilização de webfólio ${ }^{1}$ como possibilidade avaliativa desenvolvido na disciplina Avaliação da Aprendizagem no curso de Licenciatura em Ciência da Computação. Tivemos como objetivo geral compreender como o uso de webfólios como procedimento avaliativo pode contribuir no processo de aprendizagens dos estudantes. Como objetivo específico analisar os sentidos, os significados e os desafios do trabalho com o webfólio no processo de aprendizagens. Esse trabalho pautou-se na contribuição teórica de autores que fizeram a tessitura dos eixos Webfólio e Avaliação das aprendizagens. A metodologia foi de cunho qualitativo, por meio de um estudo de caso. Utilizamos a observação, - questionário e a pesquisa bibliográfica. Foram participantes da pesquisa estudantes que estavam matriculados na disciplina Avaliação da Aprendizagem. Os resultados apontam que houve maior espaço para a construção, reflexão e criatividade acerca das aprendizagens pelos estudantes; permitiu o acompanhamento de forma processual das aprendizagens; maior convivência com os recursos tecnológicos e a superação da prática avaliativa excludente.
\end{abstract}

Palavras-chave: Webfólio. Avaliação das aprendizagens. Processo de aprendizagens.

\begin{abstract}
This article reflects on the use of webfólio as an evaluation possibility developed in the discipline Evaluation of Learning in the course of Degree in Computer Science. We had as a general objective to understand how the use of webfolios as assessment procedure may contribute to the students' learning process. As a specific purpose: to analyze the meaning, the meanings and the challenges of working with webfolio in the process of learning. This work was guided in theoretical contribution of authors who made the tessitura of the axes Webfolio and evaluation of learning. The methodology was qualitative in nature, through a case study. We use observation, questionnaire and literature. Participants in the survey were students who were enrolled in the Learning Assessment course. . The results show that: there was more room for the construction, reflection and creativity about learning by students; allowed the monitoring of procedural way of learning; greater familiarity with the technological resources and overcoming the evaluative exclusionary practice.
\end{abstract}

Keywords: Webfolio. Assessment of learning. Learning process.

MIRANDA, Joseval dos Reis. O Webfólio como procedimento avaliativo no processo de aprendizagens: sentidos, significados e desafios. Informática na Educação: teoria \& prática, Porto Alegre, v. 20, n. 2, p. 272-286, mai./ago. 2017.

${ }^{1}$ O Termo Webfólio ou portfólio online serão considerados sinônimos no decorrer do texto, pois ambos significam estar disponível para o acesso imediato a uma página da internet. 


\section{I ntrodução}

O presente texto apresenta aspectos abordados em nossas pesquisas no campo da avaliação das aprendizagens com a utilização do webfólio ou portfólio online e tem como objetivo central compreender como o uso de webfólios, como procedimento, avaliativo pode contribuir para o processo de aprendizagens dos estudantes.

Pensar na utilização do webfólio significa inseri-lo no contexto também das tecnologias da informação e comunicação a serviço das aprendizagens e do processo avaliativo. É indiscutível a necessidade de inovação no processo de ensino e, nesse sentido, a utilização do webfólio possibilita a criação de um ambiente para as aprendizagens que ultrapassa o modelo avaliativo que se utiliza somente da sala de aula.

Tanto o portfólio como o webfólio ou portfólio online são procedimentos de trabalho utilizados no campo da avaliação que coadunam com uma concepção de práticas avaliativas a serviço das aprendizagens.

A organização do trabalho pedagógico por meio do webfólio cria alternativas para a efetivação dos processos de ensino e de aprendizagens permeados pela reflexão, pelo diálogo e compartilhamento do conhecimento, pela autonomia, criatividade e outros elementos que regem o portfólio e se adequam perfeitamente ao webfólio. (VILLAS BOAS, 2004).

A construção deste texto pautou-se em revisão bibliográfica, observação participante, além de questionário semiestruturado, o qual contou com a participação de quinze estudantes regularmente matriculados na disciplina "Avaliação da Aprendizagem", no curso de Licenciatura em Ciência da Computação, no ano letivo de 2015.

Por meio da revisão bibliográfica, foi possível constatar que há várias produções que abordam a temática central do nosso estudo: o webfólio como procedimento avaliativo. Essas produções apontam as múltiplas possibilidades de utilização no webfólio como ferramenta produtiva na organização do trabalho pedagógico e na construção de uma prática avaliativa a serviço das aprendizagens.

No que diz respeito à observação, esta foi realizada durante os dois semestres letivos de 2015 e possibilitou-nos o acompanhamento das construções dos webfólios pelos estudantes, evidenciando aspectos como: a organização, os formatos, a continuidade, a forma como postavam as atividades, as dificuldades encontradas, os momentos de socialização na turma e apresentação final dos webfólios produzidos.

Já o questionário, formulado com oito questões abertas sobre webfólios, foi respondido pelos estudantes durante a construção dos webfólios no ambiente da sala de aula.

Assim, com base nas informações colhidas, buscamos, por meio deste texto, evidenciar a importância do diálogo em torno da avaliação das aprendizagens e do trabalho com o webfólio, considerando os seus sentidos, suas possibilidades e seus desafios, tendo como premissa a construção de um trabalho pedagógico avaliativo inclusivo, reflexivo, crítico e democrático, vislumbrando as aprendizagens de todos e todas. 


\section{Reflexões sobre avaliação das aprendizagens}

O momento atual no cenário educacional tem sido marcado por um contexto de reflexões, indagações, contradições, contraposições, questionamentos, críticas e ressignificação do nosso "fazer pedagógico". Aqui destacamos a importância de que este "fazer" esteja relacionando ao trabalho pedagógico por compreendermos que o "fazer pedagógico" não pode estar apenas na esfera do "fazer" simplesmente técnico, mas também em uma esfera macro, na qual o fazer pedagógico dilui-se no sentir, no vivenciar e no ressignificar, tecendo várias relações entre a própria competência do fazer técnico e desta com outras competências - políticas, sociais, históricas, culturais - tão necessárias ao desenvolvimento do trabalho pedagógico como um todo.

A busca pela qualificação do fazer pedagógico é uma questão complexa e perpassa vários fatores, entre eles a avaliação das aprendizagens, uma vez que não se avalia para atribuir nota, conceito ou menção. Avalia-se para promover a aprendizagem do estudante e, neste sentido, a avaliação e as aprendizagens caminham de mãos dadas (VILLAS BOAS, 2004).

Desta forma, torna-se explícito o quanto a avaliação escolar interfere na construção de práticas pedagógicas mais inclusivas e dessilenciantes, considerando que o nosso olhar avaliativo muitas vezes é periférico, genérico e circunstancial, sendo o resultado de uma formação profissional docente que revela o quanto carecemos romper com o espírito da passividade e do silenciamento que nos foram impregnados pelos padrões impostos durante nossa formação, na qual a avaliação, na maioria das vezes, era vista simplesmente como notas, conceitos, menções, punições e classificações.

A avaliação faz parte da nossa vida em todos os momentos e lugares. Ela é utilizada nas mais diversas situações, por meio dos mais diferentes critérios. Muitas vezes, a avaliação ocorre como forma de testagem, julgamentos ou mesmo como medição de nossas ações para planejamentos o futuro. Entretanto, no contexto educativo a avaliação precisa desenvolver-se sob outra perspectiva, deixando de ser somente um ato normativo e padronizado.

A avaliação praticada na escola pode, portanto, cumprir duas funções, a de classificar o estudante ou a de promover a sua aprendizagem. A primeira tem sido a mais comum, porque tem em vista apenas a atribuição de notas e menções, o que, em geral, contribui para a classificação e exclusão, pois favorece a criação de rótulos e a marginalização dos estudantes. Já a segunda função da avaliação ocorre quando a prática avaliativa se desenvolve sob a perspectiva da emancipação e quando a preocupação (e ocupação) do professor recai no desenvolvimento do estudante como um todo, norteando o seu avanço, e sendo indicadora dos próximos passos durante o processo educativo.

Para Villas Boas (2004), a avaliação existe para que se conheça o que o estudante já compreendeu e o que ainda lhe falta compreender, providenciando os meios necessários para que ele dê continuidade aos estudos. Neste sentido, a avaliação será entendida como fonte principal de informação e referência para a formulação de práticas educativas e, especialmente, como um elemento indissociável do processo educativo. 
Sendo assim, a prática avaliativa, realizada de forma contínua e processual, possibilita definir critérios para planejar e realizar situações que gerem avanços significativos nas aprendizagens, bem como reflexão e tomada de decisões conscientes em relação à própria prática docente, possibilitando ao professor acompanhar as conquistas, as necessidades e as possibilidades dos estudantes ao longo do processo, pois "é função da avaliação a promoção permanente de espaços interativos sem, entretanto, deixar de privilegiar a evolução individual ou de promover ações mediadoras que tenham sentido para o coletivo" (HOFFMANN, 2006, p. 16).

Portanto, mudar a concepção e a prática avaliativa torna-se essencial para a construção de um processo educativo significativo, tanto para os professores como para os estudantes, uma vez que "a avaliação não pode se constituir um processo frio e despersonalizado, pois ela tem que estimular a reflexão do aluno, a compreensão de aspecto que ainda não domina" (GONZÁLEZ REY, 2006, p.39).

Segundo Luckesi (2002), não existe avaliação sem ação, a não ser por exercício de nominalismo, avaliar é ver, julgar e agir, num ciclo ininterrupto. Nessa perspectiva avaliativa, a ampliação do conhecimento deve ser compreendida como construções dinâmicas, por meio da interação da pessoa consigo mesma e com os outros, organizando-se, por meio do sentido subjetivo que vai se desenvolvendo na aprendizagem, pois aprender é uma produção subjetiva, cuja qualidade não está somente na definição das operações lógicas. (GONZÁLEZ REY, 2006).

Desse modo, enxergando a avaliação como ato subjetivo e complexo, percebemos que cabe à prática avaliativa romper as barreiras da padronização e da homogeneidade, as quais buscam descaracterizar o papel do estudante como sujeito do seu processo de aprendizagem, pois ele é “indivíduo concreto portador de personalidade, quem tem como características essenciais e permanentes de sua condição atual, ativo, consciente e intencional" (GONZÁLEZ REY, 2006).

A prática avaliativa, nesse contexto, consubstancia-se na diversidade como característica própria dos seres humanos, a qual é permeada pela complexidade das relações tecidas no cenário social. Vale destacar que complexidade "constitui-se um modo de compreender a realidade no qual é reconhecido o caráter desordenado, contraditório, plural, recursivo, singular, indivisível e histórico que a caracteriza" (MARTí NEZ, 2005, p.4).

Nesse sentido, a sala de aula deve ser concebida como um espaço permeado pelas diversas singularidades, e daí Romanowski (2006) ressalta:

[...] o ambiente da sala de aula é um espaço de vida coletiva, um espaço de relações únicas e originais, semelhantes a um ecossistema para a intensificação da aprendizagem, em que os vínculos dos alunos e dos professores com o conhecimento são acentuados. Professor e aluno transformam-se e transformam o conhecimento em aprendizagem (ROMANOWSKI, 2006, p. 105).

Reconhecer que o cenário, onde se realiza a prática avaliativa, é permeado por toda complexidade significa valorizarmos as diferenças individuais sem jamais perder de vista o contexto interativo entre os vários sujeitos, pois compreende-se que cada estudante constrói significações e sentidos para a sua aprendizagem de maneira própria, diferente e única. 
Nesse contexto são oportunas as palavras de González Rey:

\begin{abstract}
Os sentidos subjetivos constituem verdadeiros sistemas motivacionais que diferentes das teorias mais tradicionais da motivação - permite-nos representar o envolvimento afetivo do sujeito em uma atividade, não apenas pelo seu vínculo concreto nela, mas como produção de sentidos que implica em uma configuração única, sentidos subjetivos, emoções e processos da história individual, como os diferentes momentos atuais da vida de cada sujeito concreto. (GONZÁLEZ REY, 2006, p.34).
\end{abstract}

Em alinhamento ao que compreendemos sobre a avaliação a serviço das aprendizagens Hoffmann (2006) expõe que a prática avaliativa deve estar entrelaçada em três tempos, pois no cotidiano escolar a relação pedagógica precisa ser nutrida de sentido para todos os seus sujeitos em prol de um trabalho educativo com significação. A autora destaca, como primeiro tempo, o tempo da admiração, sendo este um tempo para conhecer o sujeito, por meio do diálogo e de um olhar mais sensível e amplo, a fim de que se possa compreender como o sujeito processa a sua aprendizagem.

Para o segundo tempo da avaliação, Hoffmann (2006) aponta o tempo da reflexão, que se constitui como um tempo para se conhecer o estudante, no que diz respeito à sua trajetória no processo de aprendizagem, tendo em vista não anunciar resultados definitivos ou padronizados.

Já para o terceiro tempo, tempo da reconstrução, é para Hoffmann (2006), o tempo da reconstrução, o tempo de fazer a diferença na prática avaliativa.

Desse modo, acreditamos que uma prática avaliativa com vistas à inclusão, leva em conta o caráter singular do aprender e a compreensão da aprendizagem como prática dialógica, para a qual se deve buscar superar as rasuras dos processos de ensino de aprendizagem centrados somente na memorização e na reprodução do conhecimento, pois a realidade da sala de aula é muito mais dinâmica, ativa e efervescente, devido às várias subjetividades que se fazem presentes nesse contexto.

Corroborando com essas ideias, González Rey (2005, p.37) salienta que o caráter complexo da subjetividade "permite transcender as representações estático-descritivas da psique e mostra a sua representação como sistema que exige a criação de um referente teórico, epistemológico e metodológico distinto".

O autor ainda acrescenta que a subjetividade:

[...] é um sistema em desenvolvimento, no qual as novas produções de sentido constituídos nas atividades do sujeito influenciam o sistema de configurações da personalidade, não de modo imediato, mas de modo mediato nos processos de reconfiguração que acompanham a constante processualidade dos diferentes sistemas de atividades e de relações do sujeito (GONZÁLEZ REY, 2005.p.35).

Não poderíamos deixar de mencionar, mais uma vez, que compreendemos uma prática avaliativa docente permeada por aspectos complexos e subjetivos, pois o próprio ato educativo é, em sua essência, admitido por princípios multifacetados, complexos, relacionais, subjetivos e dialógicos, nos quais o próprio ser humano, por meio da educação, busca o seu desenvolvimento. 
Nesse sentido, Charlot (2000) apud Libâneo (2005) esclarece que o processo da educação:

\begin{abstract}
É o processo por meio do qual um membro da espécie humana inacabado, desprovido dos instintos e das capacidades que lhe permitiriam sobreviver rapidamente sozinho se apropria graças à mediação dos adultos, de um patrimônio humano de saberes, práticas, formas subjetivas, obras. Essa apropriação the permite se tornar, ao mesmo tempo e no mesmo movimento, um ser humano, membro de uma sociedade e de uma comunidade, e um indivíduo singular absolutamente original. A educação é, assim, um triplo processo de humanização, de socialização e de singularização. Esse triplo processo é possível apenas mediante a apropriação de um patrimônio humano. Isso quer dizer que a educação é cultura, em três sentidos que não podem ser dissociados. (CHARLOT, 2000 apud LIBÂNEO, 2005, p.23).
\end{abstract}

Assim sendo, como a educação e o processo de escolarização, pelos quais o ser humano tem acesso às produções e ao conhecimento sistematizado pela humanidade, poderiam, por meio das suas práticas avaliativas, promover a inclusão e não a padronização, a exclusão e a marginalização social? E ainda, qual o papel do professor frente a esta prática avaliativa?

Questionamentos como estes são bastante atuais no seio do debate educacional, pois somos conhecedores do quanto a prática avaliativa classificatória corrobora para aumentar a exclusão e o fracasso escolar, uma vez que, não leva em consideração a complexidade e a subjetividade dos sujeitos e dos espaços que estes ocupam e que se fazem presentes na prática avaliativa. Por isso, a prática docente requer, de cada profissional envolvido no processo educativo, bom senso e responsabilidade, bem como exige atenção às diferenças e, sobretudo, cuidado no ato de avaliar.

Nessa conjuntura, é indispensável ao professor pensar em critérios e instrumentos contextualizados, específicos para cada turma, em cada tempo escolar, possibilitando a definição e o conhecimento dos mecanismos de avaliação por todos os envolvidos, pois a prática avaliativa não pode se dar em um jogo de surpresas ou de mistérios. A esse respeito Hoffmann (2006) explicita que a construção de uma avaliação mediadora é compromisso e responsabilidade de ambas as partes, tanto do professor como do estudante.

A autora menciona o equívoco em que se “discute a avaliação para tentar melhorar a aprendizagem dos alunos, quando se deveria fazer exatamente o inverso: discutir a aprendizagem dos alunos para aperfeiçoar o processo avaliativo e a educação" (HOFFMANN, 2006, p.67). Faz-se necessário, portanto, rever o papel do professor no que diz respeito ao estudante como sujeito do seu próprio processo de aprendizagem, no qual o professor assumirá a postura de facilitador, considerando que aprendizagem dificilmente poderá ocorrer de forma passivo-reprodutiva.

Neste contexto, González Rey ressalta que:

O aluno torna-se sujeito de sua aprendizagem quando é capaz de desenvolver um roteiro diferenciado em relação ao que aprende e a se posicionar crítica e reflexivamente em relação à aprendizagem. [...] A sala de aula tem que se converter em um espaço de diálogo e reflexão. (GONZÁLEZ REY, 2006, p.40).

Assim, buscar a reconstrução ou o redimensionamento das práticas avaliativas perpassa, entre outras questões, pela ressignificação dos aspectos que compõem a subjetividade individual e social na prática avaliativa, pois quando nos referimos às concepções, às 
representações ou aos valores, ali estão aspectos da subjetividade, quer sejam individuais ou sociais. (MARTINEZ, 2003).

\title{
3 Webfólio como possibilidade avaliativa
}

O webfólio ou portfólio online segue os princípios e fundamentos do portfólio construído de forma física. Nesse caso, o webfólio corresponde às produções dos estudantes disponíveis em uma página da web e com a utilização de recursos da internet.

Segundo Nunes e Moreira (2005), o termo portfólio deriva do verbo latino portare (transportar) e do substantivo foglio (folha), designando a pasta que contém desenhos, fotos, textos, pautas de músicas e outras produções dos alunos. Na literatura, é também encontrada a denominação porta-fólio, segundo Villas Boas (2004).

Alves (2006) pontua as várias denominações de acordo com a sua finalidade e o espaço geográfico: porta-fólios, processo-fólio, dossiês e webfólios:

\begin{abstract}
a) Porta-fólio - como é chamado no Canadá, significa uma amostra do dossiê. É o recipiente ou pasta onde se guardam todos os materiais produzidos pelo estudante, cronologicamente.

b) Processo-fólio - visto como instrumento que reflete a crença de que os estudantes aprendem melhor e de uma forma mais integral, a partir de um compromisso com as atividades ocorridas durante um período de tempo significativo que se constrói sobre conexões naturais com os conhecimentos escolares.

c) Webfólios - com os avanços da tecnologia da informação e comunicação, os webfólios podem guardar toda a memória do período escolar desde a educação básica até a educação superior de um estudante, memória que servirá como processo de reconstrução de suas aprendizagens e como elemento de avaliação (ALVES, 2006, p. 104-105).
\end{abstract}

Convém ressaltarmos que, o portfólio era utilizado inicialmente apenas no campo das artes; o artista o utilizava como pasta, na qual guardava seus papéis, desenhos, fotografias e gravuras, sendo o conjunto dos seus trabalhos para apresentar a um cliente ou a grandes públicos, comprovando sua competência profissional.

A exposição de trabalhos de profissionais por meio do portfólio tem como objetivo possibilitar ao destinatário conhecer e contemplar os momentos mais significativos da sua trajetória profissional e, assim, ter uma visão sobre o todo (HERNÁNDEZ, 1998; ESPINOSA e SÁNCHEZ VERA, 2008; SÁNCHEZ, 2005; ALVES, 2006; SHORES \& GRACE, 2001).

No campo educacional, nas últimas décadas, tem sido marcante a presença do portfólio como também do webfólio como procedimentos avaliativos, por se acreditar na necessidade da mudança de concepções e de práticas no campo da avaliação das aprendizagens.

Associado a posturas que visam romper com a centralidade da avaliação pelo professor, com a transmissão e reprodução de conhecimento e a passividade intelectual, o portfólio conquistou espaço como um procedimento avaliativo mais autêntico, dinâmico e reflexivo:

[...] em educação o portfólio adquire outra dimensão, não se limita a mera compilação de trabalhos, sendo que inclui uma narrativa reflexiva que permite a compreensão do processo de ensino e de aprendizagem, segundo o caso, e pode facilitar a avaliação (ESPINOSA; SANCHEZ VERA, 2008, p.21). 
Por caracterizar-se como coletânea de trabalhos produzidos pelos estudantes, evidenciando as aprendizagens, o portfólio e o webfólio consideram as subjetividades e apresentam, ainda, a vantagem de proporcionar aos professores e estudantes uma visão holística da formação, buscando a integração de saberes e o exercício reflexivo, expondo "num primeiro momento, perante si próprio, e num segundo momento, perante aqueles com que colabora no seu processo de formação" (GRILO; MACHADO, 2005, p.35).

Desse modo, diante dos avanços da tecnologia da informação e comunicação, a versão eletrônica do portfólio possibilita um salto qualitativo nos seus formatos, pois podem contar com vídeos, áudios, gráficos, imagens fixas e móveis, entre outros recursos midiáticos. Por isso, segundo Alves (2003),

[...] os webfólios podem guardar toda a memória do período escolar desde a Educação Básica até a Educação Superior de um estudante, que servirá como processo de reconstrução de suas aprendizagens e como elemento de avaliação (ALVES, 2003, p.3).

Embora o webfólio possa ser construído e organizado em forma de blog (contração do termo inglês web $\log =$ diário da rede), este recurso pode não se constituir como um webfólio. Para ser considerado de fato um webfólio ou portfólio online o próprio estudante seleciona, analisa, reflete, organiza, apresenta as suas produções, tomando, assim, as decisões sobre o quê, como, quando e onde inserir ou postar as suas reflexões.

Não poderíamos deixar de mencionar que a construção de webfólios cria a possibilidade de espaços de aprendizagens diversos, pois ultrapassa o modelo escolar vigente, no qual todas as prescrições são dadas quase que exclusivamente em sala de aula e pelo professor. Nessa perspectiva, o estudante, ao criar o seu webfólio, organiza o seu desenvolvimento intelectual, reflete sobre o seu próprio aprendizado, faz uma revisão constante sobre o que já postou e envolve-se ativamente em suas aprendizagens.

Diante de tudo isso, a utilização do webfólio, como ferramenta que auxilia na avaliação e no processo de aprendizagens, se insere na perspectiva de desenvolvimento de uma avaliação formativa. Assim, o foco principal no desenvolvermos do trabalho pedagógico por meio do webfólio e a sua utilização na avaliação, significa buscarmos o desenvolvimento de práticas avaliativas que superem a visão classificatória, excludente e punitiva.

De acordo com Hadji (2001, p. 20), para ser considerada avaliação formativa é preciso que ela seja:

a) Informativa - a partir do momento que ela informa, ela é formativa, que seja instrumentalizada ou não, acidental ou deliberada, quantitativa ou qualitativa;

b) Informa os dois principais atores do processo: o professor e o aluno - o professor seja sempre informado dos efeitos reais do seu trabalho pedagógico e poderá regular a sua ação a partir disso; o aluno poderá tomar consciência das dificuldades que encontra e tornar-se-á capaz, na melhor das hipóteses, de reconhecer e corrigir ele próprio seus erros;

c) Reguladora voltada para o professor e para o aluno - ambos devem poder corrigir a sua ação, modificando, se necessário, seu dispositivo pedagógico, com o objetivo de obter melhores efeitos. A avaliação formativa implica por parte do professor, flexibilidades e vontade de adaptação, de ajuste. Uma avaliação que não é seguida por uma modificação das práticas do professor tem poucas chances de ser formativa! (HADJI, 2001, p.20-21). 
Para Villas Boas (2005), o portfólio possibilita avaliar as capacidades de refletir criticamente, de articular e solucionar problemas, proporcionando ao estudante rever e repensar as suas trajetórias de aprendizagens. Tanto o professor quanto o estudante avaliam todas as atividades realizadas, observando o progresso, o desempenho e os avanços obtidos.

Sendo assim, acreditamos que as características atribuídas ao portfólio podem ser agregadas ao webfólios.

Cano (2005) menciona a influência desse tipo de avaliação para a prática docente:

[...] com a finalidade formativa e de reflexão sobre a ação consideramos que podem contribuir a criar uma nova cultura docente, que na sua vez ajude a desenvolver processos de ensino mais reflexivos e mais consistentes com as exigências da nova sociedade do conhecimento. [...] Serve, então, para revistar periodicamente o programa, reestruturar os conteúdos e atividades, mas também para revistar as próprias metas profissionais (CANO, 2005, p.16).

As reflexões apresentadas até aqui convergem para uma concepção de webfólio como um procedimento que visa à construção de um trabalho coletivo, dialógico e emancipador, proporcionando o exercício do protagonismo de todos os envolvidos no processo. Os autores mencionados no decorrer deste eixo apresentam o webfólio como uma possibilidade de prática avaliativa formativa e contínua que propicia a autoavaliação mediante a reflexão crítica, tanto dos professores quanto dos estudantes.

Desse modo, investigar o trabalho com o webfólio permite ampliar os estudos sobre a temática e também construir junto com os estudantes, possibilidades de avaliação que proporcionem o desenvolvimento da sua capacidade de pensar e de tomar decisões quanto ao seu próprio processo de aprendizagens.

\section{0 que a pesquisa revelou}

A utilização do webfólio como possibilidade avaliativa trouxe resultados e informações importantes. Foi considerado pelos estudantes que participaram da pesquisa que os conteúdos trabalhados adquiriram maior significado, pois ultrapassaram os limites do estudar simplesmente para cumprir as exigências disciplinares. Além disso, possibilitou a realização de pesquisas e a busca pelo aprofundamento nos temas trabalhados, seja por meio de vídeos, imagens ou de outros recursos que foram utilizados no webfólio.

Nesse sentido, sobre o que apreenderam ao construir o webfólio, os estudantes relataram:

Consegui organizar melhor as minhas atividades, desenvolvi a escrita ainda mais, aprimorei o uso e contato com tecnologias, exercitei a minha criatividade (Suzana).

Aprendi a organizar os materiais que utilizamos para construção do nosso aprendizado. E assim fixei melhor a aprendizagem adquirida em pesquisar em outras fontes e outros materiais (Saulo).

Aprendi muito com a construção do meu webfólio. Desenvolvi a leitura, a pesquisa, a escrita, saber selecionar o que postar e também fazer a reflexão sobre aquilo que postei. Foi muito interessante, pois tinha muitas dúvidas para utilizar tecnologias e a internet. (Sandra). 
Podemos notar que a utilização do webfólio foi apreciada por diversos estudantes, pois se tornou uma ferramenta utilizada durante todo o semestre letivo como forma de avaliação contínua que contava com os devidos feedbacks do professor.

O acompanhamento da sua construção e durante as aulas era realizado continuamente e havia momentos para sanar dúvidas e para socializações. Porém, inicialmente alguns estudantes tiveram receio quanto ao trabalho com o webfólio, o que ficou evidenciando em depoimentos, como os transcritos a seguir:

\section{Achava que seria um trabalho bem difícil, pois já tinha ouvido falar, mas não tinha desenvolvido (Sônia). \\ Achava que não iria conseguir desenvolver o meu webfólio. Não tinha muito conhecimento sobre como seria. E também uma coisa nova. (Sérgio). \\ Em um primeiro momento senti um pouco de indisposição, mas logo depois fui tomando gosto pela coisa, foi surgindo a possibilidade de que eu organizasse da minha forma e exercitando a minha criatividade. Depois foi legal! (Sandro).}

O comportamento do estudante ao longo do semestre mudou muito no que se refere ao trabalho com o webfólio. No início observamos certa rejeição e notamos os estudantes temerosos quanto à nova estratégia e ao fato de estarem experimentando algo diferente para serem avaliados. Contudo, iniciaram o trabalho na disciplina lendo e estudando sobre o uso do webfólio e suas possibilidades de organização, o que possibilitou elencarem combinados e algumas fases para o trabalho.

Os estudantes tiveram acesso a aportes teóricos para a construção do webfólio, a partir das ideias de Barberà (2005), que sugere as seguintes etapas:

1. A coleta de evidências - nessa fase os estudantes coletam fotos, imagens, selecionam textos ou partes dos textos estudados, imagens, vídeos, e outros materiais que farão parte do webfólio.

2. A seleção das evidências - aqui o estudante escolhe, dentre os materiais já coletados aqueles que realmente irão fazer parte do webfólio. Começa-se ai a organizar, classificar, selecionar o que está aprendendo. O estudante também nessa fase terá a oportunidade de ver e rever se os conteúdos selecionados condizem com as suas aprendizagens.

3. A reflexão - nessa fase o estudante reflete sobre as evidências de suas aprendizagens que foram selecionadas. Pensa, reflete, identifica, analisa sobre o seu processo de aprendizagem revendo os pontos fortes e o que ainda precisa ser trabalhado para que venha a aprender. É uma oportunidade de criar mecanismos para melhorar o processo de aprendizagem.

4. A publicação - aqui o estudante já organizou e realiza a divulgação das suas evidências de aprendizagens sejam por meio de textos, vídeos, imagens, charges, e outros materiais desde que contenham as reflexões feitas acerca dos conteúdos aprendidos.

Não poderíamos deixar de mencionar que o trabalho com o webfólio teve como tema central a "avaliação da aprendizagem". Nesse sentido, todas as produções giraram em torno desse tema e que também se tratava da disciplina na quais todos estavam matriculados. Cada estudante podia organizar o seu webfólio de forma criativa e livre. Foram postadas atividades 
como: leituras realizadas, mapas conceituais construídos, sínteses desenvolvidas de textos, história da vida estudantil e as marcas da avaliação, imagens, charges, vídeos outros materiais.

A partir da leitura de Lunar (2007), acreditamos que o webfólio é uma possibilidade de avaliação que busca atrelar, à sua construção, características como:

- Formativa - possibilita modificação, ajustes, reflexões durante o processo e possíveis alterações com o objetivo de melhorar a aprendizagem;

- Contínua - implica uma constante construção, reconstrução, envolvimento e não apenas em momentos isolados ou fragmentados no processo avaliativo;

- Integral - abarca os vários elementos do processo de construção de conhecimentos não só relacionados ao cognitivo, mas apresenta outros como o social, afetivo, cultural, ideológico e outras dimensões;

- Individualizada - apresenta as características de cada sujeito, as suas crenças e visões de mundo, possibilitando conhecer o ritmo e os estilos de aprendizagem de cada estudante;

- Qualitativa - baseia-se em critérios de qualidade organizados pelos estudantes e em conformidade com o objetivo do portfólio e privilegia os resultados de forma heterogênea;

- Contextualizada - está inserido em um determinado contexto que apresenta consigo suas marcas e contradições, de acordo com a realidade do estudante ao construir o seu portfólio.

Desse modo, a partir do que foi coletado por meio dos depoimentos dos interlocutores, podemos sinalizar que o trabalho avaliativo por meio do webfólio apresenta:

a) Caráter inovador - pouco trabalhado e conhecido pelos participantes além de não possuírem a vivência e a experiência do trabalho com webfólio na prática avaliativa.

Não conhecia o webfólio. Foi tudo novidade para mim e também desafiadora (Suzana).

b) Capacidade de aprender a aprender - o estudante assumiu uma postura investigativa e protagonista do seu processo de aprendizagens.

Eu fiquei muito feliz ao construir o meu webfólio. Tive que pesquisar muitas coisas como imagens, vídeos e outros materiais para o webfólio ficar legal. Deu vontade de construir em outra disciplina como EJ A (Sandra).

c) A ideia de processo de aprendizagens - cada estudante ia construindo o seu webfólio, à medida que fazia os estudos da disciplina, por meio de textos, pesquisas e outros recursos. As várias aprendizagens iam surgindo sejam essas conceituais, procedimentais ou atitudinais.

Aprendi bastante ao construir o meu webfólio. E também me senti bastante útil quando vi que outras pessoas estavam acessando o meu webfólio. Ai foi que eu comecei a postar mais materiais sobre a avaliação da aprendizagem. Foi gratificante. (Sérgio).

d) Relação entre teoria e prática - os estudantes perceberam toda a relação entre a teoria estudada/refletida e puderam pôr em prática uma concepção de avaliação formativa e participativa por meio da construção do webfólio. 
Foi interessante, porque tudo que discutíamos na disciplina sobre avaliação íamos construindo e fazendo as devidas relações, como por exemplo, os feedback, vivenciar a avaliação formativa. (Sônia).

e) Capacidade de utilizar os recursos das tecnologias da informação e comunicação outro ponto a destacar foi o maior contato com os recursos tecnológicos para a construção do webfólios.

Tive que ir pesquisar na internet. Tive que procurar vários materiais para postar no meu webfólio, ver se ia ser construído como se fosse um blog desde que tivesse relação com a avaliação da aprendizagem. Claro que tudo que eu coloquei foi feita uma reflexão sobre o porquê de postar no webfólio. (Sandro).

Segundo Araújo (2011):

Com o desenvolvimento das tecnologias informacionais e comunicacionais, os portfólios digitais ou eletrônicos ganham espaço em relação aos portfólios organizados em pastas, caixas ou outros aparatos físicos Eles podem estar agregados a um ambiente virtual de aprendizagem ou serem construídos em espaços virtuais gratuitos como blogs e wikis. (ARAUJ O, 2011, p. 176).

f) Exercício do processo de autoria - cada estudante experimentou com autonomia ser protagonista da construção do seu webfólio, vivenciando processos de criatividade, reflexão, autoavaliação e parcerias.

Foi interessante construir o webfólio, pois senti-me valorizada por que outras pessoas iam ver as minhas produções. Tive algumas dificuldades iniciais, mas valeu a pena, pois consegui aprender como organizar o meu webfólio do jeito que eu queria. Claro que dentro do tema que foi a avaliação. (Sara).

Assim, diante de tudo que foi discutido podemos expor uma síntese da pesquisa realizada com o webfólio como possibilidade avaliativa.

a) Aspectos considerados positivos pelos estudantes:

- Aprofundamento dos temas sobre avaliação.

- $\quad$ Oportunidade para construir e reconstruir o webfólio.

- $\quad$ Aprenderam a extrair informações importantes dos textos estudados.

- Utilização de diversas ferramentas tecnológicas.

- $\quad$ Estudo realizado durante todo o semestre sobre o tema da avaliação;

- Integração entre teoria e prática.

- $\quad$ Sistematização das produções feitas na disciplina.

- Aprenderam a relacionar o conteúdo da disciplina com outros temas e a avaliação.

- $\quad$ Acompanhamento de qualquer lugar que se tenha acesso à internet.

b) Aspectos considerados negativos pelos estudantes:

- $\quad$ Falta de costume no exercício da escrita e da reflexão.

- Dúvida sobre o que postar e colocar no webfólio, devido à indecisão.

- A falta de acesso à internet para manter o webfólio atualizado.

- Dúvidas sobre a organização do webfólio. 
- A falta de tempo, pois tínhamos outras disciplinas.

- $\quad$ Ansiedade inicial, diante da novidade do webfólio.

- $\quad$ Pouca vivência com alguns recursos tecnológicos.

- Pouca vivência com processos criativos, fora de "padrões e modelos fixos".

C) Sugestões realizadas pelos estudantes:

- Mais leituras e exposição de outros webfólios.

- Ter maior tempo para socializações durante o processo, porque duas foram poucas.

- Criar subtemas dentro do tema central da avaliação.

- Indicaram que o webfólio pode ser mantido como outra possibilidade de avaliação.

- Criar uma página para colocar todos os webfólios juntos.

Podemos mencionar, ainda, que o trabalho com o webfólio como prática avaliativa foi permeada de sentidos, significados e desafios, tanto para o professor como também para os estudantes. A utilização do webfólio permitiu avaliar de forma compartilhada, participativa e dialógica com todos os envolvidos nos processos de ensino e de aprendizagens.

De acordo com Moreira e Ferreira (2011) a sua utilização:

[...] facilita a avaliação colaborativa ou partilhada, bem como o estabelecimento dos objetivos pessoais, definidos que individualmente que por acordo colaborativo. O portfólio reflexivo é compreendido como instrumento facilitador dos processos de auto e heteroavaliação [...] (MOREIRA; FERREIRA, 2011, p. 65-66).

Assim, compreendemos o quanto o webfólio reflete não apenas nas produções relativas à dimensão cognitiva, no seu sentido restrito, mas também nos aspectos do fazer, do ser e do conviver que perpassam a produção intelectual do sujeito. A proposta do seu uso como procedimento avaliativo chama a atenção por configurar-se, tanto para os estudantes como para os professores, como um novo formato de prática avaliativa, ao qual as atuações docentes e discentes e a organização do trabalho adquirem novas dimensões, com vistas à formação integral dos estudantes, à reflexão e à constante formulação de indagações.

\section{Considerações finais}

Diante das evidências expostas e discutidas neste texto, no que diz respeito ao trabalho com o webfólio ou portfólio online em práticas avaliativas, podemos ratificar a necessidade do rompimento com uma avaliação que exclui e classifica e que não está a serviço das aprendizagens.

Não poderíamos deixar de mencionar que, à luz do diálogo tecido com os teóricos apresentados no decorrer deste trabalho, foi possível percebermos o quanto já avançamos em relação a outras posturas avaliativas e também quanto à utilização das tecnologias da informação e comunicação. Porém, restam-nos ainda alguns desafios, como os já mencionados, 
e outros relativos à construção de práticas avaliativas de fato formativas, participativas, dialógicas e que estejam verdadeiramente a serviço das aprendizagens.

Vale ressaltar que a nossa experiência e a pesquisa desenvolvida possibilitaram-nos algumas reflexões que foram tecidas ao longo deste texto. Esperamos que elas possam provocar outros debates e outras produções, com vistas à construção de conhecimentos para o campo da avaliação das aprendizagens.

As mudanças na organização do trabalho pedagógico e no processo avaliativo não ocorrem de um momento para o outro. É preciso ressignificar crenças e concepções por meio de uma formação teórica e metodologicamente comprometida com a transformação e com a inclusão de todos na sociedade. É necessário, ainda, abertura e disposição para o novo, para a mudança, ousando buscar formas de trabalho que respeitem a singularidade de cada sujeito, bem como o seu ritmo e seu percurso de aprendizagens.

\section{Referências}

ALVES, Leonir Pessate. Portfólios como instrumentos de avaliação dos processos de ensinagem. In: ANASTASIOU, Léa das Graças Camargos e ALVES, Leonir Pessate (Orgs.). Processos de ensinagem na universidade: pressupostos para as estratégias de trabalho em aula. 6.ed. Joinville, SC: UNIVILLE, 2006, p. 101-120.

ALVES, Leonir Pessate. Portfólios como instrumentos de avaliação dos processos de ensinagem. 26a Reunião Anual da ANPED, Poços de Caldas- MG, 5 a 8 de outubro de 2003, p. 1-14.

ARAÚJ O, Ivanildo Amaro de. O Portfólio eletrônico na formação de professores: caleidoscópio de múltiplas vivências, práticas e possibilidades da avaliação formativa. In: VILLAS BOAS, Benigna Maria de Freitas (Org.). Avaliação formativa: práticas inovadoras. Campinas, SP: Papirus, 2001, p. 167-192.

BARBERÀ, Elena, La evaluación de competencias complejas: la práctica del portafolio. Educere, vol 9, núm.31, octubre-diciembre, 2005, p. 497-504.

CANO, Elena. EI portafolios del profesorado universitario: un instrumento para la evaluación y para el desarrollo profesional. Barcelona, España; Ediciones octaedro, S.L., 2005.

ESPINOSA, María Paz Prendes e SÁNCHEZ VERA, María Del Mar. Portafolio eletrônico: posibilidad para los docentes. Pixel-Bit. Revista de Medios y Educación. n.32. Marzo, 2008, p. 21-34.

GONZÁLEZ REY, Fernando L. O Sujeito que aprende; desafios do desenvolvimento do tema da aprendizagem na psicologia e na prática pedagógica. In: TACCA, Maria Carmen V. R.(org.). Aprendizagem e trabalho pedagógico. Campinas, SP: Alínea, 2006.p. 29-44.

GONZÁLEZ REY, Fernando L. O Valor heurístico da subjetividade na investigação psicológica. In: GONZÁLEZ REY, Fernando L. (Org.). Subjetividade, complexidade e pesquisa em Psicologia. São Paulo: Thomson, 2005, p.27-51.

GRILO, João Maria e MACHADO, Constança Gomes. "Portfolios" reflexivos na formação inicial de professores de Biologia e Geologia: viagens na terra do eu. In: SÁ-CHAVES, I dália (org.). Os portfólios reflexivos (também) trazem gente dentro: reflexões em torno do seu uso na humanização dos processos educativos. Portugal: Porto Editora, 2005, p. 22-49.

HADJI, Charles. Avaliação desmistificada. Trad. Patrícia C. Ramos. Porto Alegre: Artmed, 2001.

HERNÁNDEZ, Fernando. Transgressão e mudança na educação: os projetos de trabalho. Trad. Jussara Haubert Rodrigues. Porto Alegre: Artmed, 1998.

HOFFMANN, Jussara. O J ogo do contrário em avaliação. 2. ed.Porto Alegre: Mediação, 2006.

LIBÂNEO, José Carlos. As teorias pedagógicas modernas revisitadas pelo debate contemporâneo na Educação. In: LIBÂNEO, José Carlos e SANTOS, Akiko(Orgs.). Educação na era do conhecimento em rede e transdisciplinaridade. Campinas, SP: Alínea, 2005. p.19-62. 
LUCKESI, Cipriano Carlos. Avaliação da aprendizagem escolar. São Paulo: Cortez, 2002.

LUNAR, Lisette. EI Portafolio: estrategia para evaluar la producción escrita en inglés por parte de estudiantes universitarios. Núcleo 24. 2007, p 63-96.

MARTíNEZ, Albertina Mitjáns. El profesor como sujeto: elemento esencial de la formación de professores para la educación inclusiva. Revista Movimento. n.7, maio, 2003. p.137-149.

MITJÁNS MARTíNEZ, Albertina. A Teoria da subjetividade de González Rey: uma expressão do paradigma da complexidade na Psicologia. In: GONZÁLEZ REY, Fernando L.(Org.). Subjetividade, complexidade e pesquisa em Psicologia. São Paulo: Thomson, 2005, p.01-25.

MOREIRA, Jacinta Rosa; FERREIRA, Maria José. Webfólio reflexivos: contributos para o desenvolvimiento profissional do profesor. Educação, Formação \& Tecnologias. 4, (2), 2011, 61-75.

NUNES, Alexandra e MOREIRA, António. O "Portfolio" na aula de Língua Estrangeira: uma forma de aprender a aprender e a ser (para alunos e professores). In: SÁ-CHAVES, Idália (org.). Os portfólios reflexivos (também) trazem gente dentro: reflexões em torno do seu uso na humanização dos processos educativos. Portugal: Porto Editora, 2005, p. 52-66.

ROMANOWSKI, Joana Paulin. Aprender: uma ação interativa. In: VEIGA, IIma Passos Alencastro (org.). Lições de didática. Campinas, SP: Papirus, 2006, p.101-122.

SÁNCHEZ, Raquel Barragán. El portafolio, metodología de evaluación y aprendizaje de cara al nuevo espacio Europeo de Educación Superior. Una experiencia práctica en la Universidad de Sevilla. Revista Latinoamericana de Tecnología Educativa. Volumen 4, número 1, 2005, p. 121-139.

SHORES, Elizabeth \& GRACE, Cathy. Manual de portfólio: um guia passo a passo para o professor. Trad. Ronaldo Cataldo Costa. Porto Alegre: Artmed, 2001.

VILLAS BOAS, Benigna Maria de Freitas. O Portfólio no curso de Pedagogia: ampliando o diálogo entre professor e aluno. Educação e Sociedade. vol. 26, n.90, jan/abr, Campinas - SP, 2005, p. 291- 306.

VILLAS BOAS, Benigna Maria de Freitas. Portfólio, avaliação e trabalho pedagógico. Campinas, SP: Papirus, 2004. 

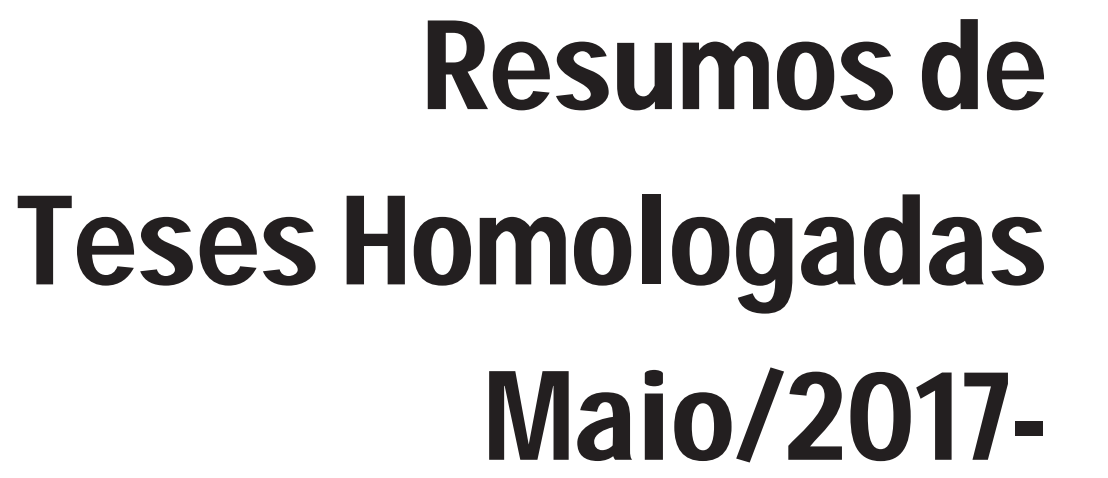

4 * $\Delta \nabla=x$ 


\section{MANUEL CONSTANTI NO ZUNGUZE}

Orientador: Prof. Dr. J osé Valdeni de Lima

Coorientador: Prof. Dr. Sérgio Roberto Kieling Franco

Data: 19/06/2017

Local: Sala 329 - Auditório do PPGIE/CINTED

TESE: ADAPTATIVA EM APRESENTAÇÕES PARALELEAS MULTIMÍDIA: TRAJETÓRIAS DE APRENDIZAGEM TEMPORAIS

Resumo: Será que os estudantes de hoje têm habilidades para alternar o foco, dividindo seu tempo de estudo entre duas ou mais "fontes didáticas" às quais são expostos? Nesta tese se entende por "fonte didática" toda fonte de comunicação que pode passar informações através de pessoas ou máquinas, com intuito de ensinar um conceito. Assim, pesquisou-se através de experimentos em que os estudantes eram expostos às diferentes "fontes didáticas", sendo medidos seus desempenhos por meio de testes como forma de entender suas capacidades de aprendizagem. As TICs têm possibilitado o acesso em simultâneo a várias "fontes didáticas" por um mesmo estudante ao mesmo tempo. Embora este acesso possa ocasionar um excesso de estímulos aos aprendizes, é preciso, então, pesquisar as consequências no processo de aprendizagem: um discente que está assistindo, por exemplo, a uma aula de um bom professor e, ao mesmo tempo, através de seu celular, consulta outras fontes didáticas disponíveis, ou simplesmente decide assistir dois objetos de aprendizagem ao mesmo tempo, sendo um interativo e outro visual, ou um visual e auditivo. Esta forma de estudo é, todavia, benéfica para seu processo de aprendizagem? É justamente na busca de respostas a estas perguntas que a presente tese de doutorado investigou a forma de navegação de estudantes quando expostos a duas apresentações paralelas multimídias e multimodais, considerando o conceito de trajetórias de aprendizagem em função dos tempos de estudo envolvidos. Este estudo tem como base teórica o construtivismo e o interacionismo de Piaget, neste contexto de exploração paralela ou alternada de vários objetos de aprendizagem. A pesquisa teve natureza explicativa, abordagem quantitativa e modalidade quase-experimental. Foi desenvolvido um sistema capaz de apresentar, ao mesmo tempo, dois objetos de aprendizagem para um mesmo estudante, e de monitorar a navegação desse aprendiz. $O$ sistema desenvolvido no âmbito dessa tese foi denominado Apresentações Adaptativas Multimídias e Multimodais (AAMM), e foi implementado em HTML, PHP, AJAX e JavaScript. Nessa pesquisa foi avaliado o desempenho dos estudantes através de dois testes diferentes (pré-teste e pós-teste), mas com os mesmos níveis de dificuldade (um antes e outro após a exploração dos objetos de aprendizagem interativos e não interativos). Após o desenvolvimento do sistema AAMM e a realização do estudo piloto apresentado na proposta da tese, foram realizados dois experimentos com o objetivo de investigar a forma de navegação dos estudantes face a duas ou mais apresentações paralelas multimídia, considerando os estilos de aprendizagem preferenciais. Foram realizados testes estatísticos de Wilcoxon e Kruskal-Wallis, e os resultados das análises mostraram evidências para afirmar que em apresentações multimídia compostas por objetos de aprendizagem interativos e não interativos (videoaulas) recomenda-se que o estudante interaja, primeiro, com o objeto de aprendizagem interativo, seguido da videoaula, como forma complementar que aborde o mesmo conceito do objeto interativo.

Palavras-chave: aprendizagem adaptativa; estilos de aprendizagem; trajetórias de aprendizagem; formas de navegação. 


\section{FABI ANA SANTI AGO SGOBBI}

Orientadora: Profa. Drạ. Liane Margarida Rockenbach Tarouco

Coorientador: Prof. Dr. Eliseo Berni Reategui

Data: $14 / 06 / 2017$

Local: Sala 329 - Auditório do PPGIE/CINTED

TESE: EXPLORANDO AUTODETERMINAÇÃO, UTILIZANDO NOVAS TECNOLOGIAS PARA ENSEJ AR AUTOCUIDADO EM OBESOS

Resumo: A obesidade, atualmente, é um dos problemas mais importantes de Saúde Pública no Brasil e em outros países do mundo. A Organização Mundial de Saúde (OMS) considera que, atualmente ela seja o principal problema de saúde. O sucesso do tratamento das doenças crônicas, como é o caso da obesidade, depende, fortemente, da participação e do envolvimento do indivíduo, enquanto sujeito ativo de seu tratamento. $O$ apoio por meio de ações educacionais, mediante evidências clínicas e/ou sensoriais, levou um maior comprometimento do indivíduo. Com o mesmo intuito, a Teoria da Autodeterminação vem embasar esta Tese. Existem seis tipos de motivação, os quais variam, qualitativamente, conforme a internalização das regulações externas para o comportamento, chamada de "contínuo de autodeterminação". A tendência crescente da obesidade exige programas para perda de peso inovadores, com grande nível de personificação e interatividade. Embora os programas comportamentais com base no face a face provaram ser os mais eficazes, são caros, muitas vezes inacessíveis. O uso de metaverso (um tipo de mundo virtual) tem surgido como alternativa para realização de vários tipos de experiências, porque oferece ao usuário a sensação de realidade, permitindo, inclusive, a interação com objetos 3D. O Sistema de validação desta Tese agregou à tal ferramenta a sensação de interação humana, apoio social e engajamento com a utilização de agente conversacionais e pedômetro. Dessa forma adicionou a possibilidade de trabalhar tecnologias da Web, de metaverso e utilização de sensores que interagiram a fim de promover motivações, apoiando, diretamente, o envolvimento e aprendizagem, como subsídio de mudança de comportamento e ganhos em qualidade de vida, durante a pesquisa. Conclui-se que novas tecnologias de metaverso e agentes conversacionais, associados a um pedômetro, podem ensejar a motivação de sujeitos obesos para o autocuidado e a perda de peso vislumbra-se uma nova e provocante maneira de ofertar motivação para mudança de comportamento.

Palavras-chave: metaverso, obesidade, autodeterminação. 


\section{ROSANA WAGNER}

Orientador: Prof. Dr. J osé Valdeni de Lima

Coorientadora: Profa. Drạ. Liliana Maria Passerino

Data: 05/05/2016

Local: Sala 329 - Auditório do PPGIE/CINTED

TESE: MOOCS DE TECNOLOGIA ASSISTIVA NA FORMAÇÃO DE PROFESSORES PARA EDUCAÇÃO PROFISSIONAL

Resumo: As habilidades e os conhecimentos necessários para a prática docente geram mudanças em todo o processo educacional. Incluir indivíduos na sociedade, possibilitando que estes tenham uma profissão e uma vida digna é um processo de colaboração que perpassa o meio educacional. Os programas de ensino profissionalizante têm como objetivo aumentar as oportunidades educacionais aos trabalhadores por meio de cursos de formação inicial e continuada ou qualificação profissional e aumentar a quantidade de recursos pedagógicos para apoiar a oferta de educação profissional e tecnológica. Com base nisso,esta tese tem como problema de pesquisa: Investigar como estruturar um Massive Open Online Course (MOOC) de Tecnologia Assistiva que apoie o processo de formação de professores do Ensino Profissionalizante que atuam na preparação para a inclusão no mercado de trabalho. A pesquisa está enquadrada como pesquisa qualitativa, utiliza o método estudo de caso, combinado com o desenvolvimento de um ambiente tecnológico, utilizando como base o conceito de MOOC. Uma ampla pesquisa bibliográfica foi desenvolvida tornando capaz a realização de um estudo exploratório e descritivo, que permitiu, confrontar os dados empíricos obtidos com as teorias previamente estudadas. O estudo de caso se estrutura a partir do desenvolvimento de um curso de formação de professores, o MOOC Solassist Learning. Os resultados obtidos através da realização do estudo exploratório e do estudo final possibilitaram a criação de um processo de desenvolvimento dos MOOCs. Através dos dados coletados nos questionário realizados durante o curso, foi possível obter informações sobre o perfil dos participantes e de suas ações em sala de aula, informações essas que foram confrontadas com as teorias apresentadas nos capítulos iniciais da tese.

Palavras-Chave: Formação de Professores, MOOCs, Ensino Profissionalizante, Pessoas com deficiência, Tecnologia Assistiva, Educação a Distância. 


\section{MARI BEL SUSANE SELLI}

Orientadora: Profa. Drạ. Margarete Axt

Coorientador: Prof. Dr. Daniel Nehme Muller

Data: 27/03/2017

Local: Sala 329 - Auditório do PPGIE/CINTED

TESE: REVERBERAÇÕES DE UMA METODOLOGIA DIALÓGICA EM EXPERIMENTAÇÕES COM TECONOLOGIAS DIGITAIS DE UMA ESCOLA DE EDUCAÇÃO DO CAMPO

Resumo: Esta tese tem o propósito de compartilhar algumas experimentações com tecnologias digitais, orientadas por uma metodologia dialógica, referenciada no dialogismo bakhtiniano, a partir do Projeto Civitas, vinculado ao Laboratório de Estudos em Linguagem Interação Cognição-Criação ? LELIC - da Universidade Federal do Rio Grande do Sul. O contexto da pesquisa envolve os acontecimentos vivenciados por uma turma de terceiro ano do segundo ciclo, de uma Escola Estadual de Ensino Fundamental, situada na zona rural de um município do Rio Grande do Sul, na Região do Vale do Rio Pardo. O problema que produziu os trajetos que percorremos ao desenvolver esta tese teve origem em nossa intenção de analisar os efeitos que uma metodologia dialógica poderia produzir no processo de (re)significar o ensinar e aprender, aliado ao uso das tecnologias digitais e o Città, no contexto de uma escola de educação do campo. Buscamos no filósofo da linguagem, Mikhail Bakhtin, os entrelaçamentos possíveis, entre a teoria e o campo empírico, tanto nos diálogos realizados entre os protagonistas desta tese ? a pesquisadora, a professora e as crianças ? em nossas inserções no contexto investigado, quanto na organização da metodologia de pesquisa e formação de professores, seguindo os princípios do Civitas, pela implicação do pesquisador, numa perspectiva ético-estética e responsiva. Como desdobramentos destas experimentações podemos afirmar que, a partir de uma metodologia, que abre espaços, pela problematização do cotidiano, para a invenção e criação na sala de aula e na escola - promovendo o protagonismo de seus diferentes atores e produzindo relações dialógicas, sentidos e autoria, pela escuta e in(ter)venção -é possível (re)significarmos os processos de ensinar e aprender, no uso das tecnologias digitais, verificando seus efeitos nos contextos micro e macro da educação.

Palavras-chave: tecnologias digitais, Città, escolas do campo, metodologia dialógica, Projeto Civitas. 


\section{ANTONIO J OSÉ DA SILVA}

Orientador: Prof. Dr. Fernando Becker

Data: 30/03/2017

Local: Sala 329 - Auditório do PPGIE/CINTED

TESE: NOÇÃO DE LIMITE DE FUNÇÕES REIAS E GEOGEBRA: UM ESTUDO EM EPISTEMOLOGIA GENÉTICA

Resumo: Esta pesquisa reporta-se ao problema descrito na literatura científica como o "fracasso do ensino do cálculo". Propusemos conhecer as noções que alunos da disciplina Cálculo Diferencial e Integral apresentam sobre limite, e também como a qualidade dessa noção ou conceito afeta a elaboração de noções sobre derivadas e integrais. Para obter essas noções, objetos de aprendizagem foram criados e disponibilizados online, em páginas de um site com domínio privado, mas de acesso aberto. Cada objeto de aprendizagem foi elaborado contendo uma situação-problema referente aos applets de cada página e um espaço de registro de respostas. Os applets abordam situações que permitem o estudo de limites, derivadas e integrais; foram elaborados no Geogebra. Os espaços de registro de respostas foram elaborados com tecnologia Google e incorporados à página do site. A metodologia consistiu na aplicação de atividades na disciplina Cálculo Diferencial e Integral. Nelas interagiram alunos e OA. As aplicações foram realizadas nas três unidades da disciplina. Para a complementação e investigação, foram feitas entrevistas inspiradas no método clínico piagetiano. Tanto os registros de respostas, quanto as entrevistas, foram autorizadas com a assinatura do termo de consentimento livre e esclarecido. Fundamenta-se a análise das respostas na Epistemologia Genética; em especial, na abstração reflexionante. A escolha deu-se devido ao caráter explicativo dessa teoria da gênese do conhecimento matemático. Os resultados demonstram que conhecimentos foram construídos em situação de interação entre alunos e OA. Várias noções foram registradas. Constatou-se, inclusive, conceituação de limite, de derivada e integral definida. Foi possível, a partir dos conhecimentos e noções apresentadas, estabelecer relações lógicas entre esses conhecimentos e, posteriormente, observar grupos com desenvolvimento cognitivo compatíveis com as relações lógicas apresentadas. O OA, com tecnologia Geogebra e Google, mostrou-se como um importante instrumento nos processos de desenvolvimento e aprendizagem do conceito de limite e dos demais conceitos da disciplina Cálculo Diferencial e Integral. Mostrou-se também como um importante instrumento para a avaliação no ambiente escolar a partir dos registros coletados.

Palavras-chave: Noção de limite. Objetos de aprendizagem. Abstração reflexionante. Geogebra. 


\section{ROBERTO FRANCISCATTO}

Orientadora: Profa. Dra Liliana Maria Passerino

Coorientador: Prof. Dr. Sidnei Renato Silveira

Data: 30/03/2017

Local: Sala 329 - Auditório do PPGIE/CINTED

TESE: SOLASSIST: BIBLIOTECA VIRTUAL DE SOLUÇÕES ASSISTIVAS ACESSÍVEL E RESPONSIVA NA PROMOÇÃO DA INCLUSÃO SOCIAL DE PESSOAS COM DEFICIÊNCIA

Resumo: O processo de inclusão de pessoas com deficiência no mercado de trabalho, tem se tornado um tema bastante pertinente e difundido atualmente, muito pelas políticas de inclusão implantadas no país, bem como, demais ações neste contexto, que tem propiciado melhorar as condições das pessoas com deficiência, de forma gradativa. Neste cenário, as tecnologias da informação e comunicação, representadas neste trabalho através de uma biblioteca virtual de soluções assistivas, surgem como elementos da educação e constituem papel fundamental no processo de mediação da ação humana, considerando uma perspectiva sócio-histórica. Partindo dessa premissa, o objetivo deste trabalho é analisar de que forma podemos organizar as soluções assistivas oriundas de diferentes fontes, para que as mesmas possam ser utilizadas no processo de inclusão de pessoas com deficiência no mercado de trabalho técnico/profissional. A partir de então, percebeu-se à necessidade de propor o desenvolvimento de um sistema web (biblioteca virtual) que pudesse gerenciar soluções assistivas de forma organizada e que estas contribuíssem com práticas que deram certo no ambiente do mercado de trabalho para pessoas com algum tipo de deficiência. Entende-se que o compartilhamento de práticas e ações desenvolvidas permitirá inúmeros benefícios para instituições, empresas e pessoas que buscam por tais informações, sendo estas estruturadas de maneira organizada, centralizada e de livre acesso. Assim, foi projetada e desenvolvida uma biblioteca virtual de soluções assistivas, que provê entre outros, recursos de usabilidade, acessibilidade e responsividade, seguindo os principais padrões web presentes no processo de desenvolvimento e validação da mesma. Quanto a metodologia presente neste trabalho a mesma contempla um estudo qualiquantitativo sendo o uso de "estudos de casos" seu método principal. A pesquisa foi complementada com uma abordagem tecnológica devido ao desenvolvimento da biblioteca virtual de soluções assistivas em questão. Quanto aos sujeitos presentes neste trabalho de pesquisa, foram convidados a participar, baseado em três contextos principais, foco desta investigação: o contexto educacional (formado por pessoas com função/cargo de gestão educacional, como por exemplo: coordenadores de curso, direção, chefia, núcleos de acessibilidade, entre outros); o contexto laboral (formado por profissionais que atuam no mercado de trabalho e exercem atividade de gestão/ contratação de pessoas, como por exemplo: administradores de empresas, analistas de recursos humanos, entre outros); e por fim pessoas com necessidades especiais, para que estas pudessem colaborar e fornecer a sua contribuição frente ao protótipo exposto. Como resultados deste trabalho, estão o processo de 
desenvolvimento tecnológico empregado na construção de uma biblioteca virtual e seus recursos acessíveis; as validações de usabilidade, acessibilidade e responsividade presentes nesta pesquisa; e a análise do perfil dos sujeitos, suas contribuições e perspectivas frente a utilização de uma ferramenta tecnológica de gerenciamento de soluções assistivas em seu diaa-dia.

Palavras-chave: Biblioteca Virtual. Soluções Assistivas. Teoria sócio-histórica. SolAssist. Acessibilidade.

\section{CRI STI NA MARI A PESCADOR}

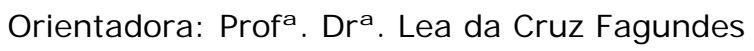

Data: $13 / 12 / 2016$

Local: Sala 329 - Auditório do PPGIE/CINTED

TESE: EDUCAÇÃO E TECNOLOGIAS DIGITAIS: CARTOGRAFIA DO LETRAMENTO DIGITAL EM UMA ESCOLA DO CAMPO

Resumo: Este trabalho tem como proposta cartografar o processo de inclusão digital em uma escola de classe multisseriada, situada em área rural no interior do estado do Rio Grande do Sul, contemplada pelo Programa Nacional de Educação no Campo (Pronacampo) em 2013. Busca-se responder a pergunta ?Que mudanças são observadas em uma escola do campo e na comunidade que a cerca com relação ao processo de letramento e possível emancipação digital de seus atores (professores, estudantes e familiares) a partir da introdução de laptops na modalidade 1:1??. O estudo visa a observar, acompanhar e cartografar os movimentos provocados e verificar se há mudanças indicando ações de letramento digital nessa escola. Tendo em vista a proposta de acompanhar um processo em andamento, optou-se pela cartografia (DELEUZE e GUATTARI) como inspiração para o método de investigação, pois ele permite produzir e construir os dados da pesquisa enquanto se realizam as observações das práticas em sala de aula, as entrevistas com os estudantes e professores, e os registros no diário de bordo da pesquisadora. Nessa caminhada, enquanto cartografa, registra suas observações e percepções com relação aos sujeitos-atores da pesquisa, a pesquisadora se transforma também em um dos atores do processo. A cartografia dos movimentos provocados pela inserção dos laptops na rotina da escola e a possibilidade de delinear algumas mudanças na rotina e nas práticas escolares fornece subsídios para analisar se essas mudanças apontam para situações de letramento e emancipação digital que ultrapassem os limites da sala de aula e da escola. Essa análise é feita à luz dos conceitos de autonomia, interação e solidariedade (PIAGET e FREIRE), cooperação e respeito mútuo (PIAGET), emancipação (FREIRE e DEMO), cultura digital (LÉVY e LEMOS), letramento digital (SOARES, COSCARELLI e RIBEIRO) e emancipação digital (SCHWARTZ e SCHLEMMER). A produção e análise dos dados é guiada por quatro pistas (PASSOS, KASTRUP e ESCÓCIA): atenção flutuante, cartografar é acompanhar 
processos, entrevistas cartográficas e registros em um diário de campo. Os dados levam a crer que, embora a inclusão digital seja um dos objetivos do Pronacampo, os movimentos identificados no estudo e que efetivamente indicam inclusão e letramento digitais são, de fato, provocados pelo comprometimento e envolvimento da comunidade escolar em buscar soluções para problemas de conectividade e manutenção dos equipamentos. Entre esses indicadores, encontra-se a busca pelo acesso à internet nas residências de alguns estudantes como alternativa à dificuldade de captação de sinal por causa da localização da escola. Também é possível identificar movimentos em direção ao letramento digital cultivado pela postura das professoras em provocar situações para que as crianças explorem recursos e possibilidades de uso dos laptops. Mesmo sem haver conexão à internet na escola, ações espontâneas com algumas crianças se tornando provedores de conteúdos digitais são acolhidas e valorizadas, em um movimento que permite que exercitem seu protagonismo na busca de soluções e alternativas para os problemas encontrados. Com a recente contratação do serviço de banda larga é possível pensar que novos movimentos de letramento e, quiçá, de emancipação digital venham a acontecer no futuro.

Palavras-chave: Autonomia. Cooperação. Cartografia. Escola do Campo. Inclusão Digital. Letramento Digital. Pronacampo.

\section{FRANCISCA KEYLE DE FREITAS VALE MONTEI RO}

Orientador: Prof. Dr. Dante Augusto Couto Barone

Coorientadora: Profá. Drạ. Magda Bercht

Data: 12/12/2016

Local: Sala 329 - Auditório do PPGIE/CINTED

TESE: FORMAÇÃO DE PROFESSORES EM SISTEMA DE COMUNICAÇÃO ALTERNATIVA PARA PESSOAS COM TEA: UMA INSERÇÃO DAS TECNOLOGIAS ASSISTIVAS EM CONTEXTOS ESCOLARES MARANHENSES

Resumo: Esta tese discute a nova classificação do Transtorno do Espectro Autista (TEA), segundo Grananã, (2014), a partir da atualização do DSM - V, (Diagnostic and Statistic Manual of Mental Disorders, Fifth Edition - Manual Estatístico e Diagnóstico de Transtornos Mentais quinta edição). Resgatou-se historicamente a Formação de Professores e a Comunicação Altenativa, articuladas com as tecnologias assistivas no âmbito das Políticas Públicas da Educação. Tem como principais objetivos: propor e investigar uma formação de professores com recursos tecnológicos em Comunicação Alternativa, para auxiliar o professor em sua práxis docente nas salas de recursos multifuncionais - SRM de alunos com TEA na rede municipal de ensino de São Luís - Maranhão. A pesquisa realizou-se sob a perspectiva sóciohistórica com observações, visitas em 05 (cinco) escolas e entrevistas com docentes-partícipes, aplicação de questionários, (antes, durante e depois) da formação presencial "Tech Educ 
Especial", implementada em 03 (três) experimentos formativos, (presencial, móvel itinerante, e de consulta). A metodologia desenvolvida enquanto estudo de caso, foi a DCC, Desenvolvimento Centrado nos Contextos de uso do software e suas correlações, e base teórica em: NOVOA, (1992, 1995); VYGOTSKY,(1998); PIMENTA, BOSA, (2002) YIN, R. K. (2003), TARDIF, (2005, 2006); VEIGA (2006), BEZ, BONOTTO, (2014) SANTOS et. all (2016) e adaptações realizadas conforme o encontrado nos contextos escolares maranhenses e a partir da questão de pesquisa: De que maneira uma formação de professores com a utilização do Sistema de Comunicação Alternativa contribui para a práxis docente nas salas de recursos multifuncionais dos alunos com TEA - Transtorno do Espectro Autista - trinta (30) professores que responderam os questionários aplicados, dos quais 03 (três) deles tornaram-se multcasos, pois fazem AEE com práticas de comunicação alternativa. Constatou-se modificações positivas na postura docente, no planejamento de atividades pedagógicas, enfim, na ação pedagógica, bem como no interesse de estudos afins, e na história sociocultural do contexto em que o professor de AEE está inserido, além de sua própria história enquanto professor, (perfil encontrado).

Palavras-Chave: Formação de Professores, Comunicação Alternativa, TEA, T.A.

\section{WALBER LI NS PONTES}

Orientadora: Profa a Drạ . Patricia Alejandra Behar

Coorientadora: Profa . Drạ. Magda Bercht

Data: 06/09/2016

Local: Sala 329 - Auditório do PPGIE/CINTED

TESE: REQUALI: UM SISTEMA DE RECOMENDAÇÃO POR QUALIDADE PERCEBIDA DE OBJETOS DE APRENDIZAGEM POR COMPETÊNCIAS A PARTIR DOS ESTADOS DE ÂNIMO DOS ALUNOS

Resumo: A presente pesquisa visou desenvolver e validar um sistema de recomendação por qualidade percebida de objetos de aprendizagem (OAs) por competência, que considera o estado de ânimo do aluno denominado Requali. Este agregou os estados de ânimo dos usuários e a avaliação de qualidade percebida à recomendação de objetos de aprendizagem por competências realizado pelo RecOAComp. Os sistemas de recomendação integram processos que permitem caracterizar o perfil do usuário, as características do objeto e a avaliação do que está sendo disponibilizado. Assim, a fundamentação teórica inclui a recomendação de objetos de aprendizagem; os estados de ânimo dos usuários; e a avaliação de qualidade percebida. Para a recomendação de OAs, adotaram-se os estudos de Cazella, Nunes e Reategui (2010) sobre a relevância e as características dos sistemas de recomendação; e de Cazella et al. (2012) que tratam do RecOAComp como sistema de recomendação de objetos de aprendizagem por competências. Acerca dos estados de ânimo, incluíram-se o trabalho de Bercht (2001), sobre a essencialidade da afetividade no processo de ensino; e o de Longhi 
(2011), sobre o mapa afetivo como funcionalidade do Ambiente Virtual de Aprendizagem ROODA (Rede Cooperativa de Aprendizagem) para reconhecimento dos estados de ânimo. Por fim, utilizou-se a teoria da qualidade percebida desenvolvida por Oliver (1997), que trata das expectativas, das percepções e da avaliação da qualidade percebida pelos sujeitos. A pesquisa possibilitou a construção da estrutura da Matriz utilizada posteriormente no Requali, a partir da sistematização dos critérios de avaliação para os elementos da qualidade percebida identificados na literatura: expectativa, percepção e qualidade percebida, com o apoio de um grupo focal realizado com professores do curso de PHP, CSS e banco de dados MySQL. O sistema foi validado por meio de um curso de extensão realizado com alunos de graduação de Administração da UFMA. Durante a validação, os registros realizados pelos alunos apontaram que o sistema é atrativo, fácil Administração. Com essa matriz, o sistema Requali foi desenvolvido com tecnologia de usar e motivador e também que fornece disponibilizações adequadas, ainda que tenham destacado limitações de uso, como dificuldades de reconhecer conceitos presentes no sistema e de recuperação de informações. Por fim, a Matriz Requali como meio de avaliação da qualidade percebida foi validada com base em valores decorrentes das avaliações realizadas segundo os parâmetros da qualidade percebida, reconhecendo por meio do Requali a adequação da recomendação.

Palavras-chave: Aprendizagem. Objetos de aprendizagem. Sistema de Recomendação por Competência. Mapa afetivo. Requali.

\section{WALTER CEZAR NUNES}

Orientador: Prof. Dr. Milton Antonio Zaro

Coorientadora: Profa. Drạ. Léa da Cruz Fagundes

Data: 25/08/2016

Local: Sala 329 - Auditório do PPGIE/CINTED

TESE: EMPREENDEDORISMO POR OPORTUNIDADE: OBJETO DE APRENDIZAGEM COM PROPOSTA METODOLÓGICA, DESENVOLVIDA À LUZ DA NEUROCIÊNCIA, PARA MELHORAR A PERFORMANCE NA CAPACIDADE DE IDENTIFICAR OPORTUNIDADES DE NEGÓCIOS

Resumo: Esta pesquisa, propondo uma metodologia auxiliar para a disciplina de empreendedorismo originou-se de uma análise mais amiúde ocorrida dentro da universidade, onde se questiona a falta de efetividade dos conteúdos programáticos e metodologias empregadas na educação empreendedora. De um modo geral as Instituições de Ensino Superior (IES), formam mais futuros empregados que empregadores. Várias instituições oferecem inúmeros cursos e disciplinas de empreendedorismo ou afins, mas continuam colocando no mercado cada vez mais jovens que irão competir à um posto de trabalho por não conseguirem ver o empreendedorismo como opção de carreira. Uma possível resposta estaria permeada por fatores identificados em estudos recentes que afirmam que é de suma 
importância entender melhor como funciona o cérebro dos empreendedores para que se possa oferecer metodologias mais assertivas. Para muitos autores o processo de descoberta de oportunidades de negócios é uma das principais características do comportamento empreendedor e entender como este processo ocorre no cérebro dele abriria novas perspectivas. Esta pesquisa, desenvolvida a partir de dois experimentos, busca contribuir no âmbito universitário com uma proposta metodológica para a disciplina de Empreendedorismo desenvolvida à luz da neurociência. No primeiro experimento, denominado de teste piloto, com o objetivo de verificar possíveis padrões nos clusters neurais dos empreendedores quando identificam uma oportunidade, foi realizado o Mapeamento Cognitivo Cerebral com o uso de eletroencefalograma em 14 indivíduos do sexo masculino, sendo sete "empreendedores estabelecidos" e sete não empreendedores. Os resultados dos testes mostraram que os mapas neurais dos empreendedores sugeriram que as áreas frontais direita e esquerda dos cérebros foram acionadas tanto no momento de descoberta de oportunidades quanto no momento de propensão a assumir riscos, enquanto os não-empreendedores mostraram organizações neurais bem distintas durante os dois momentos. Este resultado aliado a outros estudos realizados por pesquisadores de empreendedorismo levou ao segundo experimento: o desenvolvimento de uma proposta metodológica auxiliar, que melhorasse a performance de alunos no processo de identificação de oportunidades de negócios. Esta proposta metodológica, cerne deste estudo, foi apresentada em um objeto de aprendizagem denominado: MADEPERFIO, Módulo Auxiliar para Disciplina de Empreendedorismo-Performance na I dentificação de Oportunidades, um curso de 40 horas, direcionado para melhorar a performance do aluno na identificação de oportunidades. A pesquisa sobre a efetividade da metodologia oferecida através do Módulo foi feita com 45 professores de graduações e de pós graduações e com 58 alunos de pós graduação de diversas faculdades e universidades maranhenses. Através de um curso de capacitação os professores puderam acessar o objeto de aprendizagem, testar a metodologia proposta e desenvolver suas performances cujos resultados foram extremamente encorajadores. Em média, os professores submetidos à nova metodologia melhoraram em $21 \%$ suas capacidades em identificarem oportunidades de negócios. Com relação à metodologia apresentada através do MADE-PERFIO, 45\% classificaram com o conceito "ótimo" e 40\% com o conceito "muito bom". A metodologia foi apresentada aos alunos no formato de Módulo Auxiliar, pois todos declararam já ter tido contato com a disciplina de Empreendedorismo, mas ainda não haviam empreendido. A pesquisa com os alunos mostrou um acréscimo médio de $23 \%$ em suas capacidades de identificarem oportunidades e $65 \%$ deles classificaram como "excelente" a relevância do conteúdo.

Palavras-chave: Neurociência, MCC-Mapeamento Cognitivo Cerebral, Busca de Oportunidades, Empreendedorismo, Comportamento Empreendedor, MADE-PERFIO, Neurompreendedorismo. 